UNIVERSIDADE DE SÃO PAULO

FACULDADE DE FILOSOFIA, LETRAS E CIÊNCIAS HUMANAS

DEPARTAMENTO DE HISTÓRIA

PROGRAMA DE PÓS-GRADUAÇÃO EM HISTÓRIA ECONÔMICA

\title{
Trabalho, conhecimento, valor: \\ Marx frente a uma contradição atual
}

VERA AGUIAR COTRIM

VERSÃO CORRIGIDA

São Paulo

2015 
UNIVERSIDADE DE SÃO PAULO

FACULDADE DE FILOSOFIA, LETRAS E CIÊNCIAS HUMANAS

DEPARTAMENTO DE HISTÓRIA

PROGRAMA DE PÓS-GRADUAÇÃO EM HISTÓRIA ECONÔMICA

\title{
Trabalho, conhecimento, valor: Marx frente a uma contradição atual
}

\author{
VERA AGUIAR COTRIM
}

Tese apresentada ao programa de PósGraduação em História Econômica do Departamento de História da Faculdade de Filosofia, Letras e Ciências Humanas da Universidade de São Paulo, para obtenção do título de Doutora em História sob a orientação do Prof. Dr. Jorge Luís da Silva Grespan.

VERSÃO CORRIGIDA

São Paulo

2015 


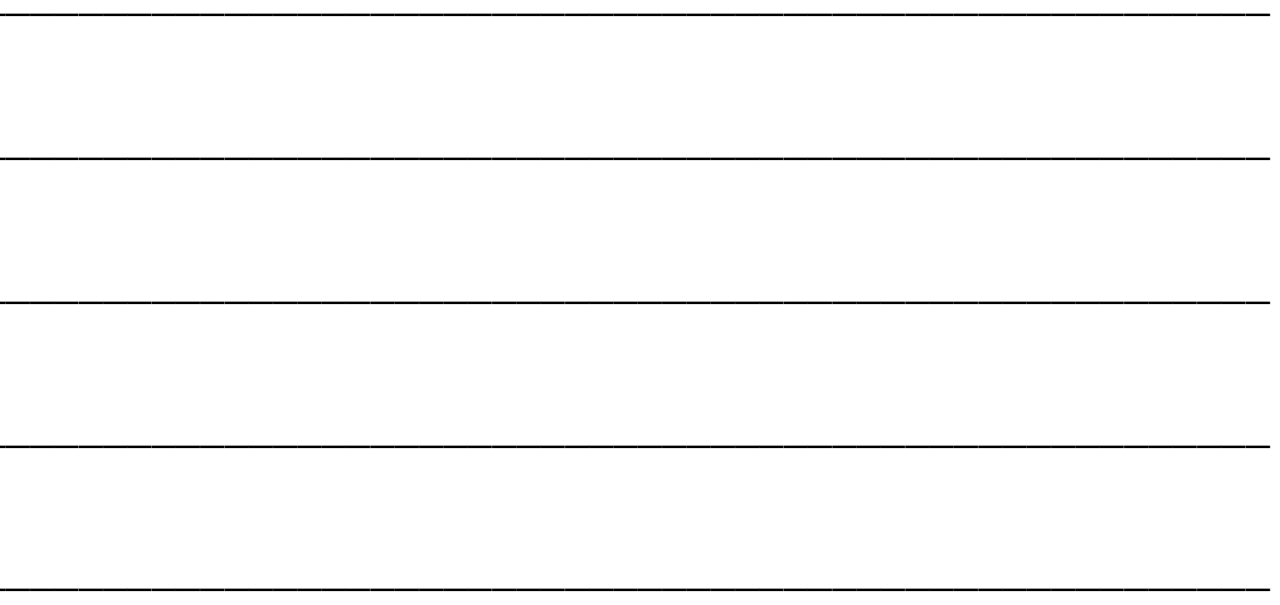


Lia, Theo, Raul e Pedro. 


\section{AgRADECIMENTOS}

Ao meu orientador, Jorge Grespan, pelo apoio à minha pesquisa acadêmica desde o início e por todos os debates a respeito das grandes questões de Marx.

Ao professor Eleutério Prado, pela generosidade em acolher minha pesquisa e tornar viva a discussão sobre a obra de Marx.

Ao professor Lincoln Secco, por acompanhar todos os passos de minha pesquisa acadêmica e se colocar como interlocutor para o debate político.

Aos professores Mario Duayer, Antonio Lopes e Ronaldo Fortes pela disponibilidade de ler a tese e participar da banca de defesa.

Ao GMarx, especialmente às mulheres, pelas conversas feministas, e ao Ciro, pelas conversas sobre natureza e natureza humana.

Às amigas e amigos queridos: Eduardo Correia, Maria Goretti, Sandro Ascencio, Léa Tosold, Sérgio Audi, Iracema Oliveira, Vagner Barnabé e Alexandre Carreira.

Ao Amaral, pela interlocução e amizade, pelos os esclarecimentos relativos à obra de Adam Smith, e por me ajudar a concluir.

Ao Tomás Bastian, pelas indicações de A Ideologia Alemã, por todos os anos de interlocução e aprendizado conjunto e pela amizade constitutiva.

À toda minha família: minhas tias Zilda e Denise, meu tio Marcus, meus primos Ricardo e Helena, pelo carinho; minha tia Márcia, por todo apoio; meu avô Aloízio, sempre presente e a quem sempre recorro, minhas avós Célia e Maria, in memorian.

Aos meus pais, Lívia e Ivan, que me apresentaram Marx. Ao meu pai, por me ajudar a situar Marx na história do pensamento, além de ser o maior entusiasta do tema que estudo. À minha mãe, pela leitura dos meus textos, por me explicar tantas passagens obscuras de Marx, além das indicações dos textos sobre história e conhecimento.

À Ana, a mais camarada das manas, que participou ativamente de todos os passos da pesquisa com ideias, correções e as mais bonitas indicações literárias.

Ao Pedro, que todo dia faz uma mágica nova.

À Lia, ao Theo, e ao Raul, que melhor que qualquer filosofia, sabem fazer todos os questionamentos imagináveis e sacudir os preconceitos.

Esta pesquisa contou como apoio da FAPESP. 


\section{RESUMO}

COTRIM, V. A. Trabalho, conhecimento, valor: Marx frente a uma contradição atual. 2015. 344f. Tese (Doutorado) - Faculdade de Filosofia, Letras e Ciências Humanas. Departamento de História, Universidade de São Paulo.

Esta pesquisa busca examinar as categorias centrais do pensamento de Marx tendo em vista uma questão atual: a expansão da atividade intelectual como forma do trabalho subsumido ao capital. Em contraposição às teorias que veem esta transformação como fator que altera a teoria do valor e torna a compreensão marxiana do capital obsoleta, examino nos textos de Marx a relação geral entre trabalho e conhecimento, pautada em sua compreensão do indivíduo e da sociabilidade. Busco então conectar essas categorias fundantes com a história, distinguindo a dialética do desenvolvimento nas sociedades pré-capitalista e no modo de produção do capital. No interior deste último, destaco dois temas centrais, a categoria de trabalho abstrato como forma social específica do trabalho, e a relação contraditória entre o desenvolvimento das forças produtivas com a forma social do capital. É este desenvolvimento que transforma a relação entre trabalho e conhecimento, bem como a divisão entre trabalho material e trabalho intelectual nesta fase avançada do evolver do capital. A partir do exame deste tema, aponto por fim algumas das mudanças atuais que revelam o aprofundamento da contradição que permeia a reprodução capitalista. $\mathrm{Na}$ abordagem destes temas, discuto com autores que buscam explicar as vicissitudes atuais, bem como com comentadores da obra marxiana que privilegiam o ponto de vista lógico ao examinar seus textos.

Palavras-chaves: Karl Marx; forças produtivas; teoria do valor; trabalho abstrato; trabalho intelectual. 


\section{ABSTRACT}

Cotrim, V. A. Labor, Knowledge, Value: Marx in face of a current contradiction. 2015. 344f. Thesis (Doctoral) - Faculdade de Filosofia, Letras e Ciências Humanas. Departamento de História, Universidade de São Paulo.

This research seeks to examine the central categories of Marx's thought regarding a current issue: the expansion of intellectual activity as a form of labor subsumed to capital. In contrast to theories that see this transformation as a factor that changes the theory of value and makes the Marxian understanding of capital obsolete, this research examines the overall relationship between labor and knowledge in Marx's texts, based on his understanding of the individual and sociability. It aims then to connect these founding categories with history, distinguishing the dialectic of development in precapitalist societies and the capitalist mode of production. Inside the latter, two central themes are highlighted, the abstract labor category as a specific social form of work, and the contradictory relationship between the development of productive forces and capital-relation. It is this development that transforms the relationship between labor and knowledge, as well as the division between material and intellectual production, at this late stage of capital expansion. From the examination of this issue, it is pointed at last some of the current changes that reveal the depth of the contradiction that pervades capitalist reproduction. In addressing these issues, authors who seek to explain the current changes are discussed as well as interpretations of Marx's thought that favor the logical point of view.

Keywords: Karl Marx; productive forces; theory of value; abstract labor; intellectual work 
Pois os próprios antigos não sabiam que um dia virá, quando a gente pode permanecer deitada em rede ou cama, e as enxadas saindo sozinhas para capinar roça, e as foices, para colherem por si, e o carro indo por sua lei buscar a colheita, e tudo, o que não é o homem, é sua, dele, obediência? 


\section{SUMÁRIO}

$\begin{array}{ll}\text { Apresentação } & 10\end{array}$

I. Novas e velhas críticas à teoria do valor de Marx: a questão do trabalho 15 complexo e do trabalho intelectual

I. 1. A datação da teoria do valor de Marx: crise do valor e valor qualitativo no 15 capitalismo cognitivo ou pós-industrial

I. 1. 1. A crise do valor segundo André Gorz 17

I. 1. 2. O conceito de valor qualitativo em Ruy Fausto 31

I. 1. 3. Trabalho imaterial e autonomia da subjetividade em Negri \& Lazzarato 45

I. 1. 4. O problema da medida do trabalho em Eleutério Prado 50

I. 2. Trabalho complexo como objeção à teoria do valor-trabalho: o velho debate 59 imaterial

I. 2. 1. O trabalho qualificado antes de Marx: a objeção de Samuel Bailey à 62 teoria do valor-trabalho de David Ricardo

I. 2. 2. Eugen Dühring e a crítica ao trabalho socialmente necessário 72

I. 2. 3. A recusa do valor-trabalho por Böhm-Bawerk 76

I. 2. 4. Castoriadis contra Marx, mas a favor dos clássicos 85

I. 2. 5. Teorias do trabalho imaterial e do valor qualitativo: questões para a obra 93

de Marx e para a atualidade

II. Trabalho, sociabilidade, força produtiva e conhecimento: os textos de 103 Marx frente a uma tese J. A. Giannotti

II. 1. Individualidade técnica: relação social para J. A. Giannotti 104

II. 2. Sociabilidade, trabalho e indivíduo em Marx 119

II. 3. Trabalho, humanização da natureza e força produtiva 146

II. 4. A questão do desenvolvimento das forças produtivas 160

III. Forças produtivas e relações de produção: a dialética do 175 desenvolvimento nas sociedades pré-capitalistas

III. 1. Introdução: modo de produção e história 
III. 2. Os pressupostos da produção social e a necessidade do dinamismo 187 histórico: a questão da propriedade

III. 3. A desagregação pelo desenvolvimento como dialética própria das 202 sociedades pré-capitalistas

III. 4. A dissolução da comunidade em capital

IV. 1. 1. A "abstração real" de Ruy Fausto: trabalho abstrato como universal 260 concreto

IV. 2. Duplo caráter do trabalho e natureza do valor como forma social

IV. 3. O limite da universalidade do trabalho abstrato

IV. 4. Quando o valor vale? O limite da lei do valor nas trocas pré-capitalistas

IV. 5. O trabalho complexo na teoria do valor

V. 1. Capital e universalização do homem: o conhecimento como força 384 produtiva

V. 2. Oposição entre potência produtiva e potência de valorização 408

Conclusão: Produção científica hoje e contradição capitalista 443

Referências Bibliográficas $\quad 461$ 



\section{APRESENTAÇÃO}

O objetivo geral deste trabalho é recompor um conjunto de categorias do pensamento de Marx em sua ampla coerência; nesta reconstituição, busco encontrar uma noção do desenvolvimento humano que fundamente uma compreensão das atuais formas do trabalho e do capital. Procuro retomar em Marx sua concepção de ser social, de trabalho e de sociabilidade; as relações entre vida social e natureza, o caráter livre da produção consciente, o conhecimento como determinação do trabalho. Ressalto o modo como a concepção de Marx acerca do desenvolvimento humano se depreende da compreensão do trabalho como atividade caracteristicamente social. Destaco a categoria de modo de produção, em que as relações sociais determinadas pelas capacidades produtivas caracterizam uma forma social que tanto se desenvolve a partir da noção do trabalho e de força produtiva, como serve de ponto de partida para especificar a sociabilidade capitalista. Retomo o lugar deste modo de produção na história e a novidade que representa para a relação entre indivíduo e gênero, entre ser humano e natureza, bem como o modo específico como esta relação social possibilita o desenvolvimento produtivo. Caracterizo o valor e o trabalho abstrato como formas definitivas desta sociabilidade. Aponto a oposição entre trabalho e conhecimento, posta na divisão de classe das sociedades pré-capitalistas, e sua dissolução no capitalismo pela subsunção da produção científica. A ideia de contradição no desenvolvimento histórico, seu caráter dialético como aparece no capital e nas sociedades pré-capitalistas, é exposta e levada em conta na análise das demais categorias. Para a reconstituição deste conjunto de categorias, lanço mão, em quase todos os capítulos, de polêmicas com autores marxistas e críticos de Marx que se propõem a examiná-las.

Com essas análises de temas da obra marxiana, o que viso é apresentar a coerência de um pensamento que possa fundar a compreensão das novas formas de trabalho, particularmente o trabalho de produção de conhecimento empregado hoje pelo capital e a nova forma de valorização dos capitais investidos em pesquisa e inovação. A ideia é buscar em Marx não respostas acabadas, mas uma compreensão do ser social e do modo capitalista de sociabilidade que não caracteriza um sistema filosófico fechado e, por isso, apresenta a abertura necessária para sua própria atualização. Frente às transformações que o capitalismo sofreu depois de Marx, pensador que melhor o 
compreendeu, busco recusar tanto as teses que apressadamente afirmam a obsolescência de sua teoria, quanto a aplicação mecânica de seus conceitos às novas realidades. Daí a importância de retomar as categorias marxianas não isoladamente, mas no conjunto que as articula e em referência aos seus desenvolvimentos históricos. É esta coerência de pensamento que pode constituir a base para uma compreensão de transformações que, enquanto criam algo novo, que demanda novas explicações, ao mesmo tempo resultam de um desenvolvimento do modo de produção e de sociabilidade desvendado por Marx. Assim, não assumo que a teoria de Marx é plenamente suficiente para explicar objetos que, recentemente desenvolvidos, não foram os seus. Mas tampouco assumo que as relações de produção se transformaram tão radicalmente a ponto de tornar ultrapassado o entendimento de Marx acerca do trabalho, do desenvolvimento histórico e da sociabilidade do capital. É, pois, a partir da reconstituição da coerência de um pensamento que concluo a pesquisa indicando um caminho para a compreensão do trabalho intelectual tornado assalariado e da valorização dos capitais pelas patentes intelectuais que não rompe com a teoria de Marx; ao contrário, parte dela sem que, contudo, esteja positivamente contido nela.

Os problemas que esta pesquisa discute partem das questões postas pelas teorias do capitalismo cognitivo e por aquelas que propõem que o valor-trabalho marxiano tenha se tornado valor qualitativo. As teorias que lançam mão do conceito de valor qualitativo sustentam que, quando o trabalho produtivo assume a forma de atividade cognitiva, e são por isso exigidas do trabalhador diversas faculdades criativas, o trabalho perde seu caráter abstrato. $\mathrm{O}$ produto das atividades intelectuais não pode reduzir-se a mera quantidade de trabalho social, e com isso o valor se transforma de medida quantitativa em substância qualitativa, desmedida. A esta concepção, subjaz ainda a tese de que há uma incomensurabilidade entre trabalho, de um lado, e a atividade científica ou criativa, de outro. Independente da função produtiva que o conhecimento assume na sociedade capitalista, a criação de conhecimento é vista como uma atividade de natureza distinta do trabalho produtivo. Isto os teóricos do valor qualitativo têm em comum com a velha crítica a Marx, proposta por Böhm-Bawerk, que vê na categoria de trabalho complexo uma incongruência lógica com a teoria do valortrabalho. A diferença entre ambas as concepções é que, no antigo debate, a discussão é categorial e pretende invalidar a teoria do valor, ao passo que, na discussão atual, é a presença determinante do trabalho intelectual e criativo, resultante do desenvolvimento 
das forças produtivas, que tornaria ultrapassada a teoria do valor de Marx. No primeiro capítulo, apresento as teorias atuais que abordam a relação entre o conhecimento e a produção de capital e as comparo com teses que se opõem à teoria do valor de modo absoluto.

No segundo capítulo, a pesquisa se volta a um exame da compreensão marxiana da categoria de trabalho, em sua relação com o conhecimento, em torno da noção original e mais geral de ser social. Tomo como ponto de partida a compreensão de J. A. Giannotti sobre o conceito de sociabilidade e de trabalho. Polemizando com o autor e incorporando pontos de sua análise, examino na categoria de trabalho a relação do ser humano com a natureza, seu caráter consciente, e aponto aspectos gerais da relação entre indivíduo e gênero humano. Neste contexto, apresento também o problema do desenvolvimento histórico e o tema das forças produtivas. Busco caracterizar o desenvolvimento ao mesmo tempo como imanente à categoria de trabalho e como dependente das relações sociais de produção.

Passo então a desenvolver o tema das forças produtivas. Como o capital determina de um modo muito específico o desenvolvimento das forças produtivas, apresento no terceiro capítulo esse processo tal como ocorre nas sociedades précapitalistas, bem como as condições de constituição da forma capitalista. A questão que permeia esta parte da pesquisa é a razão pela qual as relações de produção nas sociedades pré-capitalistas se dissolvem espontaneamente com o desenvolvimento das forças produtivas, ao passo que a relação capitalista de produção se nutre deste desenvolvimento. Busco caracterizar, nas sociedades pré-capitalistas, o lugar do conhecimento na atividade social, visto que apenas no capitalismo industrial a produção se torna um processo científico. As relações entre forma social, forças produtivas e conhecimento são abordadas neste capítulo com referência a essa fase da história, para nos seguintes serem tratadas no interior do modo capitalista.

No quarto capítulo, abordo a forma social do trabalho posta pela relação capitalista de produção. Examino a categoria de trabalho abstrato e os princípios da teoria do valor. A partir de uma polêmica com a análise proposta por Ruy Fausto acerca do trabalho abstrato, destaco o estranhamento e o fetichismo presentes nesta relação. $\mathrm{O}$ conjunto dos predicados do trabalho que participam da conceituação do trabalho abstrato, especialmente a categoria de trabalho complexo, ao lado das demais 
determinações (médio, socialmente necessário etc.), será também examinado neste capítulo, a partir da polêmica com os críticos de Marx que pretendem invalidar a teoria do valor. Neste contexto, destaco a contradição presente no duplo caráter do trabalho que produz mercadoria, contradição que permeia o desenvolvimento das forças produtivas nesta forma social.

O próximo passo é a análise do modo como a contradição capitalista se põe no desenvolvimento produtivo. O último capítulo examina esta contradição, investigando as determinações que fazem do capital a primeira forma necessária da universalização humana; forma que não é, contudo, plena, mas limitada. O desenvolvimento do trabalho intelectual e da ciência no modo de produção capitalista permeia o exame dessa contradição. Busca-se delimitar no que consiste a potência e a estreiteza do desenvolvimento capitalista e como se mostram no evolver da forma-capital, por um lado, e na divisão do trabalho, por outro.

Concluo, por fim, com uma breve indicação para uma explicação positiva da produção capitalista da ciência e do assalariamento do trabalho intelectual, ao que corresponde o advento da valorização pela propriedade intelectual. Procuro examinar a produção científica, tornada ramo autônomo do capital, como uma forma de desenvolvimento coerente com o aprofundamento das contradições do capital.

As críticas que me proponho a fazer ao longo do trabalho, tanto a comentadores que reivindicam Marx, como àqueles que o criticam, têm por finalidade afirmar a coerência específica do pensamento de Marx sobre o desenvolvimento humano. Vários problemas que as interpretações e as críticas dos textos de Marx apresentam se devem ao fato de os autores abordarem separadamente uma ou outra categoria, destacando-as do contexto teórico que elas compõem. Assim, assume-se a conceituação de trabalho de Marx sem levar em conta sua noção de sociabilidade; critica-se a teoria do valortrabalho sem considerar a categoria de modo de produção; examina-se o trabalho abstrato sem considerar o processo histórico de socialização da produção e a forma social da propriedade que estão em sua base; afirma-se erros lógicos na demonstração da lei tendencial à queda da taxa de lucro sem se considerar os processos concretos de subsunção da ciência e automação da produção que dão corpo a essa lei; sugere-se prognósticos para o devir do capital, presentes na obra de Marx, abstraindo-se da perspectiva de revolução social e emancipação que permeia sua obra; etc. As polêmicas 
suscitadas por esta pesquisa compõem o esforço de reconstituir, vale repetir, a unidade do pensamento de Marx com referência a esses temas. Assim, este é um trabalho de filosofia, mas como em Marx o objeto da filosofia é o ser social histórico, toma por objeto aspectos da história que podem contribuir para a discussão das atuais vicissitudes do capital. 


\section{Novas e Velhas CRíticas À teoria do VAlor de MARX: A QUESTÃo do tRABalHo COMPLEXO E DO TRABALHO INTELECTUAL}

\section{A datação da teoria do valor de Marx: crise do valor e valor qualitativo no “capitalismo cognitivo" ou "pós-industrial"}

Exponho nesta primeira parte do capítulo as teorias de André Gorz, Ruy Fausto e Eleutério Prado, além de uma curta passagem de Maurizio Lazzarato \& Antonio Negri. Escolhi tratar destes autores por várias razões. Primeiro, porque discutem diretamente com a teoria do valor de Marx com a finalidade de encontrar explicações positivas para as atuais feições da economia, indicando tendências para o devir do capital. Para isso, os autores discutem a reprodução do valor hoje. Segundo porque, como determinações distintivas do capitalismo atual, consideram a presença determinante do trabalho intelectual e criativo para a produção e buscam delimitar como estas formas concretas do trabalho se relacionam com a criação de valor. Este papel crescente do trabalho científico e cognitivo em geral na produção é expressão do desenvolvimento das forças produtivas: a presença crescente de trabalho científico manifesta uma redução na quantidade de trabalho imediato requerido para a reprodução de mercadorias e libera parte do trabalho social para a criação de conhecimento e inovação. Embora os autores mencionados enfoquem centralmente a natureza particular das atividades cognitivas e criativas para relacioná-las à produção de valor, o problema que propõem diz respeito ao modo como o capital pode se reproduzir com base em trabalho que não é reprodutivo apenas, mas criador do novo. Estas atividades incorporam seu tempo de dispêndio em produto social. Mas seu produto específico pode assumir a forma de mercadoria? Esta questão apenas se torna um problema efetivo quando capitais passam a investir em pesquisa científica e tornam assalariados os trabalhadores da ciência. Assim, um tema que esta pesquisa deriva da discussão sobre o trabalho intelectual é: o capital pode se reproduzir do mesmo modo independentemente do nível das forças produtivas, ou seja, é indiferente à reprodução de valor a expansão do nível técnico da produção? Para as teses que examino abaixo, o trabalho intelectual como forma do trabalho produtivo subsumido ao capital afeta a natureza do valor, por motivos diversos. Esta pesquisa diverge das razões propostas por estes autores, mas 
considera também que o desenvolvimento produtivo transforma as condições de valorização do capital.

Um dos pilares da argumentação comum a Gorz, Negri \& Lazzarato, Fausto e Prado é a consideração da produção de conhecimento como essencialmente distinta do trabalho: trata-se de uma atividade criativa que não pode ser medida pelo tempo. Com isso, restringem o trabalho capaz de reproduzir o capital a um rol determinado de funções concretas. Esta concepção afeta suas teorias a respeito da natureza do próprio capital. Este aparece nas referidas teses como restrito a um modo concreto de produzir, correspondente a um nível definido das forças produtivas: o requerido pela indústria em sua primeira forma, em que há demanda massiva de trabalho imediato do operário à máquina (Gorz). Ou então, o capital apenas se reproduz na produção automatizada que emprega apenas trabalho intelectual porque altera sua natureza: o valor deixa de se constituir em trabalho humano objetivado e se torna valor qualitativo (Fausto, Prado). Deste modo, tais teóricos se distanciam da definição de capital como uma forma da relação social de produção, caracterizada pela propriedade privada e intercâmbio mercantil, e não por uma dada configuração concreta da atividade. Neste afastamento da concepção de valor e de capital como formas sociais, os autores contemporâneos que datam a teoria do valor de Marx acabam por aproximar-se de antigas críticas que viam na categoria de trabalho complexo uma incongruência de tal monta que invalidaria a própria teoria do valor-trabalho de Marx.

Estes debates são então o ponto de partida para a pesquisa retomar as categorias de Marx com vistas ao problema atual: como as transformações na atividade do trabalho assalariado afetam a reprodução de capital. Como se define o trabalho, qual sua relação com o conhecimento, qual a especificidade do trabalho sob a forma capitalista frente às formas sociais anteriores, qual a natureza do trabalho abstrato e do valor são as questões que a primeira parte desta pesquisa aborda. Busco contrapor as teses que veem na forma concreta intelectual do trabalho uma transformação da forma social do valor, reafirmando a indiferença do caráter concreto da atividade para sua forma social. Contudo, não é possível considerar o desenvolvimento produtivo como indiferente a esta forma: como um modo histórico da vida humana, seu próprio desenvolvimento formal não se desliga do desenvolvimento das forças produtivas. Este exame da relação entre capital e desenvolvimento produtivo, bem como com o trabalho criador de ciência e força produtiva nova, é realizado na segunda parte da pesquisa, em que pretendo, mais 
do que responder às teses dos autores abordados, indicar outros aspectos que possam contribuir para a compreensão desta nova fase do capitalismo não examinada por Marx, a partir das questões postas pelo debate atual.

Neste primeiro capítulo, tenho como objeto específico a abordagem que estes autores fazem do conceito de valor no capitalismo contemporâneo, cujas características distintivas começam a se manifestar na década de 1970. Ainda que diversas, suas teorias têm um importante ponto comum referente à compreensão do valor. Desnecessário dizer que a leitura não cogita abranger o conjunto das análises desses autores. Lanço mão apenas dos textos que se voltam para o tema: de Gorz, O Imaterial - Conhecimento, valor e capital; de Fausto, "A 'pós-grande indústria' nos Grundrisse (e para além deles)"; de Eleutério Prado, Desmedida do valor-Crítica da pós-grande indústria; e de Negri e Lazzarato, Trabalho Imaterial - Formas de vida e produção da subjetividade.

\section{1. A crise do valor segundo André Gorz}

Em sua análise das transformações que o capitalismo vem sofrendo nas últimas décadas e sua relação com a teoria de Marx, André Gorz, em $O$ Imaterial $^{1}$, denomina o atual modo de organização produtiva "economia do conhecimento" ou "capitalismo cognitivo". Caracteriza-a centralmente como uma forma de capitalismo em que o conhecimento se tornou a principal força produtiva:

\footnotetext{
Os anglo-saxões falam do nascimento de uma knowledge economy e de uma knowledge society; os alemães, de uma Wissensgesellschaft; os autores franceses, de um "capitalismo cognitivo" e de uma "sociedade do conhecimento". O conhecimento (knowledge) é considerado como a "força produtiva principal”. Marx mesmo já notava que ele se tornaria "die grösste Productivkraft" e a principal fonte da riqueza (Gorz, Imaterial, 15).
}

Esta mudança no caráter das forças produtivas gera uma transformação econômica de tal monta que "compromete a validade das categorias econômicas chaves e indica a necessidade de estabelecimento de uma outra economia" (Gorz, Imaterial, 9). Em outros termos, a mudança que se verifica data as categorias econômicas tal como

\footnotetext{
${ }^{1}$ GORZ, André. O Imaterial - Conhecimento, valor e capital. Tradução de Celso Azzan Júnior. São Paulo: Annablume, 2005. Neste livro, Gorz aponta quatro temas que nos interessam: 1) o trabalho complexo em sua capacidade de criar valor; 2) a subsunção deste modo específico e novo de trabalho ao capital; 3) a nova forma complexa de trabalho como expressão de forças produtivas que restringem o poder de valorização do capital; 4) a demanda capitalista por novos instrumentos de demarcação da propriedade privada. Apenas os dois primeiros temas serão examinados neste primeiro capítulo.
} 
conceituadas por Marx, na medida em que o material histórico que Marx examinara já não é mais o conteúdo das atuais relações capitalistas. Este novo conteúdo concreto das relações de produção, que se expressa em mudanças significativas nas funções e atividades do trabalho, explicita também, para Gorz, que a relação capitalista mesma foi obsoletada, e fixa "os contornos de uma sociedade do conhecimento" (Gorz, Imaterial, 9). Esta sociedade cujos contornos já são discerníveis nas transformações produtivas concretas e que constituem um "capitalismo cognitivo" oferece as condições para que se desenvolva um modo de organização produtiva e integração social pós-capitalista, que supera a finalidade de criação de valor como condição da produção: "Uma autêntica economia do conhecimento corresponderia a um comunismo do saber no qual deixam de ser necessárias as relações monetárias e as de troca" (Gorz, Imaterial, 10).

Gorz distingue o capitalismo industrial desta nova forma de capitalismo também com base na diferença da atividade do trabalho que responde às mudanças nas forças produtivas. As determinações desta nova forma concreta da atividade produtiva principal geram a crise da categoria de valor: "O trabalho abstrato simples, que, desde Adam Smith, era considerado como a fonte do valor, é agora substituído por trabalho complexo" (Gorz, Imaterial, 10). Aqui, Gorz identifica trabalho simples e trabalho abstrato, opondo o trabalho complexo a este último. Sigo o raciocínio do autor, cujo propósito não é analisar o conceito de valor, mas apontar para uma transformação econômica constatável empiricamente e suas implicações para a forma social do capital. Ao caracterizar o que distingue esta forma complexa do trabalho das formas precedentes que dominavam na grande indústria, Gorz reconhece que a apropriação do conhecimento pelo capital caracteriza já o capitalismo industrial, mas distingue tanto o tipo de conhecimento como a forma social de sua incorporação ao capital na fase industrial e na fase atual. $\mathrm{O}$ autor escreve:

Diferente do capital humano, o capital do conhecimento não é novo. A utilização proveitosa do conhecimento em forma de capital é tão antiga quanto o capitalismo industrial. Esse aproveitamento até agora consegue ser bem-sucedido sobretudo através da mobilização de um saber "morto", objetivado em máquinas, instalações e processos (Gorz, Imaterial, 10).

Gorz destaca que o conhecimento técnico-científico é, durante o processo de industrialização, progressivamente separado e oposto ao trabalhador, "ele faz parte do capital fixo como meio de extorsão do sobretrabalho" (Gorz, Imaterial, 34). Este conhecimento existe também, por certo, durante a fase industrial, "na cabeça" dos 
engenheiros ou "oficiais da produção" (Gorz, Imaterial, 34), mas estes se distinguem do conjunto dos trabalhadores produtivos pela detenção do conhecimento: "Eles são os 'quadros' investidos do poder de comando; eles representam o patronato, oferecem soluções para gestão e para a valorização do capital fixo" (Gorz, Imaterial, 34). O foco da capitalização do conhecimento não estava em monopolizar ou privatizar a própria ciência, tampouco os saberes necessários ao desenvolvimento de inovações produtivas ou organizacionais, mas na exclusividade tecnológica que podia se manter mesmo quando o conhecimento que deu origem à tecnologia em questão é público, ou passível de livre acesso, ou seja, na maquinaria. Gorz entende que este não é mais o caso. Em primeiro lugar, sustenta que a produção do conhecimento científico foi, ela mesma, subsumida ao modo capitalista de produção, possibilitando a "capitalização" da própria ciência:

Um primeiro passo decisivo, rumo à autonomização da produção de conhecimento e sua “capitalização”, ocorrerá por volta de 1880, quando Carl Duisberg industrializa, na Bayer, o trabalho de pesquisa na indústria química. Lá, a produção de conhecimento foi submetida à mesma divisão hierárquica do trabalho, à mesma distribuição das tarefas, à mesma separação do trabalho intelectual e do trabalho manual existente nas indústrias manufatureiras. O objetivo é o mesmo: trata-se de reproduzir, no domínio da produção de conhecimentos, a mesma tripla privação que, nas manufaturas, havia permitido ao capital arruinar os artesãos independentes e generalizar o regime salarial: os trabalhadores eram privados de seus meios de trabalho, do poder sobre a natureza e sobre suas condições de trabalho, e do poder sobre seus produtos. Os meios de trabalho se tornaram a propriedade exclusiva do capital; a natureza e as condições de trabalho eram determinadas por ele, e os produtos, por ele apropriados (Gorz, Imaterial, 35).

Além da subsunção da produção científica ao capital, que monopoliza e faz do conhecimento um capital em si mesmo, o autor chama a atenção para uma mudança na forma técnica de apropriação do conhecimento, oriunda do próprio desenvolvimento tecnológico:

(...) hoje a capitalização do conhecimento se detém em uma nova fronteira. Todo conhecimento passível de formalização pode ser abstraído de seu suporte material e humano, multiplicado quase sem custo na forma de software e utilizado ilimitadamente em máquinas que seguem um padrão universal (Gorz, Imaterial, 10).

Nesta passagem, Gorz atenta para o fato de que a utilização do conhecimento como força produtiva passa a prescindir de máquinas cujo acesso era, por seu alto custo, restrito aos grandes capitais. O conhecimento se torna uma força produtiva "por si 
mesmo" na medida em que seu suporte material e as condições de sua reprodução se tornam virtualmente sem custo:

\begin{abstract}
Mas a verdadeira novidade, "revolucionária", está ainda em outro lugar: é que o conhecimento, separado de todo produto no qual esteve ou está incorporado, pode exercer em si mesmo, e por si mesmo, uma ação produtiva na forma de programas de computador. Ele pode organizar e gerir as interações complexas entre um grande número de atores e de variáveis; pode conceber e conduzir as máquinas, as instalações e os sistemas de produção flexíveis; ou seja, desempenhar o papel de um capital fixo, substituindo o trabalho vivo, material e imaterial, por trabalho acumulado (Gorz, Imaterial, 37).
\end{abstract}

Parte dos processos produtivos que demandam, na fase industrial, trabalho vivo (tanto simples como qualificado) se automatiza por meio da objetivação do conhecimento em softwares. Na fase "cognitiva" do capitalismo, outro tipo de conhecimento vem a ser requerido para a reprodução do capital. Gorz afirma: "Ora, a história da industrialização pode ser lida como a história do divórcio crescente entre o desenvolvimento dos conhecimentos científicos e técnicos, por um lado, e a cultura comum, por outro" (Gorz, Imaterial, 34). Mas, à medida que estes conhecimentos formalizáveis se autonomizam pelo desenvolvimento da tecnologia digital, as exigências que recaem sobre o trabalhador passam a dizer respeito à sua capacidade de inovar, seja a própria ciência, seja o processo produtivo ou a organização do trabalho. Ao invés de se adequar às inovações constituídas fora do processo capitalista de produção, o trabalhador passa a ser responsável por elas. Daí a cultura comum, os saberes constituídos fora da atividade e da qualificação profissionais, que não são passíveis de formalização, passarem a compor as qualificações necessárias ao trabalho imaterial que hoje se amplia, de acordo com o autor:

A profissionalização não consegue, entretanto, traduzir em conhecimentos, em procedimentos homologados, ou até em ciência, a totalidade dos saberes que os profissionais praticam. Um resíduo mais ou menos importante escapa à formalização. É porque não pode ser inteiramente ensinado, nem reduzido a um conhecimento formalizável, que o serviço profissional conserva a marca da pessoa que o exerce. O serviço profissional é, de fato, a mercantilização de um saber sob a única forma que pode objetivá-lo: a dos atos que o demonstram. A produção desses atos implica necessariamente uma parte da produção de si e de doação de si. A coisa é perfeitamente evidente nos serviços relacionais (educação, cuidados, assistência), mas também nos ofícios artísticos, na moda, no design, na publicidade (Gorz, Imaterial, 32-3). 
Estes saberes "ativados pelo trabalho imaterial" que não podem ser "destacados dos indivíduos sociais que os praticam" (Gorz, Imaterial, 33) para fins de compra e venda, funcionam como um novo tipo de capital fixo. Mas ilegítimo, porque “(...) é de essência social, comum a todos" (Gorz, Imaterial, 33). No que diz respeito à atividade concreta, a demanda pela mobilização do conjunto "das capacidades e das disposições, aí compreendidas as afetivas",2, distingue o trabalho na fase industrial e no atual momento do capitalismo. Hoje, “(...) não nos é mais possível saber a partir de quando estamos 'do lado de fora' do trabalho que somos chamados a realizar. No limite, não é mais o sujeito que adere ao trabalho; mais que isso, é o trabalho que adere ao sujeito (...)"3. O autor cita Yann Moulier-Boutang para caracterizar esta absorção do trabalhador "pós-fordista" pelo capital: "O trabalhador não se apresenta mais apenas como o possuidor de sua força de trabalho hetero-produzida (ou seja, de capacidades predeterminadas inculcadas pelo empregador), mas como um produto que continua, ele mesmo, a se produzir" ${ }^{4}$. Esta consideração é importante para a posição de Gorz a respeito da exploração do trabalho e da forma de sua subsunção ao capital. Segundo o autor, "A lógica do capital, da vida tornada capital, submete todas as atividades e espaços nos quais a produção de si era originalmente considerada gasto gratuito de energia, sem outra finalidade senão a de levar as capacidades humanas ao seu mais alto grau de desenvolvimento" (Gorz, Imaterial, 25), ou seja, submete o conjunto da vida ativa dos trabalhadores. Para o autor, a atual demanda pela atualização das capacidades integrais do sujeito no trabalho imaterial significa uma tendência à "subsunção total da produção de si pelo capital" (Gorz, Imaterial, 23), que encontra no advento do empreendedor individual, isto é, na transformação do trabalhador assalariado em uma empresa, sua forma jurídica mais apropriada. Gorz afirma: "Yann Moulier-Boutang chama de 'exploração de segundo grau' essa 'subsunção ao capital do trabalho coletivo como trabalho vivo, e não como poder da ciência e das máquinas"” (Gorz, Imaterial, 19). A "subsunção completa da produção de si" (Gorz, Imaterial, 25) ao capital encontra limites na resistência dos trabalhadores qualificados, em sua recusa à "imersão total no trabalho".

\footnotetext{
${ }^{2}$ COMBES, M., ASPE, B. "Revenu garanti et biopolitique", citado por Gorz, Imaterial, 22.

${ }^{3}$ COMBES, M., ASPE, B. op. cit., citado por Gorz, Imaterial, 22.

${ }^{4}$ MOULIER-BOUTANG, Yann. "La troisième transition du capitalisme", em AZAÏS, A. C., DIEUAIDE, P. (Orgs.). Vers un capitalisme cognitif. Paris: L'Harmattan, 2000, citado por Gorz, Imaterial, 19, itálicos de Gorz.
} 
Em resumo, Gorz aponta para três transformações produtivas importantes que distinguem o capitalismo industrial daquele que denomina "cognitivo": a subsunção da produção científica ao capital; a autonomização de parte dos conhecimentos formalizáveis em relação a seus suportes técnicos (máquinas) e subjetivos, por meio de sua codificação em programas de computador, que os torna um meio de produção direto; e a utilização capitalista dos saberes não formalizáveis ou ensináveis, que se constituem fora do âmbito da profissionalização ou, em outras palavras, o advento de nova demanda sobre o trabalhador que vai além da qualificação profissional e diz respeito ao conjunto de suas faculdades e de sua cultura. As mudanças nas formas concretas do trabalho descritas por Gorz são analisadas pelo autor como aprofundamento da subsunção do trabalho ao capital, a despeito das formas jurídicas encobrirem a relação de assalariamento e, o que é mais importante, a despeito da atividade do trabalho qualificado e imaterial não ser mais ditado pelo ritmo da máquina, mas, ao contrário, tornar-se essencialmente criativo, lançando mão do conjunto das disposições subjetivas do trabalhador.

Contudo, o autor considera que estas transformações afetam diretamente o capital enquanto forma social porque altera a produção de valor. Para o autor, o advento do trabalho imaterial, complexo, como forma principal do trabalho significa uma transformação no caráter das forças produtivas que tem implicações na reprodução da forma social. A principal força produtiva passa a ser, hoje, o conhecimento, não apenas como ciência e menos ainda em suas formas objetivadas nas máquinas, mas o conhecimento em ação, vivo, e portanto os próprios sujeitos em suas múltiplas capacidades constituídas e em constituição. Como força produtiva central em uma economia capitalista, o conhecimento se torna também a principal fonte de valor. É este fato que engendra o que o autor chama de "crise do conceito de valor" e caracteriza o capitalismo cognitivo como fase do capitalismo em crise ou crise inescapável do capitalismo. O próprio valor entra em crise porque a atividade econômica concreta se torna indisponível à forma social do capital. Gorz escreve:

Se não for uma metáfora, a expressão "economia do conhecimento" significa transtornos importantes para o sistema econômico. Ela indica que o conhecimento se tornou a principal força produtiva, e que, consequentemente, os produtos da atividade social não são mais, principalmente, produtos do trabalho cristalizado, mas sim do conhecimento cristalizado. Indica também que o valor de troca das mercadorias, sejam ou não materiais, não é mais determinado em última análise pela quantidade de trabalho social que elas contêm, mas, principalmente, pelo 
seu conteúdo de conhecimentos, informações, de inteligências gerais. É esta última, e não mais o trabalho social abstrato mensurável segundo um único padrão, que se torna a principal substância social comum a todas as mercadorias. É ela que se torna a principal fonte de valor e de lucro, e assim, segundo vários autores, a principal forma do trabalho e do capital (Gorz, Imaterial, 29).

Esta passagem suscita desde logo a seguinte questão relativa à substância do valor de troca das mercadorias: se esta não é mais definida pela quantidade de trabalho social, mas pelo seu conteúdo concreto ("conhecimentos, informações e inteligências gerais") ou seja, pelas capacidades concretas do produtores nelas objetivadas, como estes conteúdos específicos podem se configurar em uma "substância social comum", se cada mercadoria, de acordo com suas determinações específicas, objetiva capacidades distintas? Em outras palavras: na teoria marxiana do valor, as diferentes mercadorias têm valor de troca porque apresentam uma substância homogênea, de qualidade igual. O trabalho social só é "mensurável segundo um único padrão" porque as diferentes atividades são formas particulares do trabalho humano. Só por isso assumem forma social abstrata, e não porque seus modos concretos sejam homogêneos. Como pode o valor de troca ser definido por uma substância única, já que é comum às mercadorias, e ao mesmo tempo caracterizar-se por ser tão heterogênea como as múltiplas subjetividades responsáveis por criá-las? Gorz postula uma diferença radical de natureza entre o produto do trabalho e o produto do conhecimento. As atividades que criam conhecimento não são uma forma do trabalho humano em geral, e por isso as atividades que se tornaram fonte de valor são heterogêneas. Daí a origem da crise do valor. Esta crise se define como perda da medida. A ausência de medida comum advém do fato de que as atividades concretas se tornaram diretamente criadoras de valor; ou seja, em virtude da transformação das forças produtivas e das atividades individuais que lhe correspondem, o valor deixa de ter como fonte o trabalho abstrato, uma vez que as atividades que criam valor não se reduzem a trabalho. Nos termos do autor:

\footnotetext{
O conhecimento, diferentemente do trabalho social geral, é impossível de mensurar em unidades abstratas simples. Ele não é redutível a uma quantidade de trabalho abstrato de que ele seria o equivalente, o resultado ou o produto. Ele recobre e designa uma grande diversidade de capacidades heterogêneas, ou seja, sem medida comum, entre as quais o julgamento, a intuição, o senso estético, o nível de formação e de informação, a faculdade de aprender e de se adaptar a situações imprevistas; capacidades elas mesmas operadas por atividades heterogêneas que vão do cálculo matemático à retórica e à arte de convencer o interlocutor; da pesquisa técnico-científica à invenção de normas estéticas (Gorz, Imaterial, 29, itálicos do autor).
} 
A ausência de medida comum às atividades produtivas de conhecimento se origina, para o autor, na heterogeneidade concreta das capacidades exigidas, que torna o trabalho complexo impassível “de mensurar em unidades abstratas simples”. Há neste raciocínio uma identificação entre o trabalho abstrato e o trabalho simples. A atividade que lida centralmente com o conhecimento não é "redutível a uma quantidade de trabalho abstrato" e, portanto, o trabalho abstrato se vincula necessariamente a uma determinação específica do trabalho concreto, que o caracteriza como simples. Gorz escreve:

\begin{abstract}
A heterogeneidade das atividades ditas "cognitivas", dos produtos imateriais que elas criam e das capacidades e saberes que elas implicam, torna imensuráveis tanto o valor das forças de trabalho quanto o dos seus produtos. As escalas de avaliação do trabalho se tornam um tecido de contradições. A impossibilidade de padronizar e estandardizar todos os parâmetros das prestações demandadas se traduz em vãs tentativas para quantificar sua dimensão qualitativa (...) (Gorz, Imaterial, 29-30, itálicos meus).
\end{abstract}

A crise de medida do trabalho resulta da impossibilidade de reduzir atividades distintas por sua qualidade a um padrão que torne possível quantificá-las porque suas naturezas não são comparáveis. Trata-se da impossibilidade de reduzir a multiplicidade qualitativa à quantidade. O mesmo não se dá, de acordo com Gorz, com o trabalho simples. Ainda que diversos qualitativamente, os trabalhos simples podem se reduzir à quantidade, oferecem um padrão de comparação pelo tempo. Ou seja, a dimensão concreta da atividade simples é em si mesma própria à forma abstrata, se não for em si mesma - em sua dimensão concreta - já abstrata. Assim, o trabalho simples, por sê-lo, não apresenta os problemas de medida que o trabalho complexo traz. Com isso, por um lado, o autor exclui o trabalho complexo da substância comum às múltiplas atividades produtivas e, por outro, identifica a atividade não complexa, não intelectual à forma abstrata. $\mathrm{O}$ conceito de trabalho abstrato parece ir se transformando, de forma social das atividades produtivas independente de suas dimensões concretas, em uma forma ligada intrinsecamente a certo tipo de atividade concreta. Com isso, também a medida do trabalho que determina a quantidade de valor parece ser uma medida empírica de tempo, possível para o trabalho simples, mas impossível para o trabalho complexo dada sua dimensão "qualitativa". Lemos em Gorz:

A crise de medição do trabalho engendra inevitavelmente a crise de medição do valor. Quando o tempo socialmente necessário a uma produção se torna incerto, essa incerteza não pode deixar de repercutir sobre o valor de troca do que é produzido. O caráter cada vez mais qualitativo, cada 
vez menos mensurável do trabalho, põe em crise a pertinência das noções de "sobretrabalho" e "sobrevalor". A crise da medição do valor põe em crise a definição da essência do valor. Ela põe em crise, por consequência, o sistema das equivalências que regula as trocas comerciais (Gorz, Imaterial, 30).

A razão pela qual o trabalho criativo não pode ser medido pelo tempo é a impossibilidade de prever ou planejar o tempo que será utilizado para a produção, e isso "torna imensuráveis tanto o valor das forças de trabalho quanto o dos seus produtos". Além disso, “o tempo socialmente necessário a uma produção se torna incerto". Este ponto é importante porque o tempo de trabalho socialmente necessário se caracteriza, em Marx, pela sua imposição post festum, isto é, justamente por não poder ser determinado previamente. Pode-se prever o tempo de uma produção singular, mas não a média social que define o tempo socialmente necessário. Para o autor, contudo, o tempo socialmente necessário parece ser previsto pela produção que utiliza centralmente trabalho simples, ao contrário da teoria marxiana, que distingue os tempos empíricos dos processos produtivos singulares do tempo socialmente necessário para a criação de uma dada espécie de mercadoria. É nesta impossibilidade de previsão e de medida do tempo necessário à produção que o autor instala a crise do valor. Para Gorz, contudo, o valor não pode deixar de ser uma medida quantitativa de uma substância comum à atividade humana de produção, e por isso, quando o trabalho produtivo de conhecimentos - que “"não se prestam à apropriação privada', nem à troca comercial, pois é impossível reduzi-los a uma substância social comum mensurável que permita determinar as relações de equivalência entre eles" (Gorz, Imaterial, 31) - se torna "a principal forma do trabalho e do capital" (Gorz, Imaterial, 29), este trabalho complexo engendra, por sua dimensão concreta, a crise do valor. A produção de conhecimento não se presta à forma de valor: "Um mercado de conhecimentos em que eles se troquem pelos seus 'valores' é impensável. Não podendo se exprimir em unidades de valor, sua avaliação como capital resta problemática" (Gorz, Imaterial, 31).

Esta é uma concepção comum a diversos autores que abordam a transformação produtiva recente e o ponto que os leva a datar o conceito de valor de Marx, validado para a fase industrial em que o trabalho simples predomina na produção, mas não para o capitalismo cognitivo ou pós-industrial, fase em que o próprio valor se transforma. Em Gorz essa transformação aparece como artificialidade. O autor escreve: 
Essa irredutibilidade dos conhecimentos [a valor - VC] será uma fonte de dificuldades, de incoerências, de trapaças e de fantasias econômicas. O capital não pode deixar de tratar e de fazer funcionar o conhecimento como se ele fosse um capital. O problema, para o capital, é o de se apropriar, valorizar e subsumir uma força produtiva que, em si mesma, não se deixa devolver às categorias da economia política (Gorz, Imaterial, 31).

Coerentemente com sua concepção segundo a qual no novo trabalho imaterial a subsunção ao capital se aprofunda e estabelece uma "exploração de segundo grau", Gorz aponta para o fato de que, embora a natureza dessa força produtiva (o conhecimento) seja avessa à forma de valor, não deixa de se subsumir a ela. Mas o modo como a subsunção ocorre é imposto pelo capital "pelo viés das barreiras artificiais":

O capital tudo fará para 'capitalizar o conhecimento', para fazê-lo corresponder às condições essenciais pelas quais o capital funciona e existe como tal, a saber: o conhecimento deve economizar mais trabalho do que originalmente custou, deve submeter a seu controle a utilização que dele é feita; e, enfim, deve-se tornar a propriedade exclusiva da firma que o valoriza incorporando-o nas mercadorias que com ele se produzem (Gorz, Imaterial, 31).

A privatização do acesso, "forma privilegiada de capitalização das riquezas imateriais" (Gorz, Imaterial, 31), é uma barreira artificial porque contrária à natureza concreta de tais riquezas. O que nos leva a considerar que, na concepção do autor, a riqueza material, produzida majoritariamente com trabalho simples - mas que conta também com o trabalho científico objetivado nas máquinas, determinante dos modos mecânicos ou repetitivos do trabalho simples - se não é especialmente afeita à apropriação privada, não a contraria: sua natureza concreta é adequada à propriedade privada. Gorz dá a entender que a apropriação das forças produtivas materiais pelo capital tem uma legitimidade porque estas se encontram fora do sujeito, mas as capacidades subjetivas e saberes são ilegitimamente apropriados pelo capital porque pertencem aos indivíduos.

A crise do valor explicita, para Gorz, as possibilidades objetivas de superação do capital: o autor distingue riqueza efetiva e valor, e divisa uma contradição entre a ampliação da riqueza e a ampliação do valor na produção do capitalismo cognitivo. Embora restrinja esta contradição à nova fase do capitalismo, que por isso mesmo é para ele a crise do capitalismo, e a explique a partir do problema de medida e da distinção entre trabalho e conhecimento, é interessante assinalar que o autor enxerga no atual momento produtivo uma obsolescência da forma capitalista. Ele escreve: 
A partir do momento em que se entende a importância decisiva de recursos que, como a inteligência coletiva, não têm equivalentes, não são quantificáveis nem mensuráveis, e consequentemente não são permutáveis no mercado, chega-se a uma outra concepção da riqueza e dos objetivos da atividade humana. (...) A ligação entre "mais" e "melhor", entre "valor" (no sentido econômico) e "riqueza" se rompe (Gorz, Imaterial, 61).

Em Gorz, o próprio desenvolvimento produtivo, ao pôr o conhecimento, que para ele "não tem valor de troca", como força produtiva central, explicita que o valor não se identifica com a riqueza. Esta explicitação é econômica, e se dá quando o custo de produção dos produtos tende a zero:

\footnotetext{
O conhecimento é em grande parte "inteligência geral”, cultura comum, saber vivo e vivido. Ele não tem valor de troca, o que significa que ele pode, em princípio, ser partilhado à vontade, segundo a vontade de cada um e de todos, gratuitamente especialmente na Internet. Contudo, a parte do knowledge que não é originalmente geral e comum, ou seja, o conhecimento formalizado, separável de seus produtores e que não existe senão para ter sido deliberadamente produzido, essa parte do knowledge também é virtualmente gratuita, pois que pode ser reproduzida em quantidades ilimitadas a um custo desprezível, e partilhada sem ter que passar pela forma valor (pelo dinheiro). Ademais, ela é geralmente acessível, ao menos em princípio, graças à Internet, o que significa que a principal força produtiva, e principal fonte de valor, é pela primeira vez suscetível de ser subtraída à propriedade privada (Gorz, Imaterial, 36-7).
}

Essas passagens reiteram sua concepção de que é a natureza concreta do produto que se dá ou não à forma de valor e ao intercâmbio mercantil. Percebe-se que, para ele, o trabalho material fabril, ao contrário da "inteligência geral", não podia ser subtraído à forma privada. Por outro lado, Gorz subestima a necessidade das forças produtivas objetivadas, da riqueza material constituída, para que o próprio conhecimento possa ser apropriado de modo privado. Não menciona o fato de que a riqueza material demanda a atividade material para ser reproduzida; tampouco questiona o caráter privado das forças produtivas materiais (terra, máquinas etc). A separação radical entre o material e o imaterial na riqueza social será posta em questão e confrontada com a teoria de Marx no capítulo III, em que examino a produção objetiva e subjetiva do homem pelo trabalho.

Mas também é de se notar que a virtual gratuidade dos produtos - ou a redução de custos de produção, ou ainda a diminuição da quantidade de trabalho necessária à produção - é vista por Gorz como determinação da obsolescência da forma de valor (ou dinheiro, como ele coloca) que o produto social assume. $\mathrm{O}$ autor continua: 
Posto que o custo marginal dos programas de computador é bastante pequeno, até desprezível, o conhecimento pode economizar muito mais trabalho do que custou, e em proporções gigantescas, inimagináveis há pouco tempo. Isso significa que se o conhecimento é, por certo, fonte de valor, ele destrói muito mais "valor" do que serve para criar. Dito de outro modo, ele economiza quantidades imensas de trabalho social remunerado, e consequentemente diminui, ou mesmo anula, o valor de troca monetária de um número crescente de produtos e serviços (Gorz, Imaterial, 37, itálicos do autor).

Desde que faz do conhecimento a sua força produtiva principal, o capitalismo cognitivo cria um aumento da produtividade do trabalho que torna possível economizar trabalho social em proporções inéditas. Esse fato contradiz a produção na forma de valor e capital, e por isso, "O capitalismo cognitivo é a crise do capitalismo em seu sentido mais estrito" (Gorz, Imaterial, 37). Em outras palavras: "Como a sociedade da mercadoria pode perdurar, se a produção de mercadorias utiliza cada vez menos trabalho e põe em circulação cada vez menos moedas?" (Gorz, Imaterial, 43).

A proposição do tema da produtividade do trabalho em sua relação contraditória com a forma social do capital, bem como a afirmação da obsolescência desta forma com base no desenvolvimento produtivo, depende de se aceitar, com Marx, que a substância do valor é e não pode deixar de ser a quantidade de trabalho necessário à produção. Diferentemente de outros autores, Gorz mantém esta definição conceitual do valor para a presente fase do capitalismo.

$\mathrm{O}$ autor responde à pergunta acima afirmando que a sociedade da mercadoria não pode perdurar com base no valor, mas, como de fato o capitalismo perdura, Gorz explica que a produção mercantil se mantém com base no capital fictício e nas barreiras artificiais que bloqueiam o acesso geral ao conhecimento. Esta restrição ao uso do conhecimento é tanto mais importante quando o processo parcial material da produção, por sua intensa automação, passa a ter custo insignificante. Isto é, quando a produção imediata das mercadorias requer quantidades ínfimas de trabalho, e a atividade principal passa a ser a inovação científica e técnica (dos meios de produção). Gorz cita Enzo Rulani para argumentar que o custo de produção do conhecimento se distingue radicalmente do custo de sua reprodução: "Uma vez que uma primeira unidade seja 
produzida, o custo necessário para reproduzir as outras unidades tende a zero", . E exemplifica:

\begin{abstract}
Essas observações valem particularmente para os conhecimentos presentes nos programas de computador. Sua elaboração e sua transcrição em linguagem binária, digital, têm um custo frequentemente elevado, porém os programas podem ser reproduzidos em número praticamente ilimitado, e a um custo desprezível. De fato, a mesma coisa vale para a indústria farmacêutica da época de Duisberg: os comprimidos de um medicamento podiam ser fabricados em quantidade ilimitada, e seu custo marginal unitário tendia a se tornar mínimo qualquer que fosse o custo do desenvolvimento do seu princípio ativo (Gorz, Imaterial, 35-6).
\end{abstract}

O resultado desta nova condição produtiva, em que a "materialidade" da mercadoria tem custo unitário insignificante, de modo que ela se torna "o vetor ou a embalagem de seu conteúdo imaterial" (Gorz, Imaterial, 36) é que o capital só pode explorar de modo lucrativo o processo de produção do conhecimento, o processo parcial "imaterial", e para isso tem que privatizar o processo produtivo e seu produto. $\mathrm{O}$ autor cita outra passagem de Enzo Rulani: “O valor de troca do conhecimento está, pois, inteiramente ligado à capacidade prática de limitar sua difusão, ou seja, de limitar com meios jurídicos (...) ou monopolistas, a possibilidade de copiar (...) conhecimentos dos outros" $"$; e assinala que, no que diz respeito à transformação do conhecimento em capital, "O que conta, em suma, é principalmente transformar a invenção em mercadoria e pô-la no mercado como um produto de marca patenteada" (Gorz, Imaterial, 42). Se para Gorz esta privatização é artificial dada a natureza em si mesma coletiva do conhecimento (em oposição ao trabalho material que, para ele, assume a forma de valor sem contrariar sua natureza), o que nos interessa destacar como outro ponto alto de sua análise é que essas "barreiras artificiais" implicam, para o autor, em um bloqueio ao desenvolvimento produtivo. Gorz se refere à valorização como um constrangimento: "Relações de saber e produção de saber apontam a saída para escapar às relações mercantis e à sociedade da mercadoria desde que possam se desenvolver livremente sem o constrangimento da valorização" (Gorz, Imaterial, 68). Contudo, é preciso destacar que ele restringe tanto a diferença de custo entre produção e reprodução, quanto o efeito constrangedor da necessidade de valorização para o desenvolvimento produtivo aos produtos imateriais e ao conhecimento. Marx se refere a ambos os aspectos ao abordar a produção material.

\footnotetext{
${ }^{5}$ RULANI, Enzo. "Le capitalisme cognitif: du déjà vu?", em Multitudes n. 2, maio de 2000, p. 87-94, citado por GORZ, Gorz, Imaterial, 36.

${ }^{6}$ Op. cit., citado por GORZ, Gorz, Imaterial, 36.
} 
Um ponto alto da teoria de Gorz que põe questões para esta pesquisa é esta consideração de que a produção de ciência, ao mesmo tempo em que o custo de sua reprodução é virtualmente nulo, deve valorizar o capital, uma vez que se realizou como um investimento capitalista. Disto deriva a necessidade de privatizar algo que existe como um produto social. A ciência é um produto social porque depende da conexão do conjunto de "saberes", da intelectualidade geral, para se constituir, ainda que pesquisas sejam realizadas na forma de uma empresa capitalista, por produtores assalariados. Em Marx, também os produtos materiais têm por condição o desenvolvimento social e a interconexão das atividades produtivas, de modo que a produção material singular é também um produto social. Por outro lado, Marx se refere à ciência como um produto de caráter mais universal que os produtos materiais singulares.

Outro apontamento relevante presente na teoria de Gorz é a consideração de que a ciência passa a ser "industrializada". Em termos marxianos, sua produção se subsume materialmente ao capital. Isso explicita, em primeiro lugar, que o capital submete um novo campo de atividade humana que gozava antes de relativa autonomia, ao mesmo tempo em que era um campo mais restrito. Em segundo lugar, que este campo é a produção de conhecimento e o desenvolvimento de inovações, atividades que são historicamente função do trabalho intelectual reservado à classe dominante. $\mathrm{O}$ trabalho intelectual se torna assalariado, função da classe trabalhadora, o que indica que a divisão de classe na sociedade capitalista não se identifica mais com a divisão entre trabalho material e trabalho intelectual, como define Marx.

Retomarei nos capítulos seguintes os pontos positivos referentes à análise de Gorz das recentes transformações produtivas: a subsunção material da ciência ao capital; o aumento da exploração e aprofundamento da subsunção do trabalho ao capital; a contradição entre valorização e o advento do conhecimento como força produtiva central; a consideração de que a capitalização do conhecimento significa um entrave ao desenvolvimento produtivo. E também os problemas centrais: a cisão entre trabalho e conhecimento, bem como entre a atividade do sujeito e o mundo humano objetivo; a questão da natureza do valor em relação à diferença concreta de atividades e à qualificação, buscando afirmar seu caráter de forma social do produto; a diferença de legitimidade entre a apropriação pelo capital do trabalho material e da atividade intelectual. Sobre este último ponto, pretendo defender que a subjetividade do 
trabalhador é apropriada pelo capital em todas as fases de seu desenvolvimento, e não apenas hoje, quando o trabalho é cognitivo e criativo.

\title{
1. 2. O conceito de valor qualitativo em Ruy Fausto
}

Em um texto que recebeu o nome de "A 'pós-grande indústria' nos Grundrisse (e para além deles) "7 quando publicado independentemente, mas que faz parte do primeiro capítulo de seu Marx: Lógica e Política $I I I^{8}$, “A apresentação marxista da história: modelos", Ruy Fausto propõe-se a analisar as recentes transformações econômicas tendo por base os textos dos Grundrisse de Marx. Segundo o autor, estaríamos vivendo uma terceira fase do capitalismo, pós-industrial, prevista no manuscrito de Marx. Para Fausto, "Os Grundrisse prospectam as modificações por que deve passar o sistema em seu desenvolvimento, modificações que introduzem, sem dúvida, uma ruptura qualitativa" (Fausto, LP III, 128) com o capitalismo industrial. O autor reconhece que Marx não apresenta estas modificações pelas quais o capitalismo passaria em seu desenvolvimento produtivo como uma ruptura em relação à fase industrial, e por isso propõe-se a fazê-lo:

\begin{abstract}
Mas o texto não caracteriza de uma forma bem clara essa ruptura enquanto ruptura. Sem dúvida, as negações aparecem como negações no sistema, entretanto elas são tomadas antes como negações no interior da forma específica. Elas não são apresentadas, pelo menos explicitamente, como seríamos tentados a fazer hoje (mutatis mutandis), como constituindo uma terceira forma, cuja predominância definiria um novo período na sucessão das formas do sistema, sucedendo à manufatura e à grande indústria. É isto o que tentaremos fazer aqui, elaborando para essa terceira forma conceitos análogos aos que Marx utilizou para a primeira e a segunda (Fausto, LP III, 1289).
\end{abstract}

De acordo com Fausto, Marx prevê transformações no sistema capitalista, desencadeadas por sua própria lógica, que se constituem como "negações". Estas não são apresentadas por Marx, contudo, como constituindo uma forma pós-industrial do capitalismo, mas "como negações no interior da forma específica" da indústria ou do capitalismo industrial. Fausto não concorda, entretanto, que esta terceira forma do capitalismo, que sucede a manufatura e a indústria e cuja apresentação ele vê nesses escritos de Marx, seja uma explicação válida da atual forma da produção. Ele anuncia

\footnotetext{
${ }^{7}$ FAUSTO, Ruy. "Pós- grande indústria nos Grundrisse (e para além deles)", in Lua Nova, São Paulo, n ${ }^{\circ}$ 19, pp. 47-67, Nov. 1989.

${ }^{8}$ FAUSTO, Ruy. Marx: Lógica e Política - Investigações para uma reconstrução do sentido da dialética, Tomo III, São Paulo: Ed. 34, 2002. Doravante, LP III, seguido do número da página.
} 
desde o início uma crítica a Marx e deixa claro que a "previsão" marxiana tem apenas analogias com a realidade de hoje ${ }^{9}$. Esta crítica não é objeto desta pesquisa, que se restringe a examinar a compreensão que o autor tem do texto de Marx no que diz respeito às mudanças na substância do valor e que definem, em sua visão, o advento de uma terceira forma histórica do capital. Procurarei expor o que Fausto entende pelas "modificações que introduzem uma ruptura qualitativa" no modo de produção capitalista, prospectadas pelos Grundrisse.

Seu texto se aproxima das atuais teorias do trabalho imaterial ao defender que, de acordo com a teoria de Marx, o capitalismo se desenvolve ao ponto de negar o tempo de trabalho como substância do valor. Embora vá muito além deste aspecto e aborde diversas questões relativas à obra de Marx, interessa neste momento apenas o modo como o autor alcança esta conclusão específica. Isso porque a conceituação do valor como "qualitativo" toca diretamente na questão da transformação do trabalho produtivo em atividade intelectual: é o fato do trabalho em sua forma concreta se tornar intelectual que apoia, no texto de Fausto, esta nova determinação do valor. Exponho em seguida a interpretação que o autor busca construir sobre algumas passagens dos Grundrisse $^{10}$ a fim de sustentar sua proposição de que o conteúdo do valor se transforma.

$\mathrm{O}$ autor começa por afirmar que o período da grande indústria constitui a primeira negação do processo de trabalho, que se dá quando o capital imprime sua própria forma ao processo de produção material:

\footnotetext{
A propósito da grande indústria, Marx observa que, a rigor, nela já não se tem processo de trabalho: "A apropriação do trabalho vivo através do trabalho objetivado - a força ou atividade de valorização através do valor que é para si - que está contida no conceito de capital, é posta na produção que se baseia na maquinaria como caráter do próprio processo de produção, também segundo seus elementos materiais e seu movimento material. O processo de produção deixou de
}

\footnotetext{
${ }^{9}$ Ver $L P$ III, 179, nota 115.

${ }^{10} \mathrm{Na}$ edição da MEW de 1983 (MARX, Karl, Ökonomische Manuskripte 1857-1858, MEW Band 42, Berlim: Dietz Verlag, 1983), estas passagens situam-se entre as páginas 592 e 594. Na tradução para o espanhol (Elementos Fundamentales para la crítica de la Economia Política - Borrador, tradução de Pedro Scarón, Buenos Aires: Siglo Veintiúno), utilizada por Fausto, aparecem entre as páginas 227 e 230 do segundo volume. Na edição brasileira, (Grundrisse: Manuscritos econômicos de 1857-1858: esboços da crítica da economia política, tradução de Mário Duayer e Nélio Schneider, São Paulo: Boitempo; Rio de Janeiro: Ed. UFRJ, 2011) as passagens encontram-se entre as páginas 587 e 589 . Citamos do texto de Fausto as passagens de Marx que ele reproduz.
} 
ser processo de trabalho no sentido de que o trabalho nele interviria (übergriffe) como unidade que domina (beherrschende) ${ }^{11}$ " (Fausto, LP III, 129, itálicos de Fausto).

A partir desta proposição de Marx, Fausto sustenta que "Se a grande indústria aparece como a negação do processo de trabalho, a pós-grande indústria seria a segunda negação do processo de trabalho, e na realidade a negação da negação" (Fausto, LP III, 129). Fausto chama de negação do processo de trabalho o fato de que, com a maquinaria, a atividade imediata do trabalho deixa de ser o princípio do processo produtivo - em Marx, a "unidade que domina" a produção. A pós-grande indústria transforma concretamente o processo produtivo, de modo a se constituir como uma "segunda posição do capital no processo material de produção" que implica uma "segunda negação do trabalho como princípio do processo produtivo" (Fausto, LP III, 129). A pós-grande indústria impõe uma segunda negação do processo de trabalho, já que o trabalho direto, ao contrário de voltar a ser determinante nesta nova forma concreta da produção, se afasta ainda mais do processo produtivo imediato. Mas se constitui também como "negação da negação" porque o trabalho, em sua nova forma intelectual, voltará a dominar o processo produtivo nesta terceira fase do capitalismo.

Para explicar a fase da pós-grande indústria, Fausto cita as passagens em que acredita ver a abordagem de Marx de uma fase do desenvolvimento capitalista que sucederia à grande indústria ${ }^{12}$, que também transcrevemos. Fausto escreve:

\footnotetext{
Para analisar este terceiro momento, é essencial examinar em detalhe alguns textos - embora longos - dos Grundrisse (...): “A troca de trabalho vivo contra o trabalho objetivado, isto é, a posição do trabalho social na forma de oposição entre capital e trabalho - é o último desenvolvimento da relação de valor, e da produção que repousa sobre o valor. Sua pressuposição é e permanece [sendo] - a massa de tempo de trabalho imediato, o quantum de trabalho utilizado como fator decisivo da produção da riqueza". Até a grande indústria, a massa de tempo de trabalho, o quantum de trabalho, é o elemento decisivo; é esse tempo que deixará de ser a "medida do movimento" (Fausto, LP III, 129, os itálicos na última frase citada de Marx são de Fausto).
}

Pautado na afirmação de Marx segundo a qual a quantidade de trabalho "deixará de ser a 'medida do movimento'”, Ruy Fausto assume que na pós-grande indústria o quantum de trabalho deixa de ser o "elemento decisivo" para a criação de valor. O autor toma esta afirmação como uma referência a um desenvolvimento no interior da produção de

\footnotetext{
${ }^{11}$ Marx, Grundrisse, op. cit., pp. 584-5; Borrador, 2, p. 219.

${ }^{12}$ Nos Grundrisse, op.cit, pp. 592-4; no Borrador, 2, op.cit, pp. 227-30.
} 
capital, e cita a sequência do texto de Marx para concluir que a valorização se torna independente do tempo de trabalho:

“(...) Mas à medida que a grande indústria se desenvolve [aqui, Fausto insere uma nota observando que Marx não fala em uma terceira fase do capitalismo - VC], a criação da riqueza efetiva torna-se menos dependente do tempo de trabalho e do quantum de trabalho utilizado, do que da força dos agentes (Agentien, agentes materiais, RF) que são postos em movimento durante o tempo de trabalho (...)" (...) A "valorização" se liberta do tempo de trabalho, mas com isto ela não será mais valorização (Fausto, LP III, 129, os itálicos são de Fausto).

Quando Marx afirma que a criação da riqueza efetiva se torna menos dependente da quantidade de trabalho imediato, Fausto conclui que a “"valorização' se liberta do tempo de trabalho". Assume, portanto, que com a expressão "riqueza efetiva" Marx se refere à riqueza como valor. É o que se lê em seu comentário à sequência do texto de Marx:

“(...) [agentes $^{13}$ ] os quais, eles próprios - sua poderosa efetividade (powerful effectiveness) por sua vez não tem mais nenhuma relação com o tempo de trabalho imediato que custa sua produção, mas [a criação da riqueza efetiva, RF] depende antes da situação geral da ciência, do progresso da tecnologia, ou da utilização da ciência na produção". Temos assim um "poder" que escapa do tempo como medida. O "valor" passa a ser qualitativo, e nesse sentido a "riqueza efetiva" não é mais valor (trabalho abstrato cristalizado, medido pelo tempo), mas "valor negado" (Fausto, LP III, 130, itálicos de Fausto, com exceção do termo em inglês).

Para o autor, o valor deixa de ser "trabalho abstrato cristalizado, medido pelo tempo" para se tornar "qualitativo" porque o poder de criar valor escapa do tempo como medida ao passar a depender mais da utilização da ciência na produção. Com isso, o valor perde sua substância própria - o trabalho social meramente quantitativo - e passa a ter como conteúdo a qualidade. Esta qualidade diz respeito tanto à atividade humana requerida pela produção quanto à ação das próprias máquinas. O poder que escapa ao tempo como medida é o poder dos agentes - Agentien, agentes materiais, como Fausto destaca - que a seu ver concorrem ativamente para a valorização. (Aqui, aparece já a interpretação que Fausto explicitará adiante: as forças produtivas objetivas ou materiais são, para ele, agentes da criação de valor.) Ao perder o conteúdo que o define - tempo de trabalho - o valor é negado. Por isso, a riqueza efetiva, que o autor identifica com o valor, deixa de ser valor conforme Marx o conceitua nesta terceira fase do capitalismo.

\footnotetext{
${ }^{13}$ Trata-se da continuação do texto citado acima por Fausto, em que Marx afirma que a criação da riqueza efetiva depende mais dos agentes (materiais) postos em movimento pelo trabalho do que da quantidade de trabalho imediato despendido.
} 
Esta pesquisa diverge da interpretação que Fausto apresenta das passagens citadas dos Grundrisse em um ponto crucial e, embora a análise positiva das referidas passagens vá encontrar lugar nos capítulos seguintes, adianto aqui alguns comentários, antes de seguir com a exposição do texto do autor. Isso introduz um dos temas centrais da pesquisa, que consiste na contradição entre riqueza efetiva e valorização tanto no nível conceitual do duplo caráter do trabalho, como também com referência ao desenvolvimento produtivo.

Diferente de Ruy Fausto, entendemos que nas passagens citadas dos Grundrisse Marx afirma que o desenvolvimento da indústria conduz o processo produtivo a reduzir progressivamente a quantidade de trabalho imediato requerida para pôr em movimento as forças produtivas materiais, ou seja, o conjunto da maquinaria se transforma, pela aplicação da ciência, em um sistema paulatinamente mais automático. Assim, a riqueza concreta - real ou efetiva, como Marx coloca - se torna cada vez mais livre da quantidade de trabalho (embora não do trabalho).

Em diversos textos, Marx se dedica a distinguir a riqueza efetiva (wirkliche Reichtum) da riqueza na forma de valor. Na passagem citada do texto de Marx, seu objetivo é distinguir os fatores que concorrem para a produção da riqueza concreta e da riqueza na forma de valor, para então demonstrar que a relação entre a produção de valores de uso e a criação de valor não apenas é contraditória, mas que esta contradição se aprofunda conforme se desenvolva a produtividade do trabalho. Em Marx, "a massa de tempo de trabalho imediato", ou "o quantum de trabalho", é o fator decisivo da produção de riqueza "que repousa sobre o valor". A relação de valor tem seu desenvolvimento último na "troca de trabalho vivo contra trabalho objetivado", ou seja, na "oposição entre capital e trabalho". A pressuposição da "relação de valor" ou da "produção que repousa sobre o valor" é sempre, necessariamente, a quantidade de trabalho como fator decisivo da produção de riqueza, isto é, como fator determinante da produção de riqueza que tem a forma de valor. Enquanto o trabalho social tem a forma de trabalho assalariado, ele se realiza sob a relação de valor, e a produção repousa sobre o valor. É isto que se lê no texto de Marx: a pressuposição da produção fundada no valor "é e permanece [sendo] - a massa de tempo de trabalho imediato, o quantum de trabalho utilizado como fator decisivo da produção da riqueza" (citado acima). Alguns parágrafos antes das passagens citadas por Fausto, Marx escrevia: 


\begin{abstract}
Na mesma medida em que o tempo de trabalho - o simples quantum de trabalho - é posto pelo capital como único elemento determinante de valor, desaparece o trabalho imediato e sua quantidade como princípio determinante da produção - a criação de valores de uso -, e é reduzido tanto quantitativamente a uma proporção insignificante, quanto qualitativamente como um momento ainda indispensável, mas subalterno frente ao trabalho científico geral, à aplicação tecnológica das ciências naturais, de um lado, bem como [à] força produtiva geral resultante da articulação social na produção total - que aparece como dom natural do trabalho (embora seja um produto histórico). O capital trabalha, assim, pela sua própria dissolução como a forma dominante da produção (Marx, Grundrisse, tradução brasileira citada acima, p. 583).
\end{abstract}

Marx escreve que, com o desenvolvimento da indústria, a produção da riqueza efetiva se torna paulatinamente menos dependente da quantidade de trabalho imediato e mais dependente das forças produtivas mobilizadas pelo trabalho. Trata-se da riqueza efetiva, isto é, concreta, e não do valor. Assim, o "poder" que escapa ao tempo como medida é o das forças produtivas sociais, é o poder dos agentes que, postos em movimento durante o tempo de trabalho, tornam a criação de riqueza concreta relativamente independente da quantidade de trabalho imediato. Mas Fausto não considera a distinção, que constitui em verdade uma oposição, entre riqueza efetiva, concreta, e sua forma social de valor, presente no texto de Marx, e com isso deixa passar o núcleo da argumentação, qual seja, a contradição existente entre ambas.

Marx define a contradição intrínseca ao desenvolvimento capitalista: “(...) o capital é ele próprio a contradição em processo, porque ele reduz (zu reduzieren stört) o tempo de trabalho a um mínimo, enquanto põe, por outro lado, o tempo de trabalho como única medida e fonte de riqueza" (Grundrisse, apud Fausto, LP III, 123, na edição brasileira, pp. 588-9). O capital põe o tempo de trabalho como única fonte de riqueza na forma de capital -, mas reduz a um mínimo, através do desenvolvimento da produtividade, a quantidade de trabalho requerida para a produção. Ou seja, seu movimento próprio restringe as bases da valorização.

Trata-se da contradição que a lei tendencial à queda da taxa de lucro expressa. Mas, para Fausto, esta contradição apresentada pelos Grundrisse não é a mesma que Marx expõe em $O$ Capital. Neste último texto, a contradição seria apenas formal, interna ao sistema, e expressa pela lei tendencial à queda da taxa de lucro, enquanto que, nos Grundrisse, a contradição que aparece em seus efeitos materiais não seria apenas interna ao sistema, mas "provoca a explosão de suas bases" e tem como resultado a "revelação do que é a 'verdadeira riqueza"” (Fausto, LP III, 123). Em Marx, contudo, a 
"explosão de suas bases" ou o desenvolvimento concreto com o qual "desmorona a produção baseada no valor de troca" significa a superação da relação de valor, da produção capitalista, portanto. Diferentemente, Fausto projeta as transformações na produção concreta, que certamente afetam as condições de produção na forma de valor, ao seu conceito: em sua concepção, do fato de o trabalho complexo, científico e de vigilância do processo produtivo tornar-se decisivo para a criação de riqueza efetiva deriva-se que o valor se torna qualitativo. Marx propõe o contrário quando afirma que "a massa de tempo de trabalho imediato" é o fundamento inescapável da produção fundada "na relação de valor".

Em síntese, o texto de Fausto parece apresentar dois problemas: primeiro, toma as afirmações de Marx em que se pressupõe a superação da relação de valor como descritivas de uma terceira forma histórica de capitalismo ${ }^{14}$. Além disso, toma as passagens em que Marx aborda o desenvolvimento da produção da riqueza efetiva como descritivas do devir da valorização; com isso, deixa de atentar não apenas para a distinção entre riqueza efetiva e valor, mas para a oposição dessas categorias, que constitui o cerne do raciocínio de Marx nestas passagens.

A partir da conclusão de que a substância do valor se transforma, Fausto procura caracterizar as relações capitalistas próprias de uma conjuntura ou estágio de desenvolvimento em que a forma-valor já não é mais aquela que Marx define. Ou seja, procura examinar a relação de valor quando o conceito de valor se desvincula do trabalho abstrato, distinguindo-se assim precisamente da forma social do trabalho que define a valorização. $\mathrm{O}$ autor extrai do texto de Marx o seguinte desenvolvimento histórico do capitalismo:

Temos assim três formas de capitalismo, no plano do processo material de produção. A essas três formas correspondem configurações distintas no plano formal, ou níveis diferentes de

\footnotetext{
${ }^{14}$ Outros autores atestam que Marx está tratando, nestas passagens, da produção social livre da relação de valor, e portanto não pós-industrial, mas pós-capitalista. Ver ROSDOLSKY, R. Gênese e estrutura de $O$ Capital de Karl Marx, capítulo 28: "O limite histórico da lei do valor - Observações de Marx sobre a ordem social socialista”. Tradução de César Benjamin, Rio de Janeiro: EDUERJ, Contraponto, 2001; DUSSEL, Enrique, A Produção Teórica de Marx - Um comentário aos Grundrisse, capítulo 14.4 "Um 'reino da liberdade' mais além da contradição capitalista?". Tradução de José Paulo Neto, São Paulo: Expressão Popular, 2012; e o próprio Gorz que, a despeito de também assumir que o valor se torna "qualitativo" na medida em que o trabalho complexo se torna determinante na produção capitalista (sua substância passa a ser o conteúdo de conhecimentos), reconhece, com Dussel e Rosdolsky, a contradição entre a riqueza efetiva e o valor ( $O$ Imaterial, p. 37). Em Gorz, a conclusão de que o valor se torna qualitativo segue uma análise própria, que declaradamente se afasta de Marx. A identificação que Fausto sustenta entre as duas categorias, com base na análise de um texto em que Marx expõe a contradição que existe entre elas de mais de uma maneira, surpreende.
} 
desenvolvimento dessas formas. Na primeira forma, o desenvolvimento da exploração da maisvalia relativa só pode ser limitado (...). Na segunda forma, temos o pleno desenvolvimento da exploração da mais-valia relativa (...). Na terceira forma, tem-se a 'negação' do trabalho como fundamento do valor, e do tempo de trabalho como medida da grandeza do valor. Esses três momentos são formas sucessivas do modo de produção capitalista (Fausto, LP III, 133).

Chama atenção nesta passagem a ausência de menção à mais-valia nesta terceira fase do capitalismo. O autor afirma que, na primeira forma do capitalismo, a mais-valia é predominantemente absoluta; na segunda, há o pleno desenvolvimento da mais-valia relativa; e, na terceira, o valor deixa de ser tempo de trabalho abstrato cristalizado. Com a supressão do trabalho abstrato como fonte de riqueza, cabe ao autor expor qual seria a nova fonte do valor, como ele seria criado e em que se constituiria positivamente.

Para Gorz, na fase cognitiva do capitalismo, o valor é criado pelo trabalho em sua forma contemporânea e sua substância consiste no conteúdo concreto dos trabalhos imateriais e complexos. Fausto parece assumir a mesma posição quando afirma que "A riqueza agora é cristalização do "trabalho" científico (...)" (Fausto, LP III, 138). Contudo, a riqueza não é definida como quantidade de trabalho, tampouco como trabalho em sua dimensão qualitativa. Isso porque, para o autor, nesta terceira forma, que prescinde, ou "quase" prescinde do trabalho, o capital se relaciona de um modo novo com a ciência, distinto da forma como se apropriava da ciência na grande indústria:

O que ocorre na segunda posição, isto é, na terceira forma? Se, na grande indústria, tínhamos uma posição da forma na matéria através de uma organização material adequada, temos agora uma espécie de posição na matéria da forma enquanto forma. É a forma enquanto tal - mas, atenção, trata-se aqui da forma material, da ciência, não da forma formal, o capital (que já era e continua sendo posta) - que agora é posta na matéria. A ciência se objetiva enquanto ciência na matéria. Surge assim uma espécie de ciência objetivada na maquinaria da pós-grande indústria (Fausto, LP III, 134).

Fausto procura distinguir a objetivação da ciência na maquinaria da grande indústria da objetivação da ciência na maquinaria da pós-grande indústria. Naquela que o autor chama de segunda posição da ciência, ela seria objetivada sem a mediação da técnica, direta ou imediatamente, enquanto ciência. A questão que se coloca é: como um conteúdo intelectual (a compreensão da natureza, nos termos de Fausto) pode pôr-se em um objeto material sem que este ato seja técnico? "A compreensão da natureza está objetivada nas novas máquinas" (Fausto, LP III, 134), mas não estava na máquina a 
vapor? Para Fausto, não estava, porque as máquinas na grande indústria são um mecanismo meramente objetivo. Para o autor, na máquina da fase pós-industrial, que se tornou "simples suporte da ciência",

(...) já não se tem mais, propriamente, um objeto artificial. Antes uma espécie de objeto intelectual ou espiritual: é o logos - mas logos da natureza assimilado pelo intelecto - que é posto no processo de produção. Com isto, a ruptura entre trabalho vivo e trabalho morto é relativizada, a máquina passa a ser uma espécie de força de trabalho (intelectual), no sentido de que ela não necessita mais (quase) nenhum trabalho para ser vivificada. $\mathrm{O}$ autômato é agora autômato espiritual, não simples autômato "vivo" (Fausto, LP III, 134-5).

Coerentemente com a afirmação de que a ciência se objetiva enquanto ciência, ou seja, sem mediação da técnica ou da atividade material como na grande indústria, as "novas máquinas" são sujeitos, entes vivos e intelectuais, uma espécie de força de trabalho. Embora o termo seja impreciso, a concepção é manifesta: já que aquilo que foi objetivado tem agora as determinações da força de trabalho, subjetiva por definição, suprime-se a distinção entre trabalho vivo e morto. Ou seja, a interpretação que Fausto apresenta das passagens citadas dos Grundrisse leva-o a considerar que as "novas máquinas" são dotadas de subjetividade criadora.

Para o autor, nesta terceira forma, ocorre uma transformação na relação entre o processo material de produção e o capital, sua formal social ("forma formal", nos termos de Fausto). Este processo concreto no qual a ciência se objetiva "enquanto ciência" se torna inadequado ao capital. A razão desta inadequação não fica totalmente clara:

Mas no momento em que a forma material [ciência -VC] se adequa inteiramente à matéria, no sentido de que ela a domina inteiramente, a forma (formal) enquanto tal, isto é, o capital, já não se adequa mais à matéria (à forma material mais a matéria material). A posição plena da forma material, pelo fato de que ela é plena já não serve mais à forma enquanto tal. A forma material passa a servir a si própria em vez de servir à forma formal. Esta última, o capital, funciona assim como aprendiz de feiticeiro. Ela utiliza uma "alma material" que se volta contra ela. É como se o capital, processo quase-vivo, se perdesse, no momento em que ele mobiliza o espírito enquanto tal. É evidente a extração hegeliana de todo esse desenvolvimento. (...) Assim, o capital que era uma alma apetitiva - ele tem 'fome devoradora' de trabalho alheio (W 23, K I, p. 425; C, I, 2, p.29) - se apossa de um intelecto; mas acaba sendo dominado por ele (Fausto, LP III, 135).

Para Fausto, o processo de produção baseado nas "novas máquinas" que são a objetivação da ciência em si mesma porque não necessitam de quase nenhum trabalho 
para serem vivificadas, é inadequado ao capital. Mas a razão disso é apenas um postulado lógico: “A posição plena da forma material, pelo fato de que ela é plena já não serve mais à forma enquanto tal", ou seja, quando a forma material (ciência) se adequa plenamente à matéria (às novas máquinas), ela deixa de ser adequada à forma formal - que entendemos como forma social (capital). Mais do que isso, “(...) a matéria, a 'forma material', comanda o processo. É como se a forma material exigisse uma posição adequada na forma. O capital é inadequado a esse novo processo material de produção" (Fausto, LP III, 135-6). Ao se tornar inadequado ao processo material de produção, o capital é dominado pelo intelecto incorporado nos novos "autômatos espirituais", pela ciência que vem a servir a si mesma: "A forma material passa a servir a si própria em vez de servir à forma formal’. A produção passa a ter a ciência, o próprio desenvolvimento produtivo, como finalidade? O fim não é mais capitalista, mas tampouco visa os indivíduos produtores? O raciocínio do autor parece hesitante neste ponto.

Fausto sustenta que, de acordo com os Grundrisse, esta terceira fase pósindustrial do capitalismo implica o fim da subsunção material do trabalho ao capital: "Se a subordinação material desaparece é porque o processo de trabalho perdeu completamente o seu caráter de processo de trabalho" (Fausto, LP III, 135). Fausto já havia mencionado que na indústria, conforme Marx, o processo de produção já perdera este caráter, de modo que a diferença entre as duas fases parece residir na completude deste processo. Mas ao completar este caminho de distanciamento entre o processo de produção e o processo de trabalho, a subsunção material do trabalho desaparece. $\mathrm{O}$ autor continua: "O processo de produção tem um caráter muito próximo ao de um processo de produção de ciência. São as novas máquinas que o executam, o indivíduo sai até certo ponto do processo. (...) Assim, a subordinação material desaparece" (Fausto, LP III, 135). Quando o trabalho imediato é dispensado da produção e a ciência se põe plenamente na matéria, a subordinação material do trabalho desaparece. Com isso, some a oposição entre indivíduo e o "processo material”, porque o trabalhador, ao deixar de se subordinar à máquina, não é mais negado no processo produtivo. Mas "se restabelece a oposição entre matéria e forma", ou seja, entre a ciência objetivada nas novas máquinas e o capital. $\mathrm{O}$ autor defende então que a forma material (a ciência) se opõe à "forma formal" (o capital), e a domina. A ciência domina o capital? 
Quanto ao trabalho intelectual, Fausto afirma que "Em relação aos indivíduos fica apenas a interversão forma/conteúdo, não mais a inversão na forma material" (Fausto, LP III, 136). Isso significa que o modo concreto do trabalho não se opõe mais ao indivíduo, como na grande indústria; o indivíduo domina sua própria atividade na medida em que se liberta do trabalho imediato e, consequentemente, da subsunção material ao capital. No plano material, a atividade vem a ser livre quando a ciência se põe plenamente no processo de produção, preservando-se apenas a subordinação formal do trabalho ao capital. Segundo Fausto, esta posição estaria manifesta nos Grundrisse, mas o autor discorda dela:

\begin{abstract}
Marx crê que a espiritualização do objeto implica uma libertação (que, bem entendido, é para ele, apenas a libertação material, isto é, interior ao processo de trabalho). Mesmo isso é, entretanto, excessivo. Arriscaria aqui alguns conceitos novos. Diria que pode haver uma espécie de subsunção intelectual (ou espiritual) do trabalho ao capital. Teríamos assim a subordinação formal, a subordinação formal-material (em sentido próprio), e a subordinação formalintelectual (ou espiritual) do trabalho ao capital. As duas últimas seriam reais (na minha versão; na de Marx só a segunda é real, a primeira e a terceira são formais). E se, no caso da subordinação formal, o trabalhador é (formalmente) portador (suporte), sem ser (materialmente) apêndice, se no caso da subordinação formal-material ele é apêndice, além de ser portador (suporte), na subordinação intelectual ele é de certo modo servidor do novo mecanismo, que é um autômato espiritual. (Fausto, LP III, 136).
\end{abstract}

Assim, para Fausto, Marx estaria defendendo que, com o desenvolvimento da indústria, a atividade concreta se liberta materialmente do capital, ainda que se mantenha nos limites da produção de capital. Para ele, esta liberdade não emerge porque o trabalho, tornado intelectual em sua forma concreta, subsume-se ao capital não apenas formalmente, mas também na dimensão intelectual, fazendo do trabalhador um servidor do mecanismo. Mas um servidor que, em primeiro lugar, passa a dominar o processo:

\footnotetext{
O homem não é mais sujeito da produção, ou antes, a segunda negação faz com que se rompa a estrutura do processo de produção como processo de trabalho. O homem é de certo modo "posto para fora", liberado (freigesetzt) do processo, mas é assim mesmo que ele passa a dominar o processo (Fausto, LP III, 131).
}

Em segundo lugar, este trabalho subsumido formal e intelectualmente ao capital é, para Fausto, um não-trabalho, que se realiza no tempo livre e não cria riqueza abstrata, embora crie "valor". É o que se lê na passagem abaixo: 
Com a pós-grande indústria, (...) A riqueza não é mais produzida pelo trabalho, mas pelo nãotrabalho. Isto num duplo sentido. Em primeiro lugar, a riqueza material já não depende essencialmente do trabalho. Em segundo lugar, a riqueza passa a ser essencialmente a ciência (a arte etc.), e esta é produzida no tempo de não-trabalho. Assim, a substância da riqueza não é mais o trabalho, mas o não-trabalho. $\mathrm{O}$ trabalho era a substância da riqueza abstrata. A matéria (mas a matéria substancial) da riqueza concreta era a natureza (o trabalho concreto só modificava a forma). Tinha-se assim uma oposição entre, de um lado, o universo concreto, o dos valores de uso, no interior do qual se tinha matéria e forma, e de outro lado o universo abstrato, do valor e do trabalho abstrato, que era pura forma (incluindo a substância da forma, o próprio trabalho abstrato). Agora a substância da forma [o capital -VC] não é mais o trabalho, mas o não-trabalho (é a ciência que cria “valor”) (Fausto, LP III, 137).

Com o advento da pós-grande indústria, fase da produção capitalista em que o trabalho imediato é tornado dispensável e que a criação científica vem a ser o fator central da produção, a riqueza passa a ser gerada pelo não-trabalho. O autor não considera a subsunção material da produção científica ao capital. A atividade de produção científica, artística etc. é compreendida como algo que não se enquadra na categoria de trabalho, porque são atividades que se realizam no tempo livre. A fonte da riqueza é assim definida por Fausto: “A riqueza é agora cristalização do 'trabalho' científico, mas o trabalho científico entra no tempo livre”. Esta proposição, Fausto a deriva da passagem em que Marx argumenta que o tempo social gasto para a produção dos elementos do capital fixo deve ser tempo social disponível, não necessário para o trabalho imediato que cria meios de subsistência. É atividade que deve se realizar no tempo livre, tempo que, do ponto de vista social, sobra para a realização de atividades distintas da produção dos meios de vida imediatos, tanto as que produzem conhecimento, arte etc., quanto as de lazer. Trata-se do tempo excedente da sociedade, em oposição ao tempo necessário. Como não se constitui como trabalho, "Longe de significar uma invasão do espaço de não-trabalho pelo do trabalho, esse movimento representa o contrário disso" (Fausto, LP III, 137). Criada pelo não-trabalho, atividade que não chega a ser definida positivamente, a riqueza deixa de ser produto do trabalho abstrato, mas com isso desaparece o trabalho (sem mais determinações) como fonte da riqueza. Fausto escreve: “Ora, com a mutação que se produz após a grande indústria, a riqueza interverterá o próprio tempo de trabalho em tempo de não-trabalho. E mais ainda, ela mesma tornar-se-á tempo de não-trabalho" (Fausto, LP III, 139). E adiante: "O tempo se torna substância, substância da riqueza" (Fausto, LP III, 140). Assim, a riqueza capitalista, na terceira forma de sua produção, tem como substância o tempo em 
si mesmo ${ }^{15}$. Com isso, não há e não pode haver explicação a respeito da mais-valia na terceira forma. Fausto estaria lendo em Marx o desenvolvimento de uma forma de capitalismo sem mais-valia? Ou a reprodução de um capital, cuja "finalidade posta nos termos do autor - é criar valor e apropriar trabalho excedente" (Fausto, LP III, 138), sem trabalho?

O não-trabalho, a despeito de ser uma definição negativa, é caracterizado como concreto, em oposição a abstrato:

\footnotetext{
Porém, enquanto não-trabalho concreto, a (nova) ciência fará mais do que modificar a forma dos objetos naturais. O que era assim forma abstrata (do lado da forma) e simples forma (do lado do conteúdo) diante do conteúdo substancial, passa a ser forma "concreta", diante de um simples suporte material. A forma abstrata se torna forma concreta, e a matéria substancial se reduz a simples matéria (Fausto, LP III, 137).
}

O valor, e por conseguinte o capital, de abstrato se torna concreto, e de forma, se torna matéria. Torna-se qualitativo, como Fausto afirma logo no início do texto, e este qualitativo tem como conteúdo a ciência e o produto intelectual, ou o intelecto em si mesmo. A substância do valor e do capital se torna concreta, e assim desaparece o duplo caráter do trabalho. Ainda que a forma social do capital seja inadequada ao processo material de produção, como quer Fausto, ela está presente e parece dominar, inclusive para o autor, a atividade produtiva: os trabalhadores intelectuais (talvez "nãotrabalhadores") são subsumidos formal e intelectualmente ao capital. Embora, por outro lado, o intelecto passe a dominar a forma. Essas proposições não parecem compatíveis, a não ser que se desvincule a ciência, enquanto produto objetivado no autômato espiritual de Fausto, das atividades dos produtores individuais que a desenvolvem. Com efeito, é este o caso: o intelecto domina o capital e o faz adquirir substância concreta, idêntica ao próprio intelecto e seu produto, mas os indivíduos são subsumidos formal e intelectualmente ao capital. O intelecto é supra-individual, além de ativo - "uma espécie de força de trabalho" - e material, tendo a nova máquina como suporte.

Com relação à mudança na substância do valor, temos então em Fausto o seguinte posicionamento: 1) a ciência e as novas máquinas criam valor, de modo que a fonte de valor (antes o trabalho, antes apenas subjetiva) se torna também objetiva. Se,

\footnotetext{
${ }^{15}$ Dois sentidos parecem possíveis de se extrair da ideia de que o tempo é a substância da riqueza. Por um lado, pode denotar que as coisas são criadas pela ciência e pelo (não-) trabalho científico, que se realiza no tempo livre; por outro, pode significar que esta forma da produção permite a apropriação de tempo livre para os indivíduos, de modo que este tempo constitua sua riqueza. Fausto não especifica.
} 
em Marx, as máquinas são forças produtivas definitivas para a criação de valores de uso, em Fausto vêm a ser fonte de valor. 2) A ciência é criada em tempo livre e se constitui como não-trabalho. O tempo livre ou de não-trabalho é, por isso, produtivo em sentido tanto geral (criador de valor de uso), quanto para o capital, na medida em que seu produto gera e constitui o conteúdo do valor. 3) A atividade produtiva, definida negativamente como oposta ao trabalho (não-trabalho), é subsumida ao capital formal e intelectualmente. 4) O valor é qualitativo e sua substância é o conteúdo concreto da riqueza, o próprio intelecto objetivado. Temos, a despeito destas determinações, a terceira fase do modo de produção capitalista.

Não é tarefa fácil encontrar a coesão e a linha de raciocínio do texto de Fausto; há conceitos que não são esclarecidos positivamente (suporte, apêndice, portador, nãotrabalho etc.); há afirmações que parecem ser incoerentes, especialmente se os conceitos forem tomados à luz de Marx - temos um exemplo na ideia de uma atividade que se constitui a um só tempo como não-trabalho, porque se realiza no tempo livre, e como atividade concreta subsumida formal e intelectualmente ao capital, além de criadora de riqueza; e mesmo sua linguagem, que lança mão repetidas vezes de expressões como "uma espécie de" e "é como se", é vacilante. O que demonstra que a relação do trabalho científico, intelectual, complexo, bem como da automação do processo produtivo, com a produção de capital são questões desafiadoras e polêmicas.

Há um ponto comum entre as posições de Fausto e Gorz. Para ambos o valor se torna qualitativo, isto é, seu conteúdo passa a ser imediatamente a riqueza intelectual/imaterial concreta, de modo que o trabalho abstrato deixa de ser a fonte da riqueza que assume a forma de capital. Está na base da concepção de ambos a cisão entre a atividade que é trabalho e aquela que cria conhecimento, tendo naturezas distintas e sendo incomensuráveis. A criação de valor, como definido por Marx, se realiza por uma categoria específica de atividade concreta, a atividade imediatamente material, não criativa. Mas há divergências importantes. Se para Fausto a subsunção material do trabalho ao capital desaparece quando o trabalho se torna científico, para Gorz esta subsunção se aprofunda. Para este último, o capital passou a dominar o tempo total do trabalhador, absorvendo o tempo livre em tempo de trabalho, e a determinar sua formação, a "produção de si"; para o primeiro, a atividade produtiva de riqueza se dá no tempo livre, o tempo do trabalhador de fato foi liberado quando se tornou cientista e o tempo de trabalho desaparece. Para Gorz, a produção de conhecimento é trabalho, 
embora não possa se reduzir a trabalho abstrato; para Fausto, é não-trabalho. Se em Fausto a indústria é intelectualizada, em Gorz a ciência é industrializada. Ambos concordam, contudo, que o capital não é mais forma adequada à produção material.

\section{3. Trabalho imaterial e autonomia da subjetividade em Negri \& Lazzarato}

Outros autores que enfrentaram este problema e se aproximam de algumas das posições de Fausto, embora por vias distintas, são M. Lazzarato e A. Negri. Os autores de Trabalho imaterial ${ }^{16}$ comentam a mesma passagem dos Grundrisse examinada por Fausto com o objetivo de demonstrar que, hoje, dada a transformação integral do trabalho "em trabalho imaterial e a força de trabalho em 'intelectualidade de massa' (os dois aspectos que Marx chama de General Intellect)", esta mesma intelectualidade "pode transformar-se em um sujeito social e politicamente hegemônico" (L\&N, Trabalho Imaterial, 27). Para isso, sustentam que o trabalho imaterial, por sua natureza mesma de imaterial, não é determinado pela "organização capitalista", de modo que se origina desta forma de trabalho uma nova subjetividade que é livre em sua atividade. As passagens são citadas sequencialmente ${ }^{17}$, e nelas os autores veem

\footnotetext{
${ }^{16}$ LAZZARATO, Maurizio; NEGRI, Antonio. Trabalho imaterial - Formas de vida e produção de subjetividade. Tradução de Giuseppe Cocco. Rio de janeiro: DP\&A, 2001. Doravante L \& N, Trabalho Imaterial, seguido do número da página.

${ }^{17}$ Transcrevemos as passagens dos Grundrisse como citadas no segundo item ("Intelectualidade de massa e nova subjetividade") do capítulo 1 ("Trabalho imaterial e subjetividade") do texto de Lazzarato e Negri, p. 28-9, extraídas da tradução italiana dos Grundrisse (Lineamenti fondamentali della critica dell'economia política, Florença: La Nuova Italia, 1978):

"Como, com o desenvolvimento da grande indústria, a base sobre a qual ela se funda - ou seja, a apropriação de tempo alheio - cessa de constituir ou criar a riqueza, assim, com ele, o trabalho imediato cessa de ser, como tal, a base da produção, porque por um lado vem transformado em uma atividade prevalentemente de vigilância e regulamentação; mas também porque o produto cessa de ser o produto do trabalho isolado imediato e é, ao contrário, a combinação da atividade social a apresentar-se como o produtor".

"Mas na medida em que se desenvolve a grande indústria, a criação da riqueza real vem a depender menos do tempo de trabalho e da quantidade de trabalho empregado do que da potência dos agentes que veem colocados em ação durante o tempo de trabalho e que, por sua vez -, esta sua powerful effectiveness - não é minimamente em relação ao tempo de trabalho imediato que custa sua produção, mas depende, ao contrário, do estado geral da ciência e do progresso da tecnologia, ou da aplicação desta ciência à produção".

"Nessa transformação, não é nem o trabalho imediato, executado pelo próprio homem, nem é o tempo que ele trabalha, mas a apropriação de sua produtividade geral, a sua compreensão da natureza e o domínio sobre esta através de sua existência enquanto corpo social - em uma palavra, é o desenvolvimento do indivíduo social que se apresenta como o grande pilar de sustentação da produção e da riqueza. $O$ furto do tempo do trabalhador alheio, sobre quem se apoia a riqueza atual, se apresenta como uma base miserável em relação a esta nova base que se desenvolveu e foi criada pela própria indústria. Logo que o trabalho em forma imediata deixou de ser a grande fonte da riqueza, o tempo de trabalho cessou e deve cessar de ser a sua medida, e portanto, o valor de troca deve cessar de ser a medida do valor de uso. $A$ mais-valia da massa cessou de ser a condição do desenvolvimento da riqueza geral, assim como o nãotrabalho dos poucos cessou de ser condição do desenvolvimento das forças gerais da mente humana. Com isso a produção baseada sobre valor de troca desmorona e o processo de produção material imediato
} 
(...) a tendência geral de um paradoxo que é (...) o seguinte: de um lado, o capital reduz a força de trabalho a "capital fixo", subordinando-a sempre mais no processo produtivo; de outro ele demonstra, através dessa subordinação total, que o ator fundamental do processo social de produção é tornado agora "o saber social geral” (L\&N, Trabalho Imaterial, 30).

Este saber social abrange, para os autores, tanto o trabalho científico quanto a cooperação social. Mas, para eles, esta tendência se realiza hoje, ainda sob a forma capitalista, e resulta na "transformação radical do sujeito na sua relação com a produção" (L\&N, Trabalho Imaterial, 30). As mudanças produtivas concretas transformam a relação entre trabalho e capital:

Esta relação não é mais uma relação de simples subordinação ao capital. Ao contrário, esta relação se põe em termos de independência com relação ao tempo de trabalho imposto pelo capital. Em segundo lugar, esta relação se põe em termos de autonomia com relação à exploração, isto é, como capacidade produtiva, individual e coletiva, que se manifesta como capacidade de fruição. A categoria clássica de trabalho se demonstra absolutamente insuficiente para dar conta da atividade do trabalho imaterial. Dentro desta atividade, é sempre mais difícil distinguir o tempo de trabalho do tempo da produção ou do tempo livre. Encontramo-nos em tempo de vida global, na qual é quase impossível distinguir entre o tempo produtivo e o tempo de lazer ((L\&N, Trabalho Imaterial, 30).

Ao contrário de Gorz, que considera este "tempo de vida global" a expressão da subsunção não apenas do tempo de trabalho, mas da produção de si e das atividades do tempo livre ao capital, tendência que não deixa de sofrer a resistência de parte dos trabalhadores intelectuais "dissidentes" (Gorz, Imaterial, 63), Negri e Lazzarato a tomam por manifestação de independência subjetiva com relação ao capital; enquanto Gorz toma o trabalho intelectual empregado pelo capital como objeto de uma

tende a perder também a forma da miséria e do antagonismo. [Subentra] o livre desenvolvimento das individualidade e, portanto, não a redução do tempo de trabalho necessário para criar mais trabalho, mas em geral, a redução do trabalho necessário da sociedade a um mínimo, ao qual correspondem, em seguida, a formação e desenvolvimento artístico, científico etc. dos indivíduos graças ao tempo que se tornou livre e aos meios criados por todos eles. O capital é ele mesmo a contradição em processo, pelo fato de que tende a reduzir o tempo de trabalho a um mínimo, enquanto do outro lado põe o tempo de trabalho como única medida e fonte da riqueza. Ele diminui, portanto, o tempo de trabalho na forma de tempo de trabalho necessário, para acresce-lo na forma de tempo de trabalho supérfluo; fazendo, portanto, do tempo de trabalho supérfluo - em medida crescente - a condição question de vie et de mort daquele necessário. De um lado ele evoca, portanto, todas as forças da ciência e da natureza, bem como das condições sociais e das relações sociais, com a finalidade de tornar a criação da riqueza (relativamente) independente do tempo de trabalho empregado nela. De outro lado, ele pretende criar as gigantescas forças sociais assim criadas à medida do tempo de trabalho e aprisiona-las nos limites que são necessários para conservar como valor os valores já criados. As forças produtivas e as relações sociais - ambas sendo os lados diversos do desenvolvimento do indivíduo social - figuram para o capital somente como meios, e são para ele somente meios para produzir sobre sua base limitada. Mas, na realidade, elas são as condições para fazer explodir esta base". 
"exploração de segundo grau", os autores italianos consideram que "o trabalho imaterial não se reproduz (e não reproduz a sociedade) na forma da exploração, mas na forma de reprodução da subjetividade" (L\&N, Trabalho Imaterial, 31). Esta "independência da atividade produtiva em face à organização capitalista da produção e o processo de constituição de uma subjetividade autônoma ao redor do que chamamos 'intelectualidade de massa"” (L\&N, Trabalho Imaterial, 31) se dá no interior do capitalismo. Os autores afirmam a autonomia da atividade concreta, de seu "conteúdo", defendendo que a constituição do sujeito produtivo é anterior ao capital: "Nas fábricas pós-fordistas e na sociedade produtiva pós-industrial, os sujeitos produtivos se constituem, tendencialmente, primeiro e de modo independente da atividade empreendedora capitalista" (L\&N, Trabalho Imaterial, 31), e isto ao mesmo tempo em que o capital abrange o conjunto da produção social. Para eles, a forma imaterial (intelectual) do trabalho escapa à determinação capitalista em sua atividade concreta. Nos termos dos autores:

\footnotetext{
No momento em que o controle capitalista da sociedade tornou-se totalitário, o empreendimento capitalista vê as suas características constitutivas tornarem-se puramente formais. De fato, ele exercita hoje sua função de controle e de vigilância do externo do processo produtivo, porque o conteúdo do processo pertence sempre mais a outro modo de produção, à cooperação social do trabalho imaterial. A época em que o controle de todos os elementos da produção dependia da vontade e da capacidade do capitalista é superada: é o trabalho que, cada vez mais, define o capitalista, e não o contrário (L\&N, Trabalho Imaterial, 31-2).
}

A progressiva determinação do capital pelo trabalho assalariado exprime o "paradoxo do capitalismo pós-industrial". Ou seja, no interior do modo de produção do capital, e justamente quando este se torna total, o trabalho se torna independente devido a sua natureza concreta, pela razão de que se caracteriza como imaterial ou intelectual, isto é, lida com "saberes". Trata-se do trabalho complexo na reprodução de capital. Sabemos que, para os autores, o trabalho imaterial altera alguma coisa na reprodução capitalista ao mesmo tempo em que constitui uma autonomia em relação ao capital:

O trabalho imaterial se constitui em formas imediatamente coletivas e não existe, por assim dizer, senão sob forma de rede e fluxo. A submissão à lógica capitalista da forma de cooperação e do 'valor de uso' desta atividade não tolhe a autonomia e a independência de sua constituição e de seu sentido. Ao contrário, ela abre antagonismos e contradições que, para remeter a uma fórmula marxista, pedem no mínimo uma ‘nova forma de exposição' (L\&N, Trabalho Imaterial, $50)$. 
Assim, a autonomia no âmbito da atividade concreta coexiste com o domínio capitalista: "o fato de que o trabalho imaterial produz ao mesmo tempo subjetividade e valor econômico demonstra como a produção capitalista tem invadido toda a vida (...)" (L\&N, Trabalho Imaterial, 46).

Mas, assim como Gorz prefere não "entrar aqui nas sutilezas da teoria do valor", deixando "de lado a questão da substância do valor" e ocupando-se "exclusivamente da questão da grandeza do valor" (Gorz, Imaterial, 30, nota 23), também para Lazzarato e Negri não lhes "cabe sublinhar, aqui, como o domínio capitalista exerce o seu 'despotismo' e quais consequências derivam dele nesta fase de desenvolvimento" (L\&N, Trabalho Imaterial, 32); ou ainda, "O processo pelo qual o 'social' (...) torna-se econômico não foi ainda suficientemente estudado" (L\&N, Trabalho Imaterial, 47), o que nos deixa sem explicação quanto ao conteúdo positivo da relação capital-trabalho nesta fase do desenvolvimento capitalista.

Negri \& Lazzarato e Fausto veem no trabalho científico (ou que manipula saberes) atividades que se libertam do jugo da subsunção material ao capital, ou seja, que são, por sua natureza concreta, livres em sua atividade. São, por isso, independentes do capital em seu caráter concreto, subjetivo. Para os primeiros, "a categoria clássica de trabalho se demonstra absolutamente insuficiente para dar conta da atividade do trabalho imaterial (L\&N, Trabalho Imaterial, 30, citado acima). Porque a atividade produtiva é outra que não o trabalho tal como Marx o definiu, ela escapa às determinações do valor; de modo que, a despeito da manutenção da relação de troca entre a força de trabalho e o capital, sua natureza concreta a resguarda de ser dominada pelo capital. Aparece aqui, como em Gorz e Fausto, a concepção de que apenas as atividades imediatamente materiais e mecânicas são trabalho, e apenas nesta determinação específica a atividade produtiva é adequada à subsunção ao capital.

Negri \& Lazzarato tomam a descrição de Marx do que viria a ser uma sociedade em que as relações capitalistas deixassem de constituir a forma das relações de produção, a saber, "o livre desenvolvimento das individualidades", "a formação e o desenvolvimento artístico, científico etc. dos indivíduos graças ao tempo que se tornou livre", como determinações presentes hoje, alcançadas espontaneamente pelo desenvolvimento da indústria, e compatíveis com a subsunção formal do trabalho ao capital. O mesmo questionamento apresentado ao texto de Fausto cabe aqui. Em Marx, 
essa condição social depende de que "a produção baseada no valor de troca" de fato desmorone, e que o processo de produção material imediato perca realmente "a forma da miséria e do antagonismo", ou seja, a forma de produção de capital. Pois este faz do trabalho excedente criador de mais-valia "a questão de vida ou morte" do trabalho necessário, aprisiona as forças produtivas sociais nos limites necessários para "manter como valor os valores já criados", isto é, para manter a riqueza na forma de capital. Isso impede, em Marx, "o livre desenvolvimento das individualidades", ainda que o trabalho venha a ser imaterial, intelectual, complexo. No texto citado de Marx (nota 22 acima), o desenvolvimento da indústria, ou das forças produtivas sociais, é a condição material para a superação da forma de capital que hoje o conjunto - cada vez mais amplo - da riqueza e da atividade produtiva assume. Os autores não desenvolvem o que compreendem por capital. Negri \& Lazzarato e Gorz supõem que a relação de troca entre trabalho e capital se mantém ao mesmo tempo em que a atividade realizada pela força de trabalho não pode mais criar valor (Gorz) ou não se subsume ao capital (Negri \& Lazzarato). Em Fausto, a troca mantém a subsunção formal do trabalho ao capital, mas, por um lado, não há mais subsunção material e, por outro, o valor se torna qualitativo. Põe-se, pois, uma questão fundamental para tornar consistente o debate com tais autores. Além da definição de trabalho, decisiva ao tema, é preciso investigar a natureza do valor e do capital. Esta pesquisa buscará defender que o capital é uma relação de produção, um modo específico da divisão do trabalho, em que as transformações no conteúdo concreto das atividades, embora não deixem de afetar a reprodução do capital, não são determinantes de sua definição e tampouco capazes de realizar uma metamorfose silenciosa, não revolucionária, do capitalismo em outro modo de produção.

Tanto Fausto quanto Lazzarato e Negri tomam as condições materiais que permitem a transformação das relações de produção como novas relações já postas concomitantemente ao domínio (“totalitário", no termo de Lazzarato e Negri) do capital, e por isso veem no atual trabalho intelectual subsumido ao capital (apenas formal, ou formal-intelectualmente) uma atividade concreta autônoma e, por conseguinte, uma subjetividade menos determinada pelo capital e mais livre. Em Gorz, diferentemente, o domínio capitalista na produção imaterial é artificial, o que nos leva a compreender que considera natural este domínio na produção material, no sentido de que é adequado à sua natureza. No caso de Fausto, este trabalho que se subsume ao capital é não-trabalho, 
de modo que o tempo livre toma o tempo de trabalho e nele se produz a riqueza riqueza na forma de capital, dado que em sua visão é a ciência que cria valor. Estas conclusões são diferentes das de Gorz, para quem o trabalho intelectual empregado na produção capitalista é integralmente subsumido ao capital, porque o capital tende a se apoderar da totalidade do tempo de vida do trabalhador, de toda sua constituição subjetiva. Há em Gorz a consideração, ausente nos demais autores, de que a propriedade privada constitui obstáculo ao desenvolvimento produtivo, o que o leva a concluir que o capital vem a ser forma social obsoleta da riqueza. Parece haver ambiguidade na teoria de Gorz quando ele considera, por um lado, que o capital não é uma forma que se transmuta, em sua natureza de forma social, concomitantemente às forças produtivas e transformações nos modos concretos do trabalho: ele se mantém como capital, ainda que artificialmente. Mas, por outro, sustenta que o valor se torna qualitativo, e portanto nega sua definição. Põe-se a necessidade, vale repetir, de um exame da categoria de capital. Em Fausto esta ambiguidade específica não existe porque, quando o valor vem a ser qualitativo, também a substância do capital e sua relação com o trabalho se transforma.

\section{4. O problema da medida do trabalho em Eleutério Prado}

Outro pesquisador que aborda este conjunto de temas é Eleutério Prado, em seu Desmedida do valor $^{18}$. Neste livro, o autor debate com A. Negri e M. Hardt ao desenvolver uma crítica a Império ${ }^{19}$, e com $O$ Imaterial de A. Gorz, além de assumir parcialmente as proposições elaboradas por Fausto no texto comentado acima. Examinamos alguns pontos da posição do autor expressa nos capítulos "Trabalho imaterial e fetichismo" e "Crítica à economia política do imaterial".

De acordo com Prado, a história recente tem sido palco de mudanças significativas na forma concreta da produção, iniciadas após a segunda grande guerra e que se põem com especial intensidade nas duas últimas décadas do século XX. Essas mudanças caracterizam o momento atual como pós-grande indústria, termo que compartilha com Ruy Fausto. A pós-grande indústria distingue-se da grande indústria

\footnotetext{
${ }^{18}$ PRADO, Eleutério. Desmedida do valor: crítica da pós-grande indústria. São Paulo: Xamã, 2005. Doravante, Desmedida, seguido do número da página.

${ }^{19}$ HARDT, M.; NEGRI, A. Império. Rio de janeiro: Record, 2001.
} 
pelas formas concretas do trabalho produtivo, que se tornam cada vez mais intelectuais, mas também porque estas formas, de acordo com Prado, relacionam-se de outro modo com a forma social de trabalho abstrato e com a forma de valor do produto do trabalho. Embora o texto de Prado abranja uma ampla gama de temas, restrinjo-me a destacar o caráter qualitativo que o valor assume quando o trabalho produtivo vem a ser intelectual. No que se refere a essa questão, o texto apresenta o seguinte problema: ao mesmo tempo em que o autor critica Negri e Hardt por tomarem o caráter concreto do trabalho como fonte de valor, e por isso apresentarem uma teoria que não escapa ao fetichismo (ao incorporar à natureza da atividade uma determinação que pertence às relações sociais de produção), ele afirma que, com o advento do trabalho intelectual como forma privilegiada do trabalho produtivo, o valor "passa a depender também de diferenciais de qualidade", ou seja, passa a ser constituído também pelo caráter qualitativo, e portanto concreto, da atividade.

(...) toda riqueza no modo de produção capitalista, ou seja, toda mercadoria, tem de poder ser medida pelo tempo de trabalho socialmente necessário à sua produção. Entretanto, se uma parte importante do trabalho social torna-se espiritual, intelectual, moral ou artístico, do processo de trabalho e do processo de produção resultam valores de uso que não podem ser quantificados, para efeito de troca, apenas com base no tempo de trabalho. Em consequência, os valores de troca passarão a depender também dos diferenciais de qualidade postos pelo trabalho durante o tempo de trabalho (Prado, Desmedida, 51-2).

Para o autor, o valor muda de natureza em uma fase avançada do capitalismo. Essa nova forma espiritual do trabalho produtivo é distinguida do antigo trabalho fabril e caracterizada como atividade que repõe o momento subjetivo como determinante, analogamente ao trabalho artesanal da manufatura. Prado a descreve:

Já na pós-grande indústria, o domínio dos processos naturais e artificiais que a ciência possibilita estão agora incorporados em algoritmos ou programas de computador, que são instalados dentro ou ao lado do corpo das máquinas. Assim, as máquinas e os sistemas constituídos por máquinas tornam-se inteligentes. Em consequência da própria natureza do processo produtivo, que vai se livrando pouco a pouco dos trabalhadores, o trabalho que o vigia - sem com ele se imiscuir volta a ganhar um momento subjetivo. Pois passa a pôr em prática durante o tempo de trabalho aqueles conhecimentos que são adquiridos fora do tempo de trabalho (Prado, Desmedida, 63).

Dos autores que comentamos acima, reaparece na visão de Prado a caracterização do trabalho intelectual como atividade em que o caráter "subjetivo" é determinante, em oposição ao caráter "objetivo" do trabalho na grande indústria, em que um princípio 
objetivo se apresenta na maquinaria e demanda trabalho "mecânico", centralmente manual. De Fausto, reaparece a noção de máquinas “inteligentes”, que naquele autor se manifesta na concepção de que as máquinas se tornam "uma espécie de força de trabalho", e portanto são dotadas de algum tipo de subjetividade.

Estas determinações concretas trazem mudanças na relação do trabalho com a criação de valor. O tema do trabalho complexo aparece em Eleutério Prado como um dos modos de apresentar esta transformação histórica na natureza do valor. O autor afirma:

Para Marx, o trabalho simples coexiste com o complexo na economia capitalista em toda sua duração histórica. (...) Vale notar, então, em primeiro lugar, que o trabalho complexo na formulação original de $O$ Capital não representa problema algum para o desenvolvimento dos primeiros passos da teoria do valor, pois, de acordo com esse autor, ele "vale apenas como trabalho simples potenciado ou, antes, multiplicado" (MARX, 1983a, p. 51-2). O trabalho complexo, segundo ele, é constantemente reduzido a trabalho simples pelo processo social, em proporções determinadas, e isto ocorre sem que os produtores se apercebam, parecendo-lhes que são dadas pela tradição. Nos primeiros capítulos de $O$ Capital, que são os mais abstratos de toda a obra, essa redução é pensada sob a suposição de que tanto o trabalho simples quanto o trabalho complexo possam ser medidos pelo tempo de um modo economicamente significativo (Prado, Desmedida, 75).

No entanto, as recentes transformações que põem o trabalho intelectual no centro da atividade produtiva furtam ao trabalho complexo sua capacidade de valer como trabalho simples potenciado, isto é, fazem com que este modo do trabalho, ainda que subordinado ao capital, não possa mais ser resolvido em uma medida quantitativa: “(...) o trabalho complexo - que agora é técnico-científico -, enquanto gerador de valores de uso, não pode mais ser medido apenas pelo tempo de um modo economicamente significativo" (Prado, Desmedida, 85). Ao caráter intelectual do trabalho e ao aumento de sua importância na produção deve-se, portanto, a impossibilidade de este trabalho ser medido pelo tempo e reduzido a trabalho abstrato: “Ora, - afirma o autor - é verdade que essa mutação do trabalho concreto, de predominantemente manual para predominantemente mental, torna-o especialmente imensurável enquanto tal. Sobre isto não há dúvida" (Prado, Desmedida, 87). Isto é, o valor passa a ter um componente qualitativo porque o trabalho concreto, ao se tornar científico, perde a capacidade de reduzir-se a mera quantidade de trabalho humano. O problema da medida redunda, portanto, na questão da substância do valor: ao perderem sua comensurabilidade, os 
múltiplos trabalhos perdem também a natureza comum que mantêm depois que foram abstraídas suas particularidades úteis. Esta abstração não se realiza mais na realidade. Assim, para o autor, com o advento da pós-grande indústria, a história dissocia a categoria de valor da de tempo de trabalho socialmente necessário:

Ora, a pós-grande indústria emerge quando a produção capitalista passa a ser mais e mais dependente de um princípio conceitual, ou seja, vem a ser caracterizada por crescente intervenção de conhecimentos durante o tempo de trabalho. Este, então, deixa novamente - ainda que por razão diferente daquela vigente na manufatura - de ser algo que pode ser reduzido pelo processo social cego a tempo de trabalho socialmente necessário. Agora, aquilo que é socialmente necessário enquanto trabalho contém, também, elementos qualitativos (Prado, Desmedida, 85).

Por um lado, Prado destaca a importância de considerar a mercadoria e o valor como formas das relações sociais, e por isso independentes em suas definições do caráter concreto de seu suporte, das “(...) coisas que, nas palavras de Marx, não são mais do que depositários materiais das determinações formais" (Prado, Desmedida, 54). O autor critica a noção de trabalho intelectual de Hardt e Negri porque estes explicam as transformações econômicas ou formais do capitalismo pela determinação concreta do trabalho: “(...) esses dois autores centram a caracterização do modo de produção capitalista recente no caráter concreto do trabalho" (Prado, Desmedida, 54). Por outro lado, aceita que o valor criado pelos trabalhos intelectuais tem um caráter concreto, porque qualitativo. Encontramos a mesma duplicidade de posição na questão do serviço. “As noções de bem e serviço classificam os valores de uso, mas não contribuem para a compreensão do capitalismo como tal. Como se sabe, para tanto é preciso se ater à noção de mercadoria”, que é “(...) apenas uma forma do produto do trabalho” (Prado, Desmedida, 51). Contudo, "Não se deve esquecer, entretanto, de que a matéria adequada para o trabalho cristaliza-se numa coisa que tem existência independente da própria laboração" (Prado, Desmedida, 54-5). Assim, nem o serviço, por seu modo concreto, é plenamente adequado à forma mercadoria, nem o trabalho intelectual, também por seu caráter concreto, é adequado à forma social abstrata do trabalho.

Prado resolve esta duplicidade na relação entre modo concreto e forma social na afirmação de que o valor é, em Marx, "medida que tende constantemente à desmedida e que pode ser negado dialeticamente na história" (Prado, Desmedida, 55). Explica esta alteração na natureza do valor por meio da mudança histórica no modo da produção 
concreta e concorda com Fausto quanto à interpretação das passagens destacadas dos Grundrisse, afirmando que esta mudança na forma social originada do desenvolvimento produtivo foi prevista por Marx. Essa alteração na natureza social do trabalho e do valor não é razão, de acordo com Prado,

(...) para modificar a teoria do valor de Marx, mesmo porque essa teoria prevê a própria vicissitude do valor numa fase avançada de desenvolvimento do capitalismo, quando o trabalho, de modo importante, passa a produzir valores de uso espirituais, quando os trabalhos concretos não podem mais ser reduzidos simplesmente a trabalho abstrato e quando os serviços assumem amplamente a forma de mercadoria. Isto requer, entretanto, uma aplicação de textos dos Grundrisse de 1857-1858 (Prado, Desmedida, 52).

Para o autor, do mesmo modo que para Gorz e Fausto, as atuais formas concretas do trabalho impedem que este seja reduzido a simples trabalho abstrato, de modo que a teoria do valor de Marx é válida hoje apenas porque prevê alterações no conceito de valor oriundos do próprio desenvolvimento histórico. Estas mudanças não são secundárias, mas afetam a natureza do valor, uma vez que este, quando constituído por trabalhos que têm conteúdo espiritual, ganha um caráter qualitativo, e portanto concreto. A argumentação segue parcialmente a de Fausto ${ }^{20}$ : "Acompanhando Marx, pode-se dizer que o capital põe o tempo de trabalho como único elemento determinante da produção, mas, ao fazê-lo, devido ao seu próprio desenvolvimento, faz com que esse tempo tenda a desaparecer como determinante exclusivo da produção" (Prado, Desmedida, 82$)^{21}$.

\footnotetext{
${ }^{20}$ Mas não a leva às últimas consequências presentes no texto de Fausto, como a proposição de que a riqueza capitalista pós-industrial teria como fonte o não-trabalho realizado no tempo livre, tampouco assume que os meios objetivos de produção venham a criar valor.

${ }^{21}$ As passagens citadas por Prado são as que se seguem:

"[O tempo de trabalho] é reduzido tanto quantitativamente a menores proporções quanto qualitativamente [...] a um momento indispensável, mas subordinado, quando comparado com o trabalho científico geral, com a aplicação tecnológica das ciências naturais, de um lado, e com a força produtiva social que surge da combinação social na produção total, de outro. [...] O capital trabalha na direção de sua própria destruição como uma forma dominante de produção (MARX, 1973, p. 1970)".

"A troca de trabalho vivo por trabalho objetivado, ou seja, a posição do trabalho social na forma da contradição entre o capital e o trabalho assalariado, é o último desenvolvimento da relação de valor e da produção baseada no valor. O pressuposto dessa produção é, e segue sendo, a massa de tempo de trabalho imediato, a quantidade de trabalho empregada como fator determinante na produção de riqueza. Todavia, à medida que a grande indústria se desenvolve, a criação de riqueza real torna-se menos dependente do tempo de trabalho e da quantidade de trabalho empregada, passando a depender mais da capacidade conjunta dos agentes postos em ação durante o tempo de trabalho, capacidade cuja eficácia (powerful effectiveness) não mantém nenhuma relação com o tempo de trabalho imediato que sua produção exige; depende do estado geral da ciência e do progresso técnico, ou da aplicação da ciência à produção.

[...] A riqueza efetiva manifesta-se mais - e isto a grande indústria revela - na enorme desproporção entre o tempo de trabalho empregado e seu produto, assim como na desproporção qualitativa entre o trabalho, reduzido a pura abstração, e o vigor do processo produtivo que ele vigia. [...] Nessa transformação, o que
} 
De acordo com a interpretação de Prado, Marx descreve nos Grundrisse a fase da pós-grande indústria, em que a valorização deixa de ser determinada pelo tempo de trabalho: “(...) a geração de valor deixa de depender inteiramente do tempo de trabalho, passando a se sujeitar também ao emprego de recursos sociais de produção que o ato de trabalhar mobiliza durante o tempo de trabalho" (Prado, Desmedida, 83, itálicos meus). Como Fausto, o autor vê no conceito de valor a mesma transformação que acontece na natureza do trabalho concreto criador da riqueza efetiva como resultado da ampliação das forças produtivas: se o trabalho se torna primordialmente intelectual, se a quantidade de trabalho imediato deixa de ser a força produtiva principal da produção social, então também a substância do valor vem a constituir-se, ao menos em parte, das próprias qualidades intelectuais do trabalho. De uma transformação nas forças produtivas e na atividade concreta, o autor faz decorrer uma transformação na natureza do valor:

(...) na pós-grande indústria, como já se disse, o tempo de trabalho direto empregado na produção perde importância na produção da riqueza. Por um lado, o tempo de trabalho concreto gasto na produção perde expressão como fonte da força produtiva. Por outro, em consequência, o tempo de trabalho em si mesmo deixa de ser a fonte exclusiva de valor, de tal modo que o valor deixa de ser estritamente um quantum de trabalho socialmente necessário medido pelo tempo (Prado, Desmedida, 89).

Como em Fausto, parece haver aqui uma identificação entre os fatores determinantes da produção material e da valorização, uma identidade de suas medidas. Em Marx, como procuro defender adiante, a quantidade de trabalho imediato deixa de ser determinante da produção material, mas continua sendo a substância do valor, e precisamente aí reside a contradição do capitalismo desenvolvido.

Prado não compartilha, contudo, da proposição de Fausto segundo a qual as próprias máquinas, por se tornarem suportes da ciência, passam a compor também a

aparece como pilares fundamentais da produção e da riqueza não são nem o trabalho imediato executado pelo homem nem o tempo em que este trabalha, mas sim sua força produtiva geral, sua compreensão da natureza e seu domínio sobre ela graças à sua existência como corpo social; em uma palavra, o desenvolvimento do indivíduo social” (MARX, 1973, p. 704-5)" (Prado, Desmedida, 82-3).

A pesquisa procurará mostrar que, nestas passagens, Marx se refere à produção efetiva, concreta, e não à criação de valor: "O pressuposto dessa produção [baseada no valor] é, e segue sendo, a massa de tempo de trabalho imediato, a quantidade de trabalho empregada como fator determinante da produção de riqueza", enquanto a riqueza real ou efetiva, isto é, concreta, deixa de depender deste tempo. Aí reside a contradição: o trabalho que se mantém "reduzido a pura abstração" e a produção real, efetiva, concreta que se torna "menos dependente do tempo de trabalho"; a contradição não reside na transformação da natureza do valor. 
criação de valor. Esta proposição torna indistintas a produção concreta e a produção de valor, bem como torna irracional a noção de produtividade do trabalho (dado que produzir não é mais determinação exclusiva da atividade), invalida as diferenças entre trabalho vivo e trabalho morto (como Fausto defende) e entre capital constante e capital variável, uma vez que a atividade humana não é mais a única fonte de valor, mas as condições de produção adquirem, como suportes da ciência, a capacidade de criar valor. Em Prado, a única fonte de valor é a atividade produtiva, e no que diz respeito à dimensão formal, é exclusividade do capital variável: “(...) não se trata de dizer que a ciência e a tecnologia em si mesmas, independentemente do trabalho, são agora as produtoras do valor. Quem produz valor é ainda o trabalho, (...) a ciência e a tecnologia tornam-se produtoras de valor por meio do trabalho" (Prado, Desmedida, 89). Mas não se pode dizer o mesmo dos meios de produção na grande indústria?

Para o autor, com a pós-grande indústria, a categoria de produtividade do trabalho ganha novas determinações. Deixa de ser a relação entre a quantidade de trabalho e a quantidade de produto e passa a ser definida qualitativamente:

Assim, para considerar um caso limite, não se pode medir a produtividade de uma equipe de engenheiros de informática contando o número de programas de computador que ela faz e põe em operação num período, por exemplo, de um ano. A produtividade dessa equipe mostra-se como capacidade de produzir bons programas num certo período de tempo. Ademais, note-se que nesse caso o produto não é homogêneo e que o resultado alcançado depende pouco do tempo de trabalho - sua eficácia como produto depende da competência científica e tecnológica da equipe de engenheiros, assim como do desenvolvimento da ciência e da computação (Prado, Desmedida, 84).

Nesta passagem, Prado apresenta uma questão de grande importância que diz respeito à diferença entre a produção direta de mercadorias e a criação de inovações, ou ainda, entre o desenvolvimento de novos produtos e sua reprodução. É preciso investigar se o conceito de produtividade do trabalho se aplica à criação de novos métodos produtivos ou ao desenvolvimento da própria ciência, isto é, à criação de forças produtivas novas que concorrem para o aumento da produtividade do trabalho que gera mercadorias. Aos setores que desenvolvem novas forças produtivas, hoje subsumidos ao capital, parece se referir a seguinte afirmação do autor:

Ora, se na grande indústria observa-se um ardor para reduzir a magnitude do tempo de trabalho (dados certos níveis padronizados de qualidade), na pós-grande indústria esse ardor se arrefece e surge uma preocupação maior com o melhoramento da qualidade do tempo de trabalho (dadas 
certas disponibilidades de tempo). E, assim, o trabalho de produção aproxima-se do trabalho artístico e do trabalho intelectual (Prado, Desmedida, 84).

No cômputo deste problema, é preciso levar em conta que o controle do tempo e imposição de alta intensidade de trabalho na grande indústria tem como função a redução máxima dos custos de produção. O capital não pode deixar de economizar em seus investimentos. Mas se, para Marx, toda economia se reduz em última instância a economia de tempo, como explicar a economia do capital pós-industrial em sua relação com o trabalho, se o capital, segundo o autor, não procura mais reduzir a magnitude do tempo de trabalho com o mesmo ardor? Na pergunta sobre o que viria a ser a economia, se não é mais economia de tempo, encontra-se também a questão sobre qual se teria tornado a substância da riqueza que ainda se denomina de capital. Se não é mais tempo de trabalho abstrato acumulado e posto para se multiplicar pela absorção de mais tempo de trabalho, o capital passaria a se confundir com a riqueza efetiva, concreta? Nesta concepção, ao pôr o trabalho intelectual no centro da produção e ampliar a importância dos serviços no conjunto dos valores de uso, o desenvolvimento histórico nega o valor. Não no sentido de que a produção deixa de ter o valor como produto, mas no sentido de que sua definição -ou conceito - é negada. O conteúdo do valor muda de natureza e vem a abarcar um componente qualitativo, concreto. $\mathrm{O}$ valor seria uma forma social que, sem deixar de ser valor, assume historicamente natureza oposta àquela que o define: medida quantitativa da riqueza e, como tal, produzida pelo trabalho abstrato. Mas então, se o valor se torna distinto de si mesmo e adota determinações próprias ao valor de uso - qualidade, caráter concreto - que é seu oposto, o que vem a defini-lo positivamente? O que vem a ser o valor? Como se distingue do valor de uso? Como se caracteriza agora o duplo caráter do trabalho?

Este conjunto de questões é especialmente relevante quando se observa que, ao contrário de estar se desagregando, o capital vem se tornando cada vez mais dominante, como o autor reconhece. Embora considere, com Fausto em sua interpretação de Marx e com Negri e Lazzaratto, que o trabalho intelectual foge à "subsunção material característica da grande indústria" (Prado, Desmedida, 63), na produção pós-industrial o capital amplia seu domínio e abrangência:

Em razão mesmo dessa mudança do modo de trabalhar, o capital tem de passar a comandar não apenas o tempo de trabalho, mas também o tempo de não-trabalho, que se torna menos livre. (...) Agora, ele [o capital] tem de passar a controlar o trabalhador não apenas como trabalhador e 
consumidor, mas também como político, religioso, profissional, etc., de um modo que tende a ser total (Prado, Desmedida, 63).

Para Prado, não apenas o tempo de vida do trabalhador individual, para além do tempo formal de trabalho, é subsumido pelo capital, que amplia seu controle, como também a produção científica e intelectual vem a ser realizada sob o modo capitalista. Em nota, o autor completa:

\footnotetext{
Em particular, o capital tem de passar a dominar e a controlar a produção dos conhecimentos científicos e tecnológicos, seja por meio da criação de departamentos de pesquisa nas próprias empresas, seja criando empresas especializadas de pesquisa, seja subordinando de fora as universidades e centros de investigação, formalmente independentes, por meio do controle das verbas de pesquisa. Assim, também as atividades criadoras de subjetividade e geradoras de cultura são incorporadas à produção capitalista (Prado, Desmedida, 63, nota 8).
}

Nesta consideração, Prado se aproxima de Gorz, que destaca a crescente subsunção tanto do indivíduo quanto das múltiplas esferas da produção da vida ao capital - com destaque à produção científica - como determinações centrais do capitalismo cognitivo; e se afasta de Fausto, para quem a ciência é produzida no tempo livre e como atividade livre e a riqueza, sob a forma de capital, vem a ser produzida pelo não-trabalho.

Em síntese, o capital controla o trabalhador, o conhecimento passa a ser produzido dentro das empresas, mas ainda assim ele é incapaz de subsumir tal trabalho, devido a suas determinações concretas. A necessidade de o capital expandir seu domínio sobre a atividade individual ao mesmo tempo em que o valor adquire um componente qualitativo é um processo contraditório. O valor, se não é negado, torna-se desmedido. O autor escreve: "De qualquer modo, se o valor deixa de ser um quantum de tempo de trabalho abstrato, é porque sofreu um abalo significativo" (Prado, Desmedida, 88). Esta desmedida do valor, oriunda das transformações no trabalho concreto - que se torna "criativo, inteligente, cognoscitivo" - criam um problema para a medida de uma riqueza que, sendo capital, precisa ser mensurada: "O valor desmedido continua dependente de um processo social de redução - mas este não é mais uma operação puramente quantitativa" (Prado, Desmedida, 89). Como o capital se define como riqueza quantitativa, Prado compartilha com Gorz a conclusão de que a atual fase do capitalismo é a crise do capitalismo, constituindo-se em um momento transitório entre o apogeu capitalista - a grande indústria - e o socialismo ou a organização social que supera o antagonismo de classe (embora esta transição não possa ser, para o autor, 
espontânea). Esta fase crítica se caracteriza pela contradição entre a atual forma intelectual do trabalho e a forma social do capital: "A economia baseada no trabalho conceitual e no conhecimento científico e tecnológico avançado é incongruente com a relação social do capital" (Prado, Desmedida, 94). Esta incongruência tem como centro, como se viu, a desagregação da substância do valor, que se deve à impossibilidade de medir pelo tempo, ou abstrair as qualidades e isolar a quantidade, dos atuais trabalhos complexos.

\section{Trabalho complexo como objeção à teoria do valor-trabalho: o velho debate}

Os textos examinados acima abordam uma diversidade de temas e põem diversas questões para a atual configuração da produção capitalista após a informatização de processos produtivos e da inclusão da ciência como um ramo capitalista. Algumas dessas questões serão abordadas ao longo do trabalho. Aqui, tomo apenas a transformação que os autores apontam na substância do valor. As teses dos pesquisadores em foco têm em comum a concepção de que, quando o trabalho produtivo assume a forma de atividade que envolve o conhecimento, e são por isso exigidas diversas faculdades subjetivas criativas, torna-se impassível de redução a trabalho abstrato. O valor se transforma, em Fausto e Prado, de medida meramente quantitativa em medida que abrange componentes, aspectos ou um caráter também qualitativo. A produção capitalista entra numa fase em que o valor - forma abstrata do trabalho objetivado - já não é sua substância. Para Fausto, a valorização se dá pelo caráter concreto da atividade intelectual e pela própria força produtiva objetivada que é a ciência. Em Gorz, que sustenta a definição de valor de Marx, a sociedade do conhecimento que vem se constituindo não é compatível com a valorização. Mas em todos os autores, a atividade intelectual, cognitiva ou criativa não pode assumir a forma de trabalho abstrato, porque não se reduz a trabalho social. Prado destaca que essas mudanças na forma social da produção se põem de fato apenas quando parte importante do trabalho concreto se torna intelectual e quando parte significativa dos valores de uso se tornam serviços.

Para os autores em questão, o que torna o trabalho complexo incongruente com a forma abstrata de trabalho é a impossibilidade de medir, como quantidade de trabalho, o dispêndio de força de trabalho individual nestas atividades intelectuais e criativas, e por 
isso, seu produto não pode reduzir-se a mera quantidade de trabalho social. Se elas vêm a ser o centro do trabalho produtivo (Eleutério Prado pondera que isto ainda não se deu, o que não altera a questão conceitual neste nível), o conjunto do modo de produção concreto se torna incongruente com a produção de valor porque a atividade produtiva não pode mais ser reduzida a trabalho abstrato. Estas atividades teriam, então, um componente qualitativo inalienável, do qual não se pode abstrair. Deste modo, estaria ausente nesses produtos a substância comum que permite igualar todos os trabalhos concretos, sem exceção, ou resolvê-los em trabalho social, como Marx propõe. Na atual fase do capitalismo, a abstração deixaria de ser real, e com isso também o duplo caráter do trabalho que caracteriza esta forma social.

Essa pesquisa se opõe à noção de valor qualitativo. Primeiro, este não pode ser definido positivamente senão como um valor de uso, portanto um não-valor: algo que não pode ser abstraído de qualidades singulares concretas não pode circular de modo autônomo ou independente do corpo do valor de uso, ou seja, não pode percorrer as metamorfoses formais do valor, ao qual é imanente o caráter abstrato da riqueza que assume esta forma.

A concepção de um valor qualitativo pode significar, então, que o produto do trabalho intelectual, imaterial, ou complexo é simples valor de uso, como parece defender André Gorz, e só permite a ampliação do capital nele investido na forma de renda, analogamente à renda da terra Constituiria, assim, um ramo improdutivo da produção capitalista, cuja remuneração teria de fluir dos ramos produtivos, como parte da mais-valia ali gerada. O produto científico funcionaria como um valor de uso necessário aos demais capitais produtivos, que pagariam pelo acesso a este produto - os royalties devidos aos proprietários das patentes - como compram os elementos do capital constante. A produção intelectual seria, então, um ramo da produção que 1) prova ser necessário, parte da divisão social do trabalho, constituindo-se como um processo parcial da criação das mercadorias; 2) cria um valor de uso produzido pelo trabalho, sob o modo capitalista de produção; mas que, 3) não pode assumir a forma de riqueza abstrata. Deste modo, a única razão para que esta forma concreta do trabalho não possa assumir a forma de valor - como Marx o define - é este caráter concreto mesmo: ser complexo, intelectual, ter como produto imediato um valor de uso imaterial. 
De outro ângulo, a teoria de que o valor se tornou qualitativo pode se basear ainda no pressuposto de que o conjunto, ou parte majoritária do trabalho social se torne complexo e intelectual. É certo que essa não é a realidade, mas, assumido que isso ocorra, põe-se o tema do conceito de trabalho simples e de trabalho médio. A qualificação média é uma determinante central do trabalho médio. Se o trabalho simples se identifica com o trabalho médio, então o trabalho intelectual, ao se tornar a forma geral do trabalho, se transforma em trabalho simples. Basta pensar que, hoje, saber ler e escrever é qualificação exigida na maioria das funções do trabalho assalariado, e nos trabalhos menos qualificados do comércio, por exemplo, é requerido saber lidar com programas básicos de computador. De modo que a qualificação média se transforma historicamente e, com ela, o caráter concreto dos trabalhos simples. Na concepção dos autores abordados, há uma imbricação conceitual entre o trabalho abstrato - forma social - com o trabalho manual, mecânico, repetitivo, passível de decomposição, isto é, com determinada forma do trabalho concreto. O modo concreto do trabalho simples do operário à máquina se coloca, no discurso dos pesquisadores examinados, como aspecto necessário da forma social abstrata do trabalho.

Esta compreensão restritiva do trabalho abstrato, do valor e sua medida não é, contudo, nova. Se os autores em foco neste capítulo examinam o tema da medida do valor pelo trabalho a partir das transformações produtivas recentes, outros autores lançam mão de argumentos semelhantes ao debaterem os textos de Marx. Neste debate, o trabalho complexo serviu como objeção contra a teoria do valor de Marx, e esta objeção teve como argumento central, em mais de um autor, a alegação de que os trabalhos que demandam qualificações intelectuais (técnicos, artísticos etc.) não podiam ser reduzidos a mera quantidade de trabalho humano. Outros autores marxistas, além do próprio Marx, já se opuseram a este argumento da irredutibilidade dos trabalhos intelectuais a trabalho abstrato, argumentando que o que caracteriza esta forma social do trabalho é precisamente sua capacidade de igualar atividades tão distintas como a da arquiteta e a do mineiro, ou a do trabalhador rural e a da cantora. E esta igualação se dá pelo valor, pela forma mercantil do intercâmbio de produtos dos diversos trabalhos, e não pela medida imediata de tempo. Esta antiga discussão pode lançar luz sobre este aspecto conceitual fundante da teoria de Marx: qual a natureza do trabalho abstrato, sob que determinações o trabalho é a medida do valor? Esta questão levará necessariamente ao exame do que é o trabalho, e sob quais circunstâncias históricas torna-se possível 
falar em trabalho humano em geral, que fundamenta a forma abstrata, tema central nesta pesquisa. O exame das objeções antigas à teoria do valor que lançam mão da categoria de trabalho complexo visa contribuir para a análise do tema do trabalho e de sua forma abstrata no interior dos textos de Marx.

Não estou com isso assumindo a posição, vale repetir, de que as atuais transformações nas formas concretas do trabalho não resultam em mudanças formais, ou seja, para a reprodução do capital. As teses examinadas neste capítulo não são restritas ao tema do trabalho abstrato: a ampliação da pesquisa científica, o desenvolvimento tecnológico que leva à automação do processo produtivo, a crescente presença do trabalho intelectual na produção põem questões que demandam o exame da reprodução

do capital de modo mais amplo. É precisamente para compreender como o advento das novas forças produtivas que ampliam a importância da ciência e do trabalho intelectual na produção material afeta esta reprodução que procurarei mostrar que esta mudança não reside em uma irredutibilidade das atividades intelectuais a trabalho abstrato, e que não é a categoria ou conceito de valor que se transforma.

Apresento essas velhas objeções em seguida. As respostas do velho Marx (a Bailey, por exemplo), as de Engels a Düring, a de Hilferding a Böhm-Bawerk, retomada por Rubin e Rosdolsky; as reflexões destes e outros autores, como Otto Bauer, tanto sobre a categoria de trabalho complexo como em resposta às transformações reais, lançam luz sobre a atual discussão sobre o trabalho intelectual na reprodução de valor. Estas serão expostas nos próximos capítulos, ao longo da pesquisa, no contexto da análise do pensamento do próprio Marx.

\section{1. O trabalho qualificado antes de Marx: a objeção de Samuel Bailey à teoria do valor-trabalho de David Ricardo}

Antes mesmo do desenvolvimento da elaboração de Marx, o tema do trabalho qualificado aparece na polêmica que Samuel Bailey trava contra a teoria do valortrabalho de David Ricardo. Esta passagem do debate econômico é interessante porque, em primeiro lugar, Marx sai em defesa de Ricardo e acaba por elucidar um aspecto importante de sua própria explicação sobre o trabalho complexo. Em segundo lugar porque, ao tematizar as diferentes qualidades de trabalho em sua capacidade desigual de criar valor, Bailey tem o intuito de formular uma objeção à teoria do valor-trabalho de Ricardo, semelhante à que Böhn-Bawerk e Cornelius Castoriadis elaboram ao lançar 
mão da categoria de trabalho complexo; mas, desta vez, a crítica é dirigida contra a teoria do valor de Marx. A finalidade desta objeção é desconstruir a possibilidade de medir o trabalho por sua quantidade e, por conseguinte, o valor pela quantidade de trabalho. A crítica intenta, com isso, opor-se ao trabalho como substância do valor. Eugen Dühring critica também a explicação marxiana acerca das diferentes qualidades do trabalho que cria valor - sua teoria do trabalho complexo - mas com finalidade diversa.

Bailey elabora diversas objeções à teoria do valor-trabalho de Ricardo em suas obras voltadas à economia política ${ }^{22}$. Marx critica Observations on certain disputes in political economy no terceiro volume de Teorias da mais-valia ${ }^{23}$. Observations... assume, de acordo com Marx, os mesmos fundamentos expressos na obra principal do autor contra Ricardo, A critical dissertation on nature, measures and causes of value, que, por sua vez, "Procura pôr abaixo o fundamento da doutrina - o valor" (TMV III, 1180). Bailey recusa o trabalho como substância do valor, e além disso, recusa qualquer medida imanente para a determinação do valor $^{24}$. Uma das objeções que Bailey desenvolve diz respeito às diferentes qualidades de trabalho. $\mathrm{O}$ autor afirma:

(...) não basta replicar, com Ricardo, que 'a avaliação em que se apresentam qualidades diferentes de trabalho logo se ajustam no mercado com suficiente precisão para todos os fins práticos'; ou, com Mill, que 'ao se avaliarem quantidades iguais de trabalho, serão levados em conta, por certo, graus diferentes de dificuldade e de habilidade'. Exemplos desta natureza destroem por completo a integridade da regra (BAILEY, Observations..., p. 210 da edição de 1821, apud MARX, TMV III, 1219).

Isso porque, para ele,

\footnotetext{
${ }^{22}$ Marx menciona A critical dissertation on the nature, measures and causes of value; chiefly in reference to the writings of Mr. Ricardo and his followers. By the author of Essays on the formation and publication of opinions. Londres, 1825; A letter to a political economist; occasioned by an article in the Westminster Review on the subject of value, Londres, 1826; e Observations on certain verbal disputes in political economy, Londres, 1821, publicado anonimamente no contexto de um caloroso debate teórico entre os defensores e opositores à teoria de Ricardo. O conjunto dos textos foi publicado sob o título do primeiro, mais conhecido, em 1967 (BAILEY, Samuel, A critical dissertation on the nature. Measures and causes of value. New York, Augustus M. Kelley, 1967).

${ }^{23}$ MARX, Karl. Teorias da mais-valia. História crítica do pensamento econômico - Vol. III. Tradução de Reginaldo Sant'Anna. São Paulo: Difel, 1980-1985. Doravante, TMV III.

${ }^{24}$ Em Marx, a medida imanente do valor é a unidade ou identidade que permite medi-lo, e portanto sua substância: “A 'causa' do valor é a substância do valor e por isso é deste a medida imanente” (TMV, III, p. 1216, p. 162). De acordo com Marx, Bailey tem uma concepção fetichista que se expressa de modo magistral nas passagens seguintes, citadas também no primeiro capítulo de $O$ Capital: "Riqueza é atributo do homem, valor é atributo das mercadorias. Um homem ou comunidade são ricos, uma pérola ou um diamante são valiosos" (Observations..., p. 165 da edição de 1821, citada por Marx em TMV, III, p. 1216, p. 162), ou ainda, "Valor é propriedade das coisas, riqueza é propriedade dos homens (Observations..., p. 16 da edição de 1821 citada por Marx em TMV, III, p. 1184, p. 126).
} 
Só há dois métodos possíveis de comparar uma quantidade de trabalho por outra; um consiste em compará-los pelo tempo despendido, e o outro, pelo resultado produzido. (...) O primeiro é aplicável a todas as espécies de trabalho; o segundo só pode ser usado para comparar trabalho empregado em artigos iguais. Por isso, na avaliação de duas espécies de trabalho, se o tempo não determina a relação entre as duas quantidades de trabalho, tem essa relação de ficar indeterminada e indeterminável (BAILEY, Observations..., p. 210 da edição de 1821, apud MARX, TMV III, 1219).

Se a única forma de comparar as quantidades de trabalho de duas espécies distintas de atividade é pelo tempo durante o qual cada uma delas é despendida, e, concomitantemente, o tempo efetivo de dispêndio individual de atividade não estabelece estas quantidades; ou seja, se são necessários ajustes no mercado ou se são levados em conta os graus distintos de habilidade, o tempo deixa de ser a medida da quantidade de trabalho. Assim, torna-se impossível estabelecer uma relação quantitativa entre trabalhos de qualidades distintas. Por essa razão, qual seja, a de que os trabalhos concretos diversos não apresentam medida quantitativa comum, não é possível fundar o valor dos produtos na quantidade de trabalho despendida em sua produção. Marx expõe esta objeção de Bailey como se segue:

\begin{abstract}
Sua última objeção: os valores das mercadorias não podem ser medidos pelo tempo de trabalho se o tempo de trabalho num ramo não é do mesmo nível do tempo de trabalho nos outros, de modo que a mercadoria em que se corporificam, por exemplo, 12 horas de um técnico tem o dobro do valor da mercadoria em que se materializam 12 horas de um trabalhador rural. Isso redunda nisso: uma jornada de trabalho simples (ein einfacher Arbeitstag), por exemplo, não é medida do valor se há outras jornadas de trabalho (Arbeitstage) que estão para as jornadas simples (days of simple labour) como jornadas complexas (composite days) ${ }^{25}$ (TMV III, 1218).
\end{abstract}

$\mathrm{Na}$ forma em que Marx expõe a objeção de Bailey, chamam atenção as expressões jornada simples e jornada complexa. Jornada é uma medida de tempo. Então, em Marx, não apenas o trabalho como atividade é simples ou complexo, mas também o tempo pelo qual é despendido é tempo simples ou composto. As expressões indicam então o simples e o complexo como determinações do caráter abstrato do trabalho. Marx continua: "Ricardo mostrou que esse fato não impede medir as mercadorias pelo tempo de trabalho se é dada a relação entre trabalho simples e trabalho complexo. É verdade que deixou de expor como essa relação se desenvolve e se determina" (TMV III, 1218).

\footnotetext{
${ }^{25}$ Esta frase, no original: "Ein einfacher Arbeitstag z. B. nicht Maß des Werts, wenn es andre Arbeitstage gibt, die sich als composite days to the days of simple labour verhalten" (MARX, K. Theorien über den Mehrwert, Dritter Teil, Marx-Engels Werke, Band 26.3. Berlin: Dietz Verlag, 1968, p. 164).
} 
Em sua objeção, Bailey concebe o tempo de trabalho que se impõe como medida do valor como o tempo individual imediato de trabalho, tempo passível de ser medido empiricamente. Não atenta para o fato de que este tempo é tempo social, e apenas dessa forma pode se explicar que tempos iguais de trabalho individual criem diferentes magnitudes de valor, ou, inversamente, diferentes durações de atividade individual criem montantes iguais de valor. Bailey não opõe, contudo, sua argumentação à teoria de Marx, mas à de Ricardo. Neste autor, a distinção entre trabalho individual e trabalho social não é posta, e por isso Marx afirma que ele "deixou de expor como essa relação [entre trabalho simples e trabalho complexo - VC] se desenvolve e se determina".

Uma explicação sobre as razões pelas quais a diferença de qualificação ou habilidade, bem como outras diferenças, como de intensidade do trabalho, se reduzem ao fim e ao cabo a uma diferença quantitativa não está presente em Ricardo. Ainda assim, em nenhum momento ele toma essas diferenças qualitativas entre as atividades produtivas por um problema ou contradição que afetem a medida do valor pelo tempo de trabalho. O autor dedica uma pequena seção no primeiro capítulo, "Sobre o valor", de sua obra principal ${ }^{26}$ ao tema, e baseia sua explicação na que Adam Smith desenvolvera, citando passagens deste último. Nesta seção, intitulada "Trabalhos de diferentes qualidades são remunerados diferentemente. Isto não é causa de variação no valor relativo das mercadorias", o autor afirma:

\begin{abstract}
Ao falar do trabalho, no entanto, como fundamento de todo valor, e da quantidade relativa de trabalho como determinante quase exclusivo ${ }^{27}$ do valor relativo das mercadorias, não se deve crer que eu negligencio as diferentes qualidades de trabalho, nem a dificuldade de comparar o trabalho de uma hora ou de um dia, numa atividade, com a mesma duração do trabalho, em outra. A valorização (estimation) das diferentes qualidades de trabalho se ajusta rapidamente no mercado, com suficiente precisão para todos os fins práticos, e depende muito da habilidade relativa do trabalhador e da intensidade do trabalho realizado. Uma vez constituída, esta escala fica sujeita a poucas variações. Se o trabalho de um dia de um joalheiro vale mais que o trabalho de um dia de um trabalhador comum, esta relação foi há muito tempo ajustada e colocada na devida posição na escala do valor (Ricardo, Princípios, 264).
\end{abstract}

\footnotetext{
${ }^{26}$ RICARDO, David. Princípios de economia política e tributação. Tradução de Rolf Kuntz. Trechos selecionados. São Paulo: Abril Cultural. Coleção Os pensadores, volume Adam Smith, Ricardo. $2^{\mathrm{a}}$ edição. 1979. Doravante Princípios, seguido do número da página.

${ }^{27} \mathrm{Na}$ primeira seção voltada à definição de valor, Ricardo afirma: "Possuindo utilidade, as mercadorias derivam seu valor de troca de duas fontes: de sua escassez e da quantidade de trabalho exigida para obtêlas" (Princípios, 259). A primeira fonte diz respeito às mercadorias que não podem ser reproduzidas pelo trabalho social, e é por isso secundária. Ademais, expressa a identificação de Ricardo entre valor e preço.
} 
Há, pois, para Ricardo, uma escala de valor em que as atividades de qualidades distintas ocupam diferentes posições. Ou seja, a realização de cada uma delas por dado intervalo de tempo cria magnitudes de valor diferentes de acordo com uma escala. Esta, embora se determine a partir das diferenças de habilidade e intensidade do trabalho ${ }^{28}$, dispõe as múltiplas qualidades de atividades de modo quantitativo. Na passagem transcrita acima, Ricardo insere uma nota em que cita um trecho da explicação de Adam Smith, onde se lê: "Pode haver mais trabalho numa hora de atividade penosa que em duas horas de uma fácil ocupação, ou numa hora de aplicação a uma especialidade que se leva dez anos de esforço para aprender, do que num mês de trabalho numa atividade comum e simples" 29 . Há, pois, uma escala quantitativa referente à capacidade que diferentes trabalhos apresentam de criar valor, isto é, as diversas qualidades de atividade resolvemse em diferentes quantidades por sua capacidade de produzir valor. Determinado intervalo de tempo cria valor maior ou menor, conforme seja preenchido com atividade de um ou outro nível de intensidade, dificuldade ou qualificação. E, ainda assim, é o tempo de trabalho que determina o valor. As atividades qualitativamente distintas estão umas para outras como proporções. Para Ricardo, importa destacar que estas proporções, ou os graus que as diferentes atividades ocupam na escala do valor, são dados no mercado, tornando desnecessário investigar qual grau cada atividade ocupa e qual é a magnitude de valor que cada uma cria em dado intervalo de tempo. As diferenças quantitativas entre as atividades por sua capacidade de criar valor aparecem apenas na proporção efetiva da troca entre seus produtos. Nem toda diferença qualitativa expressa uma diferença na quantidade: Ricardo coloca no grau mais baixo da escala a atividade do "trabalhador comum", que abarca variadas espécies de trabalho. O que mantém a lei do valor como tempo de trabalho é o fato de que a qualidade manifesta variações nas atividades quanto ao "esforço", no termo de Smith citado por Ricardo, de modo que uma atividade exige, em mesmo tempo, "mais trabalho" que outra. Quanto à qualidade comum necessária à comparação das diversas atividades, Ricardo afirma que todas as espécies são abarcadas pelo "trabalho humano". O autor escreve:

Como a investigação para a qual eu quero dirigir a atenção do leitor se refere ao efeito das variações no valor relativo das mercadorias, e não no seu valor absoluto, será pouco importante

\footnotetext{
${ }^{28}$ Ricardo menciona também o tempo de aprendizado entre essas determinações, conforme citação seguinte.

${ }^{29}$ SMITH. A Riqueza das nações, livro I, cap. 10, apud Ricardo, Princípios, 264.
} 
examinar o grau comparativo de valoração das diferentes espécies de trabalho humano. Podemos concluir, com justiça, que, qualquer que tenha sido a desigualdade original entre eles, qualquer que tenha sido o engenho, a habilidade ou o tempo necessário para adquirir destreza num tipo de trabalho manual mais do que em outro, tal desigualdade se mantém aproximadamente a mesma de uma para outra geração; ou, ao menos, a variação é muito pequena de um ano para outro, e, portanto, pode afetar muito pouco, em curto prazo, o valor relativo das mercadorias (Ricardo, Princípios, 265).

Mais ocupado com as relações de troca efetivas, Ricardo destaca que as alterações no "grau comparativo de valoração das diferentes espécies de trabalho humano", isto é, na proporção entre as atividades por seu poder de criar valor, não são significativas em curto prazo, e por isso afetam muito pouco "o valor relativo das mercadorias". Estão aqui referidos tanto o valor "do trabalho" quanto do produto que este cria: independentemente das variações que apresenta no decorrer do tempo, a "valoração das diferentes espécies de trabalho humano" afeta "o valor relativo das mercadorias", de modo que a diferença de valor "do trabalho" - de remuneração do trabalhador reaparece na mercadoria que este produz.

Ademais, como Ricardo toma o valor das mercadorias como idêntico ao seu valor de troca - expresso nas demais mercadorias - ou ao seu preço, as mudanças nas proporções de valor entre os diversos trabalhos são visíveis imediatamente nas trocas efetivas de seus produtos:

\footnotetext{
Se um pedaço de pano valer agora duas peças de linho, e se, dentro de dez anos, o valor ordinário de um pedaço de pano alcançar quatro peças de linho, poderemos concluir, com segurança, que ou será necessário maior trabalho para fazer o pano, ou menor para fazer o linho, ou ainda que ambas as causas influíram (Ricardo, Princípios, 265).
}

Nesta passagem, fica claro que, em primeiro lugar, as mudanças na proporção da troca efetiva a longo prazo explicitam imediatamente alterações no valor, ou quantidade de trabalho necessário para a criação das mercadorias em questão, como dissemos. Em segundo lugar, que as variações relativas ao "engenho, a habilidade ou o tempo necessário para adquirir destreza num tipo de trabalho manual mais do que em outro" significam mudanças na produtividade do trabalho. Produtividade do trabalho é a relação quantitativa entre o trabalho e seu produto. Se para dada função do trabalho o grau de habilidade necessário diminui, isto implica que, nesta função específica, o trabalho amplia sua produtividade, isto é, vem a ser necessário dispender menos trabalho para produzir determinada quantidade de produto. Ou seja, engenho, 
habilidade, tempo de aprendizado, que se manifestam na atividade como qualidades, reduzem-se a quantidade de trabalho humano.

O mesmo se conclui da comparação entre habilidade e intensidade. Esta última determinação, o grau de tensão da atividade, é claramente quantitativo, uma vez que a mesma atividade pode ser realizada em maior ou menor tempo, dependendo do ritmo em que se trabalha manualmente, do ritmo da máquina, do número de máquinas sob responsabilidade do trabalhador. A atividade mais intensa comprime o tempo, de modo que, por exemplo, levam-se apenas duas horas para realizar o que normalmente se faz em três. O mesmo não se pode dizer da habilidade e da qualificação, ou seja, sua resolução em quantidade não é explícita porque não pode ser explicada apenas a partir do trabalho individual. Há que ser levada em conta a atividade individual como parte do trabalho social. Mas, em Ricardo, como em Smith e também em Marx, é o que se passa. Embora afirme que diferentes qualidades de trabalho pertencem a graus distintos em uma escala quantitativa, e por essa razão podem criar, em mesmo tempo, quantidades desiguais de valor, Ricardo não explica como este salto da qualidade para a quantidade se dá, não desenvolve o que o justifica. Adam Smith, de cuja proposição a respeito das diferenças qualitativas do trabalho Ricardo se apropria, explica esta transição da qualidade para a quantidade, que justifica a lei do valor, por meio de uma comparação com o capital. Smith escreve:

\footnotetext{
Quando se constrói uma máquina cara, espera-se que a quantidade extraordinária de trabalho por ela executado antes de ser posta fora de serviço reponha o capital empenhado para construí-la com, pelo menos, os respectivos lucros normais. Um homem especializado (educated) a custa de muito tempo e trabalho, em qualquer tipo de ocupação que exija destreza e habilidade extraordinárias, pode ser comparado a uma dessas dispendiosas máquinas. Espera-se que o trabalho para o qual se prepara o recompense, para além dos salários do simples trabalho, de todo o custo de sua preparação (education) com, pelo menos, os lucros normais de um capital de igual valor. É necessário que se garanta essa recompensa dentro de um prazo razoável, levando em conta a duração muito incerta da vida, tal como se considera a mais certa duração de uma máquina. É sobre esse princípio que se funda a diferença entre os salários do trabalho especializado e os do trabalho comum ${ }^{30}$.
}

\footnotetext{
${ }^{30}$ SMITH, Adam. A riqueza das nações. Tradução de Alexandre Amaral Rodrigues e Eunice Ostrensky. São Paulo: Martins Fontes, 2003, p. 128 (vol. I). Doravante, A riqueza das nações, seguido do búmero da página. Esta passagem demostra também que a comparação da qualificação do trabalhador com o capital fixo, tão em voga nas teorias que lançam mão do conceito de capital humano, é tão antiga quanto a economia política.
} 
Smith aborda nesta passagem a remuneração pela atividade do trabalho qualificado, o salário, mas a relação não deixa de dizer respeito também ao valor do produto que a atividade produz. $\mathrm{O}$ autor escreve, capítulos antes (e este parágrafo é citado integralmente por Ricardo em nota):

\begin{abstract}
Mas, embora o trabalho seja medida real do valor de troca de todas as mercadorias, não é por trabalho que normalmente se estima o valor delas. Não raro é difícil determinar a proporção entre duas diferentes quantidades de trabalho. $\mathrm{O}$ tempo despendido em dois gêneros distintos de trabalho não basta, por si só, para determinar essa proporção. É preciso levar em conta os diferentes graus de fadiga e engenho. Pode haver mais labuta (labour) numa hora de trabalho árduo do que em duas horas de trabalho leve; ou mais numa hora de aplicação a uma atividade cujo aprendizado custou dez anos de labuta do que num mês de ocupação numa tarefa trivial e óbvia. Todavia, não é fácil encontrar uma medida exata tanto da fadiga como do talento. De fato, é preciso normalmente ter em conta uma e outro ao trocar os diferentes gêneros de trabalhos uns pelos outros. Essa conta, todavia, não é regulada por uma medida exata, mas pelo regateio e pela negociação do mercado, de acordo com aquela espécie de igualdade tosca que, apesar de inexata, é suficiente para levar a cabo as atividades da vida cotidiana (Smith, A riqueza das nações, 3940).
\end{abstract}

O ajuste do valor dos produtos dos trabalhadores comuns e qualificados no mercado, apontado por Smith, demonstra que o valor não é dado pela produção individual isolada, mas pela comparação do conjunto das produções individuais no mercado. $\mathrm{O}$ valor do produto individual só existe como parte do valor global realizado no mercado. Também em Ricardo, o valor parece como uma criação do trabalho social na consideração da concorrência como fator determinante do valor: "Ao falar, portanto, das mercadorias, de seu valor de troca e das leis que regulam seus preços relativos, sempre nos referimos àquelas (...) em cuja produção a concorrência opera irrestritamente" (Ricardo, Princípios, 260). Se o tempo de trabalho é, por um lado, medida imanente do valor e, por outro, o valor é determinado na concorrência, este não pode constituir-se senão como uma medida social do tempo de trabalho. Smith expõe ainda sua compreensão de que o trabalho individual produz valor na medida em que é parte alíquota do trabalho social ao tomar em consideração o salário do trabalho qualificado. Numa passagem muito esclarecedora, ele escreve:

Numa profissão em que vinte pessoas fracassam para cada uma que alcança êxito, este um deveria ganhar o que os outros vinte malsucedidos poderiam ganhar. O consultor jurídico, que talvez só comece a tirar partido de sua profissão com cerca de quarenta anos de idade, deveria receber retribuição não apenas pela educação longa e custosa, mas ainda pela de vinte outros 
estudantes, aos quais tal profissão provavelmente nada trará. (...) Calculemos a soma provável do ganho anual de todos os trabalhadores empregados numa atividade comum, num lugar específico, como os sapateiros e tecelões, e a soma provável de sua despesa anual, e veremos que em geral a primeira dessas duas somas excede a última; mas façamos o mesmo cálculo em relação aos advogados e estudantes de direito em todas as escolas de jurisconsultos e concluiremos que a soma de seus ganhos anuais está em proporção muito pequena com sua despesa anual (...) (Smith, A riqueza das nações, 134).

A "despesa anual dos trabalhadores", ou seja, o custo de produção "do trabalhador" é, para o autor, a determinação central do salário. Mas esta determinação diz respeito não apenas ao indivíduo, mas à classe ou espécie de trabalho. Deste modo, a concorrência que existe entre os trabalhadores compõe o custo social de cada espécie de atividade. Se para que um advogado realize efetivamente suas funções é necessária a formação de quatro estudantes, por exemplo, de modo que três receberão a qualificação mas não exercerão a atividade, o custo de produção de um advogado inclui as despesas realizadas pelos outros três estudantes. Deixamos de lado a defesa que Smith faz da baixa remuneração proporcional do trabalho qualificado em relação ao simples. Importa destacar que o cálculo dos custos de produção do trabalho ou dos trabalhadores é feito com base na despesa social necessária produzir dadas qualidades de trabalhadores, a despeito dos desembolsos serem sempre privados. No exemplo de Smith, o quanto a sociedade como um todo gastou para formar um advogado. O que explica o valor "do trabalho", explica também os valores dos produtos. O valor, que em Smith se expressa pelos custos de produção, só existe em sentido social.

Esta questão será retomada no debate posterior relativo à teoria de Marx: em seu exame da categoria marxiana de trabalho complexo, Isaak Iliich Rubin, por exemplo, defende tese análoga à de Smith. O autor afirma que, se a formação de três engenheiros, por exemplo, é necessária para que um deles se empregue na produção capitalista, o produto de seu trabalho incorpora o tempo de trabalho despendido na educação dos três ${ }^{31}$. Esta questão é de fundamental importância porque explica o caráter social e determinado post festum do valor. Com isto, contribui para explicar a pertinência de qualquer forma concreta do trabalho, por mais qualificada, criativa ou imaterial, à teoria do valor de Marx. Esclarece, ademais, que a exigência de prever o tempo de trabalho para dada produção (criativa, por exemplo), ou de medir o desgaste empírico, individual de força de trabalho, não cabe na teoria do valor de Marx, ou ainda, revela uma

\footnotetext{
${ }^{31}$ RUBIN, I. I. A Teoria marxista do valor, São Paulo: Pólis, 1987, p. 181.
} 
incompreensão de seu conteúdo. Marx encontrará esta explicação da redução das qualidades em quantidade no duplo caráter que o trabalho assume no modo capitalista de produção, isto é, na determinação de que o caráter social do trabalho assume forma abstrata. Mas também Smith e Ricardo pressupunham, sem explicar, o trabalho humano ou geral como trabalho social, ainda que não tenham desenvolvido a categoria de trabalho abstrato, e, sem isso, identifiquem a sociabilidade em geral com sua forma capitalista. O fundamento dessa possibilidade de reduzir as qualidades concretas das atividades a distinções meramente quantitativas reside no reconhecimento de uma natureza comum a tais atividades produtivas. Embora não desenvolvam a forma abstrata que os trabalhos assumem quando são produtivos de valor, referem-se ao conjunto das atividades como trabalho humano. O limite da teoria de ambos, neste tema, é assumir a criação de valor como imanente à atividade produtiva, já que o trabalho humano em geral cria valor, como determinação natural de seu produto concreto. Um dos pontos centrais da crítica de Marx, que desenvolvemos adiante, é mostrar que o valor resulta do trabalho sob determinadas relações de produção, distinguindo assim trabalho em geral de trabalho abstrato. Mas de modo algum, em Smith e Ricardo, as qualificações específicas, mesmo intelectuais - como atesta o exemplo de Smith -, são fatores que impõem a exclusão dos trabalhos criativos ou cognitivos da natureza de trabalho humano, passível de medida quantitativa.

As teorias do valor-trabalho desenvolvidas por Ricardo e Smith não se fundamentam no tempo empírico da atividade e tampouco requerem a possibilidade de medir este tempo empírico das atividades individuais, ou de prever o tempo de trabalho necessário à produção de dada mercadoria, pois a redução das qualidades diversas de trabalho a mera diferença quantitativa se dá no mercado, por meio do valor de troca de seus produtos. Bailey não aceita a proposição de Ricardo, segundo a qual as diferentes qualificações dispõem as espécies de trabalho em uma escala quantitativa, que por sua vez só se manifesta na troca efetiva. Não aceita a redução da qualidade do trabalho a quantidade, isto é, concebe que se a qualificação faz caber "mais trabalho" em dado tempo, o tempo não é medida da quantidade de trabalho. Por conseguinte, o trabalho não tem medida quantitativa. E como não há unidade que o torne mensurável, não pode ser ele mesmo a medida do valor. O pressuposto de sua crítica é a ausência de uma natureza comum ao conjunto das atividades produtivas. 
A teoria marxiana do valor explica a redução da qualidade dos trabalhos a quantidade, bem como a multiplicação do tempo de trabalho social que as atividades qualificadas são capazes de realizar, por meio da categoria de trabalho abstrato, o trabalho humano em geral sob uma dada especificidade social. Na exposição da categoria de trabalho abstrato, são examinadas várias dimensões que o caracterizam, como o trabalho complexo, o trabalho simples ou médio e o trabalho socialmente necessário. Isso não impediu que a teoria de Marx fosse alvo de críticas semelhantes à que Bailey dirige a Ricardo, e que expressam incompreensões relativas ao caráter social do valor.

\section{2. Eugen Dühring e a crítica ao trabalho socialmente necessário}

A teoria de Marx acerca da categoria de trabalho complexo foi alvo da crítica de Eugen Dühring. Diferentemente de Böhm-Bawerk, Dühring não lança mão da categoria de trabalho complexo para justificar a recusa de qualquer forma que a teoria do valortrabalho assuma: ele mesmo defende que o trabalho é a medida do valor das mercadorias, mas não aceita a versão marxiana da teoria do valor. Engels dedica um pequeno capítulo de seu Anti-Dühring ${ }^{32}$, na parte voltada à economia política, a responder a esta crítica relativa ao trabalho complexo. Apresentamos os argumentos de Eugen Dühring a partir do texto de Engels ${ }^{33}$.

O crítico de Marx não vê problema algum na afirmação de que espécies de trabalho que se distinguem quanto ao nível de qualificação criem todas, igualmente, valor. As mais distintas atividades produtivas têm substância comum de trabalho humano, para Dühring. Sua oposição se volta à capacidade de o trabalho complexo criar valor multiplicado, ou seja, às razões que Marx oferece para explicar por que o produto de dado tempo de trabalho qualificado contém valor maior que o produto de tempo igual de trabalho simples. Segundo ele, se o tempo de trabalho invertido é a medida do que chama de "custo natural" ou "valor absoluto" das "coisas econômicas", os tempos

\footnotetext{
32 ENGELS, Frederico. Anti-Dühring, ou a subversão da ciência pelo Sr. Eugênio Dühring (Parte II Economia Política, Capítulo VI: Trabalho simples e trabalho complexo). Tradução de Isabel Hub e Teresa Adão. Lisboa: Edições Afrodite, 1971. Doravante Anti-Dühring, seguido do número da página.

${ }^{33}$ Engels cita as seguintes obras de Dühring: Cursus der Philosophie als streng wissenschaftlicher Weltanschauung und Lebensgestaltung, Leipzig, 1875 (republicado em 2010 por Kessinger Legacy Reprints); Kritische Geschichte der Nationalökonomie und des Sozialismus, 2. Aufl., Theobald, Berlin, 1875. (publicado pela primeira vez em 1871); Cursus der National- und Sozialökonomie, 2. Aufl., Leipzig, 1876. (publicado pela primeira vez em 1873).
} 
individuais de trabalho devem ser equiparados de modo absoluto, de forma que o trabalho de todos os indivíduos "deve valer" exatamente o mesmo. Condena a ideia de Marx segundo a qual o trabalho complexo condensa o tempo e cria valor multiplicado com referência ao trabalho simples:

A ideia que se pode ter do valor diferencial do chamado trabalho qualificado fica, nesta teoria, na mais completa obscuridade. É certo também que, de acordo com a nossa teoria, só o tempo de trabalho invertido é que pode medir o próprio custo natural e, portanto, o valor absoluto das coisas econômicas. Mas, para isso, se equipara, de antemão, de modo absoluto o tempo de trabalho de todos os indivíduos (...) (Dühring, Kritische Geschichte..., p. 499-500, apud Engels, Anti-Dühring, 246).

O tempo de trabalho que consiste na medida do valor é, em Dühring, o tempo individual imediato, portanto empírico. Em Marx, o valor é medido pelo tempo de trabalho médio, isto é, necessário em média, ou ainda, socialmente necessário para produção de dada espécie mercadoria. Dühring rechaça a compreensão de que o trabalho médio (ou social) se constitui como medida do valor; para ele, a ideia de média é alheia à medida do valor:

\footnotetext{
Não se trata, pois, como o Sr. Marx, nebulosamente, imagina, de que o tempo de trabalho de uma pessoa valha, por si só, mais do que o de outra, como se nele se condensasse mais tempo de trabalho médio, e sim, do fato de que todo tempo de trabalho é perfeitamente equiparável, sem exceção, por princípio, sem que seja pois necessário que se tire uma média (Dühring, Kritische Geschichte..., 499-500, apud Engels, Anti-Dühring, 246-7).
}

Daqui decorre uma importante divergência com relação à teoria marxiana, no que diz respeito ao fundamento do valor. Os exemplares de uma dada espécie de mercadoria não são produzidos todos sob as mesmas condições técnicas, de modo que podem conter magnitudes distintas de tempo de trabalho empírico; mas não podem ter valores distintos. O valor de cada espécie de mercadoria é por isso determinado, em Marx, pela quantidade de trabalho socialmente necessário. A média é, pois, a expressão do caráter social do valor: criar valor não é uma determinação intrínseca à natureza individual do produtor, ou de sua atividade em si mesma, mas a capacidade de produzir valor torna-se um atributo dos trabalhos dos indivíduos devido à relação de produção capitalista em que se dão. Nesta, a força de trabalho individual se torna parte alíquota da massa homogênea de força de trabalho social, e esta equiparação dos produtores individuais se realiza pela média, que se refere a diversos aspectos do trabalho. Engels afirma, 
dirigindo-se contra a possibilidade de os trabalhos individuais empíricos se igualarem em sua dimensão concreta:

\footnotetext{
Se a equiparação de valor do tempo de trabalho significa que cada operário produz, no mesmo espaço de tempo, valores iguais, sem que seja necessário, portanto, estabelecer uma média, a tese é absolutamente falsa. Entre dois operários, até de um mesmo ramo industrial, o produto do valor criado em cada hora de trabalho se diferenciará sempre, quer devido à intensidade do trabalho, quer à habilidade do trabalhador. E este "mal", que existe somente para homens do gênero do Sr. Dühring, não pode ser remediado nem mesmo pela Comuna Econômica, ao menos em nosso planeta (Engels, Anti-Dühring, 251-2).
}

O valor, que tem como substância o trabalho abstrato, implica diversas médias - tanto referentes aos indivíduos produtores quanto à força produtiva utilizada por cada empresa privada - que expressam seu caráter social. A ausência da consideração da média ou do caráter social do trabalho que cria valor implica considerar o trabalho concreto como diretamente criador de valor, e o tempo empírico como sua medida. Deste modo, Dühring faz aderir à natureza do trabalho, da atividade produtiva individual, o predicado de criar valor.

Dühring não nega, no entanto, o maior valor do produto do trabalho qualificado, e procura explicá-lo sem contradizer sua defesa de que o tempo de trabalho de todos os indivíduos vale o mesmo. Deveria dizer, "cria mesma magnitude de valor". Engels ressaltará esta confusão entre valor da força de trabalho e do produto que ela cria, bem como a referência frequente de Dühring ao "valor do trabalho". O autor justifica o maior valor do produto do trabalho qualificado afirmando que no tempo de trabalho individual do trabalhador qualificado incorpora-se o tempo de trabalho de outras pessoas:

(...) se equipara, de antemão, de modo absoluto o tempo de trabalho de todos os indivíduos, devendo se ter em conta apenas que, quando se trata de trabalhos qualificados, vem incorporar-se ao tempo de trabalho individual de uma pessoa, o tempo de trabalho de outras pessoas, em cooperação com ela, por exemplo, no instrumento que se utiliza (Dühring, Kritische Geschichte..., 499-500, apud Engels, Anti-Dühring, 246).

O que Dühring argumenta é que há tempo de trabalho de outras pessoas envolvido na atividade produtiva de um indivíduo, que aumenta o valor do produto criado. Este trabalho das demais pessoas pode estar incorporado tanto no instrumento de trabalho 
utilizado, quanto na própria pessoa do trabalhador, na forma de qualificação artesanal ou intelectual:

(...) ante a atividade despendida por uma pessoa, principalmente diante de um produto acabado qualquer, devemos ver apenas quanto tempo de trabalho de outras pessoas se oculta sob essa inversão de trabalho, aparentemente próprio e exclusivo. Para a rigorosa aplicação da teoria, não importa absolutamente que se trate de um instrumento de produção a ser utilizado pelas mãos ou que se trate das mãos e da própria cabeça, consideradas como instrumentos, as quais, sem o tempo de trabalho de outras pessoas, não teriam jamais adquirido a necessária capacitação para o trabalho (Dühring, Kritische Geschichte..., 499-500, apud Engels, Anti-Dühring, 247).

Dühring equipara o tempo de trabalho de outras pessoas contido no instrumento e o tempo de trabalho de outras pessoas incorporado subjetivamente, nas mãos ou na cabeça, pela atividade daqueles que o qualificaram. Em ambos os casos, o tempo de trabalho destas outras pessoas é transferido ao produto, de modo que o tempo de trabalho imediato tanto do trabalhador não-qualificado que utiliza dado instrumento de produção, quanto do trabalhador qualificado que utiliza seus conhecimentos ou técnicas como instrumentos de produção, "vale o mesmo" (cria o mesmo valor). Assim, o valor mais alto do produto do trabalho complexo não se deve à capacidade deste produzir valor multiplicado em relação ao trabalho simples, mas à transferência de tempo de trabalho de outras pessoas.

Este crítico explica ainda a razão que leva Marx a defender a capacidade potenciada de o trabalho complexo criar valor: segundo ele, Marx é presa do preconceito das classes cultas que não aceitam equiparar sua atividade qualificada à atividade comum das classes baixas. É como se, para Marx, o valor multiplicado produzido pelo trabalho complexo se devesse à qualidade ou especificidade útil deste trabalho:

O Sr. Marx, em suas elucubrações sobre o valor, não consegue desfazer-se do fantasma do tempo de trabalho qualificado que se ergue ao fundo. O tradicional modo de pensar das classes cultas, às quais têm necessariamente que parecer monstruoso o fato de se equiparar, plenamente, no terreno econômico, o tempo de trabalho do carregador e o do arquiteto, como valores, foi que lhe impediu que acabasse com essa quimera" (Dühring, Kritische Geschichte..., 499-500, apud Engels, Anti-Dühring, 247).

A crítica de Engels a Dühring dirige-se à confusão entre valor do produto do trabalho e valor da força de trabalho, à noção de "valor do trabalho", à tese de que 
nenhuma média é necessária para a determinação do valor, e, especialmente à desconsideração do caráter histórico do valor expressa pelo conceito de "valor absoluto", com o que Dühring vincula o valor à natureza do trabalho, prevendo inclusive a relação de valor na "comuna econômica", como denomina a sociedade póscapitalista.

\section{3. A recusa do valor-trabalho por Böhm-Bawerk}

Se Eugen Dühring propõe uma teoria do valor-trabalho em que a atividade produtiva de valor é o trabalho concreto imediato, e sua medida é o tempo de desgaste empírico, de modo que a categoria de trabalho abstrato se torna desnecessária, Eugen von Böhm-Bawerk procura demonstrar as incongruências presentes na categoria de trabalho complexo para desconstruir a teoria do valor-trabalho em geral. Se para Dühring a criação de valor multiplicado pelo trabalho complexo é a justificativa teórica de um preconceito das classes cultas compartilhado por Marx, para Böhm-Bawerk é um meio de dizer que o trabalho não pode constituir a medida do valor, uma vez que ele mesmo não apresenta medida quantitativa.

São bem conhecidas as objeções com que Böhm-Bawerk, em seu texto Sobre a conclusão do sistema de Marx ${ }^{34}$, alveja a teoria que Marx desenvolve em sua obra principal. De modo geral, esta crítica pretende demonstrar que a teoria de Marx não explica o objeto que investiga - segundo ele, a troca de mercadorias -, fazendo uso de argumentos circulares e contando com um conjunto de incoerências, que acometem os dois momentos centrais de $O$ Capital: os princípios da teoria do valor, expostos no primeiro livro, e a compatibilidade desta com as leis de mercado descritas no livro terceiro. Böhm-Bawerk apresenta divergências ao texto de Marx desde a definição de mercadoria até a formação dos preços de produção. Recusa a definição de valor de Marx e, nesta crítica, a categoria de trabalho complexo desempenha importante papel; ataca a formação da taxa geral de lucro e a determinação dos preços - momento em que propõe a conhecida teoria em que o "trabalho" aparece como um dos componentes do custo da mercadoria, ao lado do capital; e não aceita a unidade destes dois momentos da teoria de Marx, que o leva a afirmar que Marx tem duas teorias, ambas equivocadas.

\footnotetext{
${ }^{34}$ Zum Abschluss des Marxschen Systems, publicado pela primeira vez em 1896. Utilizo a tradução para o inglês: BÖHM-BAWERK, Eugen von. Karl Marx and the closure of his system; HILFERDING, Rudolf. Böhm-Bawerk's criticism of Marx. Tradução de Eden e Cedar Paul. Introdução de Paul Sweezy. New York: Augustus M. Kelley, 1949. Doravante, o texto de Böhm-Bawerk será referido como A conclusão de Marx, seguido do número da página.
} 
Böhm-Bawerk está ciente de que sua crítica a Marx é também uma recusa de todas as formas históricas da teoria do valor-trabalho, e portanto também de Adam Smith e David Ricardo. Argumenta que sua crítica deve se dirigir à teoria marxiana por ser esta a única que procura provar que o trabalho é a substância do valor das mercadorias, enquanto as anteriores apenas postulavam esta definição do valor. Sua teoria positiva funda subjetivamente a medida do valor, e do mesmo modo explica, em última instância, as leis de mercado.

A crítica da teoria do valor, que traz à tona a questão do trabalho complexo, origina-se da compreensão desta como uma mera explicação da proporção nas trocas individuais, de modo que Böhm-Bawerk não alcança o valor em seu sentido amplo de forma social da produção. Este ângulo estreito de abordagem do valor se expressa na acusação de incompatibilidade entre valor e preço de produção, o velho "problema da transformação":

\footnotetext{
Em que relação a doutrina do terceiro volume se coloca frente à célebre lei do valor do primeiro volume? Ela contém a solução procurada com tanta ansiedade para a aparente contradição? Ela prova "como não apenas sem contradizer a lei do valor, mas mesmo em virtude dela, uma taxa média igual de lucro pode e deve ser criada"? Não contém em vez disso o oposto exato desta prova, ou seja, a proposição de uma contradição efetivamente irreconciliável, e não prova que uma taxa média igual de lucro apenas pode manifestar-se se, e porque, a mencionada lei do valor não funciona? (Böhm-Bawerk, A conclusão de Marx, 29).
}

O desvio dos preços com relação ao valor é em si mesmo, para Böhm-Bawerk, a refutação da teoria do valor. O autor escreve: "O terceiro volume de Marx contradiz o primeiro. A teoria da taxa média de lucro e dos preços de produção não pode reconciliar-se com a teoria do valor" (Böhm-Bawerk, A conclusão de Marx, 30). A análise da teoria do valor é trazida à tona como o ponto inicial de uma demonstração do percurso que o erro de Marx segue, e que leva à falta de coerência presente em sua obra.

\footnotetext{
Um sistema bem fundamentado só pode ser eficazmente superado ao descobrir-se com precisão absoluta o ponto em que o erro se insere no sistema e a maneira como se espalha e ramifica. Como adversários, devemos estudar o começo, o desenvolvimento e o resultado final do erro que culmina em contradição interna (Böhm-Bawerk, A conclusão de Marx, 64).
}

Assim, para demonstrar a origem da incoerência que acredita encontrar na obra de Marx, Böhm-Bawerk procura desconstruir os passos de sua teoria. Não acompanharemos seu raciocínio completo, mas apenas sua crítica aos princípios da 
teoria do valor, que lança mão do trabalho complexo como uma expressão da contradição interna. Seu primeiro questionamento diz respeito à medida do valor como quantidade de trabalho e se constrói com base na observação empírica da avaliação subjetiva do valor das coisas, o que explicita hesitação na distinção entre valor de uso e valor. Sua própria concepção é a de que esta distinção não é necessária, uma vez que a utilidade pode se constituir como medida válida do valor. $\mathrm{O}$ autor escreve:

Valor e esforço, como expus longamente em outro lugar, não são ideias tão intimamente ligadas a ponto de sermos forçados imediatamente a adotar a visão de que o esforço é a base do valor. (...) Quando portanto se afirma que a correspondência natural e necessária entre valor e esforço existe por toda parte, cabe a nós oferecer a nós mesmos e a nossos leitores alguns fundamentos para justificar tal proposição (Böhm-Bawerk, A conclusão de Marx, 65).

Marx fornece esta explicação, mas seu “(...) raciocínio é repleto dos mais óbvios erros de lógica e método que o privam de qualquer poder de persuasão" (Böhm-Bawerk, A conclusão de Marx, 65). Para provar que a troca de mercadorias é determinada pelo seu valor - como tempo de trabalho necessário para produzi-las - Marx teria duas opções metodológicas, na visão do autor. A primeira delas é empírica. Nela, a prova da lei do valor deveria se fundar na comparação entre os tempos de trabalho incorporados nas mercadorias efetivamente trocadas. Mas Marx não segue esse caminho, de acordo com Böhm-Bawerk, porque sabe que nas trocas efetivas o preço se afasta do valor, como fica claro no terceiro livro. Ele escreve:

O raciocínio do terceiro volume prova que ele tinha plena ciência da natureza dos fatos empíricos, e que eles eram opostos à sua proposição. Ele sabia que os preços das mercadorias não eram proporcionais à quantidade de trabalho incorporado, mas ao custo de produção total, que compreende também outros elementos. Por conseguinte, ele não negligenciou este fato acidentalmente, a prova mais natural de sua proposição, mas virou às costas a ele com plena consciência de que neste caminho nenhum elemento favorável à sua teoria seria encontrado (Böhm-Bawerk, A conclusão de Marx, 67).

A segunda opção seria, para Böhm-Bawerk, a psicológica, ou seja, Marx poderia ter procedido na investigação daquilo que motiva os indivíduos em suas atividades econômicas. Para o autor, Marx lança mão deste caminho em diversos momentos com a finalidade de explicar outras leis do sistema, mas não para provar a teoria do valor:

Este método foi utilizado com frequência precisamente em questões similares, com os melhores resultados - por exemplo, a justificação usual da lei da oferta e da demanda e da lei dos custos de produção, e a explicação da renda da terra, baseiam-se nele. E o próprio Marx, pelo menos de 
maneira geral, fez uso frequente dele; mas precisamente ao lidar com sua proposição fundamental, ele o evita. Embora, obviamente, a alegada conexão externa entre as relações de troca e as quantidades de trabalho só possa ser compreendida pela descoberta dos vínculos psicológicos que conectam a ambas, ele renuncia a qualquer explicação dessas conexões internas (Böhm-Bawerk, A conclusão de Marx, 67).

O exemplo que ele oferece da utilização que Marx faz do método psicológico é elucidativo de sua própria concepção:

\footnotetext{
No terceiro volume, por exemplo, ele realmente apresenta, sob o nome impreciso e geral de "concorrência", os motivos que operam na produção e na troca, a "análise mais profunda" a que ele renuncia aqui e em todo lugar, e demonstra que esses motivos na realidade não levam a um ajuste dos preços às quantidades de trabalho incorporadas nas mercadorias, mas que, ao contrário, afastam-nos deste para um nível que implica ao menos um outro fator coordenado. É de fato a concorrência que, de acordo com Marx, leva à formação da célebre taxa média de lucro e à "transformação" dos puros valores-trabalho em preços de produção, que se distinguem daqueles e contêm uma porção do lucro médio (Böhm-Bawerk, A conclusão de Marx, 67-8).
}

O que salta aos olhos nesta passagem é a transferência que autor faz de seus próprios conceitos para o texto de Marx. A concorrência é tomada por Böhm-Bawerk como um fenômeno de origem psicológica, e assim a compreende quando lê a análise de Marx sobre as relações de mercado. Em outra passagem do texto, o autor afirma: “'Concorrência', como já indiquei, é um tipo de termo generalizante para todos os motivos psíquicos e impulsos que determinam a ação dos agentes no mercado, e que portanto influenciam o estabelecimento dos preços" (Böhm-Bawerk, A conclusão de Marx, 91). Ela é um termo generalizante apenas porque é entendida como uma motivação, impulso, ou disposição individual, entre muitas outras, que definem as ações pontuais de cada um no mercado. Em Marx a concorrência é uma determinação objetiva da atividade econômica, oriunda da forma de propriedade: sob a propriedade privada não há outra relação de produção possível senão a concorrência. Mas para BöhmBawerk a concorrência é uma forma de relação com fundamento subjetivo; o autor recusa ou não alcança o fato de haver determinações sociais objetivas da atividade de produção. Por isso, não pode deixar de compreender o modo como Marx expõe a teoria do valor como um raciocínio puramente lógico, uma "dedução dialética". O autor escreve:

Mas Marx, ao invés de provar sua tese a partir da experiência ou de seus motivos operantes - isto é, empírica ou psicologicamente - prefere outro [método], e para tal matéria uma linha de 
demonstração um tanto singular - o método da prova puramente lógica, uma dedução dialética a partir da natureza mesma da troca (Böhm-Bawerk, A conclusão de Marx, 68).

Assim, para o crítico de Marx, onde a empiria, em sua forma material ou psicológica, não está presente, resta apenas a pura lógica.

Böhm-Bawerk afirma que a equivalência nas trocas entre mercadorias é uma consideração desnecessária para a compreensão das determinações dos preços: as mercadorias não precisam ser equivalentes em aspecto algum para serem trocadas. Assim, a comensurabilidade, ou substância comum aos produtos do trabalho é também descartada como condição da troca, como afirma na seguinte passagem:

\footnotetext{
Com efeito, os economistas políticos modernos concordam que a velha teoria escolásticoteológica da "equivalência" das mercadorias trocadas é insustentável. Não me estenderei, contudo, neste ponto, mas avançarei na investigação crítica dos processos lógicos e sistemáticos de destilação por meio dos quais Marx encontra o almejado "fator comum" no trabalho (BöhmBawerk, A conclusão de Marx, 69).
}

Seu primeiro argumento contra o que ele considera o ponto mais vulnerável da teoria é o de que Marx, desde o início, peneira as coisas trocáveis, selecionando apenas aquelas que fundamentam a tese do trabalho como fator comum, isto é, limitando desde o princípio o escopo das mercadorias àquelas que são produto do trabalho, em oposição às dádivas da natureza. Böhm-Bawerk defende que, se a troca significa realmente uma equalização e assume, portanto, a existência de um "fator comum de mesma magnitude", este deveria ser encontrado em todas as espécies de bens trocados. Isto é, não apenas nos produtos do trabalho, mas também nas dádivas da natureza, como o solo, a madeira das árvores, a força hidráulica etc. O crítico de Marx considera esta exclusão das dádivas naturais do campo das mercadorias um erro grosseiro de método, ainda mais injustificável quando se tem em vista que muitos destes bens naturais são importantes objetos de propriedade e comércio. $\mathrm{O}$ autor escreve:

Se Marx não houvesse restringido sua pesquisa, no ponto decisivo, aos produtos do trabalho, mas houvesse buscado o fator comum também nas dádivas trocáveis da natureza, teria se tornado óbvio que o trabalho não pode ser o fator comum. Se tivesse explicitado esta limitação de modo claro e aberto esta falácia grosseira de método teria inevitavelmente surpreendido tanto a ele como a seus leitores (Böhm-Bawerk, A conclusão de Marx, 73).

Além da exclusão das dádivas naturais do campo de determinação do valor, Böhm-Bawerk destaca o argumento negativo que Marx utiliza para demonstrar que, 
com a abstração das determinações úteis das mercadorias, resta nelas apenas a característica de ser produto do trabalho. De acordo com o crítico, restariam ainda outras propriedades:

\footnotetext{
Pergunto hoje o que perguntei há doze anos atrás: há apenas uma propriedade? A propriedade de ser escasso em proporção à demanda não é também comum a todos os bens trocados? Ou a de serem objetos de demanda e oferta? Ou a de serem apropriados? Ou a de serem produtos naturais? (Böhm-Bawerk, A conclusão de Marx, 75).
}

Böhm-Bawerk questiona, deste modo, a razão pela qual Marx decide pela propriedade de as mercadorias serem produto do trabalho e não nenhuma outra destas propriedades que, segundo ele, também caracterizam as mercadorias mesmo após a abstração de seu valor de uso. Constituir-se em um produto escasso, ser objeto de demanda ou de apropriação pelos indivíduos são fatores que caracterizam a utilidade de um produto ou objeto. O autor defende uma teoria da utilidade, em que a medida das trocas é determinada pelo quantum de utilidade e tem, pois, determinação subjetiva. Ele escreve: "E do mesmo modo que se pode comparar diferentes tipos de trabalho de acordo com sua quantidade, também é possível comparar valores de uso de diferentes tipos de acordo com sua variável quantidade do valor de uso" (Böhm-Bawerk, A conclusão de Marx, 76). Para Böhm-Bawerk, se os trabalhos de qualidades diferentes são comparados quanto à sua quantidade, também a utilidade ou o caráter de valor de uso, como característica comum dos bens trocáveis, pode, na sua concepção, ser passível de medida. Ou seja, os valores de uso poderiam apresentar-se em uma escala quantitativa de utilidade, em que se mede a quantidade de valor de uso, tomado como uma qualidade comum das mercadorias.

A oposição central de Böhm-Bawerk se dirige à desconsideração do valor de uso para a determinação do valor de troca. Argumenta que o erro de Marx foi confundir o gênero com as formas específicas em que o gênero se manifesta: as particularidades dos valores de uso devem ser excluídas da determinação do valor, mas não o valor de uso em geral. Isto porque, onde não há valor de uso, não pode haver troca - como o próprio Marx admitia - de modo que na relação de troca absolutamente não se abstrai o valor de uso. Assim, o crítico confunde a condição da troca com sua medida:

As formas especiais sob as quais os valores de uso das mercadorias aparecem, se servem para alimentação, abrigo, vestimenta etc., são certamente desconsideradas, mas o valor de uso da mercadoria como tal nunca é desconsiderado. Marx deve ter visto que não desconsideramos 
absolutamente o valor de uso, dado o fato de que não pode haver valor de troca onde não há valor de uso - fato que o próprio Marx é recorrentemente obrigado a admitir (Böhm-Bawerk, $A$ conclusão de Marx, 74-5).

O autor considera factível a comensurabilidade das mercadorias com base em seu caráter útil, a despeito do fato de considerar desnecessária qualquer equivalência para a efetivação das trocas. Essa proposição se opõe à qualidade do fator comum aos objetos trocáveis: o trabalho não precisa ser esta medida. Não poderia ademais ser esta medida porque as diferentes qualidades de trabalho não se reduzem a trabalho humano em geral. Nesse sentido, considera as afirmações de Marx relativas à categoria de trabalho complexo como incongruentes com a teoria do valor. Böhm-Bawerk argumenta que no produto do trabalho complexo - por exemplo, de um escultor - não há tempo algum de trabalho simples, mas apenas tempo de trabalho qualificado: um dia de trabalho de um escultor não pode equivaler a cinco dias de trabalho de um minerador, pois seus produtos não incorporam trabalho de um mesmo tipo em mesma quantidade. A questão de Böhm-Bawerk é a possibilidade de igualar, em uma mesma substância, trabalhos de diversas espécies. Ao abordar o tema do trabalho qualificado como produtivo de valor multiplicado em relação ao trabalho simples, Böhm-Bawerk compreende que, em Marx, a substância do valor deixa de ser o trabalho em geral - em nenhum momento o autor menciona o trabalho abstrato - e passa a consistir em trabalho simples:

\footnotetext{
O fato com que somos obrigados a nos haver é o de que o produto de um dia ou uma hora de trabalho qualificado é mais valioso que o produto de um dia ou de uma hora de trabalho simples; que, por exemplo, o produto de um dia de um escultor é igual ao produto de cinco dias de um minerador. Mas Marx nos diz que coisas equiparadas na troca devem conter "um fator comum em mesma quantidade", e este fator comum deve ser o trabalho e o tempo de trabalho. Ele se refere ao trabalho em geral? As primeiras proposições de Marx até a página 45 nos levam a supor que sim; mas é evidente que alguma coisa está errada, pois o trabalho de cinco dias não é obviamente "a mesma quantidade" que o trabalho de um. De modo que Marx, no caso com que nos deparamos, não está mais falando do trabalho como tal, mas do trabalho simples. O fator comum consiste portanto em possuir uma quantidade igual de trabalho de uma espécie particular, nomeadamente, trabalho simples (Böhm-Bawerk, A conclusão de Marx, 81-2).
}

O autor entende que a medida do valor é uma classe específica de trabalho, o trabalho simples, e não o trabalho abstrato. Sua crítica se baseia no argumento de que o produto do trabalho complexo não contém trabalho simples algum, de modo que não há um fator comum nos produtos do trabalho simples e do trabalho complexo: um dia de trabalho de um escultor não pode equivaler a cinco dias de trabalho de um minerador, pois seus 
produtos não incorporam trabalho de um mesmo tipo em mesma quantidade. Na tese de Marx, o trabalho complexo, em sua capacidade de criar valor, conta como trabalho simples multiplicado, o que se justifica com base no fato de que $o$ valor dos produtos os iguala, e, por conseguinte, que a redução do trabalho complexo ao simples se dá na prática das trocas e só se manifesta a posteriori. Para Böhm-Bawerk, esta explicação é circular, dispondo o efeito no lugar da causa:

Independente de qualquer outra coisa, isso significa que Marx está argumentando em um círculo completo. O objeto real de investigação é a relação de troca das mercadorias: por que, por exemplo, uma estatueta que custa ao escultor um dia de trabalho deve ser trocada por uma carroça de pedras que custou ao minerador cinco dias de trabalho, e não por uma quantidade de pedras maior ou menor, em cuja extração foram despendidos dez ou três dias de trabalho. Como Marx explica isso? Ele diz que a relação de troca é esta, e não outra - porque um dia de trabalho do escultor é redutível a exatamente cinco dias de trabalho simples. E por que é redutível a exatamente cinco dias? Porque a experiência demonstra que é reduzido nesta proporção por um processo social. E o que é esse processo social? O mesmo processo social que deve ser explicado, o processo mesmo por meio do qual o produto de um dia de trabalho do escultor tornou-se igual ao valor do produto de cinco dias de trabalho comum. Mas se de fato ele fosse regularmente trocado pelo produto de apenas três dias de trabalho simples, Marx teria igualmente nos levado a aceitar a taxa de redução de 1:3 como derivada da experiência e teria fundado nela, e explicado por meio dela, que a estatueta é equivalente a exatamente três dias de trabalho do minerador - nem mais, nem menos. Em resumo, está claro que não poderemos nunca apreender desta maneira as razões reais pelas quais os produtos de diferentes tipos de trabalho devem ser trocados nesta ou naquela proporção. Eles são trocados nesta proporção, Marx nos diz, embora com termos ligeiramente diferentes, porque eles são trocados nesta proporção! (Böhm-Bawerk, A conclusão de Marx, 83-4).

No problema de definir a proporção, há tanto a recusa do fato de que é a própria troca que estabelece a equiparação dos produtos dos trabalhos, como o questionamento da possibilidade de igualar, em uma mesma substância, trabalhos qualificados e simples. Como dirá Rosdolski, o problema posto por Böhm-Bawerk deveria se aplicar à comparação entre quaisquer espécies de trabalho, entre duas funções do trabalho simples, por exemplo, e não apenas entre estas duas categorias. Mas o autor não vê problemas em comparar quantitativamente diferentes qualidades de trabalho que incorporam, por seu nível igual de qualificação, mesma quantidade de valor em dado tempo de dispêndio produtivo. Ou seja, diferentes qualidades de trabalhos simples. Böhm-Bawerk entende essas diferentes qualidades como manifestações do gênero trabalho, e lança mão dessa ideia para argumentar que com os valores de uso se dá o 
mesmo: são todos manifestações singulares do gênero "utilidade", de modo que a utilidade mesma pode ser maior ou menor e, assim, constituir a medida do valor das mercadorias, tanto quanto o trabalho. Mas quando se trata da distinção entre trabalho simples e trabalho complexo, estes deixam de se constituir em manifestações do gênero trabalho porque a medida do valor, conforme ele entende, vem a ser o trabalho simples.

Trata-se, pois, de uma recusa ou incompreensão da categoria de trabalho abstrato, como forma social que o trabalho concreto individual assume por se realizar por meio das relações capitalistas de produção, ou ainda, por ter como produto o valor. Daí a insistência de Hilferding em demonstrar a confusão de Böhm-Bawerk entre o dado natural e a forma social, como será desenvolvido em outro capítulo. Essa incompreensão do caráter social do trabalho que se objetiva em valor aparece também em outra crítica de Böhm-Bawerk, relativa à explicação do valor superior criado pelo trabalho complexo com base no tempo de aprendizado. O autor escreve:

\begin{abstract}
Não tenho nada contra a visão de que ao trabalho em operação deve-se acrescentar a quota devida à aquisição da capacidade de trabalho. Mas é claro que a diferença no valor do trabalho qualificado em oposição ao trabalho simples só poderia ser explicada com referência a esta quota adicional se a quantidade da última correspondesse à quantidade desta diferença. Por exemplo, no caso que mencionamos, só poderia realmente haver cinco horas de trabalho simples em uma hora de trabalho qualificado se houvesse quatro de trabalho preparatório para cada hora de trabalho qualificado; ou, calculado em unidades maiores, se dos cinquenta anos que o escultor dedica ao aprendizado e à prática de sua profissão, ele despendesse quarenta anos em trabalho educacional para realizar trabalho qualificado por dez. Mas ninguém sustentaria tal proporção nem existe realmente qualquer proporção próxima a esta (Böhm-Bawerk, A conclusão de Marx, 84-5).
\end{abstract}

No que diz respeito a esta explicação, Böhm-Bawerk leva em conta apenas o tempo do trabalhador despendido em seu aprendizado, e desconsidera o trabalho social, de outros indivíduos, gasto na formação do trabalhador qualificado. Para ele, a substância do valor como Marx a explica é o "esforço" em si mesmo, e portanto o trabalho em sua natureza concreta, independente de qualquer forma social. $\mathrm{O}$ autor entende que o valor tem como medida, em Marx, o desgaste individual imediato, fisiológico, sem consideração pelo conjunto de mediações sociais que o definem ${ }^{35}$.

\footnotetext{
35 "Valor e esforço, como expus longamente em outro lugar, não são ideias tão intimamente ligadas a ponto de sermos forçados imediatamente a adotar a visão de que o esforço é a base do valor. 'Que eu tenha me desgastado em uma coisa, é um fato, que a coisa valha o meu esforço, é um outro e distinto fato,
} 


\section{4. Castoriadis contra Marx, mas a favor dos clássicos}

Um pesquisador que retoma em parte a argumentação de Böhm-Bawerk na crítica à teoria do valor de Marx é Cornelius Castoriadis. Mas, diferentemente do primeiro, Castoriadis intenciona pôr abaixo a teoria do valor de Marx sem alvejar ao mesmo tempo o valor-trabalho de Smith e Ricardo. Também Castoriadis compreende a teoria do valor como uma explicação dos preços ou da proporção em que as coisas são trocadas. Esse compreensão restritiva da teoria o leva a considerar o trabalho social que se configura em medida do valor como uma substância metafísica. O autor lança mão do trabalho complexo e de sua redução ao trabalho simples para desconstruir a definição de valor de Marx.

Começamos com a distinção que estabelece entre o valor-trabalho na economia política clássica e o de Marx. A diferença central diz respeito à substância do valor:

(...) o valor trabalho dos clássicos, de Smith e de Ricardo, não invoca a categoria da "substância" e se aí se descobrisse a palavra, seria sem dúvida num emprego inocente. Que as mercadorias são trocadas em proporção ao trabalho que sua produção custa, isso quer dizer para os clássicos: se alguém me propusesse trocar um produto que me custou dez horas de trabalho por um de seus produtos cuja fabricação só me custaria nove horas de trabalho, eu recusaria sua proposta; e, mediante a concorrência, a relação dos respectivos tempos "médios" de trabalho regulamentará a relação das quantidades trocadas. O "valor-trabalho" é assim, antes das imensas (e insuperáveis) complicações criadas pelas diferenças dos trabalhos individuais, pelo "capital", pela "terra", pelo "tempo", etc., um assunto de bom senso e mesmo uma tautologia simples: quem daria dez para ter nove? $?^{36}$

Enquanto, para Böhm-Bawerk, Smith e Ricardo apenas postulavam aquilo Marx procurou provar, para Castoriadis os autores clássicos elaboram teoricamente o bom senso. A teoria do valor-trabalho de Smith e Ricardo, que de acordo com o autor se volta a explicar a proporção nas trocas, se reduz a uma tautologia simples. Esta pressupõe que sejam conhecidos os tempos de trabalho que cada produto custou: “(...)

\footnotetext{
e que os dois fatos não andem sempre de mãos dadas está estabelecido pela experiência de modo sólido demais para comportar dúvida. É provado por todo o trabalho diariamente gasto em resultados sem valor, devido tanto à falta de habilidade técnica, a um risco mal calculado, ou mero azar; e não menos por cada um dos numerosos casos em que um pequeno esforço alcança resultados de grande valor'” (BöhmBawerk cita seu próprio texto, Capital and interest, p. 377, in A conclusão de Marx, p. 65).

${ }^{36}$ CASTORIADIS, Cornelius. "Valor, igualdade, justiça, política: de Marx a Aristóteles e de Aristóteles até nós", in As encruzilhadas do labirinto - vol. I. Tradução de Carmem Sylvia Guedes e Rosa Maria Boaventura. São Paulo: Paz e Terra, 1997, 2a ed., p. 336. Doravante Encruzilhadas I, seguido pelo número da página.
} 
se alguém me propusesse trocar um produto que me custou dez horas de trabalho por um de seus produtos cuja fabricação só me custaria nove horas de trabalho, eu recusaria sua proposta". Por outro lado, o conhecimento do tempo empírico incorporado em cada produto, ainda que pudesse ser calculado, não basta para pôr em prática o bom senso dos trocadores, já que as trocas se pautam nos tempos médios de produção, que por sua vez são estabelecidos na concorrência: “(...) e, mediante a concorrência, a relação dos respectivos tempos "médios" de trabalho regulamentará a relação das quantidades trocadas”. Assim, não fica clara a compreensão que Castoriadis tem dos clássicos: a proporção nas trocas se determina pelo bom senso dos agentes ou pela ação da concorrência, processo social indiferente ao senso individual? Castoriadis procura explicar o valor-trabalho de Smith e Ricardo pelas decisões individuais pautadas no interesse privado - que para ele se identificam com o bom senso ${ }^{37}$ - mas não escapa da interferência do processo social que constitui a concorrência e o estabelecimento dos tempos médios de trabalho. Deste modo, sua tentativa de resguardar os clássicos da crítica que dirige a Marx frustra-se pela ambiguidade do raciocínio.

Se o valor-trabalho dos clássicos é uma formalização do bom senso, a reformulação que Marx faz da teoria do valor é, para Castoriadis, metafísica. O autor escreve:

O primeiro capítulo do Capital é metafísico. A questão colocada pela economia política clássica: por que os objetos trocados o são em tal proporção e não em outra, Marx a reformula a seu modo, numa formulação que já contém, ou predetermina, a resposta: "Qual é o igual/idêntico (das Gleiche), isto é, a substância comum (die gemeinschaftliche Substanz) que a casa representa para a cama na expressão do valor da cama?" (Castoriadis, Encruzilhadas I, 336).

Smith e Ricardo pressupõem esta medida comum aos objetos trocados sob a denominação "trabalho humano". Böhm-Bawerk não tem dúvida sobre isto, e por essa razão, ao recusar a teoria do valor de Marx, condena ao mesmo tempo o valor-trabalho dos clássicos, que, segundo ele, apenas postulam esta medida, e considera "escolástica" a investigação sobre a equivalência nas trocas. No discurso de Castoriadis, a medida do valor dos produtos nos clássicos pode existir sem que haja uma unidade comum. Em sua concepção, Marx criou a ideia de que deve haver algo comum entre as mercadorias para

\footnotetext{
${ }^{37}$ A troca de força de trabalho por produtos do trabalho, em que os trabalhadores, por mais que sejam dotados de bom senso, não podem "recusar a proposta" de trocar dado tempo de trabalho vivo por produtos cuja fabricação custou tempo menor de trabalho não é abordada por Castoriadis.
} 
que sejam medidas em seu valor, e definiu esta substância como "Trabalho Simples,

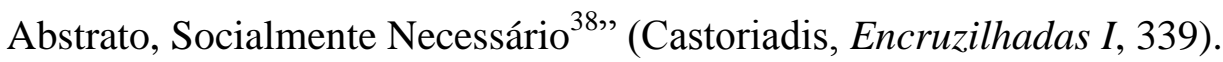

Mas é importante destacar que o próprio Castoriadis não consegue fugir à equiparação das mercadorias na troca. Quando afirma que faz parte do bom senso dos trocadores recusarem-se a trocar nove por dez, isso significa que a medida das mercadorias é objetivamente "nove" ou “dez”. Se é possível medi-las quantitativamente, é porque há um substrato contável. O autor poderia defender, como faz Böhm-Bawerk, que essa medida é dada pela utilidade em si mesma. Mas aí, como a medida do valor teria um componente subjetivo, não haveria como atribuir quantidades objetivas, "nove" ou "dez", e o próprio "bom senso" seria variável. De modo que o que Castoriadis pretende defender, não é o que ele afirma. Sugerir uma quantidade objetiva por meio da qual se comparam duas coisas (isso vale nove, aquilo dez) e ao mesmo tempo recusar qualquer medida ou substância comum entre elas é tão irracional quanto se perguntar “Qual é a distância entre a letra A e uma mesa?” (TMV III, 1197).

O autor propõe o problema da redução social dos trabalhos concretos efetivos a trabalho socialmente necessário, a trabalho simples e a trabalho abstrato, ou seja, à forma social que as atividades efetivas assumem enquanto produtivas de valor. Para ele, todas essas operações de redução são impossíveis, e resultam de raciocínio metafísico:

O que é, "em verdade”, o Trabalho Simples, Abstrato, Socialmente Necessário? Qual é o modo de ser dessa Substância/Essência e como chegamos a isola-la em estado puro (quimicamente) ou determina-la plenamente (fisiologicamente)? O que se passa no mundo vulgar da aparência não é o Trabalho, mas trabalhos heterogêneos e incomparáveis: ofícios diferentes, exercidos cada um em condições diferentes aqui e acolá, por indivíduos diferentes em força, capacidade, diligência, etc. Passar dessa diferença fenomenal à unidade da Substância/Essência Trabalho requer múltiplas operações de redução (em todos os sentidos do termo). Vamos ver, resumidamente, que essas operações são "em verdade” impossíveis, que o Valor e Sua Substância (como, aliás, sua grandeza), longe de serem "determinados", são antes nebulosas de enigmas e que essa situação está profundamente enraizada no caráter antinômico do pensamento de Marx (Castoriadis, Encruzilhadas I, p. 339).

Castoriadis começa sua demonstração resumida da impossibilidade da redução dos trabalhos efetivos às categorias sociais com a categoria de trabalho socialmente

\footnotetext{
${ }^{38} \mathrm{O}$ autor escreve estes termos com letra maiúscula, o que é de sua própria lavra. Acredito que Castoriadis tenha feito esta escolha para propor uma imagem irônica de sua interpretação, segundo a qual todas as categorias da teoria do valor de Marx são entidades metafísicas.
} 
necessário. Para ele, há três interpretações possíveis desta expressão. Pode significar, por um lado, o tempo despendido pelas empresas mais eficazes na produção de determinado artigo, e por outro, o tempo despendido pelas empresas menos eficazes. No primeiro caso, a lei do valor não funcionaria, porque, ao tomar o mercado das demais, as empresas que lançam mão de tecnologias mais avançadas constituiriam um monopólio, limitando a concorrência de que depende a redução dos trabalhos a trabalho socialmente necessário. Tampouco a lei seria válida no segundo caso, em que o lucro seria mais bem explicado pela "concepção neoclássica como uma 'quase renda' diferencial" (Castoriadis, Encruzilhadas I, 341), em que as empresas menos eficazes realizariam lucro mínimo ou nulo. No raciocínio de Castoriadis, a legitimidade da lei do valor deveria basear-se na confirmação de que as mercadorias se trocam pelo tempo de trabalho incorporado, e portanto as empresas lucram a mais-valia que criam. Resta a última interpretação, segundo a qual trabalho socialmente necessário significa o tempo médio de produção de dado artigo. Castoriadis condena esta explicação como uma abstração vazia, uma vez que as empresas não produzem efetivamente pelo tempo médio. O conceito apenas deixaria de ser vazio se o produto da maioria das empresas efetivamente fosse criado neste tempo médio. Esta possibilidade não existe, continua Castoriadis, porque significaria uma ausência de alteração na produtividade: quando a técnica é aprimorada, as empresas necessariamente superam o nível médio. As mudanças técnicas compõem a natureza do capital. Para que a criação dos produtos fosse reconduzida aos tempos médios após uma mudança na produtividade, a concorrência teria de ser perfeita. Em seus termos:

\footnotetext{
(...) é preciso a mobilidade perfeita e instantânea dos capitais e dos operários, a ausência de todo entrave à "entrada" num ramo de produção, a existência, em cada ramo, de uma porção de empresas, cada uma insignificante em relação à procura total do ramo, a "transparência" de mercado e a informação instantânea e gratuita, etc.; é preciso, em todo caso, que um capitalismo ao mesmo tempo "desenvolvido" e "puro" tenha sido estabelecido e funcione segundo o modo "concorrencial" (Castoriadis, Encruzilhadas I, 343).
}

Se todas essas condições se efetivassem, as mercadorias não seriam, contudo, trocadas pelos seus valores, mas pelo preço de produção, o que leva Castoriadis a concluir que a lei do valor não funciona no capitalismo desenvolvido. Mas tampouco vale para a simples produção mercantil, porque neste caso não haveria trabalho socialmente necessário, dada a ausência da concorrência. Castoriadis resume: 
(...) quando uma parte das condições de validade da "lei do valor" é dada sob a forma da concorrência, etc., estamos em plena produção capitalista desenvolvida que implica ipso facto a troca não segundo os "valores", mas segundo os "preços de produção". E quando a troca não está ainda submetida às leis do capital e da perequação da taxa de lucro, na simples produção mercantil, não é possível definir um "tempo de trabalho socialmente necessário" médio, pois a mediação essencial para a dominação efetiva de um tal tempo médio, a "concorrência" do tipo capitalista, não existe (Castoriadis, Encruzilhadas I, 344).

Assim, em nenhuma das interpretações possíveis do significado de trabalho socialmente necessário, esta categoria se sustenta. Percebe-se que Castoriadis exige da categoria de trabalho socialmente necessário que se constitua como um atributo das produções singulares concretas. Sob esse pressuposto, é evidente que a categoria não se sustenta, porque aí o trabalho que cria valor não é médio, mas uniforme. Em Marx, ao contrário, a categoria tem importância justamente porque as produções singulares de determinada espécie de valor de uso não ocorrem sob as mesmas condições. Se Marx houvesse afirmado que os trabalhos singulares são ou devessem ser médios em seu caráter concreto, efetivo, a categoria seria dispensável. O autor a toma por uma abstração vazia sem atentar para o fato de que o conteúdo real dessa abstração pressupõe o trabalho social. O mesmo se passa com a tese de Castoriadis referente à legitimidade da lei do valor. Ele assume que esta lei consiste em uma norma técnica e imediata de determinação dos preços de mercado. Nesse sentido, ela seria realmente contraditada pelo preço de produção. E o texto de Marx, de uma incoerência interna tal que seria de se estranhar que só fosse notada por Castoriadis - que aliás não menciona Böhm-Bawerk - um século depois de sua publicação. As razões que explicam por que o valor apenas se manifesta na forma transfigurada de preço, e nunca de modo imediato, estão também no bojo do trabalho social. Como o valor, o preço expressa uma relação social, ponto que o autor não toca. Nem o preço, nem o valor, nem o trabalho ou qualquer categoria econômica de Marx pode ser compreendida apenas por meio da análise do processo produtivo concreto, da troca pontual ou da demanda individual, mas apenas pela consideração da forma social da produção, conforme desenvolvo adiante.

Castoriadis pretende ter demonstrado que a operação de redução dos trabalhos reais a trabalho socialmente necessário é impossível, e busca explicitar do mesmo modo que a redução do trabalho complexo a simples também o é. Seu argumento, neste tema, é essencialmente o mesmo de Böhm-Bawerk. Citamos um trecho longo em que o autor pergunta e responde: 
Como podemos operar a "redução" do trabalho complexo a Trabalho Simples? "A experiência mostra", diz Marx "que essa redução se faz constantemente". Mas o que se faz na experiência não é senão uma redução de fato; e não pode ser considerada, sem círculo vicioso, como traduzindo uma comensurabilidade de direito, substancial/essencial, das diversas variedades de trabalho. A redução que se faz na experiência não é a redução de todos os trabalhos a Trabalho Simples; é "redução" de todos os trabalhos a dinheiro (ou a um outro "equivalente geral" ou numerário socialmente instituído), o que não é absolutamente a mesma coisa, o que já sabíamos sem “teoria do Valor", o que a "teoria do Valor" deveria explicar - e ao invés disso é onde ela se apoia para existir como teoria. E como poderia ela explica-lo um dia? Talvez um dia a fisiologia ou a química poderão dizer como, em que grau e em que sentido, como "gasto do cérebro, dos músculos, dos nervos", etc., o trabalho da rendeira é intrinsecamente "múltiplo" ou submúltiplo do trabalho do mineiro ou da datilógrafa, representa um quantum diferente da mesma Substância/Essência e fornecerá os coeficientes de conversão correspondentes (Castoriadis, Encruzilhadas I, 346-7).

Há dois pontos centrais da crítica de Castoriadis: primeiro, a inexistência de uma medida ou substância comum aos trabalhos simples e complexo: não há nem trabalho simples no trabalho complexo, nem uma terceira substância comum ambos. Segundo, deveria ser possível determinar a priori a proporção entre os diferentes graus de qualificação do trabalho. Poderíamos dizer, como Rosdolsky diz de Böhm-Bawerk, que o problema colocado se aplica também às múltiplas qualidades de trabalho simples. $\mathrm{E}$ acrescentar que, ainda que se tome um produto singular, não há como calcular com exatidão, dada a divisão do trabalho, nem mesmo o tempo empírico de trabalho aí incorporado. $\mathrm{O}$ autor se opõe, assim, à consideração de que as atividades produtivas, inclusive as qualificadas e intelectuais, são formas do trabalho humano em geral, e à de que a medida quantitativa do valor é uma medida social, dependente do conjunto da produção no interior de um mercado.

Para Castoriadis, todos os trabalhos se reduzem a dinheiro. É importante destacar que, para ele, esta redução não merece qualquer investigação. Ele não se pergunta, por exemplo, por que as mercadorias se reduzem a esta ou aquela quantia de dinheiro. Ademais, salta aos olhos, nesta passagem, a definição que Castoriadis dá ao dinheiro: "numerário socialmente instituído". Portanto, algo convencional, talvez politicamente estabelecido, e não desenvolvido no bojo das relações econômicas históricas. $\mathrm{O}$ autor não explica a relação das mercadorias com o dinheiro, de modo que as relações de trocas devem ser também determinadas por convenção: dada a ausência de qualquer questão posta pelo autor ao fato de as coisas "se reduzirem" a dinheiro, 
parece que para ele as mercadorias são etiquetadas com este ou aquele preço também por determinações externas às relações efetivas entre os produtores. O que parece denotar que as relações de troca se baseiam em última instância na utilidade, ou seja, subjetivamente.

Nesta passagem se torna claro também que Castoriadis entende o trabalho, em Marx, como uma função da fisiologia humana, um dispêndio fisiológico ou mesmo químico - de qualquer modo, meramente natural - de energia física. Além disso, entende o valor, para Marx, como cristalização de trabalho simples, ou seja, de um conjunto definido e limitado de atividades concretas ecoando diretamente a concepção de Böhm-Bawerk. O autor também não investiga o trabalho abstrato:

\footnotetext{
A mesma coisa vale enfim para o que se refere à redução do trabalho efetivo, concreto, a Trabalho Abstrato. Não podemos nisso nos demorar. Notemos apenas que com duas páginas de distância o Trabalho Abstrato é, sucessivamente, "gasto produtivo do cérebro, dos músculos...", etc., ou "gasto, no sentido fisiológico, de força humana e, por essa razão como trabalho humano igual, forma o Valor das mercadorias" - e "unidade social... (que) só pode manifestar-se nas transações sociais" (sublinhado por mim). Essa abstração é afinal "fisiológica" ou "social" - ou então essa distinção não tem razão de ser? Os nervos e os músculos são "forma de aparecimento" do social - ou então o social é "expressão" e "apresentação" dos nervos e dos músculos? (Castoriadis, Encruzilhadas I, 349).
}

Para compreender o dispêndio de força de trabalho como medida do valor ao lado de seu caráter de unidade social, é necessário demorar-se na categoria de trabalho abstrato. Não apenas no exame desta forma social histórica do trabalho, mas também na categoria de trabalho mesmo. Os capítulos seguintes retomam essas categorias fundantes do pensamento de Marx.

Castoriadis não teria mesmo condições de compreender o que é o trabalho abstrato porque identifica a troca comercial ao intercâmbio humano de produtos, isto é, ao intercâmbio em geral, e deixa passar a especificidade desta forma social do intercâmbio. Com isso, não pode ver que o trabalho assume duplo caráter na forma de sociabilidade em que a produção se volta para a troca. Castoriadis escreve:

O Valor já estava aí desde que houve "troca". Mas há sempre troca onde há sociedade inclusive no "comunismo primitivo": o feiticeiro fornece feitiços e recebe uma parte da caça. Há até trocas, se ousamos dizê-lo, "antes da sociedade - em todo o caso, há, segundo Marx, Valor para Robinson, salvo que para ele o valor é 'transparente': 'como bom inglês' (o que quer dizer homo economicus 'racional'), ele mantém um 'inventário detalhado' do tempo de trabalho que, 
em média, quantidades determinadas de seus produtos lhe custam... Todas as determinações essenciais do valor estão aí contidas". E a mesma coisa será válida para uma sociedade comunista futura, essa "reunião de homens livres trabalhando com meios de produção comuns... segundo um plano estabelecido. Tudo o que dissemos do trabalho de Robinson se reproduz aqui, mas socialmente e não individualmente" (Castoriadis, Encruzilhadas I, 351).

O crítico interpreta a teoria de Marx no sentido de que o trabalho é, por sua natureza de trabalho, criador de valor. Em outras palavras, o produto do trabalho é valor, porque valor é tempo de trabalho. Em segundo lugar, qualquer intercâmbio humano ou sociabilidade é troca: a divisão do trabalho em uma tribo se torna em Castoriadis "troca de feitiços por caça". Desta forma, se valor é tempo de trabalho cristalizado em um produto posto para a troca, e troca se identifica com intercâmbio social ou sociabilidade, valor e produto não se distinguem, aquilo que é valor de uso é também necessariamente valor. Por isso, inverte o sentido da passagem sobre o fetichismo. Nela, Marx explica que o valor é uma forma social específica do produto do trabalho quando este ocorre sob as relações determinadas pela propriedade privada, ou seja, quando se produz para a troca. Deste modo, o valor pressupõe a produção humana e os fatores que determinam o valor estão presentes na consideração abstrata da produção, sem levar em conta a forma social. Mas o próprio valor é uma forma específica do produto social. O exame do capítulo sobre o fetichismo da mercadoria faz parte do capítulo IV desta pesquisa.

Se por este ponto de vista o valor tem, na leitura que Castoriadis faz de Marx, validade universal, de outro ângulo, a lei do valor é uma explicação da determinação imediata dos preços que nunca é válida. Quando enquadra o pensamento de Marx em um sistema de normas positivas para explicar o funcionamento imediato das ações econômicas pontuais, o autor perde a reflexão propriamente dita:

Quando é portanto que a "lei do valor-trabalho" vale? Num sentido, nunca, em nenhum grupo de condições sociais e histórias efetivas ou construíveis de maneira coerente. Em outro sentido, sempre, desde sempre e no sempre. Pois resulta da Posição dessa Substância, o Trabalho, que existe do começo ao fim da história humana e se "cristaliza" em produtos (Castoriadis, Encruzilhadas I, 344).

A ausência de consideração do valor como forma social do produto do trabalho que se realiza com vistas à reprodução do capital, e por conseguinte do duplo caráter que o trabalho assume neste modo de produção, é que o leva a identificar valor e produto. Nesta identificação, o valor se torna um nome para tempo de trabalho em geral e com 
isso perde o sentido. Tornam-se indistintas a riqueza na forma de valor e a riqueza concreta. A riqueza moderna - a monstruosa coleção de mercadorias - é a mesma riqueza, embora em maior quantidade, que a caça e os feitiços que Castoriadis menciona. Como adere a criação de valor à atividade do trabalho, o valor como medida das trocas é também concebido como uma determinação imediata. A mediação social que faz do valor uma medida que apenas se manifesta no preço, como forma transfigurada do valor, é vista então por Castoriadis como um campo metafísico.

\section{5. Teorias do trabalho imaterial e do valor qualitativo: questões para a obra de Marx e para a atualidade}

Os teóricos que defendem um valor qualitativo ou veem no trabalho intelectual, hoje empregado pelo capital, uma transformação na relação de valor são importantes por buscarem investigar o significado do desenvolvimento econômico para a transformação social e abordarem o devir do capital. O problema que pretendem resolver é o da forma social da atual reprodução da vida. Buscam fornecer indicações que contribuam para compreender em que relação social se dá a produção atual. Os autores assumem alguns pressupostos em comum. Primeiro, consideram que a teoria do valor de Marx explica o capitalismo industrial. Segundo, assumem que a teoria do valor de Marx deve hoje ser posta em questão. Por que esta teoria tem hoje de ser revista? Centralmente porque atividade produtiva, o trabalho, se transformou em suas determinações concretas. Da atividade mecânica do operário à máquina, tornou-se atividade que requer conhecimento e criatividade. Não apenas a atividade, mas a própria força produtiva hoje tem outro conteúdo: dos sistemas de máquinas que caracterizavam a força produtiva determinante nas duas primeiras revoluções industriais, a ciência, o conhecimento em si mesmo, é o que passa a constituir hoje a força produtiva determinante. Essas mudanças dizem respeito ao conteúdo ou caráter concreto do trabalho, do produto e da força produtiva. Mas desta transformação, em terceiro lugar, os autores derivam um problema para a forma valor do produto e a forma abstrata do trabalho: o conteúdo concreto da atividade não permitiria mais sua medida pelo tempo. Desta inadequação resultaria uma mudança formal na atividade produtiva, impedindo seu produto de assumir a forma social de valor, ao menos como Marx o definiu.

Dois fatores fornecem a base para esta tese comum. Primeiro, os autores incluem na medida pelo tempo a determinação da previsão. Medir o trabalho pelo tempo inclui, 
para esses autores, a possibilidade de prever o tempo de trabalho necessário em que o produto será criado. Esta previsão, se é necessária para cada empresa singular em seu interesse privado, não o é para a determinação do valor das mercadorias, visto que este se constitui pelo tempo de trabalho socialmente necessário, e não empírico ou individual. E se estabelece no mercado, aparecendo necessariamente pela forma transfigurada do preço, de modo que o valor individual das mercadorias não é determinado pelo tempo de trabalho imediato incorporado à mercadoria e tampouco se manifesta diretamente. Sua forma própria de manifestação é o preço.

Segundo, na concepção de Gorz, Negri \& Lazzarato, Fausto e Prado, há uma imbricação conceitual do trabalho abstrato - forma social - com o trabalho manual, mecânico, repetitivo, passível de decomposição, isto é, com determinada forma do trabalho concreto característica do operário à máquina na indústria anterior à informatização. O modo concreto do trabalho simples se coloca, no discurso dos pesquisadores examinados, como aspecto necessário da forma social abstrata do trabalho. O trabalho que demanda qualificação, diferentes faculdades subjetivas e saberes não assume forma abstrata porque não se reduz a mera quantidade de trabalho social. Seus diferenciais qualitativos impossibilitam a comensurabilidade entre tais atividades e o trabalho simples. O que se depreende desta tese é que a expressão trabalho humano em geral não envolve o conjunto das atividades produtivas. Sabemos que é condição da forma social abstrata do trabalho a consideração de que as atividades de qualidades distintas são todas formas particulares do trabalho humano. Como tais, são comensuráveis. Por isso, seu produto, quando assume a forma de mercadoria ou valor de troca dos demais, é valor, quantidade de trabalho humano objetivado. Parte dos produtos hoje criados - softwares, por exemplo - a despeito de desempenhar funções centrais para a reprodução capitalista, não seria valor de troca dos produtos materiais, visto que não apresentam as condições de comensurabilidade.

A questão da medida da atividade pelo tempo fundamenta o conjunto da argumentação que defende a crise do valor ou o valor qualitativo. Medida designa uma qualidade comum que permite determinar diferenciais de quantidade. A quantidade de trabalho tem o tempo como sua unidade de medida, porque trabalho é ação. Para os teóricos do trabalho imaterial (Gorz e Negri \& Lazzarato) ou do valor qualitativo (Fausto e Prado), as atividades criativas não se adequam ao tempo como unidade de medida. Disto, concluem que a natureza ou medida da atividade é distinta. Do problema 
da medida quantitativa do trabalho, os autores defendem uma tese relativa à medida como qualidade comum das atividades humanas: nem todas apresentam a qualidade comum de trabalho humano, esta natureza que possibilita determinar as diferenças quantitativas de valor pela unidade de medida da ação que é o tempo. Porque não se medem pelo tempo, as atividades cognitivas e criativas têm outra medida qualitativa, uma natureza diversa. Nem todas as atividades produtivas são, pois, formas particulares do trabalho humano.

Assim, partindo da questão do valor como produto das atividades humanas, isto é, do problema da forma social do produto, os teóricos do valor qualitativo acabam por defender uma diferença de natureza entre as atividades intelectuais e as atividades mecânicas para além do problema da criação de valor ou da forma social específica: as múltiplas atividades produtivas repetitivas e simples podem todas ser vistas como formas concretas distintas do trabalho social, mas atividades cognitivas não são apenas formas particulares do trabalho humano em geral. Não apresentam esta qualidade comum, e portanto não podem ser comparadas com as atividades simples e distinguidas pela quantidade, nem mesmo quando o produto de todas elas é valor - mercadoria que funciona como valor de troca das demais. $\mathrm{O}$ valor tem pois duas naturezas, uma quantitativa e outra qualitativa? Como o valor qualitativo se distingue então do valor de uso?

Em resumo, os autores que defendem o advento de um valor qualitativo partem de uma verificação de transformações concretas no trabalho, resultantes do desenvolvimento técnico, consideram que a atividade criativa intelectual não pode ser medida pelo tempo e disto concluem que o valor muda de natureza. Nesta conclusão, está implícita a diferença de natureza entre os trabalhos humanos reprodutivos e os criativos, que os tornam incomensuráveis. Desta diferença concreta, portanto, deriva a transformação da natureza social do produto, que é o valor. A alteração no caráter social do produto não é argumentada com base em mudanças nas relações sociais de produção, mas em uma determinação concreta da atividade que acarretaria uma de duas consequências necessárias: ou tornaria impossível à forma intelectual da atividade criar valor (Gorz) ou, ainda, daria a esta forma concreta de trabalho o poder de transformar a natureza do valor, e portanto o conjunto da relação social do capital (Fausto e Prado, com a transformação substancial do valor prevista nos Grundrisse, e Negri \& Lazzarato, 
com o advento de uma nova relação social de produção, comunista, nos interstícios da sociedade capitalista).

$\mathrm{Na}$ argumentação dos autores que pretendem datar a teoria do valor aparecem aspectos de uma interpretação do valor e de uma caracterização do trabalho humano que apresentam pontos em comum com as antigas críticas à teoria do valor-trabalho. A tese de que as atividades intelectuais não podem ser reduzidas a mera quantidade de trabalho humano ecoa as contraposições à teoria do valor escritas por E. Böhm-Bawerk e C. Castoriadis. Tanto estas críticas, que pretendem invalidar a teoria de Marx, quanto as teses do valor qualitativo, que pretendem datá-la, parecem desconsiderar o que há de central na categoria de trabalho abstrato, que é a forma social da relação de produção que ele expressa: o que caracteriza esta forma social do trabalho é precisamente sua capacidade de igualar atividades tão distintas como a da arquiteta e a do mineiro, ou a do trabalhador rural e a da cantora. E esta igualação se dá pelo valor, pela forma social do produto que se constitui como valor de troca dos demais, e não pela medida imediata do trabalho pelo tempo. A crítica antiga à teoria do valor apresenta duas posições: a principal sugere que as atividades simples e complexas não podem ser igualadas, porque não têm a mesma natureza, de modo que não é possível a abstração das determinações concretas e portanto qualquer medida de valor - "não há trabalho simples no trabalho complexo"; a segunda defende que as atividades são todas imediata e empiricamente iguais no que diz respeito à criação de valor. Dühring descarta qualquer mediação social na determinação do valor ao afirmar, em sua crítica da redução o trabalho complexo ao simples, que o tempo empírico é definitivo do valor; Böhm-Bawerk recusa a medida comum aos diversos trabalhos e por conseguinte, a redução do trabalho complexo a trabalho simples; assim como Castoriadis, que chega a quantificar o que não tem medida. Nenhum deles se volta à análise da categoria de trabalho abstrato ou à natureza do valor. Contudo, em uma conhecida carta a Engels de 1867, referindo-se ao livro primeiro de $O$ Capital, Marx afirma:

O que há de melhor no meu livro é: 1) (e é sobre isso que repousa toda a compreensão dos fatos) a colocação em destaque, desde o primeiro capítulo, do duplo caráter do trabalho, que se exprime em valor de uso ou em valor de troca; 2) A análise da mais-valia, independentemente de suas formas particulares: lucro, juros, renda fundiária, etc. ${ }^{39}$

\footnotetext{
${ }^{39}$ Carta de Marx a Engels de 24 de agosto de 1867. MARX, K., ENGELS, F. Selected Correspondence, $2^{\mathrm{a}}$ ed., Moscou: Progress Publishers, 1965, p. 192.
} 
O duplo caráter do trabalho é a determinação sobre a qual repousa toda a compreensão dos fatos, ou seja, da produção capitalista, na teoria de Marx. É talvez sua maior contribuição à economia política e está na base da crítica à economia clássica: o duplo caráter do trabalho - o trabalho abstrato, e seu produto, o valor - é uma forma da atividade correspondente especificamente à relação capitalista de produção, e não à produção em geral. A consideração da natureza social do trabalho abstrato não pode pois ser deixada de lado em uma leitura consistente, mesmo que crítica, do texto de Marx.

Também os defensores de um valor qualitativo tiram conclusões extremas a respeito do capitalismo atual - o valor passa a ter outra natureza, ou não é mais possível produzir valor - examinando as atividades cognitivas singulares em sua relação com a medida pelo tempo, em especial ao destacar a impossibilidade de prever o tempo que custará a conclusão de dada tarefa criativa. Tais conclusões são defendidas sem um exame demorado da natureza social do valor, isto é, da forma de propriedade que define o produto do trabalho humano como capital. Um ponto a se investigar é então a própria determinação do valor como uma forma da relação social de produção. Busco mostrar que o caráter concreto da atividade individual, ainda que cognitiva e criativa, é indiferente a esta forma, analisando sua natureza e a especificidade do trabalho complexo.

A crítica da noção de valor qualitativo não esgota, entretanto, as questões postas à atual fase do capitalismo pelos teóricos que abordam a questão do trabalho imaterial ou intelectual. À forma social do capital não é indiferente o desenvolvimento das forças produtivas, que impõe novas formas concretas à atividade individual do trabalho. Ao abordar a criação da mais-valia relativa n'O Capital, Marx descreve o processo em que a relação capitalista de produção se põe e se desenvolve. Ao subsumir a produção, o capital toma o trabalho conforme existe na produção tradicional - o trabalho artesanal da indústria doméstica complementar rural - e o concentra em casas de trabalho, criando o trabalho cooperativo da manufatura. O processo natural de desenvolvimento deste trabalho coletivo é a divisão do trabalho, e sua especialização é ao mesmo tempo a simplificação do trabalho que se mantém, contudo, artesanal. A criação da máquinaferramenta, oriunda da especialização das ferramentas levada a cabo pelo desenvolvimento da manufatura, transfere a técnica subjetiva ao mecanismo, subtraindo ao trabalho seu caráter artesanal e simplificando-o ainda mais. O advento da máquina 
motriz a vapor e o desenvolvimento do sistema de máquinas, que define a indústria, completa a simplificação do trabalho à máquina, reduzindo a quase nenhuma as habilidades requeridas pela atividade. Mas este processo é ao mesmo tempo a criação de um segundo grupo de trabalho produtivo responsável pela criação e aprimoramento técnico das máquinas e sistemas. Trata-se da incorporação do trabalho intelectual, da ciência, ao trabalho produtivo; da criação de um modo de produção que se define como "aplicação consciente da ciência" a um mecanismo automático. A tendência técnica deste processo é a eliminação da interferência humana no funcionamento deste mecanismo, o que se alcança por meio da produção científica e técnica. Esse campo de atividade produtiva tende a se ampliar conforme o trabalho simples direto seja substituído por mecanismos automáticos. De modo que o desenvolvimento mesmo das forças produtivas impõe mudanças às formas concretas do trabalho individual no decorrer da história do capital, e entre elas, a subsunção do trabalho intelectual ao capital. A ideia de que o trabalho que resulta em conhecimento ou que demanda o conhecimento como meio principal de produção altera por si mesmo a relação capitalista implica a defesa de que o capital, no processo de seu desenvolvimento, dissolveria sua natureza própria, a forma de relação que o define. Ou seja, o que está na base da concepção de valor qualitativo é a ideia de que o aprimoramento material, por si mesmo, seria então capaz de alterar a natureza da relação-capital.

As teorias do valor qualitativo supõem a atividade material e a atividade intelectual como distintas na raiz. Mas não investigam como o conhecimento se relaciona com a produção no capitalismo atual, isto é, como se integra à produção material e que papel desempenha nesta produção. É importante destacar que nunca se produziu tanta mercadoria, tão imensa massa de bens materiais, como na "sociedade do conhecimento". Assim, a subsunção da ciência ao capital (tornada um ramo de investimento de capital e emprego de trabalho assalariado, que coletiviza, especializa e aprimora a produção científica, "industrializa" a produção de conhecimento) é parte de um processo de ampliação da produção material. Mais do que isto, nos processos produtivos automatizados as atividades intelectuais se tornaram o meio pelo qual se produzem coisas materiais. Já o eram no sistema de máquinas, em todas as produções industriais que se caracterizam como aplicação consciente da ciência. Mas na automação, que completa a mecanização do processo, a atividade intelectual se torna virtualmente a única atividade produtiva. Suponhamos, por exemplo, que a criação de 
um dado produto parcial alcançou tal nível de automação que pode ser produzido pela operação de um software. Como fica neste caso a distinção entre trabalho material e trabalho intelectual? Um ponto que esta pesquisa investiga é esta distinção na teoria de Marx, destacando tanto sua imbricação necessária, quanto sua separação, que coincide e é definitiva da divisão de classe nas sociedades pré-capitalistas. No capitalismo, esta coincidência entre a divisão entre trabalho material e trabalho intelectual e divisão de classe entre trabalho e capital se desconstrói progressivamente. Em Marx, a relação entre a produção material e a produção intelectual é determinante na caracterização da forma de sociabilidade, e o advento do trabalho intelectual como forma da atividade produtiva material vem mostrando que a relação capitalista tem a especificidade de criar um novo patamar histórico da produção em seu processo de constituição. Este patamar se expressa nas recentes transformações da relação entre trabalho material e intelectual.

Estas mudanças colocam a questão da mercadoria como forma elementar da riqueza que é valor. Para a reprodução do capital, é preciso que o trabalho produtivo seja incorporado em produtos que assumam a forma de mercadoria. $\mathrm{O}$ valor, determinado pelo tempo de trabalho socialmente necessário para a criação de dada espécie de produto, se aplica a mercadorias reprodutíveis, àquelas que precisam ser constantemente reproduzidas. Como Gorz destaca, as descobertas científicas, os novos conhecimentos, as inovações organizacionais no processo produtivo, se se põem como condições de produção, não são reprodutíveis, ou seja, não necessitam ser reproduzidas para serem utilizadas ou apropriadas em novos processos produtivos. Diferentemente das condições materiais da produção que se desgastam e precisam ser produzidas novamente, como máquinas e matérias-primas, um novo conhecimento ou uma ideia inovadora, uma vez criados, não demandam ser novamente produzidos. Ou seja, sua reprodução ou apropriação para processos produtivos diversos não requer qualquer trabalho. Por essa razão, não é possível falar em trabalho socialmente necessário para a criação de novos conhecimentos. Cada conhecimento é novo, e o tempo para sua produção ou conquista depende do nível de desenvolvimento da pesquisa sobre cada objeto específico e do próprio objeto, que impõe mais ou menos dificuldades. De fato, este tempo não é previsível. Mas não é esta imprevisibilidade que impede a medida pelo tempo ou a manifestação de um tempo de trabalho necessário à criação científica, mas o fato de que, pela sua própria natureza teórica, o conhecimento não se desgasta e não requer trabalho para ser reproduzido. O conhecimento, que consiste em uma força produtiva imediata ao colocar-se na forma de softwares e tornar-se diretamente um meio 
de produção, não requer trabalho para sua reprodução. Além da capacitação dos indivíduos requerida para a apropriação do conhecimento criado, apenas seu suporte material tem de ser reproduzido. A questão que se coloca então é: o tempo de trabalho empregado na pesquisa científica cria valor? O que implica investigar se $o$ conhecimento pode assumir a forma de mercadoria. Assim, o problema da capacidade do trabalho científico criar valor não é baseado na determinação concreta da atividade como intelectual ou criativa, mas na determinação formal de seu produto na reprodução social.

Outra transformação relativa à forma social, que acompanha estas mudanças de conteúdo da atividade advinda do desenvolvimento técnico, é o fato de que os produtores de conhecimento se tornaram assalariados do capital, como também aponta Gorz. A presença de atividades e produtos que não criam valor mas são necessários à reprodução capitalista não é um aspecto que ponha em xeque esta reprodução, como se evidencia se consideramos o trabalho social empregado nas funções improdutivas da esfera da circulação. Mas quando o trabalho produtivo empregado pelo capital se volta à criação de novas forças produtivas ou inovações, isto significa que a parte do trabalho social que escapa ao trabalho necessário à reprodução imediata da sociedade e se dedica ao trabalho excedente foi também subsumido ao capital. Este aspecto afeta a forma social do capital: parte dos capitais na esfera da produção deixa de ser investida na criação imediata de mercadorias ou de valor e passa a ser investida para a realização de funções historicamente alheias à classe trabalhadora.

Assim, questões como: a produção de conhecimento é trabalho?, o trabalho envolve necessariamente o conhecimento?, o conhecimento é em sua natureza uma força produtiva ou apenas na indústria, quando a produção se torna "uma aplicação consciente da ciência"? continuam em aberto. Os debates apresentados no capítulo anterior atestam que não se argumenta sobre uma compreensão unívoca da categoria de trabalho, sua relação com o conhecimento e com o desenvolvimento produtivo, e das formas sociais em que se põe. Expressam uma caracterização ampla que conecta um caráter quantitativo ao trabalho (ao menos aquele que se realiza na indústria) e um caráter qualitativo àquelas atividades que criam conhecimento ou que são de algum modo criativas, isto é, requerem a utilização da criatividade para que algo novo, produto ou processo técnico que não existia, venha a existir. Assim, o trabalho material é 
repetição e o trabalho imaterial é criação. Em Metamorfoses do Trabalho ${ }^{40}$, Gorz afirma que trabalho, nas sociedades pré-capitalistas, sempre designou a atividade material restrita ao campo da necessidade, aquela realizada por mulheres e escravos na Antiguidade e por servos na Idade Média. O trabalho intelectual ou o trabalho de artesãos qualificados não eram considerados trabalho (Gorz, Metamorfoses, 22). Hoje, as "qualificações superiores" são inseridas no campo do trabalho, e a atividade intelectual se tornou trabalho (Gorz, Metamorfoses, 79). Mas não há um exame do que é atividade do trabalho e como se distingue ou se identifica com a atividade de produção de conhecimento e com as atividades criativas nos textos de Marx. Nestes, há uma exposição do processo social que cria a riqueza como "uma imensa coleção de mercadorias" e iguala o conjunto das atividades produtivas como formas específicas do trabalho social. Para que a expressão trabalho humano viesse de fato a abarcar o conjunto da atividade produtiva, inclusive as de "qualificação superior", foi necessário o desenvolvimento histórico de uma forma social particular da produção em que os indivíduos são efetivamente igualados: a propriedade privada. $\mathrm{O}$ exame das categorias de trabalho, trabalho material e trabalho intelectual, bem como do processo histórico que estabelece o trabalho humano em geral e o trabalho abstrato, nos textos de Marx, pode trazer elementos para a compreensão do atual momento histórico em que as atividades características do "reino da liberdade" são imersas no "reino da necessidade" pelo assalariamento, que caracteriza um patamar novo da divisão do trabalho, uma forma social em que a divisão de classe não se identifica mais com a divisão entre trabalho intelectual e trabalho material.

Deste modo, para responder às questões postas à atualidade por estes autores, é preciso levar em conta temas que não estão desenvolvidos em seus textos, em particular, as determinações da categoria de trabalho, a especificidade da forma social do capital, e a relação entre esta forma e o desenvolvimento das forças produtivas. A pesquisa dos textos de Marx começa, por isso, com um capítulo que examina as categorias centrais de trabalho e sociabilidade. Nos capítulos seguintes, a pesquisa se volta à possibilidade de dissolução ou de subversão da natureza da relação-capital pelo desenvolvimento produtivo, a partir de uma comparação entre esta forma social e as formas précapitalistas; e para a caracterização do capital por meio do exame, primeiro, do trabalho

\footnotetext{
${ }^{40}$ GORZ, André. Metamorfoses do trabalho - crítica da razão econômica. Tradução de Ana Montoia. São Paulo: Annablume, 2007. Doravante Metamorfoses, seguido do número da página.
} 
abstrato, e então, de como esta forma social se move no desenvolvimento produtivo. Ao longo do trabalho, busco retomar os argumentos específicos das teorias expostas nestes dois primeiros capítulos para criticar sua compreensão do valor, a tese de que a teoria do valor trabalho não é válida para o capitalismo atual, bem como a proposta de que Marx teria previsto uma subversão do conteúdo do valor em uma suposta última fase do capitalismo. O objetivo central desta pesquisa, contudo, é o de recuperar a teoria de Marx para destacar o modo como o capitalismo atual, tendo desenvolvido as forças produtivas, passa a subsumir a produção do conhecimento e o trabalho excedente da sociedade, criando formas novas de reprodução de capitais singulares, alterando a relação entre trabalho material e trabalho intelectual e redefinindo a divisão de classe em novos termos. Abordo ao final esses aspectos como formas do acirramento das contradições imanentes ao capital, procurando indicar respostas distintas às daqueles que defendem o atual valor qualitativo ou o fim do valor, para as questões que os mesmos autores colocam. 


\section{TRABalho, sociabilidade, forÇA PROdutiva e conheCimento: os textos de MARX FRENTE A UMA TESE DE J.A. GIANNOTTI}

O trabalho é em Marx uma categoria complexa. É a atividade produtiva que caracteriza o modo de ser do homem, a especificidade que o define frente às demais espécies animais, sua atividade vital. É uma atividade material que se realiza sobre o objeto natural, mas ao mesmo tempo consciente, implicando uma determinação intelectual e constituindo-se como atividade de um sujeito. É uma atividade necessariamente individual, cuja realização efetiva só pode se dar mediante a ação do indivíduo, ao mesmo temo em que se define como atividade social. É uma atividade histórica: seus modos se transformam ao incorporar os resultados alcançados pelas gerações anteriores. De modo que traz em si a determinação do desenvolvimento. Este diz respeito tanto ao domínio da natureza quanto ao indivíduo, sendo o processo de individuação também um produto central do trabalho, para além de seu produto material imediato. É uma atividade mediada por uma forma de apropriação do objeto material, uma relação social ou modo da divisão do trabalho. Esta se põe como divisão entre trabalho material e trabalho intelectual no seio da sociedade, e estabelece a divisão e o poder de classe. A separação entre as funções material e intelectual do trabalho, característica deste domínio, autonomiza o trabalho intelectual. Esta autonomização significa tanto uma cisão dos dois momentos do trabalho - a separação entre os aspectos material e intelectual da atividade produtiva por diferentes membros da sociedade - como a criação de atividades de trabalho novas, puramente intelectuais. A separação entre a ciência do objeto e sua transformação material tem por condição um dado desenvolvimento de forças produtivas e expressa certo nível de universalização do trabalho, de modo que a própria divisão entre trabalho material e intelectual, que em Marx caracteriza a divisão de classe, é distinta nas diferentes formas de sociabilidade, e não pode ser compreendida por meio de uma análise meramente conceitual dessas duas espécies de trabalho.

Assim, o homem como um ser específico na natureza; a relação entre indivíduo e gênero humano; a consciência e a subjetividade; a auto-produção do homem e a produção de um mundo humano; o desenvolvimento ou a história; a divisão do trabalho e a forma de sociabilidade; a imbricação e a cisão entre trabalho material e trabalho 
intelectual são aspectos envolvidos na categoria fundante de trabalho. Compreender esta categoria conforme Marx a desenvolve em passagens de diversos de seus textos contribui para esclarecer questões relativas à atual separação e imbricação entre trabalho material e intelectual; à criação de valor pela atividade intelectual, examinando o valor como forma social da atividade do indivíduo, um produto que é e não é individual; a relação entre essas duas formas de trabalho e a divisão de classe no capitalismo; a ciência como trabalho; a transformação histórica da noção de não-trabalho; entre outras. O trabalho é pois uma categoria cujo exame contribui para esclarecer diversas questões sobre o capitalismo atual, e por isso examino-a nos dois próximos capítulos. Neste, priorizo as definições gerais: a especificidade humana na natureza, a relação do homem com a natureza, a consciência, a criação de um mundo humano, a relação entre indivíduo e gênero, a relação social e a ideia de auto-constituição do homem, ainda sem levar em conta qualquer especificidade histórica. No seguinte, discuto temas ligados à questão do desenvolvimento, destacando pontos relativos a conhecimento e ao trabalho intelectual na história.

\section{Individualidade técnica em lugar do indivíduo: a relação social para J. A.}

\section{Giannotti}

O trabalho é uma forma de atividade que envolve tanto o metabolismo do homem com natureza como as relações sociais. Este capítulo começa com a tematização das relações sociais como determinações necessárias da atividade especificamente humana. Trata em seguida da transformação na natureza, tema em que a definição de força produtiva é abordada. Por fim, propõe a questão do desenvolvimento das forças produtivas, ligada tanto às transformações da natureza quanto com a forma de sociabilidade. Para todos os temas deste capítulo, lanço mão das contribuições do filósofo brasileiro José Arthur Giannotti, seja para polemizar com suas teses, seja para elucidar pontos do pensamento de Marx. Utilizo passagens dos três primeiros ensaios de seu Trabalho e Reflexão ${ }^{41}$.

\footnotetext{
${ }^{41}$ GIANNOTTI, J. A. Trabalho e reflexão - Ensaios para uma dialética da sociabilidade. São Paulo: Brasiliense, 1983. Os ensaios que utilizo são "Imperativos da ilusão" (pp. 15-79), "O ardil do trabalho" (pp. 80-125) e "Formas de sociabilidade primitiva" (pp. 126-173). Doravante, Giannotti, Trabalho, seguido do número da página.
} 
Neste item, tenho como foco os fundamentos da sociabilidade. Tomo como ponto de partida uma tese pela qual Giannotti busca explicar a relação social como imanente à atividade de trabalho, ou seja, em que ele oferece uma interpretação das razões que fazem do trabalho uma atividade necessariamente social. Nesta tese, Giannotti define a relação social como "referência a outrem" e cria o conceito de “individualidade técnica". Tanto a definição de relação social como o conceito elaborado derivam de sua concepção do trabalho como um "esquema operatório", um circuito lógico. Exponho sua teoria, desenvolvida ao final do primeiro ensaio do livro, "Imperativos da ilusão" e utilizada nos demais ensaios. Busco contrapô-la à teoria de Marx expressa especialmente em passagens dos Manuscritos Econômico-Filosóficos de $1844^{42}$, de A Ideologia Alemã $\tilde{a}^{43}$ e da Introdução de $1857^{44}$, mas também em outros textos de sua obra econômica madura.

Em "O outro e a individualidade técnica", item que fecha o primeiro ensaio do livro de Giannotti, o autor tematiza o trabalho e tem como um de seus objetivos contrapor-se às teses sociológicas que autonomizam o fenômeno social da esfera da produção da vida. Busca demonstrar que as relações sociais não se separam de suas condições de efetividade, de modo que os fenômenos sociais não configuram um tecido autônomo, carente de pressupostos. Opõe-se à "ciência do social" que, assim considerando os fenômenos sociais, aborda-os a partir de diferentes paradigmas ou pontos de vista, mas com isso não supera seu "funcionamento de superfície", ou seja, não alcança explicá-los:

\footnotetext{
Um investigador procurará constatar entre eles relações do tipo 'x varia com y', (...) outro ainda tentará captar o sentido de uma cadeia de ações. Esta ciência do social, mobilizada por diversos paradigmas, como hoje se costuma dizer, oculta entretanto uma questão de raiz: o lado representativo do fenômeno, a regra pela qual ele se dá; labora com dados, conteúdos, cuja efetivação se situa além desse funcionamento de superfície (Giannotti, Trabalho, 59).
}

\footnotetext{
42 MARX, K., Manuscritos Econômico Filosóficos. Tradução de Jesus Ranieri. São Paulo: Boitempo, 2010. Doravante $M E F$, seguido do número da página.

${ }^{43}$ MARX, K., ENGELS, F., A Ideologia Alemã - Crítica da mais recente filosofia alemã em seus represenstantes Feuerbach, B. Bauer e Stirner, e do socialismo alemão em seus diferentes profetas (1845-1846). Tradução de Rubens Enderle, Nélio Schneider e Luciano Cavini Mantorano. São Paulo: Boitempo, 2007. Doravante IA, seguido do número da página.

${ }^{44}$ MARX, K., "Introdução" in Grundrisse, op. cit., pp. 37-64. Doravante Introdução, seguido do número da página.
} 
Diferentemente, Giannotti busca explicar a constituição do tecido social para além do campo do fenômeno, perseguindo sua origem e caracterizando as condições em que a sociabilidade se estabelece. O autor escreve:

Como nascem os nomes próprios é uma questão que ultrapassa o terreno da linguística para cair nos abismos da ontologia. (...) Do mesmo modo, as várias camadas do tecido social se constituem a partir de conteúdos cuja origem pede uma investigação" (Giannotti, Trabalho, 59).

Com Marx, Giannotti situa a origem do tecido social na atividade humana: "Neste recuo, haveremos de chegar a um ponto em que a ação social revela seu caráter próprio de transformação dos homens e das coisas" (Giannotti, Trabalho, 59). Também com Marx, toma o trabalho como este agir social que está no fundamento da sociabilidade:

Posto que nenhuma sociedade logra manter seu metabolismo social sem alinhavá-lo a seu metabolismo com a natureza, posto que qualquer sociedade pereceria rapidamente se seus membros deixassem de trabalhar e produzir o que necessita, encontramos no trabalho uma condição básica de sua existência” (Giannotti, Trabalho, 59).

Assim, para Giannotti, o que fundamenta o conjunto da vida humana em suas múltiplas formas de manifestação, os fenômenos sociais, é o trabalho, caracterizado aqui como atividade de "produzir o que [se] necessita". Na atividade do trabalho Giannotti vê dois lados que se condicionam mutuamente, a relação do homem com a natureza, e as relações sociais entre os homens:

Tratemos de dar a maior ênfase possível a esse mútuo condicionamento de homens e coisas, a fim de evitar o engano, hoje muito frequente, que separa, pela raiz, uma relação significante entre os homens, da relação muda do homem com as coisas. Nosso propósito é estudar como ambos os lados instauram um único movimento reflexionante. No próximo capítulo, sublinharemos o aspecto ardiloso do trabalho, que cria entre polos abstratos, homem e natureza, o domínio dos objetos trabalhados, os quais se consomem produtivamente para constituírem os pressupostos a partir de que se arma a trama social. Aqui, procuraremos salientar outro aspecto, aquele que marca a sociabilidade propriamente dita (Giannotti, Trabalho, 60).

Giannotti recupera alguns pontos fundamentais do pensamento de Marx quando afirma, primeiramente, que o trabalho é condição da sociabilidade e, em segundo lugar, que esta atividade produtiva tem dois momentos: a transformação da natureza material e a relação social. Com isso, destaca a especificidade a atividade produtiva do homem: seu caráter social. Esta ampla caracterização do trabalho é explicada ou referida em diversas passagens dos textos de Marx. Sobre o trabalho como condição permanente da 
sociabilidade, Marx e Engels, opondo-se à concepção feuerbachiana que localiza o caracteristicamente humano na capacidade de contemplação, escrevem:

\footnotetext{
E de tal modo é essa atividade, esse contínuo trabalhar e criar sensíveis, essa produção, a base de todo o mundo sensível, tal como ele existe agora, que, se ela fosse interrompida mesmo por um ano apenas, Feuerbach não só encontraria uma enorme mudança no mundo natural, como também sentiria falta de todo o mundo humano e de seu próprio dom contemplativo, e até mesmo de sua própria existência” $(I A, 31)$.
}

No mesmo texto, Marx e Engels destacam os dois aspectos igualmente definitivos do trabalho, a ação dos homens sobre a natureza, e as relações sociais, ou formas de intercâmbio, i.e., a ação dos indivíduos uns sobre os outros: “(...) um aspecto da atividade humana, o trabalho dos homens sobre a natureza. $\mathrm{O}$ outro aspecto, o trabalho dos homens sobre os homens" (IA, 39).

Giannotti pretende definir a relação social e demonstrar que ela é imanente ao processo de trabalho, bem como descrever o modo como ela se faz constituinte da definição de trabalho. Enquanto processo de transformação da natureza, abstraído das formas sociais específicas, o trabalho será mais bem analisado no ensaio seguinte, "O ardil do trabalho". Seguindo o autor, coloco primeiramente a temática da relação social em relevo, sem discutir o outro aspecto do processo de trabalho. Em vários momentos deste segundo ensaio, as explicações de Giannotti lançam luz sobre o texto de Marx, e aproveito este esforço em minha própria linha argumentativa. Há também, contudo, distanciamentos importantes da compreensão de Marx acerca dos fundamentos da relação social que procuro apontar. Sem a pretensão de esgotar os problemas, lanço mão da polêmica especialmente como meio de explicitar as dificuldades presentes na teoria de Marx, mas também para trazer à tona pontos da posição de uma importante interpretação que, embora muito referida e talvez comentada em seus traços amplos, foi pouco examinada em seus temas específicos. Tomo apenas três temáticas desta obra de Giannotti: o modo como explica a relação social como aspecto determinante do trabalho; o trabalho como atividade de transformação da natureza; sua compreensão da categoria de força produtiva e das condições de seu desenvolvimento.

O ponto de partida da análise de Giannotti a respeito do caráter social do trabalho é a compreensão do processo de trabalho - atividade de transformação do objeto, por meio de um instrumento, para a consecução de um fim anteposto - como um esquema operatório, isto é, um sistema que funciona autonomamente, com momentos 
determinados e limitado pela sua finalidade. Justifica seu ponto de partida pelo fato de não ser possível explicar as relações sociais de produção a partir dos sujeitos, ou dos indivíduos como sujeitos previamente constituídos. Argumenta que o trabalhador como o conhecemos não existe nas sociedades pré-capitalistas, e que o processo de constituição do sujeito é um processo histórico. O autor evita tomar por pressuposto das relações sociais configurações subjetivas que decorrem delas. Assim, o indivíduo, o sujeito ou o trabalhador não se colocam como pontos de partida para a fundamentação das relações sociais porque carecem de pressupostos, entre os quais estas mesmas relações. O esquema operatório do trabalho parece a Giannotti um ponto de partida objetivo e suficientemente autônomo em que o produtor, e também o consumidor, aparecem como posições ou figuras no esquema operatório. Assim, a questão da relação social é posta nos termos da figura do outro no interior deste esquema. Em suas palavras:

É conhecida a definição marxista do processo de trabalho como uma atividade orientada, que fere um objeto por meio de um instrumento ${ }^{45}$. Cabe notar o cuidado de Marx em não vincular diretamente esta atividade à figura de um trabalhador perfeitamente delineada. Este, de fato, não se dá como tal em outros sistemas produtivos - é sabido que entre os povos primitivos o trabalhador se identifica antes de tudo como co-proprietário. Por isso, nada mais incorreto do que tomar como ponto de partida trabalhadores na qualidade de sujeitos, que superando suas identidades pressupostas passassem a tramar uma teia de relações com as coisas e os homens. Esta é a razão pela qual nossa análise se inicia pelo processo de trabalho como um esquema operatório capaz de manter a si mesmo. Como nesse processo se demarca a figura do outro? (Giannotti, Trabalho, 60-1).

O autor toma a atividade vital do homem pelo ponto de vista de seu circuito operativo ou lógico: atividade que utiliza um meio para ferir um objeto criando um produto planejado. Deste esquema, deduzirá a relação social, como forma por meio da qual um indivíduo refere a outro ou outrem no interior do processo, em cada um de seus momentos. A relação social é desde logo delimitada pelas posições em que os indivíduos, tomados apenas como agentes em posição pré-definidas no interior do esquema lógico do trabalho, têm necessariamente de referirem-se a outrem para que o esquema se efetive. Giannotti argumenta que apenas este ponto de partida é capaz de estabelecer a sociabilidade, ou a origem do tecido social, sem que se tome o resultado -

${ }^{45}$ Esta definição de trabalho é mais bem explicada no ensaio seguinte, "O ardil do trabalho" (em Trabalho e Reflexão, op. cit., pp. 83-92), em que o foco é o metabolismo entre homem e natureza. Aqui, o autor apenas a assume. 
sujeitos determinados historicamente - como causa. Parece conceber, com Marx, que os indivíduos humanos se constituem em sua atividade, de modo que não se pode partir das formas determinadas dos indivíduos. Mas parte das posições pressupostas em que os indivíduos devem se encaixar para que o esquema operatório do trabalho seja levado a cabo. Os momentos do processo de trabalho são distinguidos por Giannotti pelos seus elementos materiais, de modo que são três os momentos que perfazem este processo e comportam a relação: o objeto, o meio e o produto. Para que as funções de objeto, meio e produto do trabalho se efetivem, é necessário que o agente de cada um desses momentos se refira a outros indivíduos, requisitando sua parceria na atividade. De sorte que o ponto de partida lógico situa os indivíduos em posições no interior do esquema operatório, fazendo com devam, de um modo ou de outro, estar aptos a cumprir suas funções, tanto na produção como no consumo. Um ponto importante que pretendo elucidar expondo os textos de Giannotti e de Marx é que este último não parte do trabalho como uma estrutura operativa esquemática, mas precisamente dos indivíduos:

\footnotetext{
Os pressupostos de que partimos não são pressupostos arbitrários, dogmas, mas pressupostos reais, de que só se pode abstrair na imaginação. São os indivíduos reais, sua ação suas condições materiais de vida, tanto aquelas já encontradas como as produzidas por sua própria ação. Esses pressupostos são, portanto, constatáveis por via puramente empírica. O primeiro pressuposto de toda a história humana é, naturalmente, a existência de indivíduos humanos vivos $(I A, 87)$.
}

Marx assume um ponto de partida natural ou empírico: os indivíduos humanos. Marx parte do reconhecimento pré-teorético da existência do mundo e dos homens: o pressuposto não é uma determinada teoria sobre os homens e o mundo, mas o reconhecimento de que existem. Giannotti assenta a relação social sobre um pressuposto lógico: visto que o trabalho é condição da vida humana e que se define como atividade que fere um objeto por meio de instrumento para gerar um produto; considerando ainda que todos os seus momentos técnicos demandam a atividade de mais de um indivíduo, a relação social se define como referência de um a outro necessária à efetivação da lógica operativa do trabalho.

Exponho abaixo a argumentação de Giannotti em defesa da necessidade da relação social - a referência a outrem -, em que o autor distingue cada um dos momentos do trabalho para mostrar que sua realização apenas é possível mediante a participação de mais de um indivíduo. Sobre o processo de trabalho, o autor afirma: “(...) cada um de seus momentos implica uma referência formal a outrem, que só pode 
ser abstraída quando deixamos de considerar os passos pelos quais o próprio processo de trabalho se efetiva" (Giannotti, Trabalho, 62). É a referência formal a outro em cada um de seus momentos, sem a qual o processo de trabalho seria interrompido, que expressa a imbricação entre trabalho e relação social e define a própria relação. Giannotti procura demonstrar a necessidade da relação social para o que objeto, meio e produto do trabalho existam como tais.

Sobre o primeiro momento do trabalho, ele escreve: “(...) o objeto de trabalho sempre apresenta obstáculos de ordem formal, dando-se como terreno coletivo limitado por outro grupo, sob a forma de dádiva, mercadoria, etc." (Giannotti, Trabalho, 61). A terra, por exemplo, deve ser mantida como propriedade do grupo, e isto consiste em um primeiro obstáculo, de ordem formal, para que se ponha como objeto de trabalho. Ou seja, determinadas relações delimitam a apropriação da terra, de modo que manutenção da terra como objeto de trabalho demanda trabalhos de ordem diversa daqueles para os quais é objeto, como a guerra. O objeto de trabalho apresenta ainda obstáculos de ordem material requerendo trabalhos distintos daquele em que funciona como objeto, para preservar-se:

Essa manutenção do território - fenômeno que já podemos observar entre os animais superiores - implica no outro, a saber, noutro processo de trabalho, diferente do primeiro, mas que não se efetua sem ele. Em outras palavras, a repetição do processo de trabalho, que fere um objeto, depende de uma atividade produtiva diferente, que venha a assegurar a identidade de seu próprio objeto (Giannotti, Trabalho, 61).

No que diz respeito ao objeto, portanto, a referência a outrem é necessária tanto nos trabalhos coletivos de manutenção do território, como nas atividades materiais distintas que, garantindo a identidade do objeto, isto é, as determinações que fazem dele um objeto de trabalho, mantêm-no como condição de produção. No instrumento, o outro é posto como necessidade de um parceiro para sua manipulação. Exemplificando com uma rede de pesca, o autor escreve: "O outro comparece aqui como parceiro na efetivação dum instrumento, especificando-se então como segurador, puxador e assim por diante (...)" (Giannotti, Trabalho, 61). No produto, o outro aparece como não trabalhador que é consumidor. Para o autor, todo produto de trabalho tem para si consumidores não-trabalhadores, e portanto desde a origem o produto do trabalho é criado para outrem, mesmo que sejam apenas os velhos e as crianças: "Inclusive de um ponto de vista animal, o homem também trabalha para um terceiro que apenas consome, 
como as crianças e os velhos, impedidos de exercer uma atividade produtiva" (Giannotti, Trabalho, 61). Convém ponderar que esta associação do sustento dos velhos ao ponto de vista animal não procede, visto que nenhuma espécie animal produz para alimentar seus velhos. O cuidado com os velhos é mesmo oposto ao processo de seleção natural e por isso seu advento pressupõe o desenvolvimento das relações humanas. No objeto e no instrumento, a referência a outrem se dá no interior do processo de trabalho, ao passo que o outro que se faz presente no produto, alheio à atividade produtiva e visando o consumo, tem como condição de existência a peculiaridade de o produto poder se separar do produtor. Ele escreve: "Este outro, que é o outro do processo de trabalho - diferente dos outros do objeto e do instrumento, que se especificam no interior da reflexão do próprio processo - está ligado a uma condição muito peculiar do produto, o fato dele se pôr como ente, coisa-aí, pronta a ser consumida por um terceiro" (Giannotti, Trabalho, 61-2). Ou seja, se o produto do trabalho não pudesse se distinguir e se separar do produtor, não poderia ser consumido por outro senão este. Mas não é também o instrumento um produto e uma coisa-aí? Sabemos que a existência independente do produto é uma condição para que seja consumido por outro que não o produtor, mas a questão que se coloca é se esta condição é suficiente para isso. Em outras palavras, o que leva o ser humano a produzir para outro? Em Marx, produzir para outro é a forma especificamente humana de produzir para si mesmo.

Em Giannotti, a questão do outro se resolve em três fatores: primeiro, a impossibilidade material de o conjunto das tarefas produtivas ser realizada por um único indivíduo, isto é, a necessidade da "parceria" para a "efetivação dum instrumento" (Giannotti, Trabalho, 61); segundo, o objeto do trabalho - primordialmente o território - não poder ser defendido ou mantido por um único indivíduo e, terceiro, o fato de que comparecem para o consumo do produto, dada sua existência objetiva independente do produtor, outros indivíduos que não podem produzir. Esta compreensão se distancia das teses de Marx. No que diz respeito ao primeiro fator, antes de conceber uma atividade coletiva específica, Marx busca explicar como se desenvolveram as atividades produtivas, tanto aquelas que não podem ser realizadas por um único indivíduo, quanto as que são individuais, ou seja, o modo como se constituem as atividades propriamente humanas. Um problema central da definição de Giannotti da relação social como referência a outrem dentro do esquema da produção é que ele parte de atividades humanas, processos produtivos já constituídos socialmente, e mostra que para serem 
realizadas demandam uma forma de sociabilidade, mas não explica o papel da sociabilidade na constituição do trabalho. Os dois últimos fatores aparecem em Marx no interior do tema da apropriação da natureza e das formas de propriedade, que caracterizam a relação social de produção.

Desta necessidade de outrem para cada um dos momentos do processo de trabalho, atividades distintas demarcadas pelo autor por seus elementos materiais - o objeto, o meio e o produto - deriva o necessário consenso relativo ao reinvestimento produtivo, à quantidade de produtos que reingressarão na produção sendo consumidos produtivamente:

O produto configura os restos mortais do movimento reflexionante. Isto significa que o próprio auto-consumo $^{46}$, porque se faz num contexto em que terceiros comparecem sob várias formas, já implica um reconhecimento de que o resultado morto do trabalho possa voltar, segundo um consenso de todos, para o processo de trabalho que lhe deu origem (Giannotti, Trabalho, 62).

$\mathrm{Na}$ visão de Giannotti, as relações são necessárias porque o conjunto das atividades produtivas não pode ser efetivado por um único indivíduo e porque há indivíduos que não podem absolutamente produzir. Deste reconhecimento, deriva o consenso do conjunto de indivíduos relativo à continuidade do processo produtivo: a destinação dos produtos - e portanto também da atividade - à reprodução das condições de produção. A necessidade de recorrer a um consenso, uma decisão coletiva, extrapola o processo de trabalho como mero esquema operatório. Os sujeitos que Giannotti procura evitar enquanto ponto de partida das relações sociais são aqui pressupostos como seres conscientes e capazes de consenso, cuja decisão possibilita a continuidade do processo produtivo.

A necessidade do outro, nestas três distintas formas em que o outro se põe, bem como o consenso relativo à reprodução social, têm por fundamento a necessidade lógica de funcionamento do trabalho já estabelecido como um esquema operatório:

Como resultado final, temos o processo de trabalho desde o início se fazendo num contexto já determinado por posições sociais, aquelas que respeitam à sua qualidade de esquema operatório.

\footnotetext{
${ }^{46}$ Giannotti se refere com esta expressão ao consumo da atividade, a produção efetiva ou consumo produtivo, como explica em outra passagem de seu livro ("O Ardil do Trabalho - 4. Dissolução das relações econômicas", pp. 100-109), tomando por base o texto da Introdução de 1857, em que Marx discute as relações entre produção, distribuição, consumo e troca e subverte o sistema elaborado pela economia clássica.
} 
Por isso, cada um de seus momentos implica uma referência formal a outrem (...) (Giannotti, Trabalho, 62, grifo meu).

Giannotti parte das posições dos indivíduos no processo de trabalho para sustentar a necessidade da referência a outrem, de modo que seu ponto de partida são figuras, funções pré-definidas, que não poderiam definir-se senão em relação. Além disso, se a relação é um reportar-se a outro, convém questionar, o outro de quem?:

(...) no exercício desta mesma atividade encontramos uma referência a outrem, como momento de sustentação dos outros momentos do esquema. Por sua vez, nessa atividade orientada do outro também se inscreve uma referência a outrem, ao primeiro eu, que imaginamos iniciar a trama (Giannotti, Trabalho, 63, grifo meu).

O autor parece tomar as atividades parciais de produção como dadas, em que os indivíduos são figuras pré-determinadas pelo funcionamento do trabalho como esquema composto de três diferentes partes ou momentos, e articular a relação social a partir do caráter parcial destas atividades. Trata-se da necessidade lógica de um dado esquema operatório, que só funciona mediante a reunião de indivíduos e de momentos. Seu argumento lembra, a despeito da particular conotação lógica, algumas explicações de Adam Smith, ou J.-J. Rousseau, que derivavam a associação entre indivíduos da consideração das vantagens ou facilidades que esta poderia trazer para sua própria sobrevivência individual $^{47}$. O que seria este consenso senão uma espécie de contrato tácito? Não soa também contratualista e carente de demonstração esta imbricação do processo de trabalho com as relações sociais a partir de "um primeiro eu, que imaginamos iniciar a trama"?

\footnotetext{
${ }^{47}$ Rousseau escreve que o homem selvagem, "Instruído pela experiência de que o amor do bem-estar é o único móvel das ações humanas, encontrou-se em estado de distinguir as raras ocasiões em que o interesse comum devia fazê-lo contar com a assistência de seus semelhantes (...). Quando se tratava de caçar um veado, cada qual sabia bem que devia, para tanto, ficar fielmente em seu lugar; mas, se acontecesse de uma lebre passar ao alcance de um deles, não se deve duvidar que ele a perseguisse sem escrúpulo, e que, tendo agarrado sua presa, não se preocupasse com a de seus companheiros" (ROUSSEAU, J.-J., Discurso sobre a origem e os fundamentos da desigualdade entre os homens. Tradução de Iracema Gomes Soares e Maria Cristina Roveri Nagle. Brasília: ed. UNB; São Paulo: Ática, 1989, p. 87). Smith afirma que, se os indivíduos adultos das espécies animais são inteiramente independentes, “(...) o homem quase sempre precisa da ajuda de seus semelhantes, e seria vão esperar obtê-la somente da benevolência. Terá maiores chances de conseguir o que quer se puder interessar o amor-próprio deles a seu favor e convencê-los de que terão vantagem em fazer o que deles pretende. Todos os que oferecem a outro qualquer espécie de trato propõem-se fazer isso. Dê-me aquilo que desejo, e terás isto que desejas, é o significado de todas as propostas desse gênero e é dessa maneira que nós obtemos uns dos outros a grande maioria dos favores e serviços de que necessitamos" (SMITH, Adam. A riqueza das nações - vol. I. Tradução de Alexandre Amaral Rodrigues e Eunice Ostrensky. São Paulo: Martins Fontes, 2003, p. 19).
} 
Giannotti não quer partir de sujeitos constituídos previamente à atividade, mas se manifesta de modo ambíguo a esse respeito:

\footnotetext{
Podemos fazer da relação social um pacto porque um indivíduo se reporta a outrem por intermédio de um objeto que carrega uma dimensão representativa, a antecipação duma ação a que deve corresponder uma reação de terceiros. Mas seria incorreto identificar esse pacto com um contrato, limitação de vontades pessoais no sentido de alcançarem um fim previamente antevisto (Giannotti, Trabalho, 59).
}

A relação social não é um contrato porque a parceria não se funda na vontade pessoal das partes. Como Giannotti explicará no segundo ensaio de seu livro, há uma necessidade oriunda das condições naturais, que determinam a forma da atividade (o indivíduo não é livre para escolher um estilingue como instrumento de pesca etc.). Não deixa, contudo, de caracterizar-se como um pacto, em que já estão definidos o eu e o outro, ou seja, indivíduos que são sujeitos. Em sua análise da relação social, o autor procura “(...) evitar dois enganos paralelos; de um lado, o subjetivismo que resolve a relação social numa trama de consciências previamente constituídas; de outro, o objetivismo que retira dela qualquer dimensão representativa, antecipatória" (Giannotti, Trabalho, 59). Ou seja, a consciência não é autônoma na constituição das relações sociais, mas estas tampouco são puramente objetivas, como o metabolismo que caracteriza a natureza anterior ao homem, carente de finalidade e representação subjetiva. Pretende distinguir-se, vale repetir, da concepção que toma os sujeitos dados por ponto de partida da relação social, porque os concebe como resultados de sua determinação recíproca - a própria relação social - no processo de trabalho. Além disso, na explicação da relação social, afasta-se das teorias fenomenológicas que tomam a relação na forma da inter-subjetividade, isto é, da interação puramente subjetiva que independe da atividade produtiva. Contudo, não apresenta uma explicação desta constituição recíproca dos sujeitos no processo produtivo: sua finalidade de evitar aqueles dois enganos paralelos e fazer do sujeito um resultado da produção humana se resolve ao inserir o indivíduo em um esquema operatório:

É corriqueira a afirmação de que uma relação social comporta uma referência a outrem. O que vem a ser, porém, esse outro? Se logo de início admitíssemos um sujeito dotado duma individualidade constituída, o que equivale a supor uma via de acesso especialíssima que chegasse até ela, caberia tomar esse outro como algo que também fosse atingido por uma representação do singular. Essa experiência do outro, entretanto, termina por resolver-se em um ideal, espécie de horizonte sempre visado mas nunca atingido. É conhecido de todos o impasse 
em que desembocou a fenomenologia da inter-subjetividade, a qual, quanto mais aprofundava a análise dessa experiência, tanto mais descobria fatores mediadores, o corpo próprio, o corpo alheio, a reflexibilidade das mãos e assim por diante. Não é aconselhável abandonar de vez essa aspiração de capturar um sujeito e um terceiro singularizados para sempre, e procurar discernilos na trajetória de sua determinação recíproca? É por isso que tentamos localiza-lo no esquema operatório (...) (Giannotti, Trabalho, 63).

Neste enquadramento do processo de trabalho em um esquema, em que os indivíduos são posições funcionais, a relação social pode ser concebida como ação em que "um indivíduo se reporta a outrem por intermédio de um objeto que carrega uma dimensão representativa, a antecipação duma ação a que deve corresponder uma reação de terceiros" (Giannotti, Trabalho, 59, citado acima). A relação social é um reportar-se a outro com a expectativa de sua reação, constituindo um pacto ou um compromisso. Este não é autônomo, resultante das vontades pessoais, porque a função dos indivíduos, que não são sujeitos constituídos, mas agentes indefinidos, está de antemão determinada pelas posições no esquema do trabalho: "A indefinição do outro se encastoa, pois, numa norma" (Giannotti, Trabalho, 59). O pacto, se não implica a livre vontade porque submetida à finalidade do esquema e às suas condições materiais, não deixa de pressupor certa independência entre os indivíduos, ou ao menos sua constituição prévia como indivíduos. Ainda que as condições materiais não ofereçam outras escolhas senão a associação, a forma de pacto pressupõe partes independentes entre si. A relação entre mãe e criança, por exemplo, não pode ser um pacto, porque o vínculo é pressuposto. Em Marx, como veremos, o indivíduo gregário tem o mesmo tipo de dependência da comunidade que aquele que a criança tem dos adultos. Um cordão umbilical liga o indivíduo à comunidade. De fato, "é aconselhável abandonar de vez essa aspiração de capturar um sujeito e um terceiro singularizados para sempre, e procurar discerni-los na trajetória de sua determinação recíproca" e é o que Marx busca fazer. Contudo, esta determinação recíproca não é derivada do trabalho enquanto um esquema operatório, mas sim como um modo específico de atividade criada pelos homens e cuja natureza é social.

Giannotti chama de individualidade técnica o esquema operatório a que se reduziu o processo de trabalho. Esta se caracteriza pela unidade do sistema em que cada momento materialmente determinado comporta uma relação social, isto é, uma referência de um a outrem: 
(...) o exercício do processo de trabalho - uma atividade orientada que se exerce sobre um objeto por meio dum instrumento - importa em cada um de seus passos uma referência formal a outrem. Denominamos esse esquema operatório de individualidade técnica. Ela pressupõe individualidades previamente determinadas $-\mathrm{o}$ objeto, o instrumento, o indivíduo biologicamente configurado, teia de relações sociais resultando em coisas e organismos concretos (Giannotti, Trabalho, 59).

Trata-se de um esquema que abrange não apenas a relação do homem com a natureza, mas as relações sociais requeridas para o metabolismo especificamente humano com a natureza. Como esquema que inclui as relações sociais requeridas pela atividade produtiva, cujos momentos implicam sempre uma referência a outrem, a individualidade técnica é o contorno da sociabilidade, a relação social tomada abstratamente. A individualidade técnica

Toma, porém, tais unidades [o objeto, o instrumento, o "indivíduo biológico" etc. - VC] unicamente como pressupostos, ponto de partida do movimento reflexionante instaurado pelo trabalho coletivo, que possui a característica de amalgamar tais pressupostos numa singularidade sui generis, determinando e especificando em seu seio homens e objetos, firmando, por conseguinte, uma forma de sociabilidade abstrata que, a despeito deste seu caráter, instaura uma unidade em que forma e conteúdo se determinam reciprocamente (Giannotti, Trabalho, 62-3).

Do mesmo modo em que Marx delineia os traços gerais do trabalho, o processo de trabalho visto como metabolismo do homem com a natureza sem consideração da forma de sociabilidade em que se dá - embora o caráter social seja pressuposto -, Giannotti procura delinear os traços gerais e fundantes da própria sociabilidade, independentemente de sua forma específica. Tomado o processo de trabalho, por um lado, como "uma condição sine qua non de toda outra forma de sociabilidade" (Giannotti, Trabalho, 63), por outro, como um esquema operatório, a relação social que caracteriza o trabalho aparece como ação recíproca entre posições definidas no esquema do trabalho. Visto que a relação é a forma social da produção, a individualidade técnica “instaura uma unidade em que forma e conteúdo se determinam reciprocamente", de modo a estabelecer um modo definido da sociabilidade. Mas a forma geral da sociabilidade, abstraídas suas determinações históricas específicas, é sempre uma individualidade técnica: uma unidade dada pelo caráter técnico da operação, o circuito lógico do trabalho, que comporta diversos indivíduos em referência uns aos outros. A individualidade técnica é a unidade social do trabalho. No interior dela, a determinação recíproca entre o conteúdo do trabalho (sua especificidade material) e sua forma (as 
relações entre indivíduos) é chamada por Giannotti de "movimento reflexionante" do trabalho.

A individualidade técnica pressupõe o objeto, o instrumento e os indivíduos que, embora não sejam sujeitos, mas apenas "biologicamente determinados", devem estar capacitados para assumir suas "posições". De modo que este conceito definitivo da relação social pressupõe o trabalho como uma atividade existente. Mas a verdadeira dificuldade não está em explicar por que razão a atividade de pesca não pode ser realizada por um indivíduo isolado, ou por que um indivíduo é incapaz de realizar todas as atividades produtivas necessárias para sua reprodução, mas a necessidade da relação social para que se tenha desenvolvido uma atividade de pesca, ou qualquer atividade que não esteja inscrita na natureza biológica imediata do homem. Esta necessidade vai além da cooperação imediata em um processo produtivo parcial em que as posições estão estabelecidas de antemão. À investigação de Marx importa explicar por que as atividades propriamente humanas, que estabelecem as "posições" ou funções do trabalho, são um processo social.

Assim, a noção de individualidade técnica deve ser posta em questão. A tentativa de delinear os traços gerais da sociabilidade a partir do processo de trabalho em sua forma lógica, como esquema, resulta em um engessamento das relações sociais a uma dada estrutura abstrata que, no máximo, repete a definição de trabalho. E não abrange o papel das relações sociais em um momento fundante deste processo que é a criação das necessidades humanas e da forma especificamente humana de atividade. A individualidade técnica é pensada como a "forma mais simples" da relação social, o modo como "a sociabilidade natural coloca um pressuposto sempre reposto, expresso em novos termos, mas que não pode ser suprimido" (Giannotti, Trabalho, 63-4), e que em última instância determina as demais relações que ultrapassam a produção ou o consumo imediatos:

\footnotetext{
Nada mais absurdo do que reduzir diretamente um relacionamento tão complexo como aquele que o crente tece com seu deus a uma relação de trabalho. Sempre permanece, todavia, a tarefa de indicar como, no caso, o comportamento religioso perdura porque labora com conteúdos informados pelas relações que permitem ao grupo, de que o crente participa, resolver de modo satisfatório os problemas de sua sobrevivência material (Giannotti, Trabalho, 64).
} 
Giannotti procura, como Marx, basear as relações sociais na produção material da vida, mas em sua definição do processo de trabalho, a formação das necessidades novas, especificamente humanas, que está na base da "dimensão antecipatória" que distingue o trabalho humano das atividades animais, não é investigada. $\mathrm{O}$ autor escreve: “O que importa é portanto assinalar que temos, de um lado, um sistema de necessidades, (...) De outro, um sistema de objetos, qualitativa e quantitativamente determinado" (Giannotti, Trabalho, 65). Ao propor um princípio lógico, o processo de trabalho como esquema operatório, o movimento social que põe as necessidades e as transforma fica sem explicação: é pressuposto um "sistema de necessidades". Além disso, mesmo no interior das atividades de trabalho já dadas em uma sociedade, o enquadramento em uma individualidade técnica não pode senão ser artificial no caso de algumas delas. No terceiro ensaio de seu livro, "Formas da sociabilidade primitiva", Giannotti não hesita em concordância com Marx - em considerar a magia nas sociedades primitivas como uma forma de trabalho. Mas o esquema operatório em que um indivíduo fere um objeto por meio de um instrumento para criar um produto pré-ideado, e no qual cada um dos momentos definidos pelos elementos materiais do processo requer uma referência a outrem, não funciona para o trabalho da magia, e tampouco para os trabalhos cujo produto é o conhecimento. Por que Giannotti cria a categoria de individualidade técnica, que define uma forma geral da relação social que seria então sobredeterminada pelas formas históricas específicas? Para assentar, como já explicitado, a origem das relações sociais em um princípio lógico, que não tenha outros pressupostos que não o trabalho em ação. Mas o que salta aos olhos é que isto que Giannotti chama de individualidade técnica tem um conjunto de pressupostos: sua finalidade pressupõe necessidades novas, não dadas na natureza imediata do homem, e a referência a outrem que permeia cada momento do esquema do trabalho pressupõe a linguagem, que em si mesma implica a formação especificamente humana da sensibilidade e da consciência. Ademais, é curioso que um autor que tanto se debruçou sobre a questão da linguagem não a mencione em sua investigação da origem da relação social, já que na referência a outrem dentro de um esquema operatório de trabalho a linguagem é pressuposta.

Mas para além daquilo que o conceito criado por Giannotti não é capaz de explicar, é preciso ainda pontuar que ele traz uma visão do agente ou sujeito da atividade humana. Para que serve este conceito que se interpõe entre o indivíduo e a sociedade e restringe a definição de relação social? Giannotti escreve: 
A unidade formada pelo trabalhador e as condições de trabalho por ele mesmo apropriadas, dentre as quais o outro ainda aparece como categoria indiferente, constitui o que chamamos de individualidade técnica. O novo conceito serve para salientar o caráter relativo da unidade formada pelo processo de trabalho. Aliás, Marx tem o cuidado de colocar, em lugar do trabalhador, o trabalho enquanto momento essencial dele, desvinculando assim esse momento do agente concreto. $\mathrm{O}$ indivíduo trabalhador não se confunde com a individualidade biológica, o representante da espécie, nem se confunde, obviamente, com a individualidade jurídica. Além de incorporar pedaços domados da natureza, a individualidade técnica não precisa ter o indivíduo biológico como polo dinâmico: "O homem só se individualiza (vereinzelt) mediante processo histórico. Aparece originalmente como ser genérico, vinculado a uma tribo e animal de rebanho [Gattunswesen, Stammwesen, Herdentier], por isso de modo algum como zõon politicón no sentido político" (Marx, G., 395-6) (Giannotti, Trabalho, 109).

O conceito de individualidade técnica serve então para que a fundação da relação social prescinda de indivíduos e se dê na forma de um sujeito coletivo: "o indivíduo trabalhador" deixa de ser o "indivíduo biologicamente determinado", mas um coletivo interligado no esquema técnico que faz da relação social uma estrutura funcional. Fica claro que o autor vê a necessidade de abordar a relação social sem precisar partir dos indivíduos. Mas é precisamente este o ponto de partida de Marx, e apenas porque os indivíduos se relacionam na produção é que se caracterizam como seres sociais que individualizam no decorrer do processo histórico. Esboçamos abaixo, sem qualquer pretensão de esgotar o tema, o modo como Marx alcançou "chegar a um ponto em que a ação social revela seu caráter próprio de transformação dos homens e das coisas" (Giannotti, Trabalho, 60).

\section{Sociabilidade, trabalho e indivíduo em Marx}

Os textos de Marx apresentam outros aspectos da sociabilidade como constitutiva da atividade especificamente humana que são importantes para delinear as categorias de trabalho, força produtiva e conhecimento em suas relações recíprocas. Expomos em seguida aspectos ontológicos da sociabilidade, buscando indicar a complexidade que a definição de relação social alcança em Marx, e que não aparece no texto de Giannotti. Como Giannotti define a relação social como "referência a outro", ao passo que se recusa a partir dos indivíduos como sujeitos - o que o leva a conceber o trabalho na forma lógica de um esquema operatório constituído do qual deriva a relação - examinamos como Marx define a alteridade e o indivíduo. 
Em Marx, a multiplicidade é uma determinação imanente à natureza. Todo ser natural é sensível e tem objetos fora de si: "É idêntico: ser (sein) objetivo, natural, sensível e ao mesmo tempo ter fora de si objeto, natureza, sentido, ou ser objeto mesmo, natureza, sentido para um terceiro" $(M E F, 127)$. Esta definição do ser é geral, isto é, vale igualmente para todas as categorias de seres naturais, sejam os apenas objetivos que não possuem órgãos de sensibilidade - sejam os seres vivos; e no interior destes, os vegetais, que não são ativos, os animais, dotados pulsão e de atividade, e o homem, que dentre os animais desenvolve uma forma nova de pulsão e de atividade que caracteriza sua diferença específica. Assim, o ser natural é objetivo e ser objetivo significa ter fora de si objetos, ou seja, ser um frente a outros, ou ser outro para os demais: "Um ser que não tenha nenhum objeto fora de si não é nenhum ser objetivo. Um ser que não seja ele mesmo objeto para um terceiro ser não tem nenhum ser para seu objeto, isto é, não se comporta objetivamente, seu ser não é nenhum [ser] objetivo" $(M E F, 127)$.

Assim, a objetividade implica a multiplicidade porque o ser objetivo se define como tendo objetos fora de si. Estes são seus objetos e, por conseguinte, cada ser objetivo é também objeto para outros.

\footnotetext{
Assenta um ser, que nem é ele próprio objeto nem tem um objeto. Um tal ser seria, em primeiro lugar, o único ser, não existiria nenhum ser fora dele, ele existiria isolado e solitariamente. Pois, tão logo existam objetos fora de mim, tão logo eu não esteja só, sou um outro, uma outra efetividade que não o objeto fora de mim. Para este terceiro objeto eu sou, portanto, uma outra efetividade que não ele, isto é, [sou] seu objeto. Um ser que não é objeto de outro ser, supõe, pois, que não existe nenhum ser objetivo $(M E F, 127)$.
}

Ser objetivo é, portanto, ser objeto, existir para outros seres objetivos. Aqui é preciso destacar que, em Marx, não é necessário ser sujeito para ter objetos. Como se verá, a subjetividade é uma forma específica do ser objetivo. Ao abordar a natureza em geral e defini-la como uma objetividade múltipla e sensível - que pode ser apreendida pelos sentidos - o modo de ter objetos para si e ser objeto para outros varia conforme as determinações específicas de cada ser, e não significa a posição de uma finalidade sobre o objeto, o para si consciente, que é específico do ser social. Não significa também necessariamente uma forma de atividade, que é comum apenas aos seres animados. 
Marx acrescenta uma determinação fundamental aos seres vivos, que é o ser carente, padecente, limitado pela necessidade de seres fora de si, seus objetos, e dependente deles:

\begin{abstract}
A fome é uma carência natural; ela necessita, por conseguinte, de uma natureza fora de si, de um objeto fora de si, para se satisfazer, para se saciar. A fome é a carência confessada de meu corpo por um objeto existente (seienden) fora dele, indispensável à sua integração e externação essencial $(M E F, 127)$.
\end{abstract}

Os seres naturais vivos são padecentes, e sua carência de objetos fora de si se sacia apenas por meio da sensibilidade. O caráter padecente dos seres vivos se vincula essencialmente ao seu caráter sensível: mesmo no caso dos seres humanos historicamente desenvolvidos, em que a sensibilidade já se desdobrou em consciência e sentimentos - sentidos práticos para além dos cinco sentidos imediatos - a sensibilidade é mediação necessária e inescapável da satisfação das necessidades de todos os tipos. Além disso, o ser natural que padece é dotado de pulsões, forças que caracterizam a vida. Estas resumem as capacidades naturais que o ser vivo tem de satisfazer suas necessidades, e que, no caso dos animais, se põe como atividade. Todo ser natural vivo animado é ativo. Marx escreve:

\footnotetext{
O homem é imediatamente ser natural. Como ser natural, e como ser natural vivo, está, por um lado, munido de forças naturais, de forças vitais, é um ser natural ativo; estas forças existem nele como possibilidades e capacidades (Anlagen und Fähigkeiten), como pulsões; por outro, enquanto ser natural, corpóreo, sensível, objetivo, ele é um ser que sofre, dependente e limitado, assim como o animal e a planta, isto é, os objetos de suas pulsões existem fora dele, como objetos independentes dele. Mas esses objetos são objetos de seu carecimento (Bedürfnis), objetos essenciais, indispensáveis para a atuação e confirmação de suas forças essenciais (MEF, 127).
}

Nos seres naturais não vivos, a dependência dos outros seres não aparece como carência ou padecimento, visto que, sendo sensíveis, ou apreensíveis pelos sentidos, não são dotados de órgãos da sensibilidade. $O$ fato de terem objetos aparece na forma da interação em que necessariamente existem: a diferenciação da matéria, suas determinações químicas e físicas específicas se constituem apenas em conjunto, de modo que alterações em um de seus elementos significam uma transformação em todo o conjunto. Um exemplo emblemático desta integração em que todos os seres naturais se encontram é a influência da Lua nas marés. Podemos distinguir duas formas de 
alteridade: uma em que o outro aparece como uma exterioridade indiferente, nos casos em que não há qualquer integração entre os seres; e a segunda, em que um existe para o outro, de modo a constituírem-se como objetos recíprocos. De acordo com o texto de Marx, não há na natureza esta alteridade em que tudo que é outro se põe como mera exterioridade indiferente, visto que o conjunto dos seres naturais existe de maneira interdependente. Se retirássemos um dos seres de seu contexto natural, de sua natureza exterior, um dado conjunto seria modificado. Nos seres vivos, isso se torna manifesto se tomarmos em consideração os ecossistemas: qualquer mudança em um de seus elementos destrói o equilíbrio em que o conjunto existe e força transformações que repõem o equilíbrio em uma nova forma, alterando o modo como os seres se colocam como objetos recíprocos. Isso não significa que cada ser tem todos os outros como objeto, mas que todos têm objetos. Se a diferença específica dos seres objetivos vivos é ser carente - e no animais sentir sua carência - esta ausência de padecimento nos seres não vivos não exclui sua determinação de ser objeto para outros, e tampouco de ter objetos para si: "O sol é o objeto da planta, um objeto para ela imprescindível, confirmador de sua vida, assim como a planta é objeto do sol, enquanto externação da força evocadora de vida do sol, da força essencial objetiva do sol” (MEF, 127). Em primeiro lugar, o sol é objeto da planta: ela integra a si a energia solar como faz com a água, por exemplo. Mas também a planta é objeto do sol porque seu ser é a confirmação da "força evocadora de vida do sol". A planta não é necessária para a existência do sol, visto que o sol não padece; contudo, essa força do sol de evocar a vida não existe sem os seres vivos. Os seres naturais externam suas determinações apenas no outro: "Tão logo eu tenha um objeto, esse objeto tem a mim como objeto" $(M E F, 127-$ $8)$.

Os seres naturais caracterizam-se por terem objetos e serem objetos uns para os outros. A objetividade é o que caracteriza a natureza. Mas todos os seres são objetivos, e portanto naturais: "Um ser não-objetivo é um não-ser" ( $M E F, 127)$. Aquilo que podemos delimitar enquanto um ser é, pois, necessariamente objetivo e natural, condição que, em Marx, coincide com a multiplicidade e com a alteridade: apenas sou um ser porque sou objeto para os demais, ou “(...) tão logo eu não esteja só, sou um outro, uma outra efetividade que não o objeto fora de mim" (MEF, 127, citado acima). Veremos que todos os seres objetivos que emergem da vida social - seres humanos e seus produtos - são formas especificamente sociais da natureza. Marx escreve: "Mas 
um ser não objetivo é um ser não efetivo, não sensível, apenas pensado, isto é, apenas imaginado, um ser da abstração" $(M E F, 128)$. A abstração é um atributo específico do ser consciente, isto é, humano. O pensamento ganha existência prática quando se manifesta sensivelmente em linguagem, mas ainda assim o ser pensado não ganha existência sensível, nem o pensamento ou a linguagem em si mesmos tornam-se seres objetivos, mas são predicados do ser que pensa e fala. Do mesmo modo: o trabalho, a guerra, o capital, o Estado não são seres em si mesmos, mas existem como formas da relação ou da atividade de seres sensíveis humanos. Enquanto tais formas de exteriorização de seres objetivos, são objetivos, mas não são entes, e sim, formas objetivas do ser humano ${ }^{48}$.

A delimitação do ser que encerra em si mesmo a alteridade, como sua determinação central, não especifica a relação social; esta especificação, contudo, deve partir dela. Como ser natural sensível vivo, o homem é padecedor: "Ser (sein) sensível, isto é, ser efetivo, é ser objeto do sentido, ser objeto sensível, e, portanto, ter objetos sensíveis fora de si, ter objetos de sua sensibilidade. Ser sensível é ser padecente" $(M E F, 128)$. Além disso, como animal, o ser humano é dotado de forças vitais que o impulsionam a seu objeto:

Que o homem é um ser corpóreo, dotado de forças naturais, vivo, efetivo, objetivo, sensível significa que ele tem objetos efetivos, sensíveis como objetos de seu ser, de sua manifestação de vida (Lebensäusserung), ou que ele pode somente manifestar (äussern) sua vida em objetos sensíveis efetivos (wirkliche sinnliche Gegenstände) $(M E F, 127)$.

Até aqui, as determinações do ser humano não se distinguem das do animal: um ser sensível singular que padece - portanto limitado e dependente da natureza exterior - e que encontra em si pulsões, forças vitais que o impulsionam ativamente aos objetos de seu padecimento. Como os demais seres naturais, existe em imbricação com a multiplicidade natural que é para ele objeto necessário:

\footnotetext{
A natureza é o corpo inorgânico do homem, a saber, a natureza enquanto ela mesma não é corpo humano. O homem vive da natureza significa: a natureza é o seu corpo, com o qual ele tem de ficar num processo contínuo para não morrer. Que a vida física e mental do homem está interconectada com a natureza não tem outro sentido senão que a natureza está interconectada consigo mesma, pois o homem é uma parte da natureza $(M E F, 84)$.
}

\footnotetext{
${ }^{48}$ Esta distinção é de importância fundamental para a compreensão do valor, discutida no capítulo IV deste trabalho.
} 
O homem é pois um ser natural e sua vida especificamente humana tem origem na atividade vital natural que o põe em metabolismo com "a natureza enquanto ela mesma não é corpo humano". O corpo humano é natureza, e a natureza de que ele carece é sua natureza inorgânica. A diferença específica do gênero humano se define pela forma particular desta atividade vital, que é o trabalho:

Pois primeiramente o trabalho, a atividade vital, a vida produtiva mesma aparece ao homem apenas como um meio para a satisfação de uma carência, a necessidade de manutenção da existência física. A vida produtiva é, porém, a vida genérica. É a vida engendradora de vida. No modo $(A r t)$ da atividade vital encontra-se o caráter inteiro de uma species, seu caráter genérico, e a atividade consciente livre é o caráter genérico do homem $(M E F, 84)$.

Toda atividade produtiva, animal ou humana, é um meio para satisfação de necessidades que são dadas na condição de ser sensível padecente: a manutenção da existência física requer objetos que devem ser ativamente apropriados, ou mesmo formados pela atividade. A atividade resulta, nos animais e também no homem, de forças vitais dadas no organismo que os impelem ao objeto. $\mathrm{O}$ modo da atividade vital do indivíduo caracteriza o gênero animal a que pertence. No homem, o modo de atividade que caracteriza o gênero é a atividade consciente livre. O caráter livre da atividade produtiva humana consiste em ultrapassar a medida natural de sua espécie. A atividade humana deixa por isso de ser específica - medida pela espécie - e se torna universal. Marx escreve:

É verdade que também o animal produz. Constrói para si um ninho, habitações, como a abelha, castor, formigas etc. No entanto, produz apenas aquilo de que necessita imediatamente para si ou sua cria; produz unilateral[mente], enquanto o homem produz universal[mente]; o animal produz apenas sob o domínio da carência física imediata, enquanto o homem produz mesmo livre da carência física, e só produz, primeira e verdadeiramente, na [sua] liberdade [com relação] a ela; o animal só produz a si mesmo, enquanto o homem produz a natureza inteira; [no animal,] o seu produto pertence imediatamente ao seu corpo físico, enquanto o homem se defronta livre[mente] com o seu produto. O animal forma apenas segundo a medida e a carência da species a qual pertence, enquanto o homem sabe produzir segundo a medida de qualquer species, e sabe considerar, por toda parte, a medida inerente ao objeto $(M E F, 85)$.

A liberdade que caracteriza a atividade humana aparece aqui determinada como liberdade relativa à carência física. Esta carência imediatamente natural é a medida da espécie. O ser humano, na atividade que o caracteriza, ultrapassa esta medida, e, 
portanto, a carência imediata. Isso significa, em primeiro lugar, que a atividade produtiva do homem responde a necessidades que não estão dadas na natureza original do homem. Só por essa razão pode o homem se defrontar livremente com seu produto, ou seja, libertar o produto do pertencimento imediato ao corpo físico, que caracteriza a produção animal. A afirmação de Giannotti segundo a qual um outro, que não o produtor, comparece no consumo do produto, é explicada por Marx pelo caráter livre da atividade, e não pela mera existência objetiva do produto como ente distinto do produtor. Também o produto das abelhas, o mel, é uma coisa-aí, e o prova o fato dos homens e outros animais se apropriarem dele. É objeto de carecimento alheio. Mas o defrontar-se livremente com seu produto - que significa libertar-se da carência física atual, imediata - demanda uma forma específica de atividade que extrapola a "medida da espécie" ao pôr necessidades que não existem em sua imediaticidade natural, mais amplas. Estas necessidades, por conseguinte, devem ser novas com relação à naturalidade imediata, devem ser criadas. Ser consciente e ser livre ${ }^{49}$ são determinações idênticas ao se referirem à forma geral da atividade humana. Trata-se da liberdade de atividade do gênero, com relação aos limites impostos pela natureza imediata, ou dada. Necessidade nova não significa apenas a carência de um produto inexistente na

\footnotetext{
${ }^{49}$ Em termos gerais, liberdade significa autodeterminação. Quando trata das determinações gerais do trabalho como atividade especificamente humana, a liberdade se refere à determinação natural imediata, à forma como a natureza põe o homem. Ao criar necessidades e formas de atividade novas, caracterizandose como um ser cuja atividade vital é consciente, o homem é livre. Essa liberdade diz respeito aos limites postos pela natureza, tanto a exterior como a sua própria, à sua atividade, e se refere ao gênero humano em sua distinção dos demais gêneros animais. A liberdade aqui é definitiva da atividade vital do gênero, e portanto, do próprio gênero. Contudo, o desenvolvimento histórico das forças produtivas, ou seja, do domínio que o homem tem sobre a natureza, caracteriza também um aumento da liberdade do gênero com relação aos limites da natureza. Assim, se a atividade é por princípio livre, o grau de liberdade efetiva do gênero está determinado pelo aumento de sua capacidade de inscrever suas próprias finalidades no curso da natureza, dominando-a. Além disso, a liberdade individual não diz respeito apenas à natureza, mas é relativa aos outros homens e à comunidade humana. Ao tratar das transformações no homem introduzidas pela consolidação do capitalismo, Marx afirma que o indivíduo se tornou livre dos vínculos pessoais que definem as relações sociais nas sociedades pré-capitalistas. Trata-se de uma efetiva liberdade com relação à dominação política a que estava sujeito o indivíduo e das restrições ao seu campo de atividades, dentro da totalidade das atividades sociais; especificamente, trata-se da liberdade política. Ainda no que diz respeito à liberdade individual, Marx aponta que, no capitalismo pleno ou industrial, o gênero humano alcançou grande liberdade relativa aos limites naturais devido à desvinculação da terra, quando os pressupostos do trabalho passam a ser criados pelo próprio trabalho, mas o indivíduo não se apropriou desta liberdade. Mostra a contradição entre liberdade do gênero e liberdade individual. O indivíduo não é livre porque se encontra restrito, no campo de suas atividades e da fruição da produção genérica, pela propriedade privada ou divisão do trabalho, que põe o indivíduo como unilateral. Assim, se esta forma de propriedade é historicamente a base para ampliação da individuação e da liberdade, põe um limite à liberdade que apenas seria superado com a própria superação da propriedade privada e da divisão do trabalho. Aqui, liberdade significa ampliação das possibilidades de atividade e de fruição, bem como da capacidade de determinar sua vida, pelo indivíduo, não mais constrangido pela dominação de classe. De modo que a autodeterminação tem múltiplos aspectos e graus. Neste capítulo, abordo a liberdade apenas em seu primeiro aspecto, que é base para todos os seus desdobramentos. Alguns destes serão abordados, com maior ou menor desenvolvimento, ao longo do trabalho.
} 
natureza, mas também uma forma nova de se apropriar do existente ou mesmo a ampliação quantitativa da necessidade. A transformação no modo como as necessidades naturais são satisfeitas implica o advento de uma nova necessidade. Marx escreve:

Fome é fome, mas a fome que se sacia com carne cozida, comida com garfo e faca, é uma fome diversa da fome que devora carne crua com mão, unha e dente. Por essa razão, não é somente o objeto do consumo que é produzido pela produção, mas também o modo do consumo, não apenas objetiva, mas também subjetivamente (Introdução, 47).

Se a fome muda de forma é porque se tornou uma necessidade nova: esta fome específica não se sacia com carne crua, portanto, é necessidade de outro objeto. A qualquer forma mínima de estoque de objetos e à posse de qualquer objeto da natureza utilizado como instrumento que amplia a capacidade de se apropriar de objetos de consumo correspondem necessidades não dadas ao homem, mas criadas. Por isso, livres da determinação da espécie. Mas é condição da existência de uma necessidade nova a previsão das necessidades dadas, ou seja, a consciência da própria necessidade. Uma necessidade nova, para cuja satisfação cria-se uma forma nova de produzir, deve ser consciente precisamente porque, ao extrapolar o dado orgânico, é criada. A carência põe a finalidade da atividade produtiva quando é conhecida, consciente. Assim, criação de necessidades, posição de finalidades, liberdade e consciência são expressões que designam o mesmo salto que a atividade humana significa em relação à atividade animal, e caracterizam esta atividade.

Como atividade criada para a realização de fins criados, a atividade livre é necessariamente particular, no sentido de que é uma possibilidade dentre outras. É definitivo da criação o caráter múltiplo: se houvesse apenas uma forma de se criar, esta não seria efetivamente criativa, mas dada. Assim, grupos humanos primitivos em condições naturais similares desenvolvem-se muito diferentemente, criando a multiplicidade cultural, ainda que no interior dos mesmos modos de produção e com mesmo nível de força produtiva ${ }^{50}$. A atividade consciente livre é criativa e, por sua

\footnotetext{
${ }^{50} \mathrm{O}$ modo de produção de uma sociedade se caracteriza pela forma das relações de produção ou da divisão do trabalho, que é determinada pelo nível das forças produtivas ou domínio da natureza. O mesmo modo de produção está presente em povos entre os quais não há intercâmbio. Por exemplo, o comunismo primitivo está no limiar de todos os povos e a consciência mitológica é a forma de consciência primeira de todos os povos, por mais que se distingam os conteúdos das mitologias; encontramos o modo de produção feudal na França e no Japão, em momentos distintos, como explica o historiador Perry Anderson (ANDERSON, P., Linhagens do Estado Absolutista. Tradução de João Roberto Martins Filho. São Paulo: Brasiliense, 1998, pp. 433-459). Assim, as formas gerais da divisão do trabalho, porque condicionadas pelo desenvolvimento das forças produtivas, se repetem. Entretanto, mesmo quando isso
} 
própria natureza, múltipla. Porque é nova em relação à natureza dada, a atividade é livre, mas ocorre sob condições determinadas, no interior das possibilidades naturais existentes, que se amplia conforme o aumenta o domínio da natureza. Este domínio significa o "saber considerar a medida imanente ao objeto" ( $M E F, 85$, citado acima). Não apenas a carência é consciente, mas também o objeto é conhecido ou dominado na medida em que é trabalhado. Quanto maior tal domínio, mais livre é a atividade com relação ao limite imposto pela natureza. Isso significa que mais possibilidades se apresentam à atividade produtiva: "o homem sabe produzir segundo a medida de qualquer species". Dominar a natureza, que designa o conjunto de objetos da atividade produtiva, é conhecê-la, saber a medida de seus diversos seres.

Este caráter consciente e criativo da atividade vital humana, que tende à universalização ao extrapolar a medida específica ou natural do gênero, faz da própria natureza do homem, objeto de sua atividade. Ao pôr a si mesmo como seu objeto, o homem se caracteriza como o único dentre os animais que é um ser genérico:

O animal é imediatamente um com a sua atividade vital. Não se distingue dela. É ela. O homem faz da sua atividade vital mesma um objeto da sua vontade e da sua consciência. Ele tem atividade vital consciente. Esta não é uma determinidade com a qual ele coincide imediatamente. A atividade vital consciente distingue o homem imediatamente da atividade vital animal. Justamente, só por isso, ele é um ser genérico. Ou ele somente é um ser consciente, isto é, sua própria vida lhe é objeto, precisamente porque é um ser genérico. Eis porque sua atividade é atividade livre $(M E F, 84)$.

A vida do indivíduo animal não é objeto de sua atividade: este faz de outros seres da natureza objetos para manter e reproduzir sua vida. A atividade vital do animal é também sua diferença específica, aquilo que o caracteriza. Mas esta determinação está dada a cada indivíduo por seu mero pertencimento ao gênero, de modo que o conjunto dos indivíduos são todos exemplares imediatos deste. Por isso, não se distinguem de sua atividade vital, mas são esta atividade. A liberdade não existe na identidade imediata de todos os indivíduos com o gênero, porque estes só são exemplares imediatos do gênero quando não são livres: suas diferenças específicas se restringem àquelas que são fisicamente dadas. No ser humano, a própria atividade vital se torna objeto para ele na medida em que se torna mediada por finalidades conscientes. A atividade vital humana

ocorre, os modos específicos das atividades, os produtos que cada sociedade cria, suas línguas, suas manifestações artísticas etc. são absolutamente diversas. 
é pois mediada pelo próprio homem: ser consciente é ter a si mesmo como objeto. A atividade não é, pois, imediatamente dada nas determinações do gênero, mas posta de modo mediado, e, por essa razão, o indivíduo humano não coincide imediatamente com sua atividade vital. Pôr finalidades, criando assim necessidades, é ser ativo para si. Ser genérico é, pois, ser para si, ser mediado pela sua própria criação, autoprodutor; e a atividade livre, atividade que visa ou se põe para o gênero.

O homem é um indivíduo particular: não existe o homem senão como indivíduos particulares, visto que tudo o que existe - como um ser ou ente, e não como qualidade, predicado ou forma de ser - é sensível. Na crítica que faz de Feuerbach, Marx considera idealista o fato de que "ele diz 'o homem', em vez de 'os homens históricos reais"” (IA, 30). Como não existe "o homem", o gênero humano existe apenas como os múltiplos indivíduos que pertencem ao gênero. O mesmo se passa com os gêneros animais: não há realmente "o leão", mas apenas os leões efetivos, de modo que o gênero leonino existe também apenas nos múltiplos indivíduos. Por conseguinte, a atividade vital, tanto nos animais como nos homens, é atividade individual. Vimos o modo como o indivíduo animal coincide com seu gênero: a atividade vista está dada para o indivíduo na natureza de sua espécie, e por isso a atividade individual de manutenção e reprodução da vida característica de cada espécie resume o gênero. Por isso, nas espécies animais o caráter genérico é abstrato, mudo: o gênero se caracteriza pela abstração das determinações comuns aos indivíduos. No ser humano, o gênero não pode ser a abstração do que há de comum nos indivíduos, pois esta definição excluiria tudo aquilo que é criado pelo homem - o novo, livre, para si e múltiplo - que é justamente o que o caracteriza o gênero humano. Este é, pois, a totalidade das atividades individuais, de sorte que nem consiste em uma abstração dos traços comuns aos membros individuais, e tampouco se identifica imediatamente com nenhum indivíduo singular" : "Mas a essência humana não é uma abstração intrínseca ao indivíduo isolado. Em sua realidade,

\footnotetext{
${ }^{51}$ Essa diferença entre o indivíduo e o gênero, ou entre a atividade individual e o produto do gênero é uma das determinações do homem como um ser cuja natureza é social e histórica. A atividade humana é consciente, mas esta consciência é o pôr de finalidades específicas: para cada produção, o homem prevê os resultados. Contudo, como a satisfação de necessidades impulsiona a criação de novas necessidades, e o intercâmbio se amplia criando, além de necessidades, novas formas de relação, não é possível prever o resultado do conjunto das atividades humanas. Ainda que, no comunismo, a produção global da sociedade seja planejada mediante a consciência das necessidades dos indivíduos, o que cria um domínio maior sobre a atividade total e maior poder de previsão dos resultados, ainda assim, pelas mesmas razões, o resultado histórico do conjunto das atividades não pode ser previsto: que necessidades surgirão, que conflitos serão postos a partir das novas relações, nada disso pode ser previsto ainda que se planeje a produção social. O comunismo não finda a história, ainda que signifique um salto inédito no grau de domínio social sobre a natureza do próprio homem.
} 
ela é o conjunto das relações sociais" (IA, 534). O indivíduo traz em si a totalidade do gênero:

\footnotetext{
"O homem - por mais que seja, por isso, um indivíduo particular, e precisamente sua particularidade faz dele um indivíduo e uma coletividade efetivo-individual (wirkliches individuelles Gemeinwese - coletividade individual efetiva - VC) - é, do mesmo modo, tanto a totalidade, a totalidade ideal, a existência subjetiva da sociedade pensada e sentida para si, assim como ele também é na efetividade, tanto como intuição e fruição efetiva da existência social, quanto como uma totalidade de externação humana de vida" $(M E F, 108)$.
}

Sendo necessariamente particular, e porque é particular, o indivíduo é uma "coletividade individual efetiva", ou seja, é o gênero como ele existe na realidade efetiva. Esta passagem do texto do Marx considera, em primeiro lugar, que o homem é um indivíduo humano particular, ou seja, que, à diferença dos animais singulares coincidentes com o gênero, é singularizado. Esta é uma implicação de seu caráter consciente: o homem é consciente de si mesmo e portanto sabe que é um frente a outros. Os espécimes animais não se individuam, ou seja, a forma de sua atividade e de sua sensibilidade não distingue um espécime singular de outro. A particularização é apenas física. No homem, o caráter consciente pressupõe a individuação e, portanto, sua posição como ser singular que se distingue dos demais. Além disso, a atividade consciente ou para si do homem, que põe a si mesmo como objeto, define o ser humano como sujeito. Assim, a singularidade é presente na natureza em geral, tudo que existe, existe como algo singular; a individuação, por outro lado, é um processo estritamente social: os seres humanos passam da condição de meramente singulares para a condição de indivíduos. Ser indivíduo humano, ser consciente e ser sujeito expressam um mesmo modo de ser, a singularidade social.

Mas, em segundo lugar, sendo o homem necessariamente o indivíduo singular, ele não pode ser, como os animais, uma expressão imediata do gênero. Por essa razão o gênero passa a se definir como a totalidade das formas de atividade e de sensibilidade dos indivíduos humanos. Na passagem acima, Marx afirma que o indivíduo é "tanto a totalidade, a totalidade ideal, a existência subjetiva da sociedade pensada e sentida para si, assim como ele também é na efetividade". Abstraindo inicialmente do fato de que o indivíduo é a existência subjetiva da sociedade pensada e sentida para si em sua totalidade, é importante explicitar como o indivíduo é na efetividade: ele é tanto fruição efetiva da existência social, quanto uma totalidade de externação humana de vida. Se o 
indivíduo é singular e distinto dos demais - não importa em que grau - ele à primeira vista aparece como parcial com relação ao gênero, diferentemente dos animais que, por não se distinguirem em sua atividade vital, expressam, cada um, a essência do gênero. $O$ que Marx destaca é que, neste seu caráter particular e especialmente devido à forma social de existência de sua singularidade, o indivíduo é a totalidade do gênero. Isso ocorre tanto no nível da sensibilidade, "como intuição e fruição da existência social", como no da atividade, como "totalidade de externação humana de vida". Em sua atividade e sensibilidade parciais com relação ao gênero, porque singulares, o indivíduo traz em si a totalidade do gênero. Também a consciência do indivíduo é a consciência do gênero, mediada pelas particularidades que a caracterizam, "a totalidade ideal, a existência subjetiva da sociedade pensada e sentida para si”. O que Marx demonstra é que o indivíduo não é outro com relação ao gênero, mas é ele mesmo o gênero em forma singular, a única que existe efetivamente. E que, além disso, a singularidade que faz do ser humano um indivíduo parcial frente ao conjunto da vida genérica, é o único e necessário modo de existência do gênero. $\mathrm{O}$ indivíduo se define como "um ser genérico determinado" $(M E F, 108)$. Mas o indivíduo traz em si o gênero não apenas porque, na efetividade, "o homem" total não existe, como se este fosse uma soma que só se apresenta em suas partes componentes. Cada singularidade humana traz de fato a totalidade. Isso porque o indivíduo, ou a atividade consciente livre, se constitui na relação social. O que Marx explicita e é a chave para a compreensão da relação social é que a consciência, que faz do ser humano um objeto de sua própria atividade e a torna mediada, apenas se desenvolve porque o ser humano é ativo em sociedade: “(...) ele somente é um ser consciente, isto é, sua própria vida lhe é objeto, precisamente porque é um ser genérico" ( $M E F, 84$, citado acima). Como ser genérico, a atividade individual existe para o gênero. Marx escreve: "Mas o homem não é apenas ser natural, mas ser natural humano, isto é, ser existente para si mesmo, por isso, ser genérico (...)" (MEF, 128). Isso significa que o homem é um ser existente para si mesmo porque é um ser genérico, de modo que o indivíduo apenas existe para si porque existe para outros. $\mathrm{O}$ para si que caracteriza a atividade vital do homem significa que esta atividade, que é predicado do indivíduo, se realiza necessariamente para outrem, ou seja, ser genérico é ser social. Constituir-se como indivíduo e como ser genérico são dois aspectos indissociáveis do ser que se constitui em relação: ao realizar sua atividade produtiva em relação com outros o indivíduo se produz como ser genérico, mas pelo mesmo motivo, a 
relação põe os indivíduos uns frente aos outros e com isso individualiza. O ser social implica a determinação individual e a individuação implica a relação social.

Por que Giannotti quer evitar partir de "sujeitos constituídos", dos indivíduos? Porque, de fato, o trabalhador tal como o conhecemos não existiu sempre, o indivíduo se transforma. O processo de individuação está diretamente ligado ao desenvolvimento da divisão do trabalho e ao desenvolvimento do gênero. O nível de individuação amplia-se neste processo histórico. Mas tão logo se põe a relação social, que coincide com a criação da linguagem e também da consciência, põe-se o indivíduo e a subjetividade. A condição de sujeito é imanente ao ser humano e é sua própria definição: ser para si. Além disso, como só há seres naturais, a subjetividade não pode existir como ente autônomo, mas apenas como forma do ser efetivo, individual: “(...) parte-se dos próprios indivíduos reais, vivos, e se considera a consciência apenas como sua consciência" (IA, 94).

Como se desenvolve o modo humano de ser? Na atividade produtiva mesma, cujo caráter é a diferença específica do humano. Necessidade nova, consciência, subjetividade ou individualidade, relação social e transformação objetiva da natureza são todas aspectos da categoria do trabalho e o definem. O homem se desprende da imediaticidade da natureza quando sua atividade é trabalho, e nele, todos esses momentos inseparáveis são desenvolvidos concomitantemente, de modo que não há um anterior e um posterior. É o que Marx e Engels demonstram ao caracterizarem "o primeiro ato histórico":

\footnotetext{
O primeiro ato histórico é, pois, a produção dos meios para a satisfação das necessidades, a produção da própria vida material, e este é, sem dúvida, um ato histórico, uma condição fundamental de toda a história, que ainda hoje, assim como há milênios, tem de ser cumprida diariamente, a cada hora, simplesmente para manter os homens vivos. (...) O segundo ponto é que a satisfação dessa primeira necessidade, a ação de satisfazê-la e o instrumento de satisfação já adquirido conduzem a novas necessidades - e essa produção de novas necessidades constitui o primeiro ato histórico $(I A, 33)$.
}

O primeiro ato histórico o é em dois sentidos. Como origem, significa que o homem deixa de ser apenas mais um ser da natureza e se torna um ser natural de novo tipo, que é o ser social: sua natureza deixa de ser dada e passa a ser criada historicamente nas relações sociais. Segundo, significa fundante, na medida em que é um ato que deve ser reproduzido ao longo da história, embora em formas novas. A reprodução de um modo 
de vida pelas gerações novas, modo que não se transmite mais hereditariamente como nas demais espécies animais, mas por meio de aprendizado, ou seja, socialmente, é parte do primeiro ato histórico. A produção de meios de vida não dados na natureza não seria um ato histórico se não fosse repetido pelas gerações novas, mas seria apenas um ato pontual, que desapareceria ${ }^{52}$. O resultados acumulados do trabalho, a apropriação e reprodução de um mundo humano pelas gerações novas é o que permite que o ato de produção de meios de vida novos se constitua em ato histórico, que cria necessidades de natureza social. Na categoria de trabalho, estão envolvidas portanto a criação e a reprodução (ou fixação) social das novas práticas. Esta reprodução dos meios de vida por novas gerações sobre os resultados do trabalho passado é ao mesmo tempo produção de indivíduos determinados, o modo de atividades que apreendem é seu modo de ser, seu caráter social: "Tal com os indivíduos exteriorizam sua vida, assim são eles. O que eles são coincide, pois, com sua produção, tanto com $o$ que produzem como também com o modo como produzem. O que os indivíduos são, portanto, depende de suas condições materiais de produção" (IA, 87). Nesta reprodução dos meios de vida, consolida-se a atividade produtiva como uma necessidade nova, não dada na natureza imediata do homem, consolidação que é ao mesmo tempo impulso à criação de novas necessidades.

Na explicação de Marx e Engels sobre a consciência e a linguagem como momentos do trabalho, a necessidade do caráter social também se explicita. $O$ pôr de algo não inscrito na espécie e portanto novo, tanto objetiva como subjetivamente, depende da relação social:

(...) esta também não é, desde o início, "consciência "pura". O "espírito" sofre, desde o início, a maldição de estar "contaminado" pela matéria, que, aqui, se manifesta sob a forma de camadas de ar em movimento, de sons, em suma, sob a forma de linguagem. A linguagem é tão antiga como a consciência - a linguagem é a consciência real, prática, que existe para os outros homens e que, portanto, também existe para mim mesmo; e a linguagem nasce, tal como a consciência,

\footnotetext{
${ }^{52}$ Alguns primatas chegam a utilizar instrumentos de trabalho: pegam, por exemplo, pedaços de pau para alcançar frutas, mas não fixam esta experiência e não a transmitem para os demais. Esgota-se quando a fruta é alcançada e não é utilizada para alcançar a próxima fruta. Não é reconhecida por outro, e portanto não leva à necessidade de comunicação que cria a linguagem e a consciência. Se for repetida, todo o processo de tentativa e erro se repõe. Não há relação social e portanto não há o acúmulo requerido para que, a partir de uma necessidade satisfeita, as novas gerações desenvolvam novas necessidades.
} 
do carecimento, da necessidade de intercâmbio com outros homens. Desde o início, portanto, a consciência já é um produto social e continuará sendo enquanto existirem homens $(I A, 34-5)^{53}$.

O pôr de finalidades que caracteriza o trabalho está fundado na consciência de si mesmo e das próprias necessidades. A consciência apenas se constitui na relação social: como o indivíduo só existe para si mesmo quando existe para outro, a consciência, que é este para si, apenas se desenvolve no intercâmbio que cria a linguagem. Um pensamento não existe separado de sua expressão em linguagem: é certo que os indivíduos podem pensar sem comunicar o pensamento, mas a elaboração do pensamento, a forma como ele existe subjetivamente, é linguagem. A consciência se cria enquanto se objetiva em linguagem, de modo que a criação coletiva da linguagem, cuja natureza é social, é ao mesmo tempo a constituição da consciência individual. Parte da necessidade de ampliar a comunicação entre os homens e, quando esta necessidade se realiza por meio da linguagem, a comunicação assume forma humana, social. Desnecessário mencionar que o indivíduo privado do intercâmbio humano não aprende a falar e tampouco a pensar, do mesmo modo que as crianças em qualquer fase social apenas desenvolvem a consciência na medida em que aprendem a falar ou se apropriam da linguagem. Se a consciência se desenvolve socialmente, também as finalidades do trabalho são sociais, necessidades coletivas. O desenvolvimento da linguagem e da consciência é também a criação da subjetividade como determinação do ser objetivo, o ser para si. Mas o homem só se põe como objeto para si ao se pôr para o outro, de modo que é na relação social, e portanto coletivamente, que o homem se torna sujeito. Ao se colocar para outro, o ser humano se constitui como indivíduo específico frente aos demais, de modo que a relação social individualiza. O caráter genérico e a individualidade aparecem então como aspectos interdependentes de um único modo de ser, de uma mesma forma de atividade, a atividade social. A atividade social tem pois como ponto de partida e como produto indivíduos determinados por esta atividade: "Indivíduos produzindo em sociedade - por isso, o ponto de partida é, naturalmente, a produção dos indivíduos

\footnotetext{
${ }^{53}$ Marx não é único a ver como momento de um mesmo processo a sociabilidade e a linguagem. Por supor os homens isolados por natureza e a sociabilidade como um ato de vontade, Rousseau se vê em dificuldades para explicar a linguagem: "Quanto a mim, assustado com as dificuldades que se multiplicam e convencido da impossibilidade quase comprovada de que as línguas tenham podido nascer e se estabelecer por meio puramente humanos, deixo a quem queira empreender a discussão desse difícil problema: o qual foi mais necessário, à sociedade já formada, se a instituição das línguas ou as línguas já inventadas, ao estabelecimento da sociedade" (ROUSSEAU, J.-J., Discurso sobre a origem e os fundamentos da desigualdade entre os homens, op. cit., p. 71). Rousseau não conecta, contudo, a produção material de algo novo à sociabilidade e à linguagem, mas concebe o atributo da perfectibilidade como inerente à natureza do homem, ou seja, inscrito na espécie.
} 
socialmente determinada" (Introdução, 39). O indivíduo determinado é "um resultado histórico" do desenvolvimento (Introdução, 40).

Em Marx, a atividade social de produção da vida abrange não apenas a criação de meios de vida, mas também a reprodução dos indivíduos: “A terceira condição que já de início intervém no desenvolvimento histórico é que os homens, que renovam diariamente sua própria vida, começam a criar outros homens, a procriar - a relação entre homem e mulher, entre pais e filhos, a família" (IA, 33). A família é uma relação social, e portanto existe sob diferentes formas. Embora a reprodução da vida humana seja uma atividade dada na natureza imediata do homem, assume forma social à medida que o homem se torna ser social. Marx afirma:

A produção da vida, tanto da própria, no trabalho, quanto da alheia, na procriação, aparece desde já como uma relação dupla - de um lado, como relação natural, de outro, como relação social -, social no sentido de que por ela se entende a cooperação de vários indivíduos, sejam quais forem as condições, o modo e a finalidade $(I A, 34)$.

Também esta relação natural de procriação se desenvolve em formas sociais ao responder a necessidades que vão além do impulso natural imediato, conferindo formas novas a este impulso. $\mathrm{O}$ conjunto das necessidades originais no homem não se distingue daquelas dos outros animais: estão dadas em sua forma de existência imediata, são determinadas por sua estrutura biológica e se referem à manutenção da vida e à satisfação de impulsos físicos, como a relação sexual. É importante pontuar que esta última não se confunde com a finalidade de procriação, visto que a reprodução como finalidade é estritamente humana e pressupõe já certo desenvolvimento: os animais procriam porque a atividade de reprodução está inscrita em seu organismo como impulso, e não porque seu resultado, ter filhotes, exista para eles enquanto fim anteposto. A condição de ser natural não é apenas a situação original do homem que está para se tornar humano, mas é uma condição que não pode ser suprimida. As carências imediatamente físicas jamais desaparecem, mas, com o processo de humanização do homem, tornam-se carências humanas. A transformação de uma necessidade natural em uma necessidade humana é exposta na consideração de Marx sobre a relação homem-mulher ${ }^{54}$ :

\footnotetext{
${ }^{54}$ Marx não aborda a relação sexual entre indivíduos do mesmo sexo, que resulta de um desenvolvimento caracteristicamente humano.
} 
A relação imediata, natural, necessária, do homem com o homem é a relação do homem com a mulher. Nesta relação genérica natural a relação do homem com a natureza é imediatamente a sua relação com o homem, assim como a relação com o homem é imediatamente a sua relação com a natureza, a sua própria determinação natural $(M E F, 104)$.

Nesta passagem, Marx destaca o fato de que a relação entre os sexos é imediata e natural, como entre os animais. Por isso, a relação sexual entre os indivíduos é ao mesmo tempo relação do homem com a natureza, especificamente com sua própria natureza. Neste sentido, o homem nunca deixa de ser natural, mas a forma de sua naturalidade muda, torna-se forma humanizada da natureza, natureza humana em transformação. Marx caracteriza a relação entre mulher e homem como a relação social mais natural:

(...) a relação do homem com a mulher é a relação mais natural do ser humano com o ser humano. Nessa relação se mostra também até que ponto o comportamento natural do ser humano se tornou humano (...). Nesta relação também se mostra até que ponto a carência do ser humano se tornou carência humana para ele, portanto, até que ponto o outro ser humano se tornou carência para ele (...) $(M E F, 105)$.

A necessidade sexual imediatamente dada no organismo humano não implica carência de outro ser humano: a realização do impulso demanda sem dúvida uma interação com outro indivíduo, do mesmo modo que o impulso da fome demanda a integração de outro ser orgânico em seu próprio corpo para se realizar; mas a carência de um outro que caracteriza a carência humana pressupõe a relação social e a condição de indivíduo. A carência sexual imediata impulsiona a outro indivíduo indiferentemente. Se este impulso é mediado pela beleza ou pelo amor, torna-se uma necessidade humana, portanto nova, que não está dada na imediaticidade. A carência meramente natural se desenvolve em carência humana, ao mesmo tempo em que a sensibilidade se desdobra em sentimento. Mas independente do nível de desenvolvimento social, esta relação continua sendo a relação mais natural do ser humano com o ser humano, porque sempre implica a mesma interação física, natural. É precisamente a naturalidade desta relação que se transforma, pelo desenvolvimento de mediações - beleza, amor, obrigação, interesses de outras ordens - que determinam o modo como esta relação natural se dá. Neste sentido, a natureza humana se desenvolve, se torna natureza social, e isso se expressa no modo como se dão as relações. A sociabilidade, portanto, não se opõe à 
natureza, e tampouco é uma natureza segunda, mas uma forma específica da natureza, uma mediação no evolver do curso natural ${ }^{55}$.

Os indivíduos se constituem na medida em que se relacionam. Mas os sujeitos não se criam apenas em sua recíproca relação imediata. É por meio da apropriação, fruição e criação ativa - "externação humana de vida" - do mundo humano objetivo que se formam os indivíduos como seres genéricos. A teoria de Marx relativa ao desenvolvimento da sensibilidade humana lança luz ao modo como a totalidade da atividade social está presente em cada indivíduo parcial e a necessidade de que isto se realize por meio da criação objetiva de um mundo humano, pela atividade produtiva do conjunto dos indivíduos. Por meio da presença do objeto criado por outros indivíduos é que a sensibilidade se constrói. Vale citar uma longa passagem de Marx:

Por outro lado, subjetivamente apreendido: assim como a música desperta primeiramente o sentido musical do homem, assim como para o ouvido não musical a mais bela música não tem nenhum sentido, é nenhum objeto, porque o meu objeto só pode ser a confirmação de uma das minhas forças essenciais, portanto só pode ser para mim da maneira como a minha força essencial é para si como capacidade subjetiva, porque o sentido de um objeto para mim (só tem sentido para um sentido que lhe corresponda) vai precisamente tão longe quanto vai o meu sentido, por causa disso é que os sentidos do homem social são sentidos outros que não os do não social; [é] apenas pela riqueza objetivamente desdobrada da essência humana que a riqueza da sensibilidade humana subjetiva, que um ouvido musical, um olho para a beleza da forma, em suma, as fruições humanas todas se tornam sentidos capazes, sentidos que se confirmam como forças essenciais humanas, em parte recém-cultivados, em parte recém-engendrados. Pois não só os cinco sentidos, mas também os assim chamados sentidos espirituais, os sentidos práticos (vontade, amor etc.), numa palavra o sentido humano, a humanidade dos sentidos, vem a ser primeiramente pela existência do seu objeto, pela natureza humanizada $(M E F, 110)$.

Cada sociedade conforma o modo da sensibilidade dos indivíduos na medida em que seus objetos são o mundo humano criado pelo conjunto dos indivíduos, a natureza humanizada. A existência do objeto conforma os órgãos subjetivos de apropriação e de fruição. Nesta constituição dos sentidos humanizados, adequados aos objetos, conforma-se também a necessidade dos objetos. A criação de objetos é ao mesmo tempo

\footnotetext{
${ }^{55}$ A concepção de que o ser humano tem uma dupla natureza, natural e social, parece-me dar margem à ideia de que convivem no indivíduo impulsos imediatamente naturais, sobredeterminados ou coagidos por necessidades desenvolvidas em sociedade. Em Marx, não aparece a ideia de duas naturezas; ao contrário, a sociabilidade aparece como uma mediação que confere novas formas aos impulsos dados na natureza imediata do homem. Assim, a ideia de um afastamento das barreiras naturais propiciado pelo desenvolvimento produtivo é mais um domínio da natureza que confere forma social à naturalidade.
} 
o desenvolvimento de necessidades e de capacidades subjetivas: daí a fruição (artística, no caso) ser uma confirmação das forças essenciais humanas, e não forças imediatamente naturais, pois os sentidos são engendrados, cultivados, constituídos como sentidos capazes de apropriar-se dos objetos sociais. Em outro texto, Marx escreve: "A produção não apenas fornece à necessidade um material, mas também uma necessidade ao material. O próprio consumo, quando sai de sua rudeza e imediaticidade originais, (...) é mediado, enquanto impulso, pelo objeto" (Introdução, 47). Os objetos são a forma material das necessidades e da capacidade de fruição. Como produtos, expressam as formas do conjunto das atividades. Pela fruição do mundo humano, cada indivíduo se apropria, de modos mais ou menos singularizados, da natureza genérica do homem, da forma específica como dada sociedade reproduz os indivíduos, e por isso da totalidade, embora isso não signifique necessariamente a totalidade extensiva das atividades: a forma dos sentidos se constitui na apropriação dos objetos criados pelo conjunto, de sorte que, ao compartir o mundo objetivo, os indivíduos constroem uma forma comum dos sentidos. "A formação dos cinco sentidos é um trabalho de toda a história humana do mundo até aqui" $(M E F, 110)$, do mesmo modo que a construção do mundo objetivo humano é resultado histórico. Por sentidos, Marx entende não apenas os cinco sentidos naturais que se humanizam historicamente, mas os sentidos que denomina espirituais ou práticos, e que são formas de sentir que se desdobram da sensibilidade imediata, os sentimentos e vontades. Os sentidos naturais se tornam humanos na medida em se desdobram em novos sentidos especificamente humanos, que atuam como mediação na sensibilidade ${ }^{56}$.

Além disso, nas atividades produtivas diretamente coletivas, os indivíduos têm na ação do outro uma forma de apropriação da vida genérica. Desenvolvem-se órgãos, ou seja, capacidades de criação e fruição, que são imediatamente sociais:

\footnotetext{
${ }^{56}$ Uma ilustração deste caráter prático dos sentidos que se desenvolvem para além dos cinco sentidos naturais e os medeiam é dada por Thomas Mann em José e seus irmãos. Ao tematizar a beleza humana, o autor escreve: "Supõe-se existirem leis reguladoras da beleza. Mas uma lei que fala ao entendimento, não às emoções, porquanto estas refogem à tutela daquele. (...) Uma lei obriga e edifica exteriormente, a compulsão interior não é coisa de lei mas de mágica. A beleza é uma mágica exercida sobre as emoções e, como tal, sempre meio ilusória, muito vacilante e efêmera em seus efeitos. Coloque-se uma cabeça feia sobre um corpo formoso: este já não será formoso em nenhum sentido que possa impressionar as emoções, a não ser, talvez, no escuro, e então trata-se de uma ilusão. Na verdade quanta ilusão, quanta trapaça, quanto engano andam metidos nesse negócio! O mundo está cheio de histórias de moços vestidos de mulheres, virando a cabeça dos homens, de moças de casaco e de calças despertando paixões nas pessoas do seu próprio sexo. E em cada caso destes, uma vez descoberto o embuste, as emoções arrefecem, porque a beleza perdeu seu objetivo prático" (MANN, Thomas, José e seus irmãos - vol. 1 As histórias de Jacó; O jovem José. Tradução de Agenor Soares de Moura. Rio de Janeiro: Nova Fronteira, 1983, pp. 319-20).
} 
Da mesma maneira, os sentidos e o espírito de outro homem se tornaram a minha própria apropriação. Além desses órgãos imediatos [o olho, o ouvido etc. - VC] formam-se, por isso, órgãos sociais, na forma da sociedade, logo, por exemplo, a atividade em imediata sociedade com outros etc., tornou-se um órgão de minha externação de vida e um modo de apropriação da vida humana $(M E F, 109)$.

Nas atividades coletivas, como as ações individuais são associadas e constituem-se no conjunto, a ação de um se torna uma forma de externação da vida do outro. Assim, os indivíduos, em sua sensibilidade, atividade e consciência, são produto do gênero ao se constituírem na atividade coletiva de humanização do mundo objetivo; por conseguinte, o modo de vida do indivíduo traz consigo a totalidade do gênero, de um modo determinado.

Mas a sociabilidade não se põe apenas onde existe a atividade coletiva ou a relação imediata: "A atividade social e a fruição social de modo algum existem unicamente na forma de uma atividade imediatamente comunitária, (...)" $(M E F, 107)$. Como constituinte do indivíduo, o caráter social existe no conjunto de sua manifestação de vida:

Posto que também sou cientificamente ativo etc., uma atividade que raramente posso realizar em comunidade imediata com outros, então sou ativo socialmente porque [o sou] enquanto homem.

Não apenas o material de minha atividade - mas a própria língua na qual o pensador é ativo - me é dado como produto social, a minha própria existência é atividade social. $(M E F, 107)$.

O trabalho do indivíduo isolado - o trabalho intelectual, no exemplo de Marx - é social na medida em que a atividade consciente é sempre para outro: a língua, o material, os pressupostos da atividade são postos pelo gênero. E ainda que fosse possível pensar em uma finalidade puramente individual ${ }^{57}$, o desenvolvimento dos sentidos, a capacidade de fruição e os objetos das carências do indivíduo são determinados pela apreensão de um mundo humano objetivo criado pelo gênero. A mediação da atividade consciente, o modo como o homem é mediador de sua própria atividade, e por isso auto-determinado, é o mundo humano objetivo: "O engendrar prático de um mundo objetivo, a elaboração da natureza inorgânica é a prova do homem enquanto ser genérico consciente, isto é, um ser que se relaciona com o gênero enquanto sua própria essência ou [se relaciona] consigo enquanto ser genérico" $(M E F, 85)$. De modo que o resultado da atividade

\footnotetext{
${ }^{57}$ Em uma sociedade desenvolvida em que já é possível isolar-se, dado o desenvolvimento da divisão do trabalho.
} 
consciente individual é o resultado da atividade genérica. É um produto do gênero para o gênero. Marx escreve:

Acima de tudo é preciso evitar fixar mais uma vez a "sociedade" como abstração frente ao indivíduo. O indivíduo é o ser social. Sua manifestação de vida - mesmo que ela também não apareça na forma imediata de uma manifestação comunitária de vida, realizada simultaneamente com outros - ée, por isso, uma externação e confirmação da vida social. A vida individual e a vida genérica do homem não são diversas (...) $(M E F, 107)$.

A relação social é a essência tanto do gênero quanto do indivíduo. A vida genérica e a vida individual não são diversas, de modo que a sociedade - ou o gênero - não é uma abstração frente aos indivíduos, mas a totalidade de sua atividade.

Retomo em seguida a interpretação que Giannotti realiza da categoria de trabalho como esquema operatório e o conceito derivado de individualidade técnica como contorno lógico da relação social de produção, destacando alguns pontos de sua divergência com relação à teoria de Marx, bem como algumas consequências de sua tese.

Como já exposto, o trabalho é visto por Giannotti como uma estrutura funcional ou esquema lógico da função produtiva. Uma vez que os indivíduos relacionados nos três momentos materiais do esquema operatório se vinculam em uma única finalidade produtiva, esta unidade produtiva é tomada por Giannotti como uma individualidade técnica. A relação social é fixada neste esqueleto lógico do trabalho que, embora flexível, permitindo variadas formas, determina de antemão as posições em que os indivíduos devem encaixar-se. Portanto, a atividade produtiva já posta como atividade especificamente humana, que põe seus próprios fins, é ponto de partida da necessidade da relação social. Como descreve a relação social em seu traço abstrato, as relações de produção efetivas são formas da individualidade técnica. Há uma estrutura pressuposta que põe a relação social, mas esta estrutura mesma não parece fundamentada pelo desenvolvimento dessas relações. É certo que Giannotti está ciente que os indivíduos e os sentidos se conformam pelas relações sociais de produção. Mas por que vê então a necessidade de criar a categoria de individualidade técnica, que abstrai o comum das relações sociais em um esquema lógico? O autor escreve:

Não temos dúvida em reconhecer o caráter social dos indivíduos e dos sentidos, mas queremos ainda refletir sobre essa sociabilidade, mostrar seu fundamento in fieri, tomar enfim a sociedade 
como um processo simbólico capaz de gerar a si mesmo, de constituir por si próprio os passos em que assenta suas representações (Giannotti, Trabalho, 300).

O autor tem por objetivo, como já enunciado, mostrar a sociedade ${ }^{58}$ em seu processo de vir a ser a partir de si mesma (in fieri), sem demandar pressupostos apriorísticos ou alheios aos seus elementos constitutivos; em seus termos, optando "pelo radicalismo que nega qualquer identidade prévia indeformável" (Giannotti, Trabalho, 300). Entende que tomar os indivíduos como ponto de partida é assumir como pressuposto identidades constituídas. Como procurei expor, Marx parte precisamente dos indivíduos e busca desenvolver sua constituição em sujeitos ou seres sociais demonstrando sua extração a partir da naturalidade. E o faz ao caracterizar o trabalho como atividade consciente que, por conseguinte, não pode senão ser atividade social. Os indivíduos se definem então como identidades plásticas não pressupostas, mas formas determinadas efetivas do ser genérico. É possível e necessário, para Marx, partir dos indivíduos ao mesmo tempo em que se assume que estes mesmos só podem ser compreendidos in fieri: Marx distingue o homem por sua atividade característica, o trabalho, mas o único ser ativo é o indivíduo, que constitui seu mundo e a si mesmo em sua atividade social. A individualidade técnica, conceito que pressupõe o trabalho - atividade com finalidade consciente - e os indivíduos, ainda que vicários, em posições dadas pelo sistema lógico, acaba por partir do indivíduo consciente e portador de linguagem capaz de pôr finalidades à produção para calcar a relação social, na forma de referência a outrem ou como um tipo de pacto - não livremente baseado na vontade, mas em necessidades impostas ao trabalho pela natureza - entre indivíduos. Mas a linguagem, a consciência, a necessidade, as finalidades e o trabalho, ou seja, o vir a ser humano do homem, não é explicado como tendo origem na relação social. Giannotti, ao basear as relações sociais na necessidade de referência a outrem em cada um dos momentos do esquema operatório do trabalho, parece não considerar o fato de que, ao existir já como outro, a relação social é pressuposta. Parece que, no conceito de individualidade técnica, Giannotti realiza aquilo que pretende evitar.

Em Marx, "Toda produção é a apropriação da natureza pelo indivíduo no interior de e mediada por uma determinada forma de sociedade" (Introdução, 43), e a crítica a

\footnotetext{
${ }^{58}$ Aqui, particularmente as representações e as instituições políticas e jurídicas da sociedade. Esta passagem encontra-se no último artigo de Trabalho e Reflexão, "História e Revolução", que não examino neste trabalho.
} 
esta substituição dos sujeitos individuais por um sujeito coletivo aparece em diversas passagens de A Ideologia Alemã, como a seguinte:

Essa visão pode, agora, ser apreendida de modo especulativo-idealista, isto é, de modo fantástico, como "autocriação do gênero" ("a sociedade como sujeito") de maneira que a sequência sucessiva de indivíduos em conexão uns com os outros é representada como um único indivíduo que realiza o mistério de criar a si mesmo $(I A, 41)$.

A ideia de uma "individualidade técnica", elaborada por Giannotti, parece consistir precisamente nesta abstração. Giannotti caracteriza as relações de produção como encaixe de individualidades técnicas. Assim, a relação não se dá entre indivíduos, mas entre unidades técnicas, que, por outro lado, são o lócus da relação de produção. O autor escreve:

Os indivíduos se relacionam segundo as formas de apropriação dos meios de produção, a sociedade não é mais do que um sistema de relações e encaixamentos de individualidades técnicas. Daí não haver lugar para o relacionamento de indivíduos entre si, tese aliás que aparece desde o tempo da Miséria da Filosofia: as relações sociais "não são relações de indivíduo a indivíduo, mas de operário a capitalista. De rendeiro a proprietário fundiário etc. Apague essas relações e terá aniquilado toda a sociedade... (Marx, M., 80) ${ }^{59}$ (Giannotti, Trabalho, 117).

A passagem citada de Marx significa que os indivíduos se relacionam entre si de acordo com a classe social a que pertencem, ou seja, com o lugar que ocupam na divisão do trabalho. Não significa que os indivíduos não se relacionam entre si, mas que o fazem enquanto indivíduos determinados, e não como indivíduos abstratos. Esta determinação consiste em um papel na divisão social do trabalho, e portanto no pertencimento a uma classe. Mas Giannotti compreende que não há lugar para relação entre indivíduos, mas entre individualidades técnicas. Assim, o agente ou sujeito da produção não são os indivíduos, mas sujeitos coletivos em que os indivíduos tomam parte, ora num, ora noutro. O próprio esquema lógico que define a unidade produtiva é sujeito do processo: "A unidade técnica se apropria de seus meios de trabalho, do mesmo modo que uma pessoa domestica seu próprio corpo" (Giannotti, Trabalho, 152). Diga-se de passagem que, a despeito de sua crítica a Althusser, Giannotti em muito se aproxima da ideia de que os indivíduos são suportes das relações sociais dadas na estrutura lógica da individualidade técnica deduzida do esquema operatório do trabalho.

\footnotetext{
${ }^{59}$ Nas passagens em que Giannotti cita o texto de Marx, reproduzo sua tradução.
} 
A imbricação entre os indivíduos determinada por suas posições em um esquema operatório específico, ou seja, técnico, é a relação social. Por isso, as atividades singulares não são entendidas pelo autor como atividades sociais em si mesmas, e o caráter de indivíduo genérico não aparece em sua definição de relação social. Por isso, o próprio caráter social das atividades torna-se obscuro:

Segundo suas necessidades, um organismo trabalhador dispensa sua atividade produtiva em diversas individualidades técnicas, participa deste trabalho individual ou daquele outro coletivo, deste ou daquele relacionamento social imposto por sua participação num esquema operatório qualquer. Mas nem por isso sua atividade, individualizada pelo esquema, é social, no sentido mais eminente da palavra, vale dizer, relativo à sociedade como um todo (Giannotti, Trabalho, $65)$.

Nenhuma atividade, nem mesmo nos níveis mais desenvolvidos da divisão do trabalho, é diretamente relativa ao todo da sociedade, no sentido de que se realiza diretamente com ou para a totalidade dos demais indivíduos. Por outro lado, atividades individuais, como a científica, são mais universais, no sentido de terem como pressuposto o desenvolvimento total da atividade social. Em uma passagem d'O Capital que será mais bem examinada no capítulo IV deste trabalho, Marx escreve:

\footnotetext{
Diga-se de passagem que é preciso diferenciar entre trabalho geral e trabalho em comum. Ambos desempenham seu papel no processo de produção, ambos se confundem, mas ambos também se distinguem. Trabalho geral é todo trabalho científico, toda descoberta, todo invento. É condicionado em parte pela cooperação com viventes, em parte pela utilização de trabalhos de antecessores. $\mathrm{O}$ trabalho em comum supõe a cooperação direta dos indivíduos ${ }^{60}$.
}

Assim, qual seria "o sentido mais eminente" da palavra social para Giannotti: a ampla coletivização direta ou a universalidade do desenvolvimento social que a atividade incorpora?

Além desta carência de elaboração do caráter social da atividade humana, o conceito de individualidade técnica tem outras implicações. Uma delas é o velamento da relação de propriedade que existe no interior das individualidades técnicas, que aqui apenas aponto e que receberá alguns desenvolvimentos ao final do capítulo. Um exemplo disso é o modo como Giannotti aborda a família em comunidades tribais. A

\footnotetext{
${ }^{60}$ MARX, K. O Capital - Crítica da Economia Política - Livro Terceiro: O processo global da produção capitalista. Editado por Friedrich Engels. Tradução de Regis Barbosa e Flávio R. Kothe. Coordenação e revisão de Paul Singer. Col. Os Economistas - Volume IV. São Paulo: Nova Cultural, 1985-1986, p. 80. Doravante C, III, 4, seguido do número da página.
} 
família é considerada, nas sociedades examinadas pelo autor, uma individualidade técnica e, mais do que isso, um indivíduo: "E aqui, indivíduo significa família restrita ${ }^{61}$, o pressuposto biológico da família social (...)" (Giannotti, Trabalho, 137). Esta funciona no conjunto da sociedade como um único sujeito conformado por uma aliança ou pacto, em relação às demais unidades produtivas: “A estrutura familiar conforma a unidade técnica, inscrevendo-a num contorno em que naturalmente não cabe. Configura, em última instância, o mapa pelo qual a individualidade trabalhadora recruta os outros de que necessita, a fim de assegurar sua permanência" (Giannotti, Trabalho, 160-1). A "individualidade trabalhadora", esta abstração do coletivo familiar que constitui a unidade produtiva na sociedade em questão é quem "recruta os outros de que necessita", ou seja, estabelece as parcerias necessárias com as demais famílias, ou indivíduos. Esta é, pois, um sujeito.

No entanto, lemos também que "nas sociedades primitivas, o trabalhador se identifica antes de tudo como proprietário de seu corpo inorgânico e dos membros de sua família conjugal" (Giannotti, Trabalho, 137). De modo que o trabalhador coletivo é representado pelo chefe patriarcal, pelo "cabeça do casal" (Giannotti, Trabalho, 167). Assim, por um lado, Giannotti menciona que o homem é proprietário da mulher e dos filhos, mas o faz para caracterizar "o trabalhador". De modo que entende por trabalhador o homem, “proprietário dos membros de sua família conjugal”. Por outro lado, caracteriza o sujeito que trabalha como um coletivo, a "individualidade trabalhadora". Aqui, a questão do agente do trabalho fica confusa: este é a "individualidade trabalhadora", mas, como uma abstração não pode agir por si, na prática o chefe de família é considerado este agente e, por isso, “o trabalhador”.

Entretanto, na condição em que a mulher pertence ao homem, ela trabalha. Ao examinar uma sociedade primitiva em que o chefe tinha em torno de sessenta esposas, Giannotti escreve:

Já Lévi-Strauss assinalara que, além da contraparte moral e sentimental representada pela poligamia, esta se torna necessária para dar cumprimento às pesadas obrigações do chefe. Como poderia dispensar o trabalho de várias mulheres num período de fome, quando a efetividade de

\footnotetext{
${ }^{61}$ Esta concepção que identifica a família ao indivíduo está presente em Hegel. Ao abordar a sociedade civil, ele afirma: "A substância, que, como espírito, se particulariza abstratamente em muitas pessoas (a família é uma única pessoa), em famílias ou indivíduos (...)” (Hegel, Encyclopedia das sciencias philososophicas - Em compêndio. Trad. Lívio Xavier. São Paulo: Impressora Comercial, 1936, p. 493, apud Weffort, Francisco, Os clássicos da Política vol. II. São Paulo: Ática, 1990, 115).
} 
seu poder coordenador é posta à prova? Trata-se, porém, de uma poligenia muito particular, em que a primeira mulher desempenha o papel habitual numa família monogâmica, sendo as outras verdadeiras auxiliares da produção (Giannotti, Trabalho, 160) ${ }^{62}$.

No interior da família, há, pois, uma relação de produção baseada em uma forma de propriedade. Esta consiste já em um modo embrionário de dominação, a divisão sexual do trabalho, que caracteriza a transição para a exploração de classe. Marx e Engels afirmam:

Com a divisão do trabalho, (...) está dada a propriedade, que já tem seu embrião, sua primeira forma, na família, onde a mulher e os filhos são escravos do homem. A escravidão na família, ainda latente e rústica, é a primeira propriedade, que aqui, diga-se de passagem, corresponde já à definição dos economistas modernos, segundo a qual a propriedade é o poder de dispor da força de trabalho alheia $(I A, 37)$.

Em Giannotti, esta propriedade da mulher e dos filhos pelo homem aparece como um "poder coordenador". Não é pautada a relação de produção presente nas unidades familiares, a escravidão das mulheres e dos filhos, uma relação de dominação que é pressuposto histórico da dominação de classe. Por tomar a família como uma "individualidade trabalhadora", a relação de propriedade no interior da família determinada pelo casamento não é considerada em sua análise. Não examina a relação do "trabalhador" com o "outro" que existe no interior da família, e vê como caráter social do casamento apenas a troca de mulheres, portanto, a relação de intercâmbio entre homens: "A aliança contraída com um doador de outro grupo, com o fito de obter mulher, transforma a relação sexual numa relação social" (Giannotti, Trabalho, 154). A relação de subordinação da mulher e dos filhos ao homem no interior da produção familiar é vista como uma "relação sexual". A relação é social apenas quando se dá entre os chefes de família. De modo que, sem deixar de destacar que o homem é proprietário dos membros de sua família conjugal, desconsidera a relação social na produção familiar, bem como o fato de que as mulheres são trabalhadoras na condição social de escravas do homem. Elas aparecem como "auxiliares de produção", órgãos naturais do trabalho do chefe, visto que se trata de uma relação sexual. Mesmo a condição de proprietário do homem se transfigura em passagens do texto do autor: "A unidade técnica se apropria dos filhos assim como se apropria da parte do produto a ser

\footnotetext{
${ }^{62}$ É sintomático da concepção que naturaliza a subordinação da mulher o referir-se às funções do chefe como "pesadas obrigações", enquanto o trabalho das "verdadeiras auxiliares de produção" não recebe este atributo.
} 
diretamente consumida, produto que retorna à condição de pressuposto" (Giannotti, Trabalho, 154). A "unidade técnica", a família como indivíduo único, incorpora o trabalho dos filhos como dos demais indivíduos, mas quem detém a propriedade dos filhos em uma família patriarcal é o pai. Do mesmo modo que faz quando menciona o cuidado com os velhos, Giannotti naturaliza condições que são já resultados sociais, nomeadamente, a família patriarcal e o domínio do homem sobre a mulher: para ele, há um "princípio biológico que faz do casal e seus filhos a unidade elementar da espécie" (Giannotti, Trabalho, 167) e o fato de o homem ser o chefe não merece outras considerações.

É importante notar que esta descaracterização da relação de produção central dessas formas de sociedade primitiva, a escravidão latente na família, resulta da concepção de que o agente da produção, o indivíduo que trabalha, não é o indivíduo efetivo ou, como o chama Giannotti, "biologicamente determinado", mas a individualidade técnica, o coletivo de produção. Como depositário do caráter ativo do trabalho, esta individualidade trabalhadora tem finalidades e se relaciona socialmente. Como, contudo, um coletivo não é de fato um ente com finalidades próprias ou um corpo sob o comando de um cérebro, a finalidade e as relações sociais da individualidade técnica aparecem como as relações que o chefe estabelece com os demais chefes de família. Um aspecto definitivo dessas formas primitivas de sociedade - a escravidão no interior da família - desaparece da caracterização de Giannotti, e a relação central da sociedade primitiva examinada é transfigurada em trocas de dádivas, porque o autor considera que um coletivo pode ser, enquanto coletivo, um indivíduo ${ }^{63}$. Enquanto Giannotti recusa partir dos indivíduos, propondo um esquema lógico na base da relação social que acaba por tomar lugar de agente da produção, Marx considera que "O indivíduo é o ser social" (MEF, 107, citado acima). Precisamente porque o indivíduo é o ser genérico efetivo, e, por outro lado, o ser efetivo é sempre o ser sensível objetivo, portanto individual, não há um ser que seja uma coletividade, um ser genérico abstrato. As relações sociais são por essa razão necessariamente relações entre indivíduos. Deste modo, a história é um processo de individuação. O indivíduo se torna

\footnotetext{
${ }^{63}$ Esta ideia de sujeito coletivo desemboca ainda em uma concepção do capital em que os produtos do trabalho humano assumem a condição de agentes. Nas sociedades primitivas, o sujeito é o coletivo porque definido pela individualidade técnica. No modo de produção capitalista, Giannotti fará do capital o agente de sua própria reprodução: "No caso do sistema capitalista, graças ao fetichismo da mercadoria, o capital será o próprio agente de sua reprodução" (Giannotti, Trabalho, 140).
} 
um ser genérico mais singularizado conforme se desenvolve a divisão do trabalho e com ela a multiplicidade de atividades produtivas. A distinção entre os seres objetivos e as formas objetivas dos seres, bem como a consideração da subjetividade como forma específica do ser sensível objetivo, o indivíduo, estão na base da teoria de Marx. São precisamente essas compreensões que fundam o caráter materialista de seu pensamento.

\section{Trabalho, humanização da natureza e força produtiva}

O trabalho é a atividade produtiva especificamente humana. Como capacidade de produzir, a força produtiva é uma determinação imanente à atividade de produção, sua potência própria, e não existe fora dela. Força produtiva é sempre do trabalho, ou em outros termos, o trabalho é a força produtiva em ato. Assim, produtividade do trabalho e força produtiva são expressões sinônimas. Conforme exposto, os animais produzem, mas apenas na forma naturalmente delimitada pela espécie. A capacidade produtiva das espécies animais é fixa, não se desenvolve, e por isso não faz sentido falar em produtividade de suas atividades. Consistem, mais precisamente, em capacidades reprodutivas que definem, em sua imutabilidade, cada espécie. O trabalho é um modo potencialmente universal de produzir porque supera o limite da espécie e cria o novo, ao pôr suas finalidades e assim mediar seu próprio metabolismo com a natureza. A vida natural também se transforma. Mas seu modo de desenvolvimento se distingue do humano, que é histórico. A evolução das espécies tem por motor as mutações genéticas casuais nos indivíduos que diversificam e complexificam as espécies, e caracteriza o modo específico de desenvolvimento da vida natural, não-social. $\mathrm{O}$ advento do gênero humano afeta o curso dessa transformação natural, de modo que com o desenvolvimento humano, a história natural passa a se determinar também pelas transformações sociais. A atividade humana vem moldando a dinâmica das espécies ao alterar os ecossistemas e, hoje, produz novas espécies por meio de alteração genética. Também o desenvolvimento da natureza meramente material, cujos modos se distinguem tanto do histórico como da evolução das espécies vivas, é afetado pela produção humana e se incorpora em sua história: terra, rios, atmosfera e mesmo os contornos da superfície do globo - devido, por exemplo, ao chamado aquecimento global - têm suas características alteradas pela produção social. A história natural se torna história humana no processo de desenvolvimento da potência do trabalho. 
O objetivo desta parte da pesquisa é examinar nos textos de Marx a categoria de trabalho como a atividade que se apropria da natureza para criar nela um mundo humano e transforma a si mesma neste processo. Esta transformação da própria atividade tem por base o fato de que os resultados do trabalho se tornam seus próprios pressupostos expandidos. O texto de Giannotti contribui para a compreensão de como o homem põe na natureza seus fins e de como essa criação de um mundo humano amplia sua potência, isto é, a força produtiva do trabalho.

Ao examinar a teoria de Marx sobre a especificidade da atividade humana em "O Ardil do Trabalho", Giannotti escreve:

O que significa afirmar que o trabalho humano se distingue do animal precisamente porque depende de uma construção prévia, "na cabeça do indivíduo", do objeto a ser realizado ${ }^{64}$ ? Seria ingênuo atribuir caráter exclusivamente psicológico a essa antepresença da coisa. Não importa a imagem prévia, mas a ante-posição (vorstellen) do objeto situado idealmente, para que alteração efetuada pelo processo mecânico de intercâmbio entre o organismo e o meio fique desde logo subordinada à realização de um fim (Giannotti, Trabalho, 85).

O produto realiza um fim posto pelo homem, e por isso sua pré-ideação, que é anteposição ideal da finalidade, subordina a finalidade. Mas a atividade efetiva de produção não se explica como objetivação de uma vontade, uma vez que a própria vontade é subordinada à necessidade do modo de trabalho. A finalidade da produção responde a necessidades criadas - a própria finalidade não é uma vontade arbitrária - e tão logo este fim seja posto objetivamente como atividade produtiva, a vontade não pode dominar a ação, ao contrário, submete-se a ela. Giannotti cita Marx e explicita o problema:

"No término de um processo de trabalho surge um resultado que já estava presente idealmente
(ideel) desde o início na representação do trabalhador (in der Vorstellung des Arbeiters). Não é
que ele apenas efetua (bewirkt) uma alteração de forma no natural mas efetiva, no natural,
concomitantemente, seu fim, que é conhecido por ele e que determina o modo e a maneira de seu

${ }^{64}$ Referência à famosa passagem de Marx: "Pressupomos o trabalho numa forma em que pertence exclusivamente ao homem. Uma aranha executa operações semelhantes às do tecelão, e a abelha envergonha mais de um arquiteto humano com a construção dos favos de suas colmeias. Mas o que distingue, de antemão, o pior arquiteto da melhor abelha é que ele constrói o favo em sua cabeça, antes de construí-lo em cera. No fim do processo de trabalho obtém-se um resultado que já no início deste existiu na imaginação do trabalhador, e portanto idealmente" (MARX, K. O Capital - Crítica da economia política - Livro primeiro: O processo de produção do capital. Tradução de Regis Barbosa e Flávio R. Kothe. Coordenação e revisão de Paul Singer. Coleção Os economistas - Vol. I. São Paulo: Nova Cultural, 1985, p. 149-50). Doravante $C$, I, 1, seguido do número da página. 
fazer como lei e ao qual deve subordinar sua vontade" (Marx, K. I., MEW., 23, 193). Essa subordinação da vontade mostra as limitações de uma interpretação psicológica. O produto surge como explicitação de um fím, de uma condição que se dá idealmente e se efetiva de modo a adequar o resultado ao início pressuposto, num movimento em que o trabalhador e sua vontade, de um lado, as coisas, de outro, perdem autonomia para transformarem-se em momentos de um processo mais amplo (Giannotti, Trabalho, 86).

Embora o objetivo seja posto pelo homem, ele mesmo, sua vontade, subordina-se à lei imposta por este fim, já que, para atingi-lo, o modo da atividade é determinado pela natureza dos objetos e pela própria finalidade. Contudo, não é por ter sua vontade subordinada à disciplina da atividade que o produtor perde autonomia: como ser imediatamente natural, o ser humano não tem autonomia alguma. Além disso, a subordinação da vontade é um modo pelo qual a atividade produtiva humana se emancipa da determinação imediatamente natural. A própria vontade é transformada neste processo. Marx afirma na sequência da passagem citada por Giannotti acima:

E essa subordinação não é um ato isolado. Além do esforço dos órgãos que trabalham, é exigida a vontade orientada a um fim, que se manifesta como atenção durante todo o tempo de trabalho, e isso tanto mais quanto menos esse trabalho, pelo próprio conteúdo e pela espécie e modo de sua execução, atrai o trabalhador, portanto, quanto menos ele o aproveita, como jogo de suas própria forças físicas e espirituais $(\mathrm{C}, \mathrm{I}, 1,150)$.

A vontade do produtor não tem autonomia no processo de realização de fins, mas o produtor força a si mesmo e se molda no exercício da atividade do mesmo modo que força a matéria natural e a molda em um produto. Ao mesmo tempo em que o homem domina a atividade ao exercê-la para si, sua natureza é subordinada pela disciplina da atividade; mas ao sujeitar-se a esta disciplina, o sujeito aprende a dominar suas próprias capacidades. É útil acompanhar o raciocínio de Marx. "Antes de tudo, o trabalho é um processo de que participam o homem e a natureza, um processo em que o homem, por sua própria ação, media, regula e controla seu metabolismo com a natureza": por sua atividade específica, o homem é mediador de seu metabolismo com a natureza, ou em outros termos, o metabolismo do homem com a natureza é mediado - regulado, controlado - por ele mesmo. Mas, "Ele mesmo se defronta com a matéria natural como uma força natural”, ou seja, o homem é natureza, uma força natural que entra em metabolismo com os demais objetos da natureza. Marx continua: 
Ele põe em movimento as forças naturais pertencentes à sua corporalidade, braços e pernas, cabeça e mãos, a fim de apropriar-se da matéria numa forma útil à sua própria vida. Ao atuar, por meio desse movimento, sobre a natureza externa a ele e ao modificá-la, ele modifica, ao mesmo tempo, sua própria natureza. Ele desenvolve as potências nela adormecidas e sujeita o jogo de suas forças ao seu próprio domínio (C, I, 1, 149).

$\mathrm{Na}$ atividade que dá forma útil à matéria natural, o homem dá forma às suas próprias capacidades. Suas forças naturais também são domadas pela atividade. O homem é, pois, um ser natural, mas com a diferença específica de regular seu metabolismo com a natureza e com isso dominar a si mesmo e desenvolver sua natureza, isto é, suas potências latentes. Por meio da atividade que modifica e com isso domina a natureza externa, o homem domina a si mesmo, e assim se caracteriza como autoprodutor. À natureza humanizada corresponde pois o homem humanizado, uma natureza construída como humana: "Milton produziu o Paraíso Perdido pelo mesmo motivo por que o bicho-da-seda produz seda. Era uma atividade própria de sua natureza"65. Esta necessidade humana de Milton, desenvolvida como criação social, constitui sua natureza do mesmo modo que produzir seda compõe a natureza do bicho-da-seda. Se neste a natureza é imediatamente dada, no homem ela é produto de seu metabolismo com a natureza dada, e, portanto, é mediada. Esta mediação confere caráter histórico à natureza humana, de modo que não é possível delimitá-la em termos gerais ou abstratos, como são circunscritos os demais gêneros animais. Assim, o domínio da vontade não é uma perda de autonomia do sujeito, mas ao contrário, é meio para a própria autodeterminação de sua natureza.

Por outro lado, "as coisas perdem autonomia" e têm seu "estatuto ontológico" (Giannotti, Trabalho, 88) transformado por meio do trabalho: "Se o produto surge da subordinação de um sistema mecânico a um fim determinado, que natureza ontológica possui, desde logo marcada pela exteriorização de uma interioridade e vice-versa?" (Giannotti, Trabalho, 86). O homem se exterioriza na natureza ao pôr suas finalidades no mundo objetivo e interioriza a natureza ao dominá-la. O trabalho confere uma natureza nova aos seus objetos naturais ao efetuar a "cristalização da coisa em objeto humanizado" (Giannotti, Trabalho, 87). Giannotti explica o que designa por transformação ontológica da coisa com dois exemplos elucidativos, que reproduzimos.

\footnotetext{
${ }^{65}$ MARX, K. Teorias da mais-valia: História crítica do pensamento econômico - volume I. Tradução de Rinaldo Sant'Anna. Rio de janeiro: Civilização Brasileira, 1980, p. 396. Doravante, TMV I, seguido do número da página.
} 
O autor começa destacando que os momentos essenciais do processo de trabalho são a atividade orientada, seu objeto e seu meio. Escreve que "O primeiro objeto é a terra, solo sofrendo uma atividade discriminadora primordial a eleger, dentre as várias coisas, aquelas a serem transformadas", e cita Marx: "Todas as coisas que o trabalho apenas desprende (löslot) de sua imediata conexão com a totalidade da terra (Erdganzen) são objetos de trabalho encontrados a partir da natureza (Marx, K., I., MEW., 23, 193)" (Giannotti, Trabalho, 86). A coisa a ser extraída de seu contexto natural é condição primordial do trabalho e seu objeto, configurando, pois, um meio de produção. Giannotti exemplifica com o peixe a ser retirado da água:

\footnotetext{
Por mais que pareça paradoxal, esclarece Marx, o peixe ainda não capturado surgir como meio de produção, ainda não se encontrou um jeito de apanhá-lo em águas em que não exista (Marx, K., I., MEW., 23, 196, nota 6). (...) Enquanto objeto de trabalho e primeira condição dele, incorpora as propriedades necessárias para a efetivação desse mesmo trabalho. Existe num elemento determinado, em águas rasas ou profundas, com hábitos próprios, alimentação peculiar. Cada uma dessas determinações obriga o pescador a agir adequadamente, permanecer na margem ou afastar-se dela, encontrando os esconderijos na pedra ou preparar iscas apropriadas (Giannotti, Trabalho, 86-7).
}

O "agir adequadamente" do pescador é um exemplo da subordinação da vontade que deve se dar para que a finalidade do trabalho seja alcançada. Implica o desenvolvimento da capacidade subjetiva de pescar e o conhecimento de parte do comportamento da natureza, que se constituem na experiência, por meio da própria atividade. A subordinação da vontade é a disciplina subjetiva da qual a atividade não pode se privar e se identifica com o saber fazer. Isto pelo lado da atividade, que Giannotti não desenvolve. No que diz respeito ao objeto, o autor destaca que, ao penetrar o processo de trabalho, "a coisa pronta", separada de seu contexto natural anterior à atividade do homem, "ganha novas dimensões" ao cristalizar-se como "objeto humanizado" (Giannotti, Trabalho, 87). Mas é no instrumento de trabalho que esta modificação ontológica da natureza aparece de modo mais patente.

Objeto é aquilo sobre o que recai o trabalho, instrumento é aquele elemento da natureza, trabalhado ou não, que o homem interpõe entre sua atividade e o objeto. $\mathrm{O}$ primeiro instrumento de trabalho, imediato, é o corpo. Mas o instrumento propriamente dito, que funciona como prolongamento do corpo, é mediação entre a atividade e o objeto. A utilização desta mediação altera a forma do trabalho, de modo que a criação 
de instrumentos é ao mesmo tempo criação de novas formas de atividade e consequentes novas capacidades subjetivas. Como mediador, o instrumento "canaliza a atividade orientada e graças a ele pode o trabalhador utilizar 'as propriedades mecânicas, físicas, químicas das coisas para deixar que atuem como meio de potência (Machtmittel) sobre outras coisas, conforme seu fim' (Marx, K., I., MEW., 23, 194)” (Giannotti, Trabalho, 87). O instrumento é um elemento específico separado do contexto natural e cuja utilização isola uma de suas determinações naturais:

\footnotetext{
Ao transformar um pedregulho bruto de sílex em um instrumento de percussão, este o toma no sentido longitudinal, de forma ao aproveitar ao máximo sua resistência; qualquer outra direção o lascaria ou diminuiria seu efeito. Ao converter um galho de árvore numa alavanca, transforma-o em braço indeformável em torno do qual faz girar um sistema de forças. Neste sentido, pedregulho e alavanca são objetos isolados da natureza para que uma determinação natural possa ser aproveitada em virtude desse isolamento (Giannotti, Trabalho, 87).
}

A utilização dos elementos da natureza como instrumentos de trabalho implica a separação de suas qualidades úteis daquelas que não tem funcionalidade para a realização de dado fim. Giannotti afirma que, com este isolamento, "ocorre então na coisa um verdadeiro processo de abstração", a abstração precisamente da parte funcional do objeto. "E graças a essa separação da coisa em duas partes, uma funcional e outra representando um verdadeiro contrapeso, ela se transforma em instrumento; só assim pode existir como meio de potências, sobre outras" (Giannotti, Trabalho, 88). Também aqui, esse processo de separação que define a criação desses primeiros instrumentos apenas desprendidos da multiplicidade natural é acompanhado do discernimento subjetivo, ou seja, é ao mesmo tempo um processo de criação de conhecimento. Ainda sobre a criação dos meios de produção, Giannotti escreve:

\footnotetext{
Outro exemplo tornará ainda mais evidente a transformação do estatuto ontológico da coisa. Suponhamos um grão de trigo que o trabalhador reserve para o plantio. $\mathrm{O}$ uso imediato como alimento foi sustado e o grão existe de modo exclusivo como semente, vir a ser da planta e da espiga e, dessa maneira, como potência de reprodução e multiplicação. Nesta qualidade de meio de produção, existe como ciclo natural de que o homem se apropria para, deixando correr o curso biológico, inscrever nele seu próprio fim (Giannotti, Trabalho, 88, grifo meu).
}

Os homens fazem uso das propriedades naturais das coisas e do curso biológico da natureza para inscrever sua finalidade no natural. Porque as determinações da natureza põem as possibilidades da atividade, o trabalho submete a vontade do indivíduo. A 
liberdade que caracteriza o trabalho humano frente à vida animal não está na escolha arbitrária do indivíduo, mas em amoldar a coisa e em guiar o fluxo natural para a realização de finalidades antepostas, essas mesmas partindo do campo de possibilidades presentes na natureza. Em cada processo produtivo, o homem separa da natureza os elementos úteis e recorta suas propriedades funcionais, o que demanda o discernimento subjetivo do objeto e a representação mental do processo; conhecimento que se determina como saber fazer e é constituído na prática. Isso se dá em todos os exemplos oferecidos por Giannotti. A semente, cumprindo sua determinação natural, cumpre a finalidade do trabalho; o pedregulho cortado longitudinalmente tem em si a resistência para percutir, embora a percussão apenas se realize mediante o trabalho que discerne esta propriedade do pedregulho; o galho deixa de dar origem a folhas de determinado tipo e se torna alavanca quando separado da árvore e desbastado; o peixe é em si alimento para o homem, mas apenas quando se encontra em suas mãos, e livre das partes não aproveitáveis para a alimentação. O novo está em conduzir o curso biológico - como na agricultura, na pesca que atrai o peixe para a isca, na criação de animais - ou em conduzir os efeitos físicos e químicos que resultam das próprias determinações naturais dos objetos, quando postos em determinadas conexões pela atividade. Como atividades conscientes, subordinadas a fins, há em todos os casos o saber fazer, que se desenvolve concomitantemente à atividade e é testado e comprovado na prática. Por meio desta atividade específica, os homens se apropriam do ciclo natural, tanto objetiva como subjetivamente.

O sentido desta transformação ontológica da coisa é o tornar-se para o homem dos objetos naturais. De coisa meramente natural, os meios de trabalho se tornam coisas humanas. Não é preciso para isso que se tenha transformado materialmente a coisa embora o desprendimento da multiplicidade natural que cria os instrumentos rudimentares seja já uma transfiguração do objeto e uma incorporação de trabalho. Esta condição de natureza transformada, humanizada, é o que, nos termos de Giannotti, altera o estatuto ontológico da coisa e cria, nas palavras de Marx, um mundo humano. Sua inserção no processo de trabalho torna o objeto histórico. Ontologicamente, tornase, pois, coisa determinada pela história humana, que altera o curso de desenvolvimento biológico ou físico a que o objeto estava submetido, exclusivamente, antes de sua manipulação pelo trabalho. 
Ao tornar o objeto natural um objeto humano, o homem amplia suas possibilidades produtivas. A capacidade de inscrever seus próprios fins na natureza expressa a força produtiva do trabalho, e a utilização do instrumento amplia esta capacidade. Giannotti escreve: "A introdução do meio-termo entre a atividade do sujeito e a resistência e as fintas do objeto permite ampliar de maneira insuspeitada a potência do trabalhador, que passa a ter parte da natureza à sua disposição" (Giannotti, Trabalho, 87). Esta potência do trabalhador se identifica com "ter parte da natureza à sua disposição". A natureza se torna mais amplamente disponível ao homem com a criação de instrumentos de trabalho novos, (embora não apenas) porque quanto mais numerosos e elaborados são os instrumentos, mediadores e condutores do trabalho, mais desenvolvido é o campo de mediação humana no metabolismo entre o homem e natureza. Como mediadores da atividade, os instrumentos expressam o nível de desenvolvimento da atividade produtiva, isto é, a extensão do domínio humano da natureza. Este fato faz com a que a força produtiva da atividade seja imediatamente identificada, por alguns autores ${ }^{66}$, com os instrumentos de produção. Este ponto é importante para elucidar o que é força produtiva, e mostrar que ela, embora exista nos produtos do trabalho, não se identifica com os instrumentos de trabalho como coisas-aí. Vale destacar ainda outros aspectos do meio de trabalho para trazer mais elementos que contribuam para a tematização da força produtiva.

Marx expõe o modo com o instrumento funciona como meio de trabalho:

O fim do processo de trabalho é o produto, onde a matéria-prima aparece ligada ao trabalho e o instrumento de trabalho igualmente se transportou, da mera possibilidade, para a efetividade, transformado em condutor efetivo do trabalho, a fim de que, entretanto, por meio de sua relação mecânica ou química com o material do trabalho, seja ele próprio consumido em sua forma repousada (Marx, G. 208, citado por Giannotti, Trabalho, 89).

Ao ser consumido pelo trabalho e ter sua "forma repousada" destruída ou desgastada, o instrumento se torna efetivo, transformado de "mera possibilidade" em "condutor efetivo do trabalho". Mas sua forma repousada, com suas determinações materiais específicas, é necessária para que o objeto seja um instrumento de trabalho. Contudo, é

\footnotetext{
66 Ruy Fausto, por exemplo, vê nos meios de produção atuais mais desenvolvidos (máquinas computadorizadas ou robóticas atuais) forças produtivas em si mesmos, quase agentes da produção, porque não requerem quase nenhum trabalho para serem postos em movimento, como exposto no primeiro capítulo. Giannotti cita adiante outros autores que identificam a técnica incorporada na coisa com a força produtiva, desconsiderando que esta é um atributo do trabalho por seu caráter criativo.
} 
apenas quando esta forma é consumida que o objeto se põe como instrumento. Nos termos de Giannotti, “o instrumento põe a nu sua capacidade desencadeando no produto a força natural reprimida" (Giannotti, Trabalho, 89). Ou seja, o instrumento apenas é efetivo na ampliação da potência do trabalho em sua conexão com a atividade, mediante seu próprio desgaste. Não é pois, em si mesmo, como mera coisa ou fator objetivo, que o instrumento é força produtiva, mas apenas como mediador de trabalho.

O que faz de um objeto um meio de trabalho? Instrumentos que mediam e canalizam a atividade são criações humanas e caracterizam a especificidade do trabalho em oposição às atividades produtivas das demais espécies animais. A mera separação de um pedaço de árvore que serve como alavanca é produção humana, atividade subordinada a um fim, que responde a uma necessidade criada: possibilitar uma segunda atividade produtiva. A alavanca incorpora trabalho humano, e o objeto sobre o qual a atividade de trabalho mediada ou canalizada pela alavanca recai, tem por condição a atividade de criação do instrumento. $\mathrm{O}$ objeto desta segunda atividade produtiva incorpora não apenas o trabalho imediato realizado com o uso da alavanca, mas os trabalhos pressupostos a essa atividade, entre eles o da criação da alavanca. Do mesmo modo que, como afirma Marx, a conformação atual dos sentidos humanos é resultado de todo o desenvolvimento histórico, também o produto material atual resulta do acúmulo passado de trabalho e sintetiza esse desenvolvimento histórico. Como seu pressuposto necessário, o produto atual incorpora o conjunto do trabalho passado. Não é, contudo, essa incorporação que faz de um objeto um meio de trabalho. Giannotti sustenta que "Não há necessidade alguma, ao menos inscrita no conceito de processo de trabalho em geral, de que os meios de produção sejam produtos, objetivação de trabalho anterior" (Giannotti, Trabalho, 91), e cita a seguinte passagem de Marx:

Mediante a entrada como meio de produção em novo processo de trabalho, os produtos perdem com isso o caráter de produto. Funcionam agora unicamente como fatores objetivos do trabalho vivo. O tecelão maneja o fuso apenas como meio, o linho apenas como objeto que ele tece. Por certo não se pode tecer sem o material-de-tecer e o fuso. A presença desse produto está pressuposta no início do ato de tecer. Para esse processo entretanto é totalmente indiferente tanto o linho e o fuso serem produtos de trabalho passado, quanto no ato de nutrição é indiferente ser o pão produto do trabalho passado do lavrador, do moleiro, do padeiro e assim por diante. Em compensação, os meios de produção fazem valer, no processo de trabalho, seu caráter de produto do trabalho passado, através de seu defeito. Uma faca que não corta, um fio que arrebenta constantemente etc. lembram de modo vivo um fabricante de faca A, um fiandeiro E. No produto 
bem elaborado desaparece a mediação de suas propriedades de uso através do trabalho passado (Marx, K., I., MEW., 23, 197) (Giannotti, Trabalho, 91).

Para o processo de trabalho mesmo, é indiferente a procedência dos meios de produção, tanto do objeto quanto do meio de trabalho pressupostos na produção. Que os meios de produção não precisam ser produtos do trabalho é evidente por si, se consideramos que o homem é um ser natural. Seu primeiro objeto de trabalho necessário é a terra e seus elementos, sua natureza inorgânica, não criada por ele. O objeto é meio de trabalho por suas determinações materiais imanentes, sejam imediatamente naturais, sejam elaboradas pelo trabalho humano. De modo que para o processo de trabalho presente, independente do nível de desenvolvimento histórico da produção, suas condições materiais aparecem como pressupostos naturais, elementos presentes na natureza, seja imediata, seja transformada em maior ou menor grau pelo homem. Porque a natureza humanizada é a própria natureza conforme se imiscuiu no processo de desenvolvimento social. Marx escreve:

Ao produzir, o homem só pode proceder como a própria natureza, isto é, apenas mudando as formas das matérias. Mais ainda. Nesse trabalho de formação ele é constantemente amparado por forças naturais. Portanto, o trabalho não é a única fonte dos valores de uso que produz, da riqueza material. Dela, o trabalho é o pai, como diz Willian Petty, e a terra é a mãe (C, I, 1, 51).

Os meios de trabalho, que ampliam "de maneira insuspeitada a potência do trabalhador", podem ser tanto elementos da natureza imediata quanto instrumentos elaborados pelo trabalho. As forças produtivas do trabalho se ampliam, portanto, mediante a utilização de ambos os tipos de meios de trabalho. Quanto maior a incorporação de trabalho, quanto mais o dado natural é trabalhado, maior força produtiva tem a atividade, pois mais amplos se tornam seus pressupostos, sua natureza inorgânica. Essa incorporação de trabalho não pode ser entendida, contudo, apenas como aprimoramento direto das ferramentas. Para abordar a relação entre ampliação das forças produtivas, acúmulo de trabalho passado e transformação material da natureza lanço mão de uma passagem em que Marx compara o emprego de quedas d'água e da máquina a vapor como força motriz.

Marx desenvolve esta comparação para explicar os fundamentos da renda da terra no contexto da produção capitalista, mas recorro aqui a este exemplo apenas para tematizar a força produtiva, particularmente, apontar em que elementos a força 
produtiva do trabalho se incorpora. Marx considera que o uso da queda d'água como força motriz de um sistema de máquinas-ferramenta em um processo produtivo qualquer torna o trabalho mais produtivo do que se uma máquina a vapor fosse utilizada para a mesma função. A maior força produtiva do trabalho se deve ao emprego da queda d'água como meio de trabalho em lugar da máquina a vapor, deve-se "a uma força natural, a força motriz da queda d'água, que se encontra na natureza (...). Ela é um agente natural de produção, em sua criação não entra nenhum trabalho"67. Assim, a queda d'água é, em primeiro lugar, uma força natural, e, em segundo lugar, elemento do processo de trabalho que o torna mais produtivo do que se em seu lugar houvesse uma máquina, meio de produção em que se incorporou trabalho humano. Ou seja, um meio de produção imediatamente natural pode ampliar a produtividade do trabalho em maior grau que um meio de produção cuja criação que resulta de acúmulo de trabalho passado. Assim, poderíamos concluir, ao contrário do que já foi dito, que o acúmulo de trabalho passado nos meios de produção não é fator que necessariamente torna o trabalho mais produtivo?

Marx pondera, em terceiro lugar, que também a máquina a vapor conta com "forças naturais" e com "o incremento da força de trabalho acarretada por elas": "a capacidade da água de transformar seu estado físico de passar a vapor", "a elasticidade do vapor etc.” (C, III, 5, 143). Então, a queda d'água e a própria água, por sua capacidade de se tornar vapor, são forças produtivas? Sim e não. Não podem ser consideradas forças produtivas se tomadas como dados da natureza. A queda d'água existe antes de o homem vir ao mundo e se tornar homem, e a água traz em si a capacidade de se transformar em vapor desde que é água. Contudo, elas apenas são forças produtivas quando utilizadas no processo produtivo, no exemplo de Marx, como força motriz ou material da máquina a vapor. Não em si mesmas, mas apenas quando $o s$ homens se apropriam de seu ciclo natural, por meio da atividade do trabalho, do mesmo modo que a semente de trigo, no exemplo de Giannotti.

É evidente que uma diferença entre uma alavanca de galho de árvore e uma máquina a vapor é a quantidade de trabalho incorporado ou nível de desenvolvimento social da natureza. Certamente há pressupostos incorporados na criação da alavanca de

\footnotetext{
${ }^{67}$ MARX, K. O Capital - Crítica da economia política - Livro terceiro: o Processo global da produção capitalista. Tradução de Regis Barbosa e Flávio R. Kothe. Coordenação e revisão de Paul Singer. Coleção Os economistas - Vol. V. São Paulo: Nova Cultural, 1985, p. 143. Doravante $C$, III, 5, seguido do número da página.
} 
galho: a finalidade de levantar algo pesado, seja para a utilização da pedra suspensa, ou do terreno livre da pedra etc.; isto é, uma necessidade criada que já resulta de dado desenvolvimento humano. O mesmo se dá com o pedregulho de sílex: ele pressupõe a utilização para fins humanos de algo que não pode ser cortado com os dentes. Mas a máquina a vapor pressupõe um vasto acúmulo de trabalho passado, não apenas em sua elaboração material, mas na necessidade que impõe sua utilização: da arte da fundição de ferro à física newtoniana, do aumento da produção agrícola à universalização das trocas. No caso da força motriz da água, há mais trabalho incorporado em uma alavanca feita de um galho de árvore apenas separado de seu corpo natural do que em uma queda d'água, na qual não há trabalho algum. A queda d'água não foi sequer separada de seu contexto natural. Contudo, há muito mais trabalho incorporado na utilização de uma queda d'água como força motriz do que na utilização do galho como alavanca; ou seja, a primeira atividade pressupõe muito mais trabalho incorporado na natureza, embora nenhum para a transformação da própria queda d'água. A capacidade de utilizar a queda d'água como força motriz de um sistema de máquinas é resultado de acúmulo de trabalho passado em grandes proporções. De modo que quando afirmamos que o maior acúmulo de trabalho passado amplia a força produtiva do trabalho, este trabalho não é necessariamente o trabalho de elaboração direta dos meios de produção: mas aquele pressuposto no domínio de uma força natural, que se realiza mediante sua apropriação. Força produtiva se define por esta capacidade de usar, esta apropriação que depende não apenas da atividade de transformação imediata, mas do conjunto do trabalho passado acumulado moldando a atividade atual. É, pois, um atributo imanente ao trabalho, e se identifica com a potência da atividade, e não um atributo das coisas ou da matéria, transformada ou não:

Força produtiva é sempre, naturalmente, força produtiva de trabalho útil concreto, e determina, de fato, apenas o grau de eficácia de uma atividade produtiva adequada a um fim, num espaço e tempo dado. O trabalho útil torna-se, portanto, uma fonte mais rica ou mais pobre, em proporção direta ao aumento ou à queda de sua força produtiva $(\mathrm{C}, \mathrm{I}, 1,53)$.

A ampliação da força produtiva é o aumento do grau de eficácia de uma atividade, desta fonte de riqueza. Força produtiva é atributo do trabalho, mas a eficiência de uma atividade depende não apenas da capacidade do sujeito, mas também de suas condições. É a realização efetiva do trabalho e a consequente posição de produtos objetivos que amplia a força produtiva do trabalho, a "potência do trabalhador", expandindo as 
condições da atividade. No "Prefácio de 1859", Marx refere-se às forças produtivas como "forças produtivas materiais"68. $\mathrm{Na}$ "Introdução de 1857", insere a expressão "meios de produção" entre parênteses para explicitar a que se refere quando aborda o "conceito força produtiva" (Introdução, 62). De modo que a força produtiva do trabalho se põe em seu produto, os meios de produção. Mas não se identificam com instrumentos e objetos como coisas-aí, mas apenas enquanto meios da atividade, o que significa: matéria onde se cristaliza o domínio do homem sobre a natureza. Os meios de produção em geral, e não apenas o instrumento, embora este tenha papel central e expresse o nível de força produtiva ao manifestar o modo da atividade, são forças produtivas. Tornam-se forças produtivas ao mesmo tempo em que passam a constituir partes da natureza à disposição do ser humano, isto é, dominadas por ele. Nos termos de Giannotti, “(...) o conjunto das forças naturais domadas que chamamos de forças produtivas" (Trabalho, 104). Estas são então as próprias forças naturais, mas na medida em que são domadas pelo homem. No caso da queda d'água, seu domínio não implica incorporação de trabalho em sua transformação material, mas pressupõe acúmulo de trabalho passado na medida em que tem por condição certo nível de desenvolvimento produtivo. Em todos os casos, o domínio de uma força natural envolve as próprias capacidades humanas, domadas, e assim desenvolvidas, na atividade produtiva. Giannotti destaca os aspectos ativo e objetivado da força produtiva:

Em suma, tanto aqueles que identificam o desenvolvimento das forças produtivas com o desenvolvimento tecnológico, quanto Castoriadis ou Sartre, que fazem do instrumento o terreno onde nascem as significações técnicas, ignoram o caráter ardiloso do trabalho, essa transformação da passividade da coisa intermediária em atividade, a violenta conquista da vida interna da matéria ao ser dominada para fins humanos; só isto permite ao trabalho, ao menos por instantes, contemplar a natureza desgastando-a para governar o todo com menor pena. Daí não poderem chegar a uma correta compreensão da categoria marxista de força produtiva, desse recurso da produção que somente funciona como tal no contexto do trabalho morto cristalizado na coisa, memória do trabalho passado agulhando a direção do trabalho futuro (Giannotti, Trabalho, 130).

O ardil do trabalho consiste em lançar mão de uma "coisa intermediária" como "recurso da produção" para "conquistar a vida interna da matéria", o que se realiza mediante a transformação da passividade do instrumento em atividade. Esta é determinação

\footnotetext{
68 MARX, K. Contribuição à crítica da economia política. Tradução e Introdução de Florestan
} Fernandes. São Paulo: Expressão Popular, p. 47. Doravante Contribuição, seguido do número da página. 
imanente do trabalho. Por outro lado, embora seja atributo da atividade ardilosa, sua força produtiva apenas varia mediante a incorporação do ardil na coisa, na transformação material que adequa sua forma aos fins da atividade. $\mathrm{O}$ meio de trabalho é produto privilegiado nessa incorporação do ardil do trabalho porque materializa o modo da atividade criada. A memória do trabalho passado incorpora-se no produto objetivo, na natureza humanizada. A efetivação da força produtiva é dependente, contudo, da atividade contínua dos indivíduos, o que requer apropriação subjetiva dos processos produtivos pelas novas gerações. O conhecimento empírico envolvido na prática produtiva, o "saber fazer" do trabalho, é um elemento da força produtiva: como o trabalho se define como atividade consciente, teleológica, que conhece seus fins e seus modos, trabalho e o conhecimento são um único processo e não há como dissocia$\operatorname{los}^{69}$. Também o conhecimento científico que se desenvolve ulteriormente, já com a divisão entre trabalho material e trabalho intelectual, é força produtiva porque se constitui como mediação da atividade produtiva de domínio da natureza. $\mathrm{O}$ conhecimento científico existe nos sujeitos como domínio intelectual, mas não apenas: é conhecimento objetivado em linguagem, resultado universal da produção social, ou como colocaria André Gorz, formalizado. Assim, a força produtiva do trabalho - as forças naturais domadas - incorporam-se no próprio trabalho, como capacidade e atividade subjetivas, em seus produtos materiais e nos seus produtos não-materiais, intelectuais.

A força produtiva do trabalho não se incorpora apenas nos indivíduos, nos objetos materiais transformados e na produção intelectual objetivada. Um fator central da força produtiva é, por exemplo, o tamanho da população, a quantidade de indivíduos em sociedade. Não apenas a dimensão da integração social, mas a forma em que os indivíduos interagem, a forma de seu intercâmbio social. A própria sociabilidade é pois uma força produtiva, maior ou menor conforme as dimensões da sociedade e suas formas específicas. A forma das relações sociais de produção é ainda um fator determinante do impulso ou da restrição ao desenvolvimento das forças produtivas ${ }^{70}$.

\footnotetext{
${ }^{69}$ Com o desenvolvimento da divisão do trabalho, a atividade que cria conhecimento se emancipa da atividade produtiva e cria a teoria, o saber teórico, não diretamente prático ou aplicável. Mas o saber fazer do trabalho não se extingue por isso. O conhecimento separado é assim uma atividade social nova, cuja autonomia é relativa. Desenvolveremos esse assunto adiante.

${ }^{70}$ Quando Marx afirma que "Força produtiva é sempre, naturalmente, força produtiva de trabalho útil concreto" isto significa que cada trabalho específico pode ter, em um único momento de dada sociedade, níveis distintos de força produtiva. Já a comparação entre graus de eficácia de duas atividades distintas demanda uma explicitação da medida da comparação. Por exemplo, pode-se comparar o grau de
} 
Assim, a força produtiva do trabalho se incorpora em todos os seus momentos, que abrangem os sujeitos construídos, a matéria natural manipulada, o conhecimento e as relações sociais.

Este conceito de força produtiva como o conjunto das forças naturais domadas indica também já a medida das forças produtivas, tema importante para a abordagem do capitalismo atual especialmente com vistas à comparação com a medida da valorização, de que tratarei no capítulo $\mathrm{V}$ : a medida das forças produtivas de dada sociedade não pode ser outra que não a extensão do domínio das forças naturais. O conjunto do trabalho passado está incorporado no produto presente. Mas, como veremos, na atual produção capitalista o conjunto do trabalho historicamente acumulado não se incorpora como quantidade de valor nos produtos. Além disso, há fatores que ampliam a produtividade do trabalho sem aumentarem o valor de seus produtos. A diferença entre a medida da força produtiva e a medida da valorização, bem como a distinção entre trabalho incorporado em geral e trabalho incorporado que se objetiva em valor, serão centrais no debate com os autores que vêm no desenvolvimento produtivo uma crise do valor ou sua transubstanciação em "valor qualitativo"; contribuirão, ademais, para indicar uma compreensão alternativa de como o desenvolvimento produtivo afeta a forma capital, de acordo com os textos de Marx.

\section{A questão do desenvolvimento das forças produtivas}

O trabalho objetivado nas transformações da natureza é a expressão do caráter histórico do desenvolvimento humano. Pressupõe a manutenção dos resultados do trabalho anterior e novas formas de trabalhos que tenham por pressuposto tais resultados. Trata-se de um percurso sem rota definida de antemão, mas cujo campo de possibilidades é delimitado pelas condições encontradas, ou seja, cada geração põe as condições de produção para a seguinte e assim circunscreve o desenvolvimento ao definir as bases sobre as quais o trabalho irá se realizar. Assim, a determinação histórica da autoprodução humana está pautada no caráter reiterativo imanente à categoria de

mecanização do processo produtivo, ou o tempo de trabalho necessário pra produzir, de cada produto, o suficiente para suprir as necessidades de um número determinado de pessoas por um período definido, sendo estas necessidades determinadas de antemão. A medida da produtividade dos trabalhos deve de qualquer forma ser estabelecida para que haja uma comparação. Mas se a força produtiva é sempre força produtiva de trabalho útil concreto, como avaliar a força produtiva geral de uma dada sociedade para, por exemplo, comparar diferentes momentos históricos? Um indicativo do nível de desenvolvimento produtivo geral de uma sociedade é a amplitude do intercâmbio humano e o desenvolvimento da divisão do trabalho. Ambas as questões serão abordadas adiante. 
trabalho. Este aspecto foi abordado acima no contexto da explicação de Marx e Engels sobre o primeiro ato histórico. Ressaltou-se que a reiteração é necessária para caracterizar a atividade produtiva como trabalho, e que esta necessidade se depreende da dinâmica entre a criação de necessidades e os meios de satisfação: a reprodução do objeto cria os pressupostos e o impulso para as novas atividades. Como ato isolado, a atividade produtiva não se caracteriza como trabalho, porque cada passo teria de ser refeito no decorrer da vida individual, a geração seguinte estaria sempre no mesmo ponto da anterior. De sorte que algo novo apenas se desenvolve a partir da reprodução constante dos resultados do trabalho passado. Este é uma das condições do trabalho desde o princípio do vir a ser do homem:

\footnotetext{
“(...) nenhuma produção é possível sem um instrumento de produção, mesmo sendo esse instrumento apenas a mão. Nenhuma produção é possível sem trabalho passado, acumulado, mesmo sendo esse trabalho apenas a destreza acumulada e concentrada na mão do selvagem pelo exercício repetido" (Introdução, 41).
}

Ainda quando a atividade, por sua condição incipiente, não se incorpora em transformações naturais que signifiquem bases ampliadas para a produção subsequente, ela ocorre sobre trabalho acumulado. O acúmulo de experiência resulta na domesticação das forças do produtor e na elaboração de suas capacidades; por isso não apenas conta como trabalho acumulado, mas faz parte dos resultados da produção mesmo quando esta é mais desenvolvida. Quando a produção supera este momento primitivo de seu vir a ser, o trabalho objetivado em produto aparece como condição do trabalho atual na medida em que põe os meios da produção ulterior:

Não se pode fiar algodão que ainda não se produziu, nem pôr em movimento fusos ainda a fabricar, nem queimar carvão que ainda não se extraiu da mina. Assim, entram sempre no processo como formas de existência de trabalho anterior. E desse modo trabalho existente depende de trabalho antecedente (...) (TMV III, 1326).

Por outro lado, o produto do trabalho passado apenas se realiza no consumo. Se os produtos são meios de produção, apenas se efetivam como tais no consumo produtivo. O trabalho anterior é condição para o atual, “(...) embora esse trabalho antecedente, na forma de meios de trabalho ou de material, só seja de alguma utilidade (uso produtivo) em contato com o trabalho vivo, como momento material deste. Só como momento do consumo industrial, isto é, do consumo pelo trabalho" (TMV III, 1326). Tanto o trabalho passado é condição para a produção presente, quanto o trabalho 
atual é condição para que o trabalho anterior se mantenha, ou seja, para que o produto passado se efetive como produto. Assim, se a natureza transformada substitui a natureza dada como condição material de produção, apenas se mantém como natureza humanizada por meio do trabalho contínuo. Se não são consumidos pelo processo atual de trabalho, os produtos do trabalho são reabsorvidos pela natureza, de modo que se o trabalho for interrompido, o processo natural, agora sem a direção da finalidade humana, reabsorve em seu curso próprio a matéria transformada. Giannotti utiliza o exemplo aristotélico ${ }^{71}$ da esfera de cobre:

\begin{abstract}
O trabalho que toma a esfera de cobre como ponto de partida mantém o trabalho anterior. Sem a reiteração do processo, a esfericidade do cobre se perde, a bola se oxida e o objeto produzido existe apenas no tempo do consumo individual. O homem se alimenta do trigo e o aniquila, a natureza selvagem absorve a esfera como a superfície do lago absorve as ondas provocadas pelo mergulho duma pedra - em ambos os casos o novo objeto não escapa do reino especificamente natural, seja ele físico ou biológico, nada sobrando para indicar a peculiaridade da produção humana (Giannotti, Trabalho, 83).
\end{abstract}

A produção humana é "o ato em que todo o processo transcorre novamente" (Introdução, 49), ou, como expressa Giannotti, "um movimento circular onde os resultados voltam a ser pressuposições" (Giannotti, Trabalho, 109). O trabalho é um processo. $\mathrm{Na}$ medida em que o trabalho resulta em domínio da natureza e estes resultados são seus pressupostos, a ampliação do produto coincide com a expansão das forças produtivas. A história se coloca como possibilidade no caráter reiterativo ou processual do trabalho, nesta "qualidade do trabalho de conservar e cristalizar o trabalho antigo, de formar entre o homem e a natureza brutos o intermediário constituído por sistemas de forças naturais domadas, abrindo dessa maneira o intervalo em que se localizam as forças produtivas" (Giannotti, Trabalho, 92$)^{72}$.

Apontamos de passagem que Giannotti restringe a ampliação de forças produtivas à criação de meio de produção expandidos, e não considera que o aumento

\footnotetext{
${ }^{71}$ Aristóteles, Metafísica, Livro Z, 8, 1033 a, citado por Giannotti, Trabalho..., p. 83. O autor compara a categoria de poíesis aristotélica e a de trabalho da economia moderna destacando, na primeira, a ausência de consideração pelo caráter reiterativo da produção, momento necessário para a compreensão histórica: "Deslocando o trabalho para o universo do processo, retirando-o da esfera da emersão e surgimento da coisa para situá-lo na circularidade da interiorização e da exteriorização, Marx faz dele práxis ao invés de poíesis" (Giannotti, Trabalho, 99).

72 As forças produtivas, contudo, são forças do trabalho social, e não se colocam entre o homem e a natureza, mas são as próprias capacidades humanas de produção postas subjetivamente e objetivamente no mundo humano, como natureza humanizada.
} 
quantitativo dos meios de consumo individual seja também fator de ampliação das forças produtivas:

(...) a metamorfose de tudo aquilo que cresce naturalmente (naturwüchsig) num fator propriamente histórico [se dá] graças ao domínio das forças naturais pela produção. Uma condição qualquer de trabalho, um objeto ou instrumento existente na natureza, converte-se numa condição histórica ao se repor como matéria-prima ou ferramenta fabricada. Com isso se forma o conjunto das forças naturais domadas que chamamos de força produtiva (Giannotti, Trabalho, 104).

De fato, a conversão das forças naturais em fatores históricos se dá na medida de seu domínio pelo homem, o que se realiza na atividade produtiva, mas para o autor, apenas aqueles produtos que se repõem como matérias-primas ou ferramentas compõem o conjunto das "forças naturais domadas que chamamos força produtiva". É evidente que um aumento dos meios de produção implica uma ampliação equivalente dos meios de vida dos produtores, mas o filósofo brasileiro exclui das forças produtivas materiais aqueles produtos que não retornam ao processo produtivo como condições de produção: "Se o produto for consumido individualmente, não houve ganho algum (...); se porém voltar à condição de meio produtivo, amplia-se a base material da atividade humana e com isso se abrem as portas da história" (Giannotti, Trabalho, 99). Esta afirmação subestima o consumo como momento da autoprodução do homem. O consumo individual é parte integrante do processo de ampliação das forças produtivas em dois sentidos: primeiro, ao consolidar a necessidade e pôr a finalidade do novo processo produtivo e, segundo, porque a ampliação meramente quantitativa dos meios de subsistência é o que possibilita a ampliação da população. O aumento da população é, em Marx, uma das condições da produção sobre bases materiais ampliadas e a primeira configuração do aumento das forças produtivas. Resulta do trabalho passado e é condição objetiva da produção tanto quanto os meios de produção objetivos: "Se o crescimento da população depende da produtividade do trabalho, a produtividade do trabalho depende do crescimento da população. O efeito é recíproco" (TMV III, 1239). Os indivíduos produtores são força produtiva e a ampliação da população significa expansão das forças produtivas. Na medida em que coincidem com a possibilidade de ampliação da população, os produtos do trabalho que não retornam ao processo produtivo compõem também as forças produtivas. Estas incorporam-se no conjunto de fatores envolvidos neste domínio, e incluem por isso as capacidades individuais - "a 
destreza acumulada e concentrada na mão do selvagem" - e portanto também os meios que reproduzem e capacitam os indivíduos.

Se a utilização de instrumentos para inscrever na objetividade os fins humanos amplia a potência do trabalhador e se o trabalho, por caracterizar-se como processo, é necessariamente reiterativo, podemos concluir que é da natureza do trabalho impulsionar as forças produtivas? A questão em foco é a do impulso às forças produtivas: busca-se responder se este impulso está dado já no caráter reiterativo do trabalho e quais outros fatores são determinantes para o fomento ou estagnação da produtividade. Viso especialmente investigar o papel das relações sociais como centrais na determinação do desenvolvimento. Apresento em seguida a posição de Giannotti sobre o tema e, no próximo capítulo, exponho o modo como Marx tratou a questão no texto sobre as formas sociais pré-capitalistas, destacando aspectos do modo como as relações sociais, formas vinculadas a determinados patamares produtivos ou níveis de acúmulo de trabalho passado, constituem fatores determinantes do impulso maior ou menor ao desenvolvimento.

Ao mesmo tempo em que afirma uma tendência à diferenciação das atividades de trabalho inscrita na lógica da individualidade técnica, Giannotti responde negativamente à questão da necessidade da expansão das forças produtivas: "Embora tudo faça com que os três elementos do trabalho venham a perder sua naturalidade, não podemos concluir daí a necessidade de um aumento quantitativo dos meios de produção e, por conseguinte, uma tendência natural de aumento das forças produtivas" (Giannotti, Trabalho, 92). Para o autor, esta tendência natural à ampliação da força produtiva no trabalho não se realiza necessariamente porque o fator que determina centralmente são as relações de produção. As forças produtivas são um predicado do trabalho: definem-se como níveis de potência da atividade produtiva. Contudo, o fato da produção não implica em si mesmo o impulso à criação de forças produtivas. Ou seja, nem toda forma social da produção se abre para a história.

Giannotti assume que existe no esquema do trabalho uma tendência à diversificação das atividades que se deve às determinações objetivas das condições de produção, isto é, às variações que a própria natureza ou a relação com outras comunidades impõem à atividade. Esta tendência é imanente à relação do homem com a natureza, e independe da especificidade da forma social: 
Uma individualidade técnica possui um impulso de diferenciação, que se desdobra segundo seu próprio processamento. (...) No que respeita a seu objeto, além das variações que lhe são impostas pelos ciclos da natureza, como aquelas das estações, precisamos ainda considerar aquelas provenientes de seu próprio funcionamento: o esgotamento do solo provoca culturas rotativas ou imigrações, a defesa do território depende do comportamento dos vizinhos e assim por diante. $\mathrm{O}$ mesmo, mutatis mutandis, ocorre com o instrumento. Imaginemos um grupo que vai à pesca munido duma rede coletiva. Conforme opera no mar ou num rio, no verão ou no inverno, está criando uma tensão que obriga a rede a adaptar-se à variância das condições: cumpre modificar seu cumprimento ou sua largura, a grossura de seus fios o vão de sua trama etc. Isto tem como efeito reorganizar a necessidade de parceiros, aumentando ou diminuindo seu número, criando novas tarefas pelas quais eles se especificam (Giannotti, Trabalho, 64).

A diversificação das atividades é referida por Marx como divisão do trabalho. O desenvolvimento da divisão do trabalho responde a necessidades ampliadas. Assim, a diversificação das atividades promove uma expansão do consumo ou fruição, que pressupõe o aumento da produtividade do trabalho anterior. Não é possível diversificar funções sem ampliar a produtividade do trabalho social. Contudo, desta necessidade de aperfeiçoamento da atividade produtiva e de criação de novas atividades que se impõe pelas variações naturais, pelas relações com "vizinhos" e ainda pelo resultado da própria atividade, Giannotti não deriva a necessidade da expansão das forças produtivas como imanente à produção humana. Há sociedades cujas relações de produção bloqueiam esta expansão, na medida em que não permitem a concentração de riqueza que ampliaria as bases objetivas do trabalho. Giannotti escreve: "Esta é nossa primeira tarefa: explicar por que, numa sociedade tribal, o excedente assume desde logo uma forma social que impede a acumulação, fazendo com que a sociedade gire sobre si mesma no interior dos estreitos limites duma produção para o consumo". E adiante: "Não é unicamente porque não podem que as sociedades tribais não desenvolvem uma tecnologia, mas porque não querem. E convém explicar a natureza desse querer" (Giannotti, Trabalho, 128).

O autor lança mão de uma comunidade primitiva específica para exemplificar esta ausência de abertura ao desenvolvimento inscrita nas relações sociais de produção. Examina uma organização tribal em que parte do produto de cada unidade familiar é intercambiado na forma de dádiva, doação que garante status e títulos no interior da tribo. O poder, materializado na posição de chefe da tribo, é alcançado por aquele que possui mais condições de doar produtos e demonstrar generosidade: 
A destruição ostentatória do produto obtém seu fim de arrancar do adversário seus status e seus títulos, reduzindo-o à situação de quem não pode definitivamente retribuir. Mas apesar da violência que esse mecanismo de poder é capaz de assumir, cabe notar como torna impossível sua concentração. Poderoso é quem doa: a generosidade é o traço marcante da chefia. A relativa riqueza da maloca do chefe serve para que obtenha de todos esta ou aquela forma de comprometimento; sua riqueza é sempre mutável, impossível de ser acumulada (Giannotti, Trabalho, 147).

O autor descreve a finalidade da atividade produtiva na tribo em questão como, primeiramente, o consumo individual do produto e, segundo, a conquista e manutenção do poder expressas no título de chefe da tribo e em uma hierarquia de nobreza ou prestígio entre os chefes de família. Na consecução deste fim, de acordo com o autor, os produtores se põem como adversários. O poder é alcançado pela capacidade de doar produtos às demais unidades familiares que constituem a produção coletiva da tribo. Por essa razão, o produto excedente não é acumulado ou concentrado em formas que permitam a ampliação das bases do trabalho ou desenvolvimento de sua produtividade, mas antes despendido como dádiva - e inclusive destruído - como meio de manutenção de poder. Neste sentido, a forma social da produção se estabelece como contrária ao desenvolvimento das forças produtivas. Uma vez que existe trabalho excedente, a comunidade deixa de desenvolver forças produtivas não pela ausência de condições materiais - não porque não pode - mas porque não quer: sua finalidade é outra.

Giannotti pretende distinguir a presença ou ausência de abertura para a história em cada sociedade pelo caráter modal da produção, ou seja, pela forma das relações de produção. Mas caracteriza as relações de intercâmbio primitivas como relações de troca. Ele busca distinguir a "troca primitiva" da troca moderna, apontando que a relação de equivalência, que preside o valor de troca no intercâmbio de mercadorias, não estava presente nessas comunidades. Contudo, concebe ainda como troca a relação em que parte do produto de determinada comunidade, criado no interior de unidades domésticas, constitui-se em dádiva. A doação de produtos às demais famílias é uma forma de demonstrar poder, calcado, como o coloca o autor, na generosidade. Receber presentes significa humilhação. Embora seja contra a tradição reciprocar de imediato, as famílias o fazem em outra oportunidade. Giannotti caracteriza como relação de troca uma relação em que uma parte doa algo e a outra, que não tem qualquer obrigação contratual de dar nada em troca. Aquele que recebe retribui o presente em outro momento porque não é aceito que se devolva de imediato (evitando justamente dar 
caráter de troca à dádiva), embora seja recomendável que haja uma retribuição, não necessariamente na mesma quantidade. Note-se que esta forma de intercâmbio se dá no interior da comunidade e os produtos doados são de mesma espécie. Um exemplo que o autor utiliza é o seguinte:

O cabeça do casal entrega ao marido da irmã parte de sua colheita, mas, em compensação, também recebe do irmão de sua esposa uma partida considerável de inhame. Nesse nível, porém, já se manifesta um fator de diferenciação: as prestações devem considerar o status do recebedor, de sorte que um marido mais nobre recebe mais do que outro de menor prestígio (Giannotti, Trabalho, 167).

Se tomarmos a troca como Marx a define, ou seja, como uma forma específica de intercâmbio em que, primeiro, os bens trocados são propriedade privada; segundo, constituem-se em não-valores de uso para seus proprietários; e terceiro, pressupõe liberdade de contrato (formal ou não), vemos que estas formas de intercâmbio não constituem trocas. A troca se define por esta autonomia, e por isso Marx afirma que ela tem início não no interior das comunidades, mas em suas fronteiras. Elas não são, de início, reguladas pelo valor, mas pela produção excedente e pela necessidade. Mas caracterizam-se como trocas precisamente porque o produto é excedente, não-valor de uso para a comunidade, e há autonomia entre as partes:

\footnotetext{
A troca de mercadorias começa onde as comunidades terminam, em seus pontos de contato com outras comunidades ou com membros de outras comunidades. Tão logo as coisas se tornam mercadorias no exterior da comunidade, tornam-se também por repercussão mercadorias no interior da vida comunal. Sua relação quantitativa de troca é por enquanto inteiramente casual. São permutáveis pela vontade de seus possuidores de aliená-las reciprocamente (C, I, 1, 81-2).
}

Em Marx, a troca faz necessariamente do produto uma mercadoria. Esta determinação formal adere ao produto quando ele é trocado, isto é, pela natureza da relação: a permuta daquilo que não é útil por vontade recíproca das partes, que não guardam entre si vínculos pessoais ou de obrigação. De modo que dádivas não são meios de troca, isto é, não são produtos da relação de troca entre seus possuidores: se realizam a partir de vínculos de obrigação de doar coisas que são valores de uso para seus possuidores. No exemplo de Giannotti, doam-se inhames e recebem-se inhames. Estes, ademais, não são autônomos. O próprio autor explica que as medidas destas trocas são dadas pelas relações de parentesco: 
Acresce ainda que a unidade de parentesco possui uma fixidez desconhecida por uma individualidade técnica na sua expressão mais simples. Enquanto esta última promove um sistema de distribuição em que os objetos trocáveis não possuem um padrão de medida perfeitamente estipulado, tal dificuldade já se encontra resolvida de antemão pelo sistema de parentesco, porquanto uma mulher se troca por outra, a despeito das diferenças de graça e beleza. A existência dessa medida, que o modo de produção tribal não logra obter na confluência de suas formas de distribuição, como acontece com o capitalismo, não viria a elucidar por que o sistema de parentesco se converte no referencial de todas as trocas? (Giannotti, Trabalho, 155).

Adiante, o autor afirma ainda:

Nessa altura, o sistema de parentesco surge como um pressuposto das atividades ligadas à produção e à distribuição, como espécie de quadro de referência a que todos se reportam. Por certo, a todo momento estamos assistindo a uma determinação recíproca entre o parentesco e os processos econômicos (Giannotti, Trabalho, 169).

Se o sistema de parentesco é o referencial para as "trocas" entre produtos de mesma espécie, pressuposto das relações de produção e distribuição, torna-se evidente que as relações de que trata Giannotti em nada se comparam com o comércio. Este é um intercâmbio que tem por base as relações de parentesco e portanto um vínculo pessoal, que não permite a liberdade de não trocar. Trata-se de um dever, não de uma troca. $\mathrm{O}$ próprio Giannotti escreve: “A troca primitiva, ao contrário, reafirma um vínculo social prévio pela mediação de uma coisa. (...) A troca consiste, desse modo, por excelência, numa relação de poder" (Giannotti, Trabalho, 146-7). A relação de troca propriamente dita se caracteriza exatamente por se estabelecer fora dos vínculos de obrigação.

Além disso, as mulheres são também dádivas, por meio de cuja "troca" os casamentos acontecem. As relações que caracterizam o casamento são do mesmo modo vistas como relações de troca, em que também se trocam objetos de mesma espécie, as mulheres. A consideração de Giannotti pelos atributos de "graça e beleza" da mulher apenas faz sentido se é pressuposto seu caráter de objeto sexual para o homem na forma de mercadoria. É como se os atributos de graça e beleza definissem o valor das mulheres, levando Giannotti a ponderar que nesta sociedade as trocas não são regidas pelo valor, de modo que a troca entre mulheres se dá entre não equivalentes: "uma mulher se troca por outra, a despeito das diferenças de graça e beleza". E em seguida aponta "A existência dessa medida, que o modo de produção tribal não logra obter na confluência de suas formas de distribuição (...)" (Giannotti, Trabalho, 155, citado acima). Ou seja, o modo de produção tribal não logra obter a medida das trocas, o valor, 
mas suas relações fundadas no sistema de parentesco são relações de troca. Se a troca fosse regida pelo valor, seriam levados em conta os atributos de "graça e beleza" das mulheres trocadas, seu "valores",73.

Contudo, esta relação de família em que os casamentos se dão entre membros de diferentes unidades familiares não põe a mulher como uma mercadoria e tampouco estabelece como sua função exclusiva a de objeto sexual. A relação entre homem e mulher nas sociedades primitivas é uma relação de produção, uma vez a família é a unidade produtiva. Em Marx, essa forma de domínio da mulher pelo homem que se desenvolve nas sociedades primitivas e resulta no estabelecimento do patriarcado não se caracteriza como uma relação de troca. Sobre as sociedades primitivas em geral, Marx e Engels escrevem: "Nessa fase, a divisão do trabalho é, ainda, bem pouco desenvolvida e se limita a uma maior extensão da divisão natural do trabalho ${ }^{74}$ que já existia na família. (...) A escravidão latente na família se desenvolve apenas aos poucos, com o aumento da população e das necessidades, e com a expansão do intercâmbio externo, tanto da guerra como da troca" (IA, 90). Esta "primeira forma da propriedade" é comunal, é "a propriedade tribal” (IA, 90), mas apresenta uma forma de divisão sexual do trabalho, "a escravidão latente na família”, e portanto de propriedade. Sobre esta forma de divisão do trabalho, lemos em outra passagem elucidativa:

Com a divisão do trabalho, na qual todas essas contradições estão dadas e que, por sua vez, se baseia na divisão natural do trabalho na família e na separação da sociedade em diversas famílias opostas umas às outras, estão dadas ao mesmo tempo a distribuição e, mais precisamente, a distribuição desigual, tanto quantitativa como qualitativamente, do trabalho e de seus produtos; portanto, está dada a propriedade, que já tem seu embrião, sua primeira forma, na família, onde a mulher e o os filhos são escravos do homem. A escravidão na família, ainda latente e rústica, é a

\footnotetext{
${ }^{73}$ Neste caso, se as mulheres são objetos de troca, seus atributos de "graça e beleza" não seriam de qualquer modo a medida de seu valor, visto que estas são determinações que interessam do ponto de vista de seu valor de uso de objeto sexual para o homem. Não é possível identificar as relações dos homens com as mulheres no casamento com formas dos homens distribuírem entre si produtos ou objetos sem cair em confusões, porque as mulheres, independente do nível de subordinação em que se encontram, ainda que sejam escravas, são sujeitos em relações sociais. Mas não é assim que Giannotti, pautado em LéviStrauss, nos vê.

${ }^{74}$ Parece-me que o termo natural aqui para designar a primeira forma de divisão do trabalho a sexual, não deva ser compreendido como uma determinação oriunda da natureza imediata ou biológica do homem, isto é, no interior da espécie. Considero que Marx esteja se referindo ao primeiro desenvolvimento necessário da produção humana, que deve se dar em todas as comunidades primitivas a partir do "aumento da população". Entendo que seja necessário o desenvolvimento de alguma forma de domínio do homem sobre o homem, de propriedade privada, a partir do momento em que a sociedade passa a produzir algum excedente. E me parece que a primeira forma deste domínio deva se dar no interior da família, visto que este era a unidade da produção no interior da tribo. Mas a questão da origem da divisão sexual do trabalho deveria ser mais bem investigada.
} 
primeira forma de propriedade, que aqui, diga-se de passagem, corresponde já à definição dos economistas modernos, segundo a qual a propriedade é o poder de dispor da força de trabalho alheia $(I A, 36-7)$.

Nas sociedades primitivas, o caráter de objeto sexual não é o único envolvido no casamento, porque as mulheres trabalham. Um exemplo do próprio Giannotti o atesta, quando afirma que era necessário ao chefe de uma comunidade indígena ter sessenta esposas para dar sustento "às suas pesadas obrigações" (Giannotti, Trabalho, 160, citado acima). Apesar da inversão que o autor realiza ao julgar quem mantinha as "pesadas obrigações", resta claro em seu texto que o comando do trabalho feminino é também um fator que permeia o casamento. É interessante notar que Giannotti não aponta a existência de uma relação de dominação da mulher pelo homem, mas aborda apenas a relação entre homens. Além disso, se a relação específica de casamento que ele descreve é uma relação de troca, seria relevante ressaltar a necessária propriedade das mulheres pelos homens que daí deriva, visto que só trocamos o que nos pertence, e pautar esta relação de posse, delineando o modo como esta forma social determina a produção.

Em Marx e Engels, a relação de produção que permeia o casamento nas sociedades primitivas, ou seja, a divisão do trabalho no interior da família, é uma forma de propriedade: a propriedade da mulher e dos filhos pelo homem. Ela implica uma divisão desigual do trabalho e de seus produtos. Esta forma de relação social específica determina a escravidão de uma parte dos membros da família. A mulher não é mercadoria, é escrava. Giannotti não menciona a relação social no interior da família, da “individualidade técnica". Entendo que razão desta omissão esteja dada na sua concepção lógica de trabalho, que subordina a relação social a um esquema operatório no qual as posições dos indivíduos estão já determinadas. Esta concepção acaba por alçar a "individualidade técnica" a agente da produção, em lugar dos indivíduos concretos. Já foi exposta a caracterização de Giannotti sobre o indivíduo no povo Tiv, que "significa família restrita, o pressuposto biológico da família social (...)" (Giannotti, Trabalho, 137, citado acima). A individualidade técnica - a família - é vista como um indivíduo em oposição à sociedade. Quando ela se apropria de parte do produto, ela o exclui da socialização: “O produto (...) apresenta-se igualmente dividido em duas partes, aquela apropriada pela individualidade técnica inicial, sendo desse modo surrupiada do processo de socialização, aquela destinada para outrem como forma de demonstrar sua 
colaboração no resultado final" (Giannotti, Trabalho, 141). Se a socialização se dá entre as famílias, a relação social que ocorre no interior da família, e que caracteriza a relação de produção nas sociedades primitivas, não aparece como forma de socialização. Não à toa o autor se refere à família como um corpo em que o homem é a cabeça: não há relação social ou de dominação entre os órgãos de um único organismo. Desconsiderando a forma de propriedade que existe no interior da família, Giannotti descaracteriza a sociedade primitiva: a única forma de propriedade que aparece em sua análise é a propriedade da terra pelas famílias em oposição, e portanto também do produto da terra. Daí a possibilidade das famílias "trocarem seus produtos". Contudo, na sociedade primitiva, a propriedade da mulher e dos filhos pelo homem é o que está na base da propriedade familiar da terra, ainda subordinada à propriedade tribal e à oposição entre famílias. A relação social determinante nesta sociedade que é a escravidão latente na família, primeira forma histórica do patriarcado, aparece transfigurada em relação de troca de dádivas, sejam produtos ou mulheres, referenciadas no parentesco. A equiparação assumida e não explicada entre inhames e mulheres, que confere a essa parcela dos indivíduos o status de objeto, contribui para que o que é uma relação social de produção, a família, apareça como um dado ou ente objetivo, uma individualidade técnica; ou, ao contrário, a aplicação deste conceito à unidade produtiva familiar retira das mulheres e dos filhos o caráter de sujeitos.

Sintetizando a explicação de Giannotti temos, primeiro, a defesa de uma tendência à diversificação das atividades no interior das "individualidades técnicas" em geral. Segundo, a despeito desta tendência, as relações sociais são determinantes porque podem bloquear o desenvolvimento: há sociedades que não se abrem para a história, ou seja, que não desenvolvem suas forças produtivas, porque a forma social é determinante deste impulso ou bloqueio do desenvolvimento. Exemplifica com uma sociedade primitiva cuja forma impede a acumulação de excedente e caracteriza suas relações como relações de troca, mas não determinadas pelo mercado, e sim pelo sistema de parentesco. Considera que o casamento e as doações recíprocas são troca. Então, em terceiro lugar, Giannotti vê a forma social como determinante para a distinção entre as sociedades que se abrem ou não para a história; mas, se considera até mesmo em uma sociedade primitiva com casamentos definidos pelo grupo e que doam inhames e recebem inhames, em quantidades indefinidas e com um intervalo necessário, uma relação de troca, é porque toda relação social é uma forma da relação de troca. 
Explica então por que essa forma de troca específica não impulsiona o desenvolvimento produtivo: porque é incapaz de acumular excedente. A razão disso é que a sociedade reconhece a chefia e a nobreza nos chefes de família capazes de oferecer mais dádivas de entre os produtos criados pela unidade familiar. Assim, busca-se algo que impede a acumulação do excedente. Por essa razão, a sociedade não se abre para a história: é "porque não querem” (Giannotti, Trabalho, 128, citado acima) que algumas sociedades não desenvolvem forças produtivas. Portanto, a finalidade dos chefes de família determina em última instância o devir da comunidade. Mesmo no interior desta interpretação, esta não é razão suficiente para que as forças produtivas se mantenham estagnadas. O fato é que, ainda que seja esta uma finalidade dos chefes de família, a capacidade de doar produtos é determinada pela eficiência da produção, de modo que se a finalidade não é acumular excedente, é preciso produzi-lo para ser doado. O próprio Giannotti escreve: "Se na verdade não tem condições de acumular, por causa na generosidade necessária do chefe, nem por isso os agentes perdem o interesse em abocanhar a maior parte possível do produto comunitário" (Giannotti, Trabalho, 161). E este pode ser um impulso ao aumento da produtividade: não é à toa que o chefe de tribo mencionado comanda o trabalho de suas sessenta esposas. $\mathrm{O}$ crescimento das unidades familiares não é em si mesmo um aumento de produtividade? De modo que as "individualidades técnicas", na verdade os chefes de família e da tribo em disputa, se têm algum nível de controle sobre o processo de produtivo, não o tem do evolver histórico. A "individualidade técnica" não controla os resultados de todas as suas ações. Além de tudo isso, tais sociedades não saíram das mãos da natureza assim como são, mas tiveram seu próprio processo de constituição histórico, que as levou ao nível de produtividade alcançado.

Assim, esta explicação das razões pelas quais uma sociedade não se abre para a história, deixando de realizar a tendência à diversificação de atividades, é insuficiente. Além disso, distancia-se do entendimento de Marx a respeito da especificidade da relação de troca e da especificidade da sociedade primitiva.

Ao analisar o trabalho do ângulo da relação do homem com a natureza, no nível abstrato que desconsidera as relações sociais específicas em que esta atividade se realiza, seu texto é bastante elucidativo, e por isso fiz uso de diversas de suas formulações, que sintetizam o modo particular como o homem se põe na objetividade. Contudo, a escolha de fazer o trabalho e a relação social se submeterem à 
individualidade técnica, e tomar esta unidade, e não os indivíduos, como sujeito da atividade, nos parece ser o momento que origina um distanciamento com relação às categorias de Marx. Giannotti evita partir de sujeitos ou indivíduos para que não se ponha como princípio aquilo que é resultado histórico. Mas o ser humano, que é natural e individual, é sujeito e indivíduo desde o início, ainda que não se distinga de um "animal gregário" 75 ligado à comunidade por um cordão umbilical e tenha "consciência de carneiro" (IA, 35). "Essa produção aparece, primeiramente, com o aumento da população. Ela própria pressupõe, por sua vez, um intercâmbio (Verkehr) entre os indivíduos" (IA, 87). Esta substituição do caráter individual do homem pela individualidade técnica como sujeito da atividade, derivada do ponto de partida lógico que toma o lugar do ponto de partida empírico de Marx, conduz Giannotti a uma concepção divergente da que o filósofo alemão elabora sobre a forma social ou modo de produção. Na sociedade primitiva abordada, a consideração da família como uma individualidade técnica leva a que a relação de dominação no interior da unidade familiar, definitiva das sociedades primitivas, se oculte na descrição da unidade produtiva como um corpo em que o homem é "o cabeça". A família é o indivíduo, e assim não é pautada a relação entre o homem e suas mulheres, que, caracterizados como órgão de uma individualidade, não aparecem como indivíduos em relação. Com isso, descaracteriza o modo de produção primitivo, vendo trocas de mulheres e de produtos onde há produção comunitária patriarcal. Mais do que isso, a ideia de uma individualidade técnica substitui a consideração da divisão do trabalho, que em Marx é definitiva da relação social de produção. A divisão sexual do trabalho no interior da família deixa de ser um fator determinante quando se toma o conjunto familiar por um indivíduo.

De modo que ao buscar compreender a constituição da sociedade in fieri, Giannotti adota um ponto de partida lógico, o trabalho como esquema operatório cujo agente, a individualidade técnica, é o próprio esquema. Com isso, abandona dois dos pontos fundantes do pensamento de Marx sobre o ser social: a relação social de produção é relação entre indivíduos e determina uma forma de propriedade ou divisão do trabalho. Contudo, ao expor a produção do ponto de vista do metabolismo do homem com a natureza, isto é, abstrato, sem consideração pela forma das relações, Giannotti

\footnotetext{
${ }^{75}$ MARX, K. Grundrisse: Manuscritos econômicos de 1857-1858: esboços da crítica da economia política, tradução de Mário Duayer e Nélio Schneider, São Paulo: Boitempo; Rio de Janeiro: Ed. UFRJ, 2011, p. 407. Doravante Grundrisse, seguido do número da página.
} 
examina a atividade produtiva dos indivíduos. Ali, abstrai-se da individualidade técnica e mesmo do caráter lógico do esquema operativo - por exemplo, não se pauta o consumo, mas apenas a transformação da natureza - e os indivíduos voltam a aparecer como agentes da atividade produtiva. Sua análise do processo de trabalho traz então elementos que contribuem para a compreensão do texto de Marx.

No que diz respeito à questão do impulso ao desenvolvimento, também em Marx há formas de relações que impulsionam mais vigorosamente este desenvolvimento, enquanto outras apenas muito lentamente se transformam. O dinamismo do intercâmbio externo é fator na tendência ao desenvolvimento da força produtiva. Por outro lado, o trabalho traz em si a tendência à ampliação na medida em que seus resultados são novos pressupostos da produção, e ainda que a motivação dos indivíduos seja sua reprodução sob as formas dadas, nem estes, nem o grupo, controlam o evolver social, que se desenvolve a despeito da finalidade de conservação. De modo que não há produção social estática, e transformações acabam por impor-se. O caráter histórico pertence à natureza do trabalho e se coloca não apenas como possibilidade, mas como necessidade na atividade livre e reiterativa de produção. Contudo, o modo das relações sociais determina percursos muito distintos a cada formação social, sem que haja portanto uma linha evolutiva comum, e tampouco a expansão produtiva como resultado imperioso: as formas de intercâmbio social podem levar inclusive a uma destruição de forças produtivas, retrocessos que resultam de formas determinadas dos avanços. A finalidade da produção posta em cada forma de sociabilidade conduz a resultados não previstos e isso é característico da história.

No próximo capítulo, apresento o modo como Marx explica o desenvolvimento e distingue as sociedades que "se abrem para a história". Neste contexto, busco destacar a questão da divisão do trabalho como fator central do desenvolvimento das forças produtivas na teoria de Marx e apontar aspectos da relação entre o conhecimento e a produção material em diferentes sociedades em que há separação entre trabalho material e trabalho intelectual. Aponto ainda as condições para que o conhecimento puro se ponha como força produtiva. 


\section{FORÇAS PRODUTIVAS E RELAÇÕES DE PRODUÇÃO: A DIALÉTICA DO DESENVOLVIMENTO NAS SOCIEDADES PRÉ-CAPITALISTAS}

\section{Introdução: modo de produção e história}

O modo de produção capitalista é inegavelmente uma forma muito particular do desenvolvimento das forças produtivas. Trata-se de uma forma social cuja dinâmica própria inclui o incitamento ao avanço produtivo em um nível historicamente inédito. Marx analisa nos Manuscritos de 1857-58 (Grundrisse) o modo como esta relação entre a forma-capital e o desenvolvimento material está dada imediatamente na forma de propriedade ou relação social que o conceito de capital sintetiza. No texto que analisa as formas sociais que precederam a produção capitalista, Marx demonstra a necessidade de uma dada dinâmica do desenvolvimento material posta já na forma-capital (de propriedade ou relação social), a partir da contraposição deste modo de produção às formas sociais que precederam a produção mercantil. Esta análise comparativa entre o modo capitalista de produção e os modos que o precederam também elucida aspectos da conceituação marxiana de força produtiva.

Ao abordar o desenvolvimento produtivo em termos genéricos, Marx divide a história humana em três estágios de acordo com as diferentes formas das relações de produção:

\footnotetext{
Relações de dependência pessoal (de início, inteiramente espontâneas e naturais) são as primeiras formas sociais nas quais a produtividade humana se desenvolve de maneira limitada e em pontos isolados. Independência pessoal fundada sobre uma dependência coisal é a segunda grande forma na qual se constitui pela primeira vez um sistema de metabolismo social universal, de relações universais, de necessidades múltiplas e de capacidades universais. A livre individualidade fundada sobre o desenvolvimento universal dos indivíduos e a subordinação de sua produtividade coletiva, social, como seu poder social, é o terceiro estágio. O segundo estágio cria as condições do terceiro (Grundrisse, 106).
}

Embora a história que precede a produção capitalista abarque diferentes modos de produção, estes compõem, em Marx, um único estágio amplo de desenvolvimento que se caracteriza por relações de produção pautadas na dependência pessoal e pelo caráter limitado e local do desenvolvimento da produtividade do trabalho humano. O modo capitalista de produção, segundo grande estágio histórico, caracteriza-se por romper as 
relações de dependência pessoal e estabelecer relações em que a independência pessoal se realiza sob a forma de uma dependência coisal. Esta nova forma universaliza a produção, rompe os limites locais do desenvolvimento e amplia as necessidades e capacidades humanas. Expande a produtividade do trabalho humano criando um metabolismo social universal que, no entanto, mantém-se fundado em relações de dependência da coisa, isto é, do seu próprio produto social criado como capital, sob as quais os indivíduos não subordinam sua produtividade coletiva a seu próprio poder, mas, ao contrário, permanecem subordinados a ela. A contradição, expressa nesta passagem como ausência de domínio social da capacidade produtiva, seria então superada pelo terceiro estágio de desenvolvimento histórico em que o metabolismo social universal desenvolvido sob o modo capitalista de produção, posto como efetivo poder social do conjunto dos indivíduos, permite a livre individualidade e o desenvolvimento universal dos indivíduos; ou seja, em que o desenvolvimento universal se ponha pela primeira vez na forma do desenvolvimento individual, por meio do controle social da produção.

Para compreender a ampla categorização em três estágios em que Marx indica tanto a especificidade da forma de sociabilidade do capital quanto o devir da história, é relevante expor a diferença de dinâmica essencial que separa o conjunto dos modos de produção que constituem o primeiro estágio do modo de produção capitalista. Inicialmente, procuro caracterizar em termos gerais o que Marx entende por modo de produção. O texto da "Introdução de 1857" é um manuscrito que Marx começou a preparar para introduzir a Contribuição para a crítica da economia política apresentando as categorias mais gerais de seu pensamento econômico a partir de uma crítica à teoria econômica clássica. Marx abandonou a redação de uma introdução geral precisamente porque, do ponto de vista do leitor, este nível de generalização das categorias é o resultado a que a análise deve levar ${ }^{76}$. Embora não tenha sido terminado, o texto traz um delineamento geral da categoria de modo de produção. Como, por um lado, o capítulo anterior tematizou as categorias gerais de trabalho e sociabilidade e, por

\footnotetext{
${ }^{76}$ No prefácio ao mencionado livro, Marx escreve: "Suprimo uma introdução geral que esbocei porque, depois de refletir bem a respeito, me pareceu que antecipar resultados que estão para ser demonstrados poderia ser desconcertante e o leitor que se dispuser a me seguir terá de se decidir a se elevar do particular ao geral" (Marx, K. Contribuição à crítica da economia política - Prefácio. Tradução e Introdução de Florestan Fernandes. São Paulo: Expressão Popular, 2008, pp. 45-6. Doravante, Prefácio de 1859, seguido do número da página).
} 
outro, este capítulo objetiva discutir a abertura para o desenvolvimento em diferentes modos de produção, vale expor aqui este delineamento.

Marx inicia pondo em foco a ideia de "produção em geral", e constrói a noção de modo de produção por meio de uma crítica à "representação superficial" elaborada pela economia clássica a respeito da produção, que se expressa nas "diferentes rubricas que os economistas colocam ao seu lado" (Introdução, 44). Sua crítica se dirige ao caráter autônomo atribuído pelos economistas à produção, à distribuição, à troca e ao consumo, e resulta na dissolução da autonomia dessas categorias e sua redefinição em momentos de um único processo, um modo de produção da vida humana.

Como já desenvolvido, a produção é, em Marx, atividade dos indivíduos efetivos em relação social. "Por isso, quando se fala em produção, sempre se está falando de produção em um determinado estágio de desenvolvimento social - da produção de indivíduos sociais" (Introdução, 41). A produção em geral não existe sensivelmente, como atividade efetiva: "Se não há produção em geral, também não há igualmente produção universal. A produção é sempre um ramo particular da produção - por exemplo, agricultura, pecuária, manufatura etc. - ou uma totalidade” (Introdução, 41). Por ouro lado, não se pode pensar a produção apenas como atividade singular ou ramo específico de trabalho, porque cada produção efetiva particular não existe isoladamente. Esta determinação está dada no fato de que a produção é a atividade especificamente humana ou social, e seus ramos específicos constituem-se como parcelas separadas da produção social pela divisão do trabalho, que supõe precisamente o conjunto da sociedade, a totalidade da produção social: "Finalmente, a produção também não é somente produção particular. Ao contrário, é sempre um certo corpo social, um sujeito social em atividade em uma totalidade maior ou menor de ramos da produção" (Introdução, 41). A totalidade da produção é o conjunto das atividades efetivas e, se seus resultados e relações extrapolam, dada a articulação total, a mera soma dos resultados singulares de cada produção específica, nem por isso ela se identifica com a produção em geral ou produção universal.

Isso não significa, contudo, que não se possa delinear conceitualmente este universal que, como tal, não é efetivo como a produção particular ou a totalidade social da produção, mas abstrato: “A produção em geral é uma abstração, mas uma abstração razoável, na medida em que efetivamente destaca e fixa o elemento comum, poupando- 
nos assim a repetição" (Introdução, 41). Estas linhas abstratas que definem a produção em geral constituem a categoria geral de modo de produção. A despeito de seu caráter abstrato, "esse Universal, ou o comum isolado por comparação, é ele próprio algo multiplamente articulado, cindido em diferentes determinações” (Introdução, 41), ou seja, complexo. Um fator desta complexidade é o caráter histórico da produção humana, que põe cada uma das fases ou modos particulares como resultado da produção passada e como movimento que cria os pressupostos da produção futura, ou seja, seu caráter processual. Cada modo de produção é sempre uma diferença específica no interior das determinações universais:

\footnotetext{
Nenhuma produção seria concebível sem elas; todavia, se as línguas mais desenvolvidas têm leis e determinações em comum com as menos desenvolvidas, a diferença desse universal comum é precisamente o que constitui seu desenvolvimento. As determinações que valem para a produção em geral têm que ser corretamente isoladas de maneira que, além da unidade - decorrente do fato de que o sujeito, a humanidade, e o objeto, a natureza, são os mesmos -, não seja esquecida a diferença essencial (Introdução, 41).
}

Esta diferença essencial entre as fases históricas da produção não se revela na teoria econômica burguesa porque a produção em geral é descrita não em seus termos abstratos, mas sob a forma social específica da sociedade comercial. Esta aparece como a forma geral da produção, forma que se apresenta, portanto, desprovida de seu caráter histórico. As determinações da sociedade burguesa se manifestam na concepção do indivíduo que produz isoladamente e cuja relação com os demais se estabelece pela troca de produtos: "O caçador e o pescador, singulares e isolados, pelos quais começam Smith e Ricardo" (Introdução, 39), demonstram que a especificidade da relação mercantil é alçada a determinação necessária da produção em geral. Nesta concepção, o resultado histórico de amplo desenvolvimento social aparece como ponto de partida da história e forma natural da produção humana:

\footnotetext{
Aos profetas do século XVIII, sobre cujos ombros Smith e Ricardo ainda se apoiam inteiramente, tal indivíduo do século XVIII - produto, por um lado, da dissolução das formas feudais de sociedade e, por outro, das novas forças produtivas desenvolvidas desde o século XVI - aparece como um ideal cuja existência estaria no passado. Não como um resultado histórico, mas como ponto de partida da história (Introdução, 39-40).
}

No interior desses fundamentos, a história não poderia aparecer na teoria econômica senão a partir da disjunção das categorias econômicas, que fazem com que a distribuição, associada às determinações dos âmbitos políticos e jurídicos, se dê sob 
variadas formas acordes a diferentes períodos históricos, enquanto a produção seja determinada por leis naturais:

\footnotetext{
Para os economistas, (...) a produção deve ser representada (...), à diferença da distribuição etc., como enquadrada em leis naturais eternas, independentes da história, oportunidade em que as relações burguesas são furtivamente contrabandeadas como irrevogáveis leis naturais da sociedade in abstracto. (Introdução, 42).
}

Considerando a produção, a distribuição, a troca e o consumo como fases autônomas do processo econômico e, ademais, descrevendo abstratamente a produção de modo que as relações burguesas - os indivíduos privados produzindo isoladamente apareçam como imanentes à produção em geral, enquanto as demais rubricas estão aptas a adquirir diferentes formas, os economistas apresentam uma explicação superficial da produção. Nela, a produção aparece como ponto de partida e o consumo como ponto de chegada, enquanto a distribuição e a troca figuram como meio termo: a primeira determinando quantitativamente, de acordo com leis sociais, a parcela de produto que cabe aos indivíduos e a segunda configurando a definição qualitativa individual dos produtos a serem consumidos, no interior da delimitação realizada pela distribuição. Marx resume a visão dos economistas:

\footnotetext{
A representação superficial claramente perceptível: na produção, os membros da sociedade apropriam (elaboram, configuram) os produtos da natureza às necessidades humanas; a distribuição determina a proporção em que o indivíduo singular participa desses produtos; a troca o provê dos produtos particulares nos quais deseja converter a cota que the coube pela distribuição; no consumo, finalmente, os produtos devêm objetos do desfrute, da apropriação individual (Introdução, 44).
}

Ao enfrentar a "bárbara cisão daquilo que é relacionado", Marx desenvolve sua noção de modo de produção, que articula a produção às diversas rubricas que aparecem ao seu lado na teoria econômica em um todo complexo em que a atividade imediata de transformação da natureza é mediada pela forma social.

Para demonstrar que produção, distribuição, troca e consumo articulam-se em um processo que constitui o modo de produção social, Marx começa pela imbricação entre produção e consumo, e destaca três aspectos que definem a unidade entre ambos. Primeiro, destaca o aspecto em que produção e consumo coincidem, isto é, que o ato de produzir é ao mesmo tempo um ato de consumo. Por um lado, o trabalho consome seus meios de produção, por exemplo, ao destruir a matéria-prima e desgastar os 
instrumentos. Por outro lado, "o indivíduo que desenvolve suas capacidades ao produzir também as despende, consome-as no ato da produção, exatamente como a procriação natural é um consumo de forças vitais" (Introdução, 45). De modo que a produção é sempre consumptiva tanto de seus pressupostos objetivos como subjetivos.

Este consumo produtivo distingue-se do consumo propriamente dito, isto é, o consumo individual dos produtos. Neste sentido, Marx destaca em segundo lugar o fato de que produção e consumo são mediadores recíprocos: a produção medeia o consumo ao criar seu objeto, e o consumo medeia a produção ao criar a necessidade subjetiva que a impulsiona, ou seja, cada um cria a mediação necessária para a realização do outro. Aqui, consumo e produção são interdependentes e mediadores recíprocos, mas aparecem como exteriores um ao outro: "a produção cria o material para o consumo como objeto externo; o consumo cria a necessidade como objeto interno, como finalidade para a produção" (Introdução, 48).

Em terceiro lugar, pondera que a unidade de ambos vai além desses dois aspectos de sua imbricação: “cada um deles não apenas é imediatamente o outro [como no consumo produtivo e na produção consumptiva - VC], nem tampouco apenas o medeia [pela criação de seu objeto, interno ou externo - VC], mas cada um cria o outro à medida que se realiza" (Introdução, 48). O consumo cria a produção ao completar o ato produtivo. É o consumo que realiza o produto, isto é, este só assume a determinação de produto específico no consumo. Além disso, o consumo põe a necessidade da repetição do ato produtivo e com isso "eleva à destreza" a capacidade de trabalho requerida na produção: “o consumo, portanto, não é apenas um ato conclusivo pelo qual o produto devém produto, mas também o ato mediante o qual o produtor devém produtor" (Introdução, 48). Ao impor a necessidade da reprodução do produto, o consumo impulsiona o aprimoramento da atividade produtiva, que molda o produtor em suas capacidades subjetivas. "Por outro lado, a produção produz o consumo na medida em que cria o modo determinado do consumo e, depois, o estímulo ao consumo, a própria capacidade de consumo como necessidade" (Introdução, 48). A necessidade de consumir algo de determinada forma é gerada pelo ato e pela repetição do ato de consumir os resultados da produção; é pois gerada pela presença do objeto. Assim, além de mediar o outro de modo exterior, ao criarem reciprocamente seus objetos, produção e consumo produzem um ao outro. O consumo consolida a necessidade do produto e com 
isso impõe a atividade produtiva, que por sua repetição cria a destreza subjetiva em suas funções e impulsiona aprimoramentos na produção ${ }^{77}$.

Marx desconstrói a autonomia entre a produção e consumo mostrando que "cada qual cria o outro na medida em que se realiza" (Introdução, 48). Assim, a produção não aparece mais como ponto de partida e tampouco o consumo como ponto de chegada, mas ambos formam um processo em que um é momento do outro e constituem ao mesmo tempo o resultado e o ponto de partida do outro. Neste movimento reflexionante, para usar uma expressão de Giannotti, "a produção é o ponto de partida e efetivo e, por isso, também o momento predominante [übergreifende Moment]. $\mathrm{O}$ próprio consumo, como carência vital, como necessidade, é um momento interno da atividade produtiva" (Introdução, 49). A produção é predominante porque nela se realiza o caráter reiterativo da atividade humana, ela é "o ato em que todo o processo transcorre novamente" (Introdução, 49). No consumo, o sujeito se produz, "mas como indivíduo produtivo e que se autorreproduz" (Introdução, 49). Ou seja, o indivíduo apenas se produz no consumo porque consome objetos criados pelo homem e cuja atividade cria objetos para o homem; portanto, como sujeito que produz. A autoprodução humana tem como ponto de partida a criação dos meios de vida para além dos limites da espécie, de modo que a atividade produtiva que cria o mundo humano objetivo é o momento predominante na produção da natureza humana subjetiva, como busquei mostrar no capítulo anterior.

Também naquele capítulo, foi destacada como uma diferença entre a produção meramente animal e aquela que se caracteriza como humana o fato de que os produtos não são imediatamente incorporados ao organismo: a produção especificamente humana constitui uma forma de atividade que se liberta da carência física atual, imediata. Não apenas porque é "uma condição muito peculiar do produto, o fato dele se pôr como ente, coisa-aí, pronta a ser consumida por um terceiro" (Giannotti, Trabalho..., 61-2, citado acima), mas porque, ao extrapolar a medida da espécie, o ser humano pode defrontar-se livremente com seu produto. Por essa razão, a apropriação do produto não é imediata,

\footnotetext{
${ }^{77}$ N'O Capital, Marx exemplifica este impulso que o consumo confere à transformação da produção com a necessidade de produtos estrangeiros em uma comunidade primitiva, adquiridos pela troca: (...) se consolida, pouco a pouco, a necessidade por objetos de uso estrangeiros. A constante repetição da troca transforma-a em processo social regular. Com o correr do tempo, torna-se necessário, portanto, que parte do produto do trabalho seja intencionalmente feita para a troca (C, I, 1, p. 82).
} 
mas depende de uma mediação social, de uma forma da relação entre os indivíduos que determine a distribuição de produtos. Marx escreve:

\begin{abstract}
$\mathrm{Na}$ sociedade, no entanto, uma relação do produtor com o produto, tão logo este esteja acabado, é uma relação exterior e o retorno do objeto ao sujeito depende de suas relações com outros indivíduos. Não se apodera dele imediatamente. Tampouco a imediata apropriação do produto é a finalidade do produtor quando produz em sociedade. Entre o produtor e os produtos se interpõe a distribuição, que determina, por meio de leis sociais, sua cota no mundo dos produtos, interpondo-se, assim, entre a produção e o consumo. A distribuição se coloca, então, como esfera autônoma, ao lado e de fora da produção? (Introdução, 49).
\end{abstract}

A distribuição como repartição de produtos determinada por leis sociais caracteriza a concepção da economia política clássica. Porque vê a produção como dada, Ricardo considera que a distribuição é o verdadeiro tema da economia. Marx supera a superficialidade desta teoria ao considerar que

(...) antes de ser distribuição de produtos, a distribuição é: 1) distribuição dos instrumentos de produção, e 2) distribuição dos membros da sociedade nos diferentes tipos de produção, o que constitui uma determinação ulterior da mesma relação. (Subsunção dos indivíduos sob relações de produção determinadas). A distribuição dos produtos é manifestamente apenas resultado dessa distribuição que está incluída no próprio processo de produção e determina a articulação da produção (Introdução, 51).

Como distribuição dos pressupostos materiais do trabalho e consequente divisão dos indivíduos ou das diferentes atividades produtivas entre os indivíduos, a distribuição "determina a articulação da produção", isto é, subsume os indivíduos a "relações de produção determinadas”. A distribuição é, por isso, a forma social da produção. Assim, não apenas o consumo, mas também o que é tradicionalmente chamado de distribuição aparece em Marx como um momento da produção, como "a diferença essencial" (Introdução, 41, citado acima) que especifica historicamente a produção e define sua forma particular.

A troca, como um momento subordinado à distribuição e mediador do consumo, não pode ser definitiva da produção: "Na medida em que a troca é só um momento mediador entre a produção e a distribuição, por ela determinada, e o consumo; mas, na medida em que o próprio consumo aparece como momento da produção, a troca também está evidentemente incluída como momento da produção" (Introdução, 51-2). É interessante notar que a troca não é aqui sinônima de intercâmbio, mas refere-se ao 
comércio, ou seja, caracteriza uma escolha individual dos produtos de consumo específicos, o que pressupõe um mercado onde esta escolha é possível. Há sociedades em que a distribuição e o consumo não são intermediados pela troca, ou em que são apenas parcialmente mediados por ela. A inclusão da troca como rubrica necessária ao lado da produção denota por si mesma a universalização do modo de produção mercantil pela economia burguesa. De modo que, para Marx,

É autoevidente que a troca e consumo não podem ser predominantes. Da mesma forma que a distribuição como distribuição dos produtos. No entanto, como distribuição dos agentes da produção, ela própria é um momento da produção. Uma produção determinada, portanto, determina um consumo, uma troca e uma distribuição determinados, bem como relações determinadas desses diferentes momentos entre si (Introdução, 53).

A distribuição é um momento da produção porque para produzir, dado o caráter social da atividade produtiva, é necessário que os indivíduos relacionem-se de alguma forma particular. Determinada forma de distribuição dos agentes da produção é uma condição da produção. Marx considera uma possível objeção a esta visão da predominância da produção:

Saber qual a relação dessa distribuição com a produção por ela própria determinada é uma questão que evidentemente faz parte da própria produção. Caso fosse dito, dado que a produção deve partir de uma certa distribuição dos instrumentos de produção, que ao menos nesse sentido a distribuição precede a produção e constitui seu pressuposto, deve-se responder que a produção tem de fato suas condições e seus pressupostos que constituem momentos dela própria (Introdução, 51).

A razão pela qual a "distribuição dos instrumentos de produção", sendo um pressuposto da produção, ainda assim é um de seus momentos, está na base do delineamento da categoria de modo de produção, que constitui a "abstração razoável" daquilo que é comum a toda produção e que na economia clássica aparece como produção, distribuição, troca e consumo. Marx observa que

\footnotetext{
A produção, por sua vez, é também determinada, em sua forma unilateral, pelos outros momentos. P. ex., quando o mercado se expande, i.e., a esfera da troca, a produção cresce em extensão e subdivide-se mais profundamente. Com a mudança na distribuição, modifica-se a produção; p. ex., com a concentração do capital, com diferente distribuição da população entre cidade e campo etc. Finalmente, as necessidades de consumo determinam a produção. Há uma interação entre os diferentes momentos. Esse é o caso em qualquer todo orgânico (Introdução, $53)$.
} 
Se todos os momentos da produção, que na economia clássica são categorizados com relativa autonomia, em Marx aparecem determinando-se mutuamente; se, ademais, uma dada distribuição dos agentes da produção é pressuposta a toda produção, por que esta “sobrepõe-se sobre os outros momentos", de modo que "É a partir dela que o processo sempre recomeça" (Introdução, 53)?

Em primeiro lugar, porque a distribuição dos agentes da produção, condicionada por uma dada distribuição dos instrumentos de produção, identifica-se com a divisão do trabalho, ou ainda, com um dado modo de apropriação das condições de trabalho. Distribuição é, em Marx, propriedade, e uma forma determinada da apropriação das condições de trabalho é um momento do próprio trabalho: não é possível a produção sem a apropriação de seus meios, imediatamente naturais ou historicamente modificados. Em segundo lugar, porque as formas de apropriação do material objetivo de produção transformam-se de acordo com o grau de domínio humano sobre a natureza. Ou seja, as formas de propriedade, que aparecem na economia política como formas de distribuição, são condicionadas pela produção. Marx escreve:

De início, tais condições e pressupostos podem aparecer como naturais espontâneos [naturwüchsig]. Por meio do próprio processo de produção, são transformados de momentos naturais e espontâneos [naturwüchsigen] em históricos, e se para um período aparecem como pressuposto natural da produção, para outro são o seu resultado histórico. São continuamente modificados no interior da produção. O emprego da maquinaria, por exemplo, modificou tanto a distribuição dos instrumentos de produção quanto a dos produtos. A grande propriedade fundiária moderna é, ela mesma, o resultado tanto do comércio moderno e da indústria moderna quanto da aplicação desta última na agricultura (Introdução, 51).

A produção tem diversos pressupostos: a natureza, indivíduos vivos, trabalho acumulado $^{78}$, a relação social mediante a qual os indivíduos se apropriam dos meios de produção. Todos esses pressupostos, contudo, são modificados no interior da produção à medida que esta acumula trabalho, transforma a natureza e molda os indivíduos, como foi exposto no capítulo anterior. Mas é preciso destacar que o aumento da força produtiva do trabalho impõe transformações no modo de apropriação ou distribuição, ou seja, na divisão do trabalho. As forças produtivas condicionam as relações de produção:

\footnotetext{
${ }^{78}$ Como já indicado do capítulo anterior, este trabalho passado pode ser em princípio "apenas a destreza acumulada e concentrada na mão do selvagem pelo exercício repetido" (Introdução, 41).
} 
Segue-se daí que um determinado modo de produção ou uma determinada fase industrial estão sempre ligados a um determinado modo de cooperação ou uma determinada fase social - modo de cooperação que é, ele próprio, uma "força produtiva" - que a soma das forças produtivas acessíveis ao homem condiciona o estado social e que, portanto, a "história da humanidade" deve ser estudada e elaborada sempre em conexão com a história da indústria e das trocas (IA, $34)$.

A distribuição, a que Marx se refere como divisão do trabalho ou modo de cooperação, é determinada pela produção na medida em que o desenvolvimento produtivo impõe a ela formas específicas: "na produção social da própria existência, os homens entram em relações determinadas, necessárias, independentes de sua vontade; essas relações de produção correspondem a um grau determinado de desenvolvimento das forças produtivas" (Prefácio de 1859, 47). No interior de relações de produção determinadas, contudo, as forças produtivas se desenvolvem:

\footnotetext{
Em uma etapa de seu desenvolvimento, as forças produtivas materiais da sociedade entram em contradição com as relações de produção existentes, ou, o que não é mais que sua expressão jurídica, com as relações de propriedade no seio das quais elas haviam se desenvolvido até então. De formas evolutivas das forças produtivas que eram, essas relações convertem-se em entraves (Prefácio de 1859, 47).
}

E adiante:

Uma sociedade jamais desaparece antes que sejam desenvolvidas todas as forças produtivas que possa conter, e as relações de produção novas e superiores não tomam jamais seu lugar antes que as condições materiais de existência dessas relações tenham sido incubadas no próprio seio da velha sociedade (Prefácio de 1859, 48).

Cada forma social das relações de produção tem, pois, uma história, um campo de desenvolvimento das forças produtivas que é capaz de conter. A partir de dado ponto deste desenvolvimento, as forças produtivas aprimoradas forçam a uma transformação da forma social, tornando-se base para novas relações de produção. De modo que se os outros momentos da produção determinam unilateralmente a produção no interior da sua forma, certo acúmulo de transformações produtivas impõe em última instância a transformação das relações de produção.

O modo de produção define-se pois por uma dada forma social - forma das relações de produção, da divisão do trabalho ou da propriedade - correspondente a um certo nível de forças produtivas. Refere o modo técnico em sua conexão com a forma 
social da produção. O grau de desenvolvimento a que a forma das relações corresponde não é um ponto fixo, mas um campo de desenvolvimento, de sorte que cada modo de produção tem uma história. Além disso, esta história incuba, isto é, desenvolve as bases para relações de produção novas, também dadas como campo de possibilidade nas forças produtivas desenvolvidas e, por isso, imprevisíveis. A necessidade deste desenvolvimento se mostra apenas quando este já se realizou: a força produtiva da sociedade delimita o curso possível, e uma vez que este se dá, as condições deste desenvolvimento aparecem como suas condições, pressupostos deste curso específico.

Em termos gerais, os modos de produção se transformam ao longo de seu desenvolvimento, isto é, as forças produtivas se ampliam. Também de modo geral, este desenvolvimento no interior da forma social impulsiona sua própria desagregação quando estas relações de produção dadas passam a significar uma contrição ao desenvolvimento produtivo. Todavia, o campo de desenvolvimento que cabe nos diferentes modos de produção não são regulares. Mesmo no interior dos modos de produção pré-capitalistas, há diferenças de dinamismo e impulso ao desenvolvimento e à transformação. Mas cabe examinar a especificidade do modo de produção capitalista. Este se caracteriza pelo impulso sem precedentes às forças produtivas precisamente porque sua forma social, ao contrário de desagregar-se com o desenvolvimento, expande-se. Esta especificidade faz do modo de produção capitalista um segundo grande estágio da história geral do ser humano, universal, separados do conjunto dos modos precedentes, locais. Além disso, Marx defende que ele desenvolve as forças produtivas que capacitam a transição para uma sociedade não-natural, isto é, que não se constitui espontaneamente. O que significa dizer que as forças produtivas desenvolvidas no interior do modo de produção do capital não impulsionam "metamorfoses silenciosas" que conduziriam à sua desagregação e consequente constituição de "relações de produção novas e superiores". A questão que se apresenta é então: uma vez que o aprimoramento produtivo desenvolve a relação capitalista de produção, esta não viria nunca a significar um entrave ao desenvolvimento? Uma resposta afirmativa a esta questão significa sustentar que o conjunto do desenvolvimento humano cabe nas relações capitalistas. Ou então: este modo de produção pode passar a significar um entrave às forças produtivas e ainda assim se manter indefinidamente? Esta pesquisa busca trazer elementos para discutir mais uma vez este problema, sem contudo almejar oferecer uma resposta cabal. 
Abordo o tema a partir de três questões. Primeiro, a razão pela qual esta relação de produção se nutre de e se desenvolve com base no avanço produtivo, quando este mesmo avanço desagrega as diferentes formas das relações de produção pré-capitalistas que configuram em conjunto o que Marx chama de primeiro estágio histórico. Segundo, o caráter historicamente necessário desta forma social do desenvolvimento produtivo, isto é, a necessidade do modo de produção capitalista para que se constitua "pela primeira vez um sistema de metabolismo social universal". Terceiro, o caráter contraditório da forma-capital do desenvolvimento das forças produtivas e o modo como sua contradição progride na medida da expansão produtiva. Neste terceiro tópico, inclui-se a questão da dissolução das relações de produção capitalistas: por que as formas pré-capitalistas de produção se desagregam pelo desenvolvimento, espontaneamente, e o modo capitalista, ao contrário, "jamais pode ser explodido por meio de metamorfoses silenciosas" (Grundrisse, 107)? Neste capítulo, nos debruçamos sobre a primeira questão e indicamos aspectos das outras duas, que serão, no entanto, desenvolvidas nos capítulos seguintes.

\section{Os pressupostos da produção social e a necessidade do dinamismo histórico: a questão da propriedade}

Esta pesquisa não tem como objetivo desenvolver as diferenças específicas entre as formas de propriedade nas sociedades pré-capitalistas, mas destacar seu fundamento comum, que faz de todas elas modos de produção que não comportam amplo desenvolvimento das forças produtivas, mas apenas avanço limitado e local, isto é, nos quais o desenvolvimento produtivo implica transformação das relações que os caracterizam. Trata-se de explicar, primeiramente, por que as relações de produção nas sociedades pré-capitalistas desagregam-se espontaneamente a partir do avanço das forças produtivas, ou seja, buscar em suas determinações econômicas a necessidade desta dissolução. Deste modo, é importante ressaltar inicialmente que as sociedades précapitalistas têm sua economia, e que a particularidade das formas econômicas coincide com o caráter específico das relações sociais de produção. Marx afirma:

Mas o fato de que a história pré-burguesa, e cada fase sua, também tem sua economia e uma base econômica do movimento, no fundo, é a simples tautologia de que a vida dos seres 
humanos desde sempre esteve baseada na produção, de uma ou de outra maneira, na produção social, cujas relações chamamos justamente de relações econômicas (Grundrisse, 400-1).

Nas formações sociais pré-burguesas existe uma produção social, em que o modo como os indivíduos se relacionam com as condições de produção constituem as relações econômicas. Implica, portanto, um modo de apropriação - divisão ou distribuição destas condições, uma forma de propriedade, que expressa a relação entre os indivíduos. A produção é, além disso, a base econômica do movimento, ou seja, atividade que move a transformação histórica. Em um parênteses, Marx identifica a produção com um movimento expansivo: "As condições originais da produção (ou, o que é a mesma coisa, da reprodução de um número crescente de pessoas pelo processo natural dos dois sexos (...))" (Grundrisse, 401). A "reprodução de um número crescente de pessoas", ou seja, a tendência à expansão, caracteriza a produção: seu caráter transformador faz com que novas produções aconteçam sobre os resultados anteriores, de modo que a reprodução é algo necessariamente dinâmico e expansivo.

Se a produção, na acepção geral, é tomada como um movimento de transformação e expansão, o ritmo deste desenvolvimento é distinto nos diferentes modos pré-capitalistas de produção e suas múltiplas formas locais, de acordo com as especificidades das relações de produção; mas entre as formas sociais pré-burguesas e o modo capitalista de produção, há, como mencionado, uma diferença de natureza. $\mathrm{O}$ desenvolvimento produtivo tende a dissolver as relações de produção pré-capitalistas, ao passo que é necessário e imanente à forma social do capital.

As formas sociais pré-capitalistas caracterizam-se, em traços gerais, por, primeiramente, supor "os sujeitos em uma unidade objetiva determinada com suas condições de produção" na qual, em segundo lugar, a existência de tais sujeitos "supõe as próprias comunidades como condições de produção". Os modos de produção que compõem o primeiro estágio do desenvolvimento histórico se definem, em conjunto, pela unidade tanto entre a atividade subjetiva e suas condições objetivas, quanto entre indivíduo e comunidade. Nesta unidade, em terceiro lugar, as condições de trabalho e a própria comunidade ou organização social constituem pressupostos naturais, não postos pelo trabalho. Finalmente, devido a essas determinações centrais, nos modos précapitalistas de produção o desenvolvimento das forças produtivas atua no sentido de desagregar, espontaneamente, as relações de produção que os caracterizam. 
No que diz respeito ao primeiro ponto, Marx afirma:

(...) em todas essas formas existe: 1) apropriação da condição natural do trabalho, da terra tanto como instrumento original do trabalho, laboratório, quanto depósito das matérias-primas não pelo trabalho, mas como pressuposto do trabalho. $\mathrm{O}$ indivíduo simplesmente se relaciona às condições objetivas do trabalho como sendo suas [próprias] condições; relaciona-se a elas como a natureza inorgânica de sua subjetividade, em que esta realiza a si própria; a principal condição objetiva do trabalho não aparece, ela própria, como produto do trabalho, mas está dada como natureza; de um lado, o indivíduo vivo, de outro, a terra como condição objetiva de sua reprodução (...) (Grundrisse, 397).

A unidade dos indivíduos com suas condições de produção significa a propriedade ou posse dessas condições, que se restringem originalmente à terra e seus frutos espontâneos. Os indivíduos se comportam frente às condições de produção como suas: a apropriação das condições objetivas do trabalho é um comportamento natural e imediato, que toma a terra como "natureza inorgânica de sua subjetividade", ou seja, um prolongamento natural e imediato do sujeito. As condições de produção constituem pressupostos naturais ou divinos porque “(...) originalmente, não podem ser elas próprias produzidas - não podem ser resultados da produção" (Grundrisse, 401).

Se o principal meio de trabalho não pode ser originalmente produzido pelo trabalho, de sorte que este tem como objeto a natureza que encontra dada ou pressuposta, isso implica que a produção social tem um controle reduzido das condições de sua realização, um domínio restrito da natureza. A propriedade da terra nessas formas sociais significa que o produtor existe em unidade com o objeto da atividade de reprodução da vida, em que este é inerente à existência subjetiva. Diferentemente da forma capitalista de sociabilidade, o produtor

(...) não aparece de antemão, nessa abstração, unicamente como indivíduo trabalhador, mas tem na propriedade da terra um modo de existência objetivo, que está pressuposto à sua atividade e da qual não aparece como mero resultado, e que é um pressuposto de sua atividade da mesma maneira que sua pele ou seus órgãos sensoriais, os quais ele de fato também reproduz e desenvolve etc. no processo vital, mas que, por sua vez, são pressupostos desse processo de reprodução (...) (Grundrisse, 397).

As condições de produção são pressupostas ao produtor e lhe pertencem do mesmo modo que "sua pele e seus órgãos sensoriais": “(...) mesmo o natural torna-se órgão de sua atividade, um órgão que ele acrescenta a seus próprios órgãos corporais, prolongando sua figura natural, apesar da Bíblia" (C, I, 1, 150). Assim, o caráter ativo 
ou subjetivo dos indivíduos é indissociável de sua existência objetiva na terra, no território, no objeto de sua atividade produtiva, ou seja, a existência subjetiva não se distingue da propriedade das condições de produção, mas se estende a esta de modo que o sujeito tem nela uma existência objetiva.

O que o sr. Proudhon chama de gênese extraeconômica da propriedade, pelo que entende justamente a propriedade da terra, é a relação pré-burguesa do indivíduo com as condições objetivas do trabalho, e primeiro com as condições objetivas naturais do trabalho - porque, assim como o trabalhador [era] indivíduo natural, existência natural, a primeira condição objetiva do trabalho apareceu como natureza, terra, seu corpo inorgânico; ele próprio não é só corpo orgânico, mas essa natureza inorgânica como sujeito. Tal condição não é seu produto, mas é encontrada pronta; como existência natural fora dele e que lhe é pressuposta (Grundrisse, 400).

Esta existência objetiva desaparece no modo capitalista, em que o trabalhador existe frente à comunidade apenas enquanto subjetividade, atividade desvinculada de sua base objetiva. Ao contrário, nas sociedades pré-burguesas, o produtor "não é só corpo orgânico, mas essa natureza inorgânica como sujeito". Sua existência subjetiva se põe objetivamente em sua propriedade, e a conformação material da natureza inorgânica pela atividade a constitui como sujeito, como mundo humano. O sujeito se confirma na propriedade das condições de sua atividade. A propriedade nas formas sociais précapitalistas se define como um comportamento dos indivíduos frente à terra como extensão de seu corpo e, portanto, como naturalmente pertencente a eles.

\footnotetext{
A propriedade, por conseguinte, originalmente, nada mais significa que o comportamento do ser humano em relação às suas condições naturais de produção como pertencentes a ele, como suas, como condições pressupostas com a sua própria existência; comportamento em relação a elas como pressupostos naturais do próprio ser humano, que, por assim dizer, constituem somente o prolongamento do seu corpo. O ser humano não se relaciona propriamente às suas condições de produção; mas ele existe de maneira dupla, seja subjetivamente, como ele próprio, seja objetivamente, nessas condições naturais inorgânicas de sua existência (Grundrisse, 403).
}

Marx afirma que o ser humano não se relaciona propriamente com suas condições de produção porque relação demanda o caráter ativo, subjetivo, e é por isso predicado exclusivo de indivíduos humanos. A propriedade não é uma relação do homem com a "coisa", com o objeto inorgânico, mas um modo de apropriação do material objetivo que é determinada na relação com outros indivíduos. É, portanto, uma relação social. O ser humano não se relaciona com as condições naturais de sua atividade e reprodução, 
mas existe nelas. $\mathrm{O}$ indivíduo existe, pois, de maneira dupla: como sujeito em atividade e na natureza paulatinamente humanizada pela produção.

A propriedade ou comportamento frente às condições naturais de produção como suas, dado que é uma relação entre indivíduos, pressupõe a comunidade. Este comportamento que caracteriza a propriedade individual da terra não é, pois, imediato, mas mediado pela comunidade: “A sua propriedade, i.e., a relação com os pressupostos naturais de sua produção como pertencentes a ele, como os seus, é mediada pelo fato dele próprio ser membro natural de uma comunidade" (Grundrisse, 401). Em outros termos, a "atitude do indivíduo em relação às condições naturais de trabalho e da reprodução como pertencendo a ele, como o corpo objetivo, natureza inorgânica dada, de sua subjetividade" (Grundrisse, 389), tem como pressuposto o pertencimento a uma comunidade, que, do mesmo modo que a terra, antecede os indivíduos e é seu pressuposto. Sobre este segundo ponto, Marx afirma:

(...) 2) mas esse comportamento em relação ao território, à terra, como propriedade do indivíduo trabalhador (...) é imediatamente mediado pela existência originada natural e espontaneamente, mais ou menos historicamente desenvolvida e modificada, do indivíduo como membro de uma comunidade - a sua existência natural como membro de uma tribo etc. (Grundrisse, 397).

A propriedade individual da terra é, nas sociedades pré-capitalistas, "imediatamente mediada" pelo pertencimento a uma comunidade. A mediação da comunidade é necessária e imediata porque o caráter de indivíduo produtor se subordina ao de membro de uma tribo, sendo esta uma condição natural pressuposta à propriedade apropriação da terra - e portanto também à atividade individual:

Um indivíduo isolado teria tão pouca possibilidade de ter propriedade da terra como de falar ${ }^{79}$. É claro que ele poderia nutrir-se dela como substância, como fazem os animais. O comportamento em relação à terra como propriedade é sempre mediado pela ocupação, pacífica ou violenta, da terra pela tribo, pela comunidade, em qualquer forma mais ou menos natural ou já historicamente mais desenvolvida. Nesse caso, o indivíduo jamais apresentará o aspecto pontual, em que ele aparece como simples trabalhador livre. Se as condições objetivas de seu trabalho são pressupostas como lhe pertencendo, ele próprio é subjetivamente pressuposto como membro de uma comunidade, pela qual sua relação com a terra é mediada. A sua relação com as condições

\footnotetext{
${ }^{79}$ Em outra passagem de Marx: "Com referência ao indivíduo singular, está claro, por exemplo, que ele próprio só se relaciona à linguagem como sendo a sua própria linguagem na qualidade de membro natural de uma comunidade humana. A linguagem como produto de um indivíduo singular é um absurdo. Mas o mesmo vale para a propriedade" (Grundrisse, 402).
} 
objetivas do trabalho é mediada por sua existência como membro da comunidade (Grundrisse, $397-8)$.

A linguagem é evidentemente uma relação social, na medida em que seu pressuposto é a necessidade de intercâmbio entre indivíduos, por meio do qual se desenvolve. Do mesmo modo, a propriedade é também uma relação social na medida em que significa um comportamento consciente frente ao território como seu, o que só se realiza em relação aos demais indivíduos, sejam os da tribo que compartilha a propriedade coletiva, sejam os das demais tribos excluídas desta propriedade. Como indicado acima, não há relação propriamente dita do indivíduo com os meios objetivos de produção, mas apenas entre sujeitos. A apropriação da terra é uma relação do indivíduo com os demais sujeitos e, se não é, trata-se apenas de "nutrir-se dela como substância, como fazem os animais". Assim como a terra, a comunidade aparece entre as condições naturais de produção:

Uma condição natural de produção para o indivíduo vivo é seu pertencimento a uma sociedade originada natural e espontaneamente, a uma tribo etc. Tal pertencimento é desde logo, por exemplo, condição para sua linguagem etc. A sua própria existência produtiva só existe sob essa condição. A sua existência subjetiva enquanto tal é condicionada por isso, na mesma medida em que é condicionada por seu comportamento em relação à terra como seu laboratório (...) (Grundrisse, 403).

A mediação imediata, ou natural, da comunidade é necessária à propriedade da terra em todas as condições em que há um baixo desenvolvimento produtivo - "em qualquer forma mais ou menos natural ou já mais historicamente desenvolvida" -, e este caráter imediato ou natural da mediação comunitária apenas será rompido historicamente com base em uma expansão das forças produtivas em que as principais condições de produção sejam já postas pelo trabalho, e não mais pressupostos naturais. Portanto, quando a indústria urbana se sobrepõe à produção no campo, caracterizando uma dependência da terra não mais imediata e natural, mas mediada pelos próprios resultados do trabalho acumulado. Na medida em que não apenas a terra, com seus acidentes naturais e seus frutos, é um pressuposto da produção, mas também a comunidade, a primeira forma de propriedade é necessariamente coletiva ou comunal:

As formas dessas condições naturais de produção são duplas; 1) sua existência como membro de uma comunidade; portanto, a existência dessa comunidade, que em sua forma original é um sistema tribal, um sistema tribal mais ou menos modificado; 2) o comportamento em relação à terra por mediação da comunidade, como propriedade da terra comunitária sua e, ao mesmo 
tempo, como posse individual para o indivíduo singular, ou de tal modo que só os frutos são repartidos; o próprio solo e seu cultivo, entretanto, continuam coletivos" (Grundrisse, 403).

O coletivo é necessário para a apropriação da terra uma vez que a relação social é definitiva da distinção de natureza do trabalho humano frente às atividades produtivas meramente naturais. Configura também a força produtiva mínima para a reiteração do trabalho e a reprodução de seus resultados, portanto da configuração da atividade em trabalho humano. Por isso, a condição de sujeito do indivíduo pressupõe sua existência objetiva na comunidade: "ele próprio é subjetivamente pressuposto como membro de uma comunidade". O produtor apenas existe como sujeito na medida deste vínculo: o indivíduo membro de determinada tribo, ou sua existência como sujeito não se confirma. Assim, a propriedade individual da terra, ou o comportamento do indivíduo frente à terra como sua, se identifica com a determinação do indivíduo como membro da comunidade.

\begin{abstract}
A propriedade significa, portanto, pertencer a uma tribo (comunidade) (ter existência subjetivaobjetiva dentro dela) e, por mediação do comportamento dessa comunidade em relação ao território, à terra como seu corpo inorgânico, [significa também] comportamento do indivíduo em relação ao território, à condição originária exterior de produção - porque a terra é, a um só tempo, matéria-prima, instrumento e fruto - como pressupostos pertencentes à sua individualidade; como modos de existência da individualidade (Grundrisse, 403-4).
\end{abstract}

Propriedade significa o pertencimento à tribo porque é condição tanto da apropriação do meio de trabalho primeiro, a terra, como da existência da individualidade, sua determinação própria. Daí a primeira forma de propriedade, ou distribuição, é aquela que reparte os produtos mas mantém o solo como propriedade comum. $\mathrm{O}$ indivíduo como sujeito produtor tem origem na atividade comunitária, de modo que, como exposto no capítulo anterior, o caráter social e o caráter subjetivo são determinações da mesma forma de vida. Esta caracterização que Marx realiza das condições originárias do indivíduo é genérica e indica os pressupostos do indivíduo, da atividade e da propriedade. Mas, esses pressupostos gerais existem sob formas específicas em cada comunidade: do mesmo modo que a apropriação individual é mediada pelo pertencimento do produtor à comunidade, a forma específica desta propriedade caracteriza a comunidade, denota sua forma social particular. O modo como Marx explica o desenvolvimento da sociedade in fieri não é carente de pressupostos. Pressupõe a natureza, e nesta a organização corporal dos indivíduos humanos, e a coletividade. Contudo, este desenvolvimento se explica pelas relações de 
produção efetivas, de modo que, por um lado, prescinde de um fundamento lógico e, por outro, não pode prescindir de indivíduos, distinguindo-se claramente da explicação de Giannotti. Marx escreve: “A sua relação com as condições objetivas do trabalho é mediada por sua existência como membro da comunidade; por outro lado, a existência efetiva da comunidade é determinada pela forma particular de sua propriedade sobre as condições objetivas de trabalho" (Grundrisse, 397-8). A comunidade não é nada além ou distinto do conjunto dos indivíduos que produzem em uma forma determinada de relação de produção.

As formas particulares de relações de propriedade abrem-se para diferentes desenvolvimentos. No texto sobre as formações sociais pré-capitalistas, Marx descreve três distintas formas em que a comunidade é pressuposta ao indivíduo e medeia sua apropriação da terra. Trata-se de modos de produção antigos, anteriores ao modo de produção feudal e que sucedem os modos primitivos, característicos da pré-história, nos quais a propriedade da terra é coletiva.

À propriedade coletiva corresponde o desenvolvimento da divisão sexual do trabalho, que precede a divisão do trabalho propriamente dita e tem sua própria história, ou mais precisamente, diversas histórias locais. Nos modos de produção antigos de que trata Marx, existe já a divisão social entre trabalho material e espiritual, que implica formas de propriedade privada e com isso cria a divisão de classe. A "produtividade aumentada", o "aumento da população" e o "incremento das necessidades" impulsionam a produtividade do trabalho.

Com isso, desenvolve-se a divisão do trabalho, que originalmente nada mais era do que a divisão do trabalho no ato sexual e, em seguida, divisão do trabalho que, em consequência das disposições naturais (por exemplo, força corporal), necessidades, casualidades etc. etc., desenvolve-se por si própria ou "naturalmente". A divisão do trabalho só se torna realmente divisão a partir do momento em que surge uma divisão entre trabalho material e espiritual. (IA, $35)$.

A divisão do trabalho efetiva é a que separa o trabalho material e o trabalho intelectual porque esta cisão está pautada na apropriação privada ou na exclusão da propriedade de parte dos indivíduos, o que cria duas classes de indivíduos e expande a subordinação no interior da família à relação de produção entre as famílias. Na forma de propriedade tribal, 
a divisão do trabalho é, ainda, bem pouco desenvolvida e se limita a uma maior extensão da divisão natural do trabalho que já existia na família: os chefes patriarcais da tribo, abaixo deles os membros da tribo e, por fim, os escravos. A escravidão latente na família se desenvolve apenas aos poucos, com o aumento da população e das necessidades, e com a expansão do intercâmbio externo, tanto da guerra quanto da troca (IA, 90, parcialmente citado no capítulo anterior).

Este desenvolvimento engendra a separação entre o trabalho material e o trabalho intelectual, que significa a criação de uma classe proprietária livre do trabalho necessário, imediato, e responsável centralmente pelas funções de direção e administração sociais, além da produção puramente intelectual (teoria, arte etc.). Esta função implica em propriedade ou direito ao produto social, e portanto domínio dos produtores imediatos. A dominação do ser humano pelo ser humano que se origina na família e aparece na dominação patriarcal sobre as mulheres e os filhos desenvolve-se em dominação da classe proprietária sobre a não-proprietária. Marx escreve: “Além do mais, divisão do trabalho e propriedade privada são expressões idênticas - numa é dito com relação à própria atividade aquilo que, noutra, é dito com relação ao produto da atividade" $(I A, 37)$. A primeira forma de propriedade privada, que se desenvolverá em propriedade privada da terra por uma classe, mesmo que ainda subordinada ao vínculo comunitário, é a propriedade dos próprios indivíduos.

No texto da Ideologia Alemã, Marx e Engels priorizam o modo de produção antigo clássico, Roma em particular, na medida em que da desagregação deste modo de produção desenvolve-se o modo de produção feudal, que por sua vez origina o capitalismo. No texto sobre as formações pré-capitalistas, Marx apresenta três diferentes modos de produção antigos, que se desenvolvem a partir da comunidade primitiva, limiar de todos os povos. Têm em comum a divisão entre trabalho material e intelectual, e portanto a divisão da sociedade, ainda que por vezes incipiente, em classes. Mas se caracterizam, sobretudo, pela necessidade e prioridade do vínculo comunitário. As formas de propriedade privada existem subordinadas a este vínculo e o contradizem: quando existe o desenvolvimento da propriedade, ele conduz à dissolução das bases da comunidade. Esta discussão terá por base o modo de produção antigo clássico, mas apontarei também aspectos do modo de produção asiático ou oriental, para distinguir do primeiro. Abordo este primeiro ponto, a contradição entre as formas de propriedade privada ou divisão do trabalho que vão surgindo espontaneamente a partir da expansão natural da produção e a comunidade. 
Os modos de produção asiático, antigo e germânico se distinguem pelas diferentes formas de propriedade em que estes traços comuns ao primeiro estágio da história se põem. Marx mostra como a forma da propriedade se altera naturalmente a partir da própria atividade produtiva nas conformações sociais primitivas, de modo que o desenvolvimento dos pressupostos históricos da produção apresenta ao mesmo tempo uma tendência ao desenvolvimento da propriedade privada. Como se verá, esta tendência não é uma necessidade absoluta em todas as formas da sociabilidade e dependem da abertura ao intercâmbio externo: o modo de produção asiático desenvolve a divisão do trabalho sem aprofundar a propriedade privada da terra.

A propriedade que se define como um comportamento natural diante da terra como sua apenas pode se estabelecer pela atividade efetiva que se apropria do território. A propriedade se estabelece pela própria produção, e esta consideração introduz o quarto aspecto determinante das formações sociais pré-burguesas. Marx explica:

\begin{abstract}
A propriedade, na medida em que é só o comportamento consciente - e, no que se refere ao indivíduo singular, posto pela comunidade, e proclamado e garantido como lei - em relação às condições de produção como suas, portanto, na medida em que a existência do produtor aparece como uma existência nas condições objetivas pertencentes a ele, só é realizada pela própria produção. A apropriação efetiva não aparece primeiro na relação imaginada, mas na relação ativa, real, com essas condições - o seu pôr efetivo como as condições de sua atividade subjetiva (Grundrisse, 404).
\end{abstract}

Diferentemente da forma capitalista, a propriedade nas sociedades que a precederam somente se estabelece pela relação ativa com essas condições. Mas porque é a atividade produtiva que torna o objeto de trabalho pertencente à comunidade (e por meio dela, aos indivíduos), as formas da propriedade alteram-se conforme a produção se transforma. Marx continua:

Todavia, com isso, é ao mesmo tempo claro que essas condições se alteram. É somente pela caça das tribos que uma região da terra se converte em um território de caça; é somente pelo cultivo da terra que o território é posto como um prolongamento do corpo do indivíduo. Depois que a cidade de Roma foi construída e os campos nos arredores foram cultivados pelos seus cidadãos, as condições da comunidade se tornaram diferentes do que eram antes (Grundrisse, 405).

Do fato de que a propriedade é estabelecida diretamente pela atividade produtiva, e de que é da natureza do trabalho as transformações das condições de produção - um campo cultivado, por exemplo, é uma base da produção distinta de uma floresta - a própria 
atividade se transforma, e com ela, as formas da propriedade dadas imediatamente pela atividade. Em outros termos, se a atividade específica se realiza sobre condições determinadas, seus resultados alteram essas mesmas bases e põem novas formas de atividade. Uma vez que a propriedade é dada pela atividade efetiva, a transformação da atividade conflita com as relações de propriedade postas, que lhe serviram de base.

Todas as formas (mais ou menos natural e espontaneamente originadas, mas, ao mesmo tempo, todas também resultado do processo histórico) em que a comunidade supõe os sujeitos em uma unidade objetiva determinada com suas condições de produção, ou em que uma existência subjetiva determinada supõe as próprias comunidades como condições de produção, tais formas correspondem necessariamente só a um desenvolvimento limitado, e limitado por princípio, das forças produtivas. O desenvolvimento das forças produtivas as dissolve, e sua própria dissolução é um desenvolvimento das forças produtivas humanas. Em um primeiro momento, trabalha-se a partir de uma certa base - de início, originado natural e espontaneamente -, em seguida, pressuposto histórico. Mais tarde, no entanto, essa própria base ou pressuposto histórico é abolida ou posta como um pressuposto evanescente, que se tornou muito estreito para o bando humano progressivo (Grundrisse, 407).

Esta passagem reitera o texto do Prefácio de 1859, em que Marx enuncia de forma genérica que relações de produção determinadas abrangem um campo limitado de desenvolvimento produtivo, a partir do qual as forças produtivas passam a conflitar com a forma de propriedade pressuposta a seu desenvolvimento. Marx explicita a relação entre o caráter local e limitado das sociedades baseadas na comunidade e na terra e sua desagregação pelo desenvolvimento produtivo, o que contribui ademais para dimensionar a universalização verificada com a dissolução em capital das relações comunitárias e compreender a natureza desta transformação. Esta passagem mostra ainda que o desenvolvimento histórico tem como pressuposto apenas a condição ou situação anterior já posta, seja como dado natural, ou como resultado do trabalho. A necessidade de determinado desenvolvimento se baseia apenas no efetivamente existente e só pode ser reconhecida post festum: os pressupostos objetivos do desenvolvimento estão dados, mas sua mera presença não revela o curso do desenvolvimento possível. O conteúdo do caráter dialético do desenvolvimento histórico no estágio pré-capitalista da história, em que a atividade que busca a manutenção da comunidade conduz, à revelia dos sujeitos, à sua dissolução, é a contradição entre o vínculo comunitário e a divisão do trabalho ou propriedade privada. Esta mesma dialética, segundo a qual a forma de propriedade atual incita um desenvolvimento que virá a conflitar com esta própria forma, aparecerá no capital como 
contradição interna à propriedade privada. Esta diferença de natureza da contradição leva à ausência de tendência à dissolução, e à consequente necessidade revolucionária: o desenvolvimento local sob a forma da comunidade tende, de modo geral, a desenvolverse em propriedade privada, mas a propriedade desenvolvida não tende à constituição de uma nova comunidade sob novas bases produtivas, apenas torna possível o desenvolvimento dessas últimas. Este tema será desenvolvido no último capítulo da pesquisa.

A transformação da forma de propriedade nas sociedades pré-burguesas se dá natural e espontaneamente, a partir das atividades que visam à manutenção da comunidade em suas relações características. Marx afirma:

Para que a comunidade continue a existir enquanto tal à maneira antiga, é necessária a reprodução de seus membros sob as condições objetivas pressupostas. A própria produção, ou seja, o progresso da população (também este faz parte da produção), abole necessária e gradualmente estas condições; destrói-as, em lugar de reproduzi-las etc., e com isso desaparece a comunidade, juntamente com as relações de propriedade sobre as quais estava fundada (Grundrisse, 398).

A produção tem por fim a conservação das formas estabelecidas das relações de propriedade, mas, ao ampliar as bases sobre as quais a comunidade se reproduz (o que inicialmente se resume ao mero aumento populacional), conduz à dissolução dessas relações. Nas sociedades que se baseiam na propriedade individual da terra mediada pela comunidade, a atividade dos indivíduos visa à reprodução de sua condição de proprietários. Mas esta atividade produtiva é necessariamente produção nova. É definitivo desta atividade, embora não igualmente em todos os modos de produção précapitalistas, transformar as condições de produção, conferindo a elas formas objetivas postas pelo trabalho: "Em um primeiro momento, trabalha-se a partir de uma certa base - de início, originado natural e espontaneamente -, em seguida, pressuposto histórico" (Grundrisse, 407, citado acima). Esta nova condição de produção, que representa um pressuposto já histórico, implica que também os sujeitos se transformam e tornam-se indivíduos distintos daqueles que correspondem à atividade sobre pressupostos meramente naturais:

No próprio ato da reprodução não se alteram apenas as condições objetivas, por exemplo, a vila se torna cidade, o agreste, campo desmatado etc., mas os produtores se modificam, extraindo de si mesmos novas qualidades, desenvolvendo a si mesmos por meio da produção, se 
remodelando, formando novas forças e novas concepções, novos meios de comunicação, novas necessidades e nova linguagem (Grundrisse, 405).

Nesta passagem, destacam-se duas determinações fundantes da definição de força produtiva. Primeiro, como já exposto, que o avanço das forças produtivas não se expressa em transformações apenas objetivas, mas também subjetivas. Em segundo lugar, que o desenvolvimento das forças produtivas implica "novas maneiras e combinações do trabalho", ou seja, nova forma de divisão do trabalho: a ampliação das bases objetivas da comunidade impõe o desenvolvimento da divisão do trabalho e, com isso, caracteriza mudanças nas relações de produção. Porque o aprimoramento das forças produtivas é inseparável do desenvolvimento da divisão do trabalho, o aumento das forças produtivas leva à desagregação natural das formas de propriedade nas sociedades anteriores ao capital. Marx explica esta imbricação entre o aprimoramento das forças produtivas e a complexificação da divisão do trabalho:

A que ponto as forças produtivas de uma nação estão desenvolvidas é mostrado de modo mais claro pelo grau de desenvolvimento da divisão do trabalho. Cada nova força produtiva, na medida em que não é mera extensão quantitativa das forças produtivas já conhecidas (por exemplo, o arroteamento de terras), tem como consequência um novo desenvolvimento da divisão do trabalho $(I A, 89)$.

Nas comunidades em que a forma da propriedade é posta pela atividade efetiva de produção, o desenvolvimento da divisão do trabalho que resulta do avanço produtivo não pode senão redundar em nova distribuição das condições de produção e do próprio trabalho. Por conseguinte, em mudança na forma de propriedade:

As diferentes fases de desenvolvimento da divisão do trabalho significam outras tantas formas diferentes da propriedade; quer dizer, cada nova fase da divisão do trabalho determina também as relações dos indivíduos uns com os outros no que diz respeito ao material, ao instrumento e ao produto do trabalho $(I A, 89)$.

Por um lado, a expansão da divisão do trabalho se identifica com o movimento, característico da produção humana, de ampliação das forças produtivas; por outro, mudanças na divisão do trabalho significam um desenvolvimento da propriedade privada, e portanto implicam transformações na relação que os indivíduos estabelecem com a comunidade. Nas sociedades antigas, o caráter imediato da comunidade implica que as relações entre os indivíduos sejam pessoais ou diretas. As relações entre os indivíduos se dão na forma da dependência pessoal de um com relação aos outros, 
inclusive no que diz respeito à dominação e à exploração do trabalho, de sorte que o intercâmbio social da produção se realiza por meio de vínculos pessoais. Por isso, à medida que novas funções do trabalho são desenvolvidas e novas formas de organização da produção se lhe seguem, alteram-se os vínculos diretos entre os indivíduos e, por conseguinte, transformam-se as relações de produção. Marx escreve:

\begin{abstract}
Se o indivíduo singular altera sua relação com a comunidade, então, ele altera a comunidade [já que esta não é nada além do conjunto dos indivíduos em dada relação de produção - VC] e atua destrutivamente sobre ela, bem como sobre seu pressuposto econômico; por outro lado, a mudança desse pressuposto econômico - produzido por sua própria dialética, empobrecimento etc., especialmente a influência da guerra e da conquista, que, em Roma, por exemplo, é parte essencial das próprias condições econômicas da comunidade - abole o vínculo real sobre o qual ele se fundamenta (Grundrisse, 398-9).
\end{abstract}

A manutenção dos vínculos sociais estabelecidos exigem atividades que resultam, apesar desta finalidade, na dissolução dessas relações pressupostas, porque a atividade nova implica nova divisão do trabalho e portanto novo vínculo. O fato de que “(...) a conservação da comunidade antiga implica a destruição das condições sobre as quais ela se baseia, resultando no contrário" (Grundrisse, 405, citado acima), define a dialética característica dos modos de produção pré-capitalistas. Marx especifica:

\footnotetext{
O desenvolvimento da escravidão, a concentração de posse de terra, a troca, o sistema monetário, a conquista etc. atuaram nesse sentido entre os romanos [no sentido de abolir o vínculo real sobre o qual ele [o pressuposto econômico - VC] se fundamenta], não obstante todos esses elementos pareçam, até certo ponto, compatíveis com o fundamento, e pareçam em parte apenas ampliá-lo inofensivamente, em parte brotar dele como simples abusos. (...) esse desenvolvimento está em contradição com a relação original (Grundrisse, 399).
}

A principal transformação que se origina natural e espontaneamente dos modos de vida comunitários originais é o advento da escravidão e da servidão. São estas formas da dominação direta, em que o trabalhador é inserido entre as condições objetivas de produção. Com isso, o produtor deixa de ser proprietário das condições de produção e passa a ter, como seus próprios, apenas os meios de consumo. Marx sustenta que todas as formas de comunidade em que o indivíduo se comporta com a terra como sua propriedade trazem em si mesmas a tendência a desenvolver-se em dominação direta:

As formas primitivas da propriedade se resolvem necessariamente na relação com os diversos momentos objetivos que condicionam a produção como próprios; na mesma medida em que 
formam a base econômica de diversas formas de comunidade, eles têm por pressuposto, por sua vez, formas determinadas de comunidade. Essas formas são fundamentalmente modificadas pelo deslocamento e pela inclusão do próprio trabalho sob as condições objetivas de produção (servidão e escravidão) (...). Todas contêm em si a escravidão como possiblidade e, em consequência, sua própria superação (Grundrisse, 410).

O advento das formas de dominação, presentes como tendência nas formas de sociabilidade que têm por base a propriedade da terra, provém do movimento da reprodução e, portanto, conservação, das formas já estabelecidas de propriedade. Marx fornece vários exemplos:

Eles [os povos nômades - VC] se relacionam à terra como sua propriedade, embora jamais fixem essa propriedade. $\mathrm{O}$ mesmo sucede com os campos de caça entre as tribos de índios selvagens na América; a tribo encara uma certa área de caça região como sua e a defende pela força contra outras tribos ou procura expulsar outras tribos da área por elas defendida. (...) O único obstáculo que a comunidade pode encontrar em seu relacionamento com as condições naturais de produção - com a terra - (se pularmos diretamente para os povos sedentários) como suas condições é uma outra comunidade, que já a recamou como seu corpo inorgânico. Por isso, a guerra é um dos trabalhos mais originais de cada uma dessas comunidades originadas natural e espontaneamente, tanto para defesa como para nova aquisição de propriedade (Grundrisse, 402).

A guerra se deflagra com a finalidade de manutenção das condições de reprodução da comunidade, suas formas produtivas tradicionais, e se faz necessária, centralmente, pela necessidade de aquisição de nova propriedade proveniente do aumento da população este significa e resulta do aumento da força produtiva ou da riqueza da comunidade - e, evidentemente, do ponto de vista da comunidade atacada, a guerra visa à conservação. Por originar-se na necessidade de manutenção das condições de produção da comunidade, a guerra é um trabalho necessário. Mas se, com a aquisição de novo território são apropriados os indivíduos da comunidade vencida como escravos, as relações de produção se transformam:

A condição fundamental da propriedade baseada no sistema tribal (ao qual a comunidade originariamente se reduz) - ser membro da tribo - faz da tribo estranha conquistada, subjugada, tribo privada de propriedade e a joga entra as condições inorgânicas de sua reprodução, às quais a comunidade se comporta como sendo as suas. Escravidão e servidão são, por isso, apenas 
desenvolvimentos posteriores da propriedade baseada no sistema tribal. Elas necessariamente modificam todas as suas formas (Grundrisse, 404$)^{80}$.

Por um lado, este desenvolvimento em escravidão é necessário para manter a condição de propriedade pressuposta, por outro, altera a relação de produção até fazer da escravidão um novo pressuposto necessário.

\title{
3. A desagregação pelo desenvolvimento como dialética própria das sociedades pré-capitalistas
}

Marx analisa a desagregação de Roma, e exponho de modo esquemático o percurso desta dissolução para concretar e com isso explicar o texto de Marx. Este exemplo traz ainda outro aspecto relevante para a compreensão da dialética própria às sociedades pré-capitalistas, e da própria natureza do desenvolvimento histórico, que consiste no fato de que a dissolução de Roma implicou em perda parcial de forças produtivas.

\begin{abstract}
A finalidade de todas essas comunidades é a conservação, i.e., a reprodução dos indivíduos que a constituem como proprietários, i.e., no mesmo modo de existência objetivo que constitui ao mesmo tempo o comportamento dos membros uns em relação aos outros e, por isso, a própria comunidade. Mas essa reprodução é ao mesmo tempo necessariamente produção nova e destruição da forma antiga. Por exemplo, onde cada um dos indivíduos deve possuir tantos acres de terra para cultivo, o crescimento da população já constitui um impedimento. Para controlá-lo, a colonização, e esta torna necessária a guerra de conquista. Com isso, escravos etc. Ampliação também do ager publicus, por exemplo, e em consequência, dos patrícios, que representam a comunidade etc. Desse modo, a conservação da comunidade antiga implica a destruição das condições sobre as quais ela se baseia, resultando no contrário (Grundrisse, 405).
\end{abstract}

Marx afirma que o desenvolvimento que se deu em Roma e ampliou o espectro das relações e das riquezas ao desenvolver a escravidão, o comércio e as guerras de conquista, está em contradição com a relação original em que o cidadão romano livre proprietário de terras é ao mesmo tempo produtor, seu pressuposto econômico. Por outro lado, sem este desenvolvimento, a condição pressuposta dos cidadãos

\footnotetext{
${ }^{80}$ No mesmo sentido, Marx afirma: "Escravidão, servidão etc., onde o próprio trabalhador aparece entre as condições naturais de produção para um terceiro indivíduo ou comunidade (...) - ou seja, propriedade não mais como o comportamento do indivíduo que trabalha autonomamente em relação às condições objetivas de trabalho - são sempre secundárias, nunca originais, não obstante sejam o resultado necessário e consequente da propriedade baseada na comunidade e no trabalho em comunidade" (Grundrisse, 407).
} 
proprietários de terras não se manteria. O desenvolvimento da escravidão coincide com próprio desenvolvimento do modo de produção, e o limite da primeira determina a desagregação do segundo ${ }^{81}$.

A ampliação da escravidão por meio da guerra de conquista visa à manutenção da condição livre do cidadão proprietário de terra e promove a cidadania livre na medida em que assegura a forma de propriedade. Contudo, na oposição entre homem livre e escravo, a relação do indivíduo proprietário com a comunidade se altera: este deixa de ser o proprietário que trabalha e, liberado da produção no campo, se torna cidadão urbano que realiza atividades de outras naturezas e funções, ainda que esta condição nova tenha como necessário pressuposto a propriedade da terra. $\mathrm{O}$ estatuto do escravo, de acordo com Marx, não expressa a separação entre a atividade e os meios de produção que o capital estabelece (e da qual parte) na medida em que, a despeito de não se relacionar com a terra como sua propriedade, mantém-se preso a ela como uma das condições de produção. Como propriedade sua, e oriundo de seu pertencimento ao território, mantém os meios de subsistência:

(...) comportar-se como proprietário só em relação aos meios de subsistência, encontrá-los como condição natural do sujeito trabalhador, sem se relacionar nem com o território nem com o instrumento, e, portanto, tampouco com o próprio trabalho, como seus próprios, é no fundo a fórmula da escravidão e da servidão (...) (Grundrisse, 110).

Escravidão e servidão são formas de dominação $\operatorname{direta}^{82}$ que não rompem abruptamente com a forma de propriedade antiga da terra - proprietários privados como membros do Estado -, mas acrescentam à apropriação das condições naturais de produção o próprio trabalhador, entre estes pressupostos naturais. A relação de dominação “(...) consiste simplesmente no modo de existência do próprio proprietário de terra, que não mais trabalha, mas cuja propriedade inclui nas condições de produção o próprio trabalhador (...)" (Grundrisse, 411), Todavia, a transformação do proprietário-produtor no proprietário de terras que não mais trabalha expressa uma modificação nas relações de

\footnotetext{
${ }^{81}$ Perry Anderson afirma que "O Mundo Antigo nunca foi, contínua ou ubiquamente marcado pela predominância de trabalho escravo. Mas suas grandes épocas clássicas, quando floresceu a civilização da Antiguidade - a Grécia dos séculos V e IV a.C., e Roma, do século II a.C. ao século II d.C. - foram aquelas em que a escravidão era maciça e generalizada, entre outros sistemas de trabalho. O solstício da cultura urbana clássica também sempre testemunhou o zênite da escravidão; e o declínio de uma, na Grécia helenênica ou na Roma cristã, era da mesma forma invariavelmente marcado pelo apagar-se da outra (ANDERSON, Perry, Passagens da Antiguidade ao Feudalismo, Tradução de Beatriz Sidou. São Paulo: Brasiliense, 2000, p. 22). Doravante Passagens, seguido do número da página.

82 “A apropriação da vontade alheia é pressuposto da relação de dominação" (Grundrisse, 411).
} 
produção e por conseguinte na forma da comunidade. Estas alterações se consolidam e fazem da escravidão uma base necessária do modo de existência dos proprietários: uma vez liberados da atividade produtiva material, e dedicando-se a outras atividades no âmbito político, na cidade, passam a ter a escravidão em escala crescente como pressuposto do seu modo de existência transformado. Esta necessidade implica a ampliação da colonização, e portanto do exército, que deve ser mantido pela produção agrícola, ou seja, uma expansão crescente das bases da comunidade para que se mantenha a forma de propriedade ${ }^{83}$. De sorte que as relações de dominação presentes como tendência no conjunto das comunidades primitivas em que o produtor é proprietário "logo adulteram e modificam as formas originais de qualquer comunidade, e até mesmo se convertem em seu fundamento" (Grundrisse, 403). Em termos esquemáticos, a propriedade livre passa a ter por fundamento a escravidão, mas a manutenção deste novo pressuposto requer seu próprio desenvolvimento. O processo de ampliação da escravidão é o que, em última instância, colocará em xeque a propriedade livre. Ainda que a natureza do modo de produção antigo não tendesse à colonização, qualquer forma de responder ao aumento natural das bases da comunidade - expresso em primeiro lugar no aumento populacional - no intuito de preservar a forma de propriedade conduz necessariamente à dissolução dessa forma. Marx levanta a seguinte hipótese:

Caso se pense, por exemplo, que a produtividade na mesma área possa ser incrementada pelo desenvolvimento das forças produtivas etc. (desenvolvimento que, na agricultura tradicional, é justamente o mais lento de todos), isso implicaria novas maneiras e combinações do trabalho, grande parte do dia empregado na agricultura etc., e com isso seriam superadas, outra vez, as antigas condições econômicas da comunidade (Grundrisse, 405).

A transformação das formas de propriedade pré-burguesas oriunda da ampliação das forças produtivas é necessária sobretudo porque a relação de propriedade se estabelece diretamente pela atividade produtiva que se apropria das condições de produção e por conseguinte por vínculos diretos, pessoais. O caráter natural da comunidade dado na

\footnotetext{
83 "A civilização clássica foi, por conseguinte, de caráter intrinsecamente colonial: a cidade-Estado celular invariavelmente se reproduzia, nas fases de ascensão, pelo povoamento e pela guerra. $\mathrm{O}$ saque, o tributo e os escravos eram os objetos centrais de engrandecimento, tanto meios como finalidades da expansão colonial. O poder militar estava mais intimamente ligado ao crescimento econômico do que talvez em qualquer outro modo de produção, antes ou depois, porque a principal fonte do trabalho escravo eram normalmente prisioneiros de guerra, enquanto o aumento de tropas urbanas livres para a guerra dependia da manutenção da produção doméstica por meio de escravos; os campos de batalha forneciam mão de obra para os campos de cereais, e vice-versa - os trabalhadores capturados permitiam a criação de exércitos de cidadãos" (Anderson, Passagens, 28).
} 
fixação dos produtores à terra, sua dependência das condições de trabalho imediatamente naturais ou pressupostas e do vínculo comunitário pessoal traz a tendência à dissolução aos modos de produção pré-capitalistas.

O advento da escravidão é expressão desse caráter natural do desenvolvimento, dado pela atividade de manutenção das relações de produção anteriores e mediada apenas pela comunidade, isto é, pela mediação imediata em que o pertencimento à comunidade antecede a existência individual e é a própria definição do indivíduo (“indivíduo como grego, romano etc.”). A escravidão significa em si mesma um aumento muito significativo das forças produtivas, ao passo que estabelece, por sua própria natureza, um limite ao desenvolvimento da produtividade do trabalho material. O aumento da força produtiva pela escravidão se dá na medida da expansão da massa de trabalho reunida. Essa ampliação se manifesta no aumento do produto excedente que, como já mencionado, libera o proprietário de terras das atividades produtivas e o capacita a se tornar um habitante da cidade enquanto proprietário de terras. Opera-se em Roma aquilo que Marx considera a primeira divisão importante entre trabalho material e trabalho intelectual, que é a divisão entre cidade e campo:

Com a cidade surge, ao mesmo tempo, a necessidade da administração, da polícia, dos impostos etc., em uma palavra, a necessidade da organização comunitária e, desse modo, da política em geral. Aqui se mostra, pela primeira vez, a divisão da população em duas grandes classes, que se baseiam diretamente na divisão do trabalho e nos instrumentos de produção. A cidade é, de pronto, o fato da concentração da população, dos instrumentos de produção, do capital, das fruições, das necessidades, enquanto o campo evidencia exatamente o fato contrário, a saber, o isolamento e a solidão $(I A, 52)$.

A cidade concentra a riqueza, o conjunto do intercâmbio e do dinamismo social e a atividade livre. Esta separação que concentra os resultados sociais e o advento de uma classe livre do trabalho possibilitou o desenvolvimento de atividades intelectuais em geral, da expansão geográfica do intercâmbio e também o desenvolvimento das trocas e do dinheiro. Esta separação entre trabalho material e espiritual não significa, todavia, uma divisão entre os momentos intelectual e material da atividade produtiva. A produção intelectual não teve por objeto a produção material, nem mesmo as atividades manufatureiras e qualificadas. Não significa pois uma cisão na atividade do trabalho entre os momentos de ideação e realização, isto é, uma divisão técnica do trabalho, como a que existe entre o operário e o engenheiro na grande indústria. Significa uma 
separação entre a função de dirigir e administrar a comunidade e a função de criar as condições materiais de vida. No interior da classe livre, existe também uma divisão do trabalho, de modo que parte desses indivíduos dedica-se ao conhecimento teórico:

A divisão do trabalho só se torna realmente divisão a partir do momento em que surge uma divisão entre trabalho material e espiritual. A partir desse momento, (...) a consciência está em condição de emancipar-se do mundo e lançar-se à construção da teoria, da teologia, da filosofia, da moral etc. "puras" (IA, 35-6).

Em Roma, o amplo desenvolvimento do conhecimento esteve desligado da técnica produtiva devido em especial à escravidão e à manutenção do fundamento agrícola no domínio da cidade sobre o campo e foi, em geral, expansão da teoria "pura". O crescimento das cidades teve por fundamento, não a economia urbana desenvolvida, mas ainda a produção agrícola escravista. Perry Anderson escreve que

\begin{abstract}
As cidades greco-romanas nunca foram predominantemente comunidades de artífices, mercadores ou negociantes: elas eram, em sua origem e princípio, conglomerados urbanos de proprietários de terras. Cada agrupamento municipal, fosse da democrática Atenas, da Esparta oligárquica ou da Roma senatorial, era essencialmente dominado por proprietários agrários. Sua renda provinha do trigo, do azeite e do vinho - os três grandes produtos básicos do Mundo Antigo, vindos de terras e fazendas fora do perímetro físico da própria cidade (Anderson,
\end{abstract} Passagens, 100).

De modo que este domínio anômalo da cidade sobre o campo não significou, no mundo antigo, a superação das condições do trabalho como pressupostos naturais ${ }^{84}$, embora tenha possibilitado a existência de proprietário de terras moradores da cidade e o amplo desenvolvimento do intercâmbio e da produção intelectual. A expansão da escravidão, se de um lado significa uma ampliação da força produtiva no campo pelo aumento no número de trabalhadores e a liberação da classe proprietária para atividades distintas do trabalho, de outro implicou uma restrição ao desenvolvimento técnico:

A técnica, como uma instrumentalização progressiva e premeditada do mundo natural pelo
homem, era incompatível com a assimilação em grande escala do homem ao mundo natural
como seus 'instrumentos falantes'. A produtividade era fixada pela rotina permanente do

\footnotetext{
84 “A civilização da Antiguidade clássica representou (...) a supremacia anômala da cidade sobre o campo numa economia esmagadoramente rural: uma antítese do mundo feudal primitivo que lhe sucedeu. A condição de possibilidade desta grandeza metropolitana na ausência de uma indústria municipal era a existência de trabalho escravo no campo: só ele poderia liberar uma classe de proprietários de terra tão radicalmente de suas raízes rurais de maneira a poder ser transmutada em uma cidadania essencialmente urbana que ainda assim continuava tirando suas riquezas do solo". (Anderson, Passagens, 23-4).
} 
instrumentum vocalis, que desvalorizava todo trabalho pela exclusão de qualquer preocupação com estratagemas para poupá-lo (Anderson, Passagens, 27-8).

Quando o produtor não é proprietário das condições de produção, e portanto deixa de ser usuário de seu próprio trabalho, este perde o impulso ao aprimoramento técnico e às invenções, do mesmo modo que a atividade indigna do humano, porque não é livre, não pode ser objeto de indivíduos livres: "Uma vez tornando-se o trabalho manual profundamente associado à perda da liberdade, não havia uma lógica social livre para a invenção" (Anderson, Passagens, 26). A escravidão representa uma degradação do trabalho agrícola e material em geral que se estende ao conjunto dos trabalhos:

O retraimento estrutural da tecnologia pela escravidão não assentava tanto, assim, numa causalidade intra-econômica direta, embora isto fosse importante em si, quanto na ideologia social imediata que envolvia a totalidade do trabalho manual no mundo clássico, contaminando o trabalho contratado e mesmo o independente com o estigma do aviltamento (Anderson, Passagens, 27).

Este aviltamento do trabalho se estende também às funções qualificadas, inclusive a realizada por assalariados. Havia, na cidade, escravos qualificados em vários ofícios. De acordo com Anibal Ponce ${ }^{85}$, Plutarco afirma que Catão chegava a fazer com que seus escravos fossem instruídos em várias artes para vendê-los a melhor preço. A atividade dos artesãos, mesmo sendo realizada por homens livres, não estava imbuída de dignidade, precisamente porque podia ser igualmente realizada por escravos. Do mesmo modo, as artes plásticas não eram consideradas funções superiores:

Os escultores e pintores ocupavam um nível tão inferior como qualquer outro artesão. Só se conhece em Roma um jovem nobre que se dedicara a esses ofícios. Refiro-me ao neto de Mesala. Mesala permitiu que lhe ensinassem a pintura porque se tratava de um menino surdo-mudo (Ponce, Educacion, 64).

O comércio e os negócios financeiros, como ramos de atividades práticas que visam o enriquecimento privado, eram do mesmo modo tomados por atividades desprovidas de dignidade humana. Com seu desenvolvimento, os patrícios donos de terra que passaram a tomar parte em tais negócios "não tinham o mínimo escrúpulo em equipar em nome de seus escravos ou libertos os mesmos navios que não podiam fretar sob seu próprio nome" (Ponce, Educacion, 64).

\footnotetext{
${ }^{85}$ PONCE, Anibal, Educacion e lucha de classes, La Paz: America Editorial, 1999, p. 62. Doravante, Ponce, Educacion, seguido do número da página.
} 
A função de professor primário, que em geral era "um antigo escravo, um velho soldado ou um proprietário arruinado" (Ponce, Educacion, 64) (a concentração da propriedade da terra é um processo que acompanhou o desenvolvimento do Império Romano), era uma atividade ainda menos digna:

Todo salário, aos olhos dos romanos como aos olhos dos gregos, era uma prova de servidão, e é conhecido que Sêneca, depois de Cícero, recusou-se a incluir a profissão de ensinar no grupo de profissões liberais, ou seja, das profissões dos "homens livres". Homens livres eram, sem dúvida, os ludimagister [mestres de crianças - VC]; mas o fato de terem de trabalhar para viver os situava em um plano de depreciável inferioridade (Ponce, Educacion, 65).

De sorte que o conhecimento não era suficiente para elevar as atividades a funções dignas do humano. A qualificação aprendida mediante largo tempo de dedicação ou o caráter intelectual da atividade não conferiam qualquer superioridade a seus agentes. Ao criticar os economistas burgueses que investem contra a distinção que Smith faz entre trabalho produtivo e improdutivo, Marx escreve: "Essa gente está tão submetida a suas ideias fixas burguesas, que acreditaria ofender Aristóteles ou Júlio César se os chamasse de 'trabalhadores improdutivos'. Estes já considerariam uma ofensa o título de 'trabalhadores"” (TMV I, 270)! O conhecimento que se desenvolveu nas classes dominantes foi por isso a teoria pura, desligada do conjunto das práticas produtivas. A divisão entre trabalho material e espiritual é nas sociedades antigas a separação entre o trabalho e o não-trabalho; a propriedade, a liberdade e a nobreza, por um lado, e a nãopropriedade, por outro. É pois o estabelecimento da propriedade privada. Não à toa a educação dos nobres é voltada para o aprendizado da oratória, conhecimento indispensável ao governante: "Dentro do conceito que tinham os romanos, o 'orador' era o homem por excelência" (Ponce, Educacion, 59). Demonstra que a função do trabalho intelectual é centralmente a função política, de direção e dominação social. Ainda assim, a cidade proporciona um desenvolvimento cultural sem precedentes ${ }^{86}$.

Isso não significa, contudo, que não tenha havido produção de ciência aplicada na Antiguidade clássica. Esta existiu especialmente ligada às funções de poder - a guerra - e às funções do comércio. Ao abordar a Grécia pré-helenística, em especial a

\footnotetext{
${ }^{86}$ Perry Anderson destaca o “(...) contraste dentro do próprio mundo clássico entre sua vitalidade cultural e superestrutural e seu embrutecimento infra-estrutural: a tecnologia manual da Antiguidade era exígua e primitiva não apenas pelos padrões externos de uma História posterior, mas sobretudo pela medida de seu próprio firmamento intelectual - o qual, em muitos aspectos críticos, sempre permaneceu bem mais alto que o da Idade Média ainda por chegar. Há pouca dúvida de que a estrutura da economia escrava é que foi fundamentalmente responsável por essa extraordinária desproporção" (Anderson, Passagens, 26).
} 
região da Jônia em que primeiro se desenvolveu a filosofia como investigação da natureza, Agnes Heller aponta a prioridade da ciência contemplativa em relação à ciência ligada à techné. Mas destaca também o espaço aberto pelas ciências aplicadas:

\begin{abstract}
Há, no entanto, três zonas distintas nas quais, por razões particulares, começa a experimentar-se a necessidade científica: as matemáticas, indispensáveis para a navegação comercial; a engenharia militar, necessária para a guerra; e a medicina, útil, logicamente, para o tratamento dos doentes. Os que se dedicam à ciência têm de lutar, como é óbvio, contra muitos preconceitos sociais. O ideal do gentleman antigo, a kalokagathia, não permite nenhuma especialização das faculdades humanas. (...) No pensamento jônico, a reflexão especulativa se considera, pois, por definição, superior ao empírico. Quando se começa a fazer notar a necessidade efetiva das ciências, estas últimas declaram guerra às rígidas exigências da kalokagathia. As três ciências acima mencionadas não só experimentam um rápido auge, como ademais, ganham a estima da sociedade. Trata-se, verdade seja dita, mais da estima dos governantes do que da do demos. Os governantes descobrem logo nelas um aliado capaz de temperar as armas do poder. Filipe II, da Macedônia, por exemplo, faz com que técnicos da Jônia construam suas célebres máquinas de guerra, que superam em muito a técnica geral da época e que logo desempenharão um papel básico em suas vitórias. As conquistas da medicina se difundem com rapidez nas cidades gregas. E enquanto as matemáticas, a geometria e a mecânica só alcançarão seu apogeu na época do helenismo, a medicina chega ao ponto culminante de seu desenvolvimento com Hipócrates, no momento de transição para essa época ${ }^{87}$.
\end{abstract}

Já na Grécia, a oposição entre trabalho e liberdade obstaculizava o desenvolvimento das ciências voltadas à técnica. A generalização da escravidão permitiu a separação entre o trabalho material e o intelectual, delimitando a atividade da classe proprietária tanto quanto a dos escravos. Definiu a ausência de dignidade de qualquer forma do trabalho, que se torna então diametralmente oposto à liberdade: "Pois foi exatamente a formação de uma subpopulação escrava nitidamente delimitada o que, inversamente, elevou a cidadania grega [o que se repete posteriormente em Roma - VC] a alturas até então desconhecidas de liberdade jurídica consciente. A liberdade e a escravatura helênicas eram indivisíveis (...)" (Anderson, Passagens, 23). Por outro lado, contribui para o desenvolvimento urbano e do dinheiro ao ampliar o comércio de escravos e o intercâmbio entre as cidades. O desenvolvimento da escravidão significa, portanto, em sua natureza própria, tanto o desenvolvimento produtivo característico do mundo antigo, representado na expansão geográfica, no aumento da população trabalhadora, na produção cultural e intelectual e, especialmente, o desenvolvimento do

\footnotetext{
${ }^{87}$ HELLER, Agnes. Aristoteles y el mundo antiguo. Barcelona: Península, 1983, pp. 151-2.
} 
comércio com outras cidades, que dinamiza o conjunto da economia, quanto o limite a esse desenvolvimento, representado na limitação tanto ao aprimoramento técnico da manufatura urbana, como à produtividade do trabalho no campo. Anderson resume:

\begin{abstract}
O trabalho escravo da Antiguidade clássica, portanto, incorporava dois atributos contraditórios em cuja unidade está o segredo da paradoxal precocidade urbana do mundo greco-romano. Por um lado, a escravidão representava a mais radical degradação do trabalho rural imaginável - a conversão de seres humanos em meios inertes de produção (...). Por outro lado, a escravidão era simultaneamente a mais drástica comercialização urbana concebível do trabalho (Anderson, Passagens, 24) ${ }^{88}$.
\end{abstract}

A necessidade do desenvolvimento de formas de dominação a partir da comunidade primitiva está dada na própria organização da produção e seu intercâmbio externo. Por isso, difere de acordo com a forma da propriedade que caracteriza cada modo de produção. O que Marx denomina asiático ou oriental não apresenta, por sua forma específica de propriedade, a mesma tendência ao desenvolvimento da escravidão que o mundo antigo clássico. Neste, a propriedade mediada pela existência na comunidade se apresenta como propriedade da unidade comunitária, em que o indivíduo é apenas possuidor. Não há propriedade privada da terra propriamente dita, como na forma dupla em que existe no modo de produção antigo, ou como nas unidades familiares independentes do modo de produção germânico. A terra pertence à unidade, na pessoa do príncipe, e os indivíduos que possuem terra como membros da comunidade são subsumidos à unidade. Caracteriza este modo de produção o fato de que

a unidade coletiva que se situa acima de todas essas pequenas comunidades apareça como o proprietário supremo ou o único proprietário, ao passo que as comunidades reais apareçam apenas como possuidoras hereditárias. Sendo a unidade o proprietário real e o pressuposto real da propriedade comunitária, essa própria unidade pode aparecer como um particular acima das numerosas comunidades particulares reais, em que o indivíduo singular é então de fato privado de propriedade (...) (Grundrisse, 389).

A divisão incipiente de classe se mostra nesta personificação da unidade à qual pertence o trabalho excedente das diversas comunidades efetivas menores que compõem a

\footnotetext{
${ }^{88}$ O historiador explica ainda: “(...) sua reunião, alocação e despacho eram normalmente efetuados a partir dos mercados das cidades, onde muitos deles, claro, eram empregados também. Assim, a escravidão era o vínculo que unia cidade e campo, para o desmedido benefício da polis. Ela tanto mantinha a agricultura cativa que permitia o dramático distanciamento de uma classe dominante urbana de suas origens rurais, quanto promovia o comércio interurbano que era o complemento desta agricultura no Mediterrâneo" (Anderson, Passagens, 25).
} 
unidade mais ampla, seja na forma de tributo, seja na forma do trabalho diretamente coletivo "para a glorificação da unidade, em parte do déspota real, em parte do ente imaginário do clã, do deus" (Grundrisse, 389-90). Sua forma autossuficiente de produção, que integra em unidades familiares os trabalhos da agricultura e da manufatura, desestimulam o intercâmbio externo e a formação de cidades, tendendo, ao contrário, para a estagnação, de modo que apenas lentamente se transformam. Marx compara o modo de produção antigo com o asiático:

\footnotetext{
Quanto mais tradicional o modo de produção - e este dura muito na agricultura; dura mais ainda na complementação oriental de agricultura e manufatura -, ou seja, quanto mais invariável for o processo efetivo da apropriação, tanto mais constantes serão as antigas formas de propriedade e, em decorrência, a comunidade de modo geral. Ali onde já existe a separação entre os membros da comunidade como proprietários privados de si mesmos como comunidade urbana e proprietários de território urbano, também já estão dadas as condições pelas quais o indivíduo singular pode perder sua propriedade, i.e., a relação dupla que o torna cidadão igual aos demais, membro da comunidade, e que o torna proprietário. Na forma oriental, essa perda dificilmente é possível, exceto por influências completamente externas, uma vez que o membro singular da comunidade jamais entra em uma relação livre com ela, e pela qual ele possa perder seu vínculo (objetivo, econômico com a comunidade). Ele é enraizado. Isso depende também da associação entre manufatura e agricultura, entre cidade (o povoado) e campo (Grundrisse, 405-6).
}

A autossuficiência familiar baseada na associação entre manufatura e agricultura desestimula o intercâmbio, tornando a atividade efetiva de produção invariável. A produção familiar é patriarcal, de modo que há "a escravidão latente na família”, ou seja, uma forma de divisão sexual do trabalho. Há já também uma separação entre a condição de nobreza e a condição de produtor comum, que autoriza a posse da terra, mas não o título de propriedade. Restringe-se com isso ao mesmo tempo a liberdade característica da propriedade privada e a possibilidade de perda do acesso à terra. A quase ausência do comércio e do desenvolvimento do dinheiro implica um mais profundo enraizamento do indivíduo na unidade comunitária, que se distingue da propriedade privada - ainda que com fundamento comunitário oculto - característica do modo de produção antigo. Referindo-se à servidão e à escravidão, Marx afirma:

É na forma asiática onde elas menos podem se realizar. Na unidade autossuficiente de manufatura e agricultura, sobre a qual se baseia esta forma, a conquista não é uma condição tão necessária quanto ali onde a propriedade da terra, a agricultura, predomina exclusivamente. Por outro lado, como nessa forma o indivíduo singular jamais se torna proprietário, mas só possuidor, no fundo ele próprio é a propriedade, o escravo daquilo [em] que existe a unidade da 
comunidade, e, nesse caso, a escravidão não abole as condições de trabalho nem modifica a relação essencial (Grundrisse, 404).

A necessidade que os modos de produção primitivos apresentam de desenvolverem-se em formas de dominação direta, ou ainda, a necessidade do conjunto do desenvolvimento que dissolve as relações de produção em que o indivíduo é proprietário e trabalha, está fundada exclusivamente nas condições e relações de produção postas, efetivas. Se a forma social do trabalho não impulsiona a divisão do trabalho, ou a expansão geográfica, ou o intercâmbio externo sob qualquer forma, não há uma tendência de dissolução dos vínculos. Contudo, a sociedade não é estática, uma vez que o próprio aumento da população ou qualquer necessidade pontual vinda de fora pelo comércio pode incitar transformações.

No modo de produção asiático, ainda que as sociedades sejam fechadas, não deixam de possibilitar o desenvolvimento de forças produtivas. Esta "forma rudimentar em que a divisão do trabalho se apresenta entre os hindus e entre os egípcios provoca nesses povos o surgimento de um sistema de castas próprio de seu Estado" $(I A, 44)$ e consequentemente uma divisão entre trabalho manual e trabalho espiritual que caracteriza a transição para a divisão de classe propriamente dita, realizada na divisão entre cidade e campo. No caso do Egito, temos um exemplo de uma forma de produção agrícola que demanda a ciência. Diferentemente da produção agrícola escravista, cuja força produtiva se resume à quantidade de braços, a agricultura no Egito assume a forma de um mecanismo orientado pelo conhecimento científico, separado da atividade de produção. No interior da classe dirigente, houve desenvolvimento das ciências da natureza que permitia, por exemplo, a previsão das enchentes do Nilo e capacitava o planejamento científico da irrigação na agricultura. Ponce afirma:

Vocês sabem que, no Egito, um dispositivo, admirável para a época, chamado nilômetro, permitia conhecer com bastante exatidão o crescimento das águas do rio e prognosticar o volume da futura colheita. De acordo com estas informações, mantidas em segredo, os sacerdotes aconselhavam os lavradores. As classes inferiores recebiam assim um serviço extraordinário que a própria ignorância em que viviam, determinada por um trabalho sem descanso, tornava-os incapazes de realizar. Mas aquele nilômetro servia também às classes dirigentes, de duas maneiras que convergiam ao mesmo ponto. Por um lado, quanto mais abundante se anunciava a colheita, tanto mais a autoridade redobrava os impostos. Por outro lado, aquelas indicações precisas sobre a iminência do crescimento das águas - que só a autoridade estava em condições de possuir - emprestavam ao soberano a ascendência das divindades: no momento oportuno o 
faraó enviava ao Nilo suas ordens escritas e então - oh!, então - as águas obedientes começavam a subir... (Ponce, Educacion, 23).

Não apenas o conhecimento pertence à classe dominante e tem caráter divino, como significa um controle da produção e da natureza, um meio de guiar o curso natural para fins humanos, que não pertence aos produtores e domina sua atividade. A separação entre trabalho material e espiritual significa aqui, ainda que a propriedade privada seja apenas incipiente, uma separação entre os momentos intelectual, de pré-ideação, por um lado, e prático ou material, por outro, do trabalho. Primeiro, a ciência é necessária ao trabalho produtivo imediato; segundo, este conhecimento requerido diretamente para a prática é separado dos produtores imediatos. Na Grécia e em Roma, o conhecimento necessário tanto ao trabalho agrícola como aos ofícios urbanos artesanais eram apenas empíricos e pertenciam, portanto, aos produtores imediatos. Não havia esta separação presente no Egito faraônico entre os momentos intelectual e prático da produção, porque a necessidade de expansão da produtividade impulsionou as guerras de conquista e o aumento das terras e dos escravos, e não a divisão do trabalho no interior do território e da comunidade dados ${ }^{89}$. Também no Egito havia a distinção de dignidade das atividades da classe dominante em oposição às tarefas baixas de produção material: nem toda a técnica era objeto da ciência, nem todas as áreas do conhecimento eram dignas da escrita. Gordon Childe escreve:

(...) a atitude geral para com os empregos burocráticos e a ciência teórica, em contraste com o trabalho manual e as ciências aplicadas, provavelmente remonta às fases mais antigas da vida urbana e foi a mesma na Suméria e no Egito. (...) na divisão de classes da sociedade urbana, os escribas pertencem às "classes superiores", em contraste com os artesãos e os agricultores; a escrita é uma profissão respeitável, enquanto a agricultura, a metalurgia, a carpintaria, não o são. As ciências aplicadas e práticas da Botânica, Química e Geologia não estavam, dessa forma, compreendidas na tradição literária, cujos expoentes viam com desprezo o trabalho manual; a tradição artesanal não era reduzida à escrita nem transmitida em forma de livro. Por outro lado, certas ciências ou pseudociências - matemática, cirurgia, medicina, astrologia, alquimia, aruspício - tornaram-se assuntos de tratados escritos. Formaram, assim, um corpo de ciências cultas, só acessível aos que se haviam iniciado nos mistérios da leitura e da escrita. Mas por esse fato mesmo, as disciplinas em questão eram passíveis de se divorciarem da vida prática. Ao

\footnotetext{
${ }^{89}$ É importante ressaltar que em todos os modos de produção, diversas relações de produção coexistem: no Egito, as obras arquitetônicas diretamente comunitárias, para a "glorificação da unidade", foram realizadas por meio de trabalho escravo massivo, e coordenadas cientificamente pela classe dominante. Mas na produção dos meios de vida - a agricultura e a manufatura doméstica e o artesanato (metalurgia, carpintaria) - não era esta a forma predominante.
} 
ingressar na escola, o aluno voltava as costas ao arado e à oficina; não tinha desejo de voltar a eles $(\ldots)^{90}$.

Se a agricultura é coletivizada e ganha a forma de sistema, a manufatura se realiza como trabalho artesanal. O conhecimento que envolve tais funções pertence portanto ao produtor. Childe destaca que o conhecimento desenvolvido pelos próprios produtores não era registrado precisamente por ligar-se às atividades que não cabiam à classe dominante. O conhecimento criado na própria atividade de trabalho não se eleva a objeto de conhecimento geral, isto é, resultado universal da história de um povo. A própria escrita é em todos os modos de produção pré-capitalistas um fator determinante da divisão de classe, e distingue o trabalho das atividades cultas. O domínio deste código constitui o acesso exclusivo à natureza (para essas sociedades, ao divino), e caracteriza o genuinamente humano. Childe confere aos inícios da escrita o mesmo caráter divino com que Ponce caracteriza as ciências que dominavam o comportamento do Nilo: “A imortalização de uma palavra na escrita deve ter parecido um processo sobrenatural" (Childe, A Evolução, 184).

Nesta breve comparação, fica claro que dinâmica do comércio e do intercâmbio, isto é, o maior desenvolvimento da propriedade privada nas sociedades pré-capitalistas, não é elemento suficiente ou necessário para determinar o desenvolvimento científico da técnica. O que há de particular na produção agrária egípcia é seu caráter coletivo, que permite a observação da produção coletiva como uma espécie de mecanismo e oferece na prática uma análise do processo produtivo. Marx escreve que a unidade da comunidade no modo de produção asiático
pode estender-se ao caráter coletivo no próprio trabalho, que pode constituir um sistema formal, como no México, em especial no Peru, entre os antigos celtas, em algumas tribos hindus. (...) As condições coletivas da apropriação efetiva por meio do trabalho, os aquedutos, muito importantes entre os povos asiáticos, os meios de comunicação etc., aparecem então como obra da unidade superior - do governo despótico pairando acima das pequenas comunidades (Grundrisse, 390).

A condição do desenvolvimento da ciência é a separação entre trabalho material, cujos agentes estão envolvidos com funções parciais e imediatas, e uma classe de indivíduos liberados do trabalho material. Mas esta não é condição suficiente. O caráter de sistema

\footnotetext{
${ }^{90}$ CHILDE, Gordon, A evolução cultural do homem. Rio de Janeiro: Zahar, 1981, p. 184. Doravante $A$ evolução, seguido do número da página.
} 
da produção parece favorecer o desenvolvimento de uma ciência aplicada na medida em que a produção coletiva demanda uma organização que não coincide com a atividade imediata. Em Roma, apesar da crescente massa de trabalho no campo, este continuou a ser realizado do mesmo modo técnico do trabalho familiar tradicional, não se configurando em um sistema. Isso significa que há também na agricultura egípcia uma divisão do trabalho desenvolvida. Apenas a divisão do trabalho configura a produção em sistema e pode separar da atividade imediata a organização do trabalho. A respeito de outro povo sob o mesmo modo de produção, Marx afirma: "Entre os peruanos, por exemplo, o trabalho encontrava-se extraordinariamente dividido, apesar de que não se efetuava troca privada, troca de produtos em forma de mercadorias" (Contribuição, 8990). Assim, se necessariamente a divisão do trabalho é expressão da força produtiva de uma sociedade, a relação do desenvolvimento da divisão do trabalho com o desenvolvimento da propriedade privada é relativizada por Marx: "Todavia, se é certo que a troca privada supõe a divisão do trabalho, parece falso dizer que a divisão do trabalho supõe a troca privada" (Contribuição, 89). Assim, sociedades fechadas, ou seja, com pouco intercâmbio externo, podem desenvolver a divisão do trabalho e por conseguinte a força produtiva, transformando o trabalho em um sistema de aplicação da ciência, sem por isso desenvolverem a propriedade privada.

Houve maior desenvolvimento científico em um modo de produção menos dinâmico, enquanto que o desenvolvimento da propriedade privada em Roma não foi condição deste desenvolvimento específico. Visto de outro ângulo, o desenvolvimento da divisão do trabalho e da ciência não são fatores que determinem de modo absoluto: o modo de produção oriental não se abre para a história como o antigo clássico. Isto não significa, vale repetir, que as sociedades de tipo asiático são estáticas, e seu próprio processo histórico de constituição o demonstra. Mas o intercâmbio externo parece ser o impulso central à expansão da propriedade privada, à criação de novas necessidades e a consequente divisão do trabalho. A tendência a este desenvolvimento é a verdadeira tendência à desagregação dos vínculos comunitários e à consequente expansão das forças produtivas. De sorte que a tendência à dissolução não é igual em todos os modos de produção, e não é possível saber que destino teriam as sociedades sob o modo de produção asiático se não fossem desagregadas pelo comércio mundial. É notável o ponto comum entre as sociedades fechadas que tiveram processos produtivos como aplicação consciente da ciência e a indústria capitalista: em ambos a divisão do trabalho 
proporciona uma análise empírica do processo de produção, o que, de um lado, exige a organização como âmbito separado da atividade prática e, de outro, torna possível a representação do processo de produção como um mecanismo, passível de ser teorizado. Estabelece o material empírico da análise teórica. A divisão do trabalho e a especificação das ferramentas que caracterizam a manufatura realizarão uma análise do processo produtivo na realidade, o que possibilitará a elaboração da máquinaferramenta, cujo ponto de partida é o mecanismo da atividade do trabalho dividida. A ciência se desenvolverá então também como ciência deste mecanismo, e o processo produtivo se definirá como "aplicação consciente da ciência".

O domínio do conhecimento - que sintetiza os resultados mais universais do domínio sobre a natureza que a comunidade alcançou - pela classe dominante significa já uma separação entre o trabalho e suas próprias capacidades produtivas. A divisão do trabalho se define por esta separação entre o comando e prática da atividade que é ao mesmo tempo a separação entre os produtores e suas capacidades produtivas: se o produtor não tem autonomia em sua atividade, se não a controla, isto significa que sua potência produtiva em parte não pertence mais a ele, autonomizou-se dele concentrando-se na classe dominante. Por conseguinte, o próprio domínio da atividade pela propriedade do trabalho excedente é já para os produtores perda de sua força produtiva. O domínio da classe dominante se coloca como controle das forças produtivas sociais ainda quando a técnica e o saber da atividade pertencem ao produtor. No desenvolvimento da teoria "pura", não aplicada, pelos proprietários gregos e romanos, por exemplo, há também um domínio, na medida em que o trabalho escrito, que sintetiza a produção intelectual da comunidade, pertence exclusivamente à classe dominante. Assim, não é necessária a ciência aplicada à produção coletivizada e sistemática, pertencente à classe dominante, para controlar a atividade individual e fazêla perder parte de suas forças produtivas, embora apenas aquele sistema de trabalho faça do produtor uma peça de um mecanismo.

Outro aspecto importante relativo à natureza do desenvolvimento histórico nas sociedades pré-capitalistas é que a dissolução pelo desenvolvimento não resulta necessariamente em uma organização social com forças produtivas mais elevadas. No caso de Roma, emblemático porque sua dissolução é ao mesmo tempo o epílogo do mundo antigo na Europa, sua desagregação não foi capaz de conduzir a um modo de produção baseado na economia urbana (manufatureira). Em outros termos, não originou 
um modo de produção fundado em condições de produção não mais pressupostas, mas postas pelo trabalho. Este salto das forças produtivas é necessário para o rompimento do vínculo natural com a terra e para a posição de uma comunidade que é também produto do trabalho; que é, portanto, urbana. O caráter restrito da economia urbana e a conservação da agricultura como forma central da produção material determinaram a impossibilidade de consolidar o domínio da cidade sobre o campo a partir da dissolução do mundo antigo escravista. Marx escreve: "Também ali [na Roma antiga - VC] a dissolução das antigas relações de propriedade estava associada ao desenvolvimento da fortuna em dinheiro - do comércio etc. Entretanto, em lugar de levar à indústria, essa dissolução levou de fato ao domínio do campo sobre a cidade" (Grundrisse, 416). Da supremacia anômala da cidade sobre o campo, a dissolução de Roma implicou o domínio do campo sobre a cidade a partir da retração da escravidão, que constituía a condição daquela supremacia. A desagregação da forma antiga de propriedade implicou perda de força de produtiva social já alcançada:

Os últimos séculos do Império Romano em declínio e sua conquista pelos bárbaros destruíram uma enorme quantidade de forças produtivas; a agricultura havia diminuído, a indústria decaíra por falta de mercados, o comércio adormecera ou fora violentamente interrompido, as populações da cidade e do campo haviam diminuído (IA, 90-1).

Duas questões se destacam aqui. Primeiro, o fato de que o desenvolvimento histórico não é caracterizado por Marx como uma sequência necessariamente crescente de desenvolvimento produtivo: a transformação das relações de produção baseia-se tão somente nas relações efetivas anteriormente postas, de modo que não há qualquer determinação de outra natureza que imponha um caráter absolutamente necessário ao desenvolvimento produtivo. Por outro lado, o desenvolvimento é uma tendência da própria produção porque esta se realiza sobre o resultado do trabalho acumulado, de modo que o processo de reprodução põe o novo, cada produção é necessariamente produção nova. A desagregação das relações de produção pode, contudo, como na dissolução do Império Romano, impedir que os resultados do desenvolvimento se consolidem como base de uma nova organização da produção. Em segundo lugar, estes resultados não se resumem à técnica. Nesta passagem, Marx caracteriza as forças produtivas, elencando alguns de seus fatores. De início, como a capacidade de reprodução da atividade produtiva já consolidada: "a agricultura havia diminuído, a indústria decaíra". Ainda que a técnica não se tenha perdido, outras condições desta 
produção se dissolveram. Estas condições são, no caso da agricultura, o esgotamento da expansão escravista, e no da indústria, a ausência de mercado. O comércio é elencado entre as forças produtivas, de modo que o intercâmbio humano não apenas é caracterizado em si mesmo como uma força produtiva, como é força produtiva central. O próprio dinheiro é elencado entre as forças produtivas como expressão de um desenvolvimento das trocas e da produção de mercadorias de caráter universal, ou seja, como expressão do intercâmbio. De modo que a ampliação da socialização, a concentração de atividades próprias do urbano e o intercâmbio são elementos centrais das forças produtivas nas sociedades pré-capitalistas, mais importantes que a técnica mesma, uma vez que a reprodução desta depende do intercâmbio. Marx escreve:

\begin{abstract}
Depende exclusivamente da extensão do comércio se as forças produtivas obtidas numa localidade, sobretudo as invenções, perdem-se ou não para o desenvolvimento posterior. Na medida em que ainda não existe comércio para além da circunvizinhança imediata, cada invenção tem de ser feita separadamente em cada localidade, e meros acasos, tais como irrupções de povos bárbaros, até mesmo guerras habituais, são o bastante para fazer com que um país com forças produtivas e necessidades desenvolvidas seja forçado a recomeçar tudo novamente a partir do início. No começo da história, toda invenção tinha de diariamente ser realizada de novo e em cada localidade, de forma independente. A prova de quão pouco as forças produtivas desenvolvidas, até mesmo no caso em que o comércio tenha atingido uma relativa extensão, estão salvas de uma destruição total é-nos fornecida pelos fenícios, cujas invenções desapareceram em sua maior parte e por longo tempo a partir do momento em que esta nação viu-se excluída do comércio pela conquista de Alexandre e pela decadência que daí se seguiu $(I A, 55)$.
\end{abstract}

A conservação das forças produtivas depende da consolidação do intercâmbio, a ruptura com o caráter local: quanto a produção é local e restrita, a probabilidade de as técnicas e invenções perderem-se é maior do que a de subsistirem.

$\mathrm{Na}$ desagregação do mundo antigo, em que o escravo paulatinamente se transforma em colono vinculado à terra ${ }^{91}$, e em que as cidades e o comércio regridem,

\footnotetext{
91 “(...) os proprietários de escravos mais perspicazes esforçaram-se em solucionar todo esse complexo conjunto de problemas substituindo a escravidão pelo arrendamento livre. (...) Para os colonos, a situação tornou-se bastante incômoda. É difícil encontrar novos arrendamentos convenientes e os antigos colonos atrasavam, cada vez mais, os pagamentos. Devido a sua debilidade econômica, viam-se obrigados a pedir empréstimos aos proprietários de suas terras, comprometendo seus materiais [sua produção]. A venda de materiais aos credores anula por um momento a dívida, mas na verdade arruína o colono. (...) Reduzidos ao desespero, chegam ao ponto de não se preocuparem mais com as dívidas. Decrescendo a produtividade de seu trabalho, deixam de cuidar dos materiais e do gado, dilapidando suas colheitas (...). Plínio se mostrará disposto a entregar escravos para ajudar os colonos, porém não existiam escravos na região. Opina, então, que a única solução seria renunciar ao arrendamento em dinheiro e passar a um
} 
assim como o dinheiro, são criadas parte das condições para a constituição do mundo feudal. O modo de produção feudal se origina de uma combinação dos resultados sociais da desagregação do mundo antigo com os modos de produção primitivos dos povos bárbaros ${ }^{92}$. Com a transformação dos escravos em colonos e a posterior constituição da servidão, os produtores no campo voltam a vincular-se e a pertencer à terra, deixando de constituir bens móveis, como são os escravos ${ }^{93}$. Embora não tenham a propriedade da terra, têm o direito de uso e não podem ser dela alijados. A descentralização e o parcelamento da terra que o mundo feudal realiza são em si mesmos uma perda de forças produtivas tanto na agricultura, quanto na manufatura: "Na agricultura, a divisão do trabalho era dificultada pelo cultivo parcelado, ao lado do qual surgiu a indústria doméstica dos próprios camponeses” $(I A, 91)$. A retração das forças produtivas desencadeada pela dissolução do Império Romano se expressa na absorção das atividades manufatureiras pela unidade doméstica, o que representa uma regressão da divisão do trabalho, e em geral no caráter mais restrito do comércio e do dinheiro. Este quadro caracteriza a desagregação geral de um modo de produção que

arrendamento por uma parte da colheita" E adiante: "O desaparecimento simultâneo da classe dos escravos e da dos proprietários de escravos foi provocada pela desagregação do modo de produção escravista, da forma escravista da propriedade. O aparecimento - para substituir a exploração escravista centralizada nos latifúndios - das pequenas explorações agrícolas, a rigor independentes, dos colonos e dos semi-colonos, foi precisamente o sinal da desagregação do modo de produção escravista e do aparecimento das premissas do modo de produção feudal" (KOVALIOV, S. I. "A crise social do século III ao V no Império Romano do Ocidente", in PINSKY, Jaime (org.). Modo de produção feudal Col. Textos 1, pp. 25-40, São Paulo: Global, 1982, p. 32 e 35). Doravante “A crise social...", seguido do número da página.

92 'Em oposição ao caráter 'cumulativo' do advento do capitalismo, a gênese do feudalismo na Europa derivou de um colapso 'catastrófico' e convergente de dois modos de produção distintos e anteriores, e a recombinação de seus elementos desintegrados liberou a adequada síntese feudal, que, portanto, sempre manteve um caráter híbrido. Os predecessores do modo feudal de produção foram naturalmente o modo de produção escravo em decomposição (...) e os primitivos modos de produção distendidos e deformados dos invasores germânicos, que sobreviveram em suas novas pátrias, após as conquistas bárbaras" (Anderson, Passagens, 18-9).

93 "A diferença entre o escravo e o colono diminui cada vez mais. Assim é que o édito de 364 proclamava, em relação aos escravos e colonos do imperador: 'os escravos e os colonos, assim como seus filhos e seus netos ou, em geral, os que têm abandonado secretamente nossas propriedades para dedicar-se a qualquer outro emprego, deverão ser devolvidos, até mesmo no caso de encontrarem-se em serviço no exército (CI, XI, 68, 3). O estatuto da descendência é idêntico, tratando-se de uma escrava ou de uma mulher-colono (CI, XI, 68, 4)'. 'Qual a diferença entre os escravos e os colonos (adscripticii) - pergunta o legislador -, se um e outro encontram-se sob a dependência de seu amo, que pode alforriar ao escravo com seu pecúlio e pode igualmente alijar de seu domínio o colono com sua terra?' (CI, XI, 48, 21; Édito de Justiniano de 530) (...) Se de um lado a situação do colono era cada vez mais semelhante à do escravo, por outro a situação do escravo ficava cada vez mais parecida à do colono. Ulpiano, referindo-se a Labeão, afirmava que o escravo que trabalha nos campos em situação de colono não entra no inventário da propriedade (Digesto, XXXIII, 7, 12, § 3). No Édito de Valentiano e Graciano pode-se ler: 'Os indígenas, tanto quanto os aldeões inscritos na lista de escravos, não podem em nenhum caso ser vendidos sem a terra' (CI, XI, 48, 7)”. (KOVALIOV, S. I., “A crise social...”, 36, grifo meu). 
começa a impulsionar novas relações de produção e dará origem ao modo de produção feudal.

Contudo, a condição de servo que não pode ser separado da terra e que, a despeito da exploração do excedente por tributo, em parte trabalha para si, e sobretudo o desenvolvimento posterior do trabalho urbano em que o produtor é proprietário, mitigam o caráter de aviltamento que o escravismo fez aderir ao trabalho manual. Esta mudança no estigma do trabalho material fornece novas bases para o desenvolvimento técnico. No modo de produção feudal já consolidado, o desenvolvimento técnico conhece avanço significativo no artesanato urbano e nas atividades produtivas ligadas ao comércio, como a navegação. Estas tiveram por base, contudo, a ampliação da produtividade no campo, em que novas técnicas são desenvolvidas e utilizadas. As novas relações de produção permitem este avanço ao possibilitarem a utilização de novas técnicas. Anderson observa, em termos gerais:

\footnotetext{
Nada é mais impressionante, em qualquer comparação retrospectiva, do que a estagnação técnica global da Antiguidade. Basta contrastar o registro de seus oito séculos de existência - da ascensão de Atenas à queda de Roma - com a extensão equivalente do modo de produção feudal que lhe sucedeu, para perceber a diferença entre uma economia relativamente estática e uma dinâmica (Anderson, Passagens, 26).
}

Depois do esgotamento do escravismo e da queda de Roma, vários séculos se passaram até que o modo de produção feudal se constituísse. O feudalismo na Europa (ocidental) começa a se estabelecer a partir do século IX: "surgiu no século X, expandiu-se durante o século XI e atingiu o auge no final do século XII e no século XIII” (Anderson, Passagens, 177).

É característica fundamental do modo de produção feudal em sua dinâmica de desenvolvimento próprio o ter criado, como seu resultado específico, a oposição entre cidade e campo, isto é, uma economia urbana que, possibilitada pela forma de propriedade feudal, opõe-se à economia no campo. Esta oposição se baseia no desenvolvimento da divisão do trabalho entre cidade e campo: as cidades antigas, embora maiores e mais vigorosas, concentravam os interesses da economia rural e eram dominadas pelos proprietários de terras; as cidades medievais desenvolverão uma economia e concentrarão interesses opostos à propriedade da terra. $\mathrm{O}$ desenvolvimento da economia urbana no interior deste modo de produção impulsionará a segunda grande 
divisão do trabalho, entre indústria e comércio. Este desenvolvimento culminará em um esgotamento da forma de propriedade feudal, que a dissolverá em relações mercantis. Comparando o caráter do urbano no feudalismo com as sociedades antigas, Marx afirma:

A história da Antiguidade clássica é a história da cidade, mas de cidades fundadas na propriedade da terra e na agricultura; a história asiática é uma espécie de unidade indiferente de cidade e campo (nesse caso, as cidades realmente grandes têm de ser consideradas unicamente como acampamentos principescos, como superfluidade acrescida à construção econômica propriamente dita); a Idade Média (época germânica) parte da terra como sede da história, cujo desenvolvimento posterior se desenrola então como oposição entre cidade e campo; a [história] moderna é a urbanização do campo, não a ruralização da cidade, como entre os antigos (Grundrisse, 395).

O primeiro ponto a se destacar é que o modo de produção feudal foi responsável por um salto de produtividade no campo que está na base e é pressuposto necessário da economia mercantil. Anderson oferece um cálculo da proporção deste aumento: “(...) entre os séculos IX e XIII, a semeadura/colheita média aumentava no mínimo de 2,5:1 a 4:1, e a porção da colheita à disposição do produtor dobrou efetivamente" (Anderson, Passagens, 184). "As inovações técnicas que eram os instrumentos materiais deste aumento foram basicamente o arado de ferro para lavrar", que permite o aumento da extensão de terra lavrada, "os arreios firmes para tração equina", que permitem a utilização do cavalo como animal de tração, mais eficiente que o boi, "o moinho de água para força mecânica, o adubo calcário para a melhoria do solo e o sistema de três campos para a rotação de semeaduras" (Anderson, Passagens, 178-9). Há um impulso ao aumento da produtividade da terra, em oposição ao aumento da extensão de terra na antiguidade clássica pelo domínio de outros povos.

A dramática aceleração das forças de produção detonou uma correspondente explosão demográfica. A população total da Europa Ocidental provavelmente foi além do dobro entre 950 e 1348, indo de uns 20 mil habitantes para 54 mil. Tem sido calculado que a expectativa média de tempo de vida, que seria de uns 25 anos no Império Romano, teria subido para 35 anos pelo século XIII na Inglaterra feudal" (Anderson, Passagens, 185) ${ }^{94}$.

O conjunto deste desenvolvimento que se vale de novas técnicas de produção apenas se torna possível nas novas relações de produção. O historiador pondera que a mera

\footnotetext{
${ }^{94}$ Apesar de "dramática", salta aos olhos a desproporção entre a expansão da produtividade feudal e a que o ocorrerá com a indústria capitalista. Do mesmo modo, as dimensões comparativas da pobreza, expressa na expectativa média de vida: hoje, no Brasil, por exemplo, esta chegou a aproximadamente 74 anos.
} 
invenção destas técnicas não é o suficiente para que sejam aplicadas efetivamente na produção, e sugere que há um intervalo de dois ou três séculos entre sua criação e sua utilização. "É na dinâmica interna do próprio modo de produção feudal - e não no advento de uma nova tecnologia, que foi uma de suas expressões materiais - que deve ser buscado o motor fundamental do progresso agrário" (Anderson, Passagens, 178). A servidão, que conecta o produtor à terra e lhe confere o direito à posse de um lote, associada ao caráter escalar do domínio senhorial da terra ${ }^{95}$, que determina a parcelização da soberania, é a relação de produção que permitiu a utilização de técnicas que alavancaram a produtividade no campo. Esta forma de propriedade, por um lado, impedia a divisão da terra em lotes autônomos permutáveis, ao mesmo tempo em que a soberania escalar restringia as possibilidades de expansão de terras dos domínios feudais. Era interesse do senhor do domínio aumentar o produto excedente advindo tanto dos lotes camponeses como dos serviços prestados em suas próprias terras. A organização da produção pelo senhor feudal ou pelos seus intendentes administrativos ${ }^{96}$ possibilitou a introdução de técnicas ligadas ao aumento da escala da produção e impostas aos camponeses por meio de coerção direta. Anderson destaca a importância desta organização voltada diretamente à ampliação do excedente, um dos motores da ampliação produtiva no campo:

O nível de organização atingido pelo nobre feudal em seu domínio era de importância crítica muitas vezes para a aplicação das novas técnicas: o exemplo mais evidente, que foi amplamente documentado por Bloch, foi a introdução do moinho de água. Que precisava de uma represa de certo tamanho para ser aproveitável, e assim deu lugar a uma das primeiras e mais prolongadas de todas as banalités ou monopólios exploratórios senhoriais - a obrigação do campesinato local de levar seu cereal para ser moído no moinho do senhor (Anderson, Passagens, 179).

A nobreza controlava assim os meios de produção mais elaborados em benefício próprio e à custa dos vilões, e desenvolveu "relativa racionalidade econômica" na exploração da

\footnotetext{
95 “O produtor imediato - o camponês - estava unido ao meio de produção - ao solo - por uma específica relação social. A fórmula literal deste relacionamento era proporcionada pela definição legal de servidão - gleba adscript ou ligados à terra: os servos juridicamente tinham mobilidade restrita. A propriedade agrícola era controlada privadamente por uma classe de senhores feudais, que extraía um excedente de produção dos camponeses através de uma relação político-legal de coação. (...) Ao mesmo tempo, os direitos de propriedade do senhor sobre sua terra geralmente eram apenas de grau: o senhor era investido neles por um nobre (ou nobres) superior, a quem passaria a dever serviços de cavaleiro - o fornecimento de um efetivo militar em tempos de guerra. Em outras palavras, suas propriedades eram mantidas como um feudo" (Anderson, Passagens, 144).

96 “O papel direto do senhor na administração e supervisão do processo de produção naturalmente declinava, enquanto o próprio excedente aumentava: desde cedo, bailios e intendentes administravam grandes propriedades para uma nobreza mais elevada que havia se tornado economicamente parasitária" (Anderson, Passagens, 179).
} 
propriedade, que, assim como a apropriação das melhores terras, se expressava na mais alta produtividade das terras senhoriais em relação às terras dos servos. Mas se a própria nobreza impulsionou a expansão da produtividade, "era na classe dos próprios produtores imediatos que residia a grande força motriz do desenvolvimento agrário medieval" (Anderson, Passagens, 180). Os servos eram livres para, nos dias da semana que podiam dedicar à produção na sua própria terra, aprimorar a produtividade. Embora parte do excedente produzido nas suas próprias terras constituísse obrigações para com o senhor feudal, quando estas obrigações adquirem estabilidade e regularidade, interessa aos próprios camponeses a ampliação de sua produção. Com isso, disseminou-se paulatinamente a produção de trigo, cereal de cultivo mais delicado, substituiu-se o uso de bois pelo de cavalos para arar o solo e as aldeias passaram a possuir forjas para a fabricação local de instrumentos de ferro - como o arreio para tração equina - além do desenvolvimento do artesanato rural. As novas técnicas permitiram uma redução da quantidade de força de trabalho nas terras senhoriais, que possibilitaram a ampliação da produtividade nos próprios lotes camponeses. $\mathrm{O}$ aumento da população que naturalmente se segue à ampliação produtiva reduzia, contudo, pela fragmentação, o tamanho dos lotes camponeses, o que também impulsionou novo arroteamento de terras não-cultivadas, o que foi também um movimento importante no desenvolvimento da produtividade no feudalismo, e não podia deixar de acompanhar a expansão produtiva baseada no avanço técnico.

O conjunto deste desenvolvimento da produtividade no campo teve por mola uma dada forma da propriedade que trazia em si mesma a disputa pela terra, especialmente as terras comunais do domínio, entre nobreza e servos: "Senhores e camponeses estavam objetivamente envolvidos num processo conflitual cujas consequências globais deveriam levar adiante toda a economia agrária" (Anderson, Passagens, 182). Esta luta contínua foi o que impulsionou de ambos os lados tanto a aplicação de novas técnicas como a expansão da terra cultivada: "A recuperação e a transformação de solo não cultivado foram daí por diante a mais frutuosa avenida para a expansão da economia rural na Idade Média, e a mais dramática expressão da capacidade produtiva aperfeiçoada da agricultura feudal" (Anderson, Passagens, 183).

Além da expansão da produção agrária, a forma de propriedade característica do feudalismo também possibilitou o desenvolvimento das cidades com relativa autonomia frente aos domínios senhoriais, isto é, na forma do desenvolvimento de uma economia 
urbana. Anderson destaca que "a parcelização feudal de soberanias ${ }^{97}$ produziu o fenômeno das cidades medievais", cuja "função na formação social era muito mais avançada" que aquela que as cidades tiveram no mundo antigo (Anderson, Passagens, 146). O caráter avançado na função da formação social atribuído às cidades medievais em comparação com as maiores e mais dinâmicas cidades antigas se deve à oposição entre a produção artesanal e comércio urbanos e a economia rural "controlada pelos nobres e organizada em terras senhoriais e pequenas propriedades, com enclaves camponeses individuais" (Anderson, Passagens, 146). Esta oposição se baseia na organização política das cidades como domínios relativamente independentes, cuja atividade própria não se subordina aos interesses da nobreza proprietária de terras. Por outro lado, sua atividade característica reproduz a hierarquia feudal nas corporações de ofício. Marx escreve:

\begin{abstract}
Essas cidades eram verdadeiras "associações", criadas pela necessidade imediata, pela preocupação com a defesa da propriedade e para multiplicar os meios de produção e os meios de defesa dos membros individuais. A plebe dessas cidades ${ }^{98}$ era desprovida de todo poder, na medida em que se constituía de indivíduos estranhos uns aos outros, que chegavam isoladamente e a cuja desorganização se defrontava um poder organizado, militarmente equipado, que os vigiava zelosamente. Oficiais e aprendizes estavam organizados em cada ofício da forma que melhor correspondia ao interesse dos mestres; a relação patriarcal que havia entre eles e seus mestres dava a esses últimos um duplo poder, de um lado pela influência direta que exerciam sobre toda vida dos oficiais e, de outro, porque para os oficiais que trabalhavam com os mesmos mestres havia um vínculo real que os mantinha coesos em relação aos oficiais dos demais mestres e os separavam destes; e, finalmente, os oficiais estavam ligados à ordem existente já pelo interesse que tinham em se tornar, eles próprios, mestres (IA, 53).
\end{abstract}

Se a forma de propriedade da terra que caracteriza a sociedade feudal, ao estimular o desenvolvimento técnico, mitiga o caráter de aviltamento do trabalho material, este se reduz de forma bem mais significativa no trabalho artesanal urbano, qualificado e

\footnotetext{
97 "O monarca, em outras palavras, era um suserano feudal de seus vassalos, aos quais estava ligado por laços de feudalidade, e não um soberano supremo colocado acima de seus súditos. Seus recursos econômicos provinham quase exclusivamente de seus domínios pessoais enquanto senhor, enquanto a seus vassalos pedia contribuições de natureza essencialmente militar. (...) Na verdade, ele só poderia ser o senhor de suas propriedades, sendo, fora delas, uma simples figura decorativa" (Anderson, Passagens, 147).

${ }^{98}$ Por plebe urbana, Marx entende os servos fugitivos que se empregavam em trabalhos não-qualificados remunerados por dia: "Nas cidades, a demanda por trabalho diariamente remunerado originou a plebe" $(I A, 53)$.
} 
organizado em guildas ${ }^{99}$. Esta dignidade do trabalho artesanal está posta na forma de propriedade que media a atividade.

No trabalho artesanal urbano da sociedade feudal, o instrumento de trabalho, que é já produto do trabalho, configura a condição de produção principal. O elemento que constitui a propriedade está conectado ao produtor por meio de sua habilidade artesanal específica, e se distingue do trabalho rural e da manufatura doméstica do camponês. Isso implica uma autonomização do proprietário que trabalha em relação à propriedade da terra, que figura ao lado do trabalho urbano e em oposição a este. Como a propriedade é mediada pela comunidade, ela mesma tem também de aparecer, neste caso, como “(...) comunidade ela própria já produzida, originada, secundária, produzida pelo trabalhador" (Grundrisse, 410). Todavia, o pertencimento à comunidade se mantém e aparece, por exemplo, no fato de que o artesão trabalha a partir da demanda efetivamente dada. Então, embora venda seu produto, esta venda é uma mediação para a realização da finalidade útil do produto e para a reprodução do artesão e de sua oficina nas condições postas. As limitações jurídicas impostas pelos sistemas de corporação impedem a concorrência e restringem o estabelecimento de novas oficinas, de modo a protegerem o modo de vida do artesão (inclusive contra a exploração dos senhores de terras). No modo de produção do artesão urbano, a propriedade privada do instrumento é autorizada pelo seu lugar naturalmente determinado na comunidade, por uma divisão do trabalho marcada pelas relações de dependência pessoal, e que se manifesta na unidade entre o trabalho e a propriedade:

\footnotetext{
Sob as condições corporativas, por exemplo, o simples dinheiro, não sendo ele próprio dinheiro corporativo, do mestre, não pode comprar os teares para se fazer com que se trabalhe neles; é prescrito com quantos cada um pode trabalhar etc. Em suma: o próprio instrumento ainda está tão organicamente ligado ao próprio trabalho vivo, em cujo domínio ele aparece, que na verdade não circula (Grundrisse, 415).
}

Nesta condição histórica em que a comunidade já é posta pelo trabalho, a propriedade é ainda definida pela atividade produtiva na forma da habilidade do artesão, o que não

\footnotetext{
99 A necessidade da "união dos trabalhadores de cada ofício em corporações" é resumida por Marx: "A concorrência entre os servos fugitivos que progressivamente afluíam à cidade, a guerra contínua do campo contra as cidades e, com isso, a necessidade de uma força militar urbana organizada, o nexo da propriedade comum com um trabalho determinado, a necessidade de estabelecimentos comuns para a venda de suas mercadorias numa época em que os artesãos eram ao mesmo tempo commerçants e, consequência disso, a exclusão de indivíduos não qualificados desses estabelecimentos, a oposição entre os interesses dos diferentes ofícios, a necessidade de uma proteção do trabalho aprendido com esforço e a organização feudal do país inteiro" (IA, 53-4).
} 
permite sua "circulação", sua transformação em dinheiro, ou seja, a mediação da relação de troca. É a maestria que autoriza a propriedade do instrumento, e portanto o indivíduo determinado como artesão. Vigora, "De certa forma, então, hereditariedade do modo de trabalhar, juntamente com a organização do trabalho e o instrumento do trabalho" (Grundrisse, 408). Deste modo, as condições objetivas de produção são ainda indissociáveis do sujeito que trabalha - habilidade e instrumento não existem separados - e da comunidade - a organização do trabalho visa a reproduzir o artesão em seu ofício. É com a mediação deste que o artesão se apropria da matéria-prima e dos meios de subsistência:

(...) onde a propriedade sobre o instrumento ou comportamento do trabalhador em relação ao instrumento como seu próprio (...), em que a forma do trabalhador como proprietário ou do proprietário trabalhador já é posta como forma autônoma, ao lado e à parte da propriedade da terra (...), também a matéria-prima e os meios de subsistência, como propriedade do artesão, primeiro são mediados, mediados por seu ofício, por sua propriedade do instrumento (Grundrisse, 409-10).

Essa mediação denota o caráter já modificado da comunidade, na qual está presente uma produção artesanal urbana autônoma em relação à propriedade da terra, fundada em meios postos pelo trabalho, e que medeia o acesso dos artesãos aos meios de subsistência e matéria-prima. Mas expressa também a manutenção do vínculo comunitário, em que o produto artesanal, embora se realize por meio de seu valor de troca, visa a necessidade comunitária efetiva, e por isso o valor de troca é meio para o valor de uso, e não o oposto, como na produção capitalista. $\mathrm{O}$ artesão urbano é ainda um elo constitutivo da comunidade:

\footnotetext{
No artesanato urbano, muito embora baseado essencialmente na troca e na criação de valores de troca, a finalidade principal e imediata dessa produção é a subsistência como artesão, como mestre artesão, logo, valor de uso; não é o enriquecimento, não é o valor de troca como valor de troca. Por isso, a produção em todos os lugares está subordinada a um consumo pressuposto, a oferta em todos os lugares está subordinada à demanda, e a produção se amplia apenas lentamente (Grundrisse, 422).
}

No que diz respeito às forças produtivas, o trabalho artesanal urbano nas oficinas medievais significa um avanço em relação tanto ao artesanato doméstico característico dos modos de produção asiático e germânico quanto ao trabalho manufatureiro urbano 
no modo de produção antigo ${ }^{100}$. Por outro lado, inscreve a força produtiva no limite do trabalho individual, que só pode se coletivizar mediante a ruptura com sua forma própria de propriedade: “(...) o comportamento do trabalhador em relação ao instrumento como seu próprio (...) pressupõe ao mesmo tempo a subsunção do instrumento ao seu trabalho individual, i.e., pressupõe um nível particular, limitado, do desenvolvimento da força produtiva do trabalho" (Grundrisse, 409). O desenvolvimento da força produtiva está dado na autonomização do trabalho em relação à propriedade imediata da terra, no caráter de economia urbana, que determina uma comunidade não mais pressuposta, mas posta pela atividade humana. No que diz respeito à técnica, o trabalho artesanal proporciona "certo desenvolvimento autossuficiente de capacidades unilaterais", ou seja, um aprimoramento na disciplina subjetiva requerida pelo trabalho que o eleva em alguma medida à condição de arte. O caráter unilateral da capacidade subjetiva do artesão é determinado pela divisão do trabalho, especialmente pela separação entre o trabalho propriamente dito, aquele que é predominante e por isso adere à noção de trabalho, o doméstico rural (que inclui também a manufatura de diversos produtos), e as artes qualificadas que distingue em uma função específica e secundária dos artesãos. Esta divisão entre a economia urbana e a economia rural é possibilitada pela relação de produção feudal e a determina. Contudo, no interior da economia urbana, além de os artesãos serem ao mesmo tempo comerciantes, a divisão entre as funções artesanais é bastante restrita. Marx escreve:

\footnotetext{
Nas cidades, a divisão do trabalho entre as diferentes corporações era ainda muito incipiente e, no interior dessas corporações, não era nem sequer realizada entre os diferentes trabalhadores. Cada trabalhador tinha de estar habilitado a executar toda uma série de trabalhos e tinha de ser capaz de produzir tudo aquilo que era possível ser produzido com suas ferramentas; o intercâmbio limitado e a fraca ligação das diversas cidades entre si, a escassez de população e a exiguidade das necessidades não permitiam que se instaurasse uma divisão do trabalho mais ampla, e, por isso, cada um que quisesse se tornar mestre tinha que dominar por inteiro o seu ofício. É por isso que nos artesãos medievais ainda se encontrava um interesse por seu trabalho específico e pela habilidade em executá-los, o que muitas vezes podia elevar-se até um limitado sentido artístico. Mas é por isso, também, que cada artesão medieval estava plenamente absorvido em seu trabalho, tinha com ele uma aprazível relação servil e estava mais submetido a ele do que o trabalhador moderno, para quem seu trabalho é indiferente $(I A, 54)$.
}

\footnotetext{
${ }^{100}$ Nas cidades do mundo antigo, “(...) as manufaturas permaneciam poucas e rudimentares (...). A técnica era simples, a demanda, limitada e o transporte era exorbitantemente custoso. O resultado era que as manufaturas na Antiguidade se desenvolviam tipicamente não por um aumento de concentração, como em épocas posteriores, mas pela descentralização e dispersão (...)” (Anderson, Passagens, 20).
} 
A explosão populacional que Anderson destaca foi apenas suficiente para impulsionar o desenvolvimento do artesanato urbano organizado em corporações, ou ainda, as próprias cidades, de onde partiu o impulso à expansão do intercâmbio comercial. Se a exiguidade das necessidades e a escassez de população não permitiam o desenvolvimento da divisão do trabalho no interior das oficinas e entre elas, a economia urbana permitiu a divisão do trabalho entre o comércio e a indústria, que autonomizou aquela espécie de atividade capaz de conectar as cidades entre si, ampliar as necessidades e a capacidade de consumo:

\footnotetext{
O processo seguinte na expansão da divisão do trabalho foi a separação entre a produção e comércio, a formação de uma classe particular de comerciantes, uma separação que nas cidades históricas tradicionais (com os judeus, entre outras coisas) foi herdada do passado e que não tardou a aparecer nas cidades de formação recente. Com isso, estava dada a possibilidade de uma ligação comercial para além dos círculos mais próximos, uma possibilidade cuja realização dependia dos meios de comunicação existentes, do estado de segurança pública alcançado no país e condicionado pelas relações políticas (ao longo de toda a Idade Média, como se sabe, os comerciantes viajavam em caravanas armadas) e pelas necessidades mais ou menos desenvolvidas das regiões acessíveis ao comércio, necessidades estas que eram condicionadas pelo correspondente grau de cultura de cada região $(I A, 54)$.
}

Dois desenvolvimentos da divisão do trabalho couberam no modo de produção feudal: a divisão entre economia urbana e economia rural, que é um desenvolvimento frente à divisão cidade e campo da antiguidade (tanto no modo clássico como asiático); e a divisão entre comércio e indústria, que se repõe sobre uma base produtiva mais avançada e permite que o comércio se desenvolva em grau bem mais elevado: a ponto de passar a determinar a produção.

É importante destacar que o desenvolvimento técnico da agricultura no modo de produção feudal foi majoritariamente realizado pelos próprios camponeses, em sua atividade, e se constituiu portanto em um aprimoramento empírico dos meios de produção. As forças produtivas no campo também foram em grande parte aumentadas pelo arroteamento de novas terras para cultivo, cujos maiores empreendimentos foram levados com a direção da nobreza, em especial do clero, mas o aprimoramento técnico deveu-se à atividade produtiva imediata. Também nas cidades, são os artesãos que dominam e aprimoram seu próprio processo de trabalho. O conhecimento dos produtores é determinado exclusivamente pela sua atividade e restringe-se ao saber fazer. A atividade intelectual, restrita ao clero, existiu apenas no interior dos 
monastérios, isto é, em domínios rurais isolados, até o século XI, quando surgiram também as escolas das catedrais, nas cidades e impulsionadas já pelo desenvolvimento da economia urbana. Enquanto a atividade intelectual foi restrita aos monastérios, antes da constituição do feudalismo propriamente dito, a separação entre esta forma do conhecimento e a técnica era tão radical quanto poderia ser, e a atividade intelectual quase não apresenta desenvolvimento ${ }^{101}$.

O foco da atividade intelectual nas escolas catedráticas urbanas é, no entanto, como nos monastérios, a teologia ${ }^{102}$. As escolas das catedrais são vistas como precursoras das universidades, mas estas últimas se originaram como associações de mestres e estudantes semelhantes às corporações de ofícios e, portanto, organizações de homens livre não nobres, os vilões ou a burguesia ${ }^{103}$. O objeto dos estudos era a ciência, especialmente o direito e as leis, mas também a geografia, a medicina, a arquitetura, embora os cursos não fossem organizados pelas áreas das ciências, cuja divisão não era desenvolvida, mas por livros: os cursos eram leituras de obras consagradas. Começavam a surgir, contudo, novos livros que reuniam o conhecimento científico até então alcançado. O surgimento desses está vinculado ao desenvolvimento urbano e ao comércio. O objeto dos estudos abrange a produção de ideias que chegam de outros lugares a partir da expansão do intercâmbio externo propiciado a partir do século XI pelas Cruzadas ${ }^{104}$. As universidades foram logo submetidas ao domínio dos reis e da

\footnotetext{
101 "Quando se diz que os monastérios foram durante a Idade Média as únicas universidades e casas editoriais, há que entendê-lo no sentido de 'universidades aristocráticas' e 'edições para bibliófilos'. Dado o tempo enorme que dispunham e a fortuna de disfrutar de sossego, em um tempo de tumultos perenes, $o$ que assombra não é que tenham sabido algo sobre as ciências, mas o pouco que chegaram a saber. Isidoro de Sevilla (570-636), um dos representantes mais perfeitos desses tempos, reuniu em um só volume chamado Origens ou Etimologias todos os conhecimentos que a seu juízo mereciam interesse. Ainda que tenha um índice impressionante - da medicina à astronomia e da metalurgia à geografia - não passa de um volume e se reduz em geral a um fastidioso catálogo de nomes" (Ponce, Educación, 93).

${ }^{102}$ Se até o século XI puderam bastar as escolas dos monastérios, se faziam necessárias agora as escolas das catedrais. Das mãos dos monges, a educação passou às mãos do clero secular. (...) As escolas catedráticas, para dizer a verdade, existiam desde um século antes com uma organização semelhante às monásticas e também com a divisão entre externas para laicos e internas para o clero. A teologia, obviamente, estava no centro de suas preocupações pedagógicas (Ponce, Educación, 100-1).

103 "A palavra universidade - universitas - se empregava na Idade Média para designar uma assembleia corporativa qualquer, do mesmo modo que a de sapateiros ou de carpinteiros. Nunca se usava por isso em um sentido absoluto, e dizer, por exemplo, 'Universidade de Bologna' não era nada mais que uma cômoda abreviação para designar 'Universidade dos mestres e estudantes de Bologna'. Em seus começos, as universidades foram reuniões livres de homens que se propunham ao cultivo das ciências" (Ponce, Educación, 102).

104 “A expansão do comércio que está na base deste renascimento - e que levou os cruzados a conquistar Dardanelos - expandiu de tal modo o horizonte da época que correntes de toda ordem começaram a revolver a atmosfera da Europa. Enquanto o mundo cristão assegurava, por exemplo, que o planeta era plano, chegavam alguns ecos de que os califas de Córdoba ensinavam a geografia com esferas" (Ponce, Educación, 102).
} 
igreja (do papa), ou seja, da instância universal que mantinha a integridade da sociedade feudal, e nunca de suas soberanias parcelares rurais. Eram, pois, urbanas e concentravam a universalidade do desenvolvimento intelectual medieval, consonante ao intercâmbio que este modo de produção foi capaz de impulsionar. Deixou rapidamente de ser local, como são a produção agrícola e a produção artesanal feudais. A ampla circulação de professores entre as universidades atesta este caráter universal. Além disso, foi a partir de seu desenvolvimento que os limites estamentais começam a ser relativizados: burgueses ricos e doutos passam a tomar parte dos cargos administrativos e recebem autorização para ingressar na carreira clerical ${ }^{105}$. "Mas ainda que nominalmente escolástica, a universidade era, por seu espírito, secular" (Ponce, Educación, 102). Seu período inicial, de desenvolvimento, entre fins do século XI, quando foi fundada a Universidade de Bologna, e o começo do século XII, é ao mesmo tempo o apogeu da heresia. No século XIII, aparecem em Bologna, Gênova e Florença, cidades comerciais, escolas municipais que substituíram o latim pela língua nacional e davam ênfase ao ensino de geografia e à contabilidade, caracterizando-se como escolas para comerciantes e banqueiros ${ }^{106}$.

Assim, o conhecimento intelectual no feudalismo dinamizou-se, do interior dos monastérios, às necessidades do comércio, da usura, da administração pública no período inicial da ascensão burguesa, que ao mesmo tempo proporcionou certa abertura e desenvolvimento da própria ciência a partir do intercâmbio que está na base desta ascensão. Contudo, manteve-se separado da técnica e do trabalho material, e, se logrou elevar o comércio e a finalidade de concentrar fortuna em dinheiro, não excluiu de pronto o aviltamento de que o trabalho era alvo. A separação entre trabalho intelectual e trabalho material se manteve como distintivo da classe: "A conquista de um título universitário punha o bom burguês quase ao mesmo nível da nobreza, e desde o momento em que investia orgulhoso os signos da dignidade doutoral - o barrete e a toga, o anel e o livro - já começavam a olhá-lo como um nobre" (Ponce, Educación, 103-4). O conhecimento alça o homem urbano livre, não-proprietário de terras, ao nível

\footnotetext{
105 "A fundação das universidades abriu para a burguesia a participação em muitos dos benefícios da nobreza e do clero que até então lhe haviam sido negados. Um dos privilégios municipais outorgados por Alfonso de Poitiers no século XIII, por exemplo, foi o de permitir aos filhos dos burgueses o ingresso nas ordens religiosas. E se isto é ilustrativo com respeito à Igreja, a lenta formação da nobreza chamada 'de toga', por oposição à autêntica 'de espada', mostra também como por intermédio das universidades a burguesia se apoderava da justiça e da burocracia" (Ponce, Educación, 103).

${ }^{106}$ Cf. Ponce, Educación, 109.
} 
da nobreza, e apenas contradiz a divisão entre trabalho material e trabalho intelectual na medida em que a própria atividade comercial e usurária adere à nobreza.

A relação de produção feudal permitiu alguma mitigação do caráter de aviltamento da técnica, e com ela do trabalho material imediato, mas nem de longe o eleva à atividade digna do humano. A sociedade estamental, que separa o indivíduo livre e senhor do servo, e também do vilão, que, a despeito de ser livre, distingue-se da nobreza, não possibilita a reabilitação do trabalho material. Este aviltamento apenas pode desaparecer com a equiparação dos indivíduos oriunda do longo processo de dissolução da sociedade estamental, baseada na hierarquia nobiliária. Quando o trabalho intelectual toma por objeto o trabalho material, a técnica, a atividade produtiva é posta como finalidade humana, e o trabalho, como atividade humana, não mais de escravos ou de indivíduos desprovidos de nobreza, mas do homem.

As relações de produção feudais são superiores às antigas porque permitem maior avanço das forças produtivas que aquele que o escravismo permitiu, apesar de este ter constituído as bases de muito maior desenvolvimento do dinheiro e da propriedade privada, além do artístico, por exemplo, no interior de suas próprias relações. O limite da sociedade feudal no que diz respeito às forças produtivas situa-se na dependência da produção agrária que é ainda a base da produção e, no que diz respeito à economia urbana, na manutenção do trabalho artesanal como trabalho individual de caráter artístico ao lado do desenvolvimento do conhecimento intelectual separado da técnica. A divisão entre trabalho material e trabalho intelectual se fixa nos próprios estamentos. De modo que o conjunto da produção é ainda determinado pelos vínculos pessoais de obrigação e pela dependência da terra, isto é, pela unidade comunitária. Caracteriza-se ainda como uma sociedade natural. Mas é a nova alavancagem do comércio e do dinheiro, que agora, tendo por base forças produtivas mais amplas, permitirá o desenvolvimento do capital e uma nova relação entre trabalho e conhecimento. Esta relação se assentará em novos fundamentos oriundos do desprendimento da terra e da comunidade e será, por um lado, comunidade criada, baseada em pressupostos produtivos que são já postos pela atividade humana, e neste sentido, sociedade não mais natural. Por outro lado, como modo de produção originado espontaneamente pelo desenvolvimento histórico e em que se mantém a ausência de controle da produção pelos indivíduos e uma forma de dependência, não mais pessoal mas coisal, segue carregando um caráter natural. As forças produtivas atingem nível 
social, de modo que as condições de produção são então criadas pelo trabalho. Isso rompe com a dependência da natureza expressa na fixação dos indivíduos à terra e possibilita uma nova unidade entre trabalho e conhecimento que confere novo sentido, no capitalismo desenvolvido, à determinação da divisão entre trabalho material e trabalho intelectual como característicos da divisão de classe. Mas as relações de produção que definem o capital são relações ainda estabelecidas natural ou espontaneamente.

Dois pontos desta discussão são desenvolvidos em seguida: a diferença de natureza desta nova forma de propriedade em relação a todas as outras, que definirá a especificidade de sua lógica de desenvolvimento, e o modo como se origina da desagregação espontânea da sociedade feudal.

\section{A dissolução da comunidade em capital}

O capital se define como uma forma determinada dos dois elementos centrais do trabalho, a atividade e as condições de produção, em que se incluem tanto o objeto quanto o meio de trabalho. Uma forma de propriedade em que a atividade do trabalho se desvincula das condições objetivas, empreendendo a ruptura do produtor com sua existência objetiva, dada nas várias formas de propriedade natural, ou seja, "em que o trabalho vivo se comporta tanto em relação à matéria-prima quanto ao instrumento e aos meios de subsistência requeridos durante o trabalho de maneira negativa, como não propriedade (...)" (Grundrisse, 409). A forma capitalista da propriedade pressupõe o trabalhador livre dos elos que o prendem à comunidade e ao território e, portanto, dos vínculos de dependência pessoal, jurídicos e políticos. Esta liberdade com relação à comunidade é ao mesmo tempo perda da propriedade da terra, do instrumento de trabalho, ou dos meios de subsistência. O trabalhador perde sua existência objetiva e se põe socialmente "como capacidade de trabalho sem objetividade, puramente subjetiva, confrontada com as condições objetivas da produção (...) como capital" (Grundrisse, 409). Implica, por isso, a dissolução da finalidade da reprodução da comunidade - que coincide com a reprodução de seus membros. De modo que à relação capitalista corresponde também o trabalhador "sem objetivo".

De um lado, são pressupostos processos históricos que colocaram uma massa de indivíduos de uma nação etc., se não de início na condição de trabalhadores realmente livres, ao menos na de 
trabalhadores que o são potencialmente, cuja única propriedade é sua capacidade de trabalho e a possibilidade de trocá-la por valores existentes; indivíduos frente aos quais todas as condições objetivas de produção se apresentam como propriedade alheia, como sua não propriedade, mas ao mesmo tempo permutáveis como valores e, em consequência, apropriáveis até certo ponto pelo trabalho vivo (Grundrisse, 412).

A liberdade jurídica é um resultado desta liberdade potencial estabelecida pela ruptura dos vínculos comunitários ou pessoais que coincidem com a ligação com o território e com a consequente finalidade da reprodução comunitária. A separação entre trabalho vivo, subjetivo, e suas condições objetivas de confirmação significa tanto a dissolução das formas de propriedade em que o proprietário trabalha, isto é, em que o produtor é proprietário, seja da terra, seja do meio de trabalho já posto pelo trabalho característico da economia urbana; quanto também das formas de dominação direta em que o trabalhador é posto entre as condições de produção, ao mesmo tempo em que é proprietário de seus meios de subsistência:

Tais processos históricos de dissolução são igualmente a dissolução das relações de dependência que prendem o trabalhador ao território e ao senhor do território, mas que pressupõem de fato sua propriedade dos meios de subsistência - esse é, em verdade, seu processo de desvinculação da terra; (...) dissolução das relações corporativas que pressupõem sua propriedade do instrumento e o próprio trabalho como habilidade artesanal determinada, como propriedade (não somente como sua fonte); da mesma maneira, dissolução das relações clientelistas nas variadas formas, em que os não-proprietários aparecem como co-consumidores do produto excedente na esteira dos seus senhores e, em contrapartida, vestem a libré dos seus senhores, participam de suas contendas, prestam-lhes serviços pessoais, imaginários ou reais etc. (Grundrisse, 412-3)

A perda da propriedade dos meios de produção, no caso do artesanato corporativo, ou dos meios de subsistência, como no caso dos servos, define a ruptura com as relações de dependência pessoais. Ela se estende às relações clientelistas no interior da nobreza: como a comunidade existe objetivamente na fixação dos indivíduos ao território, a dissolução da propriedade escalar da terra é ao mesmo tempo a dissolução dos vínculos diretos entre indivíduos.

Como na condição comunitária a produção se baseia em pressupostos naturais, isto é, comunidade e condições objetivas de produção não postos pelo trabalho, visa a reprodução da comunidade e o produto se cria essencialmente como valor de uso. Ao se desvincular de sua base objetiva (a terra), a finalidade da reprodução imediata do produtor e/ou do proprietário mediada pela reprodução da comunidade também se 
dissolve: “(...) em todos esses processos de dissolução são dissolvidas relações de produção em que predominam valor de uso, produção para consumo imediato; (...) a prestação em espécie e os serviços em espécie sobre o pagamento em dinheiro e a prestação de serviço por dinheiro" (Grundrisse, 413).

A mediação do dinheiro opõe-se à mediação comunitária, pessoal, vinculada ao uso, ou, o que é o mesmo, à reprodução da comunidade. Ao conferir a permutabilidade universal aos produtos e à prestação de serviço, a mediação do dinheiro acrescenta às determinações naturais ou materiais da atividade e de seu resultado a propriedade de valores de troca. Mas a condição de permutabilidade é baseada na forma de propriedade. O trabalho perde sua existência objetiva ao perder o vínculo imediato com suas condições objetivas e esta perda opera uma transformação social no produtor que se torna mero trabalhador. A capacidade de trabalho assume a determinação de valor de troca, que, no entanto, deve encontrar as condições de produção e de subsistência também sob esta forma de valor de troca. É a desvinculação entre os dois fatores da atividade humana, sua liberação recíproca, que confere a ambos a forma de valores:

(...) o processo de dissolução que [,por um lado,] transforma uma massa de indivíduos de uma nação etc. em trabalhadores assalariados livres potencialmente - indivíduos coagidos ao trabalho e à venda do seu trabalho só por sua falta de propriedade - , supõe, por outro lado, não que as fontes de renda e, em parte, as condições de propriedade anteriores desses indivíduos tenham desaparecido, mas, ao contrário, supõe somente que se alterou sua utilização, que o seu modo de existência se transformou, que passaram para outras mãos ou, em parte, permaneceram nas mesmas mãos como fundos livres. Mas uma coisa está clara: o mesmo processo que separou uma multidão de indivíduos de suas relações afirmativas - de uma maneira ou de outra - anteriores com as condições objetivas do trabalho, que negou essas relações e, dessa maneira, transformou esses indivíduos em trabalhadores livres, esse mesmo processo liberou potencialmente essas condições objetivas do trabalho - território, matéria-prima, meios de subsistência, instrumentos de trabalho, dinheiro ou tudo isso junto - da vinculação anterior com os indivíduos agora dela dissociados (Grundrisse, 413).

A existência das condições objetivas do trabalho como fundos livres, isto é, livres da vinculação com a atividade produtiva e da mediação comunitária, é a origem de sua forma de valor de troca. A determinação social dos meios de produção como valores é identificada por Marx com uma condição de liberdade das forças produtivas materiais. Trata-se de uma mudança na forma de propriedade que faz das mesmas condições de produção preexistentes, capital potencial. Este se constitui, portanto, em primeiro lugar, 
como uma forma social das condições objetivas do trabalho, isto é, uma relação de propriedade definida pela liberdade frente às obrigações comunitárias.

\footnotetext{
O mesmo processo que contrapõe a massa, na qualidade de trabalhadores livres, às condições objetivas de trabalho, também contrapôs essas condições, na qualidade de capital, aos trabalhadores livres. O processo histórico foi o divórcio de elementos até então unidos - em consequência, seu resultado não é que um dos elementos desaparece, mas que cada um deles aparece em uma relação negativa com o outro -, o trabalhador livre (potencialmente), de um lado, o capital (potencialmente), do outro (Grundrisse, 413).
}

O capital consiste nas condições objetivas do trabalho transformadas em fundos livres, mas não adere diretamente a estas condições em sua forma útil, concreta. Além disso, nesta separação, a constituição dos serviços do trabalho e de seus produtos como valores de troca supõe ainda a riqueza na forma de fortuna em dinheiro. A transformação das condições objetivas da produção em capital é necessariamente mediada pelo dinheiro:

A formação original do capital não se dá como se o capital acumulasse, como se imagina, meios de subsistência, instrumentos de trabalho e matérias-primas, em suma, as condições objetivas do trabalho já dissociadas do solo e já amalgamadas ao trabalho humano (Grundrisse, 416).

"Na realidade, o que se transforma em capital em sentido próprio, em capital industrial, é a fortuna mobiliária - fortuna em dinheiro" (Grundrisse, 415). O capital tem como origem o dinheiro, quer dizer, a primeira riqueza que historicamente é passível de assumir a forma de capital é o dinheiro. A condição da permutabilidade universal do dinheiro, riqueza que existe como capacidade universalmente líquida de troca caracteriza a liberdade frente à especificidade das necessidades e das relações de vínculo pessoal. A fortuna em dinheiro é a única forma de concentrar produto excedente, não apenas em grande quantidade, mas livre de relações comunitárias. Tanto a restrição quantitativa do produto excedente quanto as relações comunitárias são impeditivos do desenvolvimento do capital. A fortuna em dinheiro é capital em potencial e condição do surgimento do capital, porque capital é antes de tudo um valor de troca: apenas no intercâmbio pela troca é possível desvincular a riqueza do uso imediato e concentrar esta riqueza móvel.

(...) é inerente ao conceito de capital - em sua gênese - que ele parte do dinheiro e, por isso, da fortuna que existe na forma de dinheiro. É igualmente inerente ao seu conceito que o capital aparece como provindo da circulação, como produto da circulação. Por isso, a formação do 
capital não parte da propriedade da terra (...); tampouco parte da corporação (...); mas da fortuna mercantil e usurária (Grundrisse, 415$)^{107}$.

A fortuna em dinheiro é um dos pressupostos centrais da produção capitalista não apenas porque a forma de dinheiro da riqueza é requisito para sua transformação em capital, mas também porque ela contribui para a dissolução da forma de propriedade feudal. De modo algum, contudo, é condição suficiente para a dissolução das relações comunitárias em capital.

Em Roma, a propriedade privada e o dinheiro eram desenvolvidos, mas a baixa produtividade geral, expressa na dependência não apenas da produção na terra, como também da expansão geográfica (militar) e da escravidão, não permitiu a separação entre condições objetivas de produção e o trabalho, mas, ao contrário, sua desagregação significou um retrocesso da produção e do intercâmbio, que só após largo intervalo reorganizou-se em um modo de produção capaz de impulsionar as forças produtivas:

Mas a simples existência da fortuna em dinheiro, e até mesmo a obtenção de uma certa supremacia da sua parte, de modo algum é suficiente para que ocorra aquela dissolução em capital. Caso contrário, Roma antiga, Bizâncio etc. teriam encerrado a sua história com trabalho livre e capital, ou, antes, inaugurado uma nova história (Grundrisse, 416, citado parcialmente acima).

As formas de produção pré-burguesas, uma vez que, por um lado, baseiam-se em baixo nível de forças produtivas, na produção agrícola cujas condições são pressupostos naturais e, por outro, não podem senão visar sua reprodução imediata, já que seu produto excedente é pequeno, não possibilitam a acumulação. Contudo,

“(...) se for considerada a transformação original de dinheiro em capital (...) impõe-se naturalmente a singela observação, da qual os economistas fazem grande alarde, de que o lado que entra em cena como capital tem de estar de posse das matérias-primas, dos instrumentos de trabalho e dos meios de subsistência, para que o trabalhador possa viver durante a produção, antes que a produção esteja concluída. Ademais, isso aparece de tal modo que parece ter havido uma acumulação - uma acumulação que precedeu o trabalho e não brotou dele (...)" (Grundrisse, 414).

${ }^{107}$ N'O Capital, Marx afirma: "Historicamente, o capital se defronta com a propriedade fundiária, no início, em todo lugar, sob a forma de dinheiro, como fortuna em dinheiro, capital comercial e usurário. No entanto, não se precisa remontar à história da formação do capital para reconhecer o dinheiro como sua primeira forma de aparição. A mesma história se desenrola diariamente ante nossos olhos" (C, I, 1, 125). 
Ou seja, por um lado as relações de produção feudais, mesmo a relação do artesão com a comunidade, que é já uma relação de troca e portanto existe em forma adequada à liberdades dos fatores de produção que caracteriza o capital, não permite a acumulação; e por outro, a acumulação prévia é condição necessária da relação-capital. Nas palavras de Marx:
À primeira vista, já fica claro que existiria um círculo vicioso inepto se, por um lado, os trabalhadores, que o capital precisa pôr a trabalhar para se pôr como capital, primeiro tivessem de ser criados, tivessem de ser trazidos à vida mediante a acumulação do capital, esperassem por seu "Que se façam os trabalhadores!", enquanto, por outro, o próprio capital fosse incapaz de acumular sem trabalho alheio, se pudesse acumular no máximo o seu próprio trabalho, i.e., se ele próprio pudesse existir, portanto, na forma de não-capital e não dinheiro, uma vez que o trabalho, antes da existência do capital, só pode se autovalorizar em formas como a do trabalho artesão, da pequena agricultura etc., em suma, exclusivamente em formas que não podem acumular ou o podem apenas escassamente; em formas que permitem só um pequeno produto excedente e em grande parte o consomem (Grundrisse, 416).

A concentração de riqueza não pode advir do produto das atividades produtivas tradicionais - no campo e no trabalho artesanal urbano - cujo produto excedente (este sempre existe em algum grau a partir da Antiguidade) é em grande parte consumido. A fortuna em dinheiro se origina no interior da sociedade medieval, mas não a partir das atividades produtivas que formam sua base, seja a agricultura, seja o trabalho artesanal urbano: “(...) no que se refere à formação da fortuna em dinheiro propriamente dita, antes de sua transformação em capital, ela faz parte da pré-história da economia burguesa. A usura, o comércio, o sistema urbano e o fisco que surge com eles desempenham aí o papel principal" (Grundrisse, 419). O desenvolvimento do comércio exterior é o principal fator que concorre para a formação da fortuna em dinheiro, "Mas essa fortuna só encontra as condições para comprar trabalho livre quando este foi separado de suas condições objetivas de existência pelo processo histórico. Só então também existe a possibilidade de comprar essas próprias condições" (Grundrisse, 415).

Duas outras condições são requeridas para a formação do capital. Primeiro, como já exposto, forças produtivas capazes de criarem excedente em quantidade passível de acumulação. A possibilidade deste excedente, ou seja, forças produtivas mais desenvolvidas, se expressa na divisão entre campo e cidade que põe a autonomia do trabalho urbano como atividade baseada em condições já postas pelo trabalho: a mediação que o ofício realiza entre a matéria-prima do trabalho e os meios de 
subsistência do artesão implica uma forma de propriedade secundária, produto do processo histórico, já que autonomiza a produção artesanal do vínculo imediato com a propriedade da terra. Esta autonomia, por sua vez, está baseada no aumento da produtividade no campo, que possibilita a compra de meios de subsistência e matériasprimas para a economia urbana. Segundo, esgotamento das possibilidades de expansão produtiva no interior das mesmas relações feudais. Este se mostra primeiramente na base da produção feudal, ou seja, no campo:

O determinante mais profundo desta crise provavelmente estará num 'emperramento' dos mecanismos de reprodução do sistema até o ponto de suas capacitações básicas. Em particular, parece claro que o motor básico da recuperação dos solos, que impulsionara toda a economia feudal por três séculos, acabou ultrapassando os limites objetivos da estrutura social e das terras disponíveis (Anderson, Passagens, 191).

A expansão agrícola nestes três séculos de desenvolvimento do feudalismo gerou uma ampliação da população que foi acompanhada por uma redução dos lotes que cabiam a cada unidade familiar, e já proporcionara um aumento das relações de arrendamento, portanto salariais, que conviveu com a servidão. A técnica existente, se permitiu a expansão das terras, não foi suficiente para evitar o desgaste e a deterioração das terras mais antigas, ao mesmo tempo em que as reservas marginais eram de qualidade inferior e rapidamente se deterioraram com a pressão do aumento populacional que impunha a pressa e o mau uso. Além disso, a diversificação da produção agrícola impulsionada pelo comércio reduziu a produção de cereais em benefício de outras produções, como as vinhas e o linho, mas também a lã e a pecuária. $\mathrm{O}$ aumento populacional que se seguiu à ampliação produtiva não pôde ser sustentado por ela, e o século XIV foi marcado por escassez. A redução da produtividade aumentou a taxa de exploração tanto dos servos quanto dos arrendatários. Duas consequências se seguiram: terras foram abandonadas e a taxa de natalidade entre os camponeses caiu.

Não apenas a agricultura, mas a mineração encontrou limites técnicos, e a exploração da prata decaiu sensivelmente ${ }^{108}$. Anderson destaca que o século XIV

\footnotetext{
108 "A extração da prata, a que estava conectado organicamente todo o setor urbano e monetário, deixou de ser praticável ou rentável nas principais zonas mineiras da Europa Central, porque já não havia meios de cavar poços mais profundos ou de refinar minérios mais impuros. 'A extração da prata quase chegou ao fim no século XIV. Em Goslar, houve reclamações de uma subida do nível de água no fundo de poços; também houve problema com água nas minas da Boêmia. A recessão já iniciara na Áustria pelo início do século XIII. A atividade mineira cessou em Deutschbrod em 1321, em Freisach por volta de 1350 e em Brandes (Alpes Franceses) em torno de 1320' (Van Bath, The agrarian history of western Europe, p. 106)" (Anderson, Passagens..., p. 193).
} 
assistiu a uma escassez de dinheiro que afetou as operações bancárias e o comércio e levou a adulterações da moeda em vários países. Esta conduziu "a uma inflação em espiral" (Anderson, Passagens, 191).

A despeito da redução da produtividade e dos rendimentos no campo, o declínio da população levou à redução da demanda e consequentemente dos preços dos bens de subsistência. Ao contrário, o preço dos produtos artesanais e daqueles que vinham do estrangeiro aumentavam, criando um descompasso que pôs a classe dos senhores feudais em crise. Seus rendimentos decrescentes não mais sustentavam os bens de luxo de que a nobreza havia se tornado dependente:

O resultado foi um declínio nos rendimentos senhoriais, que por sua vez liberou uma onda de lutas sem precedentes enquanto os cavaleiros tentavam recuperar suas fortunas em todos os cantos com pilhagens. (...) A guerra, vocação dos cavaleiros nobres, tornou-se um negócio profissional: o serviço de cavalaria cada vez mais dava lugar aos capitães mercenários e à violência paga. Em toda parte a população civil era a vítima ${ }^{109}$ (Anderson, Passagens, 194).

O historiador inglês destaca ainda a Peste Negra, evento externo que se somou às contradições endógenas que se desenvolveram na economia medieval. Tendo dizimado algo como um quarto da população da Europa ocidental, aprofundou ainda mais a extração do excedente do produtor direto: “(...) o imposto cobrado por volta de 1400 ia em torno de dois quintos do rendimento bruto. O resultado foi uma devastadora escassez de mão de obra (...). Estes desastres acumulados desencadearam uma luta de classe desesperada pela terra" (Anderson, Passagens, 195).

Nesta luta, a primeira reação da nobreza ameaçada por dívidas e pela inflação foi a de fortalecer a servidão no campo, prendendo os camponeses ao território, além ampliar as rendas dos arrendamentos e baixar salários da plebe urbana e rural. Datam da metade do século XIV novas leis que regulamentam salários e obrigações dos trabalhadores em diversos países ${ }^{110}$. Os camponeses resistiram com diversos levantes e

\footnotetext{
109 Anderson especifica: "Na Alemanha e na Itália, esta busca dos saques numa época de escassez produziu o fenômeno do banditismo desorganizado (...). na Espanha, as mesmas pressões geravam uma guerra civil em Castela, enquanto a nobreza se dividia em facções rivais (...). Acima de tudo, a Guerra dos Cem Anos na França (...) afundou o país mais rico da Europa numa desordem e miséria sem paralelos. Na Inglaterra, o epílogo da última derrota continental na França foi o gangsterismo dos barões da Guerra das Duas Rosas" (Anderson, Passagens..., p. 194).

${ }^{110}$ O Estatuto dos Trabalhadores decretado na Inglaterra em 1349-1351 obriga os servos, acusados de indolência e avareza, a aceitarem as condições de exploração vigentes antes da Peste Negra sob pena de prisão, e "está entre os programas mais glacialmente explícitos de exploração em toda a história europeia da luta de classes. A Ordonannce francesa de 1351 basicamente repetia dispositivos semelhantes".
} 
revoltas $^{111}$, que ocorreram em territórios próximos às cidades e tiveram apoio de diferentes classes urbanas: "Muitas das cidades apoiaram ou deram assistência ativamente às rebeliões rurais de alguma forma, fosse a partir da incipiente simpatia popular da base, fosse de cálculos interessados dos patrícios acima" (Anderson, Passagens, 199). Todas as revoltas camponesas foram derrotadas, mas estas derrotas não foram capazes de evitar o deslocamento dos fatores da produção que vinha ocorrendo com a queda da produtividade, da população, as pilhagens generalizadas e as guerras, a subida dos preços dos produtos urbanos, e mesmo o aumento de salários que se impôs, a despeito das leis pela sua restrição, após a praga de doenças.

O resultado foi a dissolução da servidão. Mas se esta tem por base o esgotamento da expansão produtiva sobre a base das relações feudais, não poderia ter se dado sem o desenvolvimento da fortuna em dinheiro, que por si mesma contribui para a desagregação da forma de propriedade que caracteriza a servidão. Marx escreve:

\begin{abstract}
A fortuna em dinheiro - como fortuna mercantil -, entretanto, havia contribuído para acelerar e dissolver as antigas relações de produção e possibilitar ao proprietário de terra, por exemplo, como já expõe muito bem Adam Smith, trocar o seu cereal, gado etc. por valores de uso trazidos do estrangeiro, em lugar de desperdiçar com seus servos o produzido por ele mesmo e ver sua riqueza em grande parte na massa dos seus servos que compartilhavam o seu consumo. A fortuna em dinheiro havia conferido ao valor de troca de sua renda um significado mais elevado para ele (Grundrisse, 418).
\end{abstract}

Mas o desenvolvimento da própria fortuna em dinheiro tem por base a divisão do trabalho entre a indústria urbana e o comércio, que permite sua expansão. Esta resulta na interconexão entre as cidades, isto é, um passo na ruptura dos limites locais e em direção à formação do mercado mundial. Os primeiros passos desta formação é, de fato, anterior à disseminação das relações mercantis no interior dos feudos, ou da produção comunitária: do mesmo modo que, nas sociedades primitivas, a troca começa nas fronteiras das comunidades e entre elas, também no mundo feudal o comércio em maior escala aparece como intercâmbio entre cidades. É com a expansão de uma classe

Também as cortes de Castela e os príncipes germânicos da região da Bavária impuseram controles legais aos trabalhadores. (Anderson, Passagens, 195-6).

111 “Já em 1320 a Flandres Ocidental fora teatro de uma feroz guerra camponesa contra as extorsões fiscais (...) e dízimos de sua nobreza e Igreja locais. Em 1358, o Norte da França estava em chamas com a Grand Jacquerie (...). Em 1381, irrompeu a Revolução Camponesa na Inglaterra (...). No século seguinte foi a vez do campesinato calabrês, (...) na grande revolta de 1469-1475. Na Espanha, os servos da remença na Catalunha irromperam contra a divulgação dos 'maus costumes' impostos a eles pelos barões, e seguiu-se uma guerra civil em 1462 e outra em 1484. Estes eram apenas os maiores episódios de um fenômeno continental" (Anderson, Passagens, 196-7). 
especial de comerciantes que a renda feudal pode assumir a forma de valor de troca. Marx escreve:

Com o comércio constituído em classe especial, com a expansão do comércio por meio dos comerciantes para além dos arredores mais próximos da cidade, surgiu prontamente uma ação recíproca entre a produção e o comércio. As cidades estabeleceram ligação umas com as outras, novas ferramentas foram levadas de uma cidade para outra e a separação entre produção e comércio provocou rapidamente uma nova divisão da produção entre as diversas cidades, que passaram cada qual a explorar um ramo industrial predominante. A limitação inicial à localidade começou gradualmente a desaparecer $(I A, 55)$.

A propriedade feudal é uma forma social baseada em vínculos de obrigação pessoal, pautada na hierarquia dada pelo nascimento que se expressa na propriedade escalar da terra e na servidão. É pois um modo de produção dependente do vínculo imediato com a terra e com a comunidade, e sua produção principal é a produção agrária. Por isso, a desagregação deste modo de produção se identifica com a transformação da forma de propriedade da terra. Portanto, com a dissolução da servidão. O esgotamento do modo de produção não traz em si a necessidade da constituição do modo de produção capitalista: esta se constitui apenas porque, entre as contradições endógenas que o desenvolvimento do próprio modo de produção criou e que o levaram a um emperramento, também o comércio se desenvolveu como intercâmbio externo, ampliando as necessidades, e estabeleceu a possibilidade da renda senhorial da terra assumir a forma de valor de troca. A ampliação da produtividade no campo, a expansão do intercâmbio comercial externo e a técnica artesanal desenvolvida nas corporações são as condições que, em conjunto, permitem a desagregação da propriedade feudal no campo na forma da transformação dos produtos, dos serviços e da renda em valor de troca. Ou seja, permite uma desagregação que é ao mesmo tempo a dissolução da comunidade em geral.

O capital se define como uma mudança de forma social, ou de propriedade, oriundo da dissolução pelo desenvolvimento do modo de produção feudal, e esta mudança - o divórcio dos elementos da produção humana até então unidos - empreende uma transformação da natureza da produção social:

Quando essa separação havia atingido certo nível, a fortuna em dinheiro pôde se pôr como intermediária entre as condições objetivas da vida assim liberadas e as forças de trabalho vivas liberadas, mas liberadas também de todo vínculo e obrigação [los und ledig], e com as primeiras, comprar as últimas (Grundrisse, 419). 
O elemento subjetivo da produção, a capacidade de trabalho, com as habilidades específicas requeridas pela atividade, existe na produção tradicional e é apropriada pelo capital, ou seja, passa a se efetivar sob sua forma de relação: “(...) a outra condição do trabalho - certa habilidade, o instrumento como meio de trabalho etc. -, nesse seu período preliminar ou primeiro período, o capital já a encontra dada (...)" (Grundrisse, 415). Mas para isso, tiveram de ser desagregados a comunidade e o vínculo com a terra por meio da expropriação que constitui a propriedade privada:

O que capacita a fortuna em dinheiro a devir capital é encontrar, por um lado, os trabalhadores livres; por outro, é encontrar também os meios de subsistência e materiais etc. livres e vendáveis, os quais, de resto, de uma maneira ou de outra, eram propriedade das massas, agora privadas de objetividade $^{112}$ (Grundrisse, 415).

Assim, embora tenha já a forma da troca, a indústria artesanal não pode desenvolver-se em capital, ou ainda, não pode ser o primeiro passo desta transformação. Este primeiro passo deve ocorrer no campo porque aí reside a forma de propriedade dominante, característica do feudalismo: a troca urbana convive com a propriedade escalar da terra a corporação de ofício inclusive reproduz esta hierarquia - de modo que não foi um fator de dissolução da comunidade; ao contrário, embora na forma da troca, o artesão busca reproduzir-se como artesão. Por outro lado, o desenvolvimento do "comércio marítimo e terrestre em larga escala" impele ao desenvolvimento das manufaturas, que surgem "ali onde se produz em massa para a exportação, para o mercado exterior" (Grundrisse, 420). Seu ponto de partida não é a produção artesanal urbana, cuja escala restrita de produção e fundamento na habilidade artística não são adequadas à concentração que caracteriza o capital - mas a indústria rural acessória; estabelece-se inicialmente no campo, e não na cidade:

\begin{abstract}
A indústria rural acessória contém base ampla da manufatura, ao passo que a pequena indústria urbana exige um grande avanço da produção para poder ser explorada em escala fabril. (...) Não obstante essa mudança no campo se ponha por último em suas consequências extremas e em sua forma mais pura, é ali onde começa mais cedo. Os antigos, que nunca foram além da atividade artesanal urbana propriamente dita, consequentemente não podiam chegar à grande indústria. $\mathrm{O}$
\end{abstract}

\footnotetext{
${ }^{112}$ Marx explica a transformação do dinheiro em capital em uma famosa passagem d'O Capital: "Para extrair valor do consumo de uma mercadoria, nosso possuidor de dinheiro precisaria ter a sorte de descobrir dentro da esfera da circulação, no mercado, uma mercadoria cujo próprio valor de uso tivesse a característica peculiar de ser fonte de valor, portanto, cujo verdadeiro consumo fosse em si objetivação de trabalho, por conseguinte, criação de valor. E o possuidor de dinheiro encontra no mercado tal mercadoria específica - a capacidade de trabalho ou a força de trabalho (C, I, 1, 139).
} 
primeiro pressuposto dessa última é a inclusão do campo em toda a sua amplitude na produção, não de valores de uso, mas de valores de troca (Grundrisse, 421).

Marx afirma que o primeiro pressuposto da indústria é a transformação da produção no campo em criação de valor. Isso se dá porque, se a separação do produtor e seus meios de trabalho é condição do capital, ela deve ocorrer na produção em que se fundam as relações de produção feudais. A agricultura é base do modo de produção feudal, e é portanto na propriedade da terra que se estabelecem as relações de dependência pessoal que caracterizam a comunidade. $\mathrm{O}$ modo de produção feudal se desagrega quando a forma de propriedade da terra, em particular, se transforma. Daí Marx afirmar que é no campo que a mudança na propriedade se dá mais cedo. $\mathrm{O}$ desenvolvimento de suas consequências extremas - o pleno assalariamento e a indústria agrícola - é, contudo, tardio: os produtos que já eram presentes no comércio em larga escala - e que não poderiam ser o produto básico de alimentação da população produzido em relações comunitárias, mas sim produtos manufaturados - recebem o impulso inicial para a produção voltada à troca.

Antes mesmo da separação entre propriedade e atividade, dadas as condições de produtividade no campo, o dinheiro pôde apropriar-se da atividade do trabalho tornando o produto um valor de troca. Marx descreve o modo como se dá esta subordinação ao comércio prévia à perda de objetividade do produtor:

\footnotetext{
O modo como o dinheiro se transforma em capital com frequência se evidencia historicamente de maneira bem simples e palpável; por exemplo, o comerciante faz trabalhar para ele vários tecelões e fiandeiros que até então exerciam a tecelagem e a fiação como atividades rurais acessórias, e transforma sua atividade acessória em ocupação central para eles; desse modo, porém, ele se assenhorou deles e os colocou como trabalhadores assalariados sob o seu mando. $\mathrm{O}$ passo seguinte é deslocá-los para longe de seus lares e reuni-los em uma casa de trabalho. Nesse processo simples, fica claro que o comerciante não preparou nem a matéria-prima, nem o instrumento, nem os meios de subsistência para o tecelão e o fiandeiro. Tudo que fez foi restringi-los pouco a pouco a um tipo de trabalho, no qual se tornam dependentes da venda, do comprador, do comerciante e, por fim, só produzem para e por intermédio dele (Grundrisse, 420).
}

Nesta passagem, Marx descreve a transição para a subsunção formal do trabalho ao capital. Trata-se de uma transição fundamental: a atividade de trabalho passa a ser realizada tendo como finalidade a troca. Aí se põe a relação-capital, de separação entre a atividade produtiva e a reprodução imediata da vida comunitária. O trabalho se subsume 
à forma social do capital pela primeira vez ao se subordinar ao comércio exterior. A primeira forma da produção em que o sujeito é separado de suas condições de produção ao mesmo tempo em que estas se tornam "permutáveis como valores e, em consequência, apropriáveis até certo ponto pelo trabalho vivo" (Grundrisse, 412, citado acima) é a manufatura. Marx e Engels escrevem:

A divisão do trabalho entre as diferentes cidades teve como consequência imediata o nascimento das manufaturas, os ramos da produção que ultrapassavam o sistema corporativo. O primeiro florescer das manufaturas - na Itália e, mais tarde, em Flandres - teve como seu pressuposto histórico o intercâmbio com nações estrangeiras $(I A, 55)$.

Mas a mera separação do produtor de seus meios de subsistência, a perda de qualquer propriedade objetiva, não impõe por si só o assalariamento, ou a condição de valor de troca da atividade subjetiva. Na dissolução da servidão e da propriedade escalar no campo, que se deu de forma violenta, em guerras contra os camponeses e no interior da nobreza, criou-se o fenômeno da vagabundagem:

Com o começo das manufaturas deu-se, simultaneamente, um período de vagabundagem, causado pela dissolução das vassalagens feudais, pela dispensa dos exércitos que haviam sido formados e servido aos reis contra os vassalos ${ }^{113}$, pela agricultura melhorada e pela transformação de grandes porções de terras cultiváveis em pastagens. Por aí já se mostra como essa vagabundagem encontra-se intimamente ligada à dissolução da feudalidade. Já no século XIII sucedem-se diferentes épocas desse tipo, muito embora a vagabundagem só tenha se estabelecido de forma geral e permanente com o fim do século XV e início do XVI. Esses vagabundos, tão numerosos que o rei Henrique VIII da Inglaterra, entre outros, mandou enforcar 72 mil deles, foram forçados a trabalhar com as maiores dificuldades, em meio à mais extrema penúria e somente depois de longas resistências. O rápido florescer das manufaturas, especialmente na Inglaterra, absorveu-os aos poucos $(I A, 56)$.

A vagabundagem é expressão máxima da perda da existência objetiva dos produtores, que existem exclusivamente como meras subjetividades sem confirmação objetiva. A estes deslocados, a esta criação social, a nobreza - já imbuída dos interesses mercantis, da forma da renda como valor de troca - responde com violência, dada a ameaça que significava. Não apenas as manufaturas - a produção capitalista efetiva não alcançara desenvolvimento suficiente para tornar os vagabundos em trabalhadores assalariados, como aqueles recusavam esta disciplina nova de trabalho. Assim, ainda

\footnotetext{
${ }^{113}$ Marx se refere à constituição das monarquias absolutistas, que foi a forma política correspondente ao período de dissolução do feudalismo e de todo desenvolvimento pré-industrial do capital.
} 
que a técnica absorvida pelas casas de trabalho, modo de existência da atividade do trabalho criada pela forma capitalista, seja originária da indústria rural acessória do mundo feudal, sua disciplina é nova. $\mathrm{O}$ advento da casa de trabalho expressa por si a perda de propriedade e a dissolução da atividade que visa à reprodução comunitária. A disciplina se torna tanto mais exigente quando o produtor existe como "trabalhador sem objetivo". Marx escreve:

Os expulsos pela dissolução dos séquitos feudais e pela intermitente e violenta expropriação da base fundiária, esse proletariado livre como os pássaros não podia ser absorvido pela manufatura nascente com a mesma velocidade com que foram postos no mundo. Por outro lado, os que foram arrancados de seu modo costumeiro de vida não conseguiam enquadrar-se de maneira igualmente súbita na disciplina da nova condição (C, I, 2, 275).

Se, com o capitalismo desenvolvido, "o trabalhador pode ser confiado às "leis naturais da produção', isto é, à sua dependência do capital que se origina das próprias condições de produção, e é por elas garantida de perpetuada" (C, I, 2, 277), esta subordinação teve de ser imposta pela força. Na transição para a propriedade privada, não apenas a dissolução do pertencimento à terra, mas também a subordinação ao trabalho assalariado foi violenta:

Não basta que as condições de trabalho apareçam num pólo como capital e no outro pólo, pessoas que nada têm a vender a não ser sua força de trabalho. Não basta também forçarem-nas a se venderem voluntariamente. (...) A burguesia nascente precisa e emprega a força de Estado para "regular" o salário, isto é, para comprimi-los dentro dos limites convenientes à extração de mais-valia, para prolongar a jornada de trabalho e manter o próprio trabalhador num grau normal de dependência. Esse é um momento essência da assim chamada acumulação primitiva (C, I, 2, 277).

$\mathrm{Na}$ produção manufatureira, tanto o trabalho assalariado como o capital estão em formação, e a subsunção do trabalho é apenas formal:

A classe dos trabalhadores assalariados, que surgiu na última metade do século XIV, constituía então e no século seguinte apenas uma parte mínima da população (...). A subordinação do trabalho ao capital era apenas formal, isto é, o próprio modo de produção não possuía ainda caráter especificamente capitalista. O elemento variável do capital predominava fortemente sobre o constante (C, I, 2, 277).

Em seu desenvolvimento, a manufatura irá, no lado técnico, simplificar a atividade e especializar as ferramentas e, no lado da relação de produção, quebrar o artesanato das corporações, ampliar assalariamento e fomentar o comércio e a fortuna 
em dinheiro. Em seus começos, a atividade que primeiro será subsumida à disciplina das casas de trabalho é aquela que já apresenta, no interior da sociedade feudal, essas características técnicas e sociais: baixo grau de qualificação artesanal e liberdade frente às corporações. Marx e Engels afirmam:

Aquele trabalho que, desde o início, pressupunha uma máquina, mesmo em sua forma mais rudimentar, mostrou-se rapidamente como o mais capaz de desenvolvimento. A tecelagem, até então praticada no campo pelos camponeses como atividade acessória para obterem as vestimentas necessárias, foi o primeiro trabalho que, pela expansão do intercâmbio, recebeu um impulso e um amplo desenvolvimento. (...) A tecelagem, um trabalho que na maioria dos casos requer pouca habilidade e não demorou a se desdobrar em infinitos ramos, resistia, por sua própria natureza, aos grilhões da corporação. A tecelagem foi, por isso, exercida fundamentalmente em aldeias e vilas sem organização corporativa, que pouco a pouco se tornaram cidades e, até mesmo, não tardaram a se tornar as cidades mais florescentes de cada país $(I A, 55-6)$.

Se as relações de produção são desagregadas pela crise da sociedade feudal e pela expansão do comércio, a produção sob novas relações encontra seus pressupostos em formas de atividades e forças produtivas constituídas no campo sob a ordem feudal, portanto em condições em que a dependência da terra é ainda determinante. A transformação da relação de produção permite o avanço das forças produtivas, e não o contrário. Perry Anderson escreve:

Uma das conclusões mais importantes que permite o exame da grande queda do feudalismo europeu é que - ao contrário do que pensam os marxistas - a figura característica de uma crise num modo de produção não é aquela em que vigorosas forças (econômicas) de produção explodem triunfais através das relações (sociais) retrógradas e prontamente restabelecem uma produtividade mais alta e uma sociedade sobre ruínas. Pelo contrário: as forças de produção tendem habitualmente a paralisar e recuar no quadro das relações de produção existentes; estas, assim, devem ser radicalmente mudadas e reordenadas antes que novas forças de produção possam ser criadas e combinadas para um modo de produção globalmente novo. Em outras palavras, as relações de produção, em geral, mudam anteriormente às formas de produção numa época de transição e não vice-versa. Assim, as consequências imediatas da crise do feudalismo ocidental não foram algum surto rápido de novas tecnologias na indústria ou na agricultura; isto ocorreria apenas depois de um considerável intervalo (Anderson, Passagens, 197-8).

Na sociedade feudal desenvolvida, as relações de produção, tanto no campo como no artesanato urbano, não permitiam a concentração e tampouco a separação dos meios objetivos e subjetivos da produção, mas desenvolveram a produtividade necessária para 
que estas relações fossem quebradas pelo comércio. Se em Roma há suficiente desenvolvimento da propriedade privada e do dinheiro, mas não das forças produtivas, no mundo feudal as relações de servidão no campo, reproduzidas no patriarcalismo das corporações de ofício, excluíam o desenvolvimento do dinheiro e da propriedade privada, mas continham forças produtivas capazes de romper a dependência da terra e dos vínculos comunitários e autonomizarem-se. Não ainda, contudo, capazes de existirem como capital, já que dependem do campo. Esta mudança na forma de propriedade só ocorre sob a condição de que os produtores possam se separar da terra, que até então constituía a base da produção principal da comunidade: "Tais processos históricos de dissolução são igualmente a dissolução das relações de dependência que prendem o trabalhador ao território e ao senhor do território, mas que pressupõem de fato sua propriedade dos meios de subsistência - esse é, na verdade, seu processo de desvinculação da terra" (Grundrisse, 412). Esta separação é ao mesmo tempo o desenvolvimento de condições de produção postas pelo trabalho, e não mais naturais, como condições gerais da produção, isto é, de um salto no domínio da natureza pelo homem. Do mesmo modo, consiste na dissolução da comunidade natural fundada em vínculos pessoais e sua substituição por uma comunidade também produzida, e portanto mediada $^{114}$. Como na desagregação do mundo antigo, a dissolução do mundo feudal em capital é natural, no sentido de que provém da natureza de seu desenvolvimento. Ele desagrega a forma de propriedade feudal da terra e cria as condições do capital: amplia as fortunas mercantis e usurárias, desvincula paulatinamente o servo e o camponês livre da terra, e, mais tarde, "destrói o trabalho artesanal" (Grundrisse, 421) das corporações:

\begin{abstract}
A expansão do comércio e da manufatura acelerou a acumulação de capital móvel, ao passo que nas corporações, que não recebiam nenhum estímulo para a ampliação da produção, o capital natural permanecia estável ou até mesmo diminuía. O comércio e manufatura criaram a grande burguesia, enquanto nas corporações concentrava-se a pequena burguesia, que então já não dominava mais nas grandes cidades como antes, mas tinha de se curvar ao domínio dos grandes comerciantes e manufatureiros. Daí a decadência das corporações, tão logo entraram em contato com a manufatura (I.A., p. 57).
\end{abstract}

\footnotetext{
${ }^{114} \mathrm{O}$ tema da mediação que a comunidade capitalista opera entre o indivíduo e a natureza, mediação que deixa de ser imediata ou natural, como nas comunidades pré-burguesas, será amplamente tratada no capítulo seguinte. Trata-se, primeiro, do caráter mediado da própria sociabilidade, ou ainda, do fato de o caráter social do trabalho, uma de suas determinações fundantes, deixar de ser direto como nas relações de dependência pessoal. O trabalho passa a realizar-se de forma mediada ou indireta, e não mais pela mediação imediata da comunidade. E, segundo, de uma forma específica desta mediação: a partir de determinado nível produtivo alcançado pelo capital, o caráter social do trabalho não pode deixar de ser mediado e voltar a ser pessoal, mas pode adquirir outra forma social.
} 
Se a mudança na forma da propriedade é condição para a produção de capital, esta produção impulsiona o aprofundamento da forma da propriedade característica do capital, a propriedade privada e a relação de troca. O modo como o faz é a expansão do intercâmbio comercial. Este resume a natureza da relação-capital:

\begin{abstract}
A manufatura e, em geral, o movimento da produção experimentaram, um enorme impulso graças à expansão do comércio ocorrida com a descoberta da América e da rota marítima às Índias Orientais. Os novos produtos importados desses lugares, especialmente as grandes quantidades de ouro e prata que entraram em circulação, alteraram totalmente a posição das classes umas em relação às outras e aplicaram um duplo golpe na propriedade feudal da terra e dos trabalhadores, enquanto as expedições de aventureiros, a colonização e sobretudo a expansão dos mercados até a formação de um mercado mundial - expansão que, então, se tornara possível e realizava-se cada vez mais, dia após dia - despertaram uma nova fase do desenvolvimento histórico, fase da qual, em geral, não nos ocuparemos aqui. Mediante a colonização dos países recém- descobertos, a luta comercial entre as nações ganhou novo alimento e, nessa medida, uma extensão e uma animosidade maiores (I.A., p. 57).
\end{abstract}

Daí Marx afirmar que "a tendência de criar o mercado mundial está imediatamente dada no próprio conceito de capital" (Grundrisse, 332).

Voltarei ao tema do desenvolvimento histórico do capital em conexão com suas transformações técnicas e científicas no último capítulo. Aqui, importa destacar que esta transformação na natureza da sociabilidade põe um modo de produção que não se desintegra pelo desenvolvimento. O que torna possível a manutenção da forma de propriedade a despeito do desenvolvimento da divisão do trabalho é esta autonomização mesma da atividade e das condições de trabalho. Nela, os meios de produção encontram-se livres das necessidades imediatas do produtor individual e da reprodução da comunidade. Por um lado, é característica desta liberdade a expansão do intercâmbio comercial. Mas esta não existe desligada do desenvolvimento da divisão do trabalho, que por sua vez é expressão do desenvolvimento de novas forças produtivas. Por outro lado, a relação de troca pressupõe a superação de qualquer dependência pessoal ou vínculo de obrigação determinado comunitariamente, e incorpora ao valor de troca o poder da relação social, tornando os indivíduos, autonomizados de sua existência objetiva, indiferentes. Marx escreve:

A dependência recíproca e multilateral dos indivíduos mutuamente indiferentes forma sua conexão social. Essa conexão é expressa no valor de troca, e somente nele a atividade própria ou o produto de cada indivíduo devêm uma atividade ou produto para si; o indivíduo tem de 
produzir um produto universal - o valor de troca, ou este último por si isolado, individualizado, dinheiro. De outro lado, o poder que cada indivíduo exerce sobre a atividade dos outros ou sobre as riquezas sociais existe nele como proprietário de valores de troca, de dinheiro. Seu poder social, assim como seu nexo com a sociedade, [o indivíduo] traz consigo no bolso. A atividade, qualquer que seja sua forma de manifestação individual, e o produto da atividade, qualquer que seja sua qualidade particular, é o valor de troca, i.e., um universal em que toda individualidade, peculiaridade, é negada e apagada. Na verdade, essa é uma situação muito distinta daquela em que o indivíduo, ou o indivíduo natural ou historicamente ampliado na família ou tribo (mais tarde, comunidade), reproduz-se diretamente com base na natureza ou em que sua atividade produtiva e sua participação na produção são dependentes de uma determinada forma do trabalho e do produto, e sua relação com os outros é determinada da mesma forma (Grundrisse, 105).

Como exposto, as sociedades pré-capitalistas se dissolvem a partir do desenvolvimento produtivo porque este desenvolvimento implica transformações na divisão do trabalho, que se complexifica quando surge nova atividade. Nas comunidades em que as relações de propriedade são postas pela própria atividade produtiva, ou seja, estão vinculadas às necessidades imediatas do produtor e que, por isso mesmo, são estabelecidas como vínculos de dependência pessoal, novas formas de atividade que dividem de modo novo o trabalho social alteram naturalmente as formas de propriedade. Em qualquer modo de produção, "Troca e divisão do trabalho condicionam-se mutuamente" (Grundrisse, 106). Mas quando a propriedade não é mais posta pela atividade produtiva, mas existe desvinculada dela, liberada da necessidade de reprodução da comunidade ou de seus membros nas condições tradicionais de dependência pessoal, o desenvolvimento da divisão do trabalho não é mais capaz de alterar a forma de propriedade. Ao contrário, cada novo desenvolvimento produtivo, atividade nova que divide o trabalho de modo mais complexo, apenas repõe a separação entre a propriedade e trabalho, cria novas bases para esta separação. A produção capitalista tem por resultado novo capital:

Tão logo o capital e o trabalho assalariado são postos como seu próprio pressuposto, como base pressuposta da própria produção, a questão se apresenta primeiramente de tal modo que o capitalista, além dos fundos de matéria-prima e meios de trabalho necessários para o trabalhador se reproduzir, produzir os meios de subsistência necessários, i.e., realizar o trabalho necessário, possui um fundo de matéria-prima e meios de trabalho em que o trabalhador realiza o seu trabalho excedente, i.e., o lucro do capitalista. Em uma análise mais detida, a questão se configura de tal forma que o trabalhador cria constantemente um duplo fundo para o capitalista, ou na forma do capital, uma parte do qual satisfaz continuamente as condições de sua própria existência e a outra, as condições de existência do capital (Grundrisse, 414). 
Esse processo em que o capital, ao desenvolver a divisão do trabalho, o faz na forma da expansão de capital (criação de novo capital excedente), determina a reposição das relações de produção capitalistas, a propriedade separada da atividade, o trabalhador como mera subjetividade oposta ao capital e portanto sem existência objetiva, isto é, o indivíduo como determinado por esta relação:

\begin{abstract}
A produção de capitalistas e trabalhadores assalariados, por conseguinte, é um produto principal do processo de valorização do capital. A Economia corrente, que só tem olhos para as coisas produzidas, esquece isso completamente. Tendo em vista que, nesse processo, o trabalho objetivado é simultaneamente posto como não objetividade do trabalhador, como objetividade de uma subjetividade contraposta ao trabalhador, como propriedade de uma vontade que lhe é estranha (...) (Grundrisse, 422).
\end{abstract}

Esta condição de dissociação é reposta a cada nova produção capitalista, de modo que a relação de produção se complexifica na medida do desenvolvimento da divisão do trabalho, mas este não a dissolve. Ao contrário, aprofunda esta forma de propriedade, generalizando-a:

Tendo constatado, assim, que a transformação do dinheiro em capital pressupõe um processo histórico que separou as condições objetivas do trabalho, que as autonomizou em relação ao trabalhador - o efeito do capital assim originado e do seu processo é o de submeter a si toda produção, desenvolver e efetivar em todos os lugares o divórcio entre trabalho e propriedade, entre o trabalho e as condições objetivas do trabalho (Grundrisse, 421).

O capital é esta forma da propriedade que, a partir da separação entre o trabalho vivo e suas condições objetivas, realiza contudo a concentração de trabalho vivo e condições de produção em escala muito maior. Esta concentração se fundamenta na condição de valor de troca que as condições e a capacidade de trabalho adquirem ao se dissociarem. Dissociação que tem na própria ampliação das relações de troca seu impulso. Como uma relação específica de produção, o capital não pode senão reorganizar os elementos da produção pré-existentes. A privação de objetividade em que uma massa de indivíduos se encontra a partir da dissolução das relações de produção feudais concentra esses objetos - meios de subsistência e de produção - como uma massa de objetividade sem objetivo, isto é, na forma de valor de troca. É isto que capacita estes objetos a reunirem em torno de si uma massa correspondente de trabalho vivo:

A fortuna em dinheiro não inventou nem produziu a roda de fiar e o tear. Mas, separados de sua terra, os fiandeiros e tecelões caíram com seus teares e rodas de fiar sob o domínio da fortuna em dinheiro etc. Próprio do capital é unicamente a união das massas de mãos e instrumentos que 
ele encontra. Ele os aglomera sob seu comando. Essa é sua verdadeira acumulação; a acumulação de trabalhadores, juntamente com seus instrumentos, em certos pontos (Grundrisse, 417).

Esta acumulação é a forma pela qual a produção capitalista impulsiona a universalização da produção, e portanto do homem. A concentração, ou aumento da escala da produção empreendido pela produção para troca, impulsiona a divisão do trabalho.

O capital forma rapidamente um mercado interno ao destruir todas as atividades rurais acessórias, ou seja, fiando e tecendo para todos, vestindo a todos etc., em suma, põe as mercadorias antes criadas como valores de uso imediatos na forma de valores de troca, um processo que resulta por si mesmo da separação dos trabalhadores da terra e da propriedade das condições de produção (mesmo que seja na forma de servidão) (Grundrisse, 421-2).

"Fiar e tecer para todos", "vestir a todos" é ao mesmo tempo a universalização da produção: cada atividade visa um círculo amplo, e crescente, da sociedade, rompendo o limite da produção comunitária. De modo que cada sujeito se vincula a "todos" os outros. Além disso, a universalização se realiza por meio do desenvolvimento da divisão do trabalho, uma vez que aquele que, por exemplo, fia para todos passa a depender de todos aqueles que produzem os meios de satisfação do conjunto de suas outras necessidades, à exceção do fio. A universalização da produção que é ao mesmo tempo aprofundamento da divisão do trabalho depende da concentração de trabalhadores, na medida em que a ampliação da escala da produção está na base da "fiação para todos". Por essa razão, o desenvolvimento produtivo resultante da concentração se funda na separação entre propriedade e atividade; por conseguinte, na produção para troca, ou de valores de troca, ou seja, no aprofundamento da forma de propriedade capitalista. Concentrar e dividir o trabalho são momentos do desenvolvimento de uma mesma relação de produção.

Em sua análise do movimento dialético em que as comunidades pré-capitalistas se dissolvem no movimento de manutenção das relações que as caracteriza, e que se coloca também na desagregação do modo de produção feudal que origina as condições da produção capitalistas, aparecem aspectos da conceituação marxiana de força produtiva. A maior ou menor tendência ao intercâmbio externo e à divisão do trabalho é o que determina o percurso de dissolução das relações de produção comunitárias. A ampliação do intercâmbio, ao introduzir novas necessidades e atividades, conduz 
naturalmente ao desenvolvimento da divisão do trabalho e da propriedade privada. Por isso, é o motor da ampliação das forças produtivas, e pode-se dizer que, neste processo, se identifica com ela. A complexificação da divisão do trabalho se manifesta tanto em novos modos de produzir, novas técnicas, como no desenvolvimento subjetivo de novas necessidades, formas novas de disciplina da subjetividade que as atividades introduzidas requerem, novas linguagens, novas formas de consciência e desenvolvimento da sensibilidade. Força produtiva significa este desenvolvimento que acontece simultaneamente, por um lado, na atividade e no intercâmbio, portanto na conformação subjetiva dos indivíduos e em suas relações, por outro, na natureza objetiva que o conjunto das atividades produtivas e do intercâmbio humano altera. A modificação na “(...) natureza humana geral de tal modo que ela alcance habilidade e destreza em determinado ramo de trabalho" (C, I, 1, 142) constitui-se como desenvolvimento de força produtiva. Esta só existe, portanto, em forma dupla, como sujeito e objeto. Uma vez que o movimento de ampliação das forças produtivas é dado na expansão do intercâmbio humano, a própria comunidade constitui a primeira força produtiva:

\footnotetext{
A própria comunidade aparece como a primeira grande força produtiva; para o tipo particular das condições de produção (por exemplo, pecuária, agricultura) desenvolvem-se modos de produção e forças produtivas particulares, tanto subjetivas, aparecendo como atributos dos indivíduos, quanto objetivas (Grundrisse, 406).
}

Mas também, como Marx aponta ao conceber o estágio mais elevado da sociabilidade pós-capitalista, como "o desenvolvimento universal dos indivíduos e a subordinação de sua produtividade coletiva, social, como seu poder social" (Grundrisse, 106, citado acima). A força produtiva central, em qualquer nível histórico de desenvolvimento produtivo, é o indivíduo em seu intercâmbio social, o indivíduo social. Isso porque a força produtiva não é uma entidade objetiva autônoma, mas um predicado do trabalho, "forças produtivas dos sujeitos que trabalham" (Grundrisse, 406). As forças produtivas, objetivas ou subjetivas, e dentre as objetivas a combinação do trabalho, são sempre forças produtivas dos sujeitos que trabalham, e por isso consiste em uma força do trabalho social, não no poder de coisas. Mas sobretudo porque o produto central de cada forma de sociabilidade é o indivíduo determinado que cria, e que desaparece com a forma social à qual corresponde:

Esse desenvolvimento do trabalho produtivo, que necessariamente resulta do intercâmbio com estrangeiros, escravos, do desejo de trocar produto excedente etc., dissolve o modo de produção 
sobre o qual a comunidade se baseia e, em consequência, o indivíduo singular objetivo, i.e., o indivíduo singular determinado como romano, grego etc. (Grundrisse, 406).

As mudanças na forma de propriedade, ou, o que é o mesmo, a dissolução da comunidade tal como existe pela ampliação da divisão do trabalho, estão ligadas ao caráter imediato da mediação que a comunidade realiza na apropriação individual da terra. Este caráter natural da mediação comunitária se expressa nos vínculos de dependência pessoal entre os indivíduos - que os fazem grego, romano, vassalo de determinado condado etc. - e na dominação direta do trabalhador, posto como servo ou escravo entre as condições inorgânicas da produção. A dominação direta e a dependência pessoal, como formas naturais, mais ou menos desenvolvidas, da sociabilidade são os fatores que determinam a tendência à dissolução das relações de produção nas sociedades pré-capitalistas. Como cada desenvolvimento na divisão do trabalho representa um aprimoramento de força produtiva, cada avanço produtivo implica nova distribuição das condições de produção e portanto nova forma de propriedade. Por conseguinte, a cada nível produtivo correspondem formas determinadas de relações sociais de produção:

Um nível determinado do desenvolvimento das forças produtivas dos sujeitos que trabalham, ao qual correspondem relações determinadas dos sujeitos entre si em com a natureza - nisso se resolve, em última instância, tanto sua comunidade quanto a propriedade fundada sobre ela. Até certo ponto, reprodução. Em seguida, converte-se em dissolução (Grundrisse, 406).

Esta dialética, que determina que as relações de propriedade características da comunidade se dissolvam conforme a reprodução amplie suas bases, não se aplica às relações capitalistas de produção senão de modo mediado ${ }^{115}$. É exclusiva das sociedades em que o baixo nível de domínio da natureza põe os indivíduos em um vínculo natural com a terra e com a comunidade. A ruptura dos limites locais da comunidade, desencadeada pelo intercâmbio com outras comunidades (seja por meio da guerra ou do comércio), implica por si mesma a transformação nas relações de propriedade. $\mathrm{O}$ desenvolvimento das formações sociais pré-capitalistas é movido pela reprodução da comunidade ou dos indivíduos na condição de membros da comunidade. A relaçãocapital empreende uma transformação na finalidade da produção social:

\footnotetext{
${ }^{115}$ Esta mediação é posta por Marx como necessidade revolucionária. Como se verá, a transformação das relações capitalistas em um novo modo de produção que é ao mesmo tempo um novo estágio do desenvolvimento histórico, não se daria espontânea ou naturalmente, por meio de "metamorfoses silenciosas" (Grundrisse, 106, citado acima) como nos modos predecessores, mas exigiria a mediação da consciência e da vontade dos sujeitos.
} 
Nunca encontraremos entre os antigos uma investigação sobre qual forma de propriedade da terra é mais produtiva, qual cria a maior riqueza. A riqueza não aparece como finalidade da produção, embora Catão naturalmente possa examinar qual cultivo do campo é o mais rentável, ou até Brutus possa emprestar seu dinheiro aos melhores juros. A investigação é sempre sobre qual modo de propriedade cria os melhores cidadãos. A riqueza só aparece como fim em si mesma entre os povos mercantis - monopolistas do comércio de carga - que vivem nos poros do mundo antigo, assim como os judeus na sociedade medieval (Grundrisse, 399).

A universalização da produção humana levada a cabo pelas relações capitalistas de produção, em razão da modificação que opera na natureza da riqueza/relação de produção, ao contrário de dissolvê-las, desenvolve a forma de propriedade que define o capital. Todos os fatores que fazem com que as relações de produção pré-burguesas tendam à dissolução pelo desenvolvimento - propriedade fundada na atividade com mediação natural ou imediata da comunidade, ou seja, propriedade como pertencimento a uma comunidade, correspondente ao estágio em que as condições de produção são ainda pressupostos naturais, onde a agricultura é a atividade principal - devem, por conseguinte, ter sido já historicamente superados para que o capitalismo se ponha.

A dissolução em capital (Grundrisse, 416) da forma de propriedade feudal também se realiza dialeticamente de modo natural, ou seja, pelo desenvolvimento espontâneo: "A estrutura econômica da sociedade capitalista proveio da estrutura econômica da sociedade feudal. A decomposição desta liberou os elementos daquela" (C, I, 2, 262). Estes elementos são os polos da relação capitalista de produção, o capital oposto ao trabalho assalariado:

A relação-capital pressupõe a separação entre os trabalhadores e a propriedade das condições de realização do trabalho. Tão logo a produção capitalista se apoie sobre seus próprios pés, não apenas conserva aquela separação, mas a reproduz em escala sempre crescente (C, I, 2, 262).

Além disso, a universalização da produção coincide com o próprio desenvolvimento da riqueza. Marx escreve:

De fato, porém se despojada da estreita forma burguesa, o que é a riqueza senão a universalidade das necessidades, capacidades, fruições, forças produtivas etc. dos indivíduos, gerada pela troca universal? [O que é senão o] pleno desenvolvimento do domínio humano sobre as forças naturais, sobre as forças da assim chamada natureza, bem como sobre as forças de sua própria natureza? [O que é senão a] elaboração absoluta de seus talentos criativos, sem qualquer outro pressuposto além do desenvolvimento histórico precedente, que faz dessa totalidade do desenvolvimento um fim em si mesmo, i.e., do desenvolvimento de todas as forças humanas com 
tais, sem que sejam medidas por um padrão predeterminado? [O que é senão um desenvolvimento] em que o ser humano não se reproduz em uma determinabilidade, mas produz sua totalidade? Em que não procura permanecer como alguma coisa que deveio, mas é no movimento absoluto do devir? (Grundrisse, 399-400).

A riqueza é definida por Marx como o conjunto de capacidades, necessidades e possibilidades dos indivíduos. Mas a riqueza só se identifica imediatamente com a universalização se "despojada de sua forma burguesa". A forma burguesa é uma forma específica da universalização, pautada no desenvolvimento da divisão do trabalho e, por conseguinte, na troca universal. Esta forma é historicamente necessária pois a concentração das forças produtivas humanas não pode derivar diretamente da produção de valor de uso que visa a reprodução do modo de vida ou do presente. A forma-capital desta concentração é necessária porque apenas pode se originar de uma fortuna já autonomizada, mediada pela forma universal de dinheiro - e a autonomização do produto do trabalho em relação ao trabalho vivo é o que define o capital. Esta fortuna, por sua vez, tem como condição a produção de excedente para troca, certo desenvolvimento das forças produtivas expressos pela economia urbana. Por ser necessária, não deixa de ser uma forma específica da universalização, sua primeira forma histórica. Forma que carrega sua estreiteza:

\footnotetext{
“(...) as relações de dominação e servidão (...) constituem o fermento necessário do desenvolvimento e do declínio de todas as relações de propriedade e relações de produção originais, bem como expressam sua estreiteza. Entretanto, elas são reproduzidas no capital - de forma mediada - e, desse modo, constituem igualmente o fermento de sua dissolução e são emblemas de sua estreiteza" (Grundrisse, 411).
}

A estreiteza reside na forma específica de dominação do trabalho que, não obstante seja mediada, não deixa de se pôr como dominação. O fundamento dessa dominação mediada pela troca - “(...) o capital não se apropria do trabalhador, mas de seu trabalho - não diretamente, mas pela mediação da troca” (Grundrisse, 409) - é a separação entre atividade produtiva e suas condições objetivas; esta dissociação consiste, contudo, na própria condição de expansão do domínio da natureza e da universalização que a produção capitalista promove. Marx sintetiza a comparação entre o modo de produção do capital e os modos precedentes:

Nessa comunidade é pressuposta a existência objetiva do indivíduo singular como proprietário, digamos, por exemplo, como proprietário de terra, mas pressupostas sob certas condições que o acorrentam à comunidade, ou melhor, que constituem um elo de sua corrente. Na comunidade 
burguesa, o trabalhador, por exemplo, está presente de modo puramente não objetivo, subjetivo; mas a coisa que se defronta com ele deveio a comunidade verdadeira que ele procura devorar e pela qual é devorado (Grundrisse, 407).

O sentido da diferença entre a dependência pessoal e a independência pessoal baseada em uma dependência coisal está expresso nesta passagem. No primeiro estágio do desenvolvimento histórico, o indivíduo é imediatamente dado na comunidade, a existência individual pouco se distingue de sua vinculação objetiva com a natureza e da generalidade da comunidade. No segundo, o indivíduo deixa de estar aderido à natureza como condição de subsistência e rompe os elos comunitários, distinguindo-se subjetivamente da generalidade da comunidade. O caráter genérico da comunidade deixa de existir nos indivíduos e se coloca ao lado deles como coisa, como seu produto, que por ser posto como não propriedade, o enfrenta como capital. A universalização da produção se dá na forma da subordinação dos indivíduos com relação a seu produto social comum, porque esta comunidade, sendo produto dos indivíduos livres em suas relações de produção, não se põe neles, mas como coisa exterior.

O ser humano só se individualiza no processo histórico. Ele aparece originalmente como um ser genérico, ser tribal, animal gregário - ainda que de forma alguma como zoon politikon em sentido político. A própria troca é um meio essencial dessa individuação. Ela torna o sistema gregário supérfluo e o dissolve. Logo a coisa se altera de tal modo que, como individualizado, ele se relaciona mais consigo mesmo, mas os meios para se pôr como individualizado se converteram em seu meio de se fazer universal e comum (Grundrisse, 107).

O salto no processo de universalização, que coincide com a ampliação das forças produtivas e da riqueza, não pode deixar de ser um salto no processo de individuação, uma vez que a liberação das condições de produção relativamente à necessidade imediata dos produtores faz com que a reprodução dos indivíduos não dependa mais da reprodução da comunidade. Os indivíduos se libertam de seu caráter gregário e se tornam pessoalmente independentes: sua dependência recíproca muda de forma, tornase dependência do produto social na forma de uma objetividade separada, e sob essa forma cada indivíduo é dependente de um círculo cada vez maior da produção social, e se coloca por isso em um intercâmbio cada vez mais universal. Intercâmbio que, contudo, não é direto, não se dá diretamente entre os indivíduos, mas pela mediação do produto social universal, do valor de troca. $\mathrm{O}$ impulso à divisão do trabalho que esta mediação traz consigo é o que determina a possiblidade da individuação, já que tira o indivíduo da conexão imediata com a comunidade. Ao mesmo tempo, este caráter 
mediado é próprio da universalização. Mas o fato desta mediação tomar a forma de coisa, tornando a comunidade (a interdependência ou vínculo social) um objeto separado do sujeito, é específico desta primeira forma histórica da humanidade universal. Esta se caracteriza por um salto no domínio humano sobre a natureza objetiva ao qual não corresponde um domínio similar sobre "sua própria natureza". Tampouco promove a "elaboração absoluta de seus talentos criativos" como "um fim em si mesmo" mas apenas mediante "um padrão predeterminado", que é o valor. Devido à divisão do trabalho, mantém o ser humano reproduzindo-se "em uma determinabilidade", e não em "sua totalidade". Nesta forma social, o trabalhador assalariado apenas busca a sua reprodução, ou seja, "procura permanecer como alguma coisa que deveio" e não pode se impulsionar ao "movimento do devir". A forma burguesa impõe um limite à ampliação da riqueza.

\footnotetext{
Na economia burguesa - e na época de produção que lhe corresponde -, essa exteriorização total do mundo humano aparece como completo esvaziamento; essa objetivação universal, como estranhamento total, e a desintegração de todas as finalidades unilaterais determinadas, como sacrifício do fim em si mesmo a um fim totalmente exterior. Por essa razão, o pueril mundo antigo, por um lado, aparece como o mais elevado. Por outro, ele o é em tudo que busca a forma, a figura acabada e a limitação dada. O mundo antigo representa a satisfação de um ponto de vista tacanho; ao passo que o moderno causa insatisfação, ou, quando se mostra satisfeito consigo mesmo, é vulgar (Grundrisse, 400).
}

O modo de produção capitalista é ainda uma forma social que se desenvolve natural ou espontaneamente, de sorte que as relações de produção que a caracterizam, embora inaugurem uma forma de mediação não imediata, e portanto efetivamente social, com pressupostos já postos pelo trabalho, são ainda naturais. Se as forças produtivas humanas desenvolvidas sob tais relações superam o caráter natural ou imediato ao dominar a natureza (a ponto de promover a liberdade em relação à terra), as próprias relações não o são. Mas as relações de produção são a forma social da apropriação da natureza - imediata ou transformada em mundo humano. A ausência de domínio das relações de produção, que se mantém no capitalismo, implica a ausência de domínio sobre as próprias forças de produção, isto é, das forças que permitem o domínio da natureza objetiva. Daí este segundo grande estágio do desenvolvimento humano compor ainda a pré-história humana, em que os indivíduos ainda não exercem o controle de suas próprias forças. Por outro lado, se a forma social não permite que os indivíduos controlem sua própria força produtiva, esta força mesma é condição 
suficiente para a ruptura com as relações ainda naturais e o estabelecimento de relações sociais superiores, isto é, que permitam a apropriação das forças produtivas do gênero pelos indivíduos. O domínio sobre a própria relação de produção, pressuposto para o controle das forças produtivas, é identificado por Marx com a criação de uma sociedade sem classes. Esta dissolução das relações, contudo, já não pode mais ser espontânea e natural, por duas razões: a primeira delas é que não existe, na forma de propriedade que caracteriza o capital, a tendência à desagregação pelo desenvolvimento. Marx escreve:

Mas no âmbito da sociedade burguesa, da sociedade baseada no valor de troca, geram-se tanto relações de intercâmbio como de produção que são tantas outras minas para fazê-la explodir. (Uma massa de formas antitéticas (gegensätzlicher Formen - formas opostas) da unidade social cujo caráter antitético (gegensätzlicher Charakter - caráter antagônico), todavia, jamais pode ser explodido por meio de metamorfoses silenciosas. Por outro lado, se não encontrássemos veladas na sociedade, tal com ela é, as condições materiais de produção e as correspondentes relações de intercâmbio para uma sociedade sem classes, todas as tentativas para explodi-las seriam quixotadas) (Grundrisse, 107).

O caráter contraditório da unidade social capitalista "jamais pode ser explodido por metamorfoses silenciosas", como foram as formas sociais pré-capitalistas. A burguesia não é, como os cavaleiros medievais, uma classe fadada ao desaparecimento. Isto pelo lado objetivo do desenvolvimento da forma social. A segunda razão é que uma sociedade conscientemente controlada pelos indivíduos não pode se estabelecer sem que os próprios indivíduos tenham consciência da necessidade de uma tal transformação social, da necessidade de controlar a própria atividade e força produtiva. Estes são os dois imperativos da necessidade revolucionária: um modo de produção que não tende a desaparecer e cuja superação é necessariamente o estabelecimento de um controle consciente da produção social pelos indivíduos, de relações não mais naturais mas postas pelos indivíduos, o que demanda sua finalidade e vontade conscientes.

No próximo capítulo, busco desenvolver a natureza desta relação de independência pessoal baseada na dependência coisal examinando o trabalho abstrato. Ele corresponde à mediação que não é mais a mediação imediata da comunidade, natural, mas no qual a sociedade é uma mediação da atividade do indivíduo, por um lado, não mais natural, por outro, abstrata. A categoria de trabalho abstrato está na base da compreensão da relação entre a atividade individual e a produção social no modo de produção capitalista, em que a universalização e consequente ampliação sem precedentes da riqueza material se desenvolve na forma de um "esvaziamento 
completo" ou "estranhamento total" no que diz respeito ao indivíduo. No capítulo seguinte, busco indicar aspectos da transformação que o modo capitalista de produção opera na relação entre trabalho e conhecimento. 


\section{TRABALHO ABSTRATO COMO FORMA SOCIAL DA ATIVIDADE HUMANA}

\section{A "abstração real” de Ruy Fausto: trabalho abstrato como universal concreto}

Neste capítulo, busco explicar a forma que o trabalho assume no interior das relações capitalistas de produção, uma forma nova correspondente a um nível de socialização que rompe com a localidade e tende à universalidade. O modo capitalista de produção tem, como todo modo de produção, uma história. Ao analisar a relação social que o caracteriza, suponho, com Marx, sua forma desenvolvida, em que a riqueza se põe como uma "imensa coleção de mercadorias" e que corresponde a um amplo desenvolvimento da divisão do trabalho expressa na grande indústria e no mercado mundial. $O$ desenvolvimento histórico do capital e o modo como esta forma social determina a técnica e o conhecimento serão abordados no capítulo seguinte. Aqui, trata-se do modo como esta forma social determina o trabalho. O objetivo é examinar a natureza da relação de valor no interior da sociedade que cria no trabalho um duplo caráter. Viso, pois, especialmente a categoria de trabalho abstrato.

Começo com uma polêmica com Ruy Fausto, que se dedicou à compreensão desta categoria discutindo com posições assumidas pela tradição marxista. O problema gira em torno da definição que Marx dá ao trabalho abstrato, de que depende toda a compreensão do capital desenvolvida em sua obra magna.

Em "Abstração real e contradição: trabalho abstrato e valor"116, o autor se propõe a "estudar o teor lógico dos conceitos de trabalho abstrato e de valor" (Fausto, LP I, 89), e começa com uma crítica às leituras vulgares do texto de Marx que compreendem o trabalho abstrato como o trabalho em geral. Fausto parte do fato de que a abstração que caracteriza o trabalho criador de valor é uma abstração real. Para ele, as leituras vulgares que ingenuamente identificam o trabalho abstrato com a generalidade do trabalho incluem autores como Hilferding: "Por não ter uma concepção bem rigorosa da natureza da abstração que constitui o trabalho abstrato, Hilferding desliza frequentemente na ideia de simples generalização" (Fausto, LP I, 124, nota 6). Além de uma contraposição às leituras vulgares, Fausto busca ainda criticar o texto de

\footnotetext{
${ }^{116}$ Fausto, Ruy, Marx: Lógica e Política - Investigações para uma reconstituição do sentido da dialética - Tomo 1. São Paulo: Brasiliense, 1983, pp. 89-138. Doravante, LP I, seguido do número da página.
} 
Castoriadis em que o autor se opõe ao conceito de valor de Marx, mas defende o valortrabalho dos clássicos: "Valor, igualdade, justiça, política: de Marx a Aristóteles e de Aristóteles a nós", do qual destacamos algumas das passagens centrais no primeiro capítulo deste trabalho.

Marx afirma que o trabalho produtor do valor é aquele cujas determinações concretas foram abstraídas, e que portanto é trabalho indiferenciado. Nas leituras vulgares, essa igualdade dos trabalhos sem qualidades individuais é compreendida como o gênero trabalho, que abrange as várias espécies de trabalhos concretos. O trabalho abstrato se identifica, então, com o trabalho em geral. De acordo com Fausto, esta identificação faz recair a categoria de trabalho abstrato em uma concepção de trabalho como mero gasto fisiológico de energia: o que os trabalhos concretos têm de imediatamente igual é o dispêndio de energia que exigem, o gasto das funções do organismo humano $^{117}$. Ou ainda, determinam que a abstração do trabalho seja uma representação subjetiva das determinações comuns às diversas atividades. Assim, a compreensão do trabalho abstrato como gênero do trabalho "ou nos remete ao nível fisiológico (o trabalho abstrato como gasto fisiológico de músculos, nervos etc.) ou nos condena a uma subjetivação do conceito (o trabalho abstrato como a representação abstrata do trabalho em geral)" (Fausto, LP I, 89). Nesta compreensão, o trabalho abstrato não se distingue das demais abstrações que acontecem no nível da representação. Fausto se propõe a caracterizar esta abstração específica que tem não apenas um teor próprio, na medida em que é objetiva, mas uma especificidade histórica. Não há espaço para dúvida sobre o caráter real da abstração do trabalho:

\begin{abstract}
A abstração do trabalho é para Marx uma abstração real; isto está escrito literalmente no seguinte texto do capítulo I da Contribuição à Crítica da Economia Política: "Para medir os valores de uso das mercadorias pelo tempo de trabalho que elas contêm, é preciso que os diferentes trabalhos, eles próprios, sejam reduzidos a um trabalho não diferenciado, uniforme, simples, em resumo um trabalho que seja qualitativamente o mesmo e só se diferencie quantitativamente. Esta redução aparece como uma abstração, mas é uma abstração que se realiza todos os dias no
\end{abstract}

\footnotetext{
${ }^{117}$ Esta identificação do trabalho que cria valor com o trabalho em geral caracteriza o limite da economia política clássica. A produção de valor pelo conjunto dos trabalhos sociais é baseada em igualdade da espécie, que portanto vê o valor como produto natural do trabalho humano em geral. Na medida em o trabalho, sem mais especificações, produz valor, todo produto humano é naturalmente também um valor. O dispêndio de energia física na criação de um produto determina a natureza de valor do produto - em Smith, o valor de um produto se mede pela dose de incômodo e fadiga que custa a um indivíduo obtê-lo, de modo que dispêndio físico e capacidade de criar valor não se distinguem no trabalho. O que as leituras vulgares não apreendem é a especificidade da teoria marxiana do valor, que se dirige precisamente contra esta generalização.
} 
processo de produção social. A resolução de todas as mercadorias em tempo de trabalho não é uma abstração maior nem ao mesmo tempo menos real (keine grössere Abstraktion aber (...) keine minder reele) do que a resolução em ar de todos os corpos orgânicos". Mas a partir daí se propõem vários problemas, alguns dos quais reabrem o dossiê das leituras vulgares (Fausto, LP I, 90).

Ruy Fausto explicará o caráter real ou objetivo da abstração do trabalho definindo o trabalho abstrato como um "universal concreto". Seu raciocínio parte das seguintes questões:

Qual a relação que existe entre a ideia de abstração real e a ideia de generalidade (pois, embora sabendo que a primeira não se confunde com a simples generalidade, não é menos verdade que a ideia de generalidade não está ausente)? E a partir daí se propõe de novo a questão: como pensar a relação entre objetividade da abstração (...) e o tipo de objeto ao qual parecem remeter os textos em que se trata da realidade fisiológica do trabalho em geral (gasto de músculos, nervos etc.)? (Fausto, LP I, 91)

O trabalho abstrato não se identifica com trabalho em geral, mas isso não impede que uma de suas determinações seja a generalidade, quer dizer, que ele seja também trabalho em geral. Fausto inquire a relação entre a generidade do trabalho, definida como a igualdade fisiológica do dispêndio de energia orgânica, que faz parte do trabalho abstrato mas não o define, com a objetividade da abstração. $\mathrm{O}$ autor responde que a igualdade fisiológica que define o gênero trabalho não é a abstração, mas seu pressuposto natural:

A generalidade em sentido fisiológico (não mais do que a generalidade abstrata e subjetiva) retomamos o problema num nível mais elevado - não constitui o trabalho abstrato: ela é apenas a realidade natural pressuposta (à posição) deste. A realidade social faz com que valha o que era apenas uma realidade natural (Fausto, $L P I, 91-2)$.

Há um processo social que tornará efetiva uma igualdade natural que, embora deva estar presente como pressuposta, apenas é posta no nível social e se torna efetiva mediante este processo. O problema é como Ruy Fausto explica este processo social. Na sequência de seu texto, lemos:

E que a abstração do trabalho em sentido fisiológico não pode constituir o trabalho abstrato, é visível pelo fato de que lhe falta o momento da singularidade. A identidade do trabalho no nível fisiológico é a unidade dos trabalhos (fisiologicamente) idênticos. Cada trabalho considerado no nível fisiológico é igual ao outro, mas cada um é um trabalho (e além disso trabalho de alguém). Com efeito, seria impossível dizer que só existe, lá, um trabalho, ao menos que os tome no nível 
da representação. Ora, essa unidade pode (e deve) ser atribuída ao trabalho abstrato. Ele é uma unidade (mesmo se, como diz Marx, esta unidade está 'constituída por inúmeras forças de trabalho individuais'. Aqui a pluralidade é segunda) (Fausto, LP I, 92).

Antes de tudo, é preciso pôr em questão esta identidade fisiológica natural: se por um lado todos os indivíduos despendem energias físicas e mentais no trabalho, por outro, a fadiga de cada um é distinta, em vista de diferentes constituições, estados de saúde, durações da vida, necessidades específicas, por exemplo. Fisiologicamente, os indivíduos, em seus desgastes de cérebro, músculos etc. diferem mais do que o valor que seus distintos produtos criam, este sim absolutamente idêntico.

Em segundo lugar, o trabalho abstrato aparece nesta passagem como unidade. É o que faz dos múltiplos trabalhos apenas um, a unidade das singularidades. O que difere a unidade do trabalho abstrato da unidade fisiológica é que esta última não comporta singularidades, é imediata e efetivamente a mesma em todas as atividades singulares neste nível, os trabalhos são efetivamente idênticos -, enquanto o trabalho abstrato é a unidade que comporta as singularidades reduzindo-as à unidade. Se o dispêndio fisiológico de energia é imediatamente igual em todos os trabalhos singulares, a abstração reduz a multiplicidade à igualdade, de modo que a singularidade é prevista nesta equalização. A abstração não é a generalidade, porque não existe apenas no nível de representação, mas na realidade efetiva, é abstração real. Ela se faz real mediante um dado processo social, que equipara as singularidades. Mas resta ainda explicar como, por meio de que processo social põe-se o trabalho abstrato real, distinto do trabalho em geral? Nesta passagem, temos apenas uma afirmação de que a unidade fisiológica é imediata, e de que o trabalho abstrato é uma unidade que comporta os diversos trabalhos. Por que o trabalho abstrato não é apenas generalidade (representação) e como ele realiza esta unidade dos trabalhos fazendo valer uma igualdade natural pressuposta?

\footnotetext{
Dizer que a abstração do trabalho não se confunde com a simples generalidade "trabalho" não quer dizer que a primeira exclua toda generalidade. Na realidade, as abstrações reais "trabalho" e "valor" põem a generalidade. Ou antes, elas põem a universalidade, mas esta universalidade é generalidade posta. O "geral" se torna universal singular, universal concreto. Por enquanto, limitamo-nos a citar a esse respeito um texto do capítulo 1 de $O$ Capital, na versão da primeira edição da obra. Trata-se de um texto sobre a forma do valor, mas o que ele diz vale também, como veremos, para o trabalho abstrato (Fausto, LP I, p. 91).
} 
O trabalho abstrato põe a generalidade, ou seja, torna efetivo o trabalho em geral que existe apenas como realidade natural pressuposta na igualdade fisiológica imediata, por meio de um dado processo social. Esta generalidade, ao pôr-se, torna-se universalidade. A diferença entre generalidade e universalidade não é explicada, mas aparece referida em nota a uma distinção estabelecida por Hegel. Fausto cita Hegel, para distinguir o universal do geral:

Como afirma Hegel, "é da maior importância, tanto para o conhecimento como também para nosso comportamento prático, que aquilo que é simplesmente comum (das bloss Gemeinschaftliche) não seja confundido com o que é verdadeiramente geral, universal (mit dem wahrhaf Allgemeinen, dem Universellen)" ${ }^{\prime 18}$.

O autor comenta adiante, também em nota, esta passagem:

Os termos alemães allgemein, Allgemeinheit são traduzidos geralmente, em seu uso filosófico, hegeliano em particular, por "universal”, “universalidade”. Mas eles significam também "geral”, “generalidade". Como vimos acima, Hegel emprega também Universell, para designar o "verdadeiro universal", em oposição a gemeinschaftlich, o que é simplesmente comum (Fausto, $L P I, 124$, nota 6$)$.

Assim, Fausto parece assumir uma distinção hegeliana segundo a qual o geral é o "simplesmente comum”, ou seja, o que há de comum nos múltiplos que compõem um gênero, e portanto se aproxima da generalidade como representação, visto que não existe na efetividade; e o geral verdadeiro, o universal, algo específico que ao mesmo tempo incorpora a universalidade (de algo, de algum objeto ou do homem, por exemplo), e que por isso deve existir para além da representação que abstrai o simplesmente comum. Independente do que seja este universal em Hegel (ele não está tratando do trabalho, mas da categoria lógica), esta distinção entre o comum abstraído e o verdadeiro universal será base para a conceituação de trabalho abstrato por Fausto. Para este autor, o trabalho abstrato não é a generalidade porque não é o simplesmente comum a todos os trabalhos - para Fausto, sua igualdade no nível fisiológico - mas um universal. Um universal, contudo, concreto e singular, portanto efetivo, por meio do qual o "geral" existe. No trabalho abstrato, "o 'geral' se torna universal singular, universal concreto". Assim, o caráter real das "abstrações reais 'trabalho' e 'valor" é

118 Hegel, Enzyklopadie der philosophischen Wissenschäften in Grundrisse (1830), Erster Teil, Die Wissenchaft der Logik..., par. 163, Zusatz I, in Werke, 8, Berlin, Suhrkamp, p. 312; Enciclopédie des Sciences Philosophique, I, La Science de la Logique, ed. Bernard Bourgeois, Paris, Vrin, 1970, par. 163, adition I, p. 592, apud Fausto, LP I, 124, nota 4. 
sua existência concreta na efetividade, como um ser objetivo e singular. Do mesmo modo que a forma do valor, a mercadoria-dinheiro, tem uma existência sensível (singular) ao lado das demais mercadorias, também o trabalho abstrato teria esta existência efetiva ao lado dos trabalhos concretos. Sobre a passagem de Marx em que se baseia esta definição do trabalho abstrato como "universal concreto", Fausto afirma:

\footnotetext{
Trata-se de um texto sobre a forma do valor, mas o que ele diz vale também, como veremos, para o trabalho abstrato: "Na forma III, que é a segunda forma invertida e que está portanto contida nela, a tela aparece pelo contrário como a forma genérica (Gattungsform) do equivalente para todas as mercadorias. É como se ao lado ou além dos leões, tigres, lebres e todos os animais efetivamente reais, que agrupados constituem as diferentes raças, espécies, subespécies, famílias etc. do reino animal, existisse também o Animal, encarnação individual de todo o reino animal. Tal indivíduo (ein solches Einzeln) que compreende em si mesmo todas as espécies efetivamente existentes da mesma coisa é um Universal (ein Allgemeines), como por exemplo Anima, Deus etc." Estamos pois diante de uma universalidade (Allgemeinheit) que é ao mesmo tempo singularidade (Fausto, LP I, 91).
}

Do fato de que o dinheiro é uma mercadoria singular que incorpora o valor de todas as outras, e portanto é mercadoria universal que existe na efetividade em uma forma singular, sensível, como uma mercadoria específica ao lados das demais, Fausto conclui que o trabalho abstrato é um universal que incorpora em si todas as atividades concretas de trabalho e existe também como singularidade, ou seja, em um ser singular efetivo que incorpora o conjunto dos trabalho múltiplos concretos. A questão é: que o dinheiro, como forma universal do valor separada das mercadorias e incorporada em uma delas, possa ser chamado de "universal concreto" no sentido que Fausto discrimina, não é algo difícil de compreender; mas estender esta definição, por analogia, ao trabalho abstrato, que seria então o universal concreto dos trabalhos concretos, demanda explicação. Qual é este singular em que a universalidade do trabalho abstrato se põe?

O texto de Ruy Fausto continua afirmando a ideia de que a posição da abstração na realidade a distingue da abstração no nível fisiológico, mais do que isso, que esta posição - definitiva do trabalho abstrato - é o que faz com que valha a igualdade natural a ele pressuposta; mas mantém duas questões em aberto, propondo-se a desenvolvê-las adiante: em primeiro lugar, qual é o processo social que põe o trabalho abstrato? E derivada desta questão, qual o conteúdo social desta unidade universal dos múltiplos trabalhos que se distingue de sua unidade fisiológica? Em segundo lugar, qual é o singular em que esta unidade se incorpora? Definir esta singularidade do trabalho 
abstrato é fundamental para sustentar sua caracterização como um "universal concreto", tal qual o dinheiro é em referência ao conjunto das mercadorias.

Nesta primeira parte do texto, Fausto levanta outras questões, algumas das quais abordo adiante. Mas quando volta ao problema da definição do trabalho abstrato, na segunda parte do texto dedicada ao tema, vemos que não há uma explicação das razões que fazem valer o raciocínio de Marx acerca da relação entre mercadoria e dinheiro $(O$ Animal, que representa o ouro, ao lado dos leões, lebres etc., que representam as mercadorias singulares tecido, casaco etc.) para a relação entre trabalho concreto e trabalho abstrato, ou entre valor de uso e valor, que sustentaria sua definição do trabalho abstrato como universal concreto. A analogia não é óbvia, porque dinheiro e mercadorias têm a mesma natureza de valor de troca, e o advento do dinheiro é resultado necessário do desenvolvimento da mercadoria, que muito cedo já não pode mais prescindir dele. Ao passo que o trabalho abstrato não tem a mesma natureza do trabalho concreto, nem o valor a mesma natureza do valor de uso, de sorte que não se pode afirmar sem mais justificativas que a partir de um dado ponto do desenvolvimento do trabalho concreto e dos valores de uso, estes não poderiam mais prescindir do trabalho abstrato e do valor.

Ao retomar o tema da abstração real, Fausto parte do problema da contrariedade na relação entre trabalho abstrato e trabalho concreto, bem como entre valor e valor de uso, propondo investigar em que sentido estas categorias são opostas:

Marx diz do trabalho ${ }^{119}$ que ele é o contrário (Gegenteil) ou o contrário imediato (umittelbares Gegenteil) ou o oposto (Gegensatz) do trabalho concreto, e do valor ele diz que este é o contrário do valor de uso. Os críticos põem em dúvida o rigor desta determinação. Ela seria efetivamente rigorosa? Percebe-se imediatamente que dizer que o trabalho abstrato é o contrário (ou o contrário imediato) do trabalho concreto (e que o valor é o contrário do valor de uso) não tem muito sentido se não se pensar o trabalho e o valor como universais concretos. Se não se introduzir a universalidade concreta, como legitimar a ideia de oposição? (Fausto, LP I, 97).

Fausto começa por observar o que a relação entre trabalho abstrato e trabalho concreto, e entre valor e valor de uso, não é. Primeiro, um não pode ser mero gênero do

\footnotetext{
${ }^{119}$ Pode ter sido um mero erro de revisão, mas aqui o trabalho abstrato, que deve distinguir-se do trabalho em geral, aparece apenas como trabalho. Mas pode não ter sido, porque, como veremos, por mais que a intenção inicial de Fausto seja demonstrar que o trabalho abstrato é categoria que se distingue do trabalho em geral, a argumentação que se segue fará do trabalho abstrato o gênero trabalho, com a especificidade de existir também como singularidade.
} 
outro. Fausto escreve que "O gênero não é o contrário da espécie: ele apenas subsume a espécie, e não se poderia afirmar que esta subsunção constitui uma relação de contrariedade" (Fausto, LP I, 97). Tampouco tais categorias - o trabalho abstrato e o trabalho concreto, o valor e o valor de uso - podem ser categorias meramente diferentes. Isto levaria a que estas categorias fossem indiferentes uma à outra e não se constituiriam em uma relação; tampouco, por conseguinte, em uma oposição. Fausto delimita então positivamente a relação de oposição entre estas categorias:

Tudo muda, se se pensar o trabalho abstrato (e também o valor) como universal concreto, isto é, como um objeto que contém ao mesmo tempo a singularidade e a universalidade. Nesse caso, e nesse caso somente, se poderá falar em contrariedade. Vejamos isto mais de perto. Para simplificar, tomemos a relação entre dinheiro e mercadoria (em que se reflete, como vimos, a mesma oposição) (Fausto, LP I, 98).

Primeiramente, propor-se a simplificar a explicação quando se busca demonstrar o teor lógico do trabalho abstrato, categoria central para a compreensão da teoria do valor e do capital em Marx, não faz jus ao rigor de leitura anunciado. Mas bem mais importante que isso: não vimos em nenhum momento do texto como a oposição entre trabalho abstrato e trabalho concreto, ou entre valor e valor de uso, se reflete na oposição entre dinheiro e mercadoria. Ao contrário, o autor comprometera-se a explicar esta analogia: "Trata-se de um texto sobre a forma do valor, mas o que ele diz vale também, como veremos, para o trabalho abstrato" (Fausto, LP I, 91, citado acima, grifo meu).

Seu texto continua, então, simplificando o argumento, com a demonstração de que a mercadoria $e$ o dinheiro não são coisas meramente diferentes, para então justificar em que sentido eles são contrários:

Poder-se-ia dizer que o dinheiro e a mercadoria são coisas simplesmente diferentes? Não. Diferentes, simplesmente, são por exemplo mercadorias quaisquer, umas em relação às outras: a tela em relação ao casaco, para retomar o exemplo clássico, (e isto somente quando uma não funcionar como expressão do valor da outra). Mas na relação entre o dinheiro e a mercadoria há mais do que isto: há entre os dois uma espécie de tensão. Eles se atraem mutuamente, cada um deles repele a si próprio, mas por isso mesmo eles podem entrar em conflito (nas crises). E como justificar logicamente a afirmação de que se trata de contrários? Eles são contrários porque por um lado um é o gênero do outro: o dinheiro é a mercadoria geral ou universal; mas porque ao mesmo tempo esse gênero existe ao lado das espécies e dos indivíduos que o compõem: o dinheiro é também uma mercadoria. É essa dupla condição de gênero e de indivíduo, de indivíduo-gênero, que faz da coisa social dinheiro o contrário de cada mercadoria. É pois essa 
dupla condição que constitui objetivamente a tensão entre dois objetos e permite falar legitimamente de contrariedade ou de oposição entre eles (Fausto, LP I, 98).

Fausto afirma, primeiro, que há uma tensão entre o dinheiro e a mercadoria expressa no fato de que eles se atraem e repelem mutuamente. Por isso, não são meramente diferentes. Mas isto não os põe ainda como contrários, a atração e repulsão recíproca não caracteriza a contrariedade. O que os faz opostos é o fato de que, sendo o dinheiro o gênero da mercadoria, existe também como uma mercadoria singular. É essa dupla condição de "indivíduo-gênero, que faz da coisa social dinheiro o contrário de cada mercadoria", ou seja, a oposição só existe porque o gênero existe objetivamente como um singular. Esta existência singular, e por isso objetiva, do gênero é o que caracteriza o dinheiro como universal concreto. Esta oposição, assim explicada, reflete a oposição entre trabalho abstrato e trabalho concreto, ou valor e valor de uso, e acaba por defini-la. Teríamos, então, que o trabalho abstrato não é apenas diferente do trabalho concreto, mas se opõe a ele; isto devido ao fato de que o trabalho abstrato é gênero do trabalho concreto, o trabalho concreto universal, mas não gênero somente existente na representação: o trabalho abstrato se define por essa dupla condição, de gênero que existe como singular ao lado dos singulares. Mas não há tal trabalho que é ao mesmo tempo o trabalho universal e existe como um trabalho concreto singular ao lado de todos os outros. O principal problema da interpretação de Fausto é que ele ainda entende o trabalho abstrato como gênero dos trabalhos concretos, embora não apenas gênero. "Tudo muda, se se pensar o trabalho abstrato (e também o valor) como universal concreto, isto é, como um objeto que contém ao mesmo tempo a singularidade e a universalidade (Fausto, LP I, 98, citado acima).". O trabalho abstrato existe como singularidade de algum modo que não se explicita, visto que a analogia com o dinheiro não cabe.

A oposição entre mercadoria e dinheiro reflete ainda, segundo o autor, a que existe entre o valor de uso e o valor. Com isso, Fausto assume que o valor é gênero do valor de uso, embora não mero gênero: gênero que existe nessa dupla-condição de universal e singular. Do fato de que o dinheiro é o universal da mercadoria, pode-se deduzir que o valor é o universal do valor de uso?

Ao definir o trabalho abstrato como universal concreto, Fausto não escapa da interpretação desta categoria como gênero dos trabalhos concretos. O autor busca distinguir a universalidade do trabalho abstrato (e do valor) das abstrações comuns, que 
são meras representações, e da unidade natural imediata dos trabalhos, para explicá-la como uma abstração real, específica porque posta. Nas passagens citadas, este caráter objetivo da abstração do trabalho é explicado por sua dupla condição de gênero e indivíduo, o universal concreto. O lado da singularidade é referido apenas como a singularidade do dinheiro frente às demais mercadorias. O caráter de universalidade também é explicado pelo caráter universal do dinheiro frente às mercadorias: o dinheiro é a mercadoria universal. Fausto pressupõe que a oposição entre dinheiro e mercadoria deve refletir a oposição entre trabalho abstrato e trabalho concreto, que não é abordada diretamente, mas por analogia, do mesmo modo que a oposição entre valor de uso e valor. Assume-se, pois, que o trabalho abstrato é o trabalho concreto universal e o valor é o valor de uso universal. Fausto reitera sua visão, acerca da oposição dinheiromercadoria, que vale para aquelas relações:

\footnotetext{
(Observemos de passagem que, se Marx utiliza uma terminologia que não elimina a expressão do gênero: trabalho abstrato, valor - oposto a valor de uso - etc. (...) é porque ele quer exprimir que o gênero está "lá", embora como universal singular.) Esta coincidência entre o universal e o individual, Marx assinala claramente nos textos citados (“o animal ao lado do leão" etc.): é como se o universal invadisse o particular, de onde a tensão, que estaria ausente se se tratasse só do gênero ou só do indivíduo (Fausto, LP I, 98).
}

Em suma, o trabalho abstrato é gênero do trabalho concreto, valor é gênero do valor de uso, mas gênero que existe como "universal singular", do mesmo modo que "o animal ao lado do leão". Busco mostrar adiante, primeiro, que dos textos de Marx de modo algum se pode deduzir que o valor é o valor de uso universal, ou o trabalho abstrato, o trabalho concreto universal, uma vez que isto atribui a mesma natureza a essas categorias. Em segundo lugar, que sua contrariedade não advém do fato de que o gênero (trabalho abstrato, valor) existe também como um singular ao lado das espécies e indivíduos que subsume. Antes de tudo, porque tal singularidade não existe: se há uma mercadoria universal-singular, não há um trabalho concreto universal-singular, ou um valor de uso universal-singular. Proponho-me também a distinguir as relações entre mercadoria e dinheiro, por um lado, e trabalho abstrato e trabalho concreto, valor e valor de uso, por outro.

$\mathrm{Na}$ passagem em que Fausto analisa o texto de Marx sobre o fetichismo da mercadoria, no primeiro capítulo d'O Capital, a realidade da abstração será vista em sua posição. Esta posição da abstração pelo processo social não aparecerá mais em uma 
singularidade. A tese central de Ruy Fausto em sua interpretação sobre "O caráter de fetiche da mercadoria e seu segredo" é a de que a "abstração do trabalho" está presente em todas as sociedades, como um pressuposto. Como o trabalho abstrato é uma determinação do trabalho específica do capitalismo, Fausto o explica afirmando que esta abstração apenas é posta no modo de produção atual. Vale seguir seu texto:

Depois de ter observado que enquanto valor a mercadoria se apresenta como um objeto misterioso, Marx se pergunta de onde vem esse caráter misterioso da mercadoria, que será precisamente a origem do fetichismo. Esse mistério, responde Marx, não pode provir do conteúdo das determinações do valor, a saber, nem da abstração do trabalho, pois em todas as sociedades o trabalho considerado abstratamente oferece interesse, nem do tempo de trabalho, por razões mais ou menos idênticas, nem da forma social (geral) do trabalho ${ }^{120}$ (Fausto, LP I, 103).

Como veremos, em seu texto, Marx não coloca a "abstração do trabalho", termo que aliás não utiliza, entre as determinações do conteúdo do valor. Mas o que ora importa é que, ao ler entre as determinações que constituem o conteúdo do valor (e não sua forma) a abstração do trabalho, Fausto identifica novamente o trabalho em geral ao trabalho abstrato:

E para mostrar que o caráter misterioso vem da forma mercadoria, Marx compara a produção de mercadorias com outras formas de produção. Assim, ele se referirá sucessivamente a Robinson isolado na sua ilha, ao feudalismo, à "indústria patriarcal de uma família camponesa" e ao socialismo. Em cada um desses casos, ele mostrará o papel do trabalho em geral, e do tempo de trabalho, seja na planificação da produção, seja na distribuição, seja nos dois ao mesmo tempo (Fausto, LP I, 103).

De fato, Marx mostra o papel do tempo de trabalho nas várias formas sociais a que se refere, e do trabalho em geral na medida em que se refere às múltiplas funções concretas da atividade do indivíduo, da família ou da sociedade em cada formação específica. Mas o ponto central é precisamente que este tempo de trabalho, ou o caráter geral do trabalho no limite em que exista nessas sociedades, não é trabalho abstrato, não existe na forma da abstração.

Fausto escreve que: "em todos os casos, o trabalho considerado, fazendo-se abstração da sua particularidade, desempenha um papel etc.” Assim, a abstração do

\footnotetext{
${ }^{120}$ Por "forma social (geral) do trabalho", Fausto está se referindo, como Marx, ao fato de que os homens sempre trabalham uns para os outros. No texto de Marx: "Finalmente, tão logo os homens trabalham uns para os outros de alguma maneira, seu trabalho adquire também uma forma social" (C, I, 1, 70).
} 
trabalho existe em outros modos de produção como o simplesmente comum, que Hegel distinguia do Universal, mera representação do trabalho em geral, portanto como gênero dos trabalhos concretos. A abstração do trabalho aparece em Fausto entre as determinações do conteúdo do valor. Assim, o que há de específico nesta forma não é que o tempo de trabalho aparece na produção de mercadorias como uma abstração, mas esta igualdade dos trabalhos, presente em todas as formas sociais e portanto conteúdo natural do trabalho, apenas é posta na produção da mercadoria. É preciso explicar, primeiro: se a abstração está presente em qualquer forma em que há trabalho e em que o tempo de trabalho importa ao próprio produtor em algum grau, qual a diferença entre trabalho em geral e trabalho abstrato? Fausto responde: apenas sua posição. Mas então, qual a especificidade desta posição, qual o processo social que a realiza?

Fausto cita Castoriadis e Balibar que, embora com objetivos distintos - o primeiro de demonstrar uma incoerência lógica no texto de Marx, o segundo de "salvar" sua teoria - afirmam que o trabalho abstrato e o valor estão presentes em todas as sociedades e são pressupostos da produção. Castoriadis identifica toda e qualquer forma do intercâmbio humano com a troca e o trabalho medido pelo tempo como trabalho que cria valor:

O valor já estava lá, a partir do momento (dès) em que houve troca. Mas há sempre troca, onde há sociedade - inclusive no "comunismo primitivo": o feiticeiro fornece suas encantações e recebe uma parte da caça. Se se ousa dizer, há troca mesmo "antes" da sociedade -, em todo caso, segundo Marx, há valor para Robinson, só que para ele é "transparente": "como bom inglês" (o que significa: como homo oeconomicus "racional'), ele faz o "inventário detalhado" do tempo de trabalho que lhe custam em média quantidades determinadas dos seus diversos produtos... Aí estão contidas todas as determinações essenciais do valor. E a mesma coisa valerá para a sociedade comunista futura, esta "reunião de homens livres trabalhando com meios de produção comuns... segundo um plano deliberado. Tudo o que dissemos do trabalho de Robinson se reproduz aqui, mas socialmente e não individualmente"

Balibar lê no texto de Marx sobre o fetichismo da mercadoria a necessidade do trabalho abstrato como pressuposto da divisão do trabalho, e não como seu resultado. Por essa razão, acredita que Marx acaba por assumir a mesma concepção que critica na economia clássica, que é precisamente a generalização do trabalho abstrato a todas as formas sociais, como forma natural do trabalho:

\footnotetext{
${ }^{121}$ Oeuvres, Éconimie I, p. 611-613 - Castoriadis, Les Carrefours du Labyrinthe, p. 264-265, grifado por Castoriadis; apud Fausto, LP I, 104.
} 
(...) Toda essa variação [a comparação entre a produção de mercadorias e os outros modos - RF] pressupõe com efeito (bem longe de explicar a sua constituição) a representação do trabalho abstrato como existência natural, evidente, de um "trabalho em geral", do qual os diferentes ramos da divisão do trabalho só realizam formas particulares; exatamente o que, algumas linhas mais adiante, a propósito de Franklin e de Ricardo, o próprio Marx assinala uma vez mais como o limite ideológico intransponível da economia política ${ }^{122}$.

Fausto tem toda a razão quando afirma que esses autores enganam-se inteiramente. Não veem o que há de específico no valor e no duplo caráter do trabalho criador de mercadoria - no caso de Castoriadis, não vê sequer a diferença entre troca e outras formas de intercâmbio - e identificam imediatamente o trabalho abstrato ao trabalho em geral, mesmo que isto custe sustentar que Marx escreve incoerências.

De acordo com Fausto, o erro de ambos foi não ter atentado para uma passagem que é a chave para a compreensão deste aparente contrassenso, qual seja, entre a afirmação de que o duplo caráter do trabalho é uma determinação específica da produção capitalista, de sorte que trabalho abstrato e valor apenas existem nesta forma social, ao mesmo tempo que afirma que todas as determinações do valor, inclusive, segundo Fausto, a "abstração do trabalho" estão presentes no trabalho em todas as sociedades. Após afirmar que Castoriads e Balibar "não se saem bem diante deste texto" de Marx, o autor escreve:

E a explicação do fracasso não é difícil. Digamos que a pedra na qual eles tropeçam é a frase (...): 'E entretanto aí estão contidas todas as determinações essenciais ao valor' (...) Nessa frase se resume toda a dificuldade. É que é preciso compreendê-la da seguinte maneira: aí estão contidas todas as determinações essenciais do valor, menos a posição. Este é o sentido do conjunto do texto: mostrar que em todos os modos as determinações do valor, isto é, as determinações do seu conteúdo (tempo de trabalho, abstração do trabalho) estão presentes, mas que falta a posição objetiva dessas determinações: e quando falta a posição, não há valor nem trabalho abstrato (Fausto, LP I, 105).

Assim, embora a abstração do trabalho esteja presente nas considerações do tempo de trabalho pelos produtores nas sociedades não-capitalistas, como uma determinação do conteúdo do valor, não se põe como trabalho abstrato: "O valor não existe nem no comunismo, nem no caso de Robinson, nem na família patriarcal, nem na Idade Média, nem em nenhum dos casos em que não há troca" (Fausto, LP I, 105). Para o autor,

${ }^{122}$ E. Balibar, Cinq Études du Matérialisme Historique, Maspero, 1974, p. 2015, grifado por Balibar, apud Fausto, LP I, 105. 
críticos como Castoriadis e Balibar não são capazes de compreender o modo como Marx define as categorias porque estão presos à tradição kantiana. Marx se distingue de Kant porque inclui na definição das categorias a sua posição, o modo como existe de fato. O filósofo iluminista, ao contrário, não distingue o objeto posto de seu conceito: embora saiba que a existência se distingue da definição, as determinações de ambas são idênticas, pois o fato de algo ser não acrescenta nada às determinações de seu conceito. Fausto cita uma longa passagem da Crítica da Razão Pura, com a qual fecha não só a crítica a Castoriadis e Balibar, mas sua resolução do problema da abstração real em Marx. De acordo com Kant,

\begin{abstract}
Ser não é evidentemente um predicado real (kein reales Prädikat), isto é, um conceito de alguma coisa (von irgend etwas) que se possa acrescentar ao conceito de uma coisa (eines Dinges). É simplesmente a posição (Es ist bloss die Position) de uma coisa ou de certas determinações nelas mesmas (an sich selbst). (...) Quando eu concebo uma coisa, quaisquer que sejam e por numerosos que sejam os predicados por meio dos quais eu a concebo (mesmo na determinação completa), o fato de que eu acrescento que esta coisa é não acrescenta nada à coisa. ${ }^{123}$
\end{abstract}

Fausto distingue esta concepção do conceito em relação a seu objeto para Kant, daquela assumida por Marx:

Vê-se que em Kant é preciso separar as determinações de um conceito e a sua existência ou a sua posição, sendo a posição exterior às suas determinações. Para Hegel e Marx, pelo contrário, o conjunto das determinações não esgota o conceito. Mesmo plenamente determinado, o conceito

\footnotetext{
${ }^{123}$ A passagem inteira citada por Fausto é a que se segue: "Ser não é evidentemente um predicado real (kein reales Prädikat), isto é, um conceito de alguma coisa (von irgend etwas) que se possa acrescentar ao conceito de uma coisa (eines Dinges). É simplesmente a posição (Es ist bloss die Position) de uma coisa ou de certas determinações nelas mesmas (an sich selbst). Em seu uso lógico, ele não é senão a cópula de um juízo (...). Se eu tomar o sujeito (Deus) com todos os seus predicados (entre os quais está incluída a onipotência) e se eu disser: Deus é, ou há Deus, eu não ponho (setzen) nenhum predicado ao conceito de Deus, mas eu ponho (setzen) o sujeito em si mesmo (an sich selbst), com todos os seus predicados, e ao mesmo tempo, com efeito, o objeto que corresponde ao meu conceito. Os dois devem conter exatamente a mesma coisa; e pelo fato de que (pela expressão: ele é) eu concebo o seu objeto como absolutamente dado, nada mais se pode acrescentar ao conceito que exprime simplesmente a sua possibilidade. E assim o real não contém nada mais do que o simples possível. Cem talers reais não contém nada mais do que cem talers possíveis. Pois como os talers possíveis exprimem o conceito e os talers reais o objeto e sua posição (Position) em si mesmo, se este contivesse mais do que aquele, meu conceito não exprimiria o objeto inteiro, e em consequência, não seria tampouco o conceito adequado àquele. Mas no que se refere ao estado de minha fortuna, há mais com cem talers reais do que só com o seu conceito (isto é, só com a possibilidade). Com efeito, o objeto na realidade não está simplesmente contido de uma maneira analítica no meu conceito, mas se acrescenta sinteticamente ao meu conceito (que é uma determinação do meu estado), sem que os cem talers concebidos sejam de modo algum aumentados por esse ser situado fora do meu conceito. Quando eu concebo uma coisa, quaisquer que sejam e por numerosos que sejam os predicados por meio dos quais eu a concebo (mesmo na determinação completa), o fato de que eu acrescento que esta coisa é não acrescenta nada à coisa" (Kant, Kritik der Reinen Vernunft, "Die tranzendentale Dialektik. Von der Unmöglichkeit eines ontologischen Beweises vom Daseis Gottes", Hamburgo: Felix Meiner, 1956, pp. 572-573; Critique de la Raison Pure, trad. Barni revista por P. Archambaut, Granier-Flamarion, 1976, pp. 478-479; apud Fausto, LP I, 105-6).
} 
não é ele próprio se não for posto. Ora, essa relação é impensável tanto para Balibar quanto para Castoriadis (Fausto, LP I, 106).

Sua comparação com o texto de Kant mostra que Fausto entende o trabalho abstrato como conceito que existe em todas as sociedades. Como conceito, o trabalho abstrato não se distingue do trabalho em geral, ou seja, do gênero dos trabalhos concretos. Mas o próprio trabalho abstrato distingue-se de seu conceito quando existe na realidade efetiva. Fausto escreve:

\footnotetext{
Com efeito, no texto de Marx, há algo de escandaloso: Marx supõe que a posição da coisa - e a posição da coisa é a existência (social) da coisa - é essencial para que ela seja o que é. Para que o "valor" (tempo de trabalho, trabalho como generalidade abstrata) seja valor (ou o "trabalho abstrato" seja o trabalho abstrato), é essencial que, além dessas determinações, haja posição, ou que essas determinações sejam determinações postas, socialmente existentes. No socialismo, no caso de Robinson etc., as determinações essenciais do valor estão dadas, mas falta a posição objetiva dessas determinações, porque em todos esses casos elas só existem como representação - na cabeça de Robinson, dos planificadores (ou como resultado dessa representação, mas não como coisas sociais). Esta é a razão pela qual, em nenhum dos dois casos, se trata de valor nem de trabalho abstrato (Fausto, LP I, 105).
}

Assim, o conceito de valor e de trabalho abstrato existe em todas as formas sociais do trabalho mas apenas enquanto representação. $\mathrm{O}$ conceito de trabalho abstrato não se distingue, por isso, do gênero, é mera generalidade abstrata e, em consequência, o conceito de valor o define como gênero dos trabalhos concretos. Tais conceitos são referidos por Fausto como valor entre aspas e trabalho abstrato entre aspas. Mas apenas na sociedade mercantil estes gêneros dos trabalhos concretos e dos valores de uso se tornam reais, efetivos, são postos. Nesta posição, contudo, os conceitos se transformam, pois, diferentemente de Kant, em Marx um conceito não exprime integralmente o objeto, de modo que quando o objeto existe, sua posição acrescenta algo que não estava presente no conceito. Mas então, como exprimir em conceito, ou representar mentalmente, um objeto existente? $\mathrm{O}$ efetivamente existente deve poder ser representado conceitualmente. Se a posição passa a fazer parte do que a coisa é ao mesmo tempo em que não estava presente no conceito, ela deve alterar algo no próprio conceito. Por isso, há o "trabalho abstrato" (conceitual e válido para todas as sociedades) e o trabalho abstrato efetivamente existente. Em que eles se distinguem, ou seja, como o trabalho abstrato real se distingue do mero trabalho em geral, da representação do simplesmente comum que define seu conceito antes de sua posição? 
Embora não a retome nesta passagem, Ruy Fausto já dera esta resposta no início do texto. Ao se pôr na realidade, o conceito de trabalho abstrato se torna algo mais que seu conceito, isto é, ganha determinações: deixa de ser mero gênero, e passa a se definir como "universal concreto". Parece haver, pois, duas definições de trabalho abstrato: quando ele efetivamente se põe, quando existe, ele é universal concreto, antes de se pôr, era generalidade abstrata. Vira universal concreto porque se põe. Em que se põe este universal? Na singularidade, do mesmo modo que a mercadoria se põe universalmente no dinheiro (mercadoria singular ouro) como o Animal ao lado dos leões, lebres etc. Quando se põe, o valor é um universal concreto do próprio valor de uso, do mesmo modo que o trabalho abstrato é um universal concreto dos trabalhos concretos, portanto são o gênero, postos em um singular que faz parte do gênero. Primeiro, seria necessário identificar este singular. Segundo, mesmo que se considere que faz parte do valor e do trabalho abstrato efetivos a sua posição, seria necessário explicar sua distinta natureza social - que se distingue da mera generalidade - e, especialmente demonstrar o processo social por meio do qual estas abstrações se põem na efetividade.

O trabalho abstrato e o valor reais são gêneros efetivamente existentes em uma singularidade não identificada de modo positivo, mas deduzida a partir de uma questionável analogia com a forma do valor. Ao fim e ao cabo, o trabalho abstrato e o valor, mesmo postos, são gêneros dos valores de uso e dos trabalhos concretos. Mesmo que Ruy Fausto afirme que "Esse caráter misterioso só pode vir da própria forma mercadoria. (Aqui, “forma”, diga-se de passagem, não é a forma fenomenal, como por exemplo na forma de valor, mas forma no sentido de forma social específica oposta ao conteúdo antropológico geral)" (Fausto, LP I, 103), a especificidade desta forma, por qual processo social ela põe o trabalho como abstrato e seu produto como valor, desaparecem na ideia de generalidade pressuposta: o gênero dos trabalhos concretos, quando se põe, é trabalho abstrato, o gênero dos valores de uso, quando se põe, é valor.

Volto aos textos de Marx para criticar esta concepção de Ruy Fausto acerca do trabalho abstrato. Pretendo mostrar: 1) que a demonstração de Marx que conclui que o dinheiro é a mercadoria universal em uma mercadoria singular, de modo algum se aplica ao valor em relação ao valor de uso, nem ao trabalho abstrato em relação ao trabalho concreto, não apenas pela ausência da singularidade, mas porque são de naturezas distintas, ao passo que mercadoria e dinheiro têm a mesma natureza; 2) que a abstração do trabalho não faz parte das determinações do conteúdo do valor; 3) que 
valor não é gênero do valor de uso, nem trabalho abstrato é gênero do trabalho concreto; 4) que a própria igualdade fisiológica dos trabalhos, assim como o trabalho em geral como representação, são produtos históricos: a igualdade fisiológica não é natural e primeira, mas se depreende da igualdade jurídica; do mesmo modo que o trabalho em geral, como representação, resulta desta equiparação; 5) que o trabalho abstrato e o valor são formas sociais, sua natureza é uma relação social; e finalmente, 6) que esta forma social põe o trabalho em geral, mas não se identifica com ele.

\section{Duplo caráter do trabalho e natureza do valor como forma social}

Ruy Fausto desenvolve seu texto com a finalidade de demonstrar que o trabalho abstrato é real, ou seja, existe efetivamente na realidade, de modo que se distingue do trabalho em geral, isto é, da abstração do simplesmente comum aos múltiplos trabalhos efetivos. Recorre a Hegel, para quem esta generalidade abstrata se distingue do verdadeiramente universal, embora não explicite como se define o universal em Hegel, questão aliás muito complexa. Ainda assim utiliza esta distinção para demonstrar que o trabalho abstrato, como universal efetivamente existente, ou concreto, distingue-se da mera generalidade. Não se distingue pelo seu conteúdo diverso, mas sim porque existe na realidade efetiva. De modo que, em Fausto, o universal concreto é a generalidade posta: “A expressão 'as abstrações objetivas põem a universalidade' de certo modo faz um curto-circuito, pois quer dizer 'nas abstrações objetivas a generalidade é posta e enquanto tal se torna universalidade"” (Fausto, LP I, 124, nota 6). O trabalho abstrato é o trabalho universal, porque é o trabalho em geral posto na realidade efetiva.

Marx não se dedica à elucidação de categorias lógicas em si mesmas, precisamente porque seus pressupostos não são lógicos, mas em sua teoria sobre o ser social e a história toma por "ponto de partida, naturalmente, a produção dos indivíduos socialmente determinada" (Intro 1857, 39). Ainda assim, Marx distinguiu, no que diz respeito particularmente ao trabalho, em que consiste o trabalho em geral, o trabalho universal, o trabalho comum, o trabalho como totalidade etc.

Em Marx, o trabalho em geral é abstração dos traços comuns dos trabalhos reais, sua definição. Como tal, não existe na efetividade como um ente separado, mas apenas enquanto representação conceitual das determinações comuns efetivamente presentes 
nas atividades singulares, coincidindo com o simplesmente comum aos trabalhos concretos efetivos de que fala Fausto:

\begin{abstract}
A produção em geral (Produktion im allgemeinen) é uma abstração, mas uma abstração razoável (verständige Abstraktion), na medida em que efetivamente destaca e fixa o elemento comum (Gemeinsame), poupando-nos assim a repetição. Entretanto, esse Universal (Allgemeine), ou o comum isolado por comparação é ele próprio algo multiplamente articulado, cindido em diferentes determinações. Algumas determinações pertencem a todas as épocas; outras são comuns apenas a algumas, [Certas] determinações serão comuns à época mais moderna e à mais antiga. Nenhuma produção seria concebível sem elas; todavia, se as línguas mais desenvolvidas têm leis e determinações em comum com as menos desenvolvidas, a diferença desse universal e comum (Allgemeinen und Gemeinsamen) é precisamente o que constitui seu desenvolvimento (Intro 1857,41$)^{124}$.
\end{abstract}

A produção em geral é pois uma representação das determinações reais comuns, destituída de conteúdo social específico. Nesta passagem, o comum ou geral a todo trabalho aparece como sinônimo de produção universal. Mas ele explicita também que este universal, geral ou comum não é um conceito absoluto ou fixo: há na produção determinações ou leis mais gerais que outras, válidas para um conjunto maior ou menos de produções efetivas. Existem, pois, graus diferentes de universalidade, e apenas a partir das produções efetivas é possível representar o grau de universalidade de cada uma de suas múltiplas determinações. A determinação mais geral ou universal do trabalho é "o fato de que o sujeito, a humanidade, e o objeto, a natureza, são os mesmos" (Intro 1857, 41). Marx a caracteriza como a unidade de todas as produções reais. Mas há determinações gerais menos universais: vimos, por exemplo, que a dissolução espontânea das relações de produção pelo desenvolvimento produtivo é uma determinação geral, mas apenas para os modos pré-capitalistas de produção.

A produção universal, como gênero ou comum isolado na representação, não existe na efetividade:

Se não há produção em geral, também não há igualmente produção universal (allgemeine Produktion). A produção é sempre um ramo particular da produção - por exemplo, agricultura, pecuária, manufatura etc. - ou a totalidade (Totalität). (...) Finalmente, a produção não é somente produção particular (besondre). Ao contrário, é sempre um corpo social

\footnotetext{
${ }^{124}$ As expressões originais em alemão foram extraídas Marx, "Einleitung [zur Kritik der politischen Ökonomie]" in Marx-Engels Werke, Band 13, Berlin: Dietz Verlag, 1961, p. 617.
} 
(Gesellschaftskörper), um sujeito social (gesellschaftliches Subjekt) em atividade em uma totalidade maior ou menor de ramos da produção (Intro 1857, 41) ${ }^{125}$.

O trabalho que existe na efetividade é o trabalho concreto: os ramos específicos da produção, ou a totalidade destes ramos em um corpo social definido. O trabalho como totalidade é o conjunto do trabalho social, que produz não apenas a soma dos resultados particulares, mas um organismo ou sistema social em que os trabalhos particulares estão conectados na formação de uma comunidade, um sistema de interdependência determinado pela divisão do trabalho. Esta totalidade é maior ou menor conforme as sociedades são mais locais ou mais universais em seu intercâmbio. Há, pois, graus de universalidade da totalidade, definidos pelo nível de desenvolvimento da divisão do trabalho que integra um corpo maior ou menor de atividades produtivas. $\mathrm{O}$ maior grau de universalidade desta totalidade da produção é alcançado no mercado mundial, que integra a produção do conjunto dos povos humanos cujo desenvolvimento original é local. Esta totalidade sintetiza a relação social de produção em que existem os múltiplos ramos da produção: observando um processo produtivo singular, nem sempre se explicitam os fatores sociais que concorrem para determinação deste trabalho específico. Para usar um exemplo de Marx (C, I, 1, 50), a divisão do trabalho no interior de uma fábrica não expressa o caráter das relações sociais de produção: os trabalhadores no processo coletivo de produção não relacionam seus produtos singulares por meio da troca, que no entanto é a característica determinante da sociedade mercantil que possibilitou a existência de fábricas. As determinações de um ramo da produção efetivo apenas se completam na consideração de sua relação com a totalidade efetiva da produção.

Também o trabalho em comum, distinto do simplesmente comum a todos os trabalhos, se caracteriza como o trabalho imediatamente coletivo, em que vários indivíduos tomam parte na criação de um mesmo produto. "A atividade comunitária e a fruição comunitária, isto é, a atividade e a fruição que imediatamente, em sociedade efetiva com outros homens, se externam e se confirmam" (MEF, 107) distingue-se do trabalho do indivíduo isolado.

\footnotetext{
${ }^{125}$ As expressões originais em alemão foram extraídas Marx, "Einleitung [zur Kritik der politischen Ökonomie]" op.cit., p. 617-8.
} 
Em outra passagem, Marx compara o trabalho comum ou coletivo com o trabalho universal. Ali, aparece outra definição de trabalho geral ou trabalho universal distinta do comum isolado que existe como representação:

\begin{abstract}
Diga-se de passagem que é preciso diferenciar entre trabalho geral (allgemeiner Arbeit) e trabalho em comum (gemeinschaftlicher Arbeit). Ambos desempenham seu papel no processo de produção, ambos se confundem, mas ambos também se distinguem. Trabalho geral é todo trabalho científico, toda descoberta, todo invento (alle wissenschaftliche Arbeit, alle Entdeckung, alle Erfindung). É condicionado em parte pela cooperação com viventes, em parte pela utilização de trabalhos de antecessores. O trabalho em comum supõe a cooperação direta dos indivíduos (C, III, 4, 80) $)^{126}$.
\end{abstract}

Este trabalho geral não é mais a mera abstração razoável que nos poupa da repetição quando nos referimos ao trabalho sem mais. Trata-se, ao contrário, de trabalhos efetivos e concretos, que por seu conteúdo, são universais ou gerais. Trata-se pois, de outro sentido de universal (que talvez se aproxime em alguma medida do verdadeiro universal de Hegel, entes efetivos em que a universalidade existe separada dos entes singulares: a Razão, o Estado, no sentido de que a universalidade é determinada por um conteúdo universal). O que se depreende desta passagem em que "Trabalho geral é todo trabalho científico, toda descoberta, todo invento" é que esta categoria é aqui caracterizada como síntese da atividade social. Depende tanto do resultado da produção passada, de seu acúmulo, quanto da cooperação imediata do trabalho atual, isto é, da produção social, embora possa ser realizada pelo indivíduo isolado: "Posto que também sou cientificamente ativo etc., uma atividade que raramente posso realizar em comunidade imediata com outros, então sou ativo socialmente porque [o sou] enquanto homem" (MEF, 107, citado acima). O indivíduo que realiza um invento ou uma descoberta sintetiza os resultados da produção social, e assim realiza um trabalho que é geral ou universal, visto que reúne os múltiplos conhecimentos empíricos e resultados dos trabalhos efetivos passados e presentes, por meio de um trabalho que é também concreto, efetivo, singular. Na atividade científica e de criação do novo, também há graus de universalidade: descobertas pontuais são menos universais do que descobertas que transformam o conjunto da base produtiva, como a máquina a vapor ou a informatização. Nesta passagem não se trata do trabalho em geral, ou seja, do universal que é uma representação ou uma "abstração razoável", mas de um trabalho específico

${ }^{126}$ As expressões originais em alemão foram extraídas de Marx, Das Kapital - Drittes Buch Der Gesamtprozeß der kapitalistischen Produktion, Marx-Engels Werke, Berlin: Dietz Verlag, 1964, pp. 1134. 
que é em si mesmo geral ou universal, e portanto estes termos, assim empregados, não trazem qualquer sentido de abstração, mas de síntese.

Nas passagens mencionadas, Marx não parece distinguir o geral e o universal: nelas, utiliza apenas o termo Allgemein, traduzido ora por geral, ora por universal. Contudo, utiliza tal termo em mais de um sentido. Aqui, reconhecemos três deles. Primeiro, referindo-se à ideia de generalidade abstrata, ou abstração razoável, que diz respeito ao conhecimento e refere-se à representação ou ao conceito. Segundo, à ideia de expansão efetiva da articulação social das atividades produtivas singulares, ligada ao desenvolvimento da divisão do trabalho. Neste sentido, a produção capitalista é mais universal do que a realizada nas sociedades pré-capitalistas, ao mesmo tempo locais e, em diferentes graus, com baixo desenvolvimento da divisão do trabalho. Aqui, a universalidade é uma determinação da produção e do intercâmbio efetivos dos indivíduos, e não comporta em si mesma qualquer noção de abstração. Refere-se à totalidade da produção social que articula os trabalhos singulares, mas não ao trabalho singular em si mesmo, e inclui as relações de produção distintas como mais ou menos universais. Por fim, há o trabalho concreto e específico que em si mesmo é universal ou geral porque sintetiza os resultados da produção social, e tampouco traz a noção de abstração.

Marx distingue o trabalho em geral como o comum efetivo isolado na representação, o trabalho em comum, o trabalho como totalidade e o trabalho universal como síntese social. São ângulos a partir dos quais se pode considerar o trabalho e nenhum deles traz em sua definição um conteúdo social específico, ou seja, pode-se utilizar tais modos de considerar o trabalho para se referir a qualquer formação social, independente da diversidade de relações de produção ou formas de propriedade. Nenhum destes pontos de vista pelos quais se considere o trabalho se identifica com o trabalho abstrato.

Do mesmo modo que o trabalho em geral, caracterizado como o simplesmente comum aos trabalhos específicos, Marx define o trabalho abstrato em contraposição ao trabalho concreto efetivo, singular.

Todo trabalho é, por um lado dispêndio de força de trabalho do homem no sentido fisiológico, e nessa qualidade de trabalho humano igual ou trabalho humano abstrato, gera o valor da mercadoria. Todo trabalho é, por outro lado, dispêndio de força de trabalho do homem sob forma 
especificamente adequada a um fim, e nessa qualidade de trabalho concreto útil produz valores de uso (C, I, 1, 53).

A partir da abstração do que há de particular nas atividades, o trabalho abstrato aparece como resíduo, o comum isolado das atividades singulares:

Consideremos agora o resíduo dos produtos do trabalho. Não restou deles a não ser a mesma objetividade fantasmagórica, uma simples gelatina de trabalho humano indiferenciado, isto é, do dispêndio de força de trabalho humano, sem consideração pela forma como foi despendida. O que essas coisas ainda representam é apenas que em sua produção foi despendida força de trabalho humano, foi acumulado trabalho humano. Como cristalização dessa substância social comum a todas elas, são elas valores - valores mercantis (C, I, 1, 47).

Especificando o dispêndio de força de trabalho humano no sentido fisiológico, Marx escreve ainda: “(...) por mais que se diferenciem os trabalhos úteis ou atividades produtivas, é uma verdade fisiológica que eles são funções do organismo humano e que cada uma dessas funções, qualquer que seja seu conteúdo ou forma, é essencialmente dispêndio de cérebro, nervos, músculos, sentidos etc. humanos" (C, I, 1, 70).

À primeira vista, essas passagens parecem realmente identificar o trabalho abstrato à igualdade fisiológica dos trabalhos, dada no fato de serem todos funções do organismo humano. O trabalho humano assim indiferenciado, como mero dispêndio força de trabalho humano, e portanto nesta igualdade específica, é o trabalho abstrato. $\mathrm{O}$ "dispêndio de força de trabalho do homem no sentido fisiológico" é a "qualidade de trabalho humano igual ou trabalho humano abstrato" que gera o valor das mercadorias. Nesta leitura superficial, é possível se chegar à conclusão de que o trabalho abstrato nada mais é do que o trabalho sem especificidades, o trabalho em geral, ou ainda, o gênero dos trabalhos concretos: se na "qualidade de trabalho humano igual ou trabalho humano abstrato, gera o valor da mercadoria", e se "Todo trabalho é, por um lado, dispêndio de força de trabalho do homem no sentido fisiológico", então qualquer trabalho gera o valor do produto útil que cria. $\mathrm{O}$ mero pertencimento ao gênero trabalho parece caracterizar a atividade como criadora de valor, de modo que todos os trabalhos que criam coisas parecem agentes da "cristalização dessa substância social comum a todas elas".

Mas esta interpretação, traída desde logo pelas expressões objetividade fantasmagórica e substância social, não leva em conta o conjunto da exposição de Marx. Para chegar à definição do trabalho abstrato, Marx parte de seu produto, a 
mercadoria. Nesse exame, fica claro também no que consiste a universalidade do trabalho abstrato, sua forma e limite específicos.

A mercadoria é definida na primeira frase d'O Capital, como também da Contribuição à crítica da economia política, como uma forma da riqueza: "A riqueza das sociedades em que domina o modo de produção capitalista parece como uma 'imensa coleção de mercadorias', e a mercadoria individual aprece como sua forma elementar" (C, I, 1, 45).

Antes de abordar sua forma, Marx explicita o conteúdo da mercadoria. Este é idêntico ao conteúdo da riqueza em qualquer sociedade, é a riqueza material em si mesma, cuja finalidade coincide com a finalidade geral do trabalho, qual seja, satisfazer necessidades humanas: "Os valores de uso constituem o conteúdo material da riqueza, qualquer que seja a forma social desta"(C, I, 1, 45). O valor de uso satisfaz necessidades definidas, e o faz pelas suas propriedades concretas específicas: "a forma sob a qual a mercadoria é um valor de uso confunde-se com sua existência material tangível" (Contribuição, 52), de modo que sua "utilidade não paira no ar" (C, I, 1, 45). Se é a própria materialidade específica de coisa que a caracteriza como útil para satisfazer esta ou aquela necessidade singular, o tempo de trabalho que custa sua produção não tem qualquer relação com a utilidade. O objeto útil pode nem ter sido objeto de trabalho, pode ter custado muito ou pouco trabalho, sua utilidade permanece a mesma. $\mathrm{O}$ valor de uso se realiza no consumo, isto é, na satisfação efetiva de dada necessidade humana, seja individual ou produtiva. Assim, a medida da utilidade é a necessidade. Para comparar dois valores de uso quanto à sua utilidade, é preciso ter como metro uma necessidade humana definida: para a tecelagem, o algodão é mais útil que o café. A utilidade em geral não tem medida comum às várias formas em que as coisas são úteis, uma vez que a necessidade em geral é um conceito abstrato sem unidade de medida geral.

A mercadoria é antes de tudo um valor de uso, riqueza útil, mas isto não a define, porque ela é uma forma da riqueza. Como tal, expressa uma relação social que o valor de uso por si não revela:

Qualquer que seja a forma social da riqueza, os valores de uso constituem sempre seu conteúdo que permanece, em primeiro lugar, indiferente a essa forma. Ao provar o trigo, não se conhece quem o cultivou: servo russo, modesto aldeão francês ou capitalista inglês. Ainda que o valor de 
uso seja objeto de necessidades sociais e se articule, por conseguinte, à sociedade, não expressa, todavia, uma relação de produção social" (Contribuição, 52).

A mercadoria é uma forma social dos valores de uso: "Na forma de sociedade a ser por nós examinada, eles constituem, ao mesmo tempo, os portadores materiais do valor de troca" (C, I, 1, 46), "a base material com que se manifesta uma relação determinada: o valor de troca" (Contribuição, 53). O valor de troca designa pois uma relação, que "aparece, de início, como a relação quantitativa, a proporção na qual valores de uso de uma espécie se troca contra valores de uso de outra espécie" (C, I, 1, 46). Mercadoria, então, não se refere a uma coisa, mas a uma relação social mediante a qual os valores de uso são produzidos e consumidos, visto que é esta relação que especifica e define a mercadoria: o valor de troca. A partir da análise da relação de troca Marx deduzirá o valor e o trabalho abstrato.

Marx começa examinando o valor de troca. Este parece "algo casual e puramente fortuito; um valor de troca imanente, intrínseco à mercadoria, portanto, uma contradictio in adjecto" (C, I, 1, 64), precisamente porque designa uma relação, demandando duas mercadorias de espécies diferentes. Um valor de troca natural ao produto material parece uma contradição em termos, porque se afirma como imanente ao objeto sua relação com outros; o que é relativo é referido como algo absoluto. Mas esta mesma relação reveste o objeto com uma natureza nova ao torná-lo mercadoria. A troca destaca do produto a determinação que caracterizará seu valor intrínseco:

Determinada mercadoria, 1 quarter de trigo, por exemplo, troca-se por $\mathrm{x}$ de graxa de sapato, ou por y de seda, ou por $\mathrm{z}$ de ouro etc., resumindo por outras mercadorias nas mais diferentes proporções. Assim, o trigo possui múltiplos valores de troca ao invés de um único. Porém, sendo $\mathrm{x}$ de graxa, assim como y de seda ou $\mathrm{z}$ de ouro o valor de 1 quarter de trigo, $\mathrm{x}$ de graxa, y de seda, z de ouro etc. têm de ser valores de troca permutáveis uns pelos outros ou iguais entre si. Por conseguinte, primeiro: os valores de troca vigentes da mesma mercadoria expressam algo igual $(\mathrm{C}, \mathrm{I}, 1,64)$.

A relação de troca entre diversas mercadorias faz delas valores de troca umas das outras. Assim, os valores de troca de uma mercadoria singular são as outras mercadorias: independente das proporções quantitativas, o valor de troca do trigo é graxa, é seda, é ouro. Como valor de troca, uma mercadoria é qualitativamente igual a todas as outras pelas quais se troca. Mas a comparação dos produtos como valores de uso não revela nenhuma unidade capaz de abranger todo o círculo de produtos trocados. 
É o fato de que são postos em dadas proporções na troca que estabelece uma medida comum. Além disso, a troca pressupõe que seus polos sejam valores de uso distintos: assim, ela pressupõe a diferença dos valores de uso, mas ao colocá-los como valores de troca, destaca algo igual. Marx cita Barbon:

Uma mercadoria é tão boa quanto a outra se seu valor de troca for igual. Pois não existe nenhuma diferença ou distinção entre coisas de valor de troca igual (...). Cem libras esterlinas de chumbo ou ferro têm o mesmo valor de cem libras esterlinas de ouro ou prata ${ }^{127}$.

Como essa igualdade não existe nos valores de uso quando tomados em separado e comparados pela "merceologia", mas apenas quando são valores de troca uns dos outros,

(...) o valor de troca só pode ser o modo de expressão, a "forma de manifestação" de um conteúdo dele distinguível. Tomemos ainda duas mercadorias, por exemplo, trigo e ferro. Qualquer que seja sua relação de troca, poder-se-á, sempre, representá-la por uma equação em que dada quantidade de trigo é igualada a alguma quantidade de ferro. Que diz essa equação? Que algo em comum da mesma grandeza existe em duas coisas diferentes, em 1 quarter de trigo e igualmente em a quintais de ferro. Ambas são, portanto, iguais a uma terceira, que em si e para si não é nem uma nem outra $(C, I, 1,46)$.

As duas mercadorias são iguais a uma terceira coisa que, no entanto, existe nelas: "Cada uma das duas, enquanto valor de troca, deve, portanto, ser redutível a essa terceira" (C, I, 1, 46).

Trata-se de uma terceira coisa que é, ao mesmo tempo, algo comum aos múltiplos valores de troca das mercadorias, "de que eles representam um mais e um menos" $(C, I, 1,46)$. Como este algo comum, que é terceiro em relação às mercadorias, não pode ser nenhuma propriedade natural delas, ou seja, dos valores de uso que se enfrentam na troca, estes devem ser integralmente abstraídos para que o igual apareça:

(...) é precisamente a abstração de seus valores de uso que caracteriza evidentemente a relação de troca das mercadorias. Dentro da mesma um valor de uso vale exatamente tanto como outro qualquer, desde que esteja disponível em proporção adequada. (...) Como valores de uso, as mercadorias são, antes de mais nada, de diferente qualidade, como valores de troca só podem ser de quantidade diferente, não contendo, portanto, nenhum átomo de valor de uso (C, I, 1, 46-7).

127 Barbon, Nicholas, "A discourse on coining the new money lighter" in Answer to Mr. Locke's Considerations on the consequences of the lowering of interest. Londres, 1696, p. 2-3, apud Marx, C, I, 1, 47. 
Este algo igual existe e não existe nos valores de uso: é preciso abstraí-los para que a terceira coisa se revele, de modo que ela está neles apenas na medida em que são valores de troca; mas enquanto mercadorias, esta terceira coisa pertence a seu valor de uso, de modo que algo nele permite sua redução ao comum posto pela relação de troca. Para chegar a esta terceira coisa, que é o valor, Marx parte da propriedade que resta aos produtos quando seu valor de uso é abstraído, o fato de ser produto do trabalho:

Deixando de lado então o valor de uso dos corpos das mercadorias, resta a elas apenas uma propriedade, que é a de serem produtos do trabalho. Entretanto, o produto do trabalho também já se transformou em nossas mãos. (...) Ao desaparecer o caráter útil dos produtos do trabalho, desaparece o caráter útil dos trabalhos neles representados, e desaparecem também, portanto, as diferentes formas concretas desses trabalhos, que deixam de diferenciar-se um do outro para reduzir-se em sua totalidade a igual trabalho humano, a trabalho humano abstrato $(\mathrm{C}, \mathrm{I}, 1,47)$.

Esta "gelatina de trabalho indiferenciado, isto é, do dispêndio de força de trabalho humano sem consideração pela forma como foi despendida", é uma "objetividade fantasmagórica" (C, I, 1, 47): algo objetivo, porém sem corpo ou existência sensível, uma substância não natural, mas social. Todo produto resulta do trabalho, e assim é trabalho objetivado. Contudo, como resultado da atividade, esta existe no produto apenas como passividade, o caráter ativo do sujeito, se deu forma à coisa, não existe como algo à parte da existência natural do produto. Ou seja, o produto resulta da atividade, é seu objeto, mas não captura a própria atividade criadora, o caráter ativo do sujeito que produz e que é precisamente o que distingue a subjetividade da mera objetividade. Na mercadoria, contudo, é exatamente isso o que ocorre, a atividade enquanto tal se cristaliza: "Como cristalizações dessa substância social comum a todas elas, são elas valores - valores mercantis" (C, I, 1, 47).

O que há de comum nos múltiplos valores de troca, a terceira coisa a que todos são reduzidos quando se abstrai daquilo que os distingue, não é o trabalho que dá origem a todos eles, mas o valor:

\footnotetext{
$\mathrm{Na}$ própria relação de troca das mercadorias, seu valor de troca apareceu-nos como algo totalmente independente de seu valor de uso. Abstraindo-se agora, realmente, o valor de uso dos produtos do trabalho, obtém seu valor de troca como há pouco ele foi definido. $O$ que há de comum, que se revela na relação de troca ou valor de troca da mercadoria, é, portanto, seu valor (C, I, 1, 47, grifo meu).
}

O valor é, contudo, constituído por trabalho: este é seu conteúdo ou substância: 
Portanto, um valor de uso ou bem possui valor, apenas, porque nele está objetivado ou materializado trabalho humano abstrato. Como medir então a grandeza de seu valor? Por meio do quantum nele contido da "substância constituidora de valor", o trabalho. A própria quantidade de trabalho é medida pelo seu tempo de duração, e o tempo de trabalho possui, por sua vez, sua unidade de medida nas determinadas frações de tempo, como hora, dia etc. (C, I, 1, 47).

Nesta conceituação do valor, Marx parece contradizer sua própria definição de ser, exposta no terceiro capítulo desta pesquisa. Se lá se afirma que o ser é objetivo, sensível, natural, temos aqui um ser objetivo não-natural e não-sensível; se lá se afirma que a atividade é função do ser ativo, aqui a atividade aparece como uma determinação que em si mesma ganha uma objetividade, distinta do objeto que a atividade transforma e separada do sujeito ativo. O trabalho em si mesmo se torna uma substância de algo diferente do produto material do trabalho, o valor, que como substância, ganha a consistência de coisa. O valor aparece como ser objetivo não-sensível, por isso, fantasmagórico, cuja substância é a atividade produtiva humana, que se objetiva enquanto tal, isto é, o próprio movimento de produção aparece como uma objetividade separada do ser que se move para produzir.

Dito em outros termos, em todo produto, o trabalho é materializado em coisa, mas trata-se de atividade que dá forma a um objeto que é outro com relação à própria atividade. A atividade mesma não se separa do ser ativo porque é movimento, e o produto, resultado passivo deste movimento. Como movimento, o trabalho tem como medida natural o tempo: "Da mesma maneira que o tempo é a expressão quantitativa do movimento, o tempo de trabalho é a expressão quantitativa do trabalho. O tempo de trabalho (...) é sua expressão viva quantitativa, ao mesmo tempo sua medida imanente" (Contribuição, 55). Mas, o valor não é um produto da atividade que se realiza sobre um objeto distinto de si, é a própria atividade, o dispêndio de força de trabalho humano, a duração do movimento ou o tempo de trabalho que ganha em si mesmo caráter objetivo de substância no produto. Este adquire dupla substância de coisa e de valor, e assim se define como mercadoria.

Qual é o trabalho que conta como substância do valor, qual a qualidade que o determina? Marx afirma que é o trabalho geral ou abstrato, ou seja, qualquer trabalho útil cuja utilidade específica é abstraída, mas este trabalho tem pressupostos e determinações sociais específicas. Se o trabalho abstrato é indeterminado quanto à sua 
forma concreta, não o é relativamente à sua forma social. Antes, é esta forma que o define:

A mercadoria apareceu-nos, inicialmente, como algo dúplice, valor de uso e valor de troca. Depois mostrou-se que também o trabalho, à medida que é expresso no valor, já não possui as mesmas características que lhe advém como produtor de valores de uso. Essa natureza dupla da mercadoria foi criticamente demonstrada pela primeira vez por mim. Como esse é o ponto crucial em torno do qual gira a compreensão da Economia Política, ele deve ser examinado mais de perto (C, I, 1, 49).

As condições históricas para o surgimento da produção de mercadorias como forma geral da riqueza são várias, conforme exposto no capítulo anterior. Retomo o modo como essas condições aparecem na definição do trabalho abstrato. Seu primeiro pressuposto é a divisão social do trabalho:

$\mathrm{Na}$ totalidade dos vários tipos de valores de uso ou corpos de mercadorias aparece uma totalidade igualmente diversificada, de acordo com gênero, espécie, família, subespécie, variedade, de diferentes trabalhos úteis - uma divisão social do trabalho. Ela é condição de existência para a produção de mercadorias, embora, inversamente, a produção de mercadorias não seja a condição de existência para a divisão social do trabalho (C, I, 1, 50).

O segundo pressuposto é pois a autonomia e independência dos produtores, seu caráter privado: "Apenas produtos de trabalhos privados autônomos e independentes entre si confrontam-se como mercadorias" (C, I, 1, 50).

Assim, trata-se de um sistema produtivo que tem por pressuposto a ruptura dos vínculos comunitários, em que os indivíduos trabalham uns para os outros de acordo com determinações sociais específicas dadas pelo caráter dos vínculos diretos: determinações de nascimento (ser romano, ser nobre etc.), relações de dependência (servidão, vassalagem etc.) e de subordinação da vontade dos indivíduos, como na escravidão.

Mas isso não significa que não haja qualquer vínculo entre os produtores privados. Ao contrário, sua dependência não é dada pela comunidade natural, mas pela produção configurada em sistema de troca, em que cada produtor deve se colocar como um elo da divisão do trabalho. O poder direto que um indivíduo exerce sobre o outro e que caracteriza seu nexo com a sociedade dá lugar ao poder que a própria riqueza do indivíduo autônomo, como valor de troca, exerce sobre os demais, do mesmo modo que esta passa a constituir o nexo social. Assim, deve-se não apenas produzir para a 
necessidade social, mas gerar seu produto na forma da riqueza permutável ou geral, isto é, produzir mercadoria:

A dependência recíproca e multilateral dos indivíduos mutuamente independentes forma sua conexão social. Essa conexão é expressa no valor de troca, e somente nele a atividade própria ou o produto de cada indivíduo devém uma atividade ou produto para si; o indivíduo tem de produzir um produto universal - o valor de troca, ou este último por si isolado, individualizado, dinheiro. Seu poder social, assim como o seu nexo com a sociedade, [o indivíduo] traz consigo no bolso. A atividade, qualquer que seja sua forma de manifestação individual, e o produto da atividade, qualquer que seja sua qualidade particular, é o valor de troca, i.e., um universal em que toda individualidade, peculiaridade, é negada e apagada (Grundrisse, 105).

A sociedade, ou seja, o sistema social de divisão do trabalho, é pressuposta ao produtor privado autônomo, de modo que ele não é independente da comunidade humana que existe na forma da divisão do trabalho e cuja unidade é o mercado. O desenvolvimento da divisão do trabalho põe a um só tempo a autonomia privada e a interdependência material entre os produtores.

Viu-se portanto: o valor de uso de cada mercadoria encerra determinada atividade produtiva adequada a um fim, ou trabalho útil. Valores de uso não podem defrontar-se como mercadoria, caso eles não contenham trabalhos úteis qualitativamente diferentes. Numa sociedade cujos produtos assumem, genericamente, a forma de mercadorias, desenvolve-se essa diferença qualitativa dos trabalhos úteis, executados independentemente uns dos outros, como negócios privados de produtores autônomos, num sistema complexo, numa divisão social do trabalho (C, I, 1, 50).

É esta que está na base da definição do trabalho abstrato: os trabalhos distintos do conjunto da sociedade funcionarão como variações das funções do trabalho social total:

Enquanto valores, casaco e linho são coisas de igual substância, expressões objetivas do mesmo tipo de trabalho. Mas a alfaiataria e a tecelagem são trabalhos qualitativamente diferentes. Existem, entretanto, circunstâncias sociais em que a mesma pessoa, alternadamente, costura e tece. Esses dois modos diferentes de trabalho são, por isso, apenas modificações do trabalho do mesmo indivíduo, e ainda não funções fixas, específicas, de indivíduos diferentes, assim como o casaco feito, hoje, por nosso alfaiate, e as calças que ele faz amanhã somente pressupõem variações do mesmo trabalho individual. A evidência ensina ainda que em nossa sociedade capitalista, conforme a mutável orientação da procura de trabalho, dada porção do trabalho humano deverá ser alternadamente oferecida ora sob a forma de alfaiataria, ora sob a forma de tecelagem. Essa variação da forma do trabalho pode não ocorrer sem atritos, mas ela deve ocorrer. Abstraindo-se da determinação da atividade produtiva e, portanto, do caráter útil do trabalho, resta apenas que ele é um dispêndio de força humana de trabalho (C, I, 1, 51). 
Assim, o sistema produtivo que atende às necessidades dos indivíduos é estendido ao conjunto da sociedade. Isto tem duas consequências: primeiro, a capacidade produtiva do conjunto dos indivíduos conta como uma e mesma massa de força de trabalho: "A força conjunta de trabalho da sociedade, que se apresenta nos valores do mundo das mercadorias, vale aqui como uma única e a mesma força de trabalho do homem, não obstante ela ser composta de inúmeras forças de trabalho individuais" (C, I, 1, 48). Como um sistema pressuposto ao produtor autônomo, o trabalho do conjunto da sociedade é pressuposto à determinação do valor que cada produtor singular produz: o conjunto da produção de mercadorias é determinante, por isso, do valor de uma mercadoria singular e de cada espécie de mercadoria. Se a riqueza material se determina como uma função para a necessidade humana, sua definição é o serviço que presta aos indivíduos. Cada espécie de valor de uso tem sua medida concreta própria, mas uma medida do valor de uso em geral não é possível. Dada a pluralidade de necessidades, as riquezas não têm medida comum. Na troca, ao contrário, riqueza se define como uma função do trabalho para a coisa, sua definição é o serviço que os indivíduos prestam à coisa material. Na troca, o valor é a medida do valor de uso, mas o que o valor mede não é a coisa, e sim o processo de produção da coisa, e por isso é indiferente à sua utilidade, ao serviço que presta aos indivíduos.

Como valor de uso a mercadoria exerce uma ação causal. O trigo, por exemplo, atua porque é alimento. Uma máquina supre o trabalho em proporções determinadas. Essa ação da mercadoria, somente por isso é um valor de uso, um objeto de consumo, pode-se chamar seu serviço, serviço que presta como valor de uso. Mas em sua qualidade de valor de troca a mercadoria jamais é encarada senão do ponto de vista do resultado. Não se trata do serviço que presta, mas do serviço que lhe foi prestado por ter sido produzida (Contribuição, 63).

Segundo, os indivíduos são igualados, equiparados quanto à sua capacidade de comporem um elo da sociedade: são tornados indivíduos privados e autônomos, e assim iguais. A igualdade entre os indivíduos é estabelecida pela igualdade de seus produtos: independente de qualquer característica individual, a qualidade de seus múltiplos produtos é a mesma: valor de troca. Assim, sua atividade é de mesma natureza: todas são trabalho humano. Daí, o desenvolvimento da igualdade e da liberdade jurídicas, que resulta desta equiparação dada antes na troca. Como formas do trabalho humano, os trabalhos singulares que compõem os elos da divisão do trabalho contam como trabalho médio: 
Cada uma dessas forças de trabalho individuais é a mesma força de trabalho do homem como a outra, à medida que possui o caráter de uma força média de trabalho social, e opera como tal força de trabalho socialmente média, contanto que na produção de uma mercadoria não consuma mais que o trabalho em média necessário ou tempo de trabalho socialmente necessário (C, I, 1, 48).

O trabalho socialmente necessário, médio, que conta para a definição do valor da mercadoria individual é a expressão, na atividade individual, do sistema social em que a atividade produtiva é dividida pelos membros desse corpo, os indivíduos. Assim, o tempo de trabalho incorporado na mercadoria que constitui a substância do valor é o tempo de trabalho do indivíduo, visto que a atividade é sempre função do ser ativo, individual, mas não é seu tempo de trabalho empírico ou imediato:

\begin{abstract}
Além disso, no valor de troca, o tempo de trabalho do indivíduo isolado aparece diretamente como tempo de trabalho geral, e esse caráter geral de trabalho isolado reveste um caráter social. O tempo de trabalho representado no valor de troca é o tempo de trabalho do indivíduo, mas do indivíduo que não se distingue dos demais indivíduos, enquanto realizam um trabalho igual, de tal maneira que o tempo de trabalho gasto por um em produzir uma mercadoria determinada, é o tempo de trabalho necessário que qualquer outro empregaria em produzir a mesma mercadoria. É o tempo de trabalho do indivíduo, mas não é seu tempo de trabalho, posto que é o tempo de trabalho comum a todos e, portanto, é indiferente que seja o tempo de trabalho de tal ou qual indivíduo (Contribuição, 57-8).
\end{abstract}

A condição para que os trabalhos dos múltiplos indivíduos sejam indiferentes é o trabalho social total como pressuposto para a determinação dos valores das mercadorias, e estes como quotas de trabalho social. Mas os trabalhos dos diferentes indivíduos não são idênticos e portanto não são diretamente trabalho social, trabalho abstrato, e por isso Marx afirma que o trabalho representado no valor se transformou. "O próprio tempo de trabalho enquanto tal existe apenas subjetivamente, apenas na forma da atividade" (Grundrisse, 118) e por isso é sempre trabalho singular concreto:

(...) mas, como valor de troca, o tempo de trabalho deve estar objetivado em uma mercadoria que expressa somente sua quotidade ou quantidade, que é indiferente às suas propriedades naturais e, por isso, pode ser metamorfoseada, i.e., trocada em qualquer outra mercadoria que objetive o mesmo tempo de trabalho. Como objeto, deve possuir este caráter universal que contradiz sua particularidade natural (Grundrisse, 115).

Além do pressuposto necessário de todo o conjunto do trabalho social para a determinação do valor de cada mercadoria, que se define como quota de trabalho social, 
ou trabalho socialmente necessário, três pontos deve ser destacados destas últimas passagens de Marx. Primeiro, o fato de que é a igualdade dos produtos estabelecida na troca que equipara as atividades e por conseguinte os próprios indivíduos; segundo, a contradição que o trabalho social geral que constitui o valor representa frente à singularidade dos trabalhos; e, terceiro, o fato de que esta contradição entre o singular e o geral na mercadoria expressa um caráter social específico da produção: "esse caráter geral de trabalho isolado reveste um caráter social".

$\mathrm{O}$ primeiro ponto diz respeito à igualdade fisiológica dos indivíduos. Embora esta expresse o mero fato de todos os seres humanos pertencerem à mesma espécie humana, tal igualdade não é um fato social antes de a produção ganhar a forma de produção de mercadorias: os indivíduos eram distintos por seu pertencimento a diversos territórios ou comunidades e por sua posição social, dada por nascimento. Estas distinções impedem que se constitua uma categoria de trabalho em geral, ou ainda, determina que diversas atividades produtivas não se incluam no termo trabalho, conforme exposto no capítulo anterior. A igualdade fisiológica é posta socialmente pelo caráter comum de valor de troca do conjunto dos produtos dos trabalhos humanos, e se estabelece plenamente com a igualdade jurídica. Como equiparação natural dos indivíduos, isto é, igualdade de suas naturezas, a igualdade fisiológica é um produto histórico e só existe na equiparação das atividades produtivas pela troca. Na realidade efetiva da produção, contudo, não há tal igualdade: os indivíduos são peculiares e detêm diferentes capacidades produtivas. A troca iguala as capacidades fisiológicas dos indivíduos ao estabelecer seus produtos como mesmo produto, valores de troca uns dos outros, e por meio da média que impõe às suas forças de trabalho, ou seja, pelo trabalho socialmente necessário. Mas é importante notar que não os iguala concretamente: seus produtos e seus tempos de trabalho continuam sendo distintos e singulares, pode custar mais a um do que a outro realizar uma hora de trabalho social médio; mas ao produzirem valores de troca, a igualdade qualitativa dos produtos e a média quantitativa de tempo imposta ao produto estabelece socialmente a igualdade fisiológica dos indivíduos. O que Ruy Fausto põe como um pressuposto natural do valor, o pertencimento à espécie humana, é condição do próprio trabalho e da sociabilidade. Mas o pressuposto específico do valor é uma forma da propriedade e um nível de desenvolvimento produtivo, dos quais resulta o indivíduo autonomizado e o intercâmbio pela troca e daí a superação de todas as formas de diferenças de nascimento e a 
decorrente elevação da igualdade fisiológica a um dado social. Neste mesmo sentido, I. I. Rubin afirma:

\begin{abstract}
Num sistema de castas estrito, a homogeneidade fisiológica do trabalho humano não pode se expressar em significativa medida. Numa pequena comunidade baseada na divisão do trabalho, a homogeneidade fisiológica do trabalho manifesta-se num pequeno círculo de pessoas. E o caráter humano do trabalho não pode expressar-se. Somente sobre a base da produção mercantil, caracterizada por um amplo desenvolvimento da troca, uma transferência em massa de indivíduos de uma atividade a outra, e a indiferença dos indivíduos para com a forma concreta do trabalho, é possível desenvolver-se o caráter homogêneo de todas as atividades de trabalho enquanto formas de trabalho humano em geral. (...) Não estaríamos exagerando se disséssemos que talvez o conceito de homem em geral, e de trabalho humano em geral, surgiram sobre a base da economia mercantil. Era precisamente isto que Marx queria mostrar quando indicou que o caráter humano geral do trabalho se expressa no trabalho abstrato (Rubin, A teoria marxista do valor, 153-4).
\end{abstract}

Assim, a igualdade fisiológica não é, como defende Fausto, um pressuposto natural posto na troca, mas um resultado da própria troca que pressupõe, na verdade, a ruptura com os vínculos comunitários. O mesmo processo que cria o indivíduo privado autônomo cria a igualdade fisiológica, bem como o homem em geral e o trabalho em geral como representações. Tal generalidade não existe nas sociedades pré-capitalistas nem mesmo como representações ideais, de modo que estas abstrações - mentais - têm também pressupostos históricos: isolar na representação o comum a todos os indivíduos - todos são seres humanos - e às suas atividades - todas são trabalho humano - é também um resultado da sociedade mercantil. É a dissolução da comunidade que permite a ideia de homem em geral; é a ampliação dos ramos de atividade, a divisão do trabalho e essencialmente o intercâmbio das atividades pela troca comercial que põe a possibilidade de se pensar o trabalho em geral, antes aderido à forma predominante de trabalho material de cada sociedade.

O trabalho que constitui a substância do valor possui "este caráter universal que contradiz sua particularidade natural”. Marx explica esta contradição ao abordar o caráter de objetividade específica do valor, nas passagens sobre a forma de valor e sobre o fetichismo da mercadoria. Marx escreve:

A objetividade do valor das mercadorias diferencia-se de Wittib Hurtig, pois não se sabe por onde apanhá-la. Em direta oposição à palpável e rude objetividade dos corpos das mercadorias, não se encerra nenhum átomo de matéria natural na objetividade de seu valor. Podemos virar e 
revirar uma mercadoria, como queiramos, como coisa de valor ela permanece imperceptível. Recordemo-nos, entretanto, que as mercadorias apenas possuem objetividade de valor na medida em que elas sejam expressões da mesma unidade social de trabalho humano, pois sua objetividade de valor é puramente social e, então, é evidente que ela pode aparecer apenas numa relação social de mercadoria para mercadoria. Partimos, de fato, do valor de troca ou da relação de troca das mercadorias para chegar à pista de seu valor aí oculto. Nós precisamos agora voltar a essa forma de manifestação do valor (C, I, 1, 53-4).

A objetividade do valor não é natural, o valor não é um ente como um valor de uso o é. Seu caráter objetivo é "puramente social" e assim se subordina à objetividade de uma relação social. Tem, portanto, a objetividade de uma forma do ser social. A objetividade do valor é da mesma natureza da objetividade do Estado, por exemplo. Este não é um prédio ou um conjunto de armas, mas uma relação de poder. Dissolva-se esta relação e sobram o prédio e o instrumental bélico, mas não o Estado. Do mesmo modo, retire-se a "relação de mercadoria para mercadoria", isto é, a relação de troca entre os indivíduos, e o valor desaparece, restando apenas os valores de uso e as atividades produtivas concretas. Como expressão de uma relação social, sua objetividade apenas pode se manifestar nos objetos naturais. Por isso, a mercadoria reveste o valor de uso de um caráter social, e faz dele suporte desta relação. O valor de uma mercadoria só se revela no corpo de outra mercadoria. Marx mostra que o valor de uma mercadoria não se expressa fora da relação de troca:

Eu não posso, por exemplo, expressar o valor do linho em linho. 20 varas de linho = 20 varas de linho não é nenhuma expressão de valor. A equação diz, ao contrário: 20 varas de linho são nada mais que 20 varas de linho, um quantum determinado de objeto de uso linho. $\mathrm{O}$ valor do linho pode assim ser expresso apenas relativamente, isto é, por meio de outra mercadoria. A forma relativa do valor do linho supõe, portanto, que alguma outra mercadoria a ela se oponha na forma equivalente. Por outro lado, essa outra mercadoria, que figura como equivalente, não pode ao mesmo tempo encontrar-se em forma relativa do valor. Não é ela que expressa seu valor. Ela fornece apenas o material à expressão do valor de outra mercadoria (C, I, 1, 54-5).

A objetividade do valor, embora se distinga da objetividade do valor de uso das mercadorias, precisa de um material de expressão que não pode ser senão outra mercadoria. A expressão do valor do linho é a mercadoria que se opõe a ele como seu valor de troca, o equivalente em que o valor relativo do linho é expresso. Ser equivalente é sinônimo de ser permutável ou ser valor de troca. O ponto de partida da análise do valor fora que a troca põe a igualdade dos valores de uso: 
Se 20 varas de linho $=1$ casaco ou $=20 \mathrm{ou}=x$ casacos, isto é, se dado quantum de linho vale muitos ou poucos casacos, cada uma dessas proporções implica sempre que linho e casaco, como grandezas de valor, sejam expressões da mesma unidade, coisas da mesma natureza. Linho = casaco é o fundamento da equação $(\mathrm{C}, \mathrm{I}, 1,55)$.

O que há de igual é seu valor: “(...) somente como valor pode o linho relacionar-se com o casaco como equivalente ou com ele permutável" (C, I, 1, 55). Algo diferente das mercadorias como valor de uso é criado ou posto na troca, e assim reveste os produtos, com uma determinação proveniente da relação de troca:

Ao equiparar-se, por exemplo, o casaco, como coisa de valor, ao linho, é equiparado o trabalho inserido no primeiro com o trabalho contido nesse último. $\mathrm{Na}$ verdade, a alfaiataria que faz o casaco é uma espécie de trabalho concreto diferente da tecelagem que faz o linho. Porém, a equiparação com a tecelagem reduz a alfaiataria realmente àquilo em que ambos são iguais, a seu caráter comum de trabalho humano. Indiretamente, é então dito que também a tecelagem, contanto que ela teça valor, não possui nenhuma característica que a diferencie da alfaiataria, e é, portanto, trabalho humano abstrato. Somente a expressão de equivalência de diferentes espécies de mercadoria revela o caráter específico do trabalho gerador de valor, ao reduzir, de fato, os diversos trabalhos contidos nas mercadorias diferentes a algo comum neles, ao trabalho humano em geral (C, I, 1, 56, grifos meus).

O que reduz os trabalhos efetivamente existentes a trabalho indiferenciado é a relação de troca. A expressão de equivalência dos produtos, sua permutabilidade efetiva, cria a abstração trabalho humano na realidade, porque somente como valor as mercadorias se equiparam. A abstração é real no mero fato da troca. A relação que cria mercadoria cria o trabalho abstrato, que não existe nos produtos antes dela, e seu valor, como separação ou abstração efetiva de seu caráter comum. Que esta substância comum seja o trabalho está evidente nos próprio pressuposto da questão. Partiu-se do valor de troca, e portanto das relações entre diferentes produtos de trabalho de indivíduos autônomos, que intercambiam suas atividades produtivas pela troca de produtos. Apenas esta atividade, naquilo que ela é comum aos dois trocadores, pode ser a substância do valor. Marx escreve:

Não sendo, em realidade, o valor de troca mais do que a relação dos trabalhos individuais, considerados iguais e gerais, uns para com os outros, e nada mais que a expressão objetiva de uma forma social específica de trabalho, é uma tautologia afirmar que o trabalho é a única fonte de valor, partindo da riqueza, enquanto esta consiste em valores de troca (Contribuição, 61). 
É interessante notar que a representação ideal trabalho humano, como comum isolado dos diferentes trabalhos concretos, é posterior à sua posição na realidade: esta se põe com a troca nas sociedades pré-capitalistas, ainda que pontualmente. Aquela surge apenas como resultado da sociedade mercantil desenvolvida.

Se a troca iguala as mercadorias fazendo de uma valor de troca da outra, a substância social com a qual a relação reveste os produtos é distinta de sua existência natural: "Digamos: como valores, as mercadorias são meras gelatinas de trabalho humano, então nossa análise reduz as mesmas à abstração de valor, sem dar-lhes, porém, qualquer forma de valor diferente de suas formas naturais" (C, I, 1, 56). Nesta mera enunciação do que há de comum nas múltiplas mercadorias, esta substância comum não aparece, isto é, figura como uma objetividade sem matéria, fantasmagórica. “A coisa é diferente na relação de valor de uma mercadoria a outra. Seu caráter de valor revela-se aqui por meio de sua própria relação à outra mercadoria" $(\mathrm{C}, \mathrm{I}, 1,56)$.

A permutabilidade efetiva das mercadorias, ao revesti-las de uma substância que é o trabalho social como quotidade, por isso abstrato, põe ao mesmo tempo sua forma de expressão. Na troca, aquilo que é atividade humana, a quota de trabalho abstrato que presta serviço à produção de uma mercadoria específica, aparece como coisa na mercadoria diversa que a enfrenta como sua equivalente:

\footnotetext{
Não basta, porém, expressar o caráter específico do trabalho em que consiste o valor do linho. A força de trabalho do homem em estado líquido ou trabalho humano cria valor, porém não é valor. Ele torna-se valor em estado cristalizado, em forma concreta. Para expressar o valor do linho como gelatina de trabalho humano, ele deve ser expresso como uma "objetividade" concretamente diferente do linho mesmo e simultaneamente comum ao linho e a outra mercadoria. A tarefa já está resolvida (C, I, 1, 56).
}

A tarefa já está resolvida: a objetividade da gelatina de trabalho humano aparece na outra mercadoria, no exemplo de Marx, o casaco. Como o ser objetivo é o ser efetivo, para aparecer objetivamente o valor apenas pode se mostrar na materialidade efetiva de outra mercadoria, em seu valor de uso. $\mathrm{O}$ termo objetividade parece entre aspas porque não se trata do ser objetivo sensível, mas de uma determinação objetiva dada pela relação de troca. Mas apenas pode o valor do linho aparecer como casaco porque este, na relação de troca, é valor:

Na relação de valor do linho vale o casaco como seu igual em qualidade, como coisa da mesma natureza, porque é um valor. Ele vale aqui, portanto, como coisa, na qual aparece valor ou a qual 
em sua forma natural palpável representa valor. Na verdade, o casaco, o corpo da mercadoria casaco, é um mero valor de uso. Um casaco expressa tão pouco valor quanto qualquer peça de linho. Isso comprova apenas que ele significa mais dentro da relação de valor do que fora dela (C, I, 1, 56).

O mesmo processo que cria uma substância social distinta dos produtos naturais, mas que existe neles no interior da relação, dá a esta substância uma aparição natural. $O$ valor de uso da mercadoria que serve de equivalente se torna a figura do valor da mercadoria relativa. Na relação, o valor do linho ganha a figura de um casaco: "Na relação de valor, na qual o casaco constitui o equivalente do linho, vale, portanto, a forma de casaco como forma de valor. $\mathrm{O}$ valor da mercadoria linho é assim expresso no corpo da mercadoria casaco, o valor de uma mercadoria no valor de uso da outra" (C, I, 1, 57). A objetividade do valor, embora seja em si mesma uma substância social e, portanto, não-material, assume na relação a forma concreta do equivalente, a aparência do casaco, ganhando expressão material ao mesmo tempo em que a relação põe a equivalência como igualdade de uma substância não-material: "Por meio da relação de valor, a forma natural da mercadoria B torna-se a forma de valor da mercadoria A ou o corpo da mercadoria B o espelho de valor da mercadoria A” (C, I, 1, 57). Marx insere aqui uma nota:

De certa forma, sucede ao homem como à mercadoria. Pois ele não vem ao mundo nem com um espelho, nem como um filósofo fichtiano: eu sou eu, o homem se espelha primeiro em outro homem. Só por meio da relação com o homem Paulo, como seu semelhante, reconhece-se o homem Pedro a si mesmo como homem. Com isso, vale para ele também o Paulo, com pele e cabelos, em sua corporalidade paulínea, como forma de manifestação do gênero humano (C, I, 1, 57 , nota 18$)$.

A medida do valor do linho é a quantidade de trabalho social que custa reproduzi-lo, mas esta quantidade só aparece em unidades de casaco. O casaco é a forma de manifestação do trabalho humano geral, do mesmo modo que, se Paulo apenas conhece Pedro, o gênero humano, que não coincide com Pedro, apenas aparece para Paulo com a figura física de Pedro. Mas mais do que isso, Pedro apenas se reconhece como homem pela relação com Paulo, ou seja, esta relação cria o gênero humano. Do mesmo modo, apenas a relação efetiva de troca é que cria nos produtos a natureza de valor. É o fato de que uma mercadoria é permutável por outra que faz com o que 1) o trabalho concreto se manifeste como trabalho comum ou geral; 2) que esta manifestação do trabalho geral cristalizado na mercadoria se dê na figura material da mercadoria equivalente, em seu 
valor de uso. Marx escreve: "Ao relacionar-se com a mercadoria $B$ como corpo de valor, como materialização de trabalho humano, a mercadoria $A$ torna o valor de uso da mercadoria $B$ material de sua própria expressão de valor" (C, I, 1, 57). A objetividade fantasmagórica ou substância social cristalizada no linho alcança existência objetiva separada do linho no casaco, sua forma de expressão, seu equivalente: "A mercadoria linho traz sua própria qualidade de ter valor à luz, pelo fato de que o casaco, sem assumir uma forma de valor diferente de sua forma corpórea, se lhe equipara" (C, I, 1, 59). Mas o casaco, como forma de valor, não expressa de nenhum modo seu próprio valor, ao contrário, aparece apenas como uma quantidade determinada de uma coisa ou valor de uso específico que serve de unidade de medida do valor de outro valor de uso:

\footnotetext{
Dois casacos podem expressar, portanto, a grandeza de valor de 40 varas de linho, mas não podem nunca expressar sua própria grandeza de valor, a grandeza de valor de casacos. A interpretação superficial desta realidade, que o equivalente sempre possui na equação de valor apenas a forma de simples quantum de uma coisa, de um valor de uso, induziu Bailey, como muitos de seus antecessores e sucessores, a ver na expressão de valor apenas uma relação quantitativa. Pelo contrário, a forma de equivalente de uma mercadoria não contém nenhuma determinação quantitativa de valor $(C, I, 1,59)$.
}

A relação de troca entre duas mercadorias não é uma mera relação quantitativa porque a quantidade de valor da equivalente não aparece na equação. Aparece a medida do valor da mercadoria relativa na forma de um valor de uso específico: "40 varas 'valem' - o quê? 2 casacos". A equação gera a substância que iguala ambas as mercadorias ao fazer dos trabalhos distintos que a constituem o mesmo trabalho, mas expressa a quantidade de trabalho abstrato contido na mercadoria relativa como quantidade de um valor de uso distinto. Esta forma necessária da expressão do valor é contraditória: a forma do valor, cuja substância é trabalho social abstrato, é um valor de uso, produto de um trabalho concreto privado.

Marx desenvolve esta contradição ao abordar a função de equivalente do valor que uma mercadoria assume, forma que caracterizará o dinheiro: "A primeira peculiaridade que chama atenção quando se observa a forma de equivalente é esta: o valor de uso torna-se forma de manifestação de seu contrário, do valor” $(C, I, 1,59)$. O filósofo lança mão da analogia do peso com o valor: o peso de um objeto apenas pode expressar-se na comparação com um objeto distinto que representa meramente peso, e cuja unidade de peso foi anteriormente determinada, como convenção: um volume 
determinado de ferro é nomeado como pesando um quilo. Assim, a determinação de peso de um objeto não pode se expressar isoladamente, mas apenas em relação a outro objeto que representa uma medida específica de peso. Contudo, o peso é uma característica natural dos objetos corpóreos, cuja medida apenas é possível pela relação:

Aqui termina, entretanto, a analogia. O ferro representa na expressão de peso do pão de açúcar uma propriedade natural comum a ambos os corpos, seu peso, enquanto o casaco representa na expressão do valor do linho uma propriedade sobrenatural a ambas as coisas: seu valor, algo puramente social (C, I, 1, 60).

A diferença entre o peso e o valor é que o primeiro, embora não possa manifestar-se fora de uma relação, existe como propriedade de tudo que é corpóreo, de qualquer ser que ocupe o espaço. O valor não existe como propriedade natural dos produtos, mas resulta da relação social; é uma propriedade sobrenatural, puramente social, com que a relação de troca reveste o produto. Dada esta relação, contudo, o valor aparece como característica natural da mercadoria equivalente:

Expressando a forma relativa de valor de uma mercadoria, por exemplo do linho, sua qualidade de ter valor como algo inteiramente distinto de seu corpo e suas propriedades, por exemplo, como algo igual a um casaco, essa expressão mesma indica que nela se oculta uma relação social. Com a forma equivalente se dá o contrário. Ela consiste justamente em que um corpo de mercadoria, como o do casaco, tal qual ela é, expressa valor, possuindo portanto, por natureza, forma de valor. É verdade que isso vale apenas internamente à relação de valor, na qual a mercadoria linho está relacionada à mercadoria casaco como equivalente. Como, porém, as propriedades de uma coisa não se originam de sua relação com outras coisas, antes apenas atuam em tal relação, parece também que o casaco possui, por natureza, sua forma equivalente, sua propriedade de ser diretamente trocável, tanto quanto sua propriedade de ser ou de manter alguém aquecido (C, I, 1, 60).

Se, na mercadoria relativa, o fato de ter seu valor medido em casaco manifesta que sua qualidade de valor é distinta de seu corpo de linho, e que portanto há uma relação social oculta na proporção da troca, na mercadoria equivalente, cujo valor de uso manifesta o valor de outra mercadoria, parece, ao contrário, que este valor de uso da mercadoria equivalente traz em si a determinação de ser valor, de modo que o linho, no exemplo de Marx, apenas tem valor porque se troca por casaco, enquanto este é valor por sua materialidade específica, por ser casaco. Em nota, Marx escreve: "Em geral, essas determinações reflexivas são muito peculiares. Esse homem, por exemplo, é rei apenas porque outros homens comportam-se como súditos frente a ele. Eles pensam, ao 
contrário, que são súditos porque ele é rei” (C, I, 1, 60, nota 21). Ou seja, do mesmo modo que ser rei não é uma determinação natural de um indivíduo, mas uma relação com os demais, também a mercadoria equivalente não é valor, mas representa o valor de outra mercadoria na relação de troca, tornando-se forma de valor. Neste processo, "O corpo da mercadora que serve de equivalente figura sempre como corporificação do trabalho humano abstrato e é sempre o produto de determinado trabalho concreto, útil. Esse trabalho concreto torna-se portanto forma de expressão de trabalho humano abstrato" (C, I, 1, 61). Assim, dentro da relação de troca exemplificada por Marx, a utilidade da alfaiataria consiste "em que ela faz um corpo em que é visível que é valor, por conseguinte, gelatina de trabalho, que em nada se diferencia do trabalho objetivado no valor do linho" (C, I, 1, 61). Se o valor de uso casaco se torna a forma do valor do linho, "É uma segunda peculiaridade da forma equivalente que trabalho concreto [no caso, a alfaiataria - VC] se converta na forma de manifestação de seu contrário, trabalho humano abstrato" (C, I, 1, 61). Como forma de valor da mercadoria relativa, a mercadoria equivalente converte o trabalho concreto que a criou em forma de trabalho abstrato. Do mesmo modo, a forma equivalente converte o trabalho privado que a criou em trabalho diretamente social:

\footnotetext{
Mas na medida em que esse trabalho concreto, a alfaiataria, funciona como mera expressão de trabalho humano indiferenciado, possui ele a forma da igualdade com outro trabalho, o trabalho contido no linho, e é, portanto, ainda que trabalho privado, como todos os outros, trabalho que produz mercadorias, por conseguinte, trabalho em forma diretamente social. Por isso mesmo, apresenta-se ele num produto que é diretamente trocável por outra mercadoria. É, portanto, uma terceira peculiaridade da forma equivalente que trabalho privado se converta na forma de seu contrário, trabalho em forma diretamente social $(\mathrm{C}, \mathrm{I}, 1,61)$.
}

A mercadoria incorpora "trabalho em forma diretamente social" pelo caráter de permutabilidade que a define, para além do simples produto. Ao expressar o valor de outra mercadoria, um produto criado na esfera privada converte-se na forma de valor, portanto na forma do trabalho social indiferenciado. Pela análise da forma simples de valor, em que duas mercadorias se opõem nas formas relativa e equivalente, o duplo caráter do trabalho que cria a mercadoria ganha expressão. A mercadoria é unidade de valor de uso e valor, mas este caráter bipartido apenas se expressa na relação de troca. Nesta, cada uma das mercadorias torna ativa uma dessas determinações: a mercadoria relativa se põe como forma específica de valor de uso e mercadoria equivalente como forma de valor. Se isoladamente nenhuma mercadoria manifesta-se como coisa de valor, 
na relação elas podem inverter os papéis, mas não podem manifestar as duas determinações ao mesmo tempo: ou toma a mercadoria distinta como forma de seu valor, e assim vale como valor de uso cujo valor é expresso, ou espelha o valor da outra, e assim vale como forma de valor. Esta necessária exclusão de uma das determinações características da mercadoria na troca revela a contradição que existe na mercadoria, ou ainda, no trabalho que cria mercadoria: ele é ao mesmo tempo trabalho concreto e trabalho abstrato, trabalho privado e trabalho social:

O exame mais pormenorizado da expressão de valor da mercadoria A, contida na relação de valor com a mercadoria $\mathrm{B}$, demonstrou que dentro da mesma a forma natural da mercadoria $\mathrm{A}$ funciona apenas como figuração de valor de uso, a forma natural da mercadoria B apenas como forma valor ou figuração de valor. A oposição (Gegensatz) interna entre valor de uso e valor, oculta na mercadoria, é, portanto, representada por meio de uma oposição externa, isto é, por meio da relação de duas mercadorias, na qual uma delas, cujo valor deve ser expresso, funciona diretamente apenas como valor de uso; a outra, ao contrário, na qual o valor é expresso, vale diretamente apenas como valor de troca. A forma simples do valor de uma mercadoria é, por conseguinte, a forma simples de manifestação da oposição entre valor de uso e valor, nela contida $(\mathrm{C}, \mathrm{I}, 1,63)^{128}$.

A contradição está na forma social do trabalho: no caráter especificamente privado do trabalho, e não simplesmente individual, que torna seu caráter social - abstrato. Não há a princípio qualquer contradição entre o trabalho social e o trabalho individual: o trabalho individual é social na medida em que se realiza para outros. Apenas na socialização pela troca o caráter social do produto aparece como "objetivo", como coisa ao lado das coisas e dos sujeitos. Estas duas objetividades natural e social é que se chocam na mercadoria, e criam o feitiço de Áquila que permeia a relação de troca: cada mercadoria pode ser apenas uma dessas objetividades de cada vez, de modo que a forma relativa e a forma equivalente são excludentes em sua manifestação. Esta separação do processo social com relação aos sujeitos sociais que determina o conteúdo da contradição da forma mercadoria fica clara na passagem em que Marx analisa o fetichismo da mercadoria.

Antes, porém, de expor esta análise, é preciso considerar o dinheiro, cuja natureza está já configurada na forma equivalente da mercadoria. Marx afirma que “(...) a forma simples de valor é ao mesmo tempo a forma mercadoria simples do produto do

\footnotetext{
${ }^{128} \mathrm{Na}$ tradução de Kothe, o termo Gegensatz é traduzido por antítese. Alterei para oposição, com base na tradução do primeiro capítulo de $O$ Capital de Jorge Grespan, A Mercadoria, conforme bibliografia.
} 
trabalho e que, portanto, também o desenvolvimento da forma mercadoria coincide com o desenvolvimento da forma valor" (C, I, 1, 63). Daí deduz o dinheiro como desenvolvimento necessário da produção de mercadorias. A necessidade do desenvolvimento do dinheiro acompanhar o desenvolvimento do produto do trabalho como mercadoria é importante para contrapor a analogia que Ruy Fausto faz entre a mercadoria e o dinheiro, por um lado, e o trabalho concreto e trabalho abstrato, por outro. A forma mercadoria simples do produto do trabalho corresponde à forma simples do valor: a oposição entre duas mercadorias. À medida que a forma mercadoria do produto do trabalho se desenvolva, ou seja, pari passu à expansão das trocas, desenvolve a forma de valor até tornar-se dinheiro mundial ${ }^{129}$.

A forma simples do valor da mercadoria, ao distinguir a forma relativa da forma equivalente, é o germe do dinheiro, equivalente geral fixado em uma mercadoria específica excluída da forma relativa, mas não é o dinheiro. Apenas no dinheiro, "Evidencia-se que não é a troca que regula a grandeza do valor, mas, ao contrário, é a grandeza de valor da mercadoria que regula suas relações de troca" (C, I, 1, 65). São necessárias relações de troca efetivas entre diversas mercadorias para que o valor apareça como uma objetividade distinta do corpo da mercadoria. Apenas quando a mercadoria ganha, pela expansão de suas relações, múltiplos valores de troca ou espelhos de seu valor, é que uma "terceira coisa" comum a todas as mercadorias se mostra como fundamento que regula as proporções de troca. Marx escreve:

\footnotetext{
Na primeira forma: 20 varas de linho $=1$ casaco, pode ser casual que essas duas mercadorias sejam permutáveis em determinada relação quantitativa. Na segunda forma, ao contrário, transparece imediatamente um fundamento essencialmente diferente da manifestação casual e que a determina. $\mathrm{O}$ valor do linho permanece de igual tamanho, seja ele representado em casaco, ou café, ou ferro etc., em inumeráveis mercadorias que pertencem aos mais diferentes proprietários $(\mathrm{C}, \mathrm{I}, 1,65)$.
}

O valor, como forma separada e objetivada do trabalho humano geral, do mesmo modo que este trabalho, apenas aparece em um sistema de trocas:

Assim aparece esse valor mesmo pela primeira vez verdadeiramente como gelatina de trabalho humano indiferenciado. Pois o trabalho que o gera é agora expressamente representado como

\footnotetext{
${ }^{129}$ Este não é o desenvolvimento final do dinheiro. Conforme a troca se desenvolva ao ponto de tornar-se a forma central do intercâmbio humano e tomar a produção, o dinheiro também se desenvolve em capital, especificamente na forma autônoma em que o capital existe.
} 
trabalho equiparado a qualquer outro trabalho humano, seja qual for a forma natural que ele possua e se, portanto, se objetiva em casaco ou trigo, ou ferro ou ouro etc. (C, I, 1, 64)

Nesta forma que demanda já a existência de um "mundo das mercadorias", cada proprietário singular vê todas as outras mercadorias como formas de valor da sua. A "relação recíproca implicitamente contida na série" dos equivalentes da mercadoria singular relativa cria uma forma de valor comum a todas as mercadorias, ao torná-la, inversamente, equivalente geral de todas as demais. Esta é a terceira forma do valor. A mercadoria que funciona como equivalente geral se torna dinheiro quando excluída do mundo das mercadorias relativas, de modo que o caráter de forma de valor adere a ela como seu valor de uso específico:

O ouro só se confronta com outras mercadorias como dinheiro por já antes ter-se contraposto a elas como mercadoria. Igual a todas as outras mercadorias funcionou também como equivalente, seja como equivalente particular ao lado de outros equivalentes mercantis. Pouco a pouco passou a funcionar, em círculos mais estreitos ou mais extensos, como equivalente geral. Tão logo conquistou o monopólio dessa posição na expressão de valor do mundo das mercadorias, tornase mercadoria dinheiro, e só a partir do momento em que já se converteu em mercadoria dinheiro distingue-se a forma IV da forma III, ou a forma valor geral se transforma em forma dinheiro (C, I, 1, 69).

Fausto refere o dinheiro como um universal efetivamente existente, portanto singular, ao lado dos demais indivíduos e espécies que compõem o universo das mercadorias, o Animal ao lado dos leões, lebres etc. De fato, em outra passagem, Marx afirma: "Sendo todas as mercadorias equivalentes particulares do dinheiro e o dinheiro seu equivalente geral, elas se relacionam como mercadorias particulares em relação ao dinheiro" (C, I, 1, 83). O dinheiro é uma mercadoria particular que expressa o conteúdo de valor de todas as demais mercadorias, portanto universal. É valor de troca em forma imediata, seu corpo expressa diretamente o caráter de permutabilidade de todas as mercadorias. Por isso, "o valor de uso da mercadoria monetária dobra. Além de seu valor de uso particular como mercadoria, como o ouro por exemplo serve para obturar dentes, como matéria-prima para artigos de luxo etc., ela adquire um valor de uso formal decorrente de suas funções sociais específicas" (C, I, 1, 83). Seu valor de uso concreto não se altera, mas adquire a mercadoria dinheiro um valor de uso formal, referente à sua função de equivalente geral nas relações de troca. "Do fato de que a mercadoria devém valor de troca universal resulta que o valor de troca devém uma mercadoria particular" 
(Grundrisse, 114), ou seja, o dinheiro é consequência necessária do desenvolvimento da forma mercadoria do produto do trabalho. Marx escreve:

\begin{abstract}
O cristal monetário é um produto necessário do processo de troca, no qual diferentes produtos do trabalho são, de fato, igualados entre si e, portanto, convertidos em mercadorias. A ampliação e aprofundamento históricos da troca desenvolve a oposição entre valor de uso e valor latente na natureza da mercadoria. A necessidade de dar a esta oposição (Gegensatz) ${ }^{130}$ representação externa para a circulação leva a uma forma independente do valor da mercadoria e não se detém nem descansa até tê-la alcançado definitivamente por meio da duplicação da mercadoria em mercadoria e dinheiro. Na mesma, medida, portanto, em que se dá a transformação do produto em mercadoria, completa-se a transformação da mercadoria em dinheiro (C, I, 1, 81).
\end{abstract}

A contradição que torna necessária seu desdobramento objetivo é a que existe entre valor de uso e valor, em última instância, entre trabalho privado concreto e o trabalho social abstrato. A mercadoria é produto de trabalho específico, mas na troca só pode aparecer como produto de um trabalho geral, abstrato; é produto de trabalho privado, mas na troca só pode aparecer como trabalho diretamente social: apenas como valores as mercadorias se enfrentam. Do mesmo modo, o tempo de trabalho só se torna objetivo em produtos singulares, portanto como tempo de trabalho efetivo, concreto. Mas afirmar que um metro de tecido custa 10 horas de trabalho divididas entre o agricultor de algodão, o tecelão e o branqueador nada revela sobre seu valor. Ou seja, o valor não é o tempo de trabalho efetivo, mas tempo de trabalho abstrato, que não apenas não existe como sujeito, mas também não existe como objeto empírico. Marx escreve:

\begin{abstract}
A necessidade de um dinheiro distinto do tempo de trabalho surge precisamente do fato de que a quantidade de tempo de trabalho não deve ser expressada no seu produto imediato e particular, mas em um produto mediado universal, em seu produto particular como produto igual e convertível em todos os demais produtos de mesmo tempo de trabalho; o tempo de trabalho contido não em uma mercadoria, mas em todas as mercadorias ao mesmo tempo e, por isso, em uma mercadoria particular que representa todas as outras. O próprio tempo de trabalho não pode ser imediatamente o dinheiro (uma exigência que, em outras palavras, equivale a requerer que toda a mercadoria seja imediatamente seu próprio dinheiro), justamente porque, na prática, o tempo de trabalho só existe em produtos particulares (como objeto); como objeto universal, o tempo de trabalho só pode existir de forma simbólica, e, por sua vez, apenas em uma mercadoria particular que é posta como dinheiro. O tempo de trabalho não existe como objeto universal da
\end{abstract}

\footnotetext{
${ }^{130}$ A tradução de Kothe e Barbosa utiliza o termo antítese. O termo original foi extraído de Marx, Das Kapital - Ersters Buch - Der Produktionsprozeß des Kapitals, Marx-Engels Werke, Berlin: Dietz Verlag, 1962, p. 102.
} 
troca, independente e separado (dissociado) das particularidades naturais das mercadorias (Grundrisse, 115).

O tempo de trabalho em que consiste a substância do valor não pode ser expresso no "produto imediato e particular" porque não se constitui imediatamente pelo tempo de trabalho contido nele, isto é, do trabalho concreto específico de que resulta. Deve se expressar nos produtos particulares enquanto são iguais e universalmente permutáveis e, portanto como "mesmo tempo de trabalho", ou quantidade de trabalho qualitativamente igual, "contido não em uma mercadoria, mas em todas as mercadorias ao mesmo tempo"; "por isso, em uma mercadoria particular que representa todas as outras". Por quê? "justamente porque, na prática, o tempo de trabalho só existe em produtos particulares (como objeto)", ou seja, o trabalho é sempre trabalho concreto particular. Exigir que toda mercadoria seja seu próprio dinheiro é o mesmo que exigir que os trabalhos concretos sejam todos imediatamente trabalho abstrato. $\mathrm{O}$ valor deve ser expresso em produto universal, porque consiste em trabalho geral, mas este produto só pode ser mediado, visto que "O tempo de trabalho não existe como objeto universal da troca, independente e separado (dissociado) das particularidades naturais das mercadorias". O trabalho imediato e seu produto são concretos e somente com a mediação do processo social - das próprias trocas - se tornam universais: "como objeto universal, o tempo de trabalho só pode existir de forma simbólica, e, por sua vez, apenas em uma mercadoria particular que é posta como dinheiro". A forma tem caráter simbólico porque o processo social das trocas exclui uma mercadoria singular que assume a forma de equivalente, cujas peculiaridades são: fazer de um valor de uso, o ouro, forma de valor, de um trabalho concreto, o do minerador, forma de expressão de trabalho abstrato e de um trabalho privado, forma de manifestação do trabalho social. Ou seja, o dinheiro não é valor, não contém trabalho abstrato ou trabalho social geral senão de forma mediada (como qualquer mercadoria), mas torna-se a expressão de valor de troca universal, de todas as mercadorias. É uma coisa social, que dá existência material à objetividade do valor, à quota de tempo de trabalho que é e não é o trabalho do indivíduo:

Por conseguinte, não obstante o dinheiro [seja] apenas o valor de troca destacado da substância das mercadorias e deva sua origem apenas à tendência desse valor de troca de se pôr de modo puro, a mercadoria não pode ser imediatamente transformada em dinheiro; i.e., o certificado autêntico do quantum de trabalho nela realizado não pode ser utilizado como seu preço no mundo dos valores de troca (Grundrisse, 108). 
O valor não é tempo de trabalho, mas tempo de trabalho abstrato, socialmente necessário, posto como um objeto que medeia ou confere forma social ao trabalho efetivo. O trabalho objetivado apenas é valor quando este se separa do produto específico do trabalho e se autonomiza em forma imediata de valor de troca universal, isto é, em dinheiro. Esta separação se dá pela troca efetiva. Para que um produto seja uma mercadoria nas mãos de seu possuidor, é preciso que ela exista para ele como forma de valor, valor de troca das demais mercadorias que para ele têm valor de uso:

Sua mercadoria não tem para ele nenhum valor de uso direto. Do contrário não a levaria ao mercado. Ela tem valor de uso para outros. Para ele, ela tem diretamente apenas valor de uso de ser portadora do valor de troca e, portanto, meio de troca. Por isso, ele quer aliená-la por mercadoria cujo valor de uso o satisfaça. Todas as mercadorias são não valores de uso para seus possuidores e valores de uso para seus não possuidores. Elas precisam, portanto, universalmente mudar de mãos. Mas essa mudança de mãos constitui sua troca e essa troca as refere como valores entre si e as realiza como valores. As mercadorias devem realizar-se, portanto, como valores, antes de poderem realizar-se como valores de uso (C, I, 1, 80).

Na divisão social do trabalho, os produtos são criados como não-valores de uso, ou seja, são produzidos como valores, equivalentes das demais mercadorias. Para que se realizem, no consumo, como valores de uso, é preciso que antes se realizem como valores. Esta realização é a própria troca: quando a mercadoria é trocada, seu valor é separado de seu corpo material, alienada, enquanto o valor da mercadoria permanece nas mãos de seu possuidor original após a troca, mas em outra forma concreta: na forma da permutabilidade universal, o dinheiro. Este é a materialização da permutabilidade da mercadoria, e por isso a realização de seu valor. Neste processo, ela se confirma como valor de troca social:

\footnotetext{
Por outro lado, as mercadorias têm de comprovar-se como valores de uso, antes de poderem realizar-se como valores. Pois o trabalho humano, despendido em sua produção, conta somente na medida em que seja despendido de forma útil para outros. Se o trabalho é útil para outros, se, portanto, seu produto satisfaz necessidades alheias, somente sua troca pode demonstrar (C, I, 1, 80).
}

Todo produto humano é materialização de trabalho humano concreto, mas este trabalho apenas se confirma como valor quando assume a forma da permutabilidade geral, ou seja, de valor de troca universal. Apenas na troca efetiva a mercadoria prova ser resultado de trabalho útil para a sociedade, confirmando a participação efetiva do trabalho concreto que a criou na divisão social do trabalho. O trabalho concreto cria 
produto útil, mas a realização do valor de uso é mediada pela transformação do produto em forma diretamente social de trabalho, parte alíquota do dispêndio de força de trabalho que a sociedade deve despender para adquirir este produto útil específico. $\mathrm{O}$ trabalho útil deve assumir forma abstrata, o que se realiza pela metamorfose do valor da mercadoria em forma diretamente permutável, dinheiro, antes de se realizar como trabalho concreto pelo consumo de seu produto útil. A mediação da abstração do trabalho por meio da realização de seu valor torna efetiva a participação dos trabalhos concretos na divisão social do trabalho. É, por isso, seu caráter social, ou seja, caracteriza a relação social de produção:

\footnotetext{
Os equivalentes são a objetivação de um sujeito para o outro, i.e., eles próprios são de mesmo valor e se confirmam no ato da troca como valendo igual e, ao mesmo tempo, como reciprocamente indiferentes. Na troca, os sujeitos são sujeitos uns para os outros exclusivamente pelos equivalentes, como sujeitos de igual valor, e se afirmam enquanto tais pela permuta da objetividade em que um é para o outro. Uma vez que só são assim, um para o outro, como sujeitos de igual valor, como possuidores de equivalentes e como sujeitos que atestam essa equivalência na troca, como sujeitos de igual valor são ao mesmo tempo indiferentes uns aos outros; suas outras diferenças individuais não lhes interessam; são indiferentes a todas as suas outras peculiaridades individuais (Grundrisse, 185).
}

A relação econômica da troca, que cria os produtos como equivalentes ou mercadorias, põe ao mesmo tempo os sujeitos como portadores de equivalentes, e por isso, eles mesmos iguais. Esta igualdade é o modo como um sujeito existe para o outro na relação mercantil: suas diferenças e peculiaridades, que não deixam de existir, tornam-se contudo, na relação, indiferentes, na medida em que um existe para o outro como trocador. O conteúdo concreto desta relação continua sendo a reprodução dos indivíduos e satisfação de suas necessidades, ampliadas pela diversificação das mercadorias que resulta da divisão do trabalho:

No que se refere agora ao conteúdo exterior ao ato da troca, que é tanto pôr como comprovação dos valores de troca como dos sujeitos como trocadores, tal conteúdo, que se encontra fora da determinação econômica, só pode ser: 1) a particularidade natural da mercadoria que é trocada; 2) a necessidade natural particular dos trocadores; ou ambas combinadas, o valor de uso diferente das mercadorias a serem trocadas. Esse conteúdo da troca, que está totalmente fora de sua determinação econômica, longe de ameaçar a igualdade social dos indivíduos, faz de sua diferença natural o fundamento de sua igualdade social (Grundrisse, 186). 
Os indivíduos se completam porque são diferentes. Um é necessário ao outro na medida em que se objetiva em mercadoria de que o outro necessita. É a diferença entre os indivíduos, desenvolvida pela divisão de trabalho, que faz com que um dependa de todos os outros. O desenvolvimento da individuação aprofunda a conexão entre os indivíduos, mas sua relação pela troca apaga estas diferenças individuais que caracterizam a riqueza do gênero e que se objetivam no mundo das mercadorias. $\mathrm{Na}$ troca, a multiplicidade de produtos é mediada pela igualdade da substância social que os põe em conexão, o valor. Quando vale por sua determinação concreta e específica, o produto tornou-se já objeto de consumo, separado da relação social que o trouxe a esta esfera. Quando existe socialmente, vale por sua permutabilidade e é então forma de riqueza geral indiferenciada.

Os indivíduos desenvolvem sua diversidade ao produzirem seus produtos específicos como valores de troca recíprocos, isto é, ao mesmo tempo em que se afirmam como iguais pela troca. Esta igualdade social pautada na diversidade concreta caracteriza a liberdade dos sujeitos, isto é, a propriedade de sua vontade:

Ainda que o indivíduo $A$ sinta necessidade da mercadoria do indivíduo $B$, não se apodera dela pela força, nem vice-versa, mas reconhecem-se mutuamente como proprietários, como pessoas cuja vontade impregna suas mercadorias. Em decorrência, aqui entra de imediato o momento jurídico da pessoa e da liberdade, na medida em que está contida na primeira (Grundrisse, 187).

O mútuo reconhecimento dos guardiões de mercadorias como proprietário privados caracteriza sua relação como uma relação de vontade, cuja forma jurídica, desenvolvida legalmente ou não, é o contrato. "Igualdade e liberdade, por conseguinte, não apenas são respeitadas na troca baseada em valores de troca, mas a troca de valores de troca é a base produtiva de toda igualdade e liberdade" (Grundrisse, 188).

Esta base produtiva caracteriza a relação entre os indivíduos de modo que "Cada um serve ao outro para servir a si mesmo; cada um se serve reciprocamente do outro como seu meio" (Grundrisse, 187). Contudo, o fato de que o indivíduo tem necessidade dos demais, ou que sua necessidade pode ser satisfeita pelos demais apenas demonstra que o ser humano é genérico, que o indivíduo é social. Max escreve:

Que a necessidade de um pode ser satisfeita pelo produto do outro e vice-versa, que um é capaz de produzir o objeto da necessidade do outro e que cada um se enfrenta com o outro como proprietário do objeto da necessidade do outro, prova que cada um, como ser humano, vai além de sua própria necessidade particular etc. e se comporta um em relação ao outro como ser 
humano; que sua essência genérica comum é conhecida por todos. De mais a mais, não acontece de elefantes produzirem para tigres, ou animais para outros animais (Grundrisse, 186).

Em qualquer forma social, um indivíduo é meio para o outro e produz para outro. A especificidade desta forma social consiste em que a igualdade dos indivíduos (a superação das relações de consanguinidade, dos vínculos de obrigação, de domínio da vontade, na escravidão e na servidão, que caracterizam a desigualdade entre os indivíduos), se põe como equiparação que apaga as diferenças concretas, as determinações efetivamente singulares que expressam a individuação. Ou seja, como uma forma de igualdade que contradiz as peculiaridades. A liberdade, do mesmo modo, apenas supera as relações de coação na forma da indiferença de um indivíduo a outro. Assim, a reciprocidade na troca, que implica mútuo reconhecimento da liberdade e da igualdade dos trocadores, importa ao indivíduo apenas “(...) na medida em que satisfaz seu interesse, como interesse que exclui o interesse do outro, sem ligação com ele" (Grundrisse, 187).

Tanto a liberdade que se realiza como indiferença com relação aos demais indivíduos e suas necessidades, quanto a igualdade que se estabelece pela negação das especificidades concretas dos produtos e dos indivíduos carregam um caráter de compulsão, que no entanto não aparece na forma jurídica. A compulsão das necessidades, o motivo externo à relação econômica, impele à troca devido à indiferença em que as necessidades individuais existem para a sociedade, para os demais indivíduos. Ou seja, a própria liberdade, se realizada como indiferença característica do indivíduo privado, é compulsão à troca. Esta compulsão aparece, contudo, não como uma determinação social anterior aos indivíduos, posta pela divisão do trabalho, mas como resultado das próprias necessidades, ou seja, da natureza do indivíduo:

(...) essa própria compulsão é, de um lado, só a indiferença do outro ante minha necessidade enquanto tal, perante minha individualidade natural, portanto, sua igualdade comigo e sua liberdade que, no entanto, é igualmente o pressuposto da minha; de outro lado, na medida em que sou determinado, forçado por minhas necessidades, é somente minha própria natureza, que é um todo de necessidades e impulsos, que me violenta, e não algo estranho (Grundrisse, 188).

Além disso, o indivíduo deve produzir seu produto na forma da riqueza geral, mercadoria, e isso significa que apenas a mediação social da troca permite que o sujeito se aproprie de seu próprio produto: 
“(...) o pressuposto da troca, como fundamento objetivo da totalidade do sistema de produção, já encerra em si a coação sobre o indivíduo de que seu produto imediato não é um produto para ele, mas só devém para ele no processo social e tem de assumir essa forma universal e, todavia, exterior; que o indivíduo tem de produzir valor de troca e que, portanto, já está envolvida a negação total de sua existência natural (Grundrisse, 190).

A equiparação das atividades em que a igualdade existe, impõe que o produto individual seja criado na forma de um produto social exterior, abstrato, sobre o qual os indivíduos não têm qualquer controle. $\mathrm{O}$ valor apaga as peculiaridades concretas da atividade, de modo que apenas como indivíduo social abstrato seu produto adquire o caráter social necessário para a apropriação individual. Com isso, nega socialmente ao indivíduo sua existência natural, efetiva. A liberdade e a igualdade dos indivíduos, quando existentes no limite da indiferença e da equiparação, são estranhas a eles porque existem apenas como dinheiro, como coisa portanto: "Considerado o processo de troca, cada qual aparece ante o outro como possuidor de dinheiro, até mesmo como dinheiro. Por isso, a indiferença e a equivalência estão explicitamente presentes na forma de coisa" (Grundrisse, 189).

Esta autonomia e indiferença é o que faz com que o processo social apareça como estranho aos indivíduos, e ocorra às costas dos produtores. O desenvolvimento da divisão do trabalho amplia a conexão social do indivíduo e o torna mais determinado pela sociedade, ao passo que o faz mais independente e indiferente aos demais indivíduos: “(...) a conexão universal e a dependência generalizada na produção e no consumo crescem simultaneamente com a independência e indiferença recíproca de produtores e consumidores" (Grundrisse, 109). Esta contradição tem por fundamento a relação reificada em que a produção mercantil se realiza, e faz com que seu nexo social apareça ao indivíduo como um sistema autônomo e automático, ocultando o processo pelo qual os indivíduos são os reais produtores deste nexo. Marx escreve:

De resto, cabe assinalar aqui apenas que a visão geral sobre o comércio e a produção globais, na medida em que está factualmente presente nas listas de preços correntes, fornece de fato a melhor demonstração de como o seu intercâmbio e sua própria produção confrontam os indivíduos singulares como relação coisal, deles independente (Grundrisse, 109).

Esta separação entre o nexo social dos indivíduos, sua produção e seu intercâmbio, e os próprios indivíduos aparece na forma mercadoria como seu caráter misterioso, como a 
determinação mística que parece movê-la, seu valor imanente; e é exposto por Marx na famosa passagem sobre o fetichismo da mercadoria.

\section{O limite da universalidade do trabalho abstrato}

Marx começa afirmando os aspectos em que a mercadoria nada tem de obscura. O misterioso da mercadoria não advém nem seu valor de uso, nem do conteúdo das determinações de valor. Este conteúdo abrange três determinações: o fato de que todas as atividades produtivas concretas são formas do trabalho humano, o fato de que o tempo é medida da quantidade de trabalho e que esta medida é importante para os produtores em diversas formas sociais, e o fato de que o trabalho sempre ocorre sob uma forma social, na medida em que os indivíduos produzem uns para os outros. Nos termos de Marx:

\footnotetext{
O caráter místico da mercadoria não provém, portanto, de seu valor de uso. Ele não provém, tampouco, do conteúdo das determinações de valor. Pois, primeiro, por mais que se diferenciem os trabalhos úteis ou atividades produtivas, é uma verdade fisiológica que eles são funções do organismo humano e que cada uma dessas funções, qualquer que seja seu conteúdo ou forma, é essencialmente dispêndio de cérebro, nervos, músculos, sentidos etc. humanos. Segundo, quanto ao que serve de base à determinação da grandeza do valor, a duração daquele dispêndio ou a quantidade do trabalho, a quantidade é distinguível até pelos sentidos da qualidade do trabalho. Sob todas as condições, o tempo de trabalho, que custa a produção dos meios de subsistência, havia de interessar ao homem, embora não igualmente nos diferentes estágios de desenvolvimento. Finalmente, tão logo os homens trabalham uns para os outros de alguma maneira, seu trabalho adquire também uma forma social $(C, I, 1,70)$.
}

O que Marx demonstrará no texto sobre o fetichismo da mercadoria é que o mero fato de todas as atividades serem funções humanas, isto é, o advento do trabalho humano como gênero que abarca o conjunto dos trabalhos concretos, não coincide com o trabalho abstrato; que o tempo de trabalho como medida da atividade não coincide necessariamente com o tempo de trabalho abstrato e tampouco se objetiva em valor; que o fato de os indivíduos produzirem socialmente não implica produção da riqueza na forma de valor. Ao contrário do que afirma Fausto, a abstração do trabalho não é uma das determinações do conteúdo do valor: o advento do gênero humano, a abrangência do conjunto de suas atividades sob a unidade de trabalho humano, não se identifica com o trabalho abstrato, e esta distinção é fundamental para a compreensão dos diferentes 
caracteres sociais que o trabalho assume no capitalismo e deve assumir em uma sociedade planejada que rompa com a divisão do trabalho ou propriedade privada. Se o gênero humano e o trabalho humano surgem pela universalização das relações produtivas na divisão do trabalho posta pela sociedade mercantil, ele não deixa de existir em uma sociedade que supere o caráter mercantil, mas deixa de se configurar em trabalho abstrato. Além disso, o estabelecimento desta nova forma de sociedade, baseada nos resultados do desenvolvimento produtivo sob a forma do valor, ampliará a universalidade da atividade humana ao romper com o caráter abstrato do trabalho, de modo que a generalidade posta como equiparação, que caracteriza o trabalho abstrato, se significou historicamente o processo de universalização do homem, mostrar-se-á como um grau limitado desta universalidade. Ou seja, a generalidade abstrata e a universalidade não são determinações imanentes uma à outra.

Na passagem citada, Marx reúne o conteúdo das determinações do valor: a igualdade dos trabalhos como funções humanas, sua medida pelo tempo, o caráter social do trabalho. Não há mistério em nenhuma delas quando existem e se manifestam em sua efetividade concreta. A medida do trabalho pelo tempo é a medida empírica do trabalho concreto, reconhecida pelos sentidos, e a produção de uns para os outros é sua relação efetiva. A igualdade dos trabalhos incluída entre os conteúdos do valor é o fator que leva Ruy Fausto a concluir que a abstração do trabalho, por conseguinte o trabalho abstrato, é um conteúdo do valor, distinto de sua forma e por isso presente noutras formações sociais. Não é o caso: a consideração dos trabalhos distintos tomados como formas da atividade humana geral é um resultado histórico que, como uma generalização ideal, não se identifica com a equiparação dos produtos do trabalho como valores de troca uns dos outros, ou seja, não traz em si a forma mercadoria. Como se verá, esta igualdade das atividades como atividades humanas se mantém com a superação da sociedade mercantil e do valor. Esses três conteúdos concretos assumem forma misteriosa quando se tornam determinações do valor:

De onde provém, então, o caráter enigmático do produto do trabalho, tão logo ele assume a forma de mercadoria? Evidentemente, dessa forma mesmo. A igualdade dos trabalhos humanos assume a forma material de igual objetividade de valor dos produtos do trabalho, a medida do dispêndio de força de trabalho do homem, por meio de sua duração, assume a forma da grandeza de valor dos produtos de trabalho, finalmente, as relações entre os produtores, em que aquelas características sociais de seu trabalho são ativadas, assumem a forma de uma relação social entre os produtos do trabalho $(\mathrm{C}, \mathrm{I}, 1,71)$. 
Os fatores que constituem o conteúdo do valor apenas tornam-se enigmáticos quando assumem a forma de valor. A especificidade da forma social em que estes conteúdos, característicos do trabalho, se põem (embora demandem certo nível de desenvolvimento deste trabalho, como sua integração universal, que historicamente se estabelece primeiro pela sociedade mercantil), é o que confere ao produto do trabalho aparência mística. Assim, tais conteúdos podem existir sob formas distintas de relação social, nas quais não apresentam qualquer caráter enigmático. No que consiste o mistério? No fato de que eles aparecem como uma existência separada de sua existência natural, como outro ser distinto de si. "A igualdade dos trabalhos humanos", o primeiro conteúdo indicado por Marx, "assume a forma material de igual objetividade de valor dos produtos do trabalho"; "a medida do dispêndio de força de trabalho do homem, por meio de sua duração", segundo conteúdo do valor, "assume a forma da grandeza de valor dos produtos de trabalho"; e o terceiro conteúdo do valor, "as relações entre os produtores, em que aquelas características sociais de seu trabalho são ativadas, assumem a forma de uma relação social entre os produtos do trabalho", na medida em que, como trocadores, a relação efetiva de intercâmbio entre os trabalhos dos sujeitos se dá por meio das mercadorias trocadas.

\footnotetext{
O misterioso da forma mercadoria consiste, portanto, simplesmente no fato de que ela reflete aos homens as características sociais do seu próprio trabalho como características objetivas dos próprios produtos de trabalho, como propriedades naturais sociais dessas coisas e, por isso, também reflete a relação social dos produtores com o trabalho total como uma relação social existente fora deles, entre objetos (C, I, 1, 71).
}

Como valor imanente às mercadorias, a atividade produtiva (e sua duração) aparece como atributo objetivo do produto, propriedade "natural social". Não meramente natural, na medida em que não é característica física, mas natural social porque, a despeito de expressar uma relação social, pertence ao produto. Porque o valor se incorpora ao produto como seu atributo, a relação dos produtores com o trabalho da sociedade, no mercado, aparece como uma relação que os produtos estabelecem entre si de acordo com a grandeza de valor que cada um contém em si, como propriedade sua. "A forma mercadoria ou a relação de valor entre os produtos do trabalho, na qual ele se representa, não tem que ver absolutamente nada com sua natureza física e as relações materiais que daí se originam" $(\mathrm{C}, \mathrm{I}, 1,71)$. Como coisas naturais, os produtos não têm poder de determinar a relação de intercâmbio dos trabalhos entre sujeitos, mas, ao se tornarem mercadorias, os produtos determinam esta relação. Seu atributo imanente de 
valor determina de fato as relações sociais de intercâmbio de trabalhos, que parecem por isso independentes dos próprios produtores. Porque é valor, a igualdade de trabalhos aparece como um atributo mágico impondo as relações entre os homens. Daí o valor encontrar analogia na religião:

Não é mais nada que determinada relação social entre os próprios homens que para eles aqui assume a forma fantasmagórica de uma relação entre coisas. Por isso, para encontrar uma analogia, temos de nos deslocar à região nebulosa do mundo da religião. Aqui, os produtos do cérebro humano parecem dotados de vida própria, figuras autônomas, que mantêm relação entre si e com os homens. Assim, no mundo das mercadorias, acontece com os produtos da mão humana. Isso eu chamo o fetichismo que adere aos produtos de trabalho, tão logo são produzidos como mercadorias, e que, por isso, é inseparável da produção de mercadorias (C, I, 1, 71).

O espírito que toma o corpo dos produtos inertes e os torna fetiches é o próprio trabalho humano abstrato autonomizado dos sujeitos e posto como valor das mercadorias. Quando o trabalho se separa dos sujeitos, tornando-se uma objetividade das coisas ao lado de sua objetividade natural, não é mais possível reconhecer esta determinação de valor como uma forma da relação entre os trabalhos. "Esse caráter fetichista do mundo das mercadorias provém, como a análise precedente já demonstrou, do caráter social peculiar do trabalho que produz mercadoria" (C, I, 1, 71), isto é, do caráter da divisão do trabalho, baseada na propriedade privada e na respectiva relação de troca.

Em outras palavras, os trabalhos privados só atuam, de fato, como membros do trabalho social total por meio das relações que a troca estabelece entre os produtos do trabalho e, por meio dos mesmos, entre os produtores. Por isso, aos últimos aparecem as relações sociais entre seus trabalhos privados como o que são, isto é, não como relações diretamente sociais entre pessoas em seus próprios trabalhos, senão como relações reificadas entre as pessoas e relações sociais entre as coisas $(\mathrm{C}, \mathrm{I}, 1,71)$.

As relações sociais são efetivamente reificadas, e por isso não apenas aparecem como relações entre coisas, mas se dão por meio de coisas, porque o intercâmbio efetivo entre as atividades, a forma como os trabalhos privados se põem como trabalhos sociais, é a troca de produtos. A relação entre as atividades se dá por meio do valor dos produtos. Este é objetivo, mas de uma objetividade metafísica ou social, dado que seu conteúdo é a atividade produtiva e sua duração. Este conteúdo apenas se objetiva em valor porque a relação é mercantil: 
Somente dentro da sua troca, os produtos recebem uma objetividade de valor socialmente igual, separada da sua objetividade de uso, fisicamente diferenciada. Essa cisão do produto do trabalho em coisa útil e coisa de valor realiza-se apenas na prática, tão logo a troca tenha adquirido extensão e importância suficientes para que se produzam coisas úteis para serem trocadas, de modo que o caráter de valor das coisas já seja considerado ao serem produzidas (C, I, 1, 71).

A “cisão do produto do trabalho em coisa útil e coisa de valor" exprime outra em que o indivíduo se separa do caráter social de sua própria atividade: os produtos do produtor privado são específicos, coisas úteis diferenciadas, que se põem como parte componente da produção social; contudo, não como resultado de sua atividade pessoal, mas como objetividade indiferenciada de trabalho humano. O caráter social do trabalho privado se constitui desta objetividade de valor, de modo que se separa do caráter individual, específico, da atividade concreta, e se incorpora no produto como dimensão objetiva deste, fora do controle do produtor. Esta cisão que faz do caráter social do trabalho algo objetivo, exterior e fora de controle é própria da permutabilidade das mercadorias e, por conseguinte, da igualdade abstrata dos trabalhos como regulação objetiva do intercâmbio entre as atividades. A partir do momento que a produção se volta à troca,

(...) os trabalhos privados dos produtores adquirem realmente duplo caráter social. Por um lado, eles têm de satisfazer determinada necessidade social, como trabalhos determinados úteis, e assim provar serem participantes do trabalho total, do sistema naturalmente desenvolvido da divisão do trabalho. Por outro lado, só satisfazem as múltiplas necessidades de seus próprios produtores, na medida em que cada trabalho privado útil particular é permutável por toda outra espécie de trabalho privado, portanto lhe equivale (C, I, 1, 71-2).

O caráter social dos trabalhos privados se distingue de suas determinações úteis particulares, mas media a relação do produtor com sua própria atividade. $\mathrm{O}$ trabalho deve ser útil, mas no modo específico em "que o produto do trabalho deve ser útil, isto é, útil para outros" (C, I, 1, 72), para a sociedade. A atividade privada deve provar ser parte do "sistema naturalmente desenvolvido da divisão do trabalho". Este sistema se desenvolve "naturalmente" porque a relação tende necessariamente tanto à ampliação extensiva, desagregando as relações tradicionais de produção, quanto ao aumento da especialização e subdivisão dos ramos da produção ${ }^{131}$. Produzir para a sociedade é

\footnotetext{
${ }^{131}$ O caráter necessário e espontâneo, e neste sentido, natural, da expansão da propriedade privada, tanto no sentido do mercado mundial e da criação de novas mercadorias, como no sentido da especialização que aprofunda a dependência entre as produções privadas, caracteriza uma diferença central entre a produção mercantil, que é necessariamente capitalista, e as relações de produção pré-capitalistas: a forma social da propriedade, ao contrário de tender à dissolução pelo desenvolvimento, aprofunda-se a partir
} 
condição para que o produtor produza para si, de sorte que o caráter social de valor do produto medeia a relação do produtor com seu produto e com sua própria atividade. Isso faz com que a diversidade dos trabalhos privados se confirme como parte do trabalho social total mediante sua qualidade de trabalho em geral, e não diretamente, mediante suas qualidades específicas.

Ao equiparar seus produtos de diferentes espécies na troca, como valores, equiparam seus diferentes trabalhos como trabalho humano. Não sabem, mas o fazem. [Em nota: Quando, portanto, Galiani diz: O valor é uma relação entre pessoas, ele deveria ter acrescentado: uma relação oculta sob uma capa material.] Por isso, o valor não traz escrito na testa o que ele é. $\mathrm{O}$ valor transforma muito mais cada produto de trabalho em um hieróglifo social (C, I, 1, 72).

A obscuridade que reside no valor deriva de seu caráter objetivo. Como uma objetividade posta, está fora do controle dos indivíduos: embora seu próprio trabalho, em duração determinada, constitua o conteúdo do valor, sua grandeza não pode ser prevista, determinada previamente ou controlada. É esta grandeza, no entanto, que consolida a natureza de valor do produto:

O que, na prática, primeiro interessa aos que trocam produtos é a questão de quantos produtos alheios eles recebem pelo seu, em quais proporções, portanto, se trocam seus produtos. Tão logo essas proporções amadurecem, alcançando certa estabilidade costumeira, elas parecem provir da natureza dos produtos do trabalho (...). De fato, o caráter de valor dos produtos de trabalho apenas se consolida mediante sua efetivação como grandezas de valor. As últimas variam sempre, independentemente da vontade, da previsão e da ação dos que trocam $(C, I, 1,72)$.

O fato de que a grandeza do valor das mercadorias singulares não coincide imediatamente com o tempo empírico de trabalho incorporado, mas com o tempo social médio, ou socialmente necessário e, além disso, o fato de que o valor apenas se expressa na forma de valor de troca, e portanto como preço, constituem a reificação da atividade, uma vez que estabelecem a impossibilidade de o produtor prever ou medir o valor de suas mercadorias particulares pelo tempo de trabalho efetivamente despedido. Marx escreve:

A grandeza do valor da mercadoria expressa, assim, uma relação necessária imanente a seu processo de formação com o tempo de trabalho social. Com a transformação da grandeza de valor em preço, essa relação necessária aparece como relação de troca de uma mercadoria com a mercadoria monetária, que existe fora dela. Mas nessa relação pode expressar-se tanto a

dele e se identifica com a necessidade da expansão do capital. Trataremos desta questão no capítulo seguinte. 
grandeza de valor da mercadoria como o mais ou menos em que, sob dadas circunstâncias, ela é alienável. A possibilidade de uma incongruência quantitativa entre o preço e a grandeza de valor ou da divergência entre o preço e grandeza de valor é, portanto, inerente à própria forma preço. Isso não é um defeito dessa forma, mas torna-a, ao contrário, a forma adequada a um modo de produção em que a regra somente pode impor-se como lei cega da média à falta de qualquer regra $(\mathrm{C}, \mathrm{I}, 1,92)$.

A relação coisal, que "está factualmente presente nas listas de preços correntes", torna o nexo social estranho aos indivíduos. Este nexo aparece como lei cega da média que determina a grandeza de valor das mercadorias. Embora o preço, como única forma em que o valor se mostra, expresse uma relação necessária e imanente com o tempo de trabalho social, esta relação aparece na troca efetiva como um quantum de dinheiro que não mantém proporção necessária com o tempo de trabalho concreto individual, mas aparece "como o mais ou menos em que, sob dadas circunstâncias, ela é alienável", de modo que os indivíduos não têm poder sobre a proporção que seu próprio trabalho representa no conjunto do valor social.

Marx compara esta forma social de intercâmbio entre os trabalhos humanos com outras em que este nexo se dá diferentemente. Primeiramente, como caráter social do trabalho Marx entende a forma como o trabalho individual se torna trabalho para outros. Todo trabalho, como atividade, é sempre individual, visto que é função do ser ativo. (O trabalho coletivo, por exemplo, é trabalho individual que se realiza em colaboração direta ou em comum.) O caráter social é pois a relação específica em que os indivíduos intercambiam seus trabalhos. Marx compara a produção de mercadorias com o trabalho de Robinson Crusoé em sua ilha, com o trabalho do servo medieval e dos membros de uma família patriarcal camponesa primitiva, forma que caracteriza o limiar de todos os povos civilizados. Em todas elas se observa uma divisão do trabalho e por conseguinte um modo como o trabalho dos indivíduos se faz para outrem, e também a determinação do tempo de trabalho como relevante na organização produtiva. No caso de Robinson, "Apesar da diversidade de suas funções produtivas ele sabe que elas são apenas diferentes formas de atividade do mesmo Robinson, portanto, somente modos diferentes do trabalho humano" (C, I, 1, 74). O tempo de trabalho é dividido entre as múltiplas atividades de acordo com a necessidade e com a "maior ou menor dificuldade que se tem que vencer para conseguir o efeito útil pretendido" (C, I, 1, 74). São as atividades específicas. Do mesmo modo, “A corveia mede-se tanto pelo tempo quanto o trabalho que produz mercadorias, mas cada servo sabe que é certa quantidade de sua 
força de trabalho pessoal que ele despende no serviço do seu senhor" $(\mathrm{C}, \mathrm{I}, 1,74)$. E ainda, na família patriarcal, "O dispêndio das forças individuais de trabalho, medido pela sua duração, aparece aqui, porém, desde sua origem como determinação social dos próprios trabalhos, porque as forças de trabalho individuais a partir de sua origem só atuam como órgãos da força comum de trabalho". O que, então, distingue tais caracteres sociais do trabalho com aquele que caracteriza a produção mercantil? São dois os fatores que distinguem essencialmente a produção nas sociedades pré-capitalistas da sociedade mercantil. O primeiro determina a expansão sem precedentes no nível de universalização do trabalho, sua socialização. Este aspecto é base para a superação desta forma em uma sociedade futura que se determine como "associação de homens livres". O segundo expressa o limite que a forma mercantil representa à universalização e reside precisamente no caráter abstrato do trabalho, na exigência deste caráter indiferenciado do trabalho para sua validade social. Nas demais formações sociais, "A forma natural do trabalho, sua particularidade, e não, como na base da produção de mercadorias, a sua generalidade, é aqui sua forma diretamente social” (C, I, 1, 74). Na produção de mercadorias, apenas mediante a transformação do trabalho singular e sua duração em trabalho abstrato e grandeza de valor, ele se torna efetivamente social, trabalho para outros. Como função particular de indivíduos determinados, o trabalho não adquire caráter social, não se realiza para outrem. Nas outras sociedades, ao contrário, "como quer se julgue as máscaras que os homens, ao se defrontarem aqui, vestem, as relações sociais entre as pessoas em seus trabalhos aparecem em qualquer caso como suas próprias relações pessoais, e não são disfarçadas em relações sociais das coisas, dos produtos do trabalho" (C, I, 1, 74). A dimensão social dos trabalhos aparece imediatamente nos trabalhos singulares.

É preciso distinguir os seguintes aspectos: a produção mercantil cria a igualdade dos trabalhos como trabalho humano, como a universalidade das relações entre eles, desenvolvimento histórico que é base para a transformação da forma social e que não pode mais deixar de caracterizar a produção humana futura; mas o faz na forma da generalidade: cria a atividade singular, que não vale em si mas como criação de valor, e o nexo social, que apenas se dá por meio dos produtos, como estranhos. Este estranhamento, em que o caráter social do trabalho se realiza efetivamente como proporção de coisas, é o conteúdo do fetiche, que mobiliza a mercadoria como se ela mesma portasse o caráter ativo e subjetivo dos indivíduos. 
$\mathrm{Na}$ comparação com a futura "associação de homens livres", a organização social comunista, fica clara como a igualdade dos trabalhos e sua universalidade podem existir sem assumir a forma da mediação social estranhada de coisa ou de valor e, ademais, realizar-se como nível superior de igualdade e universalidade. Destaco três passagens em que Marx faz esta comparação, a primeira delas no capítulo sobre o fetichismo da mercadoria (C, I, 1, 75): “Imaginemos, finalmente, para variar, uma associação de homens livres, que trabalham com meios de produção comunais, e despendem suas numerosas forças de trabalhos individuais conscientemente como uma única força social de trabalho”. Aqui sobressai já um ponto comum e um diverso da sociedade mercantil: nesta, a força de trabalho individual existe como parte alíquota de uma única força de trabalho social, mas por meio da troca e sem organização consciente, o que impõe a forma da generalidade abstrata e de valor aos trabalhos singulares e seus produtos respectivamente. Na associação livre, as forças de trabalho sociais também são unidas em uma única força, mas conscientemente.

\begin{abstract}
Repetem-se aqui todas as determinações do trabalho de Robinson, só que de modo social em vez de individual. Todos os produtos de Robinson eram exclusivamente produto pessoal seu, e, por isso, diretamente objetos de uso para ele. O produto total da associação é um produto social. Parte desse produto serve novamente como meio de produção. Ela permanece social. Mas parte é consumida pelos sócios como meio de subsistência. Por isso, tem de ser distribuída entre eles. O modo dessa distribuição variará com a espécie particular do próprio organismo social de produção e o correspondente nível de desenvolvimento histórico dos produtores. Só para fazer um paralelo com a produção de mercadorias, pressupomos que a parte de cada produtor nos meios de subsistência seja determinada pelo seu tempo de trabalho ${ }^{132}$. O tempo de trabalho desempenharia, portanto, duplo papel. Sua distribuição socialmente planejada regula a proporção correta das diferentes funções de trabalho conforme as diversas necessidades.
\end{abstract}

Aqui, o tempo de trabalho conta como tempo específico de cada uma de suas funções, de acordo com a necessidade de cada produto particular. Por conseguinte, é o tempo de duração das atividades concretas, ou ainda, o tempo social global dividido conforme a "maior ou menor dificuldade que se tem que vencer para conseguir o efeito útil pretendido" (C, I, 1, 74, citado acima). O tempo de trabalho não se refere ao trabalho em geral, abstrato, mas aos trabalhos efetivos. Marx continua:

\footnotetext{
${ }^{132}$ A distribuição dos meios de subsistência, ou seja, dos produtos de consumo individual que são uma parte restrita do produto social, não precisa necessariamente ser determinada pelo tempo de trabalho que cada indivíduo despendeu na produção social. Em um momento pouco desenvolvido da produção comunista, este pode ser o critério determinante, que no entanto deve evoluir para uma forma de distribuição do trabalho e dos produtos pautada em um nível superior de igualdade expresso na fórmula "De cada um conforme suas possibilidades, para cada um conforme suas necessidades".
} 
Por outro lado, o tempo de trabalho serve simultaneamente de medida da participação individual dos produtores no trabalho comum, e, por isso, também na parte a ser consumida individualmente do produto comum. As relações sociais dos homens com seus trabalhos e seus produtos de trabalho continuam aqui transparentemente simples tanto na produção quanto na distribuição.

Também no que se refere à cota de meios de subsistência que o produtor individual deve receber, o tempo de trabalho que conta não é qualquer média social de trabalho em geral, mas o tempo efetivo de seus trabalhos concretos. Daí as relações, mesmo em um nível amplo de socialização do trabalho, manterem-se transparentes e diretas, como nas sociedades locais pré-capitalistas: as relações das pessoas em seus trabalhos aparecem para elas como suas próprias relações pessoais.

A segunda passagem em que Marx compara a sociedade mercantil com a organização comunista aponta para o limite da universalização alcançada pela primeira, e que reside justamente na abstração que o trabalho deve assumir para realizar seu caráter social. Ao contrário de ser a forma da universalização do trabalho por excelência, como afirma Ruy Fausto, a generalidade representa um progresso relativamente às formações pré-capitalistas e constitui a fase de criação dos nexos universais; mas também um limite, que se expressa na desproporção entre a universalização do gênero e o caráter parcial da individualidade. Ao abordar a necessidade de o tempo de trabalho incorporado nos produtos particulares se expressar em uma forma de valor distinta dele, em dinheiro, Marx escreve:

Para ser imediatamente o dinheiro universal, [o trabalho do indivíduo - VC] teria de ser, desde o início, não um trabalho particular, mas universal, i.e., ser posto desde o início como elemento da produção universal. Sob esse pressuposto, entretanto, a troca não lhe conferiria mais o caráter universal, mas seu caráter coletivo pressuposto determinaria a participação nos produtos. O caráter coletivo da produção faria do produto, desde o início, um produto coletivo, universal. A troca, que originalmente tem lugar na produção - que não seria uma troca de valores de troca, mas de atividades que seriam determinadas pelas necessidades coletivas, por fins coletivos -, incluiria, desde o início, a participação do indivíduo singular no mundo coletivo dos produtos. Sobre a base dos valores de troca, somente por meio da troca o trabalho é posto como trabalho universal. Sobre a base anterior, o trabalho seria posto como trabalho universal antes da troca, i.e., a troca dos produtos não seria de modo algum o meio pelo qual seria mediada a participação dos indivíduos singulares na produção universal (Grundrisse, 118-9).

Marx distingue dois modos em que a mediação social estabelece os trabalhos dos indivíduos como trabalho universal, isto é, social. Na sociedade mercantil, os trabalhos 
particulares, na medida em que são privados e independentes, apenas se tornam universais mediante a troca de seus produtos, tornados valores de troca uns dos outros e, por conseguinte, apenas como trabalho abstrato e valor as atividades e os produtos se tornam universais. Ao passo que, para que sejam universais enquanto trabalhos singulares concretos, devem ser parte do trabalho social antes da troca, ou seja, devem estar incluídos no planejamento da produção coletiva antes de se realizarem. Em ambas as formas, a sociedade medeia os trabalhos individuais para torná-los trabalho universal, mas de modos distintos. Marx continua:

\begin{abstract}
A mediação tem, naturalmente, de ocorrer. No primeiro caso, que parte da produção autônoma dos indivíduos singulares - por mais que essas produções autônomas se determinem e se modifiquem post festum por suas relações recíprocas -, a mediação tem lugar por meio da troca das mercadorias, do valor de troca, que são todos expressões de uma única e mesma relação. No segundo caso, o próprio pressuposto é mediado; i.e., está pressuposta uma produção coletiva, a coletividade como fundamento da produção. $\mathrm{O}$ trabalho do indivíduo singular está posto desde o início como trabalho social. Por conseguinte, qualquer que seja a configuração material do produto que ele cria ou ajuda a criar, o que compra com seu trabalho não é um produto determinado particular, mas uma cota determinada na produção coletiva. Por isso, não tem nenhum produto particular para trocar. Seu produto não é um valor de troca. O produto não tem de ser primeiro convertido em uma forma particular para adquirir um caráter universal para o indivíduo singular.
\end{abstract}

Quando a mediação social é a troca, o produto dos trabalhos privados apenas tornam-se sociais ao serem transformados em valores de troca. O caráter social é dado ao produto post festum e na forma da generalidade abstrata. Por mais que a realização efetiva dos produtos do trabalho como valores alterem a divisão social do trabalho, pela lei cega da oferta e da procura, é apenas na troca que os produtos provam ser parte da produção social e se tornam universais. Em uma sociedade comunista,

Em lugar de uma divisão do trabalho que é necessariamente gerada na troca de valores de troca, teria lugar uma organização do trabalho que tem por consequência a participação do indivíduo singular no consumo coletivo. No primeiro caso, o caráter social da produção só é posto post festum, pela ascensão dos produtos a valores de troca e pela troca de valores de troca. No segundo caso, o caráter social da produção está pressuposto e a participação no mundo dos produtos, no consumo, não é mediada pela troca de trabalhos ou de produtos de trabalho independentes uns dos outros. É mediada pelas condições sociais de produção no interior das quais o indivíduo exerce sua atividade. Portanto, querer transformar o trabalho do indivíduo singular imediatamente em dinheiro (i.e., também seu produto), em valor de troca realizado, significa determiná-lo imediatamente como trabalho universal, i.e., significa negar precisamente 
as condições sob as quais tem que ser transformado em dinheiro em valores de troca, e nas quais depende da troca privada. Tal pretensão só pode ser satisfeita sob condições em que não pode mais ser posta. Sobre a base dos valores de troca, o trabalho pressupõe justamente que nem o trabalho do indivíduo singular nem seu produto sejam imediatamente universais; que o produto só consiga essa forma por uma mediação objetiva [gegenständlich], por um dinheiro distinto dele (Grundrisse, 118-9).

Sobre a base dos valores de troca, é necessário que os trabalhos se transformem em um dinheiro distinto dele, para tornarem-se universais. Para fazer do trabalho individual um trabalho diretamente universal, é preciso que a mediação social seja pressuposta à produção, ou seja, planejada, e assim os trabalhos singulares sejam universais antes mesmo de se realizarem, pela função social que é a eles pressuposta. Por isso, para fazer os trabalhos singulares seu próprio "dinheiro", como quer, por exemplo, Proudhon (e também Castoriadis), seria necessário uma base produtiva distinta da troca: "Tal pretensão só pode ser satisfeita sob condições em que não pode mais ser posta". Mas nesta condição, o trabalho se torna universal em sua especificidade concreta, sem precisar metamorfosear-se em uma forma geral de valor, por sua função universal pressuposta. É social e universal em sua singularidade concreta.

Se o trabalho abstrato autonomiza o trabalho em geral em uma objetividade, esta determinação não está contida intrinsecamente nem no trabalho concreto, nem em sua universalização. É verdade que, historicamente, a integração dos múltiplos trabalhos, antes local, apenas pôde se realizar na forma da propriedade privada e da sociedade mercantil, mas isto não faz com que o trabalho abstrato seja a forma imanente desta universalização. É forma necessária de sua primeira fase, mas, ao contrário de significar sua forma natural, constitui um limite a esta mesma universalização. Apenas em sua fase de construção, a universalização dos trabalhos concretos deve ocorrer sob a forma de trabalho abstrato. É o que Marx desenvolve na terceira passagem, em que também compara a sociedade mercantil com a produção comunitária futura:

Foi dito e pode ser dito que a beleza e a grandeza residem justamente nessa conexão espontânea e natural, nesse metabolismo material e espiritual independente do saber e da vontade dos indivíduos, e que pressupõe precisamente sua independência e indiferença recíprocas. E essa conexão coisificada é certamente preferível à sua desconexão, ou a uma conexão local baseada unicamente na estreiteza da consanguinidade natural ou nas [relações] de dominação e servidão. É igualmente certo que os indivíduos não podem subordinar suas próprias conexões sociais antes de tê-las criado. Porém, é absurdo conceber tal conexão puramente coisificada como a conexão 
natural e espontânea, inseparável da natureza da individualidade (em oposição ao saber e ao querer reflexivos) e a ela imanentes. A conexão é um produto dos indivíduos. É um produto histórico. Faz parte de uma determinada fase de seu desenvolvimento. A condição estranhada [Fremdartigkeit] e a autonomia com que ainda existe frente aos indivíduos demonstram somente que estes estão ainda no processo de criação das condições de sua vida social, em lugar de terem começado a vida social a partir dessas condições. É a conexão natural e espontânea de indivíduos em meio a relações de produção determinadas, estreitas. Os indivíduos universalmente desenvolvidos cujas relações sociais, como relações próprias e comunitárias, estão igualmente submetidas ao seu próprio controle comunitário, não são um produto da natureza, mas da história. O grau e a universalidade do desenvolvimento das capacidades em que essa individualidade se torna possível pressupõem justamente a produção sobre a base dos valores de troca, que, com a universalidade do estranhamento do indivíduo de si e dos outros, primeiro produz a universalidade e a multilateralidade de suas relações e habilidades. Em estágios anteriores de desenvolvimento, o indivíduo singular aparece mais completo precisamente porque não elaborou ainda a plenitude de suas relações e não as pôs diante de si como poderes e relações sociais independentes dele. É tão ridícula a nostalgia daquela plenitude original: da mesma forma, é ridícula a crença de que é preciso permanecer naquele completo esvaziamento (Grundrisse, 110).

Enquanto a sociedade mercantil "É a conexão natural e espontânea de indivíduos em meio a relações de produção determinadas, estreitas", a organização comunista deve produzir "Os indivíduos universalmente desenvolvidos cujas relações sociais, como relações próprias e comunitárias", são “igualmente submetidas ao seu próprio controle comunitário". O domínio das relações sociais, sua submissão ao controle comunitário, se opõe à troca como forma ainda espontânea, naturalmente desenvolvida, das relações de produção. É esta forma em que o indivíduo "primeiro produz a universalidade e a multilateralidade de suas relações e habilidades": a ruptura dos vínculos comunitários e o desenvolvimento da divisão do trabalho proporcionam tanto a elaboração das habilidades como a expansão das relações, que acompanham o desenvolvimento produtivo. Constitui a primeira forma de universalização, pela integração dos povos antes locais. Mas o faz na forma da "universalidade do estranhamento do indivíduo de si e dos outros" porque seu nexo e sua força produtiva social se põem como coisa fora do controle dos indivíduos, no valor. O limite da universalização na forma da troca é esse "metabolismo material e espiritual independente do saber e da vontade dos indivíduos", em que estes apenas se confirmam socialmente como indivíduos abstratos, produtores de valor. Esta forma é contudo pressuposta à forma de universalização sob controle comunitário, "em que essa individualidade se torna possível”. Marx se refere àquela em 
que o indivíduo se torna universal em sua singularidade e por meio de sua atividade concreta, ou seja, em uma mediação diretamente social que se estabelece no planejamento social e permite mais amplo "grau e universalidade do desenvolvimento das capacidades". A universalidade é portanto a amplitude do desenvolvimento do indivíduo social. No capitalismo, este desenvolvimento dá um salto, criando a multilateralidade das habilidades e relações, mas é unilateral em cada indivíduo, dada a divisão do trabalho e a lei cega que a rege, a lei do valor. A universalidade pela equiparação dos trabalhos condena o desenvolvimento individual à unilateralidade e à negação social de sua individualidade. O desenvolvimento genérico alcançado é assim estranho aos indivíduos, os resultados de sua atividade e a atividade mesma se tornam estranhos e independentes de sua vontade.

A partir do modo de produção capitalista, não é mais possível deixar de considerar a igualdade da atividade dos múltiplos indivíduos como trabalho humano, porque ela deriva da igualdade entre os próprios indivíduos, da superação das diferenças postas pelo nascimento e pelos vínculos de sangue, e do indivíduo limitado pela comunidade pressuposta. Mas a produção de mercadorias, ou produção capitalista, se foi a forma necessária de superação dos limites locais e da universalização, é ela mesma histórica e limitada. O caráter fetichista da mercadoria é um dos ângulos em que este limite à universalização se apresenta. O trabalho em geral não coincide com a forma social do trabalho abstrato. O trabalho abstrato como categoria da economia capitalista designa o trabalho em geral, o gênero trabalho, que se põe à medida que a humanidade se cria como gênero em seu processo de universalização, objetivado em valor, ou seja, em um produto objetivo abstrato. "A relação social dos produtores com o trabalho total" aparece "como uma relação social existente fora deles, entre objetos" portadores de valor. Portar valor é portar a relação social de produção; por conseguinte o próprio valor é uma forma de relação social: “(...) o caráter especificamente social dos trabalhos privados, independentes entre si, consiste na sua igualdade como trabalho humano e assume a forma de caráter de valor dos produtos de trabalho (...)" (C, I, 1, 72). As coisas estabelecem pela troca o intercâmbio entre os produtores, a socialização de seus trabalhos. Assim, o caráter ativo, a relação - que não existe senão entre seres ativos dotados de vontade - é realizada pelas coisas de valor. $\mathrm{O}$ valor é o nexo dos trabalhos humanos, a "comunidade" humana, separada dos indivíduos. O trabalho abstrato é em 
certo sentido contrário à universalização dos indivíduos porque realiza "A equiparação em lugar da comunalidade e da universalidade efetivas" (Grundrisse, 109).

Esta é a contradição que permeia o duplo caráter do trabalho, e aparece como contradição entre valor de uso e valor: a atividade singular apenas se põe socialmente como geral que nega a singularidade. A crítica que a teoria do valor de Marx dirige à economia política clássica consiste na apreensão desta contradição:

\begin{abstract}
A análise da mercadoria como trabalho, sob uma forma dúplice, de valor de uso em trabalho concreto ou atividade produtiva aplicada a um fim, de valor de troca em tempo de trabalho social igual, é o resultado crítico definitivo das investigações, realizadas durante mais de um século e meio, pela Economia Política clássica, que começa na Inglaterra com Willian Petty, na França com Boisguillebert e termina com Ricardo na Inglaterra e Sismondi na França (Contribuição,
\end{abstract} 81).

A teoria do valor-trabalho da economia política não vê contradição no fato de os trabalhos singulares gerarem valor, um produto universal, e consideram que o trabalho cria valor em seu caráter imediato. Marx exemplifica com uma passagem de Benjamin Franklin:

\begin{abstract}
"O comércio, diz Franklin, como não é, em geral, outra coisa senão a troca de trabalho por trabalho, pode-se avaliar (measure) o valor das coisas mais exatamente pelo trabalho". Se aqui se substituir a palavra trabalho pela palavra trabalho real, descobre-se imediatamente que há confusão de trabalho sob uma forma com trabalho sob outra. Pelo fato de que o comércio, por exemplo, consista na troca de trabalho de sapateiro, de mineiro, de tecelão, de pintor etc., o valor das botas fica avaliado mais exatamente em trabalho de pintura? Franklin pensava, ao contrário, que o valor das botas, dos produtos das minas, da fiação, da pintura etc. é determinado pelo trabalho abstrato, que não possui qualidade especial e que pode-se medir, portanto, por meio da simples quantidade. Mas Franklin não desenvolve o trabalho contido no valor de troca como trabalho geral-abstrato, como trabalho social que procede da alienação universal de trabalhos individuais, e, forçosamente equivocado, vê no dinheiro a forma de existência imediata desse trabalho alienado. Por isso, o dinheiro e o trabalho criador de valor de troca não têm para ele conexão interna, pois o dinheiro é, antes, um instrumento introduzido de fora por comodidade técnica (Contribuição, 86) ${ }^{133}$.
\end{abstract}

\footnotetext{
${ }^{133}$ Também a teoria de Ricardo apresenta este limite: "Com frequência transparece em Ricardo a ideia de que a quantidade de trabalho - de fato assim se fala por vezes - seria uma solução do falso problema ou do problema falsamente concebido de uma 'medida invariável do valor' no mesmo estilo em que antes o trigo, o dinheiro, o salário etc. eram considerados e prescritos como drogas com essa propriedade miraculosa. Em Ricardo se impõe essa falsa aparência por lhe ser a determinação da magnitude do valor a tarefa decisiva. Por essa razão não apreendeu a forma específica em que o trabalho é elemento do valor e, sobretudo, não entendeu que o trabalho individual tem de apresentar-se como trabalho abstrato e, nessa
} 
Ora, o trabalho não é imediatamente trabalho abstrato, mas este demanda uma mediação social específica, a alienação, que reúne, pela divisão do trabalho, todas as forças de trabalho individuais em uma única força de trabalho abstrato. Isto só pode ocorrer em um sistema em que "A produção de todo indivíduo singular é dependente da produção de todos os outros; bem como a transformação de seu produto em meios de vida para si próprio depende do consumo de todos os outros" (Grundrisse, 104). Justamente porque não existe imediatamente, a objetivação do trabalho social abstrato demanda uma forma de aparição que não pode ser senão um dos valores de troca efetivos, tornado dinheiro. Se o caráter abstrato pertence naturalmente ao trabalho, o valor se materializa imediatamente no produto como sua propriedade natural, sem necessidade de mediação social, e assim podem se trocar diretamente trabalho por trabalho. Por isso, o dinheiro aparece como introdução de um meio externo que facilita a troca. Marx, ao contrário, demonstra que o dinheiro é derivação necessária da mercadoria.

A especificidade da forma mercadoria ou da relação de troca como originária do valor é o resultado crítico de Marx, cujo conteúdo é a oposição entre trabalho abstrato e trabalho concreto. Enquanto para Franklin e para os demais economistas, os produtos são trocados porque têm valor em si mesmos, em Marx os produtos têm valor porque são trocados, e deste modo toda a análise parte das coisas como valores de troca umas das outras. No primeiro caso, não há oposição entre o valor de uso e o valor, porque este é imanente ao produto; no segundo, a oposição é a contradição da forma social da troca, em que a criação do produto em forma geral de valor nega sua especificidade, e com ela as particularidades dos indivíduos produtores. No valor, o trabalho se aliena do produtor e só assim se torna social.

Esta incompreensão do duplo caráter do trabalho em que consiste o cerne da crítica de Marx à economia clássica, ao mesmo tempo em que fundamenta a contradição característica da sociedade capitalista, reaparece em Castoriadis, conforme apresentei no primeiro capítulo desta pesquisa. Ao considerar, por um lado, as formulações dos economistas políticos como uma mera formalização do senso comum e a teoria de Marx, por outro, como metafísica, Castoriadis também não alcança o duplo caráter do trabalho e a contradição que permeia esta forma social:

forma, social. Daí não ter compreendido a conexão da formação do dinheiro com a natureza do valor e com a determinação desse valor pelo tempo de trabalho (TMV, III, 1192). Adiante: "Não faz Ricardo a distinção pertinente entre o trabalho configurado em valores de uso e o configurado em valor de troca" (TMV, III, 1193). 
(...) o valor trabalho dos clássicos, de Smith e de Ricardo, não invoca a categoria da "substância" e se aí se descobrisse a palavra, seria sem dúvida num emprego inocente. Que as mercadorias são trocadas em proporção ao trabalho que sua produção custa, isso quer dizer para os clássicos: se alguém me propusesse trocar um produto que me custou dez horas de trabalho por um de seus produtos cuja fabricação só me custaria nove horas de trabalho, eu recusaria sua proposta; e, mediante a concorrência, a relação dos respectivos tempos "médios" de trabalho regulamentará a relação das quantidades trocadas. O "valor-trabalho" é assim, antes das imensas (e insuperáveis) complicações criadas pelas diferenças dos trabalhos individuais, pelo "capital", pela "terra", pelo "tempo", etc., um assunto de bom senso e mesmo uma tautologia simples: quem daria dez para ter nove? (Castoriadis, Encruzilhadas I, 336, citado acima).

O emprego do termo substância é "inocente" nos clássicos precisamente porque a quantidade de trabalho que cria o valor é a quantidade imediata de trabalho. $\mathrm{O}$ autor considera que o tempo dos diferentes trabalhos concretos podem ser imediatamente médios, sem a necessidade de que o trabalho tenha já se transformado em trabalho igual: seria possível, para usar o exemplo de Marx, fazer a média entre o trabalho contido na bota e o trabalho de pintura. Não à toa, Castoriadis acaba concluindo que tal trabalho médio não existe (ver capítulo I). De fato, o trabalho abstrato e o trabalho socialmente necessário que determinam o valor não existem como um trabalho concreto imediato, mas como trabalho social separado das atividades efetivas. Por essa razão, considera metafísica a explicação do valor como uma substância social, e inocente a explicação clássica de que o trabalho imediato traz em si a capacidade de criar valor. Para ele, não há qualquer necessidade da equiparação qualitativa dos trabalhos para a criação de valor. Com isso, a produção de valor deixa de ser uma forma social e se torna uma determinação natural do produto:

O primeiro capítulo do Capital é metafísico. A questão colocada pela economia política clássica: por que os objetos trocados o são em tal proporção e não em outra, Marx a reformula a seu modo, numa formulação que já contém, ou predetermina, a resposta: "Qual é o igual/idêntico (das Gleiche), isto é, a substância comum (die gemeinschaftliche Substanz) que a casa representa para a cama na expressão do valor da cama?" (Castoriadis, Encruzilhadas I, 336, citado acima).

Ao contrário de considerar o trabalho abstrato como parte da "nebulosa de enigmas" (Castoriadis, Encruzilhadas I, p. 339, citado acima) em que consistem os conceitos marxianos, Ruy Fausto, como se viu, busca explicá-lo.

Para explicar que o trabalho abstrato é um universal concreto, Fausto utiliza uma analogia com o dinheiro em relação à mercadoria. O primeiro é a mercadoria universal, 
e neste sentido um universal concreto, porque é o gênero valor, presente em todas as mercadorias, mas existente efetivamente em uma mercadoria singular. Do mesmo modo, o trabalho abstrato e o valor são universais concretos, em relação aos trabalhos concretos e aos valores de uso. Como o dinheiro é o gênero mercadoria efetivamente existente como singular, o trabalho abstrato seria então o gênero dos trabalhos concretos, e o valor, o gênero dos valores de uso, seu universal.

Primeiro, o fato de que nem o trabalho abstrato nem o valor existem em si mesmos em um singular ao lado dos demais é o ponto principal que não apenas leva Marx a demonstrar a gênese e a necessidade do dinheiro como desdobramento da mercadoria, como constitui o fundamento de sua crítica à economia política, a contradição que existe entre trabalho abstrato e trabalho concreto. Se o trabalho abstrato existisse como um singular, o dinheiro seria desnecessário; se existisse efetivamente apenas no dinheiro, este não se desdobraria da mercadoria, nem esta seria coisa de valor.

Em segundo lugar, do fato de que o dinheiro é a mercadoria universal, não se pode concluir que o trabalho abstrato seja o trabalho concreto universal. A mercadoria, que contém em si a dupla forma relativa e equivalente, na medida em que inclui a relação entre mercadorias ou de troca, desdobra-se necessariamente em dinheiro, ao passo que o valor de uso não contém em si mesmo o valor, e não se desdobra em valor. O valor é posto como atributo do valor de uso quando este é produzido como mercadoria, na relação social de troca, e não se depreende do valor de uso; é mesmo externa a ele. Por isso, a mercadoria é um fetiche: carrega determinações que pertencem aos sujeitos em sua atividade e relações porque a troca impõe aos trabalhos seu caráter geral. Se o dinheiro é imanente à mercadoria, o valor não é imante ao valor de uso, ao contrário, é atributo externo - o caráter ativo dos indivíduos e seu nexo social - que se objetiva no valor de uso. Ou seja, o valor é uma determinação que se depreende de uma forma social específica em que os valores de uso são produzidos, e caracteriza-se como objetivação do caráter social dos trabalhos concretos quando estes produzem valores de troca. O trabalho abstrato é uma forma social específica do trabalho, e não caracteriza o trabalho universal em si mesmo.

Já foi apontado acima, que, de fato, a relação de valor universaliza os trabalhos humanos criando historicamente o gênero humano. Significa uma real universalização 
frente às formas anteriores de produção. Mas isto não o define: o que o define é que esta generalização se realiza na forma da equiparação dos trabalhos, e que, se significa a universalidade frente às produções locais, implica também um limite a esta universalização que não alcança os indivíduos, mantidos unilaterais em seus trabalhos privados. Assim, o caráter universal pouco diz do trabalho abstrato, porque não especifica sua forma.

A analogia que Fausto utiliza buscando simplificar sua explicação para a tese de que o trabalho abstrato é um universal concreto, não apenas não é válida, como indica a naturalização do trabalho abstrato: se ele é a generalidade posta, e como tal, é universalidade, ou mais ainda, o verdadeiro universal, então Fausto identifica a universalidade do trabalho com sua posição abstrata. $\mathrm{O}$ autor afirma que a igualdade fisiológica, como generalidade meramente abstrata, é pressuposta ao trabalho abstrato. Mas apenas quando ela se põe, e o faz no trabalho abstrato, ela se torna universalidade. Ora, como unidade que determina o pertencimento à espécie, a igualdade fisiológica é pressuposta ao trabalho concreto, ou seja, a qualquer forma em que o trabalho se realize, e não apenas ao trabalho abstrato. Já a existência efetiva do gênero humano, a ruptura com a localidade e o intercâmbio genérico é posto pela relação de troca, que inclui a propriedade privada e o desenvolvimento da divisão do trabalho. Neste sentido, a universalidade do trabalho é posta, concomitantemente ao gênero humano, na forma da equiparação das atividades como criativas de valor. Em Marx, é esta forma que define o trabalho abstrato e caracteriza o limite da universalização que realiza. A universalidade será posta também na associação de livres produtores, mas não na forma da equiparação, e sim na forma superior da produção social consciente, em que o indivíduo se apropria da produção universal e domina o caráter social de sua atividade. Assim, a igualdade fisiológica não é o pressuposto posto pelo trabalho abstrato, nem este se define como um universal concreto, e tampouco a generalização humana que realiza é a forma da universalização por excelência.

Ruy Fausto não logra explicar o processo efetivo em que a abstração do trabalho se põe. Por isso, afirma que Marx cede ao idealismo em sua teoria do valor e que este fato o afasta do materialismo vulgar: "E isto num duplo sentido, ou para os dois idealismos, isto é, se guarda tanto o momento do idealismo objetivo como do idealismo subjetivo. O idealismo objetivo, pois se reconhece que, de certo modo, o real "pensa", isto é, o real põe, efetua o ato de abstrair" (Fausto, LP I, 107). Como não explica o 
processo pelo qual os trabalhos se reduzem ao trabalho abstrato, Fausto vê como único meio de abstração o pensamento. É curioso que um autor que busca explicar o caráter real da abstração do trabalho chegue à conclusão de que a abstração deve responder a alguma forma de pensamento, neste caso, do "real". O autor continua: "O idealismo subjetivo, pois se reconhece que o sujeito pode passar pelo pensamento à existência (à posição), que ele pode pôr os universais como universais concretos" (Fausto, LP I, 107). Seria necessário explicar como o valor, que para ele é universal concreto, é posto pelo pensamento dos sujeitos. Esta cessão ao idealismo é o que caracteriza, para Fausto, o caráter dialético do materialismo de Marx: "Vê-se assim que o problema da distinção rigorosa entre os dois materialismos, o vulgar e o dialético (ver o que dizem sobre isto os manuais...) tem aqui uma saída" (Fausto, LP I, 107). Quer dizer, a dialética é a parte idealista do materialismo, ou o fato de que também o real de algum modo pensa e o sujeito de algum modo põe universais concretos pelo pensamento. Voltarei ao tema da dialética, mas o ponto aqui é que a demonstração de Marx do modo como a abstração é real pelo processo efetivo independente de qualquer pensamento, não é trazida à tona por Fausto. Ele inverte o sentido em que Marx explica a abstração real. Ao fim, o autor parece desistir e ceder ao idealismo, já que neste item do texto ("Digressão"), o universal aparece como atributo do pensamento, que de algum modo se põe no real pelos sujeitos, ou se torna predicado do próprio real, fazendo deste um sujeito.

De fato, Ruy Fausto sustenta a afirmação do caráter metafísico da concepção de Marx, que reproduz a metafísica do real: ao abordar o valor e o capital, Marx teria voltado atrás de sua crítica juvenil ao idealismo neo-hegeliano e cedido por fim ao misticismo: "contra a posição que tinha na juventude - ver a Santa Família - Marx aceita assumir esse discurso 'místico' (pois o seu tratamento da forma do valor diz o objeto na forma indicada, que ele considera místico)" (Fausto, LP I, 102). Esta conclusão se baseia em textos de Marx que explicam o caráter fetichista do valor e a contradição que permeia o trabalho na forma da propriedade privada. A passagem em que Marx teria assumido o misticismo é a seguinte:

No interior da relação de valor e da expressão de valor que está incluída nela, o abstrato universal (das Abstrakt Allgemein) não vale como propriedade do concreto, do sensível efetivo (Sinnlich-Wirklichen), mas pelo contrário o sensível concreto (só vale) como pura (blosse) forma fenomenal ou forma de realização efetiva (Verwirklichungsform) determinada do trabalho abstrato (das Abstrak-Allgemeinen). Por exemplo, o trabalho do alfaiate que está contido no equivalente casaco não possui, no interior da expressão de valor da tela, a propriedade geral de 
ser também trabalho humano. Pelo contrário. Ser trabalho humano vale como sua essência, ser trabalho do alfaiate (só vale) como forma fenomenal ou forma de realização efetiva determinada desta sua essência (...) (...). Esta interversão pela qual o sensível-concreto (das SinnlichKonkrete) só vale como forma fenomenal do abstrato-universal (des Abstrakt-Allgemeinen), em vez de o abstrato universal valer, pelo contrário, como propriedade do concreto, (tal interversão) caracteriza a expressão de valor, ela torna ao mesmo tempo difícil sua compreensão. Se eu disser: o direito romano e o direito alemão são ambos direitos, isto é evidente. Mas se pelo contrário eu disser: o direito, este abstrato (Abstraktum), se realiza efetivamente no direito romano e no direito alemão, o contexto (Zusammenhang) torna-se então místico" ${ }^{\text {"134. }}$.

O abstrato vale como uma propriedade do concreto nas representações mentais, em que se destaca o comum aos vários singulares ou espécies que pertencem a determinado gênero. Assim, por exemplo, casaco e tela são valores de uso: valor de uso é o gênero abstrato de todas as coisas úteis efetivas, a representação mental da utilidade como qualidade comum das diferentes coisas úteis; trabalho é o gênero de todas as atividades produtivas concretas; direito romano e direito alemão são direito em formas particulares. Como gêneros, nenhum desses conceitos - o valor de uso em geral, o trabalho em geral o direito em geral, existem na efetividade como algo distinto das formas particulares. Neste sentido, são evidentes. A peculiaridade do valor, como desenvolvido acima, é a de pôr a universalidade do gênero trabalho como uma “objetividade". É isso que torna o valor de difícil compreensão e confere a ele a aparência de algo místico: a abstração existe ao lado da efetividade de coisas. Mais do que isso, trata-se de uma objetividade que se impõe sobre o caráter objetivo natural das coisas e as tornam essencialmente formas fenomenais do trabalho abstrato objetivado. Antes de ser valor de uso, a mercadoria é uma forma de valor: deve ser dinheiro antes de ser objeto de consumo. $\mathrm{O}$ valor parece, por isso, uma entidade geral abstrata que cria as coisas como formas fenomenais de si mesma: ao invés de o trabalho humano aparecer como uma propriedade dos múltiplos trabalhos concretos, inseparável portanto destes, eles são formas específicas de objetivação do trabalho abstrato. De fato, no sistema da divisão do trabalho, a força conjunta do trabalho social determina os trabalhos reais como funções do trabalho social total, e a quantidade que cada atividade representa efetivamente da riqueza social geral autonomizada. O conteúdo da aparência sobrenatural do valor é o nexo social autonomizado em coisa, o fetichismo que preside as relações sociais de produção quando estas, tornadas universais e sistêmicas, não são

134 "Die Wertform" (apêndice à primeira edição de O Capital) in Marx-Engels, Kleine Ökonomische Schriften, Berlin, Dietz verlag, 1955, p. 271, apud Fausto, LP I, 101-2. 
controladas pelos indivíduos, mas tornam-se estranhas a eles e se convertem em um poder sobre eles. É a contradição efetiva entre gênero e indivíduo que faz aparecer seu nexo social como um poder autônomo. É o que Marx afirma em outra passagem, que no entanto Fausto utiliza para mostrar que "se ele assume assim o 'misticismo', ele o justifica da seguinte maneira num texto que infelizmente é pouco conhecido:"

Isto mostra que o verbal observer compreendeu tão pouco quanto Bailey alguma coisa do valor ou da essência do dinheiro quando trata a autonomização do valor como uma invenção escolástica (eine scholastische Erfindung) dos economistas. Essa autonomização aparece ainda mais no capital que, por um lado pode ser chamado valor em processo (prozessiender Wert) - e portanto como valor que só existe (de um modo) autônomo no dinheiro -, pode ser chamado dinheiro em processo (prozessierendes Geld) - (ele, o capital) que percorre uma série de processos nos quais ele se conserva, sai de si e volta a si aumentado (in vergrössertem Umfang). Que o paradoxo da realidade efetiva (Paradoxon der Wirklichkeit) se exprime assim em paradoxo da linguagem (Sprachparadoxen), que contradizem o senso comum, o que os vulgares (Vulgarians) pensam e acreditam dizer (mean and believe to talf of), isto é evidente. As contradições que nascem do fato de que, sobre a base da produção de mercadorias, o trabalho privado se apresente como social, geral, que as relações entre coisas (von Dingen) e como coisas (Dinge) - essas contradições (Widersprüche) residem na coisa (Sache), não na expressão verbal (in dem Sprachlichen Ausdruck) da coisa (Sache) ${ }^{135}$ (Fausto, LP I, 102).

Trata-se de uma autonomização do caráter social, portanto da separação de algo que pertence às atividades e relações reais, e nela reside a contradição. Marx traz à tona uma contradição real que aparece imediatamente como existência de entidades místicas, mas sua análise explica a relação contraditória efetiva que gera esta aparência. Fausto entende, contudo, que isso significa que Marx cedeu ao idealismo e assumiu-se como místico ao tratar do valor, de modo que sua obra econômica é incongruente com os textos em que desenvolve sua crítica materialista original ao idealismo.

O próprio Ruy Fausto parece ceder ao fetichismo: para ele, a dialética é um modo de pensamento que se expressa em um discurso contraditório, de modo que o texto de Marx é permeado por contradições que espelham imediatamente a contradição do real: "Por um lado, ele [Marx - VC] reconhece que seu discurso tem algo de metafísico. Mas a metafísica do seu discurso é a reprodução da metafísica do real. É o real, o capitalismo que é em certo sentido metafísico, e o discurso quase metafísico é

\footnotetext{
${ }^{135}$ Werke, 26, 3, Theorien über den Mehrwert, p. 134; Théories sur la Plus-value, III, p. 162, grifos de Fausto. Na edição brasileira de Teorias da mais-valia III, traduzida por Reginaldo Sant'Anna, esta passagem aparece às páginas 1191-2.
} 
por isso o verdadeiro discurso científico" (Fausto, LP I, 101). Ora, a expressão imediata da contradição, que tem aparência metafísica, existe nos textos dos economistas clássicos, que tomam o trabalho real como trabalho geral, sem expor a mediação social que faz dos trabalhos concretos, trabalho abstrato. Marx dá um salto em relação aos economistas burgueses ao explicar a contradição entre trabalho individual e produção do gênero, de modo que seu discurso não a espelha imediatamente. A contradição real expressa sem mediação em um discurso contraditório não é desvendada, e o que Marx realiza em seus textos é esta mediação, de modo que longe de ser contraditório ou metafísico, seu discurso domina a contradição. Ela se mostra como o que é - o caráter social do trabalho autonomizado em valor - e sua aparência metafísica se desvenda como forma de aparição necessária desta relação de produção: "Mas agora não se trata mais senão da forma específica sob a qual o trabalho adquire um caráter social" (Contribuição, 58).

\section{Quando o valor vale? O limite da lei do valor nas trocas pré-capitalistas}

Uma questão abordada por Ruy Fausto que contribui para elucidar a natureza da lei do valor é a questão da validade histórica da lei do valor. Este ponto foi levantado por vários críticos de Marx, entre eles Böhm-Bawerk e Castoriadis. Ela envolve dois diferentes problemas. Em ambos, pressupõe-se que o valor é uma lei que determina imediatamente a proporção na troca singular entre duas mercadorias, ou entre uma mercadoria e o dinheiro. Um deles se refere à necessidade, na sociedade capitalista, de que o valor das mercadorias se manifeste na forma de seu preço de produção (preço de custo somado ao lucro médio) - o famoso problema da transformação do valor em preço; outro diz respeito à regulação das trocas pelo tempo de trabalho nas sociedades pré-capitalistas.

Fausto levanta o problema a partir do modo como Engels responde a Conrad Schmidt. Este qualifica o valor de "ficção teórica"136 devido ao fato de que as proporções na troca se dão conforme os preços de produção, e não conforme o valor. A resposta de Engels conclui que, primeiro, a lei do valor, isto é, o valor como

\footnotetext{
${ }^{136}$ Esta expressão consta nas respostas de Engels: Carta de Engels a Schmidt de 12 de março de 1895 e Carta de Engels a Schmidt de 6 de abril de 1985, in Werke, 39, 1973, pp. 430-434, apud Fausto, LP I, 107.
} 
determinante das proporções nas trocas, vigora a partir das primeiras trocas e, além disso, que nas trocas pré-capitalistas os preços se aproximam mais do valor do que na sociedade capitalista; em segundo lugar, que a lei do valor teria sofrido uma modificação pela emergência do capital:

Em resumo, a lei do valor de Marx é válida de forma geral (gilt allgemein), na medida em que as leis econômicas podem sê-lo, para todo o período da produção simples de mercadorias, portanto até o momento (bis zur Zeit) em que esta última sofreu uma modificação (Modification) pela emergência (Eintritt) da forma de produção capitalista. Até lá, os preços gravitam em torno dos valores determinados pela lei de Marx e os preços oscilam em torno desses valores, de modo que quanto mais plenamente se desenvolve (je voller...zur Entfaltung kommt) a produção simples de mercadorias, mais os preços médios (que se estabelecem) no interior de períodos mais longos não interrompidos por nenhuma perturbação exterior violenta coincidem, dentro de margens aproximáveis, com seus valores. A lei do valor de Marx tem pois uma validade geral (ökonomisch-allgemein Gültigkeit) por um período que vai do início da troca, que transforma produtos em mercadorias, até o século XV da nossa era. Mas a troca de mercadorias data de uma época muito anterior a toda história escrita, a qual nos conduz no Egito pelo menos a três mil e quinhentos e talvez a cinco mil anos, na Babilônia a quatro mil e talvez a seis mil anos antes da nossa era; a lei do valor reinou (geherrscht) durante um período de cinco a sete mil anos ${ }^{137}$.

A tese de Engels acaba por realizar uma inversão: a lei do valor é válida desde a préhistória, e a proporção nas trocas se baseia no valor das mercadorias - tempo de trabalho social abstrato - com maior exatidão no período que vai até a emergência do capitalismo mercantil, quando então a lei do valor sofre uma modificação. Ou seja, ela existe sempre e explica melhor as trocas pré-capitalistas do que o capital? Fausto sintetiza os problemas da resposta de Engels:

Esta resposta de Engels é hoje criticada quase unanimemente e questionada pelas duas razões seguintes: primeiro, parece bem evidente que, para Marx, a lei do valor é válida no capitalismo; segundo, não se pode aceitar sem mais - é o mínimo que se pode dizer - que a lei do valor, segundo Marx, é válida antes do capitalismo (Fausto, LP I, 108).

De fato, afirmar que a lei do valor é uma lei social desde antes da escrita, ou seja, desde a troca mais primitiva, é afirmar que o trabalho abstrato caracteriza parte dos trabalhos reais desde sempre, o que se opõe frontalmente à tese central de Marx segundo a qual o trabalho adquire um duplo caráter apenas na sociedade burguesa, que cria seu produto como uma imensa coleção de mercadorias:

\footnotetext{
137 “Ergänzung und Nachtrag zum III, Buche des 'Kapital', I. Wertgesetz und Profitrate” Werke, 25, p.
} 909, apud Fausto, LP I, 108. 
O produto de trabalho é em todas as situações sociais objeto de uso, porém apenas uma época historicamente determinada de desenvolvimento - a qual apresenta o trabalho despendido na produção de um objeto de uso como sua propriedade "objetiva", isto é, como seu valor transforma o produto do trabalho em mercadoria (C, I, 1, 63).

Ruy Fausto busca dar uma resposta a este problema: a lei do valor é válida para as trocas nas sociedades pré-capitalistas? Fausto começa aceitando a crítica que Castoriadis dirige a Marx, para a qual o texto do filósofo alemão seria incongruente e inconclusivo, na medida em que faz afirmações contraditórias a respeito do valor nas sociedades antigas. $\mathrm{O}$ autor tira suas conclusões ao criticar a famosa passagem em que Marx comenta o alcance e o limite da teoria aristotélica sobre o valor. De acordo com Marx, "O gênio de Aristóteles resplandece justamente em que ele descobre uma relação de igualdade na expressão de valor das mercadorias" (C, I, 1, 62); no exemplo de Aristóteles, a almofada e a casa. O filósofo grego, ao afirmar que a troca depende da igualdade e esta, da comensurabilidade, descobre que as mercadorias, "sem tal igualdade de essência, não poderiam ser relacionadas entre si, como grandezas comensuráveis" (C, I, 1, 62). Contudo, não alcança o conteúdo de tal essência:

O próprio Aristóteles nos diz em que fracassa o prosseguimento de sua análise, a saber, na falta do conceito de valor. Que é o igual, isto é, a substância comum que a casa representa para a almofada na expressão de valor da almofada? Tal coisa não pode "em verdade existir", diz Aristóteles. Por quê? A casa representa, contraposta à almofada, algo igual, na medida em que represente o que é realmente igual em ambas, a almofada e a casa. E isso é - trabalho humano (C, I, 1, 62).

Marx explica que Aristóteles não poderia deduzir da expressão de valor o seu conteúdo, porque as atividades dos diferentes indivíduos, livres e escravos, não eram equiparadas como formas do trabalho humano:

Que na forma dos valores das mercadorias todos os trabalhos são expressos como trabalho humano igual, e portanto como equivalentes, não podia Aristóteles deduzir da própria forma de valor, porque a sociedade grega baseava-se no trabalho escravo e tinha, portanto, por base natural a desigualdade entre os homens e suas forças de trabalho. O segredo da expansão de valor, a igualdade e a equivalência de todos os trabalhos, porque e na medida em que são trabalho humano em geral, somente pode ser decifrado quando o conceito da igualdade humana já possui a consistência de um preconceito popular. Mas isso só é possível numa sociedade na qual a forma mercadoria é a forma geral do produto do trabalho, por conseguinte também a relação das pessoas umas com as outras enquanto possuidoras de mercadorias é a relação social dominante $(\mathrm{C}, \mathrm{I}, 1,62)$. 
O valor não era decifrável na Grécia antiga porque os trabalhos não se equiparavam na realidade, dada a condição desigual dos indivíduos na divisão do trabalho. Ele só se torna decifrável quando a igualdade de direito dos indivíduos esteja consolidada. Esta igualdade resulta da criação do produto social como mercadoria, ou valor, quando a troca se torna a forma dominante da relação entre os trabalhos e a divisão do trabalho se desenvolve por conseguinte com base nesta igualdade posta pela troca. Contudo, a troca primitiva torna já a coisa trocada em uma forma de valor, em mercadoria. Põe, portanto, a igualdade e a comensurabilidade. Por outro lado, o valor existe aí dentro de um limite histórico, que impede Aristóteles de deduzir o valor porque ele não era dedutível: os trabalhos não eram iguais. Portanto, há valor dentro de algum limite em que este não implica o duplo caráter do trabalho, ou trabalho abstrato. O que se deve explicar é isto: as trocas pré-capitalistas conferem ao produto a forma de valor fazendo-os mercadorias, e em si mesmas estabelecem a igualdade dos produtos, mas esta troca não se regula pelo o conteúdo do valor porque sua substância, o trabalho social abstrato, não existe.

Castoriadis afirma que Marx é contraditório nesta passagem, pois ora sustenta que a sociedade capitalista transforma os trabalhos heterogêneos em trabalho abstrato, ora afirma que esta sociedade faz com que os trabalhos apareçam como trabalho igual. Assim, ou o valor estava presente nas trocas antigas mas não podia se mostrar, ou não havia valor, dada a heterogeneidade dos indivíduos, e portanto nada havia que permanecesse oculto a Aristóteles. O autor escreve, referindo-se ao trabalho abstrato:

\footnotetext{
$\mathrm{Na}$ economia e por ela, a abstração da quantidade, a pura repetição/cumulação do absolutamente homogêneo se torna efetiva, realidade mais real do que o real. Mas que "economia"? Constantemente, Marx oscila entre essas posições: a economia capitalista - toda economia, do início ao fim da história ${ }^{138}$.
}

Sobre a validade da lei do valor nas sociedades pré-capitalistas, Fausto sustenta que há nos textos de Marx afirmações que corroboram tanto uma resposta negativa quanto uma resposta afirmativa. Por um lado, o valor apenas é posto pela relação capitalista de produção:

Para Marx, o valor e o trabalho abstrato existem antes do capitalismo? A resposta de Marx, para o trabalho abstrato, se encontra na Contribuição à Crítica da Economia Política: "Steuart (trata-se de James Steuart, economista do século XVII - RF) sabia naturalmente muito bem que também nas épocas pré-burguesas o produto se reveste da forma mercadoria e a mercadoria da forma

\footnotetext{
${ }^{138}$ Castoriadis, Les Carrefours du Labyrinthe, Paris, Seuil, 1978, pp. 266, apud Fausto, LP I, 111.
} 
dinheiro, mas ele prova em detalhe que a mercadoria enquanto forma fundamental elementar da riqueza, e a alienação enquanto forma dominante da apropriação, só pertencem ao período da produção burguesa e que, portanto, o caráter do trabalho que põe o valor de troca é especificamente burguês (der Charakter der Tauschwert setzenden Arbeit spezifisch bürgerlich ist)". O texto se refere ao trabalho abstrato. Pode-se dizer a mesma coisa do valor? Sim. Com efeito, Marx escreve no capítulo 5 do livro III de $O$ Capital: "Se o valor das mercadorias é determinado pelo tempo de trabalho socialmente necessário que elas contêm, e não pelo tempo de trabalho em geral (überhaupt) que elas contêm, é o capital (so ist das Kapital) que realiza pela primeira vez (erst realisiert) esta determinação, e que ao mesmo tempo reduz constantemente o tempo de trabalho socialmente necessário à produção de uma mercadoria”. E no capítulo 7 do livro III ele escreve ainda: "É o capital comercial, que pela primeira vez (zuerst) determina os preços das mercadorias mais ou menos pelos seus valores (...)” (Fausto, LP I, 111-2).

Essas passagens e muitas outras dos textos de Marx estabelecem o valor e o trabalho abstrato como formas sociais específicas do trabalho e seus produtos, correspondentes à sociedade capitalista. Fausto destaca, contudo, que em outras passagens há afirmações da relação de valor referentes a trocas pré-capitalistas:

Assim, por exemplo, quando, nos capítulos 1 e 2 do livro I e também no capítulo 10 (original) do livro III, ele introduz referências "históricas" (onde se trata de trocas entre comunidades primitivas), ele fala de valor, sem que se trate evidentemente do capitalismo. Como explicar essas ocorrências? Segundo Castoriadis, haveria em Marx uma oscilação entre diversas respostas; o valor existia antes do capitalismo, o valor não existia, o valor existia mas não aparecia. (...) O que Castoriadis diz não é sem verdade, enquanto ele afirma simplesmente que se pode encontrar em Marx passagens em que ele emprega o termo valor a propósito do précapitalismo e passagens em que ele diz que só há valor no capitalismo. O problema é o de saber se aí uma oscilação, se não se trataria antes (radicalizando) de uma contradição; e de saber se uma resposta contraditória é necessariamente uma má resposta (Fausto, LP I, 112).

Assim, Fausto aceita que há contradição nos textos de Marx: nas sociedades précapitalistas, "o valor não é, mas ao mesmo tempo ele é". Trata-se de uma contradição real que, por ser objetiva, "é pois pensável na e pela contradição", de modo que "a porta de saída está no próprio obstáculo que erige diante de nós". Para que a contradição seja dominada, basta sua posição: "Basta pôr a contradição - em lugar de fugir dela - para que se a domine (e portanto se resolva o problema)" (Fausto, LP I, 112-3).

Fausto põe a contradição a partir da tese de que "O valor antes do capitalismo tem um estatuto análogo ao de um ser qualquer na sua pré-história" (Fausto, LP I, 113). Recorre ao modo como Aristóteles explica a geração dos seres: ela se dá partir de algo 
que é, mas ao mesmo tempo a partir de algo que não é, de modo que o que existe apenas em potência, mas não em ato, existe como algo que é e não é. A origem de algo só pode ser expressa por meio desta contradição, isto é, envolve sua negação ${ }^{139}$. Do mesmo modo, o valor nas sociedades pré-capitalistas é pressuposto, mas não posto, dado o limite de seu próprio desenvolvimento, e assim as afirmações do texto de Marx que Fausto considera contraditórias são explicadas pela posição da contradição que permeia a gênese do valor:

A análise que acabamos de fazer dá a resposta ao problema. Os limites da consciência de Aristóteles são limites do seu objeto. Ele não chega a exprimir a substância do valor, pois esta substância, embora estando "lá" (e é por isso que, segundo Marx, Aristóteles chega até a exprimir a exigência de "algo comum"), não estava ainda constituída enquanto tal. O valor está somente pressuposto, (e não posto) - ele é e não é - tanto na realidade grega como no pensamento de Aristóteles (Fausto, LP I, 114).

Nada se explica das trocas antigas e de sua distinção em relação às trocas capitalistas pela afirmação de que, nas primeiras, o valor é e não é. Também pouco se explica pela constatação de que nas trocas pré-capitalistas o valor está ainda em sua pré-história, é pressuposto ou existe como potência. É evidente que o valor tem um desenvolvimento que acompanha a expansão das trocas e culmina na troca como relação social determinante, ou seja, na produção para a troca. Mas falta explicar como o valor é e como ele não é nas sociedades pré-capitalistas, ou seja, o que distingue a relação de valor posta, no capitalismo, da pressuposta, que caracteriza as trocas anteriores. Sobre isto, Ruy Fausto afirma:

\begin{abstract}
Antes do capitalismo, o valor não é, porque não há tempo de trabalho necessário. Isto significa que o tempo de trabalho constitutivo do valor não é posto na própria produção (não há um tempo social que tenha uma força coercitiva no nível da produção) e que o quantum de valor (ou antes, de "valor") pelo qual as mercadorias são trocadas se constitui no nível das trocas (esse quantum não corresponde a cada tempo individual, mas ele não é senão uma resultante desses tempos individuais) E entretanto, do que acabamos de dizer resulta que antes do capitalismo as mercadorias já se trocavam segundo proporções que correspondiam ao tempo (ou aos tempos) gasto(s) na sua produção. Portanto, em certo sentido, o valor ou os valores já existiam. (...) "alguma coisa" como o valor já existia (Fausto, LP I, 112-3).
\end{abstract}

\footnotetext{
${ }^{139}$ Deixo de lado uma parte da argumentação lógica de Fausto que leva a esta conclusão. Ele faz afirmações de cunho idealista, como "No nível de sua pré-história, um ser não existe enquanto sujeito; uma pré-história é exatamente a história de seu surgimento enquanto sujeito" (Fausto, LP I, 113); quer dizer, tudo o que existe e ultrapassou sua pré-história é sujeito? O valor, que quando não existe, é, e quando não é, existe, além de tudo se determina como sujeito. O raciocínio, lançado assim sem desenvolvimentos ulteriores, não se justifica.
} 
A ausência de um tempo social que exerça força coercitiva no nível da produção e a consequente determinação da grandeza do valor das mercadorias apenas no nível das trocas é o que mostra que a lei do valor não se aplica plenamente às trocas précapitalistas. Mas a partir daí, há vários problemas nesta passagem. Primeiro, não fíca claro em que Fausto se baseia para afirmar que as mercadorias se trocam em proporções que correspondem aos tempos de trabalho gastos em suas produções. Segundo, isso significa que a proporção nas trocas resulta de algum modo do tempo de trabalho individual que custaram. Mais uma vez, como podem os distintos trabalhos concretos equivaler? Para que a quantidade de trabalho defina a proporção nas trocas, os trabalhos diferentes devem já estar equalizados socialmente.

Recuperando algumas passagens de textos de Marx, pretendo mostrar que as trocas nas sociedades pré-capitalistas não obedecem a proporção entre os tempos de trabalho que custam a produção das coisas trocadas; e que o que caracteriza as mercadorias antigas como valores é sua equiparação qualitativa, e não sua equivalência quantitativa. O fato da troca equipara os produtos de trabalhos distintos, conferindo-lhes natureza de valor, expressões da riqueza geral, abstrata; e assim, iguala também os trabalhos constitutivos dos produtos. O fato da equiparação se torna visível no dinheiro como medida de comparação de todas as mercadorias. Assim, a troca em si mesma confere natureza de valor aos produtos, formas da riqueza geral, ou produtos de trabalho humano geral, mas a quantidade de trabalho só determina a proporção nas trocas em uma sociedade que se constitui como sistema de trocas. Por isso, a natureza de valor não depende de que se obedeça esta proporção. Fausto vê como uma determinação imanente à natureza de valor das mercadorias que se troquem de acordo com a quantidade de trabalho que custa produzi-las, de modo que a determinação quantitativa é primeira na definição do valor: só há valor nas sociedades pré-capitalistas porque "as mercadorias já se trocavam segundo proporções que correspondiam ao tempo (ou aos tempos) gasto(s) na sua produção". Quer dizer, antes mesmo de uma equiparação qualitativa em trabalho abstrato, que não existia, a quantidade de trabalho (concreto?) é determinante. A tese de Fausto é uma inversão, visto que em Marx, e já em Aristóteles, a troca demanda igualdade, uma natureza comum que permita a comparação quantitativa. Em Marx, as coisas trocadas adquirem natureza de valor sem que sua troca obedeça à determinação da quantidade de trabalho. Para sustentar que Marx faz afirmações contraditórias sobre o tema do valor antes do capitalismo, Fausto menciona a presença de passagens dos 
capítulos 1 e 2 do primeiro livro d'O Capital, em que o filósofo alemão faria referência ao valor na troca entre comunidades. Marx afirma:

\begin{abstract}
A troca direta de produtos possui já, por um lado, a forma da expressão simples do valor e, por outro lado, ainda não a tem. Aquela forma era $\mathrm{x}$ da mercadoria $\mathrm{A}=\mathrm{y}$ da mercadoria $\mathrm{B}$. A forma da troca direta de produtos é: $\mathrm{x}$ objetos de uso $\mathrm{A}=\mathrm{y}$ objetos de uso $\mathrm{B}$. As coisas $\mathrm{A}$ e B aqui não são mercadorias antes da troca, mas tornam-se tais por meio da mesma (C, I, 1, 81).
\end{abstract}

A troca direta de produtos tem e não tem a forma do valor porque os produtos apenas são mercadorias na troca efetiva, de modo que têm uma existência pontual, efêmera, de valor. Estas trocas correspondem a trocas casuais entre comunidades primitivas ${ }^{140}$, dependentes do excedente casual das comunidades. Deste modo, sua relação quantitativa é arbitrária, e não mantém qualquer relação com o tempo de trabalho que custou produzi-las: "Sua relação quantitativa de troca é por enquanto inteiramente casual. São permutáveis pela vontade de seus possuidores de aliená-las reciprocamente" (C, I, 182 ). Além disso, as mercadorias ainda não têm uma expressão de valor comum, ou seja, pelo caráter incipiente das trocas, não há ainda uma mercadoria na qual as demais se medem: "O artigo de troca não adquire ainda nenhuma forma de valor independente de seu próprio valor de uso ou da necessidade individual dos permutantes" (C, I, 1, 82). Ou seja, não há ainda nenhum equivalente mais ou menos geral, e por isso a natureza de valor, dada no momento pontual da troca efetiva, não ganha expressão objetiva, e por isso é e não é. Dois fatores que se desenvolvem historicamente a partir das trocas primitivas fixam a natureza de valor aos produtos trocados: o advento de parte da produção realizada para a troca e o dinheiro como expressão objetiva do valor das mercadorias. Marx escreve:

\footnotetext{
Nesse meio tempo, se consolida, pouco a pouco, a necessidade por objetos de uso estrangeiros. A constante repetição da troca transforma-a em um processo social regular. Com o correr do tempo, torna-se necessário, portanto, que parte do produto do trabalho seja intencionalmente feita para a troca. A partir desse momento, consolida-se, por um lado, a separação entre a
}

\footnotetext{
140 "O primeiro modo pelo qual um objeto de uso é possivelmente valor de troca é sua existência como não-valor de uso, como quantum de valor de uso que ultrapassa as necessidades diretas de seu possuidor. As coisas são, em si e para si, externas ao homem e, portanto, alienáveis. Para que a alienação seja recíproca, basta que os homens se defrontem, tacitamente, como proprietários privados daquelas coisas alienáveis e portanto, por intermédio disso, como pessoas independentes entre si. Tal relação de estranhamento recíproco não existe, porém, para os membros de uma comunidade primitiva, tenha ela a forma de uma família patriarcal, de uma antiga comunidade indiana, um Estado inca etc. A troca de mercadorias começa onde as comunidades terminam, em seus pontos de contato com outras comunidades ou com membros de outras comunidades" (C, I, 1, 82).
} 
utilidade das coisas para as necessidades imediatas e sua utilidade para a troca. Seu valor de uso dissocia-se de seu valor de troca $(\mathrm{C}, \mathrm{I}, 1,82)$.

Produzir para a troca significa conferir ao produto a utilidade de ser permutável por qualquer elemento da riqueza geral, e portanto criar os produtos como quantidades de riqueza geral, valor. A expansão das trocas de que resulta a produção para a troca de parte dos produtos também cria em seu processo espontâneo uma forma de expressão do valor comum às mercadorias:

\begin{abstract}
A necessidade desta forma desenvolve-se com o crescente número e variedade das mercadorias que vão entrando no processo de troca. O problema surge simultaneamente com os meios para sua solução. Uma circulação em que possuidores de mercadorias trocam e comparam seus artigos com outros diferentes jamais se realiza sem que diferentes mercadorias de diferentes possuidores de mercadorias em sua circulação sejam trocadas e comparadas como valores com uma terceira mercadorias, sempre a mesma. Tal terceira mercadoria, ao se tornar equivalente de outras mercadorias diferentes, recebe diretamente, ainda que em limites estreitos, a forma de equivalente geral ou social. Essa forma de equivalente geral surge e desaparece com o contato social momentâneo que lhe deu vida. É atribuída alternativa e transitoriamente a esta ou aquela mercadoria (C, I, 1, 82).
\end{abstract}

Muito cedo na história do desenvolvimento das trocas, uma medida comum se impõe às mercadorias. Marx menciona peles, sal, gado, escravos entre as mercadorias que servem de equivalente antes da consolidação dinheiro propriamente dito, que se estabelecem pela necessidade de dar uma expressão objetiva comum à igualdade qualitativa dos produtos posta pela troca: "O dinheiro aparecendo como medida (por isso, por exemplo, os bois em Homero) mais cedo do que como meio de troca, porque, no escambo, cada mercadoria é ainda seu meio de troca. Mas ela não pode ser sua medida ou seu próprio padrão de comparação" (Grundrisse, 120). (Os bois em Homero não são ainda dinheiro, mas apenas germe de dinheiro, porque seu valor de uso central não é a de medir o valor das mercadorias, mas sua utilidade concreta.) Ainda que tenham adquirido medida externa, as trocas não obedecem à determinação quantitativa pelo tempo de trabalho: "Por outro lado, torna-se a relação quantitativa, em que se trocam, dependente de sua própria produção. O costume fixa-as como grandezas de valor” (C, I, 1, 82). Se as proporções na troca não são mais dadas pelo excedente casual das comunidades, é dado agora pelo montante da produção, de modo que a repetição fixa a grandeza de valor das mercadorias. Mas tais proporções são ainda independentes do tempo de trabalho gasto em sua produção. 
O que é necessário para que o tempo de trabalho se imponha como determinação quantitativa das trocas? "O que pressupõe a diferença puramente quantitativa das coisas? A uniformidade [Dieselbigkeit] de sua qualidade. Logo, a mensuração quantitativa dos trabalhos pressupõe a igualdade, a uniformidade [Dieselbigkeit] de sua qualidade" (Grundrisse, 120). Apenas quando esta igualdade qualitativa está plenamente posta, a determinação quantitativa pelo tempo de trabalho se impõe às trocas. Assim, ela demanda que a igualdade dos produtos como forma de valor deixe de ser uma determinação que adere momentaneamente ao produto; que os produtos ganhem uma expressão universal e fixa de valor no dinheiro. Estas determinações são necessárias mas não suficientes para que o tempo de trabalho se imponha como determinante quantitativa das trocas. O dinheiro explicita a natureza de valor das mercadorias, mas não é suficiente para impor o tempo de trabalho como determinante das proporções na troca porque não transforma os trabalhos concretos em trabalho abstrato. Apenas quando o dinheiro, como expressão de valor, adere aos produtos na esfera de sua produção, conferindo-lhes um preço determinado antes da troca, a mercadoria se torna o produto do trabalho por excelência, e então todos os trabalhos de fato se igualam e assumem a forma de trabalho abstrato. E apenas quando se tornam efetivamente trabalho igual, e, mais do que isso, trabalho que cria seu produto como objetivação de montantes de riqueza geral, valores permutáveis entre si, pode o tempo de trabalho determinar as trocas. Marx escreve:

\footnotetext{
A dupla forma de trabalho que [a mercadoria - VC] contém manifesta-se em que o trabalho concreto particular, que é seu valor de uso, existe realmente enquanto o tempo de trabalho geralabstrato adquire no preço das mercadorias uma existência imaginária, na qual essas constituem matéria uniforme da mesma substância de valor e diferentes somente pela quantidade (Contribuição, 99).
}

O preço fixado ao produto antes da troca faz com que o trabalho concreto exista realmente como trabalho geral-abstrato, ou seja, expressa que o trabalho adquiriu um duplo caráter. Mas a existência de um preço anterior à troca determina que o produto é criado para a troca, e portanto como forma de riqueza geral. Se o produto não tem preço definido, mas o adquire apenas no ato da troca, então não foi criado para a troca e o trabalho que o gerou não se revestiu ainda da forma de trabalho abstrato.

Há uma figuração literária que ilustra bem a troca pré-capitalista em que o dinheiro se consolidou já como medida de valor, embora não seja ainda o meio de troca 
geral, convivendo com o escambo. Ao mesmo tempo, as mercadorias têm seus preços definidos apenas no momento da troca, de modo que esta é ainda secundária como forma de apropriação de produtos. Trata-se do episódio bíblico em que José, filho de Jacó, é vendido como escravo por seus irmãos a um grupo de mercadores nômades, retratado no romance José e seus irmãos, de Thomas Mann ${ }^{141}$. Os irmãos, pastores em uma família patriarcal em aproximadamente dois mil anos antes de Cristo, o oferecem a um velho mercador ismaelita que passa por suas terras:

- (...) já que vos agrada, fazei a vossa oferta. I - Dizei antes qual é vosso preço! respondeu o velho. - É esse o meu costume. / Começou então em torno de José uma série de tratos e contratos que, de tanto regatear, durou cinco horas, indo até quando o sol se punha. Em nome de seus irmãos, Judá pedia trinta siclos de prata; mas o mineu respondeu que aquilo era uma troça de que se podia rir durante muito tempo mas com a qual não se podia iniciar nenhum negócio. (...) ele oferecera quinze siclos de prata, segundo o peso babilonico que era mais leve; quando, porém, os irmãos, valendo-se da circunstância de já se ter ele comprometido, fizeram subir o preço até vinte siclos, segundo o peso fenício, o velho se deteve (...). (...) se prontificava a pagar segundo o peso fenício vinte siclos íntegros e pesados segundo o cálculo fenício. (...) E assim entraram em acordo, fixando-se a venda em vinte siclos de prata segundo o peso usual. Em honra dos hóspedes os irmãos degolaram um cordeirinho do rebanho debaixo das árvores, fizeram correr o sangue, assaram a carne, para poderem alçar as mãos e comer todos juntos, celebrando a transação. (...) Mas o repasto e o reforço eram oportunos, porque o negócio estava bem longe de ser concluído. Estava apenas entabulado em linhas gerais depois de haver fixado o preço principal; mas começava agora a transação miúda e a realização em mercadoria do valor estabelecido. Aqui é necessário retificar a ideia, universalmente difundida e impressa na memória por uma piedosa descrição, de que os irmãos, depois de venderem José, embolsaram dos ismaelitas o preço total em metal sonante. Não era absolutamente a ideia do velho pagar em prata (...). Quem é que leva consigo tanto metal, e quem é que não prefere pagar a dívida em objetos? Com efeito, todo objeto que se paga por uma parte do preço lhe dá ocasião, tornando-se ele próprio vendedor, de melhorar o negócio e de prover melhor aos seus interesses como comprador. $O$ mineu pagou aos pastores um siclo $e$

\footnotetext{
${ }^{141}$ Mann, Thomas, José e seus irmãos, vol. I - As histórias de Jacó / O jovem José. Tradução de Agenor Soares de Moura. Rio de Janeiro: Nova Fronteira, 1983, pp. 497-9.
} 
meio de prata em moedas, pesando-as na sua graciosa balança que trazia na cintura; para o resto, teve-se de recorrer às diferentes mercadorias de que iam carregados os camelos. Assim, tudo que tinha consigo foi descarregado e espalhado sobre a erva: os incensos e as belas resinas de além do rio, e toda casta de bonitos objetos de que se tem precisão. Eram navalhas, facas de cobre e de pederneira, lâmpadas, colheres para unguentos, bengalinhas de passeio com lavores e incrustações, pedras de vidro azul, óleo de rícino e sandálias: todo um bazar, todo um negócio de secos e molhados haviam exposto aqueles negociantes diante dos olhos ávidos dos compradores, sendo que até o limite de dezoito siclos e meio de prata podiam estes levar quanto quisessem pela sua mercadoria. Mas mesmo agora se regateava por cada objeto, como se se tratasse apenas daquele, de modo que caiu a tarde antes de se chegar a uma conclusão, tendo afinal José sido vendido por pouca prata e muitas facas, um tantinho de bálsamo, lâmpadas e bengalinhas.

Esta narrativa evidencia que se trata de mercadorias, coisas úteis que se põe na troca como valores ou grandezas de valor, e que o valor de todas é expresso em dinheiro, a forma de valor que as equipara na prática. Assim, também o trabalho contido nas mercadorias se iguala pela equiparação de seus produtos. É uma equiparação qualitativa que resulta do ato da troca e não se fixa. Isto também fica claro se consideramos que a grandeza do valor das mercadorias expressa em dinheiro, seu preço, é indeterminado antes da troca e apenas se define nela. De modo que a natureza de valor não está ainda aderida aos produtos do trabalho, e só nas mãos do mercador ela dura. Mas mesmo aí, os preços variam conforme a região e as possibilidades do comprador. Em outra passagem, ervas silvestres recolhidas pelos mercadores em uma região são vendidas em outra como plantas cultivadas de múltiplas propriedades, por alto preço. A equiparação momentânea da troca, que confere ao produto forma de mercadoria, não é suficiente para impor uma regulação pelo tempo de trabalho. A proporção não guarda relação nenhuma com o tempo de trabalho que custou recolhê-las e pô-las em saquinhos. As trocas se dão, pois, entre não-equivalentes. Isso ocorre porque a troca se dá no limiar das comunidades, o que significa que a unidade comunitária não se baseia na relação de troca, mas em outras formas de vínculo. $\mathrm{O}$ velho mercador da narrativa, por exemplo, visitava o Egito a cada cinco ou sete anos. A troca é secundária porque integra comunidades locais, mas não determina as relações internas a tais povos. Assim, o trabalho considerado tanto dentro das comunidades como no contato entre elas não 
tem ainda a qualidade de ser trabalho humano em geral: nem a humanidade se tornou gênero, porque não é una, nem os indivíduos de cada povo são iguais. Apenas a troca, uma atividade secundária no modo de vida das várias comunidades, à exceção dos povos mercadores, equipara os trabalhos. Na forma dominante de sua realização e da apropriação de seus produtos, os trabalhos concretos não se põem socialmente como formas do trabalho humano geral nem seus produtos como grandezas de valor em si mesmos. Só nesta condição, a grandeza determinada de valor poderia obedecer à quantidade de trabalho. Como se tornam grandezas de valor apenas na troca, a proporção quantitativa em que os produtos se trocam é casual ou habitual.

É este, por fim, o limite do valor nas trocas pré-capitalistas: toda troca confere natureza de valor às mercadorias por sua mera permutabilidade, que faz com que os valores de uso sejam valores de troca de outros valores de uso, representantes da riqueza geral. Nesta equiparação, também os trabalhos são postos como igual trabalho humano. Contudo, se os trabalhos humanos não se põem ainda como trabalhos que criam igualmente valores de troca, tornando os produtores imbricados, portanto, pela equivalência de sua atividade, pela interdependência, e pela alienação como forma da apropriação, não se equipararam de fato. Por isso a quantidade de trabalho não pode impor-se, e a necessidade e o volume efetivo da produção mantêm-se como determinantes das proporções nas trocas. $\mathrm{O}$ valor das mercadorias não é determinado pelo tempo de trabalho que custa sua produção. A lei do valor não rege o comércio précapitalista.

De fato, trocas desiguais são a regra na condição em que os produtos são apenas parcialmente produzidos para troca e em que grupos mercadores, que muito cedo emergem na história, integram pelo comércio diferentes sociedades locais. Comprar barato em um lugar e vender caro em outro é a origem do lucro dos comerciantes até o momento que antecede as colonizações modernas e a manufatura moderna. Certamente até o século XV de nossa era, quando os portugueses trocavam espelhos e contas de vidro pelo ouro dos povos nativos de Pindorama, ou vendiam na Europa especiarias indianas, o comércio era uma forma de transferir riqueza de um lugar a outro, particularmente para as mãos dos próprios comerciantes. Ainda o tempo de trabalho mesmo que se pudesse comparar pelo tempo trabalhos concretos distintos - não rege as trocas, mas são as necessidades que as regem. Só assim o capital mercantil - a fortuna em dinheiro - que origina o modo de produção capitalista se constitui. 
O valor tem um desenvolvimento que acompanha a expansão das trocas. A troca pré-capitalista, sendo troca, põe os produtos como grandezas de valor, embora a grandeza determinada do valor não exista ainda de fato. Quando Marx fala de valor nas sociedades pré-capitalistas, é para frisar seu baixo nível de desenvolvimento, expresso precisamente no fato de que as trocas não são ainda regidas pela lei do valor.

Quais são as condições em que a lei do valor é uma lei social?

O valor se desenvolve plenamente com a produção para a troca como forma geral da produção, o capitalismo. A condição para que a quantidade de trabalho social se imponha como determinante da grandeza de valor das mercadorias é o sistema social de trocas, ou seja, o conjunto do trabalho social cujo nexo é a troca. Apenas aí o trabalho social existe como uma única força de trabalho incorporada em um único produto social - o valor de todas as mercadorias lançadas no mercado - como pressuposto das trocas singulares. Por um lado, só assim o trabalho individual é uma parte alíquota do trabalho social e seus produtos incorporam uma parte alíquota do valor social, isto é, na condição de um sistema que configura um único corpo social em que o trabalho é de fato o mesmo trabalho homogêneo. Apenas nesta condição pode o tempo de trabalho se realizar socialmente como média, tempo socialmente necessário, e assim autonomizar-se em quantidade de trabalho social abstrato. Por outro, apenas quando a alienação pela troca é a forma dominante da apropriação individual de parte da riqueza social, pode esta riqueza autonomizar-se em valor e o trabalho assumir a forma de trabalho abstrato. Assim, a lei do valor corresponde a uma forma específica da sociabilidade: "Da análise do valor conclui-se que para criar valor de troca é preciso que o trabalho esteja determinado socialmente, que seja trabalho social, não simplesmente social, mas de um modo particular. É um modo específico da socialidade" (Contribuição, 57). Este modo específico é o nexo social pautado na autonomia dos produtores e na alienação como forma de apropriação: "Para que o resultado do trabalho individual seja um valor de troca, é preciso que constitua um equivalente geral; é necessário que o tempo de trabalho do indivíduo represente tempo de trabalho geral, ou que o tempo de trabalho geral represente o indivíduo" (Contribuição, 58). Assim, a equiparação qualitativa dos trabalhos individuais em uma massa de trabalho social pressuposta aos valores individuais das mercadorias é condição para que a medida quantitativa pelo tempo de trabalho se imponha: “O trabalho de cada indivíduo, ainda que se manifeste em vários valores de troca, possui esse caráter social de igualdade, e 
não se manifesta no valor de troca senão à medida que se refere ao trabalho dos demais indivíduos como trabalho idêntico" (Contribuição, 57).

A lei do valor se aplica portanto à sociedade mercantil, única forma de sociabilidade que põe o duplo caráter do trabalho. Contudo, esta sociedade não se distingue da sociedade capitalista: a generalização da relação de troca se dá na constituição do modo de produção do capital. Quando a produção se realiza para a troca, a forma de relação entre os produtores, por meio de coisas, tem já a forma da concorrência, que desenvolve o assalariamento, a divisão do trabalho e o capital. Voltamos a essa necessidade de a sociedade mercantil ser capitalista no capítulo seguinte. Aqui, o ponto é o fato de que os preços das mercadorias, no capitalismo, não expressam imediatamente seus valores, mas são determinados pelos preços de produção (preço de custo somado à taxa média de lucro). Esse fato é suficiente para que Castoriadis questione a validade da lei do valor no capitalismo, porque entende esta lei como uma determinação da proporção em que mercadorias singulares se trocam. Ecoando as discussões sobre o famoso problema da transformação do valor em preço de produção, o autor conclui que a lei do valor não determina as trocas nem no capitalismo, nem antes dele. Este é pois o segundo problema: como a lei do valor rege as relações de intercâmbio quando as mercadorias não são trocadas por seus valores?

Ruy Fausto considera ter resolvido o problema afirmando novamente que o valor é contraditório e o único modo de resolver a contradição é colocá-la. Ele aceita a conclusão de que, porque o preço das mercadorias não expressa imediatamente seu valor, mas seu preço de produção, há uma contradição. Esta impõe que ou se sacrifique a lei do valor para explicar o fenômeno, ou se negue o fenômeno. Marx teria tido consciência de que sua resposta é contraditória e, mais do que isso, nesta afirmação da contradição estaria sua originalidade. $\mathrm{O}$ autor resume a resposta que dá ao problema da validade da lei do valor antes e no capitalismo: "se enquanto o valor não é (précapitalismo), ele de certo modo é, ele não será plenamente (capitalismo) senão quando de certo modo ele não será (existirá) mais" (Fausto, LP I, 120). Ora, essa assertiva não acrescenta qualquer explicação ao problema; ao contrário, nega o problema, aceitando que, se as mercadorias se trocam pelos preços de produção, o valor "não é". O que deve ser explicado é o fato de que, em Marx, a lei do valor rege a produção e o intercâmbio capitalista. $\mathrm{O}$ valor $e ́$ em sua plenitude no modo de produção capitalista, ainda que nas trocas singulares o preço das mercadorias afaste-se de seu valor. Em lugar algum Marx 
afirmou que no capitalismo o valor "não é mais", mas, ao contrário, a lei do valor explica o fenômeno dos preços na sociedade capitalista e, além disso, o tempo de trabalho se impõe nas trocas ainda que as mercadorias sejam vendidas por preços distintos de seu valor. Mais do que isto, é a determinação do valor como tempo de trabalho social já no nível da produção que faz com que a lei do valor se realize apenas na forma dos preços de produção.

Quando a produção para a troca, sendo dominante, estrutura-se em um sistema ou em um mercado único, criando as condições de desenvolvimento pleno do valor, este apenas se manifesta na forma de preços de produção das mercadorias. $O$ ponto fundamental é o seguinte: o fato de os preços das mercadorias serem determinados por seus preços de produção, e não por seus valores, não nega a lei do valor mas, ao contrário, é a única forma em que esta lei pode se realizar, isto é, é o modo pelo qual o tempo de trabalho social se impõe como determinante do valor do conjunto das mercadorias. Não discuto aqui a questão da transformação do valor em preço de produção, para o que seria necessário recuperar um conjunto de debates já realizados, apenas indico brevemente a posição expressa de Marx sobre o tema.

Preço de produção não é uma determinação da mercadoria indiferente ao valor, mas é a forma transmutada do próprio valor: "Nos Livros Primeiro e Segundo ocupamonos somente com os valores das mercadorias. Agora, distinguiu-se como parte desse valor, por um lado, o preço de custo e, por outro, desenvolveu-se como forma transmutada do valor o preço de produção da mercadoria" (C, III, 4, 127). Que forma transmutada é essa? Ela se baseia em uma distribuição do valor global da mercadoria social entre as mercadorias singulares que não corresponde ao valor que elas individualmente contêm. As mercadorias realizam em dinheiro montantes distintos do que contêm. Por quê? Porque a mercadoria é produto do capital. Na concorrência entre capitais, impõe-se a taxa média de lucro, um retorno médio relativo ao investimento de capital e acorde com sua própria natureza: o impulso de todos os capitais concomitantemente pelo maior lucro possível. Esta finalidade resulta em migrações de capitais de um ramo a outro e consequentes mudanças nas relações de oferta e procura, que geram um movimento de tendência a uma taxa geral de lucro. Este movimento se realiza pelas alterações dos preços das mercadorias em relação a seus valores: de modo geral, as mercadorias são vendidas por seu preço de custo acrescido do lucro médio. Contudo, no que consiste a taxa média de lucro? Na massa de mais-valia média criada 
pelo capital social, por sua vez determinada pela massa de valor incorporada no conjunto das mercadorias que se relacionam em um único mercado. Assim, se na realização efetiva do valor das mercadorias o valor que cada uma representa na riqueza social não é proporcional ao trabalho social que custou produzi-la, no conjunto das mercadorias o que se realiza é seu valor global:

(...) onde quer que se estabeleça um lucro médio, e portanto uma taxa geral de lucro - não importa a maneira com que se produziu esse resultado -, esse lucro médio só pode ser o lucro sobre o capital social médio, cuja soma é igual à soma das mais-valias, e que os preços produzidos pelo acréscimo desse lucro médio sobre os preços de custo só podem ser os valores transformados em preços de produção (C, III, 4, 136).

Os preços se compensam, de modo que o preço global das mercadorias é igual a seu valor global. Em última instância, o valor total das mercadorias determina seu preço de produção global: "Já que o valor global das mercadorias regula a mais-valia social, e esta, por sua vez, o nível do lucro médio, e portanto da taxa geral de lucro - como lei geral, ou como lei que domina as oscilações -, então a lei do valor regula os preços de produção" (C, III, 4, 140).

Outro aspecto que explicita como a lei do valor regula a produção e o intercâmbio sociais no capitalismo é a variação dos preços de produção resultante da variação da produtividade do trabalho. Marx escreve: "Como quer que se regulem os preços, resulta que: 1) A lei do valor domina seu movimento, no sentido de que a diminuição ou o aumento do tempo de trabalho exigido para a produção faz cair ou subir, respectivamente, os preços de produção" (C, III, 4, 139). Se a variação do tempo de trabalho necessário à criação das mercadorias, determinada pela variação de produtividade do trabalho no ramo de produção correspondente, não incidisse sobre os preços de produção, seria possível afirmar que a lei do valor não é uma lei social, isto é, que os valores das mercadorias não se determinam pelo tempo de trabalho social. Mas as mercadorias de fato barateiam-se com o aprimoramento técnico. Este implica uma redução do preço de custo da mercadoria. Mas esta diminuição de custo, expresse-se imediatamente em redução do preço dos meios de produção ou da quantidade de força de trabalho, significa sempre economia de tempo de trabalho: "Economia de tempo, a isso se reduz afinal toda economia" (Grundrisse, 119).

A única forma em que o tempo de trabalho determina o valor das mercadorias é aquela em que seus preços são determinados pelo custo de produção. Este é a magnitude 
de trabalho social, vivo ou objetivado, que custa a produção de dada mercadoria. Nele, a quantidade de trabalho, em forma transfigurada de custo, é considerada deste o momento da produção. Marx escreve:

Os preços são antigos; a troca também, mas a crescente determinação dos primeiros pelos custos de produção, assim como a predominância da última sobre todas as relações de produção, só se desenvolvem completamente, e continuam a desenvolver-se cada vez mais completamente, na sociedade burguesa, a sociedade da livre concorrência (Grundrisse, 104).

É importante ter em vista que o preço de produção se estabelece na concorrência entre os ramos de produção, ou seja, entre mercadorias de espécies distintas. A taxa geral de lucro é uma das médias a que a concorrência capitalista impele. Mas além dela, no interior de um ramo de produção, o valor das mercadorias produzidas em condições distintas também foi igualado em uma média: "Seu pressuposto [dos preços de produção - VC] é a existência de uma taxa geral de lucro e esta, por sua vez, pressupõe que as taxas de lucro em cada esfera particular da produção, tomada por si, já estejam reduzidas a tantas outras taxas médias" (C, III, 4, 123). A concorrência opera o nivelamento das taxas de lucro dos diversos ramos da produção, mas pressupõe a uniformização dos preços das mercadorias produzidas por capitais concorrentes no interior de um mesmo ramo, que caracteriza o valor de mercado de cada espécie de mercadoria.

Como uma espécie determinada de mercadoria é produzida por empreendimentos privados distintos em diferentes condições de produtividade e como, além disso, um exemplar de dada espécie de mercadoria não pode ter valor maior ou menor que outro exemplar da mesma qualidade, o próprio valor é já uma média expressa no tempo de trabalho socialmente necessário que custa produzi-la. Assim, o valor se distingue do tempo empírico de trabalho. Na concorrência capitalista, o tempo de trabalho socialmente necessário aparece como valor de mercado: este se define como preço de produção médio da mercadoria de determinada espécie. Marx escreve, sobre a equalização do valor das mercadorias de mesma espécie produzidas em diferentes condições ou tempo de trabalho: "O valor individual de algumas dessas mercadorias estará abaixo do valor de mercado (isto é, sua produção exige menos tempo de trabalho do que o expresso pelo valor de mercado), o de outras estará acima dele" (C, III, 4, 139). Isso significa que tempos distintos de trabalho concreto criam a mesma magnitude valor. Devido aos diferentes níveis de produtividade em um único ramo, ao realizarem a 
mercadoria pelo valor de mercado, diferentes empreendimentos privados obtêm em dinheiro, na troca de suas mercadorias, montantes iguais, maiores ou menores que seus "valores individuais", ou tempos de trabalho particulares.

Em suma, a mercadoria tem um preço pré-definido antes de sua produção, e para cada capital importa reduzir os custos de produção para que este preço signifique realização de maior montante de lucro. Apenas na sociedade capitalista a mercadoria tem preço antes da troca ao mesmo tempo em que este preço impõe que o custo seja constantemente reduzido. (Com a mudança geral na produtividade do ramo em questão o preço acaba por alterar-se.) Só nela, portanto, há "a dupla forma do trabalho" que "existe realmente enquanto o tempo de trabalho geral-abstrato adquire no preço das mercadorias uma existência imaginária" (Contribuição, 99, citado acima). Desde sua produção, a mercadoria está medida em dinheiro, em quantidade alíquota de riqueza geral.

Assim, todas as médias que se estabelecem nas trocas e que impõem o tempo de trabalho socialmente necessário como determinante do valor, a taxa geral de lucro como resultado necessário da produção capitalista, o valor de mercado de cada espécie de mercadoria, bem como a redução de custos como meio para a realização capitalista do máximo de lucro, são mediações através das quais o tempo de trabalho social se impõe como determinante do conjunto da produção. O capitalismo não opera uma modificação na lei do valor, como afirma Engels, mas antes a realiza plenamente ao submeter o conjunto da produção social à riqueza abstrata (quantitativa) e à racionalidade da economia de custos, ou tempo de trabalho. Pela mesma razão, a troca das mercadorias por seu preço de produção, e não diretamente pelo valor, longe de ser uma refutação desta lei, como querem Schmidt, Böhm-Bawerk e Castoriadis, é o único modo em que ela se realiza ${ }^{142}$. Este conjunto de mediações mostra ainda que a lei do valor não é um algoritmo que define as proporções nas trocas singulares, mas explica o modo pelo qual a quantidade de trabalho social autonomizada em valor regula a divisão do trabalho na sociedade capitalista. Caracteriza uma forma da relação social de produção.

\footnotetext{
${ }^{142}$ Diga-se de passagem, esta diferença entre o tempo de trabalho concreto imediato que custa a produção de uma mercadoria e seu preço é um dos fatores que determinam o fetichismo da mercadoria, visto que o produtor, ainda que calcule o tempo de produção, não controla o quanto de valor social seu tempo concreto representa, o preço é dado socialmente. A alienação pela troca separa o caráter social dos trabalhos concretos reais ao equipará-los, tornando-os trabalho abstrato e fazendo com que sua validade social não seja tangível. Explicita-se a separação do caráter social do trabalho.
} 


\section{O trabalho complexo na teoria do valor}

$\mathrm{Na}$ caracterização da categoria de trabalho abstrato, que denota uma forma social do trabalho, a questão do trabalho complexo e sua redução ao trabalho simples já está quase resolvida em seus termos gerais, mas vale especificar. Elucidar a questão do trabalho complexo é importante para a atual discussão referente à superação histórica ou transformação essencial da teoria do valor. Como foi apresentado no primeiro capítulo, as teses sobre a atual crise do valor e sobre a necessidade de sua atualização pelo conceito de valor qualitativo baseiam-se em que o trabalho cognitivo, por seu diferencial de qualidade, não podem ser reduzido, em sua objetivação, a mera quantidade de trabalho e, portanto, a trabalho abstrato. Por isso, não criam valor, mas valor qualitativo, uma expressão que traz em si tanto o caráter concreto da qualidade, como um caráter de medida geral, um valor que não se confunde com o valor de uso.

O objetivo deste item é mostrar que o trabalho complexo, em Marx, reduz-se a mera quantidade de trabalho, a trabalho abstrato, devido à forma social em que se realiza. Quando se materializa em mercadoria, todas as determinações que valem para a mercadoria e para o trabalho em geral têm de valer para o trabalho complexo e seu produto. Por outro lado, o trabalho intelectual não necessariamente se materializa em mercadoria: o trabalho intelectual empregado na esfera mercantil, improdutiva, não cria valor porque não participa da produção das mercadorias, mas de sua realização. Um exemplo é o trabalho publicitário. Mas há trabalho intelectual empregado na esfera produtiva, ou seja, que cria riqueza útil e é empregado de um capital, que tampouco se materializa em mercadoria. Aí, a forma específica do valor de uso, conhecimento gratuitamente reprodutível, não permite que este valor de uso assuma a forma de mercadoria, de sorte que o capital investido em pesquisa científica, por exemplo, apenas se valoriza por meio das patentes ou do direito intelectual. Considero de suma importância para a discussão sobre a capacidade de o trabalho cognitivo criar valor a separação de cada uma dessas formas em que este trabalho participa da produção social do capital. Assim, neste item, abordo apenas o trabalho qualificado que participa no trabalho coletivo de produção de mercadorias. É esse trabalho qualificado produtivo que Marx visa ao tratar da categoria de trabalho complexo: quando o trabalho que gera a mercadoria possui qualificação especial, em sua redução qualitativa a trabalho abstrato, 
ele cria valor multiplicado, e vale pois como tempo de trabalho social potenciado. $\mathrm{O}$ trabalho complexo de Marx abrange tanto a qualificação artesanal, como a do ourives, como a qualificação intelectual, como a do engenheiro de produção e "do proletário intelectual de Leipzig" (TMV I, 396). Trato no capítulo seguinte do trabalho cognitivo empregado na esfera improdutiva do capital e na pesquisa científica.

Se o aumento do trabalho cognitivo é hoje fator que leva autores como Gorz, Negri, Lazzaratto, Ruy Fausto e Eleutério Prado a considerar que o trabalho abstrato não pode mais ser substância do valor, a categoria mesma de trabalho complexo foi já considerada incongruente com a lei do valor. Como apresentado no primeiro e neste capítulos, a questão do trabalho complexo baseou críticas à validade da lei do valor e vieram em geral juntas com a ideia de que os preços de produção são também incongruentes com a lei do valor. As respostas a essas críticas têm o mesmo viés: recuperar o fato de que a produção mercantil pressupõe um corpo social integrado em que as forças de trabalho individuais autonomizam-se em uma única força de trabalho social, e seu produto, na riqueza homogênea que é o valor. De modo que seus produtos equivalentes são partes alíquotas da riqueza social. Exponho abaixo as respostas que esta crítica recebeu e o modo como alguns autores marxistas buscaram explicar o trabalho complexo no interior da teoria do valor. O problema envolve os seguintes aspectos: como o trabalho complexo se reduz a mera quantidade de trabalho ou trabalho abstrato; como se dá sua redução a trabalho simples; o que constitui o maior valor da força de trabalho qualificada; e o que constitui o valor multiplicado do produto do trabalho complexo.

Marx define o trabalho complexo, superior ou qualificado com relação ao trabalho simples pelo caráter especial de sua atividade concreta, e portanto também da força de trabalho que a efetiva. A força de trabalho qualificada, diversamente da que realiza trabalho médio, não é formada espontaneamente pelo modo de vida comum em determinada sociedade, mas requer formação ou qualificação específica prévia à realização da atividade. Os trabalhos simples e complexo distinguem-se pelas diferentes magnitudes de valor que incorporam ao produto; do mesmo modo, as forças de trabalho simples e de trabalho complexo se diferenciam pelas diversas magnitudes de valor que contêm. Marx escreve: 
Ele [o trabalho humano - VC] é dispêndio da força de trabalho simples que em média toda pessoa comum, sem desenvolvimento especial, possui em seu organismo físico. Embora o próprio trabalho médio simples mude seu caráter, em diferentes países ou épocas culturais, ele é porém dado em uma sociedade particular $(\mathrm{C}, \mathrm{I}, 1,51)$.

O trabalho simples é também chamado de trabalho médio. Pode-se assumir que o trabalho simples não é trabalho que não requer qualificação alguma, mas sim trabalho que exige a qualificação média, mas nenhuma qualificação especial. Afirmar que o trabalho simples muda de caráter é o mesmo que dizer que as capacidades médias exigidas pelo trabalho simples mudam historicamente, e portanto se ampliam ou se reduzem conforme as forças produtivas e a organização do trabalho. Mas esta distinção entre os trabalhos simples e complexo é relevante apenas na sociedade em que os trabalhos foram universalmente igualados enquanto trabalho humano. As atividades intelectuais nas sociedades pré-capitalistas não são consideradas trabalho, e mesmo a produção artesanal não é referida como trabalho qualificado frente ao trabalho simples dos servos camponeses. Trabalho complexo e trabalho simples são categorias que importam ao trabalho que cria valor. O trabalho simples é unidade de medida das diferentes espécies de trabalho em sua dimensão abstrata, ou pela sua capacidade de criar valor: "As diferentes proporções, nas quais as diferentes espécies de trabalho são reduzidas a trabalho simples como unidade de medida (...)" (C, I, 1, 52). Atividades qualitativamente distintas fazem parte do que se chama trabalho simples. Além disso, há diversos níveis de qualificação: um motorista de ambulância é um trabalhador qualificado, mas não tanto quanto um enfermeiro etc.

A razão pela qual a força de trabalho qualificado tem maior valor é relativamente incontroversa no debate marxista: vale mais porque sua reprodução tem custo mais alto, na medida em que requer o consumo de mercadorias e serviços para manter-se como força de trabalho qualificado, desnecessários à força de trabalho simples ou médio:

O trabalho que vale como trabalho superior, mais complexo em face do trabalho social médio, é a exteriorização de uma força de trabalho na qual entram custos mais altos de formação, cuja produção custa mais tempo de trabalho e que, por isso, tem valor mais elevado que a força de trabalho simples (C, I, 1, 162).

Mas as razões pelas quais o trabalho qualificado incorpora maior valor que o trabalho simples, em mesmo tempo de dispêndio, são alvo de controvérsias e polêmicas. Marx 
afirma essa capacidade específica do trabalho complexo de incorporar valor multiplicado ao produto, isto é, produzir maior valor com mesma quantidade de trabalho: "Trabalho mais complexo vale apenas como trabalho simples potenciado ou, antes, multiplicado, de modo que um pequeno quantum de trabalho complexo é igual a um grande quantum de trabalho simples" (C, I, 1, 51). Marx insere nesse ponto uma nota: "O leitor deve estar atento para o fato de aqui não se falar de salário ou do valor, que o trabalhador obtém aproximadamente por um dia de trabalho, mas sim do valor de mercadorias em que se materializa seu dia de trabalho (...)" (C, I, 1, 52, nota 15).

O trabalho qualificado gera valor, e valor maior que o trabalho simples, e por isso vale como, ou seja, se iguala a, trabalho simples potenciado. Marx é categórico ao afirmar esta igualdade qualitativa entre essas duas formas de trabalho quando empregados na esfera da produção de capital: “(...) para o processo de valorização é totalmente indiferente se o trabalho apropriado pelo capitalista é trabalho simples, trabalho social médio, ou trabalho mais complexo, trabalho de peso específico superior" (C, I, 1, 162).

Essa igualdade qualitativa consiste na forma social igual que os produtos de trabalho simples e complexos assumem: "Que essa redução ocorre constantemente, mostra-o a experiência. Uma mercadoria pode ser o produto do trabalho mais complexo, seu valor a equipara ao produto do trabalho simples e, por isso, ele mesmo representa determinado quantum de trabalho simples" $(\mathrm{C}, \mathrm{I}, 1,52)$. Ou seja, os trabalhos simples e complexos se igualam na medida em que os produtos de ambas as formas do trabalho são valor. A permutabilidade de seus produtos os equipara como valores de troca, e confere a todos os trabalhos que criam mercadorias a mesma natureza social de trabalho abstrato: "Uma mercadoria pode ser o produto do trabalho mais complexo".

Mas a determinação quantitativa desta comparação, isto é, quanto de trabalho simples vale o trabalho complexo, em seus diversos níveis de qualificação, não é passível de medida, a não ser no momento de realização do valor de seus produtos, na prática das trocas (que certamente não são expressão imediata do valor, mas mediadas pelas relações de concorrência que determinam os preços). Marx escreve: "As diferentes proporções, nas quais as diferentes espécies de trabalho são reduzidas a trabalho simples como unidade de medida, são fixadas por um processo social por trás das costas dos produtores e lhes parece, portanto, ser dadas pela tradição" (C, I, 1, 52). 
Em outra passagem: “(...) em todo processo de formação de valor, o trabalho superior sempre tem de ser reduzido a trabalho social médio, por exemplo, uma jornada de trabalho superior a $x$ jornadas de trabalho simples" $(\mathrm{C}, \mathrm{I}, 1,163)$.

Embora em Marx o valor da mercadoria não seja em nenhum aspecto determinado pela magnitude do salário, há uma relação entre os valores superiores da força de trabalho e do produto do trabalho complexo:

Se o valor dessa força é superior, ela se exterioriza, por conseguinte, em trabalho superior e se objetiva, nos mesmos períodos de tempo, em valores proporcionalmente mais altos. Qualquer que seja, porém, a diferença de grau entre o trabalho do fiandeiro e do joalheiro, a porção de trabalho com que o joalheiro apenas repõe o valor de sua própria força de trabalho não se distingue qualitativamente, de modo algum, da porção de trabalho adicional, com que gera maisvalia. Depois como antes, a mais-valia resulta somente de um excesso quantitativo de trabalho, da duração prolongada do mesmo processo de trabalho, que é em um caso o processo de produção de fios, em outro, o processo da produção de joias (C, I, 1, 162).

Em sua crítica a Bailey, Marx tira as consequências da concepção deste autor que, em última análise, não se distingue da de Böhm-Bawerk e de Castoriadis:

[Na visão de Bailey] Isso redunda nisso: uma jornada de trabalho simples por exemplo não é medida do valor se há outras jornadas de trabalho que estão para as jornadas simples como jornadas complexas. Ricardo mostrou que esse fato não impede medir as mercadorias pelo tempo de trabalho se é dada a relação entre trabalho simples e trabalho complexo. É verdade que deixou de expor como essa relação se desenvolve e se determina. $O$ assunto se enquadra na conceituação do salário e em última análise reduz-se aos diferentes valores da própria força de trabalho, isto é, aos diferentes custos de produção dela (determinados pelo tempo de trabalho) (TMV, III, 1218).

Em outra passagem, Marx exemplifica: "Se, por exemplo, o trabalho de um ourives se paga mais caro que o de um jornaleiro, então o mais-trabalho do ourives produz, na mesma proporção, mais-valia maior que a do jornaleiro" (C, III, 4, 111).

Se as questões relativas à capacidade de o trabalho complexo produzir valor multiplicado e à sua redução a trabalho simples ocuparam diversos autores no interior do debate marxista, há também aqueles que procuraram explicar no que consiste esta relação entre o valor do produto e o valor da força de trabalho qualificado. Retomo as concepções de alguns dos autores marxistas cujas posições respondem aos críticos da teoria do valor de Marx apresentados no primeiro capítulo. Rudolf Hilferding responde 
diretamente a Böhm-Bawerk; Otto Bauer recupera seu texto e discute os temas mais específicos, assim como Isaac I. Rubin e também Roman Rosdolsky, que abordam o problema em termos mais amplos. Rubin e Rosdolsky abordam o tema do trabalho complexo a partir da conceituação de trabalho abstrato. O problema principal - como se reduz a trabalho simples - é resolvido na medida em que o trabalho complexo assume a forma social de trabalho abstrato: pondo-se socialmente como trabalho abstrato o trabalho complexo se reduz a trabalho simples. Hilferding busca explicar esta redução opondo o trabalho social ao trabalho privado, mas não expressa diretamente o caráter abstrato do trabalho social. De qualquer modo, parte da equiparação qualitativa de todos os trabalhos que criam mercadorias pela forma social da relação para explicar o trabalho abstrato. Sobre esse pressuposto, as questões mais específicas, como, por exemplo, quais trabalhos sociais concorrem para compor o valor do produto do trabalho complexo, são discutidas.

Hilferding ${ }^{143}$ parte da caracterização da relação que permeia a sociedade mercantil, examina a mercadoria como coisa social, e destaca a oposição entre trabalho social e trabalho privado a partir da oposição entre valor de uso e valor. A especificidade do caráter social do trabalho explica em termos gerais a redução do trabalho complexo a simples. Da produção para troca resulta a uniformização dos múltiplos trabalhos em trabalho social, que faz da mercadoria uma unidade de termos contraditórios. O autor escreve: “(...) enquanto a propriedade privada e a divisão de trabalho reduzem a sociedade a átomos, a troca de produtos restaura à sociedade suas interconexões sociais" (Hilferding, Crítica de Böhm-Bawerk, 130). Como expressão das relações sociais entre produtores independentes realizadas por meio do que Hilferding chama de "instrumentalidade dos bens", o termo mercadoria "é um termo econômico". A oposição entre as duas determinações que conformam a unidade da mercadoria, valor de uso e valor, se apresenta como oposição entre a manifestação da mercadoria como coisa natural e como coisa social: "A mercadoria é uma unidade de valor de uso e valor, mas podemos considerar esta unidade a partir de dois diferentes aspectos. Como coisa natural, é objeto da ciência natural; como coisa social, é objeto da ciência social, objeto da economia política" (Hilferding, Crítica de Böhm-Bawerk, 130). Nesta relação, considerados em sentido econômico, os “'trabalhos' privados se manifestam como seu

${ }^{143}$ BÖHM-BAWERK, Eugen von. Karl Marx and the closure of his system; HILFERDING, Rudolf. Böhm-Bawerk's criticism of Marx. Tradução de Eden e Cedar Paul. Introdução de Paul Sweezy. Nova York: Augustus M. Kelley, 1949. Doravante, Crítica de Böhm-Bawerk, seguido do número da página. 
oposto, como 'trabalhos' sociais. A condição que confere ao trabalho sua qualidade de criar valor é, portanto, a determinação social do trabalho - é uma qualidade do trabalho social” (Hilferding, Crítica de Böhm-Bawerk, 131). Em outros termos:

\footnotetext{
O nexo social se manifesta como resultado de relações privadas, relações não de indivíduos privados, mas de coisas privadas. É precisamente isto que envolve todo o problema em mistério. $\mathrm{Na}$ medida, entretanto, em que as coisas entram em mútuas relações, o trabalho privado que as produziu adquire validade somente enquanto são um dispêndio de sua antítese, trabalho socialmente necessário (Hilferding, Crítica de Böhm-Bawerk, 131-2).
}

A uniformização social dos trabalhos em valores de troca autonomiza dos trabalhos individuais este caráter social, de modo que a mercadoria não aparece como produto do trabalho de diferentes sujeitos, mas estes aparecem, pela dimensão social de seus trabalhos, como "simples 'instrumentos de trabalho"'(Hilferding, Crítica de BöhmBawerk, 131). Assim, "O produto total do trabalho se apresenta como um valor total, que nas mercadorias individuais manifesta-se quantitativamente como valor de troca" (Hilferding, Crítica de Böhm-Bawerk, 131). Como incorporação de trabalho social, a mercadoria individual conta como parte alíquota do produto social total, e apenas como tal funciona na troca. Em uma sociedade qualitativamente determinada por esta forma de organização, o produto social é quantitativamente determinado pela soma total de trabalho social despendido em sua produção, e a mercadoria individual é quantitativamente determinada pela quota de trabalho social que incorpora, e não pelo tempo empírico de trabalho concreto despendido.

A partir desta caracterização do trabalho social como autonomizado socialmente em valor, Hilferding aborda o trabalho complexo. De acordo com o autor, a contradição que Böhm-Bawerk encontra na categoria do trabalho complexo expressa também sua confusão entre "o natural e o social” (Hilferding, Crítica de Böhm-Bawerk, 135). Para Böhm-Bawerk, a explicação de Marx é circular: afirmar que, por exemplo, o produto do trabalho de um dia do escultor equivale a cinco dias do trabalho do minerador porque a experiência mostra que o processo social efetiva esta redução é explicar a causa pelo efeito. Para Hilferding, mesmo aos "escritores mais ou menos marxistas, como Bernstein, C. Schmidt e Kautski” (Hilferding, Crítica de Böhm-Bawerk, 137) parece que o argumento de Marx sobre a redução do trabalho complexo ao simples tem uma lacuna. Hilferding pretende demonstrar o contrário. 
O autor parte do princípio, admitido em geral e até mesmo por Böhm-Bawerk, de que "a diferença no valor dos respectivos produtos deve depender de uma diferença no trabalho" (Hilferding, Crítica de Böhm-Bawerk, 138). Esta não pode ser, contudo, qualitativa, já que o trabalho que cria valor é homogêneo:

Para que este processo [da redução do trabalho complexo ao simples] seja compreensível, contudo, a teoria do valor deve considerar o trabalho disponível para a sociedade em qualquer momento dado como composto de partes homogêneas de trabalho individual, na medida em que cria valor, que são meramente uma parte alíquota deste todo quantitativo (Hilferding, Crítica de Böhm-Bawerk, 138).

$\mathrm{E}$ argumenta que este todo quantitativo depende de uma unidade de medida comum, que torna possível a homogeneização qualitativa. Esta unidade de medida é o "trabalho simples médio", que consiste "no dispêndio de força de trabalho simples, ou seja, da força de trabalho que, em média, independente de qualquer desenvolvimento especial, existe no organismo de todo indivíduo comum" (Hilferding, Crítica de Böhm-Bawerk, 138), nos termos de Marx. O trabalho qualificado conta como múltiplo desta unidade de trabalho simples médio, isto é, no que respeita à criação de valor, a diferença entre os trabalhos é quantitativa. Hilferding se pergunta se é possível definir este múltiplo, e pondera que a proporção na troca entre mercadorias, quaisquer que sejam, se estabelece por um processo social às costas dos produtores, de modo que a relação real de troca entre mercadorias define esta proporção e a expressa. Isso porque não é possível determinar a priori, com base em alguma propriedade inerente ao trabalho qualificado, em qual múltiplo do trabalho simples importa sua capacidade de criar valor. BöhmBawerk, para quem a tarefa essencial da economia é a de explicar o fenômeno do preço, busca na teoria do valor uma razão que torne possível a determinação antecipada do padrão absoluto dos preços.

Diferentemente de Böhm-Bawerk, argumenta o autor, para Marx a teoria do valor é meio para descobrir as leis da dinâmica do modo capitalista de produção e não para determinar os preços. O padrão absoluto dos preços é dado empiricamente, mas o que importa é explicitar a lei de sua variação: é indiferente se um tipo específico de trabalho qualificado produz valor quatro ou seis vezes maior que o trabalho simples, mas relevante compreender que "dobrar ou triplicar a força produtiva na esfera do trabalho qualificado reduziria o valor de seu produto duas ou três vezes face ao do trabalho simples" (Hilferding, Crítica de Böhm-Bawerk, 139). Estas variações nos 
fenômenos sociais (dos preços) são efetivadas por "variações na magnitude de uma força social, a força social de produção" (Hilferding, Crítica de Böhm-Bawerk, 139). Na medida em que a lei do valor revela que, em última análise, este desenvolvimento da força produtiva controla a variação nos preços, "e como todo fenômeno econômico se manifesta por mudanças nos preços" (Hilferding, Crítica de Böhm-Bawerk, 140), ela torna possível alcançar a compreensão do fenômeno econômico em geral.

Como sustenta Hilferding, a pergunta de Böhm-Bawerk sobre a qualidade inerente ao trabalho complexo que confere a este sua capacidade peculiar de criar valor é equivocada. Porque "A qualidade de criar valor per se não é inerente a nenhum trabalho" (Hilferding, Crítica de Böhm-Bawerk, 140), de modo que somente em dada organização social do processo de produção o trabalho cria valor. "Logo, não podemos alcançar o conceito de valor pela mera contemplação do trabalho isolado em sua completude" (Hilferding, Crítica de Böhm-Bawerk, 141). Como trabalho que cria valor, o trabalho qualificado deve ser considerado como parte do trabalho social. Portanto, deve significar que dado tempo empírico de trabalho complexo condensa mais partes alíquotas do trabalho social do que este mesmo tempo despendido por uma função do trabalho simples. Daí ser trabalho composto por mais de um trabalho.

I. I. Rubin ${ }^{144}$ também responde às duas principais objeções dos críticos da categoria de trabalho complexo, e que "veem este como a parte mais vulnerável da teoria de Marx" (Rubin, A teoria marxista do valor, p. 185), em argumentação semelhante à de Hilferding, mas desenvolve o trabalho social como trabalho abstrato. A primeira dessas objeções é a que alega que, se produtos com diferentes quantidades de trabalho incorporado trocam-se como equivalentes, a lei do valor é desconstruída. Rubin mostra que esta objeção resulta da compreensão errônea do trabalho abstrato como mero dispêndio fisiológico de energia: "não se pode negar o fato de que uma hora de trabalho do joalheiro e quatro horas de trabalho do produtor de calçados representam, do ponto de vista fisiológico, quantidades desiguais de trabalho" (Rubin, A teoria marxista do valor, p. 185). Contudo, o trabalho qualificado é "trabalho potencial condensado, multiplicado; não fisiologicamente, mas socialmente condensado" (Rubin, A teoria marxista do valor, p. 186). O autor critica a identificação do trabalho abstrato com o trabalho simples por parte de alguns marxistas, como A. Bogdanov e Karl Diehl. Essa

\footnotetext{
${ }^{144}$ RUBIN, I. I. A teoria marxista do valor. São Paulo: Polis, 1987.
} 
compreensão, que identifica o trabalho abstrato com dispêndio físico em atividade simples, caracteriza-o como um conceito baseado na natureza imediata da atividade do trabalho, retirando dele seu caráter social e estendendo-o, com isso, ao conjunto da história humana. O próprio valor, que é produto do trabalho abstrato, aparece com um “caráter material reificado" (Rubin, A teoria marxista do valor, p. 151), e como um aspecto do produto do trabalho humano independente da forma social de organização do trabalho. Para Rubin, o dispêndio de energia física é um pressuposto do trabalho abstrato, como do trabalho em geral (qualquer trabalho concreto), e nada diz sobre seu conteúdo ou sobre sua forma social. Mas o trabalho abstrato é uma forma social histórica do trabalho igualado, específica da sociedade mercantil. A própria igualação do trabalho humano - mesmo no sentido fisiológico, que demanda a equiparação dos indivíduos - é histórica, e não pode ser confundida com um dado natural. Como citado acima, o autor destaca que a produção capitalista é primeira forma social a manifestar o caráter geralmente humano do trabalho individual: "Não estaríamos exagerando se disséssemos que talvez o conceito de homem em geral, e de trabalho humano em geral, surgiram sobre a base da economia mercantil. Era precisamente isto que Marx queria mostrar quando indicou que o caráter humano geral do trabalho se expressa no trabalho abstrato" (Rubin, A teoria marxista do valor, p. 153-4). Mas isso não significa que o trabalho socialmente igualado é em si mesmo trabalho abstrato. Este é a forma mercantil do trabalho igualado ou socializado:

Se alguns autores confundem erroneamente trabalho abstrato com trabalho fisiologicamente igual, outros cometem um erro igualmente inaceitável, mas não tão grosseiro: confundem o trabalho abstrato com trabalho socialmente igualado. (...) O trabalho abstrato que Marx tratou é não só trabalho socialmente igualado, como também trabalho socialmente igualado numa forma específica, característica da economia mercantil (Rubin, A teoria marxista do valor, p. 155-6).

A especificidade histórica que imprime a forma de trabalho abstrato ao trabalho socialmente igualado é a propriedade privada, que faz com que o caráter social do trabalho se apresente nos produtos apenas como valor. Isso caracteriza o trabalho abstrato como trabalho em que o caráter social não é direto, mas mediado pela equiparação e consequente abstração. Rubin compara a forma social do trabalho em uma "economia mercantil" e em uma "grande comunidade socialista":

O trabalho em sua forma concreta é, neste caso [de uma grande comunidade socialista], diretamente trabalho social. É diferente numa economia mercantil, onde o trabalho concreto dos 
produtores não é diretamente trabalho social, mas privado, ou seja, trabalho de um produtor mercantil privado, um proprietário privado dos meios de produção, e um organizador autônomo da atividade econômica. Este trabalho privado só pode tornar-se social através de sua igualação com todas as outras formas de trabalho, através da igualação de seus produtos. Em outras palavras, o trabalho concreto não se torna social por possuir a forma de trabalho concreto que produz valores de uso concretos, sapatos, por exemplo, mas apenas se esses sapatos forem igualados a uma dada soma de dinheiro (e através do dinheiro com todos os demais produtos enquanto valores). Assim, o trabalho materializado nos sapatos (...) despoja-se de sua forma concreta determinada e se torna trabalho impessoal, uma partícula da massa global de trabalho social homogêneo (Rubin, A teoria marxista do valor, p. 157).

Assim, é nesta forma social de trabalho abstrato que o produto de menor quantidade de tempo de trabalho complexo se troca por produto de maior quantidade de trabalho simples. Rubin destaca o princípio de que é a distribuição do trabalho social homogêneo entre os diferentes ramos de atividade que determina o valor de seus respectivos produtos: o trabalho complexo condensa trabalho social abstrato, e por isso sua atividade objetiva trabalho multiplicado.

A segunda objeção dos críticos de Marx diz respeito à redução do trabalho complexo ao simples, unidade de medida do trabalho abstrato. A crítica visa à ausência de um padrão de medida que se aplique antecipadamente às diversas espécies de trabalho complexo e forneça meios para medi-lo em unidades de trabalho simples. Citando Hilferding, Rubin responde que esta não é uma tarefa da qual a teoria se incumbe e, mais do que isso, exigi-lo significaria contrariar as bases desta teoria. Sua função, como Hilferding já defendeu, é a de explicar "a causa do elevado valor do trabalho altamente qualificado bem como as modificações desses valores" (Rubin, A teoria marxista do valor, p. 187).

Roman Rosdolsky ${ }^{145}$ também se concentra em responder à crítica de BöhmBawerk que, segundo ele, “(...) tem sido reiterada com frequência" e "Ocupa o centro de qualquer crítica atual - acadêmica ou não - a Marx"146. O autor apresenta a crítica de Böhm-Bawerk destacando dois de seus argumentos. Primeiro, acusa Marx de ter

\footnotetext{
${ }^{145}$ ROSDOLSKY, R. Gênese e estrutura de O Capital de Karl Marx. Tradução de César Benjamin, Rio de Janeiro: EDUERJ, Contraponto, 2001, p. 423. Doravante, Gênese, seguido do número da página.

${ }^{146}$ De fato, ainda hoje a oposição política a Marx serve-se da argumentação de Böhm-Bawerk, inclusive fora dos âmbitos acadêmicos. Uma evidência disso é o artigo de Rodrigo Constantino, que escreve para a revista Veja: "Refutando com Böhm-Bawerk a teoria da exploração marxista": (http://veja.abril.com.br/blog/rodrigo-constantino/socialismo/refutando-com-bohm-bawerk-a-teoria-daexploracao-marxista/).
} 
substituído o termo "ser" por "valer", quando se refere à relação entre o trabalho complexo e o trabalho simples, porque o termo "ser" o colocaria em dificuldades. Nas palavras de Böhm-Bawerk, citadas por Rosdolsky:

É certo que Marx diz: o trabalho complexo "vale" como trabalho simples multiplicado, mas "valer" não é "ser", e a teoria se dirige para o ser, a essência das coisas. Naturalmente, os homens, por um motivo qualquer, podem equiparar uma jornada de trabalho do escultor a cinco jornadas de trabalho do cortador. Também podem, por exemplo, equiparar um cervo a cinco lebres. Porém, assim como essa equiparação não autoriza um estatístico a afirmar seriamente que uma área que contém 100 cervos e 500 lebres contém 1.000 lebres, tampouco um economista ou um teórico do valor está autorizado a afirmar que o produto cotidiano do escultor incorpora cinco jornadas de trabalho simples e que por isso, no ato da troca, o primeiro é equiparado ao produto de cinco dias do cortador (Rosdolsky, Gênese, 422).

A esta objeção, Rosdolsky responde lançando mão de uma passagem de Para a crítica da economia política em que Marx, diferentemente da extraída de $O$ Capital que BöhmBawerk utiliza em sua objeção, não realiza a alegada substituição de "ser" por "valer". Em $O$ Capital, lê-se:

O trabalho mais complexo conta [gilt] apenas como trabalho simples potencializado, ou melhor, multiplicado, de modo que um pequeno quantum de trabalho complexo é igual a um grande quantum de trabalho simples. Que esta redução ocorre constantemente, mostra-o a experiência. Uma mercadoria pode ser o produto do trabalho mais complexo, mas o seu valor a apresenta como igual ao produto do trabalho simples e, portanto, como sendo somente um quantum determinado de trabalho simples. As diversas proporções em que os diversos tipos de trabalho são reduzidos a trabalho simples, como a sua unidade de medida, estabelecem-se por um processo social às costas dos produtores, e parecem para eles daí como dados pelo costume. ${ }^{147}$

Na passagem destacada por Rosdolsky em Para a Crítica da economia política, temos:

Mas o que acontece com o trabalho qualificado (...)? Este trabalho se dissolve em [löst sich auf] trabalho simples composto, trabalho simples elevado a uma potência superior, de modo que, por exemplo, uma jornada de trabalho qualificado é igual a três jornadas de trabalho simples (Rosdolsky, Gênese, 428).

Rosdolsky afirma que Marx pôde apresentar a mesma definição do trabalho complexo sem utilizar a substituição condenada por Böhm-Bawerk. Mas, segundo o autor, para responder a esta objeção, o importante não é demonstrar que Marx pôde expressar-se sem lançar mão do termo "valer", mas explicitar as razões pelas quais Marx deve

${ }^{147}$ MARX, K. A mercadoria. Tradução, apresentação e comentários de Jorge Grespan. Coleção Ensaios Comentados. São Paulo: Ática, 2006, p. 28, citado acima na tradução de Os Economistas. 
utilizar o termo "valer" (ou “contar como"), que, ao contrário do que diz Böhm-Bawerk, não pode ser substituído por "ser". Rosdolsky questiona a forma de ser de que trata a teoria do valor. A teoria do valor não aborda os atributos imanentes aos diversos produtos do trabalho humano, ou às várias formas de trabalho correspondentes, em sua natureza específica, de modo a tornar possível atribuir-lhes valor natural aos produtos ou uma hierarquia natural entre as formas de atividade, que se expressassem na troca; ou ainda, que explicassem a proporção em que as coisas de fato se trocam. A teoria do valor aborda a forma social que os diversos produtos do trabalho assumem nas relações capitalistas de produção, sua medida ou substância social comum. Marx equipara o trabalho simples e o trabalho complexo enquanto atividades de produção de valor, e não os iguala em si mesmos, como atividades concretas. De fato, o produto do joalheiro não incorpora trabalho algum do pedreiro: do ponto de vista material estas atividades se distinguem, e a teoria de Marx busca encontrar precisamente o que há de comum nas diferentes atividades de trabalho que tornam seus produtos equiparáveis no mercado. $\mathrm{O}$ que os iguala é seu valor, e apenas como valor são equiparáveis. Assim, Marx não diz que 100 cervos e 500 lebres são iguais a 1000 lebres, mas que contêm a mesma magnitude de valor (se for este o caso).

Se em Böhm-Bawerk os homens podem equiparar o produto de diferentes quantidades de trabalhos qualitativamente distintos "por um motivo qualquer", é precisamente este "motivo" que Marx busca desvendar. Assim, para Rosdolsky, há um "ser" real a que Marx se refere quando diz que o trabalho complexo se reduz a trabalho simples, mas este "ser" é a forma social do trabalho que faz de seu produto, valor. Assim, o "ser" comum ao trabalho simples e complexo de que se ocupa a teoria do valor é justamente o seu "valer", que não é arbitrário como quer Böhm-Bawerk. O fundamento deste produto social comum é a forma do trabalho nas relações de produção do capital, que torna os trabalhos individuais em trabalho social abstrato. Mas, os trabalhos assumem esta forma social porque seus produtos são equiparados no mercado, ou seja, quando são criados de modo geral como mercadoria, e apenas nesta condição histórica. Böhm-Bawerk inverte a investigação, almejando encontrar na natureza dos produtos e suas atividades a determinação de valor (como Hilferding explica, procura no objeto da ciência natural as respostas econômicas). Rosdolsky afirma:

Com efeito: por que Marx serve-se nessa passagem [de $O$ Capital, citada acima] - e em algumas outras - da expressão “valer”? Simplesmente, para indicar que a qualidade criadora de valor não 
está dada de antemão, não é um fato natural, mas sim o resultado de uma equiparação de diversos trabalhos, que tem lugar no processo social. Por traz da curiosa objeção de Böhm está uma concepção ingenuamente naturalista da teoria do valor-trabalho, que nada tem a ver com Marx, mas muito tem a ver com a incompreensão que seus críticos exibem (Rosdolsky, Gênese, 428).

Trata-se mesma incompreensão da economia política clássica, que expus acima na passagem em que Marx critica a noção de trabalho de Franklin: os trabalhos reais são trabalho homogêneo não em seu caráter imediato, mas em seu caráter social estranhado.

O segundo argumento da objeção de Böhm-Bawerk, o principal, de acordo com Rosdolsky, que continua motivando os críticos de Marx, refere-se à redução do trabalho complexo ao simples. Trata-se da afirmação de que Marx explica esta redução por meio de um argumento circular, já respondida por Hilferding. Rosdolsky critica primeiramente o fato de Böhm-Bawerk escolher como exemplo de trabalho complexo o do escultor, uma vez que o trabalho de criação artística, especificamente, foi excluído por Marx da teoria do valor. Isso significa que o valor não é produto do trabalho de criação artística, esta forma do trabalho não conta como trabalho social abstrato. Marx não excluiu o conjunto do trabalho artístico do cômputo dos valores, mas apenas os nãoreprodutíveis. A razão desta exclusão passa pela consideração de que as forças produtivas sociais não dominam os meios de educação ou formação do gênio artístico, de modo que este é sempre um produto em parte espontâneo da vida social. É diferente o caso, por exemplo, de um engenheiro: mesmo que, como afirma Rubin, para produzir a força de trabalho de um engenheiro altamente qualificado seja necessário investir na educação de três alunos, ainda que com este alto custo social, os meios para esta formação são conhecidos e podem ser replicados.

Rosdolsky aponta então para a incompreensão de Böhm-Bawerk a respeito do trabalho abstrato. Destaca que a diferença qualitativa não existe apenas entre as atividades do trabalho simples e do trabalho complexo, mas entre as múltiplas espécies de trabalho, simples ou complexos. E que, além disso, o tempo empírico dos múltiplos trabalhos simples também não revela de modo imediato "a quantidade de trabalho criador de valor incorporada nos produtos do cortador, do peão, do operário da indústria do automóvel, mesmo quando sabemos que trabalham a mesma quantidade de tempo" (Rosdoslky, Gênese, 424). Isso porque outros fatores concorrem para a redução dos trabalhos diversos - ainda que todos simples - a essa unidade de "trabalho criador de 
valor", como a intensidade do trabalho, a habilidade do trabalhador e a produtividade dos meios empregados: “(...) ainda não sabemos se cada um deles elaborou seu produto sob 'condições de produção socialmente normais' e com o 'grau social médio de habilidade e intensidade de trabalho" (Rosdoslky, Gênese, 424). Para medirem-se como valores, os produtos dos diversos trabalhos devem ser reduzidos a "trabalho humano indiferenciado e uniforme" (Rosdoslky, Gênese, 424). Assim, a primeira consideração de Rosdolsky volta-se contra a exclusividade do alvo da objeção de Böhm-Bawerk, que parece aceitar a redução dos múltiplos trabalhos simples a uma idêntica qualidade, mas recusá-la ao trabalho qualificado:

\footnotetext{
Será que se trata do preconceito típico das "classes instruídas", para quem o trabalho de "profissões superiores" (por exemplo, o de um escultor) - as quais, de um lado, não querem considerar-se "improdutivas", enquanto, de outro, desejam separar-se dos trabalhadores restantes - se diferenciam de forma especial dos "trabalhadores comuns"? Serão esses "profissionais superiores" a tal ponto diferentes que é possível reduzir os trabalhadores restantes, sem inconvenientes, a "trabalho humano indiferenciado", enquanto isso não é possível no caso dos primeiros? Seja como for, Böhm não se dá conta de que deveria enfocar o tema, antes de tudo, a partir do conceito marxiano de "trabalho humano indiferenciado", e não limitar-se ao caso especial do trabalho qualificado, ao qual Marx aplica o conceito depois (Rosdoslky, Gênese, 424-5).
}

Para o autor, antes de colocar o problema do trabalho qualificado, Marx já havia demonstrado a redução de todas as espécies de trabalho a "trabalho indiferenciado, uniforme, simples", de modo que não havia necessidade de demonstrá-lo novamente com referência específica a ele. Rosdolsky apresenta sua avaliação da concepção de Böhm-Bawerk ao afirmar que esta demonstração só pode ser exigida "por quem considera que o trabalho de um trabalhador qualificado - por exemplo, um mecânico ou um engenheiro - é diferente, por princípio, dos demais trabalhos" (Rosdoslky, Gênese, 429). Para ele, o problema específico do trabalho complexo não reside na possibilidade de ser reduzido, qualitativamente, e enquanto criador de valor, a trabalho simples médio, mas nas leis que regulam esta redução, que abordo abaixo. Rosdolsky conclui sua consideração do trabalho complexo em Marx reforçando a tese de que o valor é social, e não inerente à especificidade material dos produtos ou das atividades, como aparece no valor-trabalho dos clássicos:

(...) o conceito de "trabalho que cria valor" não deve ser tomado "à escocesa", ou seja, de forma grosseiramente naturalista (...). Quem, como Böhm-Bawerk, exige que a teoria marxiana do 
valor deduza a redutibilidade do trabalho qualificado a trabalho simples "a priori, a partir de alguma propriedade inerente aos trabalhos qualificados", só demonstra como entendeu mal a teoria (Rosdolsky, Gênese, 433).

Para os autores referidos, a problema da possibilidade de redução do trabalho complexo ao simples, isto é, sua igualdade qualitativa, está contida na questão do trabalho abstrato. O trabalho complexo se reduz a trabalho simples ao assumir a forma social de trabalho abstrato: quando socialmente autonomiza seu caráter social em trabalho social meramente quantitativo, ao criar mercadoria. A redução do trabalho complexo ao trabalho simples é sua redução à unidade de medida do trabalho abstrato. O trabalho abstrato é trabalho social, e por isso médio no que diz respeito a todas as suas determinações. É trabalho de intensidade média, de periculosidade média, de produtividade média (para cada função) e também de qualificação média. O trabalho socialmente necessário designa a média do trabalho no que diz respeito à produtividade de cada função do trabalho. Por isso, refere-se à habilidade ou destreza média do trabalhador para sua função, no caso do trabalho individual (força de trabalho média), e à tecnologia média no caso do trabalho coletivo (meios de produção e organização do trabalho de nível médio), no interior de cada espécie de trabalho ou ramo da produção. Ao passo que trabalho simples designa a média dos diferentes tipos de trabalho no que diz respeito à sua qualificação. Quando a produção para a troca, equiparando os produtos como valores, iguala qualitativamente os trabalhos simples e complexos como formas do trabalho abstrato, a qualificação superior aparece como quantidade maior de trabalho social. O produto de trabalho socialmente necessário nas funções qualificadas vale mais que o produto de igual tempo de trabalho socialmente necessário em funções simples; a jornada de trabalho complexo vale como um múltiplo da jornada de trabalho simples. O que era, concretamente, uma diferença qualitativa se torna diferença meramente quantitativa quando os trabalhos criam valores de troca. Seu valor os equipara.

Sobre as diferenças qualitativas reduzirem-se na relação social a diferenças quantitativas, Rubin escreve:

(...) as diferentes formas de trabalho ocorrem em condições desiguais; diferem uma da outra segundo sua intensidade, sua periculosidade para a saúde, a duração da aprendizagem, e assim por diante. O processo de troca elimina as diferenças entre as formas de trabalho; elimina simultaneamente as diferentes condições e converte diferenças qualitativas em diferenças 
quantitativas. (...) No mercado, produtos produzidos com diferentes quantidades de tempo são igualados como valores (Rubin, A teoria marxista do valor, 175).

Nesta passagem destaca-se, primeiro, que a diferença de qualificação da atividade que existe entre o trabalho simples e o trabalho complexo não é a única que resulta na criação de magnitudes diversas de valor por trabalhos concretos despendidos durante intervalos iguais de tempo. Diferenças de intensidade, bem como diferenças relativas a periculosidade para a saúde também resultam em produtos com valores de diferentes montantes. No primeiro caso, a intensidade acima da média implica mais unidades de trabalho em mesmo tempo, e por isso produção de valor igual em tempo mais curto; no segundo, a periculosidade para saúde implica redução da vida produtiva da força de trabalho em relação à média. De modo que, se a força de trabalho média é produtiva por cinquenta anos, se aplicada a uma função que reduz o tempo produtivo médio da força de trabalho para trinta anos, esta produzirá neste intervalo a mesma quantidade de valor que nas demais funções é criado em cinquenta anos. No interior de uma mesma função, os trabalhadores qualificados podem se distinguir quanto à habilidade, mas isto faz parte da determinação do trabalho socialmente necessário, que é específico para cada função. Rubin escreve:

Esta qualificação média deve ser distinguida da qualificação individual do produtor isolado, no contexto da mesma profissão ou especialidade. O trabalho do joalheiro requer, em média, um alto nível de qualificação, mas diferentes joalheiros mostram, em seu trabalho, graus diferentes de experiência, aprendizado e habilidade; diferem um do outro em termos de destreza ou habilidade de seu trabalho (Rubin, A teoria marxista do valor, 177).

O mesmo se dá com referência à intensidade do trabalho. Assume-se a intensidade média, de modo que "Devemos explicar por que o trabalho qualificado, independente de seu nível de intensidade, cria um produto de maior valor" (Rubin, A teoria marxista do valor, 179). A redução do trabalho complexo a simples é uma das reduções à média que a forma abstrata do trabalho realiza. Ela envolve todas essas mediações. Essa é uma das razões pelas quais não é possível calcular a proporção que o trabalho complexo, que aliás tem diversos níveis, representa frente ao trabalho simples na criação de valor. Para Hilferding, a teoria marxista torna possível reconhecer os princípios que regem a redução do trabalho complexo ao simples. Torna "a magnitude do valor teoricamente mensurável", mas não faz dela "um padrão de medida imediatamente prático" ou "um meio de garantir uma lista de preços que seja o mais estável e justa possível" 
(Hilferding, Crítica de Böhm-Bawerk, 146). Assim, é possível determinar empiricamente "o dispêndio concreto de trabalho requerido para a produção de um bem específico" (Hilferding, Crítica de Böhm-Bawerk, 146), mas não é possível inferir a quantidade de trabalho socialmente necessário que esta magnitude de trabalho concreto específico representa, ou seja, sua contribuição para a criação do valor e da mais-valia, que são sociais. Para o autor,

Isto significa que estamos inquirindo do indivíduo aquilo que a sociedade empreende. Pois a sociedade é o único contador competente para calcular o padrão de preços, e o método que a sociedade emprega para este fim é o método da concorrência. Na medida em que, na livre concorrência de mercado, a sociedade trata como uma unidade o trabalho concreto despendido por todos os produtores para a produção de um bem, e uma vez que a sociedade paga pelo trabalho na medida em que seu dispêndio é socialmente necessário, é a sociedade que primeiro mostra em que grau este trabalho concreto de fato colaborou para a formação do valor e fixa o preço correspondente (Hilferding, Crítica de Böhm-Bawerk, 146-7).

Falta ainda explicar as leis que determinam esta redução específica: sabe-se que o trabalho complexo condensa maior quantidade de trabalho social, mas quais trabalhos efetivos contribuem para compor o maior valor do produto do trabalho qualificado? Marx afirma que este valor multiplicado se deve aos maiores custos de formação da força de trabalho, de modo que o trabalho envolvido na formação do trabalho qualificado é a parte alíquota do trabalho social adicional que entra no valor da mercadoria que este trabalho cria. Os autores que discutem o problema buscam especificar que trabalhos são esses. Além disso, também é levantada a questão da relação entre o valor superior da força de trabalho qualificada e do produto que cria.

Hilferding explica a origem da capacidade que tem o trabalho complexo de produzir valor multiplicado:

Trabalho simples médio é o dispêndio de força de trabalho simples, mas trabalho qualificado ou complexo é o dispêndio de força de trabalho qualificada. Para a produção desta força de trabalho qualificada, contudo, alguns trabalhos simples são requeridos. Estes são armazenados na pessoa do trabalhador qualificado, e somente quando começa a trabalhar estes trabalhos formativos fluem em prol da sociedade. O trabalho do educador técnico transmite, portanto, não apenas valor (que se manifesta na forma do salário mais alto), mas, além disso, sua própria capacidade de criar valor. Os trabalhos formativos são, deste modo, latentes no que concerne à sociedade, e não se manifesta enquanto a força de trabalho qualificada não começa a trabalhar. Seu dispêndio significa, consequentemente, o dispêndio de todos os diferentes tipos de trabalho simples que estão simultaneamente condensados nela (Hilferding, Crítica de Böhm-Bawerk, 144-5). 
$\mathrm{O}$ autor justifica com esta passagem tanto o mais alto valor da força de trabalho quanto do produto do trabalho complexo. O valor da força de trabalho se determina pelos custos de sua reprodução: a soma dos valores de todos os meios de vida necessários para que o trabalhador se reproduza como força de trabalho de sua função e forme filhos como força de trabalho da mesma função. Nas funções qualificadas, a educação especial é um custo que entra na produção da força de trabalho, ou seja, entra nos seus custos de produção, compondo os meios de vida, mercadorias e serviços, necessários para que se produza a força de trabalho de determinada função qualificada. Por isso, o trabalho envolvido na qualificação da força de trabalho incorpora valor à própria força de trabalho em formação. Este custo superior se manifesta no mais alto salário. Marx escreve:

Para modificar a natureza humana geral de tal modo que ela alcance habilidade e destreza em determinado ramo de trabalho, tornando-se força de trabalho desenvolvida e específica, é preciso determinada formação ou educação que, por sua vez, custa uma soma maior ou menor de equivalentes mercantis. Conforme o caráter mais ou menos mediato da força de trabalho, os seus custos de formação são diferentes. Esses custos de aprendizagem, ínfimos para a força de trabalho comum, entram portanto no âmbito dos valores gastos para sua produção $(\mathrm{C}, \mathrm{I}, 1,142)$.

O objeto do trabalho do formador seria, para Hilferding, a própria força de trabalho, os educandos. Além de compor, como um serviço necessário à produção da força de trabalho, o seu valor, este trabalho ainda transfere sua capacidade de criar valor à força de trabalho em processo de aprendizado. A transferência da força produtiva de valor do formador se dá por meio da transformação concreta da força de trabalho. $\mathrm{O}$ trabalho despendido em sua educação transmite o valor de uso que tem para o capital à força de trabalho qualificada:

\footnotetext{
Na medida em que o trabalho simples é utilizado na formação do trabalho complexo, cria, por um lado, o valor da força de trabalho, que reaparece no salário do trabalhador qualificado e, por outro, pelo método concreto de sua aplicação, cria um novo valor de uso que consiste nisso, em estar agora disponível uma força de trabalho que pode criar valor com todas as potencialidades do trabalho simples utilizado em sua formação (Hilferding, Crítica de Böhm-Bawerk, 145).
}

No que diz respeito à sociedade, o trabalho do educador é latente, e só funciona para ela quando a força de trabalho se torna ativa. "Portanto, em um único ato de dispêndio de trabalho complexo uma soma de trabalhos não qualificados é despendida, e deste modo há uma soma de valor e mais-valia criados correspondente ao valor total que teria sido criado pelo dispêndio de todos os trabalhos simples requeridos pela 
produção da força de trabalho qualificada e sua função, o trabalho qualificado" (Hilferding, Crítica de Böhm-Bawerk, 145). Por essa razão, o trabalho complexo aparece como um múltiplo do trabalho simples, "do ponto de vista da sociedade" e "considerada economicamente": "No que tem de dar pelo produto do trabalho complexo, a sociedade consequentemente paga um equivalente do valor que os trabalhos simples teriam criado se tivessem sido consumidos diretamente pela sociedade" (Hilferding, Crítica de Böhm-Bawerk, 145). O resultado do trabalho complexo é também produto de todos os trabalhadores envolvidos na formação da força de trabalho qualificada que diretamente o produz, mas que não criam outras mercadorias. Por isso, "o trabalho qualificado é trabalho simples multiplicado" (Hilferding, Crítica de Böhm-Bawerk, 146). Chama a atenção o fato de que Hilferding começa referindo-se ao "educador técnico" e, em seguida, aborda o trabalho simples incorporado à força de trabalho qualificada quando de sua formação. O formador não teria de realizar, ele próprio, trabalho complexo? Mas o autor parece ter utilizado o trabalho simples em sua explicação para tornar mais explícito o princípio que faz do trabalho complexo, um múltiplo. Porque afirma em seguida: "Um trabalho qualificado pode conter, não apenas trabalho simples, mas também trabalhos qualificados de um tipo diferente, e estes por sua vez são redutíveis a trabalho simples. Quanto mais são incorporados outros trabalhos qualificados em um dado trabalho complexo, mais breve será o processo formativo" (Hilferding, Crítica de Böhm-Bawerk, 145).

Em "Trabalho qualificado e capitalismo""148, artigo publicado em 1906 na Die Neue Zeit, Otto Bauer discute o trabalho complexo no modo de produção capitalista. O autor lança mão da polêmica entre R. Hilferding e Hanns Deutsch ${ }^{149}$ e, a partir dela, apresenta sua própria interpretação. Destaco dois pontos do texto de Bauer. Primeiro, a partir dos apontamentos de Deutsch, o autor acrescenta ao tempo de trabalho do educador o tempo de trabalho do próprio aluno como componentes do valor superior do produto do trabalho complexo:

\footnotetext{
Supondo que a formação normal de um pintor de porcelana consiste em que ele por dois anos pinte pratos que não são utilizáveis, somente depois de dois anos de exercício ele poderia pintar pratos vendáveis. Não é então correto que desse modo o trabalho que é socialmente necessário
}

\footnotetext{
${ }^{148}$ BAUER, Otto. "Qualifizierte Arbeit und Kapitalismus”, in Die Neue Zeit (editada por Karl Kautsky), J.H.W. Dietz Nachf., 1906. Doravante, Trabalho qualificado.

${ }^{149}$ DEUTSCH, Hanns. Qualifizierte Arbeit und Kapitalismus: Werttheorie und Entwicklungstendenzen. C.W. Stern, 1904.
} 
para a produção de um prato vendável inclui uma parte alíquota daquele trabalho exigido para o estudo e o exercício? (...) Ao lado do valor que é criado pelo trabalho imediatamente realizado no processo de produção e do valor que é transmitido pelo formador da força de trabalho qualificada é portanto também o valor produzido pelo próprio aluno no processo de formação um fundamento determinante do valor do produto gerado pelo trabalhador qualificado (...) (Bauer, Trabalho qualificado, 649-50).

O segundo ponto que aparece nesta discussão de Bauer é o modo como os trabalhos dos educadores e dos próprios alunos empregados na qualificação da força de trabalho se transferem ao produto. Deutsch se opõe à afirmação de que o trabalho do formador tem como produto a força de trabalho qualificada. Para ele, como também Bauer, Hilferding associa dois processos que são em si mesmos distintos: a produção da aula e da força de trabalho qualificada que a utiliza em sua formação. Para Hilferding, o objeto sobre o qual recai o trabalho do educador é a subjetividade do aluno, de modo que seu produto é a força de trabalho.

Segundo Deutsch não é esse o caso: este mesmo trabalho se realiza em um produto diverso da força de trabalho, de que ela se apropria como um meio de produção objetivo. O formador produz uma mercadoria totalmente diferente, qual seja, aquela soma de valores de uso imateriais que nós chamamos "aula". O aluno não é o produto do trabalho do formador, mas o consumidor da mercadoria daquele. A força de trabalho qualificada não é o produto do trabalho do formador, mas sim do próprio trabalho que o aluno realiza durante o tempo de formação (Bauer, Trabalho qualificado, 648).

É uma diferença importante esta: para Deutsch, a qualificação é resultado do trabalho dos próprios trabalhadores em formação, e não do trabalho de outros indivíduos. Estes criam o meio de trabalho sobre o qual o aluno trabalha para produzir sua qualificação:

A aula, o produto do trabalho do formador, é assim apenas o meio de trabalho de que se serve o aluno. "A força de trabalho do aluno atua, com o meio de trabalho aula, sobre o objeto de trabalho cérebro, nervos e músculos do aluno para produzir o valor de uso força de trabalho qualificada." Produção da mercadoria aula e produção da força de trabalho qualificada são dois processos de produção totalmente separados. Do mesmo modo, por exemplo, que a produção do tear e a produção do tecido (Bauer, Trabalho qualificado, 648).

A magnitude do valor da mercadoria gerada pelo trabalho complexo (ou do valor que este trabalho acrescenta à mercadoria que contribui para criar) seria determinada, então, pelo tempo de trabalho do trabalhador qualificado, ao qual se acresce partes alíquotas do tempo despendido pelo aluno e pelos formadores em sua qualificação. Bauer escreve: 
Do valor de produção da força de trabalho qualificada que durante o tempo de formação em parte é transferida dos formadores para a força de trabalho qualificada e em parte é produzido pelo próprio trabalho do aluno ou estudante, é transferido em cada hora de trabalho uma parte alíquota para o produto do trabalho qualificado, do mesmo modo como um tear em cada hora de trabalho transfere ao tecido uma parte de seu valor. A grandeza dessa parte é determinada em um caso pela duração média de vida do trabalhador, no outro caso, pela duração média da vida útil do tear (Bauer, Trabalho qualificado, 648-9).

$\mathrm{Na}$ forma de meios de trabalho consumidos pela atividade do aluno, o tempo de trabalho dos formadores, incorporados no produto "aula", transfere-se, na qualidade de valor, para a força de trabalho qualificada. Bauer faz uma analogia com a transferência de valor do capital constante à mercadoria. Contudo, afirmar que o valor superior da força de trabalho é transferido ao produto do trabalho é explicar o valor do produto pelo valor da força de trabalho, o que é não apenas alheio à teoria de Marx, como foi alvo expresso de suas críticas. Marx escreve: "Mas o trabalho passado que a força de trabalho contém, e o trabalho vivo que ela pode prestar, seus custos diários de manutenção e seu dispêndio diário, são duas grandezas inteiramente diferentes. A primeira determina seu valor de troca, a outra forma seu valor de uso" (C, I, 1, 159). Marx afirma que “(...) o valor da força de trabalho pago pelo capital é substituído por um novo equivalente" (C, I, 1, 161), e de modo algum transferido da força de trabalho ao produto. $O$ trabalho vivo cria valor novo por seu dispêndio abstrato, e por sua atividade concreta transfere o valor dos meios de produção para o novo produto, mas não transfere o valor da força de trabalho que o realiza. Esta ausência de relação entre o valor da força de trabalho e do produto que ela cria é o que possibilita, por exemplo, a ampliação da taxa de mais-valia: o valor do produto não diminui se forem reduzidos os custos de reprodução da força de trabalho. Do mesmo modo, o valor do produto não aumenta se o salário sobe. Isso põe em xeque a analogia de Bauer. O maior valor do produto do trabalho complexo deve provir de quantidades de trabalho vivo, para além do trabalho imediato do trabalhador. O modo como Hilferding descreve esta transferência parece mais coerente: como os trabalhos de formação da força de trabalho são necessários para a produção de determinados produtos, mas apenas comprovam sua utilidade quando a força de trabalho cria efetivamente a mercadoria, eles transferem sua capacidade de criar valor à força de trabalho qualificada. Ou ainda, o trabalho complexo atualiza todo o tempo de 
trabalho social que, não sendo despendido diretamente na transformação do produto, é necessário para criá-lo ${ }^{150}$.

Rubin também considera que a questão do trabalho qualificado não diz respeito ao equilíbrio entre o consumo (valor da força de trabalho) e o valor do produto que determinada espécie de trabalho cria, mas tem como ponto de partida o equilíbrio entre as diversas formas de trabalho na sociedade, ou seja, a distribuição social das múltiplas funções do trabalho. Isso porque, "a troca de produtos das diferentes formas de trabalho em termos de seus valores corresponde ao estado de equilíbrio entre dois dados ramos da produção" (Rubin, A teoria marxista do valor, 181). O autor explica:

\begin{abstract}
Suponhamos que o valor do produto de um dado tipo de trabalho qualificado é inteiramente adequado para manter a força de trabalho qualificada do produtor, mas não suficiente para tornar o trabalho na dada profissão relativamente mais vantajoso do que o trabalho em outras profissões que requerem um período de aprendizado mais curto. Nessas condições, iniciar-se-á uma transferência de trabalho para fora dessa dada profissão; isso continuará até que o valor dos produtos dessa dada profissão se eleve a um nível que estabeleça uma relativa igualdade nas condições de produção e um estado de equilíbrio entre as diferentes formas de trabalho (Rubin, $A$ teoria marxista do valor, 180)
\end{abstract}

A redução que Rubin realiza do problema do trabalho complexo "à análise das condições de equilíbrio entre diferentes formas de trabalho que diferem em termos de qualificação" (Rubin, A teoria marxista do valor, 181), é coerente, como ele mesmo afirma, com o caminho de investigação trilhado por Hilferding, Bauer e Deutsch:

\begin{abstract}
Eles concentraram sua principal atenção no fato de que o produto do trabalho qualificado é não apenas o resultado do trabalho despendido em sua produção, mas também do trabalho necessário para o aprendizado do trabalhador nessa profissão. Este último trabalho também entra no valor do produto e o torna correspondentemente mais caro (Rubin, A teoria marxista do valor, 181).
\end{abstract}

\footnotetext{
150 Por outro lado, Bauer afirma: "Hilferding, portanto, também julgou corretamente o papel do trabalho qualificado no processo de produção de mais-valia. Mas sua fundamentação é incorreta. (...) Na verdade, o processo de produção no qual o formador é ativo nada tem a ver com o processo de produção no qual a força de trabalho qualificada é produzida, assim como o processo de produção do construtor (força de trabalho) do tear com o processo de produção do tecelão (força de trabalho); o formador pode já ter preenchido sua função de produzir mais-valia se ele for um trabalhador assalariado a serviço de uma escola capitalista!” (Bauer, Trabalho qualificado, p. 655). Se considerarmos que a aula é uma mercadoria que já incorporou o trabalho do formador e realizou o valor criado ao ser vendida, então apenas o tempo de trabalho despendido pelo próprio aluno em sua formação multiplica o valor de seu produto. Não é sustentável a posição de Bauer segundo a qual os serviços consumidos pelo aluno se transferem ao produto analogamente ao capital constante. Entretanto, se a aula é mercadoria que incorpora o trabalho do educador e o realiza como valor, então o educador cria diretamente mercadorias, e o mesmo trabalho não pode criar valor duas vezes. Deixo a questão em aberto.
} 
Rubin inclui no produto do trabalho complexo, para aquelas funções em que nem todos os trabalhadores formados conseguirão participar do mercado de trabalho em funções compatíveis com sua qualificação (e que caracteriza as altamente qualificadas), também o trabalho de formação daqueles que não foram selecionados, pois a formação destes é um custo social inevitável estejam disponíveis os trabalhadores qualificados ativos de que a produção social necessita ${ }^{151}$.

Assim, de forma geral, o trabalho complexo cria valor multiplicado porque parte do trabalho social é requerida indiretamente para sua produção, e deve incorporar valor do mesmo modo que o faria se criasse diretamente mercadoria. Todos os autores partem da forma que o trabalho concreto assume: a de trabalho que vale socialmente como partes alíquotas do trabalho social. Assim, as partes alíquotas que concorrem para a qualificação da força de trabalho devem aparecer como valor nos produtos sociais. E só podem fazê-lo por meio do trabalho qualificado que cria mercadoria. Assim, embora o valor da força de trabalho e o valor do produto do trabalho não determinem um ao outro, no trabalho complexo há uma relação entre eles. Como a força de trabalho social posta para produzir valor é uma massa homogênea, o consumo de parte desta força disponível para a qualificação da força de trabalho deve reaparecer no produto desta última como valor. Rosdoslky lança mão de uma passagem de Teorias da mais-valia e de uma comparação com uma organização socialista da produção para demonstrar esta relação:

\footnotetext{
Ricardo demonstrou que este fato [de as jornadas de trabalho qualificado terem o efeito de jornadas compostas] não impede que as mercadorias sejam medidas pelo tempo de trabalho se a relação entre trabalho qualificado e trabalho simples é dada. Mas ele não descreveu como essa relação se desenvolve e é fixada. Isso pertence à exposição sobre o salário e [aqui aparece a surpresa - RR] se reduz, em última instância, ao diferente valor das próprias capacidades de trabalho, ou seja, de seus diversos custos de produção (que são determinados pelo tempo de trabalho) (Marx, TMV III, apud Rosdolsky, Gênese, 430).
}

\footnotetext{
${ }^{151}$ Esta posição também põem questões. Primeiro, no que diz respeito aos trabalhos simples: o capitalismo também forma um exército industrial de reserva, de modo que se deveria considerar que a reprodução de trabalhadores não qualificados que não se inserem no mercado de trabalho significaria custo para o capital, e os custos de sua reprodução também deveriam entrar no valor das mercadorias, o que não se realiza. Segundo, essa inserção do custo de formação de trabalhadores qualificados que não integram a produção no valor das mercadorias demanda que estes custos sejam custos capitalistas. Quando os custos de formação correm por conta das famílias, não são custos capitalistas. Se o trabalhador qualificado não integra a produção de mercadorias, pode-se pensar que os custos de formação nem retornam para a família em forma de salário, nem criam valor.
} 
Para o autor, a proposição de Marx que estabelece como medida de comparação do valor dos produtos do trabalho simples e do trabalho complexo o valor de suas respectivas forças de trabalho significa que a maior capacidade de criação de valor do trabalho complexo está fundada sobre os maiores custos de aprendizagem desta força de trabalho qualificada. O produto deste trabalhador inclui, na forma de valor, o tempo de trabalho empregado no processo de qualificação:

Suponhamos que, para completar um certo projeto, sejam necessários cem trabalhadores que trabalhem durante dez dias, sendo que dez deles têm uma qualificação especial, superior à média, e precisaram preparar-se especialmente para contribuir no projeto. Para treinar esses trabalhadores, a sociedade deve arcar com gastos que equivalem, digamos, a duzentas jornadas de trabalho. É claro que também essas duzentas jornadas devem ser "calculadas" pela sociedade, se ela não quiser que seus planos econômicos fiquem suspensos no ar. Portanto, ela terá de estabelecer que, para levar o projeto adiante, são necessárias não 1.000, mas 1.200 jornadas de trabalho. A diferença entre trabalho qualificado e não qualificado será reduzida, em última instância, à diferença no tempo de aprendizagem de diversas forças de trabalho (Rosdolsky, Gênese, 431-2).

Apesar da diferença importante que existe entre medir a distribuição do trabalho social em tempo direto de trabalho e em valor, Rosdolsky afirma que "o mesmo vale, mutatis mutandis, para o modo de produção capitalista, com a diferença de que (...) Essa tarefa fica entregue às forças espontâneas do mercado (de mercadorias e força de trabalho)" (Rosdolsky, Gênese, 432). Isso não significa, para o autor, medir os valores dos produtos pelo valor das forças de trabalho, mas que o dispêndio maior de trabalho necessário à qualificação não pode se manifestar senão nos valores mais altos de seus produtos.

Rosdolski afirma que "a sociedade socialista, como dizia Engels, tenderá a equiparar os 'salários' dos trabalhadores qualificados com os 'salários' dos não qualificados" (Rosdolsky, Gênese, 431), porque, enquanto no modo de produção capitalista o próprio trabalhador (ou sua família) responsabiliza-se pelos custos de qualificação do trabalho, o que torna necessária uma maior remuneração, no socialismo é a própria sociedade que se assume esses custos. Engels, contudo, aponta para a dissolução da divisão entre trabalhadores qualificados e não-qualificados em uma sociedade socialista. Para Engels, a sociedade em que a força de trabalho se emancipou de sua condição de mercadoria deve possibilitar "a todos os indivíduos da sociedade desenvolver, manter e exercitar, nos mais amplos aspectos, as suas capacidades" 
(Engels, Anti-Dühring, 251). De modo que não é o salário de carregadores e arquitetos que deve se igualar, mas sim as condições para o desenvolvimento individual de múltiplas capacidades:

\footnotetext{
É claro que o modo tradicional de pensar das classes cultas, herdado pelo Sr. Dühring, tem que considerar, necessariamente, como uma monstruosidade, que chegue o dia em que não existam mais carregadores e arquitetos de profissão, e no qual o homem, que passou uma meia hora dando instruções, como arquiteto, tem que servir durante algum tempo como carregador, até que seus serviços de arquiteto voltem a ser necessários. Para se eternizar a categoria dos carregadores de profissão não era preciso o socialismo! (Engels, Anti-Dühring, 251).
}

Engels indica, assim, para o fato de que a própria divisão entre trabalho simples e trabalho complexo será superada em um modo de organização socialista. A meta de uma equalização dos salários mantendo a distinção de qualificação e a unilateralidade das atividades dos indivíduos, justificada pelo igual valor que o tempo de trabalho de todos os indivíduos naturalmente tem, não visa à superação da relação de valor, à qual corresponde o indivíduo unilateral.

A questão do trabalho complexo é importante para a compreensão do trabalho abstrato como forma social do trabalho, especialmente porque, para explicar a criação de valor multiplicado pelo trabalho complexo, torna-se necessário explicitar a redução de suas diferenças qualitativas em diferenças apenas quantitativas. Assim, contribui para discutir um aspecto das teses que sustentam o conceito de valor qualitativo, posto em questão no início do trabalho.

No que diz respeito à teoria marxiana, os autores que propõem esta mudança substancial no conceito de valor adotam ao menos duas posições. André Gorz assume que as categorias centrais da teoria do valor não são mais capazes de explicar a criação da riqueza no capitalismo contemporâneo, de modo que a teoria do valor de Marx teria sido superada pelo próprio desenvolvimento histórico. Ruy Fausto e Eleutério Prado, distintamente, acreditam ver na obra de Marx, nos Grundrisse em particular, a previsão desta transformação na natureza do valor. Reivindicam, assim, a teoria marxiana. Mas se estas visões se opõem no que diz respeito à avaliação da obra de Marx, têm em comum a consideração da produção de conhecimento como incompatível com as determinações centrais da criação de valor. Ambas assumem o trabalho abstrato como medida inadequada à mensuração do valor do produto do trabalho cognitivo. 
Para Gorz, esta heterogeneidade das atividades que se tornaram fontes do valor é a origem da crise do valor. Esta crise se define como perda da medida. A ausência de medida comum às atividades produtivas de conhecimento se origina, para o autor, na heterogeneidade concreta das capacidades exigidas. A atividade que lida centralmente com o conhecimento não é, para ele, passível "de mensurar em unidades abstratas simples" ou "redutível a uma quantidade de trabalho abstrato" (Gorz, Imaterial, 29, citado acima). Em outros termos, "A impossibilidade de padronizar e estandardizar todos os parâmetros das prestações demandadas se traduz em vãs tentativas para quantificar sua dimensão qualitativa (...)" (Gorz, Imaterial, 29-30, citado acima). Além disso, "o tempo socialmente necessário a uma produção se torna incerto". É nesta impossibilidade de previsão e de medida do tempo necessário à produção que o autor instala a crise da sociedade mercantil: "Um mercado de conhecimentos em que eles se troquem pelos seus 'valores' é impensável. Não podendo se exprimir em unidades de valor, sua avaliação como capital resta problemática" (Gorz, Imaterial, 31). O mesmo não se dá, de acordo com Gorz, com o trabalho simples. Ainda que diversos qualitativamente, os trabalhos simples podem se reduzir à quantidade, oferecem um padrão de comparação pelo tempo. Na compreensão do autor, portanto, o trabalho abstrato se vincula a uma determinação específica do trabalho concreto, que o caracteriza como simples. Este desenvolvimento produtivo põe em xeque o próprio capital porque, para Gorz, o valor não pode deixar de ser uma medida meramente quantitativa do trabalho social. Na visão do autor, o conceito de trabalho abstrato se transforma, de forma social das atividades produtivas independente de suas qualidades específicas, em uma forma ligada intrinsecamente a certo tipo de atividade concreta. Do mesmo modo, como a quantidade de trabalho que determina a grandeza do valor parece ser uma medida empírica de tempo, possível para o trabalho simples, mas impossível para o trabalho complexo devido à sua dimensão "qualitativa". O modo como utiliza as categorias de Marx expressa a mesma incompreensão do trabalho abstrato como forma social que as críticas de Böhm-Bawerk e Castoriadis demonstram.

Para Ruy Fausto, no capitalismo pós-industrial, em que o trabalho científico toma o lugar das massas de trabalho operário à máquina como elemento decisivo da produção, a criação de valor também se descola do trabalho abstrato. $\mathrm{O}$ valor se torna qualitativo, e com isso sua natureza mesma se transfigura. Se Gorz vê nesta discrepância da medida uma crise do valor, Ruy Fausto a entende como um 
desenvolvimento histórico do próprio valor, previsto por Marx. A produção pósindustrial implica a negação das determinações essenciais do valor, sem deixar de efetivamente produzir capital. Assim caracteriza-se a terceira fase do capitalismo, sucedendo a manufatura e a indústria, em que o valor passa a ter outro conteúdo, e o capital, por conseguinte, uma natureza diferente. Interpretando passagens dos Grundrisse, Fausto assume que na pós-grande indústria o quantum de trabalho deixa de ser o "elemento decisivo" para a criação de valor. Para o autor, o valor deixa de ser "trabalho abstrato cristalizado, medido pelo tempo" para se tornar "qualitativo" porque o poder de criar valor escapa do tempo como medida, quando passa a depender mais da utilização da ciência na produção ${ }^{152}$. Com isso, o valor perde sua substância própria e passa a ter como conteúdo uma qualidade, a ciência. $\mathrm{O}$ trabalho científico por sua qualidade se torna produtivo de valor: "A riqueza agora é cristalização do "trabalho" científico (...)" (Fausto, LP III, 138), e não do trabalho social abstrato. Em seu texto sobre a abstração real, Fausto afirmara: "Ora, se se deve pensar o valor em termos de trabalho - e isto não depende de redução dos trabalhos, na verdade o exige - toda redução dos valores dos produtos do trabalho deve aparecer como fundada numa redução do trabalho complexo ao simples" (Fausto, LP I, 94). Este pressuposto do valor teria se transformado no capitalismo pós-industrial, em que a ciência se torna o fator preponderante da produção.

Eleutério Prado defende também esta transformação na natureza do valor na atual fase do capitalismo, mas concebe, como Gorz, que esta transformação no conteúdo do valor sinaliza um momento crítico para o capital. Para o autor, embora toda mercadoria tenha "de poder ser medida pelo tempo de trabalho socialmente necessário à sua produção", quando uma parte importante do trabalho social torna-se espiritual, intelectual, moral ou artístico, o valor de seus produtos deixa de comportar esta medida quantitativa, e faz com que "diferenciais de qualidade postos pelo trabalho durante o tempo de trabalho" (Prado, Desmedida, 51-2) componham a substância do valor. O caráter intelectual do trabalho produtivo predominante impõe a perda da comensurabilidade entre os diferentes trabalhos concretos, tornando-os irredutíveis a mera quantidade de trabalho: "Ora, é verdade que essa mutação do trabalho concreto, de

152 'O 'valor' passa a ser qualitativo, e nesse sentido a 'riqueza efetiva' não é mais valor (trabalho abstrato cristalizado, medido pelo tempo), mas "valor negado"” (Fausto, LP III, 130). 
predominantemente manual para predominantemente mental, torna-o especialmente imensurável enquanto tal. Sobre isto não há dúvida" (Prado, Desmedida, 85).

O problema da medida redunda, portanto, na questão da substância do valor, que deixa de ser vista como forma oriunda da produção para a troca. Desaparece a mediação social que deve concorrer para que o trabalho se ponha socialmente como criador de valor. Para mostrar que o trabalho cognitivo não é suscetível da forma abstrata, esses autores se baseiam em sua determinação concreta: a qualidade de tais atividades não pode ser abstraída, embora a dos diferentes trabalhos simples possa. Rosdolsky destaca esta incongruência ao responder a Böhm-Bawerk: para este, como para os teóricos do valor qualitativo, os trabalhos simples aparecem como equiparáveis em si mesmos, por suas determinações concretas; mas os trabalhos qualificados, por sua distinta qualidade, como não equiparáveis. Em Gorz, isso é manifesto: "O trabalho abstrato simples, que, desde Adam Smith, era considerado como a fonte do valor, é agora substituído por trabalho complexo" (Gorz, Imaterial, 10, citado acima). Já foi mostrado que, em Smith, o trabalho humano cria valor e, em Marx, o trabalho abstrato cria valor, podendo ser simples ou complexo em ambos os autores.

Nesta aceitação da qualidade de trabalho humano indiferenciado medido pelo tempo para as atividades simples, enquanto se nega esta qualidade para as atividades complexas, transparece a ideia de que, excetuadas as atividades complexas, "todo o tempo de trabalho é perfeitamente equiparável sem que seja necessário que se tire nenhuma média" (Engels, Anti-Dühring, 249-50, citado acima). Ou seja, de que uma determinação concreta comum é a base da abstração social do trabalho.

É preciso destacar que o trabalho simples não coincide com o trabalho mecânico, mas com o trabalho social médio. Assim, se ler e escrever eram qualificações especiais na revolução industrial inglesa, que incorporou o conjunto da família ao trabalho fabril, hoje faz parte da formação média da capacidade de trabalho: um operador de telemarketing não pode ser analfabeto.

Além disso, as mercadorias que demandam trabalho cognitivo são, em Marx, comensuráveis e medidas apenas enquanto formas do trabalho humano em geral. Ele lança mão de diversos exemplos fora da esfera da produção material para destacar o 
caráter social do valor, como o seguinte: "Um escritor é um trabalhador produtivo" 153 não por produzir ideias, mas enquanto enriquecer o editor que publica as suas obras; consequentemente ou enquanto for trabalhador assalariado de um capitalista" (TMV I, 137). Mesmo os trabalhos artísticos, necessariamente criativos, são citados como exemplos do trabalho que cria valor se postos em determinada relação de produção: "Um ator, por exemplo, mesmo um palhaço, é um trabalhador produtivo se trabalha a serviço de um capitalista (o empresário), a quem restitui mais trabalho do que dele recebe na forma de salário" (TMV I, 137). A incorporação de valor ao produto não decorre “(...) da qualificação material do trabalho (nem da natureza do produto nem da destinação do trabalho como trabalho concreto), mas da forma social determinada, das relações sociais de produção em que ele se realiza" (TMV I, 137).

O trabalho cognitivo e criativo apenas não é passível de subsunção ao trabalho abstrato, ou à criação de valor, se é o trabalho do gênio. Seu produto pode ser copiado, mas sua criatividade não pode ser reproduzida socialmente pela qualificação. Não é possível controlar pela educação as condições de formação, por exemplo, do gênio artístico e por isso não há como reproduzir esta capacidade de trabalho específica. Dentro do trabalho coletivo da produção da mercadoria, entretanto, por mais criatividade que algumas funções exijam, nenhuma delas demanda o gênio, mas apenas capacidades que podem ser aprendidas. Os trabalhadores são substituíveis, e conforme a especialização se aprofunda e a qualificação média se amplia, mais a força de trabalho qualificada se torna reprodutível.

Conceber o valor como valor qualitativo implica prescindir da mediação objetiva necessária para a universalização dos produtos, sua determinação de ser valor de troca dos demais e por isso expressar uma substância social comum. Ademais, é preciso assumir que as atividades que criam conhecimento, bem como a atividade científica que preside a produção material automatizada, não são consideradas atividades genéricas, não têm a mesma natureza das demais atividades produtivas humanas. Não podem, portanto, ser definidas como formas específicas de trabalho humano. Resta então como problema: o conhecimento não pode ser reduzido a trabalho humano, mesmo que seu produto seja objeto de necessidade social e mercadoria, mas

\footnotetext{
${ }^{153}$ Marx se refere ao trabalho produtivo para o capital, isto é, aquele que cria mais-valia. Investiguei os conceitos de trabalho produtivo e trabalho improdutivo em Trabalho produtivo em Karl Marx: novas e velhas questões, conf. bibliografia.
} 
ainda assim cria valor? Se o valor se compõe de diferenciais de qualidade do trabalho e não se deduz mais da forma mercantil da relação de intercâmbio entre os produtos, seria necessário introduzir novos conceitos de trabalho humano, de conhecimento e de valor.

Fausto e Prado buscam resolver esta ambiguidade na afirmação de que o valor é, para Marx, "medida que tende constantemente à desmedida e que pode ser negado dialeticamente na história" (Prado, Desmedida, 55, citado acima). Essa alteração na natureza social do trabalho e do valor não é razão, contudo,

(...) para modificar a teoria do valor de Marx, mesmo porque essa teoria prevê a própria vicissitude do valor numa fase avançada de desenvolvimento do capitalismo, quando o trabalho, de modo importante, passa a produzir valores de uso espirituais, quando os trabalhos concretos não podem mais ser reduzidos simplesmente a trabalho abstrato e quando os serviços assumem amplamente a forma de mercadoria. Isto requer, entretanto, uma aplicação de textos dos Grundrisse de 1857-1858 (Prado, Desmedida, 52, citado acima).

A aplicação de tais textos foi realizada por Fausto em seu artigo sobre o capitalismo pós-industrial. Marx teria previsto que, devido ao desenvolvimento produtivo que impõe transformações nas formas concretas do trabalho, e ainda no interior da relação mercantil, o valor teria sua substância transfigurada. Examino esta passagem do texto de Marx no capítulo seguinte com o objetivo de mostrar que, ao contrário de conceber uma transformação essencial no valor advindo do progresso técnico, Marx ressalta que o valor sempre é tempo de trabalho abstrato social: mais uma vez, o valor é uma forma social específica em que a igualdade dos trabalhos humanos se põe. Em Marx, por um lado, o desenvolvimento produtivo no interior da relação de valor aprofunda as contradições imantes a essa forma social de produção; por outro, esta relação de produção, caracterizada pela equiparação das atividades individuais em atividade social abstrata, não se dissolve espontaneamente pelo desenvolvimento.

Gorz, Fausto e Prado concebem o trabalho que cria conhecimento como um trabalho que, por sua qualidade concreta, não pode equiparar-se a mero trabalho social medido pela quantidade. Assim, independente da questão da produção de valor, isto é, da forma social do trabalho, os autores distinguem o conhecimento e o trabalho por sua natureza: o primeiro tem atividade qualitativa, o segundo é atividade quantitativa, já que suas diferentes qualidades podem ser abstraídas. Gorz afirma: "os produtos da atividade social não são mais, principalmente, produtos do trabalho cristalizado, mas sim do conhecimento cristalizado" (Gorz, Imaterial, 29, citado acima). Esta compreensão que 
autonomiza ambas as atividades - trabalhar e criar conhecimento - é contrária à concepção de Marx que busquei expor no segundo capítulo da pesquisa, em que o conhecimento aparece como produto do trabalho e elemento inseparável da produção humana. Se há conhecimento incorporado em softwares, também o há, para usar um exemplo de Giannotti, na pesca, que envolve o conhecimento de aspectos do comportamento dos peixes e das águas. É também contrária aos pressupostos que Engels, Hilferding, Rubin e Rosdolsky assumem ao tratar do trabalho complexo. Partese de que estudar é trabalho, e trabalho que, como parte alíquota do trabalho social requerida para a criação de determinados produtos, cria valor se for condição para a criação de mercadorias. Assim, na teoria de Marx, nada autoriza esta separação de natureza entre trabalho e conhecimento que distingue o produto do primeiro do produto do segundo: em todo produto de trabalho, há conhecimento, toda criação ou apropriação de conhecimento é trabalho.

Diga-se de passagem, nenhum dos autores explica como algo pode ser produto do conhecimento sem a mediação da atividade produtiva, o trabalho. Na verdade, tanto Gorz quanto Fausto acabam por transferir o caráter ativo característico dos sujeitos, os indivíduos, para "o conhecimento" (Gorz), ou para os meios de produção, que se tornam "logos" objetivado (Fausto). Tais produtos do trabalho humano estariam se tornando capacidades produtivas, o trabalho objetivado adquirindo a determinação central do trabalho vivo, ser produtivo. Essa visão sucumbe ao fetichismo.

Nas sociedades pré-capitalistas, contudo, o conhecimento teórico, ou o trabalho puramente intelectual, que não é tomado por trabalho pelas próprias sociedades, distingue a atividade da classe dominante, e de fato se realiza separadamente da produção material. Busco indicar no capítulo seguinte que o capitalismo não apenas equipara os trabalhos socialmente, mas também impulsiona um desenvolvimento concreto que, pela primeira vez na história, faz do trabalho puramente intelectual um componente do trabalho material, rompendo as delimitações que na prática separavam e distinguiam essencialmente suas produções. A equiparação social dos trabalhos foi condição para a unidade efetiva entre conhecimento e trabalho material, que se dá na subsunção da ciência à técnica, processo que se inicia no Renascimento. Em seu desenvolvimento, o modo capitalista de produção irá alterar o modo como se dá a divisão entre trabalho material e trabalho intelectual. Progressivamente, as atividades 
materiais e intelectuais tanto se misturam em sua realização concreta quanto adquirem idêntico caráter social. 


\section{FORÇA PRODUTIVA E FORMA CAPITALISTA}

\section{Capital e universalização do homem: o conhecimento como força produtiva}

No capítulo anterior, abordamos a questão do valor na sociedade mercantil. Quando a produção é massivamente mercantil, ou seja, quando a forma dominante da produção é a produção para a troca, ela se realiza como produção capitalista. A produção mercantil é necessariamente capitalista. Assim, a igualdade entre os indivíduos estabelecida pelo domínio da troca como forma dominante do intercâmbio humano está pautada em sua diferença no nível da divisão do trabalho ou da propriedade. Marx escreve: "No conjunto da sociedade burguesa existente, esse pôr como preços e sua circulação etc. aparece como um processo superficial sob o qual, no entanto, na profundidade, sucedem processos inteiramente diferentes, nos quais desaparece essa aparente igualdade e liberdade dos indivíduos" (Grundrisse, 190).

Já foi exposto anteriormente que a troca, por sua própria natureza, impõe ao indivíduo que participe da divisão social do trabalho apenas na medida em que cria valores de troca, o que por si só é já uma coação, porque "seu produto imediato não é um produto para ele": deve assumir a forma universal e exterior de valor, negando a particularidade do indivíduo, para existir socialmente. Mas este é apenas um aspecto da coação que a produção para a troca exerce sobre o indivíduo: "isso pressupõe, ademais, a divisão do trabalho etc., na qual o indivíduo já é posto em outras relações distintas daquelas de simples 'trocador"”. De modo que "a troca, ou as relações de produção que nela se realizam, de forma alguma permanecem nessa determinabilidade simples, na qual a maior diferença a que se chega é uma diferença formal [entre compradores e vendedores - VC] e por isso indiferente" (Grundrisse, 190-1).

Na divisão do trabalho, o indivíduo é posto em relações distintas do simples trocador: na medida em que determina a participação do indivíduo na apropriação dos meios de produção e do produto social, a divisão do trabalho estabelece a diferença de propriedade. As relações de troca que põem os indivíduos como compradores e vendedores são "as relações econômicas mais simples, as quais, tomadas autonomamente, são puras abstrações; abstrações que na realidade são mediadas pelas mais profundas antíteses [Gegensätze - oposições] e só mostram um lado, aquele em 
que a expressão das antíteses [deren Ausdruck - a expressão delas] está apagada” (Grundrisse, 191).

Esta necessidade de que os indivíduos se ponham em diferentes determinabilidades para que se dê a produção para a troca como forma geral da produção social está dada na forma de propriedade que permite a produção para a troca, a propriedade privada. O pressuposto desta forma, como já apresentado, é a dissolução dos vínculos comunitários. Este ocorre através da transformação do domínio ou propriedade escalar feudal em propriedade privada da terra ao mesmo tempo em que, correspondentemente, transformou-se o produtor pertencente ao domínio em indivíduo duplamente livre: a ruptura do vínculo de servidão libera o produtor das obrigações que este vínculo impõe (impostos e dízimos) e de seus meios de produção, já que o produtor é separado da terra. A apropriação desta passa a ser mediada pela troca quando o servo é substituído pelo arrendatário. Marx resume:

O roubo dos bens da Igreja, a fraudulenta alienação dos domínios do Estado, o furto da propriedade comunal, a transformação usurpadora e executada com terrorismo inescrupuloso da propriedade feudal e clânica em propriedade privada moderna, foram outros tantos métodos idílicos da acumulação primitiva. Eles conquistaram o campo para a agricultura capitalista, incorporaram a base fundiária ao capital e criaram para a indústria urbana a oferta necessária de um proletariado livre como os pássaros (C, I, 2, 275).

Assim, a produção de valor de troca cria o indivíduo como livre e igual ao engendrar a propriedade privada. A igualdade e a liberdade dos indivíduos é a forma específica da divisão do trabalho que determina os indivíduos como proprietários de terra, proprietários de fortuna em dinheiro e expropriados, trabalhadores em potencial. Ao desvincular-se da comunidade, o produtor se transforma em mero trabalhador, existência social puramente subjetiva, o trabalhador em sua nudez. Do mesmo modo que retira do produtor a determinação comunitária específica em que realiza sua atividade, o desenvolvimento da propriedade privada retira também das condições materiais em que a comunidade se objetiva esta sua determinabilidade específica. Tais condições, ao se libertarem da comunidade e constituírem-se elas mesmas em valores de troca, tornam-se capital. Daí Marx afirmar que "É tão piedoso quanto tolo desejar que o valor de troca não se desenvolva em capital, ou que o trabalho produtor de valor de troca não se desenvolva em trabalho assalariado" (Grundrisse, 191): a produção para a troca cria a divisão de classes característica da produção capitalista. 
Quando a comunidade é dissolvida e o mercado toma o lugar do intercâmbio direto entre os indivíduos, também as finalidades imediatas da produção se modificam: "O poder de um senhor feudal, como o de todo soberano, não se baseava no montante de sua renda, mas no número de seus súditos, e este dependia do número de camponeses economicamente autônomos" $(\mathrm{C}, \mathrm{I}, 2,264)^{154}$. Se a produção não visa mais à reprodução da comunidade em suas formas próprias, isto é, dos indivíduos em suas determinabilidades específicas; ou ainda, quando a produção social não visa mais determinadas formas de ser dos indivíduos, estabelece-se a produção pela produção. A finalidade da produção passa a ser sua própria ampliação. Não é automática e sem conflitos essa transição. A classe dos cavaleiros medievais, por exemplo, fadada ao desaparecimento quando da dissolução dos feudos em propriedade privada da terra, luta no interior da nobreza por sua manutenção. O próprio poder real, na Inglaterra, opõe-se por meio da legislação à transformação impulsionada pelo desenvolvimento ${ }^{155}$ que põe a riqueza abstrata como fim em si mesma e portanto acima da reprodução dos indivíduos:

\begin{abstract}
A legislação aterrorizou-se com este revolucionamento. (...) As queixas do povo e a legislação, que a partir de Henrique VII continuamente, por 150 anos, se voltava contra a expropriação dos pequenos arrendatários e camponeses, foram igualmente infrutíferas. O segredo de seu fracasso nos revela Bacon, sem o saber: "O decreto de Henrique VII", diz ele, em seus Essays, Civil and Moral, seção 29, "era profundo e digno de admiração ao criar explorações camponesas e casas rurais de determinado padrão, isto é, ao manter para os lavradores uma proporção de terra que os capacitava a trazer ao mundo súditos com riqueza suficiente e sem posição servil, mantendo o arado em mão de proprietários e não de trabalhadores de aluguel (...)". Mas o que o sistema capitalista requeria era, ao contrário, uma posição servil da massa do povo, sua transformação em trabalhadores de aluguel e a de seus meios de trabalho em capital (C, I, 2, 265-6) ${ }^{156}$.
\end{abstract}

154 Em nota, Marx observa que "Não se deve esquecer jamais que o próprio servo não apenas era
proprietário, ainda que proprietário sujeito a tributos, da parcela de terra pertencente à sua casa, mas
também co-proprietário das terras comunais" (C, I, 2, 264, nota 191).
155 "Foi muito mais, em oposição mais teimosa à realeza e ao Parlamento, o grande senhor feudal quem
criou um proletariado incomparavelmente maior mediante a expulsão violenta do campesinato da base
fundiária, sobre a qual possuía o mesmo título feudal que ele, e usurpação de sua terra comunal. O
impulso imediato para isso foi dado, na Inglaterra, nomeadamente pelo florescimento da manufatura
flamenga de lã e a consequente alta dos preços da lã. A velha nobreza feudal fora devorada pelas grandes
guerras feudais; a nova era uma filha de seu tempo, para a qual o dinheiro era o poder dos poderes" (C, I,
2 , 264).
156 Ao lado destas tentativas de proteção legal à reprodução econômica dos súditos, o advento de massas
de indivíduos livres de vínculos e das condições de produção, lançados na mendicância e na
vagabundagem, deram base para as chamadas "leis dos pobres", que autorizavam a escravização e a
punição física dos vagabundos. Além dessas, havia leis que determinavam o limite dos salários no campo
e na cidade: "Assim, o Estatuto dos Aprendizes de Elisabeth, nas seções 18 e 19, impunha 10 dias de 
É da natureza da criação de valor de troca a imposição da ampliação do produto como finalidade da produção e, com isso, a produção como fim em si mesma. Isto está dado no caráter abstrato do produto, cujo desenvolvimento se põe como ampliação quantitativa, e se expressa na fórmula geral do capital. Este se origina do comércio: "A circulação de mercadorias é o ponto de partida do capital" (C, I, 1, 125). A forma da circulação de mercadorias que caracteriza o capital, ou seja, que transforma o dinheiro e a mercadoria - o valor - em capital, se distingue da forma simples da circulação de mercadorias, mas está contida nela como possibilidade. Esta última se caracteriza pelo circuito em que a finalidade de vender para comprar se explicita: $\mathrm{M}-\mathrm{D}-\mathrm{M}$. O dinheiro se transforma em capital quando o ponto de partida e de chegada deste circuito é posto em outro lugar, invertendo-se. $\mathrm{O}$ valor que é capital se realiza no circuito em que a compra visa a venda: D - M - D. Não apenas esta forma está presente como possibilidade na circulação de mercadorias, como é a expressão do movimento do capital comercial, da constituição da fortuna em dinheiro que está na base do modo de produção capitalista. O dinheiro é a forma em que o produto do capital aparece:

\begin{abstract}
Abstraiamos o conteúdo material da circulação de mercadorias, o intercâmbio dos diferentes valores de uso, e consideremos apenas as formas econômicas engendradas por esse processo, então encontraremos como seu produto último o dinheiro. Esse produto último da circulação de mercadorias é a primeira forma de aparição do capital (C, I, 1, 125).
\end{abstract}

Ele é o produto da circulação de capital, mas também seu ponto de partida, a forma própria em que cada capital novo aparece pela primeira vez no mercado:

Historicamente, o capital se defronta com a propriedade fundiária, no início, em todo lugar, sob a forma de dinheiro, como fortuna em dinheiro, capital comercial e capital usurário. No entanto, não se precisa remontar à história da formação do capital para reconhecer o dinheiro como a sua primeira forma de aparição. A mesma história se desenrola diariamente ante nossos olhos. Cada novo capital pisa em primeira instância o palco, isto é, o mercado, mercado de mercadorias, mercado de trabalho ou mercado de dinheiro, sempre ainda como dinheiro, dinheiro que deve transformar-se em capital por meio de determinados processos $(\mathrm{C}, \mathrm{I}, 1,125)$.

Independentemente desses processos, a igualdade qualitativa do início e do fim do circuito manifesta a finalidade de sua ampliação quantitativa. Por isso, "O conteúdo

prisão para que pagasse salário mais alto, em contraposição a 21 dias para quem os recebesse. Um estatuto de 1630 agravou as penas e até mesmo autorizava o patrão a recorrer a coação física para extorquir trabalho pela tarifa legal de salário. (...) A coalização dos trabalhadores é considerada crime grave, desde o século XVI até 1825, ano da abolição das leis anti-coalizão. O Espírito do Estatuto dos Trabalhadores de 1349 e de seus descendentes se revela claramente no fato de que um salário máximo é ditado pelo Estado, mas de forma alguma um mínimo" (C, I, 2, 278). 
objetivo daquela circulação", D - M - D, é, pois, “a valorização do valor” (C, I, 1, 129). Este conteúdo define o capital. "De fato, portanto, D - M - D' é a fórmula geral do capital, como aparece diretamente na esfera da circulação" (C, I, 1, 131).

Mas é também este conteúdo que determina que o capital, como ponto de partida da produção, sempre cria seu produto como capital:

\footnotetext{
O fim de cada ciclo individual, em que a compra se realiza para a venda, constitui, portanto, por si mesmo o início de novo ciclo. A circulação simples de mercadoria - a venda para a compra serve de meio para um objetivo final que está fora da circulação, a apropriação de valores de uso, a satisfação de necessidades. A circulação do dinheiro como capital é, pelo contrário, uma finalidade em si mesma, pois a valorização do valor só existe dentro desse movimento sempre renovado. Por isso, o movimento do capital é insaciável (C, I, 1, 129).
}

Este caráter insaciável se depreende da forma de valor do produto, já posta na circulação simples de mercadoria: "Ele recebeu sua qualidade oculta de gerar valor porque é valor" (C, I, 1, 130). Na apropriação da riqueza como riqueza abstrata reside o fundamento da finalidade de sua expansão quantitativa, da valorização, em oposição a esta riqueza como meio para a satisfação de necessidades. A forma de valor por si mesma, pela negação da particularidade do produto oriunda da abstração que a caracteriza, tende a pôr como fim a riqueza pela riqueza, em oposição à reprodução de formas determinadas da vida. Isso se expressa em todo o desenvolvimento das formas "antediluvianas" do capital comercial e usurário que apenas não se desenvolvem em modo de produção capitalista, como expusemos no capítulo III, devido ao estágio pouco avançado das forças produtivas. É necessário certo patamar de desenvolvimento produtivo para que se estabeleça a separação entre a atividade e seus meios. Na condição em que a finalidade da troca domina a produção, a criação de mercadorias e a criação de capital constituem-se em um mesmo processo. A produção de valor como forma geral da produção tem como fim a ampliação de riqueza abstrata e é por isso modo de produção capitalista. Marx escreve:

\footnotetext{
O valor de uso nunca deve ser tratado, portanto, como meta imediata do capitalismo. Tampouco o lucro isolado, mas apenas o incessante movimento do ganho. Esse impulso absoluto de enriquecimento, essa caça apaixonada do valor, é comum ao capitalista e ao entesourador, mas enquanto o entesourador é apenas o capitalista demente, o capitalista é o entesourador racional. A multiplicação incessante do valor, pretendida pelo entesourador ao procurar salvar o dinheiro da circulação, é alcançada pelo capitalista mais esperto ao entregá-lo sempre de novo à circulação (C, I, 1, 130).
} 
Desta finalidade de aumento quantitativo, expressa na fórmula geral do capital, também se depreende que o modo capitalista de produção sempre repõe sua forma: o resultado da produção que parte do capital é o próprio capital. Isto altera o modo como o desenvolvimento produtivo afeta a forma das relações sociais, em comparação com as sociedades pré-capitalistas. Marx escreve: “A relação-capital pressupõe a separação entre os trabalhadores e a propriedade das condições da realização do trabalho. Tão logo a produção capitalista se apoie sobre os seus próprios pés, não apenas conserva esta separação mas a reproduz em escala sempre crescente" (C, I, 2, 262). Na sociedade capitalista, o desenvolvimento produtivo impulsiona nova divisão do trabalho, exatamente como já ocorria nas sociedades pré-capitalistas. Nestas, novos desenvolvimentos da divisão do trabalho significavam mudanças na forma das relações de produção, porque desfaziam vínculos comunitários e criavam novas formas privadas de propriedade. Um exemplo é o desenvolvimento dos ofícios artesanais urbanos na baixa Idade Média. No capitalismo, a criação de nova divisão do trabalho, em função do desenvolvimento das forças produtivas, expande a propriedade privada, mas isso não implica uma transformação nas relações de produção porque esta é a forma de propriedade correspondente ao modo de produção capitalista. Este constitui o desenvolvimento último da propriedade privada e da relação de troca. Assim, o capital pode trazer em si o impulso ao desenvolvimento produtivo sem que isso implique uma desagregação da forma social que o caracteriza. Ao contrário, o desenvolvimento produtivo conserva e expande a forma-capital, porque cada nova divisão do trabalho cria seu produto novo como forma de valor e, por isso, como capital.

Não apenas a forma-capital não se desagrega com o desenvolvimento produtivo, porque a divisão do trabalho que necessariamente resulta desse desenvolvimento amplia a propriedade privada e consequentemente a produção de capital, como esta forma da produção impele ao desenvolvimento. É esta uma de suas características distintivas: uma produção que se abre para a história, ou seja, visa ao futuro, e não ao passado. Esta determinação nova da produção se baseia na liberdade em que são postos não apenas os indivíduos, mas a própria riqueza objetivada: a dissolução dos vínculos da comunidade, ao separar a riqueza da finalidade da reprodução comunitária dos produtores em seus vínculos próprios, capacita-a a desenvolver-se livremente. (Esta capacidade está antes fundada em um acúmulo produtivo que permite condições de produção criadas pelo homem, urbanas, sobrepujem o produto da terra). 
O processo de constituição do capital será responsável pela universalização da produção humana, isto é, pela integração mundial da produção e dos indivíduos por meio de sua produção, processo que se baseia na ampliação da produtividade do trabalho e no aprofundamento da divisão do trabalho. Neste processo, a atividade individual sofrerá modificações fundamentais: primeiro, a multiplicação das atividades impulsionará o processo de individuação; segundo, a universalização da produção e das necessidades criará o indivíduo potencialmente universal. Esta universalidade não se realiza efetivamente para o indivíduo devido tanto à unilateralidade da atividade individual submetida à divisão do trabalho e à apropriação restrita dos resultados da produção universal pelo indivíduo, quanto à abstração em que sua atividade existe socialmente. Em terceiro lugar, este desenvolvimento da divisão e da produtividade do trabalho alterará a relação da atividade produtiva material com a criação de conhecimento, mudança pautada na habilitação do trabalho como atividade digna do humano. Esta dignificação do trabalho resulta em grande medida da liberdade em relação aos vínculos comunitários posta pela propriedade privada, que faz aparecer pela primeira vez o ser humano como produtor de seu mundo, antes dado como fato natural na comunidade. Se a preservação da comunidade fora a finalidade geral da produção pré-capitalista, a ausência dos vínculos pessoais faz desaparecer tal finalidade, e abre a possibilidade de se pôr o desenvolvimento, e não mais a reprodução, como fim da atividade.

Antes que o processo produtivo desse grandes passos em direção ao assalariamento global e ao aumento da escala da produção que vincula o conjunto da produção social, tornando os indivíduos interdependentes na mesma escala, a dissolução do mundo feudal impulsionou uma nova concepção do homem, expressa nas produções do Renascimento. A unidade entre teoria e trabalho material que o capital realiza corresponde a uma concepção de homem como artífice de si mesmo e de seu mundo. Esta posição é claramente expressa, por exemplo, em Pico Della Mirandola, em seu Discurso sobre a Dignidade do Homem ${ }^{157}$ :

Estabeleceu, portanto, o ótimo artífice que, àquele a quem nada de especificamente próprio podia conceder, fosse comum tudo o que tinha sido dado parcelarmente aos outros. Assim, tomou o homem como obra de natureza indefinida e, colocando-o no meio do mundo, falou-lhe desse modo: “Ó, Adão, não te demos nem um lugar determinado, nem um aspecto que te seja próprio,

${ }^{157}$ PICO DELLA MIRANDOLA, Giovanni, Discurso sobre a Dignidade do Homem, Lisboa: Edições 70, 1989, pp. 51-53. 
nem tarefa alguma específica, a fim de que obtenhas e possuas aquele lugar, aquele aspecto, aquela tarefa que tu seguramente desejares, tudo segundo o teu parecer e a tua decisão. A natureza bem definida dos outros seres é refreada por leis por nós prescritas. Tu, pelo contrário, não constrangido por nenhuma limitação, determiná-las-ás para ti, segundo o teu arbítrio, a cujo poder te entreguei. Coloquei-te no meio do mundo para que daí possas olhar melhor tudo o que há no mundo. Não te fizemos celeste nem terreno, nem mortal nem imortal, a fim de que tu, árbitro e soberano artífice de ti mesmo, te plasmasses e te informasses, na forma que tiveres seguramente escolhido. Poderás degenerar até os seres que são as bestas, poderás regenerar-te até as realidades superiores que são divinas, por decisão de teu ânimo. Ó suma liberalidade de Deus pai, ó suma felicidade do homem! ao qual é concedido obter o que deseja, ser aquilo que quer.

Neste discurso, ao contrário do trabalho como castigo, a indefinição da natureza do homem e a potência de sua atividade criativa aparecem como liberdade, que permite tanto a degeneração quanto o alcance do divino. Trata-se, diga-se de passagem, do germe da concepção desenvolvida por Marx segundo a qual o homem não se limita pela espécie, mas desenvolve sua própria natureza na constituição ativa do mundo humano (conforme capítulo II). De fato, esta nova compreensão do homem não restringe a liberdade de desenvolvimento ao campo do pensamento e da teoria. Mesmo o gigantesco desenvolvimento da ciência natural pura, como a astronomia, logo dependerá da construção de instrumentos de observação empírica: se a emergência de uma concepção revolucionária do homem, baseada na abertura que a dissolução do mundo feudal significou, gerou inicialmente novas compreensões puramente teóricas da natureza, como no caso de Giordano Bruno, seus passos subsequentes dependeram já da técnica, como na produção de Galileu Galilei. No período renascentista, o cientista se interessa pela primeira vez pela obra do artesão ao mesmo tempo em que o artesão não apenas desenvolve a técnica, mas registra em livros sua produção. A prática se torna objeto da ciência, de modo que a teoria pura e a atividade material ganham unidade na técnica.

Ao tratar do período que abrange a segunda metade do século XV e a primeira do XVI, época em que viveu Leonardo da Vinci, Eugenio Garin escreve:

O artista é um artesão; não um homem culto, mas um mecânico. Tem de confrontar-se com os doutos das escolas e os refinados das cortes, isto é, com todos os que ensinam as ciências nas universidades e todos os que cultivam as letras nos círculos liberais, rodeando os senhores, 
antigos e novos. É verdade que (...) a complexidade crescente das técnicas da arquitetura e da engenharia desfaz as barreiras entre os matemáticos e os mecânicos ${ }^{158}$.

Esta dissolução das barreiras entre ciência e técnica é a grande novidade renascentista que, partindo de uma transformação na forma social, está na base do modo de produção adequado ao capital. Amplia-se o interesse pela matemática e suas aplicações não tanto pelas finalidades da engenharia e da arquitetura, mas especialmente devido à navegação e à guerra, atividades diretamente ligadas ao comércio internacional. Também sobre o século XVI, Allen Debus escreve:

(...) é evidente que ao menos os que se interessavam pela arte da guerra precisavam de estudos matemáticos para manejar o canhão; do mesmo modo que os navegantes deviam realizar cálculos para determinar sua posição em mar aberto. Nesse período, presenciamos avanços impressionantes no campo dos instrumentos, desde os astrolábios práticos do marinheiro até os colossais instrumentos astronômicos construídos por Tycho Brahe. O telescópio, o microscópio, os primeiros termômetros eficazes e um sem-número de outros instrumentos foram inventados e aperfeiçoados tanto por artesãos como por cientistas. De fato, pela primeira vez os cientistas se interessavam ativamente pela obra dos artesãos. Isso pode ser interpretado em parte como uma rebelião conta a autoridade dos antigos, pois, em sua maior parte, os estudos da natureza da Antiguidade e da Idade Média estavam divorciados totalmente dos procedimentos empregados pelos trabalhadores manuais ${ }^{159}$

Ao contrário de uma divisão do trabalho entre a arte, a arquitetura, a mecânica e a matemática, diversos artistas, como da Vinci, produziam projetos de máquinas e obras urbanas. Lemos no verbete sobre tecnologia do Dicionário do renascimento italiano: “O engenheiro renascentista era necessariamente versátil, não sendo feita qualquer distinção entre arquitetos civis e militares, ou entre arquiteto e inventor de máquinas"160. O desenvolvimento de conhecimento e invenções se fazia diretamente na oficina ou no ateliê de cada pensador/artesão/artista renascentista. Para todas as áreas em que o conhecimento se desenvolvia, há livros que descrevem as técnicas, obras e máquinas, e que foram escritos pelos próprios artesãos:

Com efeito, o estudante escolástico da universidade medieval se apegava em tudo aos antigos e rara vez abandonava suas bibliotecas e suas aulas. No Renascimento, entretanto, presenciamos

\footnotetext{
${ }^{158}$ GARIN, Eugênio, Ciência e vida civil no Renascimento italiano. São Paulo: Unesp, 1996, p. 118. Doravante, Ciência e vida civil, seguido do número da página.

159 DEBUS, Allen G. El hombre y la naturaleza em el Renascimiento. México: Fondo de Cultura Econômica, 1996, p. 32. Doravante, El hombre y la naturaleza, seguido do número da página.

${ }^{160}$ HALE, John R (editor). Dicionário do renascimento italiano. Rio de Janeiro: Zahar, 1988, p. 341. Doravante Dicionário, seguido do número da página.
} 
uma grande mudança. Existem provavelmente descrições isoladas das artes mecânicas nos livros do século XV, mas a partir de 1510 as prensas começam a produzir manuais de instruções de mineração e pouco depois aparecem obras similares relacionadas com outros campos (Debus, $E l$ hombre y la naturaleza, 33).

São diversos os campos do conhecimento que se desenvolvem a partir do século XVI e no século XVII nas oficinas dos artesãos, utilizando recursos técnicos, experimentação e conhecimento teórico, e que são publicados, de modo a tornarem-se dignos das letras e da prensa. Técnicas de produção de vidro e cerâmica, assim como todo o campo da pirotecnia, que envolvia diferentes ofícios que lidam com o fogo - fundição, metalurgia, ourivesaria, fundição de sinos e armas de fogo, de estátuas, tratamento de minérios etc. - incluindo a construção da maquinaria envolvida nesses ofícios - fornos, cadinhos de forja etc. - foram desenvolvidas por artesãos que eram também artistas e registradas em livros. Debus escreve:

\footnotetext{
Os primeiros números das Philosophical Transactions of the Royal Society of London (cuja publicação se inicia em 1665) refletem os fins práticos de Bacon. Ao lado de artigos estritamente científicos, se publicavam informes médicos de interesse para os médicos. Em 1665 se estabeleceu um comitê especial com o fim de examinar o estado da agricultura e sugerir possíveis melhoras. (...) Fomentava também [observações - VC] relacionadas com a navegação (...). A mineração era considerada vital; existem numerosos informes sobre minas e minerais de todas as partes da Europa. Similarmente, se examinava toda sorte de novos produtos e processos industriais. Um arado aperfeiçoado, uma trombeta que falava, pedras para construção, manufatura do ferro, fundição dos metais, elaboração da cerveja e muitos outros temas desse tipo eram expostos detalhadamente (Debus, El hombre y la naturaleza, 249-50).
}

Também os filósofos químicos tinham essa orientação prática. Alguns "viam na química uma salvadora potencial do estado, na forma de uma reforma agrária e uma nova forma de guerra, a química (Debus, El hombre y la naturaleza, 250). Há publicações que mostram técnicas agrícolas que empregavam novos fertilizantes, bem como outras que buscam usar a química para uma nova tecnologia militar (como pequenas granadas de mão cheias de ácido para cegar adversários).

A necessidade de que o conhecimento se volte à prática é expressa pelos pensadores renascentistas e se constitui, como se sabe, em um conflito contra a filosofia tradicional: "Mas à rebelião contra as ciências mentais, contra um filosofar feito de grandes questões (...) Leonardo acrescenta um outro protesto: contra o saber contemplativo que jamais suja as próprias mãos, que não une a ação ao pensamento e 
não verifica nas coisas o conceito e o trabalho que as modifica" (Garin, Ciência e vida civil, 119). No mesmo sentido, Agnes Heller destaca que "A maior parte dos pensadores do Renascimento lutou denodadamente para ver a ciência e a técnica transformarem-se em 'temas abertos"”, o que "significava retirar-lhes o véu do mistério, declarando-as algo utilizável por qualquer pessoa e imitável por todos"161.

Se antes apenas as atividades políticas e intelectuais eram consideradas genuinamente humanas, nas concepções renascentistas também a atividade prática e cotidiana de produção elevam-se à dignidade do humano. Ao mesmo tempo em que o trabalho passa a ser considerado atividade propriamente humana, isto é, a atividade de todos os seres humanos, põe-se em questão a divisão entre atividade intelectual e trabalho material como determinação da hierarquia dos indivíduos. Inicia-se o processo que estabelece a igualdade dos indivíduos como preconceito popular, nos termos de Marx, e como igualdade jurídica. Isto está vinculado à concepção do trabalho como atividade que cria o novo, e não apenas sustenta a reprodução tradicional da vida. Heller escreve:

O que preocupava os espíritos era o trabalho em condições técnicas em constante alteração - o trabalho como um processo dinâmico que nunca se repete, nunca faz duas vezes uma coisa exatamente da mesma maneira. (...) Tinha já passado o tempo em que era possível abstrair da técnica do trabalho, pois isso só era possível em sociedades orientadas para o passado (...). Em tudo isto desempenhava um papel não negligenciável a polêmica socialmente importante contra o trabalho "estagnante", o tipo de trabalho realizado nas guildas (Heller, O homem do Renascimento, 317).

A concepção do trabalho como atividade que transforma e se transforma é o que possibilita que este seja objeto do pensamento, estabelecendo a unidade entre ciência e prática. O trabalho torna-se uma preocupação teórica e a técnica, uma finalidade da atividade intelectual. Com isso, o conhecimento, antes destacado da produção, torna-se potencialmente fator determinante da força produtiva quando se volta à técnica. Estabelecem-se as condições para que a ciência se torne uma força produtiva, ou seja, para que a produção se torne um processo científico.

A unidade entre conhecimento e prática que começa a se pôr nas produções renascentistas será consolidada na produção social com o estabelecimento da indústria, modo de produção adequado ao capital. Contudo, isso não significa que o indivíduo

${ }^{161}$ HELLER, Agnes, O Homem do Renascimento. Lisboa: Presença, 1982, p. 322. 
produtor, o trabalhador, passará a realizar uma atividade que integra conhecimento e prática, isto é, esta unidade não se constituirá na atividade individual. O trabalho intelectual voltado à técnica é função da classe dominante mesmo depois da consolidação da indústria, ou seja, a divisão entre trabalho material e trabalho intelectual como determinante da divisão de classes se mantém. Os desenvolvimentos técnicos que resultam das produções renascentistas, em que o objeto e o escopo do conhecimento se transformam, não integram o processo de produção de mercadorias da manufatura. Se transformam a navegação e a guerra, se criam o instrumental para o desenvolvimento das ciências naturais, os ramos da produção que inicialmente se subsumem ao capital não se apropriam destas descobertas e invenções imediatamente. Ao contrário, são as atividades da indústria doméstica auxiliar dos servos camponeses que primeiro são apropriadas pelas manufaturas capitalistas, nomeadamente a tecelagem, “Aquele trabalho que, desde o início, pressupunha uma máquina, mesmo em sua forma mais rudimentar" (IA, 55, citado acima).

Se o Renascimento estabelece o trabalho como objeto do conhecimento e põe as bases para que o produto social (a produção coletivizada) resulte tanto da atividade material como da atividade intelectual unificadas em um mesmo processo, isso não significa que faz dessas atividades funções dos mesmos indivíduos ou da mesma classe. A unidade entre ciência e prática na produção resultará do desenvolvimento da divisão do trabalho. Mas estabelece os fundamentos para que, hoje, o trabalho intelectual e o trabalho produtivo imediato tornem-se funções de uma mesma classe, a dos trabalhadores assalariados. (Não, contudo, necessariamente como funções do mesmo indivíduo, o que só ocorre nos processos produtivos com alto nível de automação, onde o trabalho de produção material é intelectual.) A divisão entre trabalho material e trabalho intelectual caracteriza a divisão de classe no capitalismo até que a ciência se subsuma ao capital, quando também ela passa paulatinamente a ser função do trabalho assalariado. É esse processo que cumpre explicar.

Antes da constituição do trabalho assalariado e concomitantemente aos processos de dissolução feudal e desenvolvimento da fortuna em dinheiro que caracterizam a chamada acumulação primitiva, o capital comercial em formação se apodera do trabalho da indústria auxiliar camponesa. Neste momento de transição para a subsunção do trabalho ao capital, não há venda de força de trabalho, e a submissão do trabalho à finalidade da ampliação de riqueza se dá quando o produtor compra a 
matéria-prima do capital comercial e vende o produto manufaturado ao mesmo comerciante. O trabalho se realiza sob as relações sociais tradicionais nas quais o produtor se mantém proprietário das condições de produção e do produto; a ampliação do capital se dá no processo de circulação, por meio de trocas desiguais, em que o produtor, que depende do comerciante quando produz para a troca, compra caro a matéria-prima e vende barato o produto. O processo de trabalho não assumiu a forma do processo de valorização, mas a reprodução do produtor já depende da troca e seu modo de vida já se transformou. Por outro lado, a riqueza concentrada nas mãos do comerciante apenas assume forma de valor por sua finalidade de ampliação privada, mas não se produz como riqueza abstrata. Por essa razão, Marx afirma que os trabalhos concretos não tomaram a forma real de trabalho abstrato, pois "o produtor direto mantém-se sempre como vendedor de mercadorias, e ao mesmo tempo, como usuário de seu próprio trabalho"162. Do mesmo modo, o capital comercial latente não é tampouco produzido como capital, mas assume esta forma na atividade que primeiro a caracteriza, a saber, a circulação de mercadorias, pois "o capital não se imiscui no próprio processo de produção, o qual (...) se desenvolve a margem dele" (Cap. In., 54).

A transformação do processo de trabalho que marca a subsunção do trabalho ao capital, o advento do capital produtivo e da categoria social de trabalho abstrato, é o estabelecimento da manufatura. Esta se define em primeiro lugar pela criação de casas de trabalho, que separa o trabalho das demais atividades do cotidiano, e pelo consequente assalariamento coletivo. No trabalho assalariado, a função do trabalho de gerar o produto excedente se sobrepõe e se torna condição da função de criar o produto necessário. Nele, o capital subsume o trabalho: o trabalho apenas é efetivo como meio para a criação do produto necessário à reprodução do produtor se gerar produto excedente. $\mathrm{Na}$ medida em que o produto excedente apenas se torna capital no processo de circulação, por meio da troca, e que o capital produtivo se desenvolve da fortuna em dinheiro; ou seja, na medida em que todo o processo pressupõe a forma de valor do produto, o produto excedente apenas se realiza como tal na forma de valor excedente. A transformação da força de trabalho em mercadoria é a forma necessária do trabalho que cria valor excedente porque liberta as condições de produção das finalidades de reprodução comunitárias e confere ao conjunto da relação de produção a mediação do

\footnotetext{
${ }^{162}$ O Capital - Livro I - capítulo VI (inédito). São Paulo: Ciências Humanas, 1978, p. 54, grifo meu.
} Doravante, Cap. In., seguido do número da página. 
valor. Todos os vínculos sociais se dão pela troca e se estabelecem na superfície do mercado, de modo que os indivíduos se relacionam na condição de proprietários privados. Assim, na efetivação da produção para a troca, a força de trabalho deve se tornar mercadoria, assim como as condições de produção, tornadas permutáveis pela fortuna em dinheiro; mas esta não é a única condição da criação do valor excedente: esta demanda produtividade do trabalho maior do que a produção para uso próprio. Por essa razão, a produção para a troca se realiza, desde o princípio, pelo trabalho assalariado coletivo. A necessidade de ampliação do produto excedente impõe a concentração de grande quantidade de trabalho sob o comando do mesmo capital e o aumento crescente da produtividade do trabalho. A coletivização é necessária para essa concentração (que, por outro lado, também incrementa por si mesma a produtividade do trabalho):

(...) a produção capitalista começa, como vimos, de fato apenas onde um mesmo capital individual ocupa simultaneamente um número maior de trabalhadores, onde o processo de trabalho, portanto, amplia sua extensão e fornece produtos numa escala quantitativa maior que antes. A atividade de um número maior de trabalhadores, ao mesmo tempo, no mesmo lugar (ou, se se quiser, no mesmo campo de trabalho), para produzir a mesma espécie de mercadoria, sob o comando do mesmo capitalista, constitui histórica e conceitualmente o ponto de partida da produção capitalista. Com respeito ao próprio modo de produção, a manufatura, por exemplo, mal se distingue, nos seus começos, da indústria artesanal das corporações a não ser pelo maior número de trabalhadores ocupados simultaneamente pelo mesmo capital. A oficina do mestre artesão é apenas ampliada (C, I, 1, 257).

Marx afirma ainda que, "De início, a diferença é, portanto, meramente quantitativa" (C, I, 1, 257), mas esta diferença quantitativa, associada ao assalariamento, é suficiente para estabelecer o modo de produção do capital. A diferença quantitativa põe o trabalho em condições de se tornar abstrato precisamente pela mudança na escala da produção. A força produtiva posta pela manufatura tanto na cooperação quanto nos desenvolvimentos técnicos subsequentes não incorpora o desenvolvimento do científico de sua época. Este desenvolvimento não se põe imediatamente na produção de mercadorias. Aplica-se produtivamente na navegação, nas guerras, na agricultura, mas a manufatura, em que primeiro surge o modo de produção capitalista, se apodera do trabalho tradicional e em primeiro lugar daqueles que já se realizavam com uma máquina e que não exigiam qualificação especial. Apenas na indústria, quando a produção se torna um processo de aplicação técnica da ciência, as ciências da natureza 
tornam-se necessárias ao processo produtivo geral. Assim, se "Em contraste com o que ocorria em épocas anteriores, agora os cientistas e os médicos reconheciam sem reservas que o homem de ciência devia aprender com o leigo", “(...) no entanto, mesmo admitindo esse tardio reconhecimento da tecnologia por parte dos cientistas, o certo é que a pequena comunidade científica não respondeu por nenhum aporte notável à tecnologia até bem entrado o século XVIII" (Debus, El hombre y la naturaleza, 32-34).

O desenvolvimento técnico na manufatura é ainda puramente empírico e decorrente da coletivização, esta diferença quantitativa que, pelo aumento da produtividade que acarreta, configura uma diferença qualitativa: a possibilidade de mudança na forma social da produção, a produção privada em lugar da comunidade. Mas, ao contrário de tornar o trabalho individual mediado por técnicas mais avançadas e pelo conhecimento, a divisão do trabalho da manufatura é um processo que diminui a qualificação do trabalho individual.

Quando a manufatura capitalista se apodera dos ramos de atividade tradicionalmente realizados por artesãos qualificados, após a subsunção da indústria rural acessória, os produtores passam a trabalhar segundo a técnica tradicional, mas coletivamente. A partir da cooperação origina-se natural e necessariamente a decomposição do processo de trabalho em atividades parciais cada vez mais simples. Na manufatura, a cooperação desenvolve-se em especialização dos trabalhadores parciais da oficina e, por conseguinte, também de suas ferramentas. A simplificação dos trabalhos individuais nivela-os, aprofundando sua determinação de trabalho social médio:

\footnotetext{
O trabalho é por isso dividido. Em vez de o mesmo artífice executar as diferentes operações dentro de uma sequência temporal, elas são desprendidas umas das outras, isoladas, justapostas no espaço, cada uma delas confiada a um artífice diferente e todas executadas ao mesmo tempo pelos cooperadores. Essa divisão acidental se repete, mostra suas vantagens peculiares e ossificase pouco a pouco em divisão sistemática do trabalho. Do produto individual de um artífice autônomo, que faz muitas coisas, a mercadoria transforma-se no produto social de uma união de artífices, cada um dos quais realiza ininterruptamente uma mesma tarefa parcial (C, I, 1, 268).
}

A decomposição do processo produtivo amplia a produtividade do trabalho ao mesmo tempo em que reduz os custos de reprodução da força de trabalho. Essa diminuição dos custos advém da simplificação, que torna dispensável parte do tempo de formação do trabalhador ou produção da força de trabalho: 
Se ela desenvolve a especialidade inteiramente unilateralizada, à custa da capacidade total de trabalho, até a virtuosidade, ela já começa também a fazer da falta de todo o desenvolvimento uma especialidade. Ao lado da graduação hierárquica surge a simples separação dos trabalhadores em qualificados e não-qualificados. Para os últimos os custos de aprendizagem desaparecem por inteiro, para os primeiros esses custos se reduzem, em comparação com o artesão, devido à função simplificada (C, I, 1, 276).

A especialização dos trabalhadores que a divisão do trabalho característica da manufatura requer torna desnecessária qualquer qualificação para a maioria deles, fazendo desaparecer o trabalhador qualificado que detinha a técnica artesanal dos ofícios. A manufatura apropria-se desta técnica, prescindindo do artesão, porque a incorpora na nova divisão do trabalho coletivo, tornando a própria técnica coletiva. Simplifica, por isso, a atividade individual de modo que ela só caiba na produção coletiva. O trabalho produtivo se torna menos complexo ${ }^{163}$. O processo material de trabalho na manufatura ainda se baseia na atividade artesanal e por isso Marx refere-se ao trabalhador no período manufatureiro como artífice do produto: "Composta ou simples, a execução continua artesanal e portanto dependente da força, habilidade, rapidez e segurança do trabalhador individual no manejo de seu instrumento. $\mathrm{O}$ oficio permanece a base" (C, I, 1, 269). Deste modo, o trabalho continua tendo um princípio subjetivo, já que a técnica pertence ainda aos indivíduos, embora nestes enquanto trabalham coletivamente.

Durante o período da manufatura, a ciência se desenvolve autonomamente com relação à produção. Esse desenvolvimento se dá fora das instituições medievais e é já caracteristicamente burguês. Jean Delumeau afirma: "A maior parte dos grandes intelectuais da Idade Média (...) tinham sido professores. Pelo contrário, os mais eminentes representantes da literatura europeia do século XVI (...) fizeram as suas carreiras fora da universidade. (...) E é fora dos quadros tradicionais que se desenvolveram as academias"164. Estas "multiplicaram-se na época do Renascimento, primeiro em Itália e depois no resto da Europa", de modo que "Nos séculos XVII e XVIII, as sociedades literárias, e ainda mais as sociedades científicas, deram maior impulso de progresso ao saber que as universidades" (Delumeau, A civilização do Renascimento, 74). A burguesia passa a ter acesso ao conhecimento e à educação de

\footnotetext{
163 “(...) um trabalhador, o qual executa sua vida inteira uma única operação simples, transforma todo seu corpo em órgão automático dessa função" (C, I, 1, 269).

164 DELUMEAU, Jean. A civilização do Renascimento - vol. II. Lisboa: Estampa, p. 74. Doravante, A civilização do Renascimento, seguido do número da página.
} 
modo mais amplo, de sorte que sua elevação à classe dominante é acompanhada, primeiro, pelo ingresso de jovens burgueses em universidades e ordens religiosas, mas, a partir do Renascimento, a produção de conhecimento se desvincula das instituições medievais. Isto altera não somente o propósito e os meios de pesquisa, mas alça a técnica e as ciências da natureza a objeto da formação superior. Delumeau escreve:

(...) não há dúvida de que o Renascimento assistiu, globalmente, ao declínio das universidades, privadas assim de seus mais dinâmicos elementos. Os colégios passaram a atrair a massa dos jovens que não necessitavam de uma formação estritamente especializada. A idade clássica europeia foi, portanto, marcada, de modo bastante paradoxal, pelo eclipse das universidades (...). $\mathrm{Na}$ prática, o ensino superior tendeu a restringir-se à teologia (Delumeau, A civilização do Renascimento, 72 ).

A ciência se desenvolve concomitantemente à manufatura, mas de modo autônomo. A produção intelectual, ainda que voltada à prática, mantém-se acessível apenas à burguesia e não influi no desenvolvimento técnico característico da manufatura, que consiste na especialização da atividade e das ferramentas, e é empírico. Nem o conhecimento se torna parte do trabalho, nem o trabalho ainda artesanal é suporte para incorporar o conhecimento. Não há ainda um mecanismo objetivo portador da técnica, que a ciência possa analisar e aprimorar. Na manufatura, "antes de mais nada, a análise do processo de produção em suas fases particulares coincide inteiramente com a decomposição de uma atividade artesanal em suas diversas operações parciais" (C, I, 1, 268-9).

Estes desenvolvimentos autônomos das ciências da natureza e da técnica empírica realizada pelos próprios trabalhadores das manufaturas são ambos necessários para o estabelecimento da indústria. A máquina-ferramenta é um produto da especialização das ferramentas na manufatura, mas o sistema de máquinas que se utiliza de um motor requer que a ciência se aproprie do processo produtivo.

A construção das máquinas-ferramentas tem por pressuposto a diferenciação e a especialização dos instrumentos que resulta do desenvolvimento da divisão do trabalho no interior da manufatura. Apenas esta análise efetiva do processo de produção artesanal torna possível isolar os movimentos parciais do processo de trabalho e adequar 
as ferramentas correspondentes, especificando-as ${ }^{165}$. O trabalho realizado por meio de uma máquina-ferramenta deixa de ser artesanal, já que a técnica transfere-se do sujeito para o meio de trabalho objetivo, cuja operação não demanda determinadas singularidades, dadas pelo aprendizado e pela experiência, necessárias ao manejo do instrumento artesanal: “Quando a própria ferramenta é transferida do homem para um mecanismo, surge uma máquina no lugar de uma mera ferramenta" (C, I, 2, 8). Se na manufatura a técnica é apropriada pelo trabalhador coletivo e apenas nele se realiza, com a máquina a técnica é tornada objetiva. Esta objetivação da técnica põe os fundamentos da revolução industrial: "É dessa parte da maquinaria, a máquinaferramenta, que se origina a revolução industrial no século XVIII. Ela constitui ainda todo dia o ponto de partida, sempre que artesanato ou manufatura passa à produção mecanizada" $(\mathrm{C}, \mathrm{I}, 2,8)$. O trabalho restringe-se à função de força motriz da máquina, além da de alimentá-la com matéria-prima, vigiá-la e corrigir manualmente seus erros.

A máquina-ferramenta origina-se da coletivização e divisão do trabalho que analisa, na prática, a técnica artesanal tradicional. A ciência não concorre para esta criação empírica: a construção das máquinas é ela própria trabalho ainda artesanal. Mas a máquina-ferramenta impulsiona o revolucionamento da máquina motriz. É a elaboração do motor que possibilita a constituição de um sistema de máquinas, isto é, da indústria, em que a teoria pura torna-se necessária para a elaboração de um conjunto mais amplo dos meios de produção. Desde o Renascimento, a ciência tem a prática como objeto e se constitui como força produtiva em parte dos ramos de atividade, especialmente aqueles que já se realizavam mediante o trabalho coletivo, mas apenas com a máquina motriz a ciência passa a ser parte dos meios de produção de um conjunto amplo da produção social. Mas, ainda que houvesse desenvolvimento científico suficiente para a elaboração da máquina a vapor, o impulso para a sua inserção no processo produtivo resulta do desenvolvimento da máquina-ferramenta e de seu limite ao aumento da produtividade do trabalho. Marx escreve:

\footnotetext{
165 “A produtividade do trabalho depende não só da virtuosidade do trabalhador mas também da perfeição de suas ferramentas. (...) tão logo as diversas operações de um processo de trabalho se dissociam e cada operação parcial adquire na mão do trabalhador parcial a forma mais adequada possível e portanto exclusiva, tornam-se necessárias modificações nas ferramentas anteriormente utilizadas para fins diferentes. O sentido de sua mudança de forma resulta da experiência das dificuldades específicas ocasionadas pela forma inalterada. A diferenciação dos instrumentos de trabalho, que atribui aos instrumentos da mesma espécie formas fixas particulares para cada emprego útil particular, e sua especialização, que faz com cada um desses instrumentos particulares só atue com total plenitude na mão de trabalhadores parciais específicos, caracterizam a manufatura" (C, I, 1, 270).
} 
A própria máquina a vapor, como foi inventada no final do século XVII, durante o período manufatureiro, e continuou a existir até o começo dos anos 80 do século XVIII, não acarretou nenhuma revolução industrial. Ocorreu ao contrário: foi a criação das máquinas-ferramentas que tornou necessária a máquina a vapor revolucionada. Quando o homem, em vez de atuar com a ferramenta sobre o objeto de trabalho, atua como força motriz de uma máquina-ferramenta, torna-se casual a força motriz revestir-se de músculos humanos e o vento, a água, o vapor etc. podem tomar seu lugar. Isso naturalmente não exclui que tal mudança requeira com frequência grandes modificações técnicas no mecanismo originalmente construído apenas para a força motriz humana (C, I, 2, 10).

A partir daí, surge o sistema de máquinas, que torna o conjunto do processo produtivo determinado por um mecanismo objetivo. Nele, a técnica se objetiva na máquina e a escala da produção se torna independente da força humana, de modo que o trabalho perde completamente seu princípio subjetivo, isto é, o caráter artesanal, incorporado às singularidades individuais:

\footnotetext{
$\mathrm{Na}$ manufatura, os trabalhadores precisam, individualmente ou em grupos, executar cada processo parcial específico com sua ferramenta manual. Embora o trabalhador seja adequado ao processo, também o processo é adaptado antes ao trabalhador. Esse princípio subjetivo da divisão é suprimido na produção mecanizada. O processo global é aqui considerado objetivamente, em si e por si, analisado em suas fases constituintes, e o problema de levar a cabo cada processo parcial e de combinar os diversos processos parciais é resolvido por meio da aplicação técnica da Mecânica, Química etc., no que, naturalmente, a concepção teórica precisa ser depois como antes aperfeiçoada pela experiência prática acumulada em larga escala (C, I, 2,
} $13)$.

$\mathrm{Na}$ indústria, a ciência se torna um fator determinante da produção material porque ela se define como um sistema objetivo que pode ser analisado em suas fases constituintes e aprimorado por meio da aplicação técnica da ciência. $O$ interesse na ampliação da produtividade posto pela finalidade capitalista confere o impulso ao aprimoramento técnico, mas a possibilidade de a ciência atuar neste desenvolvimento reside na objetivação da técnica, que permite a análise do mecanismo, impossível quando a técnica é artesanal. Foi primeiro necessária a análise do processo artesanal de trabalho, que se deu na prática pela subdivisão de seus movimentos constituintes, para que a ciência pudesse aprimorar o mecanismo. Ou seja, é preciso que o trabalho se torne um processo mecânico para que possa ser apropriado pela ciência, o que se dá pelo desenvolvimento empírico. Marx fornece um exemplo de como o mecanismo objetivo impulsiona o conhecimento científico: 
Já no século XVII se tentara colocar em movimento duas correias e, por conseguinte, também dois pares de mós de moinho com uma única roda hidráulica. O volume inchado do mecanismo de transmissão entrou, porém, em conflito com a força hidráulica tornada insuficiente, e essa é uma das circunstâncias que levou ao estudo mais acurado das leis da fricção. Igualmente, a atuação irregular da força motriz nos moinhos, que eram postos em movimento pelo empurrar e puxar de êmbolos, levou à teoria e à aplicação da roda volante, que mais tarde desempenha papel tão importante na grande indústria (C, I, 2, 11).

A concorrência capitalista, ao impor a cada capital singular a necessidade de redução de custos e assim impulsionar a produtividade do trabalho por meio de aprimoramentos do mecanismo, gera a propagação do modo capitalista aos ramos da produção que fornecem a matéria-prima e o instrumental de trabalho, bem como aos ramos que utilizam a mercadoria produzida industrialmente como matéria-prima. Marx exemplifica:

O revolucionamento do modo de produção numa esfera da indústria condiciona seu revolucionamento nas outras. Isso é válido primeiro para os ramos da indústria que estão isolados pela divisão social do trabalho, de forma que cada um deles produz uma mercadoria autônoma, mas que, mesmo assim, se entrelaçam como fases de um processo global. Assim, a mecanização da fiação torna necessária a mecanização da tecelagem e ambas tornaram necessária a revolução mecânica e química no branqueamento, na estampagem e na tinturaria. Assim, por outro lado, a revolução na fiação do algodão suscitou a invenção do gin para separar a fibra do algodão da semente, com que finalmente se tornou possível a produção de algodão na larga escala agora exigida. Mas a revolução no modo de produção da indústria e da agricultura exigiu também uma revolução nas condições gerais do processo de produção social, isto é, nos meios de comunicação e transporte (C, I, 2, 15).

A revolução no modo de produção social se completa quando a indústria se apodera da construção das máquinas-ferramentas, e, posteriormente, dos motores. Nas palavras de Marx:

A grande indústria teve, portanto, de apoderar-se de seu meio característico de produção, a própria máquina, e produzir máquinas por meio de máquinas. Só assim criou ela sua base técnica adequada e se firmou sobre seus próprios pés. Com a crescente produção mecanizada das primeiras décadas do século XIX, a maquinaria se apoderou, pouco a pouco, da fabricação das máquinas-ferramentas. Só durante as últimas décadas (que precedem 1866), no entanto, a colossal construção de ferrovias e a navegação transatlântica a vapor deram à luz ciclópicas máquinas para a construção dos motores $(C$, I, 2, 16). 
Os trabalhadores produtivos, cuja nova função concreta consiste em operar o funcionamento da máquina, se tornam órgãos subjetivos do mecanismo automático de produção primordialmente objetivo. Mas esta objetivação da técnica do trabalho que se realiza na criação da maquinaria e seus subsequentes aperfeiçoamentos requer uma atividade concreta específica, um tipo de trabalho produtivo que consiste no desenvolvimento da ciência e de suas aplicações técnicas. Engendra uma divisão do trabalho produtivo entre o trabalho simples direto, por um lado, e o trabalho científico e de aplicação da ciência, por outro. Se na manufatura a divisão técnica do trabalho se dá entre os trabalhadores com o conhecimento empírico que embasa sua habilidade artesanal, e aqueles que não incorporam técnica ou habilidade específica, na indústria a divisão se dá entre os trabalhadores não qualificados e os trabalhadores com qualificação intelectual. Mas estes não se inserem no processo produtivo da mesma forma, ou seja, nem todos os técnicos e cientistas são trabalhadores assalariados de um capital singular. No início da indústria, apenas os técnicos, como os engenheiros de produção, são assalariados. Neste caso, a diferença de apropriação da riqueza e do desenvolvimento social geral associa imediatamente tais trabalhadores à propriedade do capital. Embora sejam assalariados, sua renda os aproxima mais do capitalista do que do trabalhador médio. Mas os produtores dedicados à ciência e à elaboração técnica não são assalariados. Por isso, não aparecem sequer como trabalhadores e estabelecem uma relação distinta com o capital: não são subsumidos e a ele e, a despeito de sua atividade atender a necessidades capitalistas, mantêm-se usuários de seu próprio trabalho. Marx escreve: “A ciência não custa absolutamente 'nada' ao capitalista, o que não o impede nem um pouco de explorá-la. A ciência 'alheia' é incorporada ao capital como trabalho alheio" (C, I, 2, 17, nota 108). Ainda assim, "Essa contradição entre a riqueza, que não trabalha, e a pobreza, que trabalha para viver, torna antinômico o conhecimento. Conhecimento e trabalho se dissociam. O primeiro se contrapõe ao segundo no papel de capital ou de artigo de luxo dos ricos" (TMV, I, p. 291). Com o estabelecimento da indústria, a ciência não se torna imediatamente um ramo da produção capitalista, como ocorre hoje, mas se desenvolve ainda à margem da relação capitalista de produção e da concorrência entre os capitais. O capital incorpora dos resultados da ciência, produtos do desenvolvimento humano geral, do mesmo modo que se apropria das forças naturais disponíveis, elementos da natureza imediata; mas não ainda da atividade de produção de conhecimento. 
A partir do estabelecimento da maquinaria, a completude da mecanização é o modo pelo qual o mecanismo se aperfeiçoa e a produtividade do trabalho se amplia. É a necessidade de aperfeiçoamento da mecanização e o desenvolvimento da concorrência que levará ao assalariamento do trabalhador intelectual:

A máquina de trabalho combinada, agora um sistema articulado de máquinas de trabalho individuais de diferentes espécies e de grupos das mesmas, é tanto mais perfeita quanto mais contínuo for seu processo global, isto é, com quanto menos interrupções a matéria-prima passa de sua primeira à sua última fase, quanto mais, portanto, em vez da mão humana, o próprio mecanismo a leva de uma para a outra fase da produção. Se na manufatura o isolamento dos processos particulares é um princípio dado pela própria divisão do trabalho, na fábrica desenvolvida domina, pelo contrário, a continuidade dos processos singulares (C, I, 2, 13).

A ausência de interferência humana no processo material de trabalho é o fim a que se pode levar a ampliação da produtividade de um mecanismo produtivo que objetivou a técnica. Trata-se da eliminação do trabalho manual no interior do processo de trabalho material. Isso não significa, contudo, uma eliminação do trabalho, mas a transformação do modo da atividade individual cujo produto é material. Este processo de aperfeiçoamento da mecanização, que exclui a força de trabalho humano do processo imediato de produção, depende do trabalho científico. Nesse processo, o capital subsumirá o processo de produção do conhecimento, a atividade responsável pelo aumento das forças produtivas, e não mais apenas o trabalho que cria diretamente as mercadorias. Marx escreve:

(...) por um lado, é a análise originada diretamente da ciência e a aplicação de leis mecânicas e químicas que possibilitam à maquina executar o mesmo trabalho antes executado pelo trabalhador. Contudo, o desenvolvimento da maquinaria por essa via só ocorre quando a grande indústria já atingiu um estágio mais elevado e o conjunto das ciências já se encontra cativo a serviço do capital (...). A invenção torna-se então um negócio, e a aplicação da ciência à própria produção imediata, um critério que a determina e solicita (Grundrisse, 587).

A própria maquinaria, desenvolvida pelo processo empírico resultante da coletivização, deve ter alcançado certo nível de desenvolvimento para que a análise científica seja um meio para o aperfeiçoamento do mecanismo. Além disso, a própria ciência deve já ter se voltado aos problemas práticos da produção e se desenvolvido neste sentido, ter-se posto, pois, a serviço do capital, que domina a produção. Como a produção é capitalista, a invenção se torna um negócio. Mas, independentemente da forma social da produção, a ciência sintetiza o conjunto do desenvolvimento social na medida em que expressa em 
leis gerais o comportamento da natureza, ou seja, expressa o domínio humano da natureza. Quando este domínio se materializa em mecanismos objetivos mediante os quais o homem põe sua finalidade na natureza, então a atividade imediata, individual, de manipulação da natureza se torna secundária em relação à atividade científica e de aplicação da ciência ao capital. A atividade intelectual, pura e aplicada, se torna a forma central do trabalho produtivo material. Esta transformação no trabalho produtivo material se põe paulatinamente a partir do estabelecimento da indústria moderna, com a qual "aprende o homem a fazer o produto de seu trabalho anterior, já objetivado, atuar gratuitamente em grande escala como uma força da Natureza" (C, I, 2, 18). Marx expõe em que consiste esta mudança concreta no trabalho produtivo:

\footnotetext{
Não é mais o trabalhador que interpõe um objeto natural modificado como elo mediador entre o objeto e si mesmo; ao contrário, ele interpõe o processo natural, que ele converte em um processo industrial, como meio entre ele e a natureza inorgânica, da qual se assenhora. Ele se coloca ao lado do processo de produção, em lugar de ser o seu agente principal. Nessa transformação, o que aparece como a grande coluna de sustentação da produção e da riqueza não é nem o trabalho imediato que o próprio ser humano executa nem o tempo que ele trabalha, mas a apropriação de sua própria força produtiva geral, sua compreensão e seu domínio da natureza por sua existência como corpo social - em suma, o desenvolvimento do indivíduo social (Grundrisse, 588).
}

O trabalho atual sempre mobiliza o trabalho acumulado. Contudo, a socialização da produção característica do sistema de trocas e a objetivação deste desenvolvimento passado em mecanismos objetivos que medeiam a atividade individual sobre a natureza estabelece uma diferença central: a atividade individual imediata de transformação material dá lugar à operação e aprimoramento do mecanismo, necessariamente coletivos, como momento central da produção. Esta mudança caracteriza o salto de produtividade posto pela indústria capitalista que engendra um novo patamar produtivo: o segundo grande estágio da história. Este se demarca do primeiro estágio, précapitalista, pela universalização do intercâmbio humano e pelo domínio da natureza que possibilita a transição para o reino da liberdade. Isto porque cria um modo de produção que tende a pôr a atividade humana como atividade de criação, e não apenas de reprodução, o que se dá quando o conhecimento se volta à prática e se torna assim uma força produtiva. Daí este modo de produção depender do desenvolvimento do indivíduo social: o indivíduo se apropria do desenvolvimento do gênero na medida em que sua atividade, qualificada, demanda esta apropriação. Contudo, este desenvolvimento é 
levado a cabo pela ampliação da divisão do trabalho, de modo que o indivíduo social, cuja vida deixa de ser local, é apenas potencialmente universal, mas efetivamente unilateral.

A contradição entre a universalização crescente da produção humana, que põe as bases da liberdade frente às determinações naturais imediatas, e a propriedade privada ou divisão do trabalho, que limita o indivíduo, é imanente à forma capitalista e se desenvolve conforme a produtividade do trabalho e o capital se expandem. É imperativo à forma capitalista ampliar a universalização do homem ao desenvolver as forças produtivas, mas esta ampliação se dá mediante o aprofundamento de sua forma. A indústria capitalista é então a primeira forma histórica da produção em que a atividade material e a atividade intelectual se tornam momento de uma mesma atividade produtiva, conjugadas no processo social de produção. Esta unidade social entre o trabalho material e o trabalho intelectual em um mesmo processo coletivo se realiza, contudo, mediante a divisão de classe, em que as funções individuais da produção intelectual só paulatinamente vão deixando de se constituir como atividades características da classe dominante. Este desenvolvimento que torna a produção intelectual função do trabalho assalariado é o processo de subsunção do trabalho científico ao capital, a pesquisa tornada um ramo particular da produção capitalista. Mas mesmo antes desse processo, há no interior da classe dominante uma separação entre o capitalista e o cientista, ou seja, entre a propriedade e atividade intelectual, de modo que a o pertencimento à classe dominante em nada se relaciona com a apropriação científica e técnica. Marx observa que "O próprio Dr. Ure deplora o grosseiro desconhecimento de Mecânica por parte dos seus queridos fabricantes, exploradores de máquinas, e Liebig pode contar alguma coisa da pavorosa ignorância quanto à Química por parte dos fabricantes ingleses de produtos químicos" (C, I, 2, 17, nota 108). Nas sociedades précapitalistas, a divisão entre trabalho material e intelectual é necessária, dado o baixo nível de forças produtivas, para a realização das atividades que não são imediatamente requeridas para a reprodução da comunidade. A propriedade privada de uma classe está na base desta divisão de trabalho, mas a classe proprietária agrega funções necessárias para a manutenção da comunidade, em parte produtivas. No capitalismo, a divisão de classe se baseia, evidentemente, na diferença de propriedade, nas diferentes determinabilidades dos indivíduos que possibilitam a produção para a troca. Mas esta divisão em classes não é mais necessária para a realização do trabalho intelectual: o 
salto de produtividade posto pela indústria torna desnecessária a liberação de parte dos indivíduos do trabalho material para que as funções políticas e o trabalho intelectual se realizem. Ademais, o próprio trabalho intelectual se torna, em grande parte, um componente do processo de produção material. Assim, outra determinação característica deste segundo grande estágio da produção humana é que a divisão de classe deixa progressivamente de ter como uma de suas definições a separação entre trabalho material e trabalho intelectual, e a classe dominante passa a se definir exclusivamente pela mera propriedade do capital. Esta mudança também caracteriza a possibilidade de transição para o reino da liberdade.

Em seguida, desenvolvo o caráter desta contradição que permeia a universalização da produção e ampliação das forças produtivas sobre a base da divisão do trabalho, destacando o modo como ela afeta a própria forma do capital e aponta para seu devir. Busco abordar o que Marx denominou a principal contradição do capitalismo desenvolvido, que se dá entre a ampliação da produtividade do trabalho social e a valorização do capital.

\section{Oposição entre potência produtiva e potência de valorização}

No Prefácio de Para a crítica da economia política, em uma conhecida passagem, Marx apresenta de modo sintético sua concepção do desenvolvimento histórico:

O resultado geral a que cheguei e que, uma vez obtido, serviu-me de guia para meus estudos, pode ser formulado, resumidamente, assim: na produção social da própria existência, os homens entram relações determinadas, necessárias, independentes de sua vontade; essas relações de produção correspondem a um grau determinado de desenvolvimento das suas forças produtivas materiais. (...) Em uma certa etapa de seu desenvolvimento, as forças produtivas materiais da sociedade entram em contradição com as relações de produção existentes, ou, o que não é mais que sua expressão jurídica, com as relações de propriedade no seio das quais elas se haviam desenvolvido até então. De formas evolutivas das forças produtivas que eram, essas relações convertem-se em entraves.

E adiante:

Uma sociedade jamais desaparece antes que estejam desenvolvidas todas as forças produtivas que possa conter, e as relações de produção novas e superiores não tomam jamais seu lugar antes 
que as condições materiais de existência dessas relações tenham sido incubadas no próprio seio da velha sociedade. (Prefácio de 1859, 47-8).

A ideia de que um dado conjunto de relações de produção contém forças produtivas determinadas, isto é, a concepção de que nenhuma relação de produção histórica proporciona desenvolvimento ilimitado das forças produtivas parece contradizer, ou ao menos não se aplicar, ao modo de produção capitalista. As relações capitalistas que, por introduzirem a finalidade da produção pela produção, promovem uma ampliação produtiva que não encontra limites na necessidade humana, vêm propiciando um avanço técnico sem precedentes históricos e parecem não oferecer qualquer restrição ao desenvolvimento das forças produtivas. De fato, trata-se de um modo de produção que possibilitou a transformação da antiga produção artesanal doméstica e das corporações de ofício em manufaturas coletivas, a especialização das ferramentas, a criação da máquina-ferramenta, da máquina-motor, do sistema de máquinas. Impulsionou duas revoluções industriais que fizeram da produção material um sistema mundial, e a recente revolução tecnológica, ou terceira revolução industrial, que permitiu a automação completa de determinados processos parciais da produção e expandiu o intercâmbio mundial. Toda essa transformação produtiva esteve contida nas relações capitalistas de produção, ou seja, foram promovidas como formas da produção de capital e alavancadas pela necessidade de expansão de capital.

Por outro lado, afirmar que as relações capitalistas não oferecem qualquer limite ao desenvolvimento das forças produtivas é o mesmo que tomá-las por eternas, relações cujo evolver histórico não pode culminar na transformação dessas relações em entraves para o desenvolvimento. É o mesmo que subtraí-las à história e descaracterizá-la enquanto um modo de produção determinado. Assim, a forma capitalista é permeada por dois aspectos: primeiro, o fato de que o capital, a despeito de trazer o impulso ao desenvolvimento técnico em sua natureza, não é um modo de produção ilimitado e, segundo, que apesar deste limite o capital não tende a se dissolver, mas, ao contrário, repõe sua forma a cada nova divisão do trabalho. Analiso em seguida algumas passagens do texto de Marx que abordam a relação entre o desenvolvimento das forças produtivas e a valorização, e seu caráter contraditório.

Marx enuncia que há um limite produtivo para o capital como forma social e aborda este tema nos termos de uma contradição imanente ao capital. Esta contradição capitalista aparece em diversos momentos de sua exposição teórica, mas pode ser 
enunciada como contradição entre produtividade do trabalho e valorização. Na relação entre capital e forças produtivas, já foi destacado que esta forma social tem como pressuposto concreto um dado patamar de desenvolvimento produtivo: “(...) o exame mais preciso do desenvolvimento do capital mostra que (...) ele pressupõe um determinado desenvolvimento das forças produtivas - dentre essas forças produtivas, também a ciência (...)” (Grundrisse, 583). O capital se baseia já em um desenvolvimento histórico da produtividade do trabalho social, de sorte que suas condições são engendradas na antiga sociedade; este desenvolvimento não é, contudo, adequado ou suficiente para a reprodução da forma capitalista. Por isso, se por um lado o capital pressupõe forças produtivas historicamente desenvolvidas, "por outro, as impulsiona e força" (Grundrisse, 583). A partir das relações de produção que o caracterizam, o capital põe o método de produção que lhe corresponde: "O desenvolvimento do meio de trabalho em maquinaria não é casual para o capital, mas é a reconfiguração do meio de trabalho tradicionalmente herdado em uma forma adequada ao capital" (Grundrisse, 582).

O que faz com que o capital seja uma forma que por si mesma empuxa as forças produtivas é o fato de que coloca como condição do trabalho necessário o trabalho excedente, ou seja, subordina a produção concreta à valorização: “Antes de tudo: o capital força os trabalhadores ao trabalho excedente para além do necessário. Só assim ele se valoriza e cria valor excedente. (...) ele só põe o trabalho necessário desde (e à medida) que seja trabalho excedente (...)" (Grundrisse, 345). Inverte, assim, as determinações do trabalho necessário e excedente com relação aos modos de produção anteriores, em que o primeiro é condição natural do segundo. Na atual sociedade, o trabalho necessário só encontra os meios objetivos de realização quando esta é, de antemão, objetivação de trabalho excedente. Esta inversão se baseia na separação, dada pela propriedade privada, entre as condições de produção que constituem trabalho objetivado e o trabalho vivo que se define como atividade. Apenas por meio desta separação o valor antecede e se põe como condição da produção de valores de uso.

Como oposição ao trabalho vivo, o trabalho objetivado se torna capital, e a partir de sua determinação específica, adéqua o modo material da produção à sua forma. Apenas com o sistema de máquinas, o trabalho objetivado assume plenamente a forma de capital como força produtiva, e não apenas como produto. Esta mudança qualitativa no valor de uso do meio de produção, ou capital fixo, é a forma material adequada para 
o capital e posta por ele mesmo, porque efetiva a plena separação entre o trabalho vivo e trabalho morto, amplia o valor excedente relativo, socializa a produção social pelo aprofundamento da divisão do trabalho e, como resultado, transforma a força produtiva social em sua própria força produtiva. $\mathrm{O}$ conjunto de determinações que caracterizam o capital como forma social se coloca no processo material de produção ao subsumir real ou materialmente o trabalho vivo. Quando o conteúdo próprio da atividade transfere-se para máquina, limitando a atividade do trabalhador a uma mera "abstração da atividade (...) determinada e regulada em todos os aspectos pelo movimento da maquinaria, e não o inverso" (Grundrisse, 581), o trabalho deixa de presidir o processo de trabalho, e se torna um acessório vivo do mecanismo produtivo objetivamente determinado. O capital realiza assim, materialmente, as determinações imanentes a sua forma: “(...) a tendência necessária do capital é o aumento da força produtiva do trabalho e a máxima negação do trabalho necessário. A efetivação dessa tendência é a transformação do meio de trabalho em maquinaria" (Grundrisse, 581), "aplicação tecnológica da ciência" (Grundrisse, 583). De modo diverso da produção manufatureira, neste modo de produção adequado ao capital, o conjunto das forças produtivas sociais, isto é, a potência produtiva do trabalho social, se separa do trabalho vivo, tornando-o um momento do capital:

\footnotetext{
O próprio trabalho objetivado aparece imediatamente na máquina não só na forma do produto ou do produto empregado como meio de trabalho, mas na forma da própria força produtiva. (...) A acumulação do saber e da habilidade, das forças produtivas gerais do cérebro social, é desse modo absorvida no capital em oposição ao trabalho, e aparece consequentemente como qualidade do capital (Grundrisse, 582).
}

Aparece como força produtiva do capital porque "existe nele em forma objetiva" em oposição ao trabalho, e assim se põe como "força produtiva do capital". Ela "se desenvolve com esse progresso geral de que o capital se apropria gratuitamente" (Grundrisse, 582). Essa apropriação é gratuita porque as forças produtivas progridem com base no desenvolvimento da divisão do trabalho e consequente socialização da produção, que não entra nos custos dos capitais singulares: "Tal via [que deu origem à maquinaria - VC] é a análise - pela divisão do trabalho, que transforma as operações dos trabalhadores cada vez mais em operações mecânicas, de tal modo que a certa altura o mecanismo pode ocupar os seus lugares" (Gr., p. 587). A divisão do trabalho na forma de oposição privada engendra, como resultado não planejado, as forças produtivas sob a forma de capital fixo, que objetiva os resultados gerais do desenvolvimento científico. Além disso, cria a própria socialização - o nexo efetivamente social, e não mais local da 
produção humana - como força produtiva do capital:

(...) no capital fixo, a força produtiva social do trabalho é posta como propriedade inerente ao capital; tanto a capacidade científica quanto a combinação das forças sociais no interior do processo de produção e, finalmente, a habilidade do trabalho imediato transposta para a máquina, para a força produtiva morta. No capital circulante, pelo contrário, aparece a troca dos trabalhos, dos diversos ramos de trabalho, sua interpenetração e sua constituição em sistema, a coexistência do trabalho produtivo como propriedade do capital (Grundrisse, 597).

Trata-se do fetiche do capital: a força produtiva que pertence ao trabalho social aparece como força produtiva do próprio capital porque de fato os meios de produção materiais criados a partir desta socialização e do conjunto do conhecimento existe na forma de capital, como sua propriedade, assim como o capital é condição de agregação da força de trabalho coletiva e constitui o nexo de seu intercâmbio.

Ao criar a indústria, modo de produção correspondente ao desenvolvimento de sua forma, "o capital derruba todas as barreiras que impedem o desenvolvimento das forças produtivas, a ampliação das necessidades, a diversidade da produção e a exploração e a troca das forças naturais e espirituais" (Grundrisse, 334). Marx afirma ainda:

(...) a produção baseada no capital cria (...) um sistema da exploração universal das qualidades naturais e humanas, um sistema da utilidade universal, do qual a própria ciência aparece como portadora tão perfeita quanto todas as qualidades físicas e espirituais, ao passo que nada aparece elevado-em-si-mesmo, legítimo-em-si-mesmo fora desse círculo de produção e troca sociais (Grundrisse, 333).

A elevação e a legitimidade de qualquer produto ou relação humana, como meios de satisfação de necessidades individuais, se subordinam ao valor, e por isso não se impõem por si mesmos. Para a produção da riqueza concreta, esse processo resulta na liberação sem precedentes de tempo de trabalho social e na relativa liberdade com referência ao trabalho imediato.

Contudo, "A universalidade para a qual o capital tende irresistivelmente encontra barreiras em sua própria natureza, barreiras que, em um determinado nível de seu desenvolvimento, permitirão reconhecer o próprio capital como a maior barreira a essa tendência (...)" (Grundrisse, 334). Nesta passagem, elucidam-se três aspectos da compreensão de Marx acerca da contradição do capital. Em primeiro lugar, que esta contradição se impõem à progressão da universalidade, ou seja, no rompimento das 
barreiras locais e das determinações naturais sobre a produção humana; em outros termos, coloca-se como oposição ao desenvolvimento das forças produtivas sociais. Em segundo lugar, que a barreira que se contrapõe à expansão produtiva encontra-se em sua própria natureza [na natureza do capitatl - VC], de modo que não pode pertencer a uma fase específica somente de seu evolver histórico; mas, em terceiro lugar, que apenas em um determinado nível de seu desenvolvimento será possível reconhecê-lo como forma que barra a progressão produtiva.

De modo que se torna necessário considerar que as transformações qualitativas da força produtiva não são indiferentes à forma capital, isto é, sua própria contradição progride. Para Marx “(...) é só o capital que cria a sociedade burguesa e a apropriação universal da natureza, bem como da própria conexão social pelos membros da sociedade" (Grundrisse, 334), mas, desta forma necessária à ampliação da produtividade do trabalho socializado, o capital se torna "obstáculo do desenvolvimento das forças produtivas" (Grundrisse, 339). Não porque o desenvolvimento produtivo altere a natureza do capital: "Esses limites imanentes têm de coincidir com a natureza do capital, com suas próprias determinações conceituais essenciais" (Grundrisse, 339); mas porque esta que Marx considera "a contradição fundamental do capital desenvolvido" se acirra com o progressivo desenvolvimento da produção capitalista, ou seja, desenvolve-se com o capital. É o que se lê na seguinte passagem:

\footnotetext{
O próprio capital, contudo, corretamente compreendido, aparece como condição para o desenvolvimento das forças produtivas, uma vez que elas necessitam de incitamento externo, incitamento que, ao mesmo tempo, aparece como seu freio. Disciplina das forças produtivas que se torna supérflua e incômoda a certo nível de seu desenvolvimento, da mesma forma que as corporações, etc. (Grundrisse, 339).
}

Para Marx, portanto, o capital desenvolve-se de alguma maneira em um limite, "da mesma forma que as corporações etc." eram incômodas para o desenvolvimento produtivo e por isso foram historicamente desagregadas pelo modo capitalista de produção que as sucedeu. Nos termos de Marx, "há um limite, não à produção em geral, mas à produção fundada no capital" (Grundrisse, 334), que está dado em sua própria natureza e deve por isso existir como contradição desde que o capital põe o modo de produção que lhe corresponde; deve, pois, conviver com sua determinação oposta de impulsionar as forças produtivas. Esta se põe com força cada vez maior no evolver histórico, até o momento em que pode ser reconhecida. 
A contradição central do capital está no fato de "que a riqueza real tem de adotar uma forma determinada, distinta dela própria e, portanto, forma absolutamente não idêntica a ela, para se tornar objeto da produção" (Grundrisse, 339). Esta forma é o valor. Já na análise da mercadoria, Marx apresenta a capacidade produtiva e a capacidade de produzir valor como um movimento contraditório. Trata-se da oposição interna à mercadoria, devido ao duplo caráter que não apenas a caracteriza, como também "é o ponto crucial em torno do qual gira a compreensão da Economia Política" (C, I, 1, 49, citado acima). Marx afirma:

\begin{abstract}
Um quantum maior de valor de uso representa em si e para si maior riqueza material, dois casacos mais que um. Com dois casacos podem vestir-se duas pessoas, com um casaco, somente uma pessoa etc. Entretanto, à crescente massa de riqueza material pode corresponder um decréscimo simultâneo da grandeza de valor. Esse movimento contraditório origina-se no duplo caráter do trabalho $(\mathrm{C}, \mathrm{I}, 1,53)$.
\end{abstract}

Marx destaca as diferentes medidas do valor de uso e do valor e expõe os diferentes modos como a alteração na produtividade do trabalho os afeta. A medida do valor se distingue da medida da riqueza efetiva: o primeiro é o quantum de energia humana, tempo de trabalho social que os produtos demandam para ser reproduzidos, a segunda é a necessidade humana que os produtos satisfazem. Enquanto o valor de uso de uma mercadoria se mede pelo serviço que presta ao ser humano, seu valor se mede pelo serviço que o ser humano lhe prestou para que viesse ao mundo ${ }^{166}$. As naturezas do valor e do valor de uso são distintas, o que se expressa em suas determinações originárias. $\mathrm{O}$ valor de uso, riqueza efetiva, é uma ligação de trabalho com matéria natural: “(...) o trabalho não é a única fonte dos valores de uso que produz. Dela, o trabalho é o pai, como diz Willian Petty, e a natureza é a mãe” (C, I, 1, 51). Já o valor, como Palas Atena, não tem mãe, mas apenas pai: sua fonte exclusiva é o trabalho porque, como medida do serviço que os indivíduos relacionados pela divisão do trabalho prestam às coisas, sua atividade produtiva geral é seu único conteúdo. Por essa razão, suas medidas são também distintas - o valor de uso se mede pela necessidade humana concreta, o valor pelo dispêndio de força de trabalho humana, e isso altera o

\footnotetext{
166 "Como valor de uso a mercadoria exerce uma ação causal. O trigo, por exemplo, atua porque é alimento. Uma máquina supre o trabalho em proporções determinadas. Essa ação da mercadoria, somente por isso é um valor de uso, um objeto de consumo, pode-se chamar seu serviço, serviço que presta como valor de uso. Mas em sua qualidade de valor de troca a mercadoria jamais é encarada senão do ponto de vista do resultado. Não se trata do serviço que presta, mas do serviço que lhe foi prestado por ter sido produzida" (Contribuição, 63, citado acima).
} 
modo como a variação na produtividade do trabalho afeta a criação de valores de uso e de valor.

A produtividade do trabalho se define pela relação entre a quantidade de valores de uso criados e a quantidade de trabalho que custa produzi-los. Esta quantidade de trabalho, medida pelo tempo, diz respeito ao trabalho concreto, específico. Isso é evidente: pode-se ampliar por meio de uma nova técnica a produtividade de um dado ramo da produção sem que se amplie a de outro:

Força produtiva é sempre, naturalmente, força produtiva de trabalho útil concreto, e determina, de fato, apenas o grau de eficácia de uma atividade produtiva adequada a um fim, num espaço de tempo dado. O trabalho útil torna-se, portanto, uma fonte mais rica ou mais pobre de produtos, em proporção direta ao aumento ou à queda de força produtiva $(\mathrm{C}, \mathrm{I}, 1,53)$.

Contudo, o aumento da produtividade é mudança na força produtiva do trabalho concreto, mas não do trabalho abstrato:

Ao contrário, uma mudança de força produtiva não afeta, em si e para si, de modo algum o trabalho representado no valor. Como a força produtiva pertence à forma concreta útil do trabalho, já não pode esta, naturalmente, afetar o trabalho tão logo faça-se abstração da sua forma concreta útil. O mesmo trabalho proporciona, portanto, nos mesmos espaços de tempo, sempre a mesma grandeza de valor, qualquer que seja a mudança da força produtiva (C, I, 1, 53).

Como produtivo de valor, o trabalho abstrato não tem sua produtividade alterada pela mudança na produtividade do trabalho concreto, porque o valor é sempre quantidade de trabalho. A variação da força produtiva do trabalho faz com que, em dada quantidade de dispêndio de força de trabalho, varie a quantidade de valores de uso, mas permaneça sempre a mesma magnitude do valor criado.

Assim, na oposição entre valor de uso e valor está já anunciada a lei tendencial a queda da taxa de lucro. O valor se define sempre como um quantum de trabalho abstrato acumulado: o pressuposto da relação de valor “(...) é e continua sendo a massa do tempo de trabalho imediato, o quantum de trabalho empregado como fator decisivo da produção da riqueza" (Grundrisse, 587). Mas, com o avanço tecnológico, este quantum de trabalho imediato incorpora-se em montante cada vez maior de mercadorias:

Genericamente, quanto maior a força produtiva do trabalho, tanto menor o tempo de trabalho exigido para a produção de um artigo, tanto menor a massa de trabalho nele cristalizada, tanto 
menor o seu valor. (...) A grandeza de valor de uma mercadoria muda na razão direta do quantum, e na razão inversa da força produtiva do trabalho que nela se realiza (C, I, 1, 49).

Isso significa que o aumento da produtividade do trabalho impõe, para a reprodução de determinada magnitude de capital, a necessidade de produzir quantidades crescentes de valores de uso. Aqui, enuncia-se uma discrepância entre a capacidade social de produzir valores de uso e a capacidade de produzi-los na forma de valor, que aparece como contradição entre a esfera da produção e a esfera da circulação. $O$ incremento da produtividade traz a necessidade de ampliar o círculo da troca em proporção superior à valorização. Isso porque, para realizar a mesma magnitude de valor, é preciso ampliar o mercado. Marx afirma que:

(...) a produção de valor excedente relativo, i.e., a produção de valor excedente fundada no aumento e no desenvolvimento de forças produtivas, requer a produção de novo consumo; requer que o círculo de consumo no interior da circulação se amplie tanto quanto antes se ampliou o círculo produtivo (Grundrisse, 332).

Marx destaca que, com o aumento da produtividade, amplia-se o círculo produtivo ainda que a magnitude de capital permaneça a mesma. Isso significa que o avanço das forças produtivas impõe o crescimento do consumo para reproduzir o valor pressuposto do capital. Se o capital se expande, a criação de mercados deve ser proporcionalmente maior que seu crescimento como capital, porque a quantidade de mercadorias em que uma magnitude dada de valor se expressa também aumenta:

\footnotetext{
Por exemplo, com a duplicação da força produtiva, precisa ser aplicado tão somente um capital de 50 onde anteriormente se aplicava um capital de 100, de forma que são liberados um capital de 50 e o trabalho necessário correspondente a ele; desse modo, deve ser criado um ramo produtivo novo, qualitativamente diferente, para o capital e o trabalho liberados, que satisfaça e produza uma nova necessidade. O valor da antiga indústria é conservado [pelo fato de] que é criado um fundo para uma nova indústria, onde a relação entre capital e trabalho se põe em uma forma nova. Daí a exploração de toda a natureza para descobrir novas propriedades úteis das coisas; troca universal dos produtos de todos os climas e países estrangeiros; novas preparações (artificiais) dos objetos naturais, com o que lhe são conferidos novos valores de uso (Grundrisse, $333)$.
}

Daí também Marx afirmar que "O mercado mundial está contido no conceito de capital” (Grundrisse, 332). Importa ressaltar que o progressivo barateamento ou desvalorização das mercadorias unitárias acarreta por si mesmo exigências crescentes na esfera da circulação para reproduzir como valor o valor previamente criado: “(...) à mesma 
proporção que aumenta a massa dos produtos, aumenta também a dificuldade de valorizar o tempo de trabalho nela contida - porque cresce a exigência sobre o consumo (Grundrisse, 346). Na reprodução ampliada, a desproporção entre a exigência sobre o consumo necessária para realizar o novo valor aumenta também, de modo que, se este movimento expressa o aprimoramento crescente da produtividade, implica o acirramento da contradição entre as esferas. A crescente ampliação do valor excedente relativo, que resulta de forças produtivas mais altas e impulsiona o processo de reprodução ampliada do capital, aprofunda a desproporção entre as esferas da produção de valor e de sua realização.

A contradição entre produção e circulação é uma forma de expressão da contradição entre desenvolvimento produtivo e valorização. Os obstáculos que o valor (a mercadoria) enfrenta para se realizar, em comparação com a possibilidade de "ser produzido" (isto é, de se produzir mercadoria), é uma expressão do limite que o capital impõe à ampliação da produtividade do trabalho. Quando dizemos que se produz, ou é possível tecnicamente produzir, maior valor do que é possível realizar, o que se exprime é a viabilidade de se criar mais valores de uso do que aqueles que podem assumir a forma de valor. Pois só é valor o produto que passa pelas metamorfoses formais e prova, ao assumir a forma de dinheiro, ser parte efetiva da riqueza social. A definição de valor implica sua realização.

Basta considerar que, quando se produz dada espécie de mercadoria acima da demanda efetiva, ou seja, da quantidade de valor socialmente disponível para um artigo determinado, o conjunto da massa de produtos desta espécie incorpora apenas o valor daquela parte que foi realizada como valor. A procura determina, ainda que a posteriori, o tempo de trabalho socialmente necessário para a produção de cada espécie de mercadoria. Como mercadoria é em primeiro lugar valor de uso, apenas a quantidade socialmente útil, ou seja, que responde a demanda efetiva, pode realizar-se como mercadoria; portanto, se a oferta exceder a procura, apenas o valor representado pela quantidade de mercadoria que efetivamente se realiza existe como valor de uso social. $\mathrm{O}$ restante das mercadorias e, portanto, do tempo de trabalho que sua produção consumiu não é útil para a sociedade: não pode se realizar como mercadoria e existir como valor. Assim, há possibilidade técnica (e necessidade humana) para a produção de valores de uso que não podem, no entanto, ser criados na forma social de valor. 
Um momento privilegiado em que se explicita a contradição entre o impulso e o entrave que o modo capitalista desenvolvido imprime às forças produtivas é a lei tendencial à queda da taxa de lucro. Marx caracteriza o aumento da produtividade do trabalho como ampliação do volume de meios de produção que determinada quantidade de trabalho vivo é capaz de pôr em movimento:

A elevação da produtividade do trabalho consiste exatamente em que a participação do trabalho vivo diminui enquanto a do trabalho pretérito é aumentada, mas de tal modo que a soma global do trabalho contido na mercadoria diminui; portanto o trabalho vivo decresce mais do que o trabalho pretérito cresce (C, III, 4, 195-6).

Esta ampliação da produtividade se evidencia já na consideração de que "na grande indústria o homem aprende a fazer o produto de seu trabalho anterior, já objetivado, atuar gratuitamente em grande escala como uma força da Natureza" (C, I, 2, 18, citado acima). Na produção capitalista, o aumento da produtividade média do trabalho social coincide com a elevação da composição técnica média do capital social. $\mathrm{O}$ fato de que a composição técnica crescente não possa deixar de expressar-se, em maior ou menor grau, mais cedo ou mais tarde, no aumento da composição orgânica média do capital social define a tendência à queda da taxa de lucro como lei.

Mas uma lei de tendência porque, em primeiro lugar, a ampliação da composição técnica não se expressa imediatamente na composição orgânica. Como resultado de uma expansão da produtividade ou escala da produção, o aumento da composição técnica determina a redução do valor das mercadorias unitárias, e, entre estas, também o valor dos elementos que compõem o capital constante. $\mathrm{O}$ valor do capital constante não cresce proporcionalmente ao volume de valores de uso em que se incorpora. E em segundo lugar, porque o aumento da composição orgânica não resulta em decréscimo proporcional da taxa de lucro necessariamente: a elevação da taxa de mais-valia, ao contribuir para o aumento da massa de mais-valia extraída por magnitude dada de capital variável, atua no sentido de elevar a taxa de lucro. Nesta consideração, observa-se o duplo efeito do aumento da produtividade sobre a taxa de lucro, em sentidos opostos: se, por um lado, amplia a composição técnica do capital, favorecendo o aumento da composição orgânica e a consequente queda na taxa de lucro, por outro, determina a redução do valor dos elementos do capital constante, mitigando os efeitos da alta da composição técnica na composição de valor do capital. Determina também a redução do valor dos elementos que compõem a reprodução da força de trabalho, 
possibilitando o aumento da taxa de mais-valia. Este ameniza o efeito restritivo que a ampliação da composição orgânica exerce sobre a taxa de lucro.

Mesmo os autores que se opõem à existência de uma lei tendencial à queda da taxa de lucro consideram que, para Marx, esta lei é uma manifestação do processo de ampliação da produtividade do trabalho social. Em seu Introduction to the three volumes of Karl Marx's Capital ${ }^{167}$, Michael Heinrich, escreve:

\begin{abstract}
Marx busca provar que a taxa média de lucro cai devido a este método tipicamente capitalista de aumentar a produtividade: como resultado da insaciável corrida por lucro extra, não apenas deveria haver um decréscimo no valor (ou preço de produção) da mercadoria como resultado da generalização das novas condições de produção, mas também (às costas e contra a vontade dos capitalistas) um declínio na taxa média de lucro. Para Marx, a tendência à queda da taxa de lucro e o desenvolvimento capitalista das forças produtivas são duas faces da mesma moeda. Se Marx tivesse sido capaz de provar a conexão conclusivamente, então ele teria mostrado que uma taxa cadente de lucro pertence à "essência" do capitalismo (Heinrich, Introduction, 150-1).
\end{abstract}

De fato, em Marx, mais do que duas faces de uma moeda, a lei tendencial à queda da taxa de lucro é uma expressão capitalista da expansão das forças produtivas: "A tendência progressiva da taxa de lucro a cair é, portanto, apenas uma expressão peculiar ao modo de produção capitalista para o desenvolvimento progressivo da força produtiva social de trabalho" (C, III, 4, 164). Esta lei expressa, na forma do capital, o aumento da produtividade do trabalho. É, pois, expressão formal de uma transformação concreta no método de produção.

A lei tendencial à queda da taxa de lucro é uma lei que rege o desenvolvimento capitalista, isto é, depreende-se necessariamente da natureza da forma-capital: conforme a produtividade do trabalho se amplia, a taxa de lucro média do capital social tende a cair. Ela se depreende de quatro determinações. Primeiro, do fato de que o modo de produção capitalista desenvolve a produtividade do trabalho social, de modo que, no interior deste modo de produção, a composição técnica do capital social aumenta historicamente. Segundo, a ampliação da composição técnica se expressa em um aumento da composição orgânica, ou de valor, do capital social: o capital constante se amplia proporcionalmente ao capital variável. Esta ampliação não se dá na mesma proporção em que cresce a composição técnica do capital, mas acaba por ocorrer.

\footnotetext{
${ }^{167}$ HEINRICH, Michael. An introduction to the three volumes of Karl Marx's Capital. Tradução de Alexander Locascio. Nova York: Monthly Review Press, 2012. Doravante, Introduction, seguido do número da página.
} 
Assim, cada montante dado ou parte alíquota do capital social restringe sua capacidade de empregar trabalho na mesma medida em que o capital variável decresce relativamente ao constante. Terceiro, que a ampliação da taxa de exploração do trabalho não compensa a redução relativa do capital variável, ou seja, não compensa a ampliação na composição orgânica do capital. E, em quarto lugar, que o valor é criado exclusivamente pelo trabalho, de modo que quantidades determinadas de trabalho social médio criam sempre as mesmas magnitudes de valor. Logo, apenas o capital variável, investido em salários dos trabalhadores produtivos, constitui a base de criação de valor novo.

A progressiva restrição da capacidade de o capital empregar trabalho implica uma restrição da capacidade de valorização do capital. Isso se expressa no fato de que, conforme se amplia a composição orgânica média do capital social, diminui a massa absoluta de mais-valia que o capital global de determinada magnitude é capaz de gerar. Marx escreve:

Tomemos a parte alíquota do capital sobre a qual calculamos a taxa de lucro como 100, por exemplo. Esses 100 representam a composição média do capital global, digamos 80c + 20v. Vimos na Seção II deste livro como a taxa média de lucros nos diversos ramos da produção é determinada não pela composição do capital específica de cada um mas por sua composição social média. Com a diminuição relativa da parte variável em relação à parte constante, e por conseguinte em relação ao capital global de 100, a taxa de lucro cai com grau de exploração do trabalho constante e mesmo crescente, cai a grandeza relativa da mais-valia, isto é, sua relação com o valor do capital global adiantado de 100. Mas não só essa grandeza relativa cai. A grandeza da mais-valia ou do lucro, absorvida pelo capital global de 100, cai de modo absoluto. (C, III, 4, 169).

Dada a magnitude do capital, a quantidade de mais-valia que ele é capaz de gerar reduzse à medida que a composição orgânica se eleve, ainda que cresça a taxa de mais-valia. Contudo, o mesmo avanço na força produtiva do trabalho que cria amplia a proporção do capital constante em relação ao variável promove a ampliação absoluta na quantidade de capital (criação de capital adicional) que possibilita a acumulação e consequente concentração de capital. Estimula ainda a centralização do capital ao criar métodos produtivos que apenas funcionam mediante o aumento da escala da produção. Estes fatores caracterizam a expansão do capital social e o fenômeno da compensação da queda da massa de lucro que o capital médio cria pelo aumento do próprio capital: 
O fenômeno que se origina da natureza do modo de produção capitalista, de que, com produtividade crescente do trabalho, o preço da mercadoria individual ou de dada cota da mercadoria cai, o número de mercadorias sobe, a massa de lucro sobre a mercadoria individual e a taxa de lucro sobre a soma de mercadorias caem, a massa de lucro porém sobre a soma global de mercadorias sobe - esse fenômeno na superfície só apresenta: queda da massa de lucro sobre a mercadoria individual, queda de seu preço, crescimento da massa de lucro sobre o número global aumentado de mercadorias que o capital global da sociedade ou o capitalista individual produz. Isso é, então, interpretado como se o capitalista, por sua livre vontade, adicionasse menos lucro à mercadoria individual, compensando-se, porém, pelo número maior de mercadorias que ele produz (C, III, 4, 176).

À tendência à queda da taxa de lucro corresponde a tendência à elevação absoluta do capital social, que faz com que a massa de mais-valia e consequentemente de lucro que o capital social cria cresça por meio de emprego de trabalho adicional, correspondente ao investimento de capital adicional. Ambos os fenômenos decorrem do aumento da produtividade do trabalho social: "De fato, a queda dos preços das mercadorias e a elevação da massa de lucro sobre a massa aumentada das mercadorias barateadas é apenas outra expressão da lei da taxa decrescente de lucro com massa simultaneamente crescente de lucro" (C, III, 4, 176). Ao aumento da produtividade social que gera a queda da taxa média de lucro corresponde o aumento da escala da produção: “Queda da taxa de lucro e acumulação acelerada são, nessa medida, apenas expressões diferentes do mesmo processo, já que ambas expressam o desenvolvimento da força produtiva" (C, III, 4, 183).

Além disso, dado o barateamento geral das mercadorias oriundo do aumento da produtividade do trabalho social, também as mercadorias que compõem o valor da força de trabalho tendem a baratear-se e, com isso, reduz-se o valor da força de trabalho. À queda da taxa de lucro corresponde portanto o aumento da taxa de mais-valia, já que a redução do valor das mercadorias diminui o tempo de trabalho necessário em relação ao excedente. Marx escreve: "A taxa de lucro não cai porque o trabalho se torna mais improdutivo, mas porque se torna mais produtivo. Ambas, a elevação da taxa de maisvalia e a queda da taxa de lucro, são apenas formas específicas em que se expressa de maneira capitalista a crescente produtividade do trabalho" (C, III, 4, 182). Deste modo, "A taxa de lucro cai não porque o trabalhador seja menos explorado, mas porque, em relação ao capital empregado, utiliza-se em geral menos trabalho" (C, III, 4, 186). Pela mesma razão, os elementos do capital constante são barateados com a ampliação da 
produtividade nos ramos que os produzem. Este processo cria um "crescente volume de valor do capital constante - embora ele só de longe represente o crescimento da massa real dos valores de uso, nos quais o capital constante consiste materialmente" (C, III, 4, 164). A ampliação da escala de produção, que se realiza pela ampliação extensiva do capital e se dá por meio de sua concentração e centralização, pressupõe a desvalorização do capital constante existente. Do mesmo modo que o aumento da mais-valia relativa, esta desvalorização também retarda a queda da taxa de lucro.

Assim, a lei tendencial é ela mesma dúplice, porque significa tanto a tendência à queda da taxa de lucro, como à ampliação do capital e da escala da produção. Ela não é a única forma capitalista de expressão do aumento da produtividade do trabalho social: também as tendências à acumulação ampliada, à concentração de capital e ao aumento da taxa de mais-valia expressam a ampliação das forças produtivas, ou são desenvolvimentos necessários da forma capitalista desta expansão.

A partir desses fatores que refreiam a queda da taxa geral de lucro, as tendências contrariantes que se baseiam também na ampliação da produtividade, especialmente a desvalorização do capital constante e a ampliação da taxa de mais-valia, Heinrich se opõe à existência de uma tendência à queda da taxa de lucro oriunda do aumento da produtividade do trabalho. $\mathrm{O}$ autor pretende demonstrar que não há conexão necessária entre o aumento das forças produtivas sociais e a tendência cadente da taxa geral de lucro. Diverge de Marx neste ponto importante: a ampliação da produtividade do trabalho, que ocorre no capitalismo em proporção nunca antes testemunhada, não se manifesta em uma tendência a redução da capacidade do capital de empregar trabalho e criar mais-valia. Para ele, tal lei não se depreende da natureza do desenvolvimento do capital e portanto não existe como lei. Ou seja, a produtividade do trabalho pode aumentar ilimitadamente sem contraditar o processo de valorização, já que a ampliação das forças produtivas não impõe a diminuição da capacidade de valorização do capital. Como destaca o autor, o tema da lei tendencial suscitou amplos debates devido à sua relação com as crises do capital. Para ele, pesquisadores marxistas se apegam à lei porque não podem explicar as crises como fenômenos necessários decorrentes da natureza do capital sem lançar mão da taxa cadente de lucro. Ou seja, pode a crise ser 
um momento necessário ao desenvolvimento do capital quando a queda da taxa média de lucro não é? Não examino, contudo, esta questão ${ }^{168}$.

Para esta pesquisa, a relevância da discussão está no fato de que, se consideramos que o aumento da produtividade do trabalho não determina a queda na taxa de lucro e a consequente desvalorização do capital, que deve ampliar-se em proporções crescentes para se manter como capital, isto é, "para manter como valor o valor já criado", então a forma capitalista é forma que significa sempre e apenas impulso ao desenvolvimento das forças produtivas. Desaparece a contradição imanente à produção como produção de capital, em que esta forma manifesta seu caráter estreito, o limite a que restringe o avanço das forças produtivas. Sobre este caráter geral da lei tendencial, Marx escreve que a queda na taxa geral de lucro:

(...) promove superprodução, especulação, crises, capital supérfluo ao lado de população supérflua. Portanto, os economistas que, como Ricardo, consideram o modo de produção capitalista como absoluto, sentem aqui que esse modo de produção cria uma barreira para si mesmo e, portanto, atribuem essa barreira não à produção, mas à Natureza (na doutrina da renda). O importante, porém, de seu horror ante a taxa de lucro em queda, é a sensação de que o modo de produção capitalista encontra no desenvolvimento das forças produtivas uma barreira que nada tem a ver com a produção da riqueza enquanto tal; e essa barreira popular denuncia o caráter tão-somente histórico e transitório do modo de produção capitalista; testemunha que ele não é um modo de produção absoluto para a produção de riqueza, mas que antes entra em conflito com seu desenvolvimento, em certo estágio (C, III, 4, 184).

Para Heinrich, não há tal conflito. O autor cita as últimas linhas da passagem acima e comenta:

Mesmo sem isso, as limitações do modo capitalista de produção estão já manifestas no fato de que o desenvolvimento das forças produtivas e a produção de riqueza são subordinadas à valorização do valor, e que esse objetivo estreito desencadeia um excesso de forças destrutivas contra a humanidade e a natureza. Se a expressão do valor nos termos dos capitalistas e contadores sobe ou cai, isso não altera o caráter fundamentalmente cego do modo capitalista de produção (Heinrich, Introduction, 154).

De fato, não é necessário que haja um limite ao desenvolvimento das forças produtivas para que se considere a inadequação da forma capitalista ao desenvolvimento humano, ou seja, para sua crítica. Contudo, a desconsideração do limite que o capital passa a

\footnotetext{
${ }^{168}$ Heinrich explica as crises negando a validade da lei tendencial à queda da taxa de lucro no capítulo 9 de seu An introduction to the three volumes of Karl Marx's Capital, op. cit.
} 
representar, a partir de certo ponto de seu desenvolvimento, ao avanço das forças produtivas, significa afirmar o caráter não-histórico desta forma social e a universalidade de suas relações para a criação de riqueza. Isso descaracteriza o capitalismo como um modo de produção: a força produtiva do trabalho social que cabe nestas relações aparece ilimitada e, com isso, a divisão do trabalho ou a propriedade privada aparece como forma mais produtiva de organização social do trabalho. $\mathrm{O}$ fato de a força produtiva do trabalho social ser posta como força produtiva do capital em nada a restringe. Isso atesta uma recusa do limite a que as forças produtivas estão sujeitas nessa forma social e, com isso, vai-se naturalizando esta forma e um lado importante da produção capitalista desenvolvida fica oculto. Deixa-se de observar, por exemplo, o desperdício de força de trabalho social na esfera improdutiva da circulação; o caráter privado do trabalho científico, que sintetiza o desenvolvimento humano, deixa de aparecer como um limite à própria ciência; a necessidade de valorização do capital investido em dados ramos tradicionais, como o petróleo, deixa de aparecer como um limite ao investimento em combustível alternativo etc. Para Heinrich, contudo, há excesso de força de produtiva. Mas como uma força, uma capacidade humana, pode ser excessiva em si mesma?

A contraposição à lei tendencial à queda da taxa de lucro se baseia em suas tendências contrariantes, que fazem parte da própria lei. Como vimos, a lei supõe que, em primeiro lugar, o aumento da composição técnica do capital social se expressa em ampliação da composição orgânica; e, em segundo lugar, que ampliação da taxa de mais-valia não é capaz de compensar a perda absoluta de mais-valia resultante da diminuição relativa do capital variável. A argumentação contra a lei tendencial propõe que, primeiro, como os elementos do capital constante são barateados, a composição técnica pode aumentar sem que se expresse em ampliação da composição orgânica; segundo, em que a ampliação a mais-valia relativa pode compensar o efeito do aumento da composição orgânica. Não me proponho aqui a expor este debate em detalhe, apenas destacar que a oposição a Marx se fundamenta no argumento de que as tendências contrariantes à queda da taxa de lucro compensam suficientemente o fator que a leva a cair.

Enquanto Marx afirma que "as mesmas causas que acarretam a queda da taxa de lucro provocam efeitos contrários, que inibem, retardam e paralisam esta queda. Eles não anulam a lei, mas debilitam seu efeito. Sem isso, seria incompreensível não a queda 
da taxa, mas, pelo contrário, a relativa lentidão dessa queda" (C, III, 4, 181). Heinrich afirma que:

Marx baseia seus argumentos em favor da tendência a cair da taxa de lucro sobre o aumento de $\mathrm{c} / \mathrm{v}$. Se $\mathrm{m} / \mathrm{v}$ permanecesse constante, então um aumento em c/v levaria automaticamente a um declínio da taxa de lucro (...). Entretanto, Marx alega que a taxa de lucro também diminui no caso de uma taxa crescente de mais-valia. (...) Se o número de trabalhadores diminui, então se reduz a mais-valia produzida. Mas, se a taxa de mais-valia aumenta ao mesmo tempo, então o declínio no número de trabalhadores pode ser compensado, e a mesma massa de mais-valia é produzida. (...) Pode-se generalizar essa conclusão: se o número de empregados diminui para além de certa massa crítica, então, em algum momento, a quantidade de mais-valia produzida também decairá, por mais intenso que seja o aumento da taxa de mais-valia. Marx pensou ter dado prova suficiente da lei de tendência cadente da taxa de lucro com essa consideração.

Para o autor, as causas contrariantes à queda da taxa de lucro são razões suficientes para que essa tendência não possa ser vista como uma lei do desenvolvimento capitalista. Contudo, mesmo os principais fatores que contradizem a lei tendencial à taxa cadente de lucro - redução do valor do capital constante e elevação da taxa de mais-valia - contribuem, em última instância, para a queda da taxa de lucro porque resultam, do mesmo modo que o aumento da composição orgânica do capital social, do incremento da produtividade do trabalho social. Marx afirma:

Poderia ser colocada a questão de se entre as causas que inibem a queda da taxa de lucro, ainda que em última instância sempre a acelerem, também se incluem as elevações da mais-valia acima do nível geral, que são temporárias mas sempre recorrentes, que surgem ora neste, ora naquele ramo da produção, em benefício do capitalista que utiliza invenções etc., antes de terem se generalizado. Essa pergunta deve ser respondida afirmativamente (C, III, 4, 178).

O aumento da taxa de mais-valia em ramos específicos da produção, possibilitado pela composição orgânica superior à média e que proporciona lucro superior para esses capitais particulares, é fator que contribui para o decréscimo da taxa geral de lucro em longo prazo: na medida em que, por meio da concorrência, estabelece padrão mais alto de produtividade, força a ampliação da composição técnica média do capital social. Isso é verdadeiro também para os processos que determinam o aumento da taxa média de mais-valia: este se faz possível pela redução do valor dos elementos que compõem os meios de vida do trabalhador. Ou seja, nos ramos de produção de bens de consumo da classe trabalhadora, deve ter havido redução do valor, ou da quantidade de trabalho incorporada nas mercadorias que estes ramos produzem. 
A redução do valor da força de trabalho supõe ampliação da escala da produção nos ramos que produzem as mercadorias que compõe aquele valor. Também a redução do valor dos elementos do capital constante, se temporariamente restringe o aumento da composição orgânica e consequentemente a queda da taxa de lucro, em última instância contribui para acelerar esta queda. Isso porque a redução do valor dos meios de produção - maquinaria e matérias-primas - significa redução da quantidade de trabalho que estas mercadorias incorporam e consequente elevação da composição técnica do capital - ou aumento da produtividade - nos ramos que produzem estas mercadorias. Assim, o efeito do aumento da composição técnica do capital é retardado pela redução do valor dos elementos do capital; tampouco o aumento da composição orgânica se reflete de modo imediato em queda da taxa de lucro: esta é de fato atenuada pelo aumento da taxa de exploração do trabalho. Entretanto, como ambas as causas atenuantes resultam do aumento da produtividade do trabalho social, em última instância contribuem para restringir a quantidade de trabalho que cada parte alíquota do capital é capaz de comandar. Como o próprio Heinrich afirma,

Se o valor dos elementos do capital constante diminui, então o valor do capital constante também diminui, sem necessidade de qualquer mudança no método concreto de produção. $\mathrm{O}$ aumento da taxa de lucro em uma esfera é portanto o resultado do aumento da produtividade em outra esfera" (Heinrich, Introduction, 145).

Ao negar a lei tendencial à queda da taxa de lucro, deixa de ser possível afirmar a existência da contradição que permeia o capitalismo desenvolvido:

A contradição expressa de forma bem genérica, consiste em que o modo de produção capitalista implica uma tendência ao desenvolvimento absoluto das forças produtivas, abstraindo o valor e a mais-valia nele incluídos, também abstraindo as relações sociais, dentro das quais transcorre a produção capitalista; enquanto, por outro lado, ela tem por meta a manutenção do valor-capital existente e sua valorização no grau mais elevado (ou seja, crescimento sempre acelerado desse valor). Seu caráter específico está orientado para o valor-capital existente, como meio para a máxima valorização possível desse valor. Os métodos pelos quais ele alcança isso implicam: diminuição da taxa de lucro, desvalorização do capital existente e desenvolvimento das forças produtivas do trabalho à custa das forças produtivas já produzidas (C, III, 4, 188).

Se o capital apenas se valoriza com base no trabalho, quando as forças produtivas já criadas passam a ser mobilizadas, não pelo trabalho individual, mas pelo acionamento de um mecanismo, é evidente que a quantidade de trabalho que os meios de produção são capazes de absorver restringe-se drasticamente. A indústria caracteriza 
o modo de produção plenamente capitalista porque amplia a composição orgânica do capital e põe pela primeira vez um capital constante superior ao variável. À redução da taxa de lucro está ligada a ampliação absoluta do capital em termos que garantem a ampliação da massa de lucro, e, portanto, a acumulação ampliada. Marx escreve:

\footnotetext{
A massa de capital que o trabalhador põe em movimento e cujo valor ele, mediante seu trabalho, conserva e faz reaparecer no produto é totalmente diferente do valor que ele agrega. Se a massa do capital é $=1000$ e o trabalho agregado $=100$, então o capital reproduzido $=1100$. Se a massa $=100$ e o trabalho agregado $=20$, então o capital reproduzido $=120$. A taxa de lucro é, no primeiro caso, $=10 \%$, no segundo, $=20 \%$. E, mesmo assim, com 100 pode ser acumulado mais do que com 20. E assim segue o fluxo do capital (abstraindo sua desvalorização pela força produtiva) ou sua acumulação em proporção à pujança que ele já possui, não em proporção ao nível da taxa de lucro (C, III, 4, 186).
}

Como exposto acima, o aumento da produtividade é necessário para o estabelecimento de um modo de produção adequado à reprodução de capital: ao ampliar a importância do trabalho objetivado em relação ao trabalho vivo na produção efetiva, expande-se o domínio do capital sobre o trabalho. Este domínio cresce com a expansão da escala produtiva porque o trabalho individual imediato perde qualquer controle sobre o processo coletivizado e mecanizado e porque a taxa de mais-valia sobe, fazendo com que o tempo que o trabalhador produz para o capital seja crescente com relação ao que trabalha para si mesmo. A redução do valor da força de trabalho, resultado do crescimento geral das forças produtivas, não tem apenas o efeito, favorável à taxa de lucro, de ampliar a mais-valia relativa. A redução da renda do trabalho - sempre restrita à reprodução do trabalhador em sua função - relativamente à ampliação da produtividade social também é fator que impõe limites à ampliação extensiva do capital. A contradição entre a produção e a realização de mais-valia se acirra com o aumento da composição orgânica do capital:

As condições de exploração direta e as de sua realização não são idênticas. (...) Umas estão limitadas pelas forças produtivas da sociedade, outras pela proporcionalidade dos diferentes ramos da produção e pela capacidade de consumo da sociedade. Esta última não é, porém, determinada pela força absoluta de produção nem pela capacidade absoluta de consumo; mas pela capacidade de consumo com base nas relações antagônicas de distribuição, que reduzem o consumo da grande massa da sociedade a um mínimo só modificável dentro de limites mais ou menos estreitos. Além disso, ela está limitada pelo impulso à acumulação, pelo impulso à ampliação do capital e à produção de mais-valia em escala mais ampla. Isso é lei para a produção capitalista (...). A contradição interna procura compensar-se pela expansão do campo externo da 
produção. Quanto mais, porém, se desenvolve a força produtiva, tanto mais ela entra em conflito com a estreita base sobre as quais repousam as relações de consumo (C, III, 4, 185).

As condições de realização do valor tornam-se cada vez mais estreitas, dado o trabalho assalariado e a crescente elevação da taxa de mais-valia, conforme se eleve a produtividade social. O capital deve multiplicar os valores de uso para realizar uma magnitude dada de valor conforme se amplie a produtividade, e ao mesmo tempo manter o salário restrito ao equivalente a um mínimo de valores de uso para ampliar a taxa de mais-valia. De modo que, vistas a partir das relações entre produção e circulação do valor, a produção material e a forma valor do produto são progressivamente mais contraditórias.

Por outro lado, o barateamento da força de trabalho e o crescimento da população excedente relativa, ambos resultados do aumento da produtividade do trabalho sob as relações capitalistas, geram ainda um outro efeito que concorre para frear a queda da taxa de lucro, mas apenas porque implica também um freio à própria produtividade do trabalho. Ou seja, contribui para restringir o aumento da composição técnica média do capital. A oferta excessiva de força de trabalho barata constitui um incentivo ao emprego de força de trabalho, ou seja, desestímulo à implementação de métodos mais produtivos. Pois, "Para o capital, não vige incondicionalmente a lei do aumento da produtividade do trabalho. Para o capital, aumenta essa produtividade quando, mais do que se acrescenta em trabalho pretérito, se economiza em trabalho vivo pago, e não em trabalho vivo em geral". Marx fornece alguns exemplos em que a economia de trabalho não significa economia de custos, e por isso não se realiza:

\footnotetext{
Os ianques inventaram as máquinas britadoras. Os ingleses não as utilizam porque o "miserável" (wretch é o termo da Economia Política inglesa criado para o trabalhador agrícola), que faz este trabalho recebe como paga parte tão diminuta de seu trabalho que a maquinaria encareceria a produção para o capitalista. Na Inglaterra, ainda se utilizam ocasionalmente, em vez de cavalos, mulheres para puxar etc. os barcos nos canais, porque o trabalho exigido para a produção de cavalos e máquinas é um quantum matematicamente dado, enquanto, pelo contrário, o exigido para manter as mulheres da população excedente está abaixo de qualquer cálculo (C, I, 2, 22).
}

Ademais, a superpopulação relativa torna-se campo de aplicação de capital, de modo que alguns ramos, ou processo parciais de produção, "repousam no predomínio do elemento constituído pelo trabalho vivo" (C, III, 4, 180). Neste caso, 
(...) o capital variável constitui uma proporção significativa do capital global e o salário está abaixo da média, de modo que tanto a taxa de mais-valia quanto a massa de mais-valia são extraordinariamente altas nesses ramos de produção. Como a taxa geral de lucro é constituída mediante a equalização das taxas de lucro dos ramos da produção específicos, aqui, mais uma vez, a mesma causa que gera a tendência decrescente da taxa de lucro faz surgir um contrapeso a essa tendência, que paralisa mais ou menos seu efeito (C, III, 4, 180).

Ao contrário da ampliação da taxa de mais-valia, que expressa o aumento da produtividade do trabalho, neste caso, a contra tendência à queda da taxa de lucro apresenta a particularidade de constituir um entrave ao próprio desenvolvimento da produtividade do trabalho.

Otto Bauer, no artigo publicado em 1906, referido no capítulo anterior, discute esta contra-tendência à queda da taxa geral de lucro. $\mathrm{O}$ autor destaca a diferença entre uma potência de desenvolvimento produtivo posta nas próprias forças produtivas materiais e na ciência, por um lado, e a capacidade de este desenvolvimento se realizar sob o modo de produção do capital, por outro. Bauer debate uma passagem do texto de Hanns Deutsch, em que este considera que a própria expansão capitalista tende a automatizar a produção social, ao ponto de fazer do trabalho intelectual a qualidade média do trabalho social:

O estabelecimento do artesão e em parte a manufatura exige trabalho muito qualificado. Mestres e oficiais do artesanato assim como também muitos trabalhadores parciais da manufatura realizam trabalho altamente qualificado. Por meio da introdução do processo incompletamente automático, nascem dois grupos de trabalho. Um, aquele que acima nós reconhecemos como pertencente ao processo automático e outro, menos qualificado, que nasce da incompletude do método de produção utilizado. Este realiza tarefas primitivas que compõem uma parte do processo, o trabalhador se torna órgão do autômato. Em comparação com a oficina do artesão e com a manufatura ocorre portanto uma desqualificação do trabalho. Quando o processo se torna completamente automático, então o autômato assume a parte menos qualificada do trabalho. E apenas o trabalho altamente qualificado permanece. Acontece então no processo de desenvolvimento dos métodos de produção primeiro uma redução e depois novamente uma elevação da qualificação do trabalho. ${ }^{169}$

Bauer considera as tendências apontadas por Deutsch como efetivas tendências técnicas, irreconciliáveis, contudo, com o modo de produção capitalista: este cria as condições técnicas para isso, mas sua lógica - o imperativo da redução dos custos - impede a

\footnotetext{
${ }^{169}$ DEUTSCH, Hanns. Qualifizierte Arbeit und Kapitalismus: Werttheorie und Entwicklungstendenzen.
} C.W. Stern, 1904, apud Bauer, Trabalho qualificado, 645 
realização da completude da automação:

Tecnicamente, pode ser que a possibilidade de substituição do trabalho desqualificado pelas máquinas já tenha se realizado em muitos ramos. Mas na sociedade capitalista o trabalho humano é substituído pelo da máquina não somente quando assim se economiza trabalho, mas só quando por meio da transformação do processo de produção se economizam custos. Mas, por motivos importantes, a economia de custos não corresponde diretamente à economia de trabalho (Bauer, Trabalho qualificado, 645).

De fato, a tendência da automação incompleta é completar-se: dado que a técnica foi automatizada na máquina, apenas na medida em que o processo produtivo não é completamente automático, devem os seres humanos realizar ainda uma massa de trabalho que é não-qualificada. Contudo, "A diferença entre a economia de trabalho e economia de salário é tão grande, e portanto a substituição de trabalho humano desqualificado pela máquina é tão mais difícil, quanto mais baixo for o salário" (Bauer, Trabalho qualificado, 646). De acordo com Bauer, o número dos casos em que os custos de substituição das máquinas é mais alto que o salário que permite economizar aumenta ainda em decorrência dos cartéis, "que igualmente encarecem os custos da produção mecanizada e portanto obstaculizam uma substituição do trabalho qualificado por máquinas já tecnicamente possível” (Bauer, Trabalho qualificado, 646).

Deste modo, a tendência técnica à completude da automação da produção "é contraditada por fortes contra-tendências", que consistem precisamente na finalidade que a forma capital impõe à produção. Para Bauer, o trabalhador do futuro não será desqualificado, e "certamente também não um artesão com qualificação de artista como nos sonhos fantasiosos dos poetas. Ele será engenheiro, mecânico, construtor de máquinas. Ele dominará a máquina, não a servirá. As condições para essa transformação são criadas na sociedade atual; mas só o modo de produção socialista pode realizá-la" (Bauer, Trabalho qualificado, 646-7). Uma sociedade cujo trabalho médio tem a qualificação do padrão de um engenheiro ou de um pesquisador reduziu o tempo de trabalho necessário à produção a um mínimo muito estreito frente aos próprios custos de formação de sua força de trabalho média e quantidade de trabalho empregada em atividades cujo tempo não se incorpora, como valor, nas mercadorias. Por isso, não é compatível com a base necessária para a reprodução do capital.

Na dinâmica mesma da concorrência, a "disciplina das forças produtivas" se torna "supérflua e incômoda" para a reprodução de capital, embora seja também o 
motor da expansão capitalista, à qual é inerente a ampliação da massa de lucro. Este "incômodo" aparece também nos ramos em que a produção ocorre sobre bases tecnicamente superadas ou superáveis, mas nos quais a magnitude de capital investida impede que sejam revolucionados. E, além destes, nos ramos em que o produto é virtualmente gratuito e por isso não oferece razões capitalistas para sua produção. Como a valorização do capital depende do quantum de trabalho empregado, e especialmente do quantum de trabalho não-pago, a incorporação de valor excedente posta como pressuposto intransponível da produção capitalista restringe a produção a esta condição. Isto significa uma barreira para o desenvolvimento produtivo possível. Marx escreve:

\footnotetext{
A verdadeira barreira da produção capitalista é o próprio capital, isto é: que o capital e sua autovalorização apareçam como ponto de partida e de chegada, como motivo e finalidade da produção (...). As barreiras entre as quais unicamente podem mover-se a manutenção e a valorização do valor-capital, que repousam sobre a expropriação e a pauperização da grande massa dos produtores, essas barreiras entram portanto constantemente em contradição com os métodos de produção que o capital precisa empregar para seu objetivo e que se dirigem a um aumento ilimitado da produção, à produção como uma finalidade em si mesma, a um desenvolvimento incondicional das forças produtivas sociais do trabalho. $\mathrm{O}$ meio desenvolvimento incondicional das forças produtivas sociais do trabalho - entra em contínuo conflito com o objetivo limitado, a valorização do capital existente (C, III, 4, 189).
}

Contudo, se o desenvolvimento possível da produtividade do trabalho encontra limites no capital, esta forma social não deixa de desenvolvê-la. Assim como o limite que representa à ampliação das forças produtivas, o impulso que confere a elas faz parte de sua natureza. Este se deve, como se disse, à necessidade de ampliar o valor excedente, o que o capital alcança por meio da redução de seus custos. Isso pode se dar pelo estabelecimento de um nível de produtividade acima da média do ramo ou acima da média social. Se o capital singular produz sua mercadoria abaixo do valor de mercado, amplia sua taxa lucro mediante redução da massa de mais-valia que cria: seu preço de produção abaixo do médio faz com que, pela venda ao valor de mercado, sua mercadoria atraia parcelas da mais-valia social realizada pelas demais mercadorias da mesma espécie, o que possibilita o lucro-extra. Este desaparece com a generalização do método mais produtivo. No entanto, na concorrência entre os ramos da produção, a redução dos custos de produção de todo um ramo também possibilita lucro acima do médio, já que a taxa de lucro é geral: 
Se a composição do capital numa esfera da produção é inferior à do capital social médio, (...) o valor de seu produto deve encontrar-se acima de seu preço de produção. Ou seja: por empregar mais trabalho vivo, havendo igual exploração do trabalho, tal capital produz mais mais-valia, e portanto mais lucro, do que uma parte alíquota de igual grandeza do capital social médio. A mais-valia produzida pelo capital social médio é menor do que a mais-valia produzida por um capital com essa composição inferior. (...) Ocorre o inverso se o capital investido em determinada esfera da produção tem composição superior à do capital social médio. $\mathrm{O}$ valor das mercadorias produzidas por meio dele está abaixo de seu preço de produção, o que em geral ocorre com os produtos das indústrias bem mais desenvolvidas (C, III, 5, 226).

Ainda que a composição superior à média se tenha generalizado no interior do ramo, de modo que não se esteja tratando do lucro extra que qualquer investimento singular obtém ao aplicar pioneiramente uma tecnologia que amplia a produtividade do trabalho; isto é, mesmo que não haja venda acima do valor de mercado por capitais particulares no interior do ramo, mas o conjunto do ramo tenha composição superior à média, é provável que nova ampliação da produtividade geral no ramo mantenha ou amplie sua taxa de lucro particular, uma vez que o preço de produção da mercadoria, ao variar para cima do valor, realiza mais-valia superior à que contém. Assim, a lei tendencial não pode se expressar em um capital isolado, mas apenas como uma tendência do capital social. Um capital singular só expressa individualmente a tendência social se for tomado como parte alíquota do capital social, portanto de composição média, condição em que o valor da mercadoria coincide com seu preço de produção. A queda da taxa média de lucro afeta, pois, bem mais os capitais com composição orgânica abaixo da média, e portanto aqueles que criam proporcionalmente maior quantidade de mais-valia. Assim, os capitais que produzem com a técnica mais avançada ou com composição orgânica superior atuam para diminuir a massa global de mais-valia e, por conseguinte, a taxa média de lucro, como resultado da ampliação de seu lucro real particular.

Assim, a massa de mais-valia que os capitais individuais deixam de produzir implica, para eles, em aumento de lucro, e por isso os mais desenvolvidos são os que justamente menos se afetam e mais contribuem para a queda da taxa geral de lucro. Aqueles que, na consideração da redução de custos, passam a produzir com produtividade mais baixa, lançando mão da superexploração da força de trabalho, ou transferindo plantas para locais em que a força de trabalho é mais barata, contribuem para a ampliação da massa de mais-valia e da taxa de lucro média ao operarem com 
composição orgânica abaixo da média, mas apenas porque isso também deve proporcionar lucro individual superior ao que estes capitais alcançariam produzindo com maior nível de automação. Mas, no conjunto social a produtividade do trabalho não pode estagnar. A ampliação da escala da produção é impulsionada, especialmente nas crises, como meio dos capitais singulares, mais centralizados e dominando maior mercado, recomporem seu lucro a partir do capital constante desvalorizado e da produtividade do trabalho aumentada. Por essa razão, a barreira que o capital constitui para a ampliação das forças produtivas diz respeito a seu desenvolvimento possível sobre as bases técnicas e nível de universalização presentes. As possibilidades de expansão da produtividade são mais amplas do que a produção capitalista de fato atualiza.

O desenvolvimento produtivo sob a forma capitalista implica uma contradição que, no entanto, se põe de maneira distinta do que ocorre nas sociedades précapitalistas. Nestas, a ampliação das forças produtivas, ao desenvolverem a divisão do trabalho, leva a modificações nos vínculos sociais, e isso implica uma tendência à desintegração da forma social. No capitalismo, ao contrário, cada novo desenvolvimento, cada nova divisão do trabalho se põe como um novo ramo da produção de capital, e portanto contribui para generalizar e aprofundar esta forma. Assim, o desenvolvimento produtivo não leva a uma tendência à desintegração da forma de propriedade que caracteriza o capital, ao contrário. Contudo, as forças produtivas passam a colidir com a forma social à medida que restringem a capacidade de o capital comandar trabalho e se valorizar.

Neste segundo grande estágio da história humana, em que é criada a universalização da produção e do intercâmbio e o domínio humano da natureza, sob o pressuposto do estranhamento e da abstração, a contradição entre a forma social limitada e a capacidade de expansão posta nas forças produtivas atuais é imanente a esta forma, e se expressa como limite à valorização, e não como tendência à desagregação do capital. Por isso, diferentemente das sociedades locais e comunitárias, que compõe o primeiro grande estágio do desenvolvimento histórico, o capital não se desintegra por meio de metamorfoses silenciosas das relações de produção, mas apenas pela ação consciente dos indivíduos. Isso é evidente: se um novo estágio histórico significa o controle social da produção pelos indivíduos livremente associados, a constituição desta 
sociedade deve ser percebida como uma necessidade pelos indivíduos no interior do capitalismo. Daí a exigência de uma ação revolucionária consciente.

A especificidade do capital não faz com este deixe de ser um modo de produção, forma das relações sociais que contém um dado patamar de desenvolvimento das forças produtivas, mas não todo o desenvolvimento possível. Trata-se do caráter dialético do desenvolvimento capitalista, que não tende a desagregação.

É este o sentido do texto dos Grundrisse citado por Ruy Fausto, cuja interpretação foi exposta no primeiro capítulo desta pesquisa. Ruy Fausto defende que: 1) com a expansão da força produtiva, o trabalho se torna primordialmente intelectual; 2) de acordo com Marx, a força produtiva dos agentes postos em movimento durante o processo de produção deixa de poder ser medida pelo tempo por dois motivos: porque a atividade de trabalho não preside mais o processo produtivo, não sendo mais processo de trabalho propriamente dito, e porque a potência dos meios materiais cresce a ponto de não guardar qualquer proporção com a quantidade de trabalho empregada; 3) daí conclui que, ainda de acordo com Marx, a própria valorização deixa de poder ser medida pelo tempo, ou seja, que a potência de produzir valor se torna também independente da quantidade de trabalho vivo empregada na produção; 4) por isso, a própria natureza da valorização muda: torna-se dependente da qualidade do processo produtivo. Esta qualidade está incorporada tanto no sujeito individual do trabalho, que de mecânico e impessoal se torna intelectual, científico e mais dependente das singularidades individuais, quanto nos agentes materiais (meios de produção) que se tornam a própria ciência encarnada, o logos da natureza materializado, adquirindo aspectos de subjetividade, porque produzem quase sem a intervenção humana; 5) o valor se torna então valor qualitativo, de sorte que sua substância deixa de ser o trabalho social abstrato ${ }^{170}$. Assim, as dimensões concretas da atividade, e também do meio de produção, passam a constituir a substância do valor. Isso implica em primeiro lugar uma identificação entre os caráteres concreto e abstrato do produto social, que faz desaparecer o trabalho abstrato a partir do fato de que o valor deixa de ser riqueza abstrata. Isto, por sua vez, expressa uma identificação entre a produção concreta e a

\footnotetext{
170 "Tinha-se assim uma oposição entre, de um lado, o universo concreto, o dos valores de uso, no interior do qual se tinha matéria e forma, e de outro lado o universo abstrato, do valor e do trabalho abstrato, que era pura forma (incluindo a substância da forma, o próprio trabalho abstrato). Agora a substância da forma [o capital -VC] não é mais o trabalho, mas o não-trabalho (é a ciência que cria 'valor')" (Fausto, LP III, 137, citado acima).
} 
forma social capitalista da produção, uma vez que as determinações que definem o resultado concreto da produção, quais sejam, suas múltiplas qualidades, tornam-se a substância do valor e, por conseguinte, do capital. Perdem-se as distinções entre o produto que é valor de uso e o produto que é capital, e o conjunto dos produtos passa a ser capital em si mesmo - o diferencial de qualidade dos produtos constituem seu valor. 6) Esta indistinção entre a produção material em si mesma e a forma das relações de produção que determina a criação do produto social como capital se explicita ainda na afirmação de que os próprios meios de produção, hoje invólucros da ciência, participam ativamente da criação de valor ${ }^{171}$. Aqui, o problema da criação de valor se subordina a uma questão ontológica mais ampla: Fausto concebe que as novas máquinas produzem (valores de uso) por si mesmas. Com isso, ficam indistintas as fronteiras entre os meios e a atividade de produção. O caráter ativo, subjetivo, que pertence com exclusividade aos indivíduos, transfere-se para os meios materiais. Assim, se as máquinas são criativas, podem também ser criadoras de valor. Ruy Fausto acrescenta que o capital, ao tentar subsumir o espírito, é dominado por ele ${ }^{172}$, e que o valor, ao se tornar valor qualitativo, é valor negado ${ }^{173}$. Ambas as afirmações não contribuem para a compreensão do objeto porque efetivamente a ciência não domina o capital, mas está hoje mais do que nunca a serviço dele; do mesmo modo, a valorização continua sendo a finalidade da produção capitalista e o capital é mais dominante que nunca, como atestam suas próprias crises mundiais.

Esta interpretação tem ainda outras consequências. Uma delas é a equiparação da produção concreta e da produção de valor e a indistinção de suas medidas próprias: em Marx, se a medida da produtividade do trabalho é o acúmulo de trabalho passado, que potencializa a força de trabalho atual ${ }^{174}$, a medida do valor é a quantidade de

\footnotetext{
171 “(...) já não se tem mais, propriamente, um objeto artificial. Antes uma espécie de objeto intelectual ou espiritual: é o logos - mas logos da natureza assimilado pelo intelecto - que é posto no processo de produção. Com isto, a ruptura entre trabalho vivo e trabalho morto é relativizada, a máquina passa a ser uma espécie de força de trabalho (intelectual), no sentido de que ela não necessita mais (quase) nenhum trabalho para ser vivificada. O autômato é agora autômato espiritual, não simples autômato "vivo"" (Fausto, LP III, 134-5, citado acima). Ou, "O processo de produção tem um caráter muito próximo ao de um processo de produção de ciência. São as novas máquinas que o executam, o indivíduo sai até certo ponto do processo. (...) Assim, a subordinação material desaparece" (Fausto, LP III, 135, citado acima).

172 “Assim, o capital que era uma alma apetitiva - ele tem 'fome devoradora' de trabalho alheio (W 23, K I, p. 425; C, I, 2, 29) - se apossa de um intelecto; mas acaba sendo dominado por ele" (Fausto, LP III, 135, citado acima).

173 “A 'valorização' se liberta do tempo de trabalho, mas com isto ela não será mais valorização” (Fausto, LP III, 129, citado acima).

174 “A natureza não constrói máquinas nem locomotivas, ferrovias, telégrafos elétricos, máquinas de fiar automáticas etc. Elas são produtos da indústria humana. Material natural transformado em órgãos da
} 
trabalho vivo atual. É também interessante notar que, no interior da concepção de valor qualitativo, não há limites para a produção de valor, uma vez que ele é proporcional à qualidade do trabalho, elevada e crescente no que diz respeito à atividade intelectual. Uma vez que o valor é qualitativo e pautado na qualidade, quando não oriundo do próprio meio de produção, então o valor cresce junto com a produtividade do trabalho. Esta é a segunda consequência importante da tese do valor qualitativo: sua incompatibilidade com a contradição que a lei tendencial à queda da taxa de lucro expressa. A defesa desta lei depende de se considerar que o valor é quantidade de trabalho social abstrato. Se a qualidade da atividade e dos meios de produção cria valor, esta criação não seria mais função do capital variável. Assim, a criação de valor se torna função do capital global, tanto constante quanto variável e, por essa razão, o aumento da composição orgânica do capital não afetaria mais a criação de valor, que poderia crescer a despeito da redução da proporção de trabalho vivo que ele mobiliza. O trabalho poderia aumentar indefinidamente sua produtividade, e, ainda assim, porque sua qualidade cria valor e esta é crescente com o desenvolvimento da ciência, o capital seguiria criando valor em proporções crescentes. É o que Ruy Fausto expressamente afirma: a ciência, ou o logos da natureza que ganha corpo na maquinaria, cria "valor". Assim, a lei tendencial perde seu fundamento e o desenvolvimento do capital resolve por si a contradição central do capitalismo pleno: a força produtiva objetiva passa a criar valor.

Mas independente do fetichismo que permeia uma concepção em que as máquinas não apenas se tornam sujeitos produtivos, mas também criativos de valor; independente ainda da falta de verossimilhança desta interpretação frente ao que pode ser observado empiricamente, ou seja, que o capital ainda grita por campo de aplicação $^{175}$ e estabelece seu parque industrial onde a força de trabalho é mais barata, o ponto central é que esta visão não pode ser atribuída a Marx.

\footnotetext{
vontade humana sobre a natureza ou de sua atividade na natureza. Elas são órgãos do cérebro humano criados pela mão humana; força do saber objetivada. O desenvolvimento do capital fixo indica até que ponto o saber social geral, conhecimento, deveio força produtiva imediata e, em consequência, até que ponto as próprias condições do processo vital da sociedade ficaram sob o controle do intelecto geral e foram reorganizadas em conformidade com ele. Até que ponto as forças produtivas da sociedade são produzidas, não só na forma do saber, mas como órgãos imediatos da práxis social; do processo real da vida" (Grundrisse, 598).

175 "Nas crises - após o momento de pânico -, no período da estagnação da indústria, o dinheiro é fixado nas mãos de banqueiros, corretores de títulos etc., e assim como o cervo grita por água fresca, o dinheiro grita por campo de aplicação para que o capital possa ser valorizado" (Grundrisse, 519).
} 
Em Marx, a dialética do desenvolvimento capitalista não está no fato de que em um determinado ponto de seu evolver o valor se torna seu oposto, transformando-se de riqueza abstrata em riqueza qualitativa, mas, ao contrário, está no fato de que o capital impele a um desenvolvimento que restringe as bases de sua expansão. A relação entre o trabalho passado e o trabalho vivo, ou entre a atividade e seus meios, no modo capitalista de produção, em conexão com a questão do tempo de trabalho e do tempo livre, é desenvolvida por Marx na passagem dos Grundrisse de que Fausto lança mão para demonstrar sua tese. Examino a passagem, buscando destacar um sentido distinto do que o crítico de Marx confere a ela:

\begin{abstract}
O capital só emprega a máquina, melhor dizendo, na medida em que ela capacita o trabalhador a trabalhar uma parte maior de seu tempo para o capital, a se relacionar a uma parte maior de seu tempo como não pertencente a ele, a trabalhar mais tempo para o outro. Na verdade, por meio desse processo o quantum de trabalho necessário para a produção de certo objeto é reduzido a um mínimo, mas só para que, com isso, um máximo de trabalho seja valorizado em um máximo de objetos. O primeiro aspecto é importante, porque o capital aqui - de forma inteiramente involuntária - reduz o trabalho humano, o dispêndio de energia, a um mínimo. Isso beneficiará o trabalho emancipado e é a condição de sua emancipação. O que foi dito evidencia o absurdo de Lauderdale, que pretende fazer do capital fixo uma fonte autônoma de valor, independente do tempo de trabalho (Grundrisse, 585).
\end{abstract}

A ampliação da produtividade é impulsionada pelos capitais singulares como meio de redução de custos e via para a realização de lucro-extra. É de forma inteiramente involuntária que o modo de produção capitalista reduz a um mínimo o quantum de trabalho necessário à produção das mercadorias, porque o interesse é o de valorizar um máximo de trabalho. Esta redução a um mínimo não altera por si só a relação capitalista $^{176}$. Mas beneficia e estabelece as condições para o trabalho emancipado.

Marx chama de trabalho emancipado aquele que se libertou do limite da propriedade privada e da criação de seu produto como capital. Ou seja, de uma forma de relação social que põe a quantidade de trabalho como medida da riqueza, ao mesmo tempo em que, dialeticamente, cria um modo concreto de produção para o qual trabalho imediato, por sua quantidade, deixa de ser o momento predominante:

\footnotetext{
${ }^{176}$ Como afirma Marx n'O Capital: “Assim como uma mudança no valor dos meios de produção, mesmo quando ocorre retroativamente após sua entrada no processo, não altera seu caráter como capital constante, tampouco uma mudança na proporção entre capital constante e variável atinge sua diferença funcional" (C, I, 1, 172).
} 
A troca de trabalho vivo por trabalho objetivado, i.e., o pôr do trabalho social na forma de oposição entre capital e trabalho assalariado, é o último desenvolvimento da relação de valor e da produção baseada no valor. O seu pressuposto é e continua sendo a massa do tempo de trabalho imediato, o quantum de trabalho empregado como fator decisivo da produção de riqueza. No entanto, à medida que a grande indústria se desenvolve, a criação de riqueza efetiva passa a depender menos do tempo de trabalho e do quantum de trabalho empregado do que do poder dos agentes postos em movimento durante o tempo de trabalho, poder que - sua poderosa efetividade -, por sua vez, não tem nenhuma relação com o tempo de trabalho imediato que custa sua produção, mas que depende, ao contrário, do nível geral da ciência e do progresso da tecnologia, ou da aplicação dessa ciência à produção ${ }^{177}$. (Por outro lado, o próprio desenvolvimento dessa ciência, especialmente da ciência natural e, com esta, todas as demais, está relacionado ao desenvolvimento da produção material.) (Grundrisse, 587-8, parcialmente citado acima, na tradução de Fausto)

O último desenvolvimento da relação de valor, relação que começa a se desenvolver com as trocas nas sociedades pré-capitalistas, é a troca de trabalho assalariado por capital. Esta troca é o máximo desenvolvimento do valor porque determina o valor como finalidade última da produção e o nexo exclusivo entre os indivíduos na produção social. O pressuposto da relação baseada no valor é e continua sendo a quantidade de trabalho como fator decisivo da produção de riqueza, porque, nesta base, a riqueza é abstrata. Contudo, com o desenvolvimento da indústria, a criação da riqueza efetiva, isto é, riqueza útil, se torna menos dependente da quantidade de trabalho imediato do que das forças produtivas acumuladas que o trabalho põe em movimento. Marx afirma que a potência produtiva das forças materiais acumuladas é mobilizada, antes como agora, pelo trabalho vivo, ressaltando que a força produtiva é sempre do trabalho: trata-se do "poder dos agentes postos em movimento durante o tempo de trabalho", ainda que este trabalho seja de qualidade específica distinta do trabalho imediato do operário à máquina. Assim, porque o tempo de trabalho imediato deixa de ser o fator central da produção material, este modo de produção criado pelo capital restringe suas próprias bases, isto é, a criação da riqueza na forma de valor. Também por isso, a forma social de capital se torna um fundamento estreito para o desenvolvimento produtivo e da própria ciência. Marx continua: "O roubo de tempo de trabalho alheio, sobre o qual a riqueza atual se baseia, aparece como fundamento

\footnotetext{
177 É desta passagem que Fausto conclui que "Temos assim um 'poder' que escapa do tempo como medida. O 'valor' passa a ser qualitativo, e nesse sentido a 'riqueza efetiva' não é mais valor (trabalho abstrato cristalizado, medido pelo tempo), mas "valor negado"” (Fausto, LP III, 130, citado acima).
} 
miserável em comparação com esse novo fundamento desenvolvido, criado por meio da própria grande indústria" (Grundrisse, 588). A indústria desenvolve um novo fundamento da produção, mas não é capaz de romper com a forma social que baseia a riqueza no roubo de tempo de trabalho alheio.

Precisamente porque o capital sempre repõe sua forma e não se desintegra pelo mero desenvolvimento, este novo fundamento produtivo se apresenta como superior à forma social do capital:

Tão logo o trabalho na sua forma imediata deixa de ser a grande fonte da riqueza, o tempo de trabalho deixa, e tem de deixar, de ser sua medida e, em consequência, o valor de troca deixa de ser [a medida] do valor de uso. O trabalho excedente da massa deixa de ser condição para o desenvolvimento da riqueza geral, assim como o não trabalho dos poucos deixa de ser condição do desenvolvimento das forças gerais do cérebro humano. Com isso, desmorona a produção baseada no valor de troca, e o próprio processo de produção imediato é despido da forma da precariedade e da contradição (Grundrisse, 588).

Quando o tempo de trabalho deixa de ser a medida da riqueza, então, "em consequência, o valor de troca deixa de ser a [a medida] do valor de uso". Neste caso, a riqueza pode se desenvolver sem ter por condição o trabalho excedente da massa sustentando o não trabalho de poucos, ou seja, a exploração o trabalho, calcada na propriedade privada. Por outro lado, o desenvolvimento das forças gerais do cérebro humano também deixa de ter por condição a divisão de classe - o não trabalho de poucos - porque o conjunto da produção de riqueza efetiva passa a prescindir de grandes quantidades de trabalho imediato.

Entretanto, isto demanda uma alteração na forma de propriedade que suprime o valor e o capital: "o valor de troca deixa de ser a medida o valor de uso", e, portanto, a troca deixa de ser a forma central do nexo social. Só quando "desmorona a produção baseada no valor de troca, e o próprio processo de produção imediato é despido da forma da precariedade e da contradição", a produção da riqueza efetiva deixa de ser produção de valor e o tempo de trabalho imediato deixa de ser sua medida. Sob esta nova forma da produção social,

[Dá-se] o livre desenvolvimento das individualidades e, em consequência, a redução do tempo de trabalho necessário não para pôr trabalho excedente, mas para a redução do trabalho necessário da sociedade como um todo a um mínimo, que correspondente então à formação artística, 
científica etc. dos indivíduos por meio do tempo liberado e dos meio criados por todos eles (Grundrisse, 588).

Este desenvolvimento livre, em que a redução do tempo de trabalho necessário da sociedade se traduz em redução do tempo de trabalho que o indivíduo efetivamente realiza, e que por isso corresponde à formação individual (artística, científica etc.), através dos meios criados por todos no tempo liberado de todos, tem por condição uma forma de propriedade comum.

Com o capital, forma última de desenvolvimento da propriedade privada, esta redução do tempo de trabalho necessário da sociedade se realiza para o indivíduo como tempo máximo de trabalho assalariado. Para ele, toda a jornada de trabalho é tempo de trabalho necessário, já que ela inteira é trocada pelo salário. No trabalho intelectual assalariado, que se desenvolve amplamente depois que Marx escreve sua teoria ${ }^{178}$, isso não é diferente. Vale para o trabalho imediato à máquina, mas também para o trabalho indireto, responsável pela elaboração de novos produtos, técnicas e pela pesquisa científica ligada à produção. Quando o trabalhador intelectual é tornado assalariado de capitais singulares, o trabalho científico é subsumido à mesma relação de produção ${ }^{179}$. Assim, com o desenvolvimento da maquinaria, a atividade intelectual torna-se trabalho material, isto é, função parcial do processo de trabalho coletivo voltado à criação de produtos materiais. A subsunção da produção científica ao capital não é apenas formal, isto é, não se restringe ao assalariamento ou à privatização deste campo de atividade. É também real na medida em que o capital implementa seus próprios métodos de ampliação da produtividade. Isso se explicita na intensa especialização de funções na produção da ciência natural, bem como no emprego de novos meios de produção da

\footnotetext{
${ }^{178}$ Embora já no Manifesto Comunista Marx e Engels constatem que "A burguesia despiu da sua auréola sagrada todas as atividades até então veneráveis e reputadas como dignas. Transformou o médico, o jurista, o padre, o poeta, o homem de ciência em trabalhadores assalariados pagos por ela." (MARX, K.; ENGELS, F. Cultura, Arte e Literatura - textos escolhidos. Tradução de José Paulo Netto e Miguel Yoshida. São Paulo: Expressão Popular, 2010, p. 148).

179 "Com o desenvolvimento do modo de produção especificamente capitalista, onde muitos trabalhadores operam juntos na produção da mesma mercadoria, tem naturalmente de variar muito a relação que seu trabalho mantém diretamente com o objeto da produção. Por exemplo, os serventes de fábrica mencionados antes, nada têm a ver com a transformação da matéria-prima. Estão a maior distância os trabalhadores que supervisionam os que estão diretamente empenhados nessa transformação; o engenheiro tem por sua vez outra relação e em regra trabalha apenas com a mente etc. Mas o conjunto desses trabalhadores que possuem força de trabalho de valor diverso, embora a quantidade empregada permaneça mais ou menos a mesma, produz resultado que, visto como resultado do mero processo de trabalho, se expressa em mercadoria ou num produto material; e todos juntos, como órgão operante, são a máquina viva da produção desses produtos; do mesmo modo, considerando-se o processo global de produção, trocam o trabalho por capital e reproduzem o dinheiro do capitalista como capital, isto é, como valor que produz mais-valia, como valor que acresce" (TMV I, 404).
} 
pesquisa. A subsunção da ciência ao capital desenvolve a divisão técnica do trabalho e o instrumental de trabalho. Significa também uma ampliação do domínio capitalista sobre a atividade humana, um novo campo de exploração, posto que, se a produção científica nada custava ao capital, como Marx aponta, também nada rendia diretamente (o modo como ela passa a ser fonte de rendimento capitalista é comentado adiante). Para o trabalhador intelectual, sua atividade produtiva não é realizada no tempo livre, ou no não-tempo de trabalho, como quer Fausto, já que para ele esta atividade é moeda de troca do salário. Não apenas por isso esta atividade não é livre: também porque a atividade individual é função de uma produção coletiva que se volta às necessidades de valorização do capital. Deste modo, o trabalho científico atual em nada se confunde com aquela atividade, realizada efetivamente no tempo livre a fim de atender necessidades sociais, a que Marx se refere quando fala do livre desenvolvimento das individualidades $^{180}$. Novamente, a contradição do capital está na progressiva restrição de sua capacidade de comandar trabalho e na posição das condições materiais de sua superação:

\begin{abstract}
O próprio capital é a contradição em processo, [pelo fato] de que procura reduzir o tempo de trabalho a um mínimo, ao mesmo tempo em que, por outro lado, põe o tempo de trabalho como única medida e fonte da riqueza. Por essa razão, ele diminui o tempo de trabalho na formado trabalho necessário para aumentá-lo na forma do supérfluo; por isso, põe em medida crescente o trabalho supérfluo como condição - questão de vida e morte - do necessário. Por um lado, portanto, ele traz à vida todas as forças da ciência e da natureza, bem como da combinação social e do intercâmbio social, para tornar a criação da riqueza (relativamente) independente do tempo de trabalho nela empregado. Por outro lado, ele quer medir essas gigantescas forças sociais assim criadas pelo tempo de trabalho e encerrá-las no limite requerido para conservar o valor já criado como valor. As forças produtivas e as relações sociais - ambas aspectos diferentes do desenvolvimento do indivíduo social - aparecem somente como meios para o capital, e para ele são exclusivamente meios para poder produzir a partir de seu fundamento acanhado. De fato, porém, elas constituem as condições materiais para fazê-lo voar pelos ares (Grundrisse, 588-9).
\end{abstract}

A redução do tempo de trabalho social necessário não se reverte, no modo de produção de capital, em tempo livre, mas em ampliação do tempo de trabalho excedente apropriado pelo capital que o realiza na forma de mais-valia relativa. Com base naquela

\footnotetext{
${ }^{180}$ Por outro lado, a atividade que cria conhecimento é realizada pelo tempo excedente da sociedade, no sentido de que é trabalho subtraído à produção dos valores de uso imediatos, atividade não inclusa no tempo de trabalho necessário para a reprodução social imediata. Mas porque o conhecimento se inseriu na produção e a atividade de cria-lo se tornou trabalho assalariado, de modo que o capital subordinou aquelas atividades que eram antes realizadas no tempo ocioso da classe dominante. Comento esse aspecto adiante.
} 
redução, a produção se expande e amplia-se a exploração do trabalho com o objetivo de reproduzir "o valor já criado na forma de valor". Neste processo, o aumento da produtividade leva à redução do tempo necessário a um mínimo, o que está na base da lei tendencial à queda da taxa de lucro. Contudo, as forças produtivas desenvolvidas e o intercâmbio social universalizado são condições que torna possível fazer o capital "voar pelos ares", rompendo esta relação de produção.

Marx, nessas passagens, trata da diferença entre o capitalismo e uma forma de organização social superior, em que a propriedade comunista supera a relação social do valor. Fausto toma tais passagens pela terceira fase do desenvolvimento capitalista ${ }^{181}$, mesmo considerando que Marx não menciona uma terceira fase. Com isso, a perspectiva da superação da forma social do capital e de construção da propriedade socialismo desaparece de sua intepretação de Marx. Daí advêm os problemas e irresoluções de seu próprio texto.

\footnotetext{
181 “Temos assim três formas de capitalismo, no plano do processo material de produção. A essas três formas correspondem configurações distintas no plano formal, ou níveis diferentes de desenvolvimento dessas formas. Na primeira forma, o desenvolvimento da exploração da mais-valia relativa só pode ser limitado (...). Na segunda forma, temos o pleno desenvolvimento da exploração da mais-valia relativa (...). Na terceira forma, tem-se a 'negação' do trabalho como fundamento do valor, e do tempo de trabalho como medida da grandeza do valor. Esses três momentos são formas sucessivas do modo de produção capitalista" (Fausto, LP III, 133, citado acima).
} 


\section{CONCLUSÃo: PROdUÇão CIENTífICA HOJE E CONTRADIÇÃo CAPITALISTA}

Foi dito que a contradição que permeia a forma capitalista do desenvolvimento das forças produtivas a partir de seu estabelecimento pleno se aprofunda historicamente. De maneira geral, como limite que o capital encontra para sua própria realização, essa contradição se mostra de várias formas. A tendência à queda da taxa de lucro é uma delas, bem como a desproporção entre a capacidade social de produção e a capacidade de realização de valor, o limite da demanda efetiva, que restringe a ampliação extensiva do capital. Como foi destacado, essa barreira não é o limite do consumo em si mesmo, mas o limite do consumo mediado pela forma de valor: "Como poderia, se assim não fosse, faltar demanda das mesmas mercadorias das quais o povo carece (...) Porque apenas nesse contexto específico, capitalista, o produto excedente ganha uma forma em que seu possuidor só pode colocá-lo a disposição do consumo assim que se retransforma em capital para ele" (C, III, 4, 193). A contradição também aparece, em decorrência, na desproporção entre a riqueza social criada e a exiguidade da apropriação individual, isto é, entre produção social e apropriação privada, que se observa no distanciamento crescente entre "a pobreza, que trabalha para viver, e a riqueza, que não trabalha" (TMV I, 129, citado acima), ou seja, pela redução progressiva que a massa social de salário representa frente à massa social do capital. Isso determina a subsunção ao trabalho para a massa da população, inclusive no que respeita à atividade qualificada e intelectual, ao mesmo tempo em que, socialmente, reduz-se o tempo de trabalho social necessário a um mínimo.

Mas a contradição se mostra também no fato de que uma proporção cada vez maior da população é empregada em atividades não-produtivas ou que não criam valor: "Embora a massa dos trabalhadores cresça absolutamente, ela diminui relativamente, não apenas em relação ao capital constante que absorve seu trabalho, mas também em relação à parte da sociedade não estabelecida diretamente na produção material ou em absolutamente qualquer produção"182.

\footnotetext{
${ }^{182}$ MARX, K. Para a crítica da economia política - Manuscritos de 1861-1863: Cadernos I a V Terceiro capitulo - O capital em geral. Tradução de Leonardo de Deus. Belo Horizonte: Autêntica, 2010, p. 349. Doravante, Man. 1861-63, seguido do número da página.
} 
Isto é visível hoje, em primeiro lugar, na crescente massa do trabalho improdutivo, empregado na esfera da circulação. Todo esse trabalho não cria valor, mas é necessário à reprodução do capital. Os capitais comerciais se valorizam, como os capitais produtivos, pela taxa geral de lucro, mas compõem uma parcela do capital que nada soma à mais-valia social. O débito do lucro de que cada capital produtivo se priva, na concorrência, pela valorização dos capitais que atuam apenas na esfera da circulação e que medeiam a realização de sua mercadoria, é menor do que se cada capital operasse autonomamente o comércio de suas mercadorias. Trata-se da socialização da atividade comercial, que concentrada, reduz os custos de circulação para cada capital produtivo singular. O conjunto do trabalho assalariado subsumido aos capitais mercantis, embora seja remunerado por salário, não cria qualquer valor, de modo que a parte variável dos capitais mercantis funciona socialmente como custo improdutivo da esfera da circulação, do mesmo modo que são improdutivos os custos de administração e contabilidade do capital singular. Assim, toda a força de trabalho empregada na esfera improdutiva é sustentada pela mais-valia social gerada no setor produtivo, assim como os lucros dos capitais produtivos e mercantis, além dos juros e da renda. A ampliação da esfera improdutiva, por um lado, pressupõe a ampliação da produtividade do trabalho social e por outro, significa barreira para o aumento desta produtividade. Isso porque um montante de trabalho social requerido para que, nesta forma social, o produto alcance a esfera do consumo, completando sua existência de produto ao realizar-se como valor. Este trabalho é vinculado exclusivamente à forma capitalista, e desaparecia com ela. Mas é trabalho que, se fosse empregado em funções produtivas, aumentaria a produtividade do trabalho social, de modo que seu emprego em atividades que nada acrescentam ao produto social útil restringe a produtividade social possível.

O caso do trabalho publicitário é amplamente mencionado como paradigma de trabalho intimamente ligado à reprodução do capital, mas cuja função é criativa e impassível de redução a mero tempo de trabalho. Este trabalho não cria valor, mas não porque, sendo criativo, não se reduz a trabalho abstrato, e sim porque não se incorpora em mercadoria. A propaganda é um elemento da esfera da circulação de valor, da concorrência entre capitais por mercado. Trata-se de um custo improdutivo necessário aos capitais, mas que não gera valor.

O aumento do trabalho produtivo no campo da pesquisa científica e técnica empregado pelo capital tem pontos em comum com o trabalho improdutivo da esfera da 
circulação, mas apresenta também diferenças importantes. Em primeiro lugar, o pressuposto social que torna possível a ampliação da massa de força de trabalho social empregada tanto em pesquisa e inovação, quanto na esfera improdutiva é o mesmo, o aumento da produtividade social geral. Marx escreve:

A parte da produção orientada para a produção do capital fixo não produz objetos da fruição imediata nem valores de troca imediatos; pelo menos não produz valores de troca imediatamente realizáveis. Por conseguinte, o fato de que uma parte cada vez maior seja empregada na produção dos meios de produção depende do grau de produtividade já alcançado - de que uma parte do tempo de produção seja suficiente para a produção imediata. Para tanto, é preciso que a sociedade possa esperar; que uma grande parte da riqueza já criada possa ser retirada tanto da fruição imediata quanto da produção destinada à fruição imediata, para empregar essa parte no trabalho não imediatamente produtivo (no interior do próprio processo de produção material) (Grundrisse, p. 589-90).

Se isto é necessário para o crescimento do departamento de bens de produção, em que a produção de maquinaria se torna um ramo da produção capitalista de que se incumbem capitais singulares, o é ainda mais para a inclusão da produção científica como custo capitalista, dado que seu produto está ainda mais distante da produção de bens de consumo imediatos do que a criação dos meios de produção. No caso da produção material das máquinas, a força produtiva despendida apenas se reverte em riqueza social quando a máquina é posta para funcionar na produção de outras mercadorias. Do mesmo modo, seu valor se transfere paulatinamente aos produtos criados. Mas é possível afirmar que o tempo de trabalho despendido nas pesquisas científicas e na criação de novas técnicas é incorporado às novas máquinas produzidas a partir delas, e por consequência às mercadorias criadas com sua utilização? Ou seja, é possível concluir que, ao servir de condição para a elaboração de espécies determinadas de mercadorias, o tempo de trabalho despendido em pesquisa se incorpora como valor, ao fim do processo, nas mercadorias que contribui para criar?

A atividade de pesquisa científica é trabalho produtivo na acepção geral, isto é, independente da forma social: atividade humana que produz um resultado objetivo antes visado. Nos modos de produção anteriores, apenas nos ramos de trabalho coletivizados a produção científica se volta à prática produtiva, como na agricultura egípcia, ou na navegação, em vários povos. A partir do Renascimento, a produção científica assume a 
prática e a manipulação da natureza como objeto. Mas mesmo depois da constituição da indústria, esta atividade continua sendo realizada pela classe dominante e fora da esfera de reprodução capitalista. Assim, se é certo que a produção científica se incorpora no produto quando este requer os resultados da pesquisa para ser criado, seja na irrigação egípcia, seja na indústria química capitalista, a questão da criação de valor pelo trabalho de pesquisa apenas se põe quando esta atividade passa a ser realizada sob a forma de um investimento de capital. É preciso diferenciar a incorporação do produto do conhecimento, que resulta de trabalhos intelectuais, em produtos materiais, no sentido de que este desenvolvimento compõe a condição de produção de dado produto, por um lado, da incorporação do tempo de trabalho gasto pelos trabalhadores intelectuais na pesquisa aos produtos cuja criação ela possibilita, por outro.

No caso do trabalho intelectual que cria mercadoria ou se insere na cadeia produtiva de mercadorias, não há nos escritos de Marx qualquer dúvida de que criam valor e mais-valia. Em um de seus exemplos (TMV I, 396), Marx afirma o trabalho do mestre-escola como produtivo para o capital porque este trabalha "também para enriquecer o dono da escola", já que gera uma mercadoria que, numa "fabrica de ensinar", incorpora valor excedente: o valor pelo qual é vendida é maior que o pago pela força de trabalho que a produziu. Assim, ao ser vendida para os alunos, a mercadoria criada pelo mestre-escola possibilita a incorporação de mais-valia pelo dono da escola, proprietário dos meios necessários para produzi-la. Esta mercadoria, embora desapareça no momento em que termina sua produção, não deixa, por isso, de ser objetiva: objetiva-se na ação, por meio da linguagem; é, pois, um objeto, valor de uso com expressão material suficiente (a linguagem) para tornar-se mercadoria, ainda que não possa fixar-se ou expandir sua duração para além do tempo de produção. É o mesmo o caso da cantora: "se um empresário a contrata para ganhar dinheiro com seu canto, é um trabalhador produtivo, pois produz capital" (TMV I, 396). Assim, se o produto criado pode assumir a forma de mercadoria, ainda que seja como serviço, cria mais-valia como qualquer produto material. O mesmo se dá com o trabalho intelectual que compõe o trabalho coletivo que cria produtos materiais, como no exemplo do engenheiro de produção. Todo trabalho individual que compõe a produção capitalista coletiva de produtos materiais é parte de um mesmo processo de trabalho e conta como trabalho material, pois o que o define é, de acordo com a teoria de Marx, o produto do processo total, não a atividade individual. 
No caso do trabalho voltado ao desenvolvimento científico, mesmo sendo produtivo na acepção geral - trabalho que se objetiva em produto útil, me parece não ser possível afirmar que seu tempo de trabalho se incorpora nas mercadorias que contribui para criar. Deste modo, embora como condição concreta necessária da produção de mercadorias determinadas, o trabalho de pesquisa e inovação não cria valor. Ora, quando subsumido ao capital, ou seja, realizando-se como trabalho assalariado de capital particular, esta atividade deve ser meio para a valorização deste capital. Este capital é investido na esfera produtiva, e não na esfera da circulação, mas sua incapacidade de criar valor está no fato de que seu produto não é mercadoria. Em si mesmos, os conhecimentos não podem assumir a forma de mercadoria. Diferentemente das mercadorias materiais e serviços (aulas, espetáculos artísticos, serviços médicos etc.) a ciência não requer trabalho para ser reproduzida. Uma vez produzido um conhecimento (a descoberta de determinadas propriedades da matéria, por exemplo) a reprodução deste resultado é gratuita, não custa trabalho algum para a sociedade. Devido à natureza livremente reprodutível do produto que a pesquisa científica cria, não é preciso que o trabalho despendido na pesquisa seja novamente realizado para que outrem se aproprie dos mesmos resultados. Por exemplo, depois que são conhecidos os hormônios femininos e o meio para sintetizá-los em laboratório, não é preciso que se refaça a mesma pesquisa para produzir novas quantidades de pílulas anticoncepcionais, basta reproduzir o processo material, tomando os resultados da pesquisa por pressupostos. Gorz escreve:

\footnotetext{
Essas observações valem particularmente para os conhecimentos presentes nos programas de computador. Sua elaboração e sua transcrição em linguagem binária, digital, têm um custo frequentemente elevado, porém os programas podem ser reproduzidos em número praticamente ilimitado, e a um custo desprezível. De fato, a mesma coisa vale para a indústria farmacêutica da época de Duisberg: os comprimidos de um medicamento podiam ser fabricados em quantidade ilimitada, e seu custo marginal unitário tendia a se tornar mínimo qualquer que fosse o custo do desenvolvimento do seu princípio ativo (Gorz, Imaterial, 35-6, citado acima).
}

Isso quer dizer que o conhecimento torna-se um produto objetivo no mundo, um aspecto do desenvolvimento do indivíduo social, que pode ser apropriado virtualmente sem custo, a partir apenas da formação individual que torna possível sua apreensão ou do próprio processo produtivo material. Isso não significa, contudo, que o conhecimento não seja incorporado nas mercadorias. Quando o resultado da pesquisa científica constitui uma condição de produção das mercadorias, o trabalho, enquanto cria um 
produto concreto, se incorpora nos produtos para os quais é uma condição de produção. É incorporado enquanto trabalho passado. De fato, um remédio resulta não somente do trabalho imediato de sua fabricação, mas também do conhecimento do organismo humano e sua reação a substâncias. Deste ponto de vista, seria possível considerar que o trabalho aí empregado incorpora seu tempo de dispêndio, e portanto seu valor, à mercadoria, e seja trabalho produtivo de mais-valia. Por outro lado, também a lâmpada depende da antiga descoberta da eletricidade, o plástico depende da descoberta das propriedades do subproduto do petróleo, uma peça de roupa, do desenvolvimento químico do branqueamento do tecido, de que já falava Marx. E poderíamos retroceder até o domínio do fogo. De modo que o produto social total depende do desenvolvimento histórico do saber humano, e de fato todo este desenvolvimento está incorporado nos produtos humanos.

Entretanto, se o conjunto do trabalho passado está incorporado no produto atual do trabalho social, não se pode afirmar que o trabalho passado que resultou no atual estágio de desenvolvimento produtivo incorpora-se como valor, como quantidade de trabalho social necessário à criação da mercadoria, como se se mantivesse reproduzindo valor. Não é o trabalho objetivado que cria valor, este consiste em meios ou condições de produção. Apenas o trabalho vivo cria valor. E o trabalho vivo é trabalho presente, atual. Marx escreve:

\footnotetext{
Ainda que o valor de uma mercadoria seja determinado pelo quantum de trabalho contido nela, esse próprio quantum é socialmente determinado. Se muda o tempo socialmente necessário para sua produção - e o mesmo quantum de algodão, por exemplo, representa maior quantum de trabalho em colheitas desfavoráveis do que em favoráveis - há um efeito retroativo sobre a mercadoria antiga, que sempre vale como exemplo isolado de sua espécie, cujo valor sempre se mede pelo trabalho socialmente necessário, isto é, sempre pelo trabalho necessário nas condições presentes (C, I, 1, 172).
}

Com o mesmo raciocínio, Marx explica a obsolescência moral da máquina: se uma máquina mais produtiva é criada, o trabalho incorporado na antiga deixa de representar valor, ainda que ela não esteja fisicamente desgastada. Na ciência, após a conquista de dado produto, como a fórmula de um remédio, a nova produção não requer mais o trabalho que a criou. Nas condições presentes de produção, seu custo não inclui o dispêndio do trabalho científico e os materiais que foram consumidos na pesquisa. 
Assim, o dispêndio de trabalho científico não se incorpora, como valor, às mercadorias que venham a ser produzidas.

O que ocorre então com o capital investido em ciência, como ele se reproduz? Sabemos que este trabalho cria valor de uso, e também que este valor de uso, como resultado útil da atividade, incorpora-se nos produtos que o utilizam como condição de produção. Contudo, por um lado, dadas as determinações concretas deste valor de uso, o trabalho empregado na pesquisa não se incorpora em produto alienável ou mercadoria; por outro, não podemos afirmar, a partir do fato de que o conhecimento é uma condição de produção, que o tempo de trabalho despendido na pesquisa é incorporado em tais mercadorias, como valor, analogamente ao capital constante. Como já exposto, o conhecimento não se desgasta, i.e., não requer trabalho para sua reprodução ou manutenção. Não é, pois, um meio de produção. O tempo aí investido não cria maisvalia, e tampouco valor: não reproduz o valor da força de trabalho nem transfere o valor do capital constante, porque não há mercadoria no fim do processo. O que se cria, vale repetir, é um valor de uso que se torna condição para produção de novas mercadorias ou integra novos processos de produção de mercadorias já existentes.

Assim, os capitais investidos em ciência são consumidos na criação de um valor de uso que servirá à criação de mercadorias. Sabemos que a possibilidade de explorar a ciência ou qualquer atividade produtiva como ramo do capital se baseia em sua capacidade de proporcionar uma renda pelo menos compatível com o lucro social médio. A valorização dos capitais que investem na produção científica não pode vir senão do valor de uso que dela resulta. É preciso, pois, monopolizá-lo, e o desenvolvimento da propriedade intelectual na esfera jurídica responde a essa necessidade. De fato, “(...) com as cambiantes necessidades do desenvolvimento social, isto é, econômico, o 'Direito positivo' pode e precisa alterar suas definições” (C, III, 5,124, nota 26). A valorização desses capitais (ou da parcela dos capitais investida em pesquisa) acontece por meio das patentes industriais e científicas. Trata-se do monopólio de um valor de uso que garante uma renda flua para o capital proprietário da patente. Por outro lado, aqueles capitais cujo ramo de produção exige a utilização deste valor de uso, uma descoberta científica, por exemplo, ficam obrigados por lei a comprar o direito de utilização. 
As patentes de invenção existem desde o século XV e são uma criação do Renascimento $^{183}$. No século XIX, as patentes significam para os capitais que as detém um monopólio de determinada técnica de produção de mercadorias que possibilita lucro superior ao médio. Marx menciona o “(...) o lucro extra que tem o dono de uma máquina recém-inventada antes de ter expirado a sua patente de invenção e de a concorrência ter empurrado os preços para baixo (...)" (Grundrisse, p. 577-8). Aqui, o lucro extra advém de produzir a mercadoria por preço de produção abaixo no médio e vendê-la pelo preço de produção médio. Assim, é a exclusividade da aplicação da técnica que faz com que o capital atraia, pela venda de suas mercadorias e na forma de lucro, proporção da mais-valia social acima da média. Para o capital produtivo de mercadorias, a inovação garante uma vantagem na concorrência, e por isso interessa desenvolvê-la. Mas os resultados da ciência são apropriados gratuitamente pelo capital que investe em tecnologia, do mesmo modo que as forças da natureza e da cooperação disponíveis, e daí Marx afirmar que ciência não era custo para o capital de sua época. Hoje, a produção capitalista da novidade técnica se realiza de modo autônomo, como ramo do capital independente. Existe como um novo ramo da divisão do trabalho e de aplicação de capital. Assim, o próprio conhecimento ou técnica deve render independentemente da produção de mercadorias. (É claro que só haverá interesse neste produto se for condição da produção de mercadorias por algum capital particular).

Bem antes de Marx, havia esta forma de fazer o conhecimento técnico render por si mesmo para seu proprietário, por meio de patentes. Os proprietários não eram, em geral, capitalistas, mas ainda inventores individuais. Precisamente porque o capital não havia subsumido a produção da ciência, ainda existia a figura do inventor que enriquece ao implementar a produção de algo novo, ou através da patente de sua invenção ${ }^{184}$. O

\footnotetext{
${ }^{183}$ As patentes, que garantem a propriedade industrial, tiveram sua primeira aparição legal em $1474 \mathrm{em}$ Veneza, reconhecendo direitos autorais sobre o invento, garantindo a propriedade da invenção e regulamentando seu uso comercial. As patentes são meios para tornar públicas as invenções que, sem esta proteção legal seriam, na sociedade mercantil em que a produção visa o lucro, mantidas secretas. Com isso, visava-se incentivar a inovação. Os registros de patentes deviam conter informações e descrições suficientes para que o invento fosse replicado. Embora garantisse exclusividade comercial, buscava-se incentivar a inovação tornando o conhecimento técnico acessível. Hoje, com as patentes estendidas à ciência, esta exigência da descrição vem sendo discutida no âmbito jurídico em vários países. Ver PLAZA, Charlene Maria C. de Ávila. "Das patentes aos royalties: o caso da soja transgênica da Monsanto", PIDCC, Aracaju, Ano II, Edição nº 03/2013, Junho/2013, pp. 01-40. ISSN 2316-8080.

${ }^{184}$ É o caso do escocês James Watt (1736-1819), matemático, engenheiro, construtor de máquinas, responsável pelo aprimoramento da máquina a vapor que tornou possível sua utilização na indústria de grande escala no momento da revolução industrial. Sua pesquisa foi apoiada pela Universidade de Glasgow, e se desenvolveu a margem da produção capitalista. Com aperfeiçoamentos que possibilitaram um aumento da produtividade de energia, a máquina foi patenteada em 1769 . De 1776 a 1781 o próprio
} 
processo de subsunção da ciência ao capital coincide com o processo de extinção do inventor, que se realiza pela progressiva coletivização da produção científica e consequente especialização da atividade. Por esse meio, o capital subsume realmente a produção de conhecimento e impulsiona seu desenvolvimento: a pesquisa científica é coletivizada, seu instrumental é aprimorado e sua criação é mediada pela relação de concorrência entre capitais.

Para os capitas produtivos que requerem este desenvolvimento, a ciência patenteada passa a significar um custo de produção das mercadorias, encarecendo-as. $\mathrm{O}$ pagamento de royalties pelo uso de produtos intelectuais patenteados funciona então como custo improdutivo, se tem preço fixo, ou dedução de parte do lucro, se o preço for calculado como porcentagem sobre o preço de venda das mercadorias.

Se o trabalho de pesquisa científica e técnica não incorpora seu tempo nas mercadorias, mas apenas seu resultado útil é incorporado ao produto, a valorização dos capitais que criam patentes científicas se dá por meio de renda de monopólio. Uma vez que o tempo de trabalho dos cientistas não se incorpora como valor, o capital investido em pesquisa é destruído enquanto capital para a produção de um valor de uso necessário, de uma nova necessidade. A partir da monopolização deste valor de uso, o capital se reconstitui e se valoriza atraindo parcelas da mais-valia global, mas não acresce valor ao produto global. A renda que flui para o proprietário da patente se distingue, contudo, da forma de renda absoluta da terra na medida em que as mercadorias criadas mediante condições de produção monopolizadas, patenteadas, não estão subtraídas, como o produto da terra à época de Marx, do nivelamento da taxa de lucro $^{185}$. A propriedade intelectual proporciona renda que consiste em mero preço de monopólio, e não compõe a taxa média de lucro. É, por conseguinte, um débito do lucro dos capitais que têm de pagar royalties, isto é, em que o preço de monopólio de uma de suas condições de produção encontra-se entre seus custos improdutivos, custos de que

\footnotetext{
Watt viajou pelo Reino Unido instalando sua máquina em diversas fábricas. Depois disso fez outras melhorias e registrou novas patentes.

${ }^{185}$ Esta forma do monopólio - a renda absoluta da terra - se baseia na mais baixa composição orgânica do capital investido na terra em relação à composição média, e dura apenas enquanto esta condição se mantiver: "Se a composição média do capital agrícola fosse a mesma ou mais alta do que a do capital social médio, então a renda absoluta desapareceria, sempre no sentido exposto, isto é, a renda que difere tanto da renda diferencial quanto da renda baseada no preço de monopólio propriamente dito. $\mathrm{O}$ valor do produto agrícola não estaria, então, acima de seu preço de produção, e o capital agrícola não mobilizaria mais trabalho, e, portanto, não realizaria mais mais-trabalho do que o capital não-agrícola. $\mathrm{O}$ mesmo ocorreria se a composição do capital agrícola se nivelasse, à medida que avançasse o cultivo, com a do capital social médio" (C, III, 5, 230).
} 
capitais de outros ramos de atividade podem estar livres. Como qualquer forma de renda, o pagamento de royalties implica débito da mais-valia global.

Ao abordar a propriedade da terra, Marx faz uma afirmação que se aplica à propriedade intelectual: “(...) a propriedade fundiária diferencia-se das demais espécies de propriedade pelo fato de que, em certo nível de desenvolvimento, ela aparece como supérflua e prejudicial, mesmo da perspectiva do modo de produção capitalista" (C, III, $5,129)$. Quando a renda passa a ser mero preço de monopólio, ela cria um obstáculo à aplicação de capital neste ramo. Do mesmo modo, a propriedade intelectual cria mais um custo, portanto mais um obstáculo ao investimento de capital, não em pesquisa, mas nos ramos que lançam mão dos recentes resultados da ciência. Contudo, são as possibilidades engendradas por estas novas descobertas - criação de novos produtos, necessidades e formas de produzir - que estão na base da extensão do campo de aplicação do capital produtivo. Analogamente ao trabalho improdutivo do comércio, necessário para a expansão do capital na medida em que cria mercados, o trabalho investido em pesquisa amplia a gama de valores de uso que podem se tornar veículos de valor, criando campo de aplicação para o capital produtivo, e desenvolve técnicas para o barateamento dos produtos existentes, contribuindo para ampliar a escala da produção.

O advento da ciência como um ramo da produção capitalista implica uma forma nova de valorização do capital excedente aplicado em inovação, que manifesta a contradição do desenvolvimento produtivo capitalista: a parcela do capital aí investida contribui para a redução da taxa geral de lucro, ao mesmo tempo em que impulsiona a ampliação extensiva do capital. Por meio das patentes, os capitais incorporam uma parcela do lucro de ramos inteiros de produção, ao mesmo tempo em que seu produto contribui para ampliar a produtividade destes ramos.

Um exemplo bastante emblemático é o da patente de sementes transgênicas, especificamente a soja, cujo mercado mundial é dominado pela multinacional Monsanto $^{186}$. A Roundup Ready (RR), semente transgênica de soja tornada resistente ao herbicida utilizado para eliminar ervas daninhas, permite ampliação da produtividade neste ramo $^{187}$. O patenteamento desta tecnologia rende à empresa pela exclusividade na

\footnotetext{
186 As empresas que dominam o ramo extremamente centralizados das sementes transgênicas são Monsanto (EUA), Syngenta (Suiça), Dupont (EUA), Basf (Alemanha), Bayer (Alemanha) e Dow (EUA). 187 “A expansão dos transgênicos ocorreu basicamente porque foi gerada uma tecnologia que, pela percepção dos produtores, foi vista como algo que poderia resolver muitos problemas que eles tinham.
} 
venda de sementes, e proíbe o replantio da safra resultante. Para cada novo plantio, o agricultor deve recomprar as sementes. Se não o faz e os técnicos de fiscalização da empresa encontram na nova safra a genética patenteada, o proprietário deve pagar royalties. De modo que, uma vez que tais sementes sejam utilizadas, as novas safras passam a ser devedoras de royalties automaticamente. Além disso, pela sua maior resistência, a semente da soja RR contamina lavouras produzidas com sementes tradicionais. Assim, ainda que um produtor não plante as sementes com tecnologia patenteada, sua safra contaminada se torna devedora de royalties à proprietária da patente $^{188}$. Paulatinamente, uma parcela crescente do conjunto de todo o ramo da produção passa a ceder parte de seu lucro na forma de preço de monopólio do produto criado. Nota-se que, se antes o monopólio rendia pela produção da mercadoria, hoje prescinde dela e se torna preço sobre a produção alheia.

O caso da produção de soja no Brasil ${ }^{189}$ caracteriza um monopólio, visto que até 2013 a empresa tinha direitos, pela patente da RR, sobre mais de $80 \%$ da soja produzida, apenas dez anos após a introdução da semente no país. ${ }^{190} \mathrm{O}$ monopólio da técnica garante que parte do lucro de um ramo da produção flua como renda para o

Por essa razão, a área plantada com essa tecnologia avançou rapidamente e, no Brasil, talvez tenha avançado mais rapidamente do que outros países em termos de tempo e de área. (...)', diz Francisco Aragão, responsável pelos estudos sobre transgênicos da Embrapa Recursos Genéticos e Biotecnologia, órgão subordinado ao Mapa, onde coordena o Laboratório de Genética" (THUSWOHL, Maurício, “Legalizados há dez anos, transgênicos vivem 'apoteose' no Brasil”, Carta Maior, 11 de novembro de 2013. Disponível em: reporterbrasil.org.br. Acessado em: 09/04/2015).

${ }^{188} \mathrm{O}$ agricultor que tem sua produção contaminada é considerado pirata da tecnologia transgênica e recebe multas: “(...) Essa legislação é um dos maiores fatores para o predomínio da Monsanto e outras empresas do gênero, pois permite uma estratégia de dominar pela contaminação e pelo controle da produção de sementes. O agricultor que não quer plantar transgênicos acaba desistindo ao ter que pagar seguidas multas quando sua plantação é contaminada" (Thuswohl, "Legalizados há dez anos...", op. cit.). 189 "No Brasil, a produção de transgênicos foi legalizada em 2003, por meio da lei 10.688/2003. O Brasil é hoje, ao lado dos Estados Unidos, líder mundial da produção de soja transgênica. Segundo o Ministério da Agricultura, da Pecuária e Abastecimento (Mapa), 88\% da safra de soja 2012/2013, que produziu impressionantes 81,3 milhões de toneladas, era composta por grãos geneticamente modificados, que ocuparam 37,1 milhões de hectares. Impulsionada pelo restrito clube de empresas que atua no setor, a força dos transgênicos na atual safra se estende a outras importantes commodities no país, como o milho e o algodão, que também já tem a maior parte de sua produção - $60 \%$ e 55\%, respectivamente - composta por transgênicos. Na próxima safra (2013/2014), os transgênicos também serão parte do símbolo maior da alimentação do povo brasileiro, o feijão, com o plantio de uma modalidade resistente (...), desenvolvida pela Empresa Brasileira de Pesquisa Agropecuária (EMBRAPA)" (Thuswohl, "Legalizados há dez anos...”, op. cit.).

190 Como o patente da RR foi reconhecida como expirada em 2013, após diversos litígios entre a Monsanto e os proprietários rurais, outra semente patenteada, anunciada como duplamente resistente a herbicidas e mais produtiva, a Intacta, foi aprovada, no mesmo ano, para a produção exportadora. No Brasil, a patente de invenção tem validade de 20 anos, a contar da data de seu primeiro registro em qualquer país. A Monsanto pretendia fazê-la valer por 20 anos após seu registro no Brasil, e esta foi a razão dos confrontos judiciais. 
capital proprietário da patente por anos ${ }^{191}$. Na prática, os royaties configuram um direto a uma porcentagem de toda mercadoria de determinada espécie que existe em um mercado. Neste caso, a empresa produz as sementes, mas mesmo quando estas não são compradas, a patente garante o pagamento de royalties em proporção à massa do produto criado pelos agricultores ${ }^{192}$. No caso da venda de sementes, seu preço é também um preço de monopólio, já que a RR é produzida pela empresa com exclusividade. Ou seja, a própria semente, como mercadoria, é um produto monopolizado, e seu preço de mercado não é compatível com seu preço de produção, mas engloba o preço dos royalties. O lucro pela venda de mercadorias, tanto da semente como do herbicida, também produzido pela empresa, se soma à renda proveniente do preço de monopólio, principal fonte de valorização.

Caso semelhante é o da Apple, empresa de tecnologia mais lucrativa do mundo, que detém centenas de patentes relativas ao funcionamento de computadores, celulares e tablets, além de câmeras e aparelhos de áudio ${ }^{193}$. Parte do lucro da empresa advém da própria produção de mercadorias (embora em cadeias de produção terceirizadas), mas outra parte advém de royalties devidos pelos próprios concorrentes. Por meio das patentes, a Apple tem direito sobre todos os Smartphones produzidos pela Samsung, por exemplo. Do mesmo modo, a Nikkon paga royalties na produção de suas câmeras à Microsoft, porque elas funcionam com a plataforma digital Android, patenteada pela empresa. Pela patente desta plataforma, a empresa tem direito a uma parcela dos produtos criados por 21 fabricantes que a utilizam nos Estados Unidos ${ }^{194}$. Muitos desses desenvolvimentos são softwares. Uma vez que os aparelhos eletrônicos vêm sendo produzidos sobre bases tecnológicas unificadas, as grandes empresas de tecnologia que

\footnotetext{
${ }^{191}$ Ainda tomando a mesma empresa como exemplo: "Segundo os executivos da Monsanto, $85 \%$ das sementes de brócolis comercializadas no planeta levam a marca Seminis. No caso do tomate, são $40 \%$ do total. No Brasil, a cada dez pepinos consumidos, seis tem tecnologia Monsanto. Três em cada 10 tomates também. A couve detém metade do mercado brasileiro (BARROS, Bettina. "Monsanto já domina mercado mundial de sementes de hortaliças", publicada originalmente em Valor Econômico, 11 de setembro de 2014. Disponível em: ihu.unisinos.br/noticias. Acesso em: 09/04/2015).

${ }^{192}$ A empresa já é proprietária de patentes de diversos outros vegetais que servem de alimento e que receberam algum tipo de modificação: "Sob a marca Seminis - herdada da compra da empresa americana de mesmo nome, que deu início à divisão de vegetais da Monsanto -, circulam hoje no mercado mundial sementes de 25 espécies de hortaliças, entre couve-flor, brócolis, cenoura e cebola. Em 2013, isso representou US\$ 821 bilhões de receita ao braço 'verde' da multinacional. Não é pouca coisa para um mercado cuja movimentação anual média gira em torno de US\$ 4 bilhões" (Barros, "Monsanto já domina...", op. cit.).

${ }^{193} \mathrm{Em}$ seu website, patentlyapple.com, a empresa lista as patentes registradas. Apenas este ano, mais de 200 patentes foram registrados em nome da empresa.

${ }^{194}$ RUSSEL, Kyle, “Apple has 'objectively insane' patent demands for Samsung”, publicado em Business Insider. Disponível em: businessinsider.com. Acesso em: 09/04/2015.
} 
aprimoram estas bases passam progressivamente a ter direitos sobre os produtos de um conjunto cada vez maior do ramo, criados por outras empresas. Cria-se um direito sobre a produção social de dado ramo, que flui como renda, pelo monopólio de um valor de uso, para o proprietário da patente. Um exemplo singular: em um aparelho com tela touch, o mecanismo de centralizar a imagem por meio de um duplo toque é uma patente comercial da Apple. Quer dizer que todo aparelho com este recurso contém algum valor que fluirá para a empresa. Isso significa uma centralização crescente do capital e do controle sobre a produção sem que seja necessário se imiscuir na produção imediata de mercadorias, apenas por meio da propriedade intelectual de produtos e processos produtivos.

O preço das patentes não obedece a qualquer lei econômica e a valorização por patentes não guarda nenhuma proporção com o capital investido ${ }^{195}$. O capital proprietário da patente se amplia com o crescimento dos demais capitais produtivos, em proporções determinadas juridicamente, sem que some qualquer valor, pressionando para baixo a taxa geral de lucro. Discute-se hoje o direito sobre as novas descobertas: aquelas que se baseiam em técnicas e conhecimentos patenteados deveriam ainda, para sua aplicação na produção de mercadorias, pagar royalties aos proprietários das antigas patentes, de modo que uma patente monopolizaria não apenas seu conteúdo específico, mas adquiriria direitos sobre a criação e as patentes futuras. Mesmo sem isso, o desenvolvimento da propriedade intelectual que resulta da subsunção da produção de conhecimento ao capital aprofunda o monopólio do desenvolvimento tecnológico e a centralização do capital.

O fato de a ciência ter se tornado, ainda que não completamente (visto que o Estado ainda é um importante financiador da ciência e da tecnologia) um ramo de investimento de capital é um dos movimentos que mostra que o capital se expande por meios que restringem sua base de valorização. Por um lado, ao aumento relativo do trabalho intelectual na esfera produtiva, corresponde a diminuição relativa do trabalho imediato, o progresso da automação. Por outro lado, o emprego crescente de força de trabalho na produção científica e técnica contribui para o aumento da proporção da

\footnotetext{
${ }^{195}$ Em longo embate judicial entre a Apple e a Samsung, em que esta foi processada por dever os royaties de diversas patentes da Apple em um mesmo produto, a discussão sobre o preço era feita considerando-se as patentes em conjunto e buscando-se fixar quantos dólares, do preço de cada aparelho da Samsung vendido, deviam ser pagos à Apple. Assim, independente de quanto varie o lucro da Samsung, um montante fixo do preço das mercadorias pertence à proprietária das patentes. (Ver Russel, "Apple has 'objectively insane' patent demands for Samsung", op. cit.)
} 
força de trabalho subsumida ao capital, que é empregada em funções que não criam valor.

Em síntese, os capitais que se valorizam por patentes científicas e técnicas constituem partes alíquotas que pressionam a taxa geral de lucro para baixo ao mesmo tempo em que impulsionam a ampliação do campo de aplicação do capital. O trabalho que empregam não soma à mais-valia ou lucro social, ao mesmo tempo em que sua valorização, garantida juridicamente (como os juros, por exemplo), não é afetada pela variação na taxa geral de lucro como são os demais capitais produtivos e comerciais. É interessante ressaltar que estes capitais são os que dominam a ciência e a técnica mais avançadas, e que esta é, pois, a forma de valorização de capitais que tendem a ser dominantes.

André Gorz tem razão quando sustenta, citando Rulani, que "O valor de troca do conhecimento está, pois, inteiramente ligado à capacidade prática de limitar sua difusão, ou seja, de limitar com meios jurídicos (...) ou monopolistas, a possibilidade de copiar (...) conhecimentos dos outros"196. Se o processo de constituição da propriedade privada da terra e do conjunto dos meios de produção resultou na socialização da produção e em um aumento inédito das forças produtivas sociais - foi mesmo sua forma necessária - hoje a privatização do que vem se constituindo como principal força produtiva gera um entrave ao aprofundamento da socialização e ao desenvolvimento tecnológico. Gorz, que mantém de Marx o conceito de valor, reconhece a valorização como um constrangimento: "Relações de saber e produção de saber apontam a saída para escapar às relações mercantis e à sociedade da mercadoria desde que possam se desenvolver livremente sem o constrangimento da valorização" (Gorz, Imaterial, 68, citado acima).

Mas as relações de saber e de produção de saber não podem ver-se livres do constrangimento da valorização sem que o conjunto da produção material, a que está vinculada a produção do conhecimento também se emancipe. As coisas úteis não são criadas diretamente pelo saber, e o fato de a quantidade de trabalho não ser mais o fator predominante na produtividade do trabalho não significa que o conhecimento toma $\mathrm{o}$ seu lugar. Ao contrário, a atividade individual de trabalho passa a requerer $o$

\footnotetext{
${ }^{196}$ RULANI, Enzo. "Le capitalisme cognitif: du déjà vu?", op. cit., apud Gorz, Imaterial, 36, citado
} acima. 
conhecimento. Para que os saberes de todos se tornem produtivos das coisas materiais, por meio dos processos automatizados, é preciso ter a propriedade de tais sistemas materiais. As forças produtivas materiais "são órgãos do cérebro humano criados pela mão humana; força do saber objetivada" (Grundrisse, 598). Nem são criadas pela natureza, ou pelas próprias máquinas, nem somente pelo conhecimento, mas são saber objetivado. A objetivação demanda a atividade material, mesmo que seja esta apenas o vigiar e aprimorar do mecanismo objetivo, mesmo que seja atividade também intelectual. O domínio pelos indivíduos das forças produtivas gerais do cérebro humano depende do domínio do mundo humano material, das forças produtivas objetivas. Quando se afirma, por exemplo, que uma colhedeira faz o trabalho que antes requeria centenas de pessoas, na verdade está-se referindo a que meia dúzia de pessoas, mobilizando uma colhedeira, faz hoje o trabalho que antes era feito por centenas, de forma concreta diversa. Se para a nova forma é requerida formação intelectual, isso significa que o trabalho é mediado pelo conhecimento e que este, no caso, foi tornado atividade diretamente produtiva. A atividade cognitiva não é contrária ao trabalho em si mesma, não há substituição do trabalho pela atividade cognitiva, mas uma nova forma do trabalho produtivo coletivo que é cognitiva, científica, criativa, porque seus meios foram automatizados.

Com o assalariamento do cientista, completa-se ainda o processo de dissociação entre as funções na produção social e a divisão de classe. Se esta era caracterizada como separação entre a produção intelectual e a função política, ligadas à propriedade e ao domínio do trabalho social, por um lado, e o trabalho material imediato realizado pela classe produtora, por outro, hoje a divisão de classe é indiferente a essa separação: o conjunto do trabalho social, material e intelectual unidos na indústria é assalariado e se conecta com a não-propriedade. Trata-se de um aprofundamento da socialização da produção. O capitalismo constitui um segundo estágio do desenvolvimento histórico que alcança as condições necessárias ao estabelecimento de uma sociedade sob nova forma de propriedade, comum. Um desses pressupostos é a superação da divisão entre trabalho material e intelectual como forma necessária para a realização das atividades intelectuais e de desenvolvimento científico. A base econômica, em seu desenvolvimento capitalista, suprime a necessidade material da forma privada da propriedade, e torna a classe proprietária meramente parasitária. 
A barreira que o capital representa para o desenvolvimento das forças produtivas aparece mais como um entrave à automação da produção, isto é, à aplicação da ciência para a elaboração de técnicas, ou para estabelecimento efetivo na produção de técnicas já desenvolvidas, do que para o desenvolvimento da ciência em si mesma. De fato a ciência e mesmo a técnica avançam mais que sua possibilidade de serem empregadas na produção. Significa que o conhecimento técnico e o avanço da ciência são maiores do que o aumento de produtividade efetiva do trabalho social. A pesquisa científica e técnica permanece em contínuo avanço.

No entanto, a própria ciência é limitada pela forma capitalista. A finalidade capitalista guia o objeto e o caminho de desenvolvimento da ciência e da técnica conforme as possibilidades de valorização, de sorte que pesquisas deixam de ser desenvolvidas não por falta de base científica, mas pela ausência de investimento. A própria ciência é limitada quando se torna veículo de valorização, campo de investimento capitalista ${ }^{197}$.

O progresso da subsunção do trabalho científico ao capital caracteriza também uma limitação para o desenvolvimento individual do trabalhador da ciência. A ciência característica do capitalismo é centralmente a ciência natural e se desenvolve pelo caminho analítico. Cada elemento da natureza é analisado em suas mínimas partes. Isso aparece no intenso desenvolvimento das subdivisões das ciências no último século e meio e na correspondente especialização do trabalho individual. A especialização retira do trabalhador da ciência o controle de qualquer processo produtivo mais amplo e tolhe a sua criatividade ao restringir seu objeto, seu fim e seu método.

Assim, os indivíduos que as relações capitalistas produzem, mesmo aqueles que alcançam incorporar os mais universais resultados do desenvolvimento humano, os que realizam as atividades criativas e cognitivas, não são indivíduos livres, que controlam, coletivamente, sua própria produção e se beneficiam do trabalho social. Ao contrário, o cientista é sujeito ao trabalho, reproduzindo a ausência de tempo livre e de escolha de

\footnotetext{
${ }^{197}$ O fato de Cuba ser hoje o país pioneiro no desenvolvimento de diversos tratamentos médicos deve ser suficiente para atestar que os países que detém a indústria farmacêutica mais avançada não os desenvolveram por falta de investimento. Cuba é o primeiro país a eliminar a transmissão do vírus da Aids da mãe para o bebê durante o parto (brasil.elpais.com) e a desenvolver tratamentos inovadores contra, por exemplo, os efeitos da diabetes ("Fármaco cubano revoluciona tratamento do pé diabético", em diabetenet.com.br) e contra o câncer de pulmão ("Cuba anuncia vacina contra cancro do pulmão", em dn.pt/inicio/ciência). Isso mostra que a concorrência capitalista, ao definir o objeto das pesquisas, distancia-as das necessidades sociais.
} 
seus fins, que caracteriza a atividade do operário à máquina. Na prática, sua atividade é especializada e unilateral, é meio para a reprodução da vida. É, pois, trabalho abstrato. Quando se afirma que o trabalho abstrato é aquele que cria seu produto como valor, isto significa que é trabalho subsumido à relação de valor. Refere-se ao trabalho que cria seu produto na forma de valor, como um produto que lhe é estranho, visto que seus fins são ditados pela finalidade capitalista. Assim, só uma interpretação mecanicista do trabalho abstrato poderia concluir que o trabalho do caixa de supermercado, por exemplo, porque não cria imediatamente valor, não assume forma abstrata. Trata-se de um trabalho assalariado que realiza as metamorfoses do valor, e cuja atividade e resultado são indiferentes ao trabalhador. No processo coletivo de reprodução do capital, seu trabalho compõe a reprodução do valor, e só a isto serve.

O trabalho empregado na pesquisa, além de assalariado, é também voltado à mesma finalidade estranha ao produtor imediato, à valorização. $\mathrm{O}$ trabalho cognitivo não é, contudo, como o da esfera comercial, trabalho simples. Mas ainda que o trabalho intelectual requeira o emprego de capacidades inventivas, ainda que a atividade proporcione alguma satisfação e realização individual, o que se dá cada vez menos com a progressiva especialização, isto só significa que um conjunto de capacidades do sujeito está voltado à finalidade da valorização. Como atividade mediada pela troca entre força de trabalho e capital, a forma mais desenvolvida da relação de valor, a atividade de pesquisa é trabalho abstrato. A forma social da atividade é a do trabalho mobilizado diretamente pelo capital e que serve à sua reprodução: um pesquisador em biogenética, por exemplo, que fosse livre certamente não voltaria seus esforços, por impulso próprio, à criação da Intacta. Seu produto é, para ele como para a Monsanto, valor. Isto não nega, contudo, que o progresso na divisão do trabalho, o advento da forma do trabalho científico diretamente produtivo, proporciona o desenvolvimento da individuação, mas na forma de desenvolvimento de capacidades unilaterais.

Ao responder à demanda capitalista, o trabalhador individual da ciência é limitado em sua possibilidade de pensar a própria ciência, cujos fins, objetos, e mesmo os métodos, lhe aparecem como dados. Os rumos do desenvolvimento da ciência ficam, assim, reféns das leis cegas do capitalismo. A própria ciência perde sua capacidade de reflexão na medida em que não põe a si mesma como objeto e não controla seu devir. Reafirma-se assim, por um lado, o que se pôs no Renascimento: a ciência e o trabalho permanecem, na prática, conjuntos; esta unidade desenvolveu-se com as forças 
produtivas. No entanto, à medida que a ciência deixa de pensar a si mesma, ela deixa de considerar sua própria origem e vínculo imanente com o trabalho, contrariamente ao seu movimento inicial no Renascimento. Desse modo, a ciência não tem mais o próprio trabalho, em sua dimensão transformadora da natureza e de si mesmo, como objeto de sua reflexão. A ciência e sua aplicação técnica aparecem assim como estranhas ao próprio trabalhador intelectual. Nisto se mostra o limite de sua própria universalidade, determinada por sua subsunção à relação de valor. 


\section{REFERÊNCIAS BIBLIOGRÁFICAS}

\section{Obras de Karl Marx}

Manuscritos Econômico Filosóficos. Tradução de Jesus Ranieri. São Paulo: Boitempo, 2010.

Teorias da mais-valia. História crítica do pensamento econômico - Vol. I. Tradução de Reginaldo Sant'Anna. São Paulo: Difel, 1980.

Teorias da mais-valia. História crítica do pensamento econômico - Vol. III. Tradução de Reginaldo Sant'Anna. São Paulo: Difel, 1980-1985.

Grundrisse: Manuscritos econômicos de 1857-1858: esboços da crítica da economia política, tradução de Mário Duayer e Nélio Schneider, São Paulo: Boitempo; Rio de Janeiro: Ed. UFRJ, 2011.

O Capital - Crítica da economia política - Livro primeiro. Tradução de Regis Barbosa e Flávio R. Kothe. Coordenação e revisão de Paul Singer. Coleção Os economistas Vols. I e II. São Paulo: Nova Cultural, 1985.

A Mercadoria. Tradução, Apresentação e Comentários de Jorge Grespan. Col. Ensaios Comentados. São Paulo: Ática, 2006.

O Capital - Crítica da economia política - Livro terceiro. Tradução de Regis Barbosa e Flávio R. Kothe. Coordenação e revisão de Paul Singer. Coleção Os economistas Vols. IV e V. São Paulo: Nova Cultural, 1986.

Contribuição à crítica da economia política. Tradução de Florestan Fernandes. $2^{\mathrm{a}}$ ed. São Paulo: Expressão Popular, 2008.

Para a crítica da economia política. Tradução de José Arthur Giannotti e Edgar Malagodi. Coleção Os Pensadores, São Paulo: Abril Cultural, 1974.

Crítica ao Programa de Gotha. Tradução de Rubens Enderle. São Paulo: Boitempo, 2012.

Para a Crítica da Economia Política - Manuscrito de 1861-63, Cadernos I a Vterceiro Capítulo, O capital em geral. Tradução de Leonardo de Deus. Belo Horizonte: Autêntica, 2010.

O Capital - Capítulo VI (Inédito). Tradução de Eduardo Sucupira Filho e Célia Regina de Andrade Bruni. São Paulo: Ciências Humanas, 1978.

Theorien über den Mehrwert, Dritter Teil, MEW, Band 26.3. Berlin: Dietz Verlag, 1968. 
Das Kapital - Kritik der politischen Ökonomie Dritter Band - Buch III: Der Gesamtprozeß der kapitalistischen Produktion (Editado por Friedrich Engels), MEW Band 25, Berlim: Dietz Verlag, 1964.

"Einleitung [zur Kritik der politischen Ökonomie]" in Marx-Engels Werke, Band 13, Berlin: Dietz Verlag, 1961.

Das Kapital - Drittes Buch Der Gesamtprozeß der kapitalistischen Produktion, MarxEngels Werke, Berlin: Dietz Verlag, 1964.

\section{Obras de Marx e Engels}

A Ideologia Alemã - Crítica da mais recente filosofia alemã em seus representantes Feuerbach, B. Bauer e Stirner, e do socialismo alemão em seus diferentes profetas (1845-1846). Tradução de Rubens Enderle, Nélio Schneider e Luciano Cavini Martorano. São Paulo: Boitempo, 2007.

Selected Correspondence, $2^{\mathrm{a}}$ ed., Moscou: Progress Publishers, 1965.

Cultura, Arte e Literatura - textos escolhidos. Tradução de José Paulo Netto e Miguel Yoshida. São Paulo: Expressão Popular, 2010.

\section{Obras de Engels}

Anti-Dühring, ou a subversão da ciência pelo Sr. Eugênio Dühring (Parte II Economia Política, Capítulo VI: Trabalho simples e trabalho complexo). Tradução de Isabel Hub e Teresa Adão. Lisboa: Edições Afrodite, 1971.

A origem da família, da propriedade privada e do estado. Tradução de Ciro Mioranza. São Paulo: Escala, s/d.

\section{Bibliografia geral}

AMORIM, Henrique, Trabalho imaterial-Marx e o debate contemporâneo. São Paulo: Annablume; FAPESP, 2009.

ANDERSON, P., Linhagens do Estado Absolutista. Tradução de João Roberto Martins Filho. São Paulo: Brasiliense, 1998.

ANDERSON, Perry, Passagens da Antiguidade ao Feudalismo, Tradução de Beatriz Sidou. São Paulo: Brasiliense, 2000. 
BARROS, Bettina. "Monsanto já domina mercado mundial de sementes de hortaliças", publicada originalmente em Valor Econômico, 11 de setembro de 2014. Disponível em: ihu.unisinos.br/noticias. Acesso em: 09/04/2015.

BAUER, Otto, "Qualifizierte Arbeit und Kapitalismus", in Die Neue Zeit, Stuttgart, 1906, BD. I, nº 20.

BÖHM-BAWERK, Eugen von, "La conclusión del sistema de Marx" in Hilferding, R. e outros. Economía Burguesa y Economía Socialista. Cuadernos de Pasado y Presente, no 49. México, Siglo XXI, 1974. pp. 29-127.

BÖHM-BAWERK, Eugen von. Karl Marx and the closure of his system; HILFERDIN, Rudolf. Böhm-Bawerk's criticism of Marx. Tradução de Eden e Cedar Paul. Introdução de Paul Sweezy. New York: Augustus M. Kelley, 1949.

BOUDIN, Louis B., The Theoretical System of Karl Marx in the Light of Recent Criticism, Chicago: Charles H. Kerr \& Co., 1907

CANTOR, Renán Vega, "La 'sociedad del conocimento': una falácia comercial del capitalismo contemporâneo", in Herramienta - Revista de debate e crítica marxista, $\mathrm{n}^{\circ}$ 35. Buenos Aires, Argentina: Ediciones Herramienta, Junho de 2007, pp. 171-183.

CASTORIADIS, Cornelius. "Valor, igualdade, justiça, política: de Marx a Aristóteles e de Aristóteles até nós", in As encruzilhadas do labirinto - vol. I. Tradução de Carmem Sylvia Guedes e Rosa Maria Boaventura. São Paulo: Paz e Terra, 1997, $2^{a}$ ed.

CHASIN, José. Marx: "Estatuto ontológico e resolução metodológica". In TEIXEIRA, Fransciso José, Pensando com Marx - uma leitura crítico-comentada de O Capital. São Paulo: Ensaio, 1995.

CHILDE, Gordon, A evolução cultural do homem. Rio de Janeiro: Zahar, 1981.

COTRIM, Ivan. Karl Marx: a ontonegatividade originária do valor. São Paulo: Alameda, 2011.

DEBUS, Allen G. El hombre y la naturaleza em el Renascimiento. México: Fondo de Cultura Econômica, 1996.

DELUMEAU, Jean. A civilização do Renascimento - vol. II. Lisboa: Estampa.

DEUTSCH, H., Qualifizierte Arbeit und Kapitalismus, Viena, C. W. Stern, 1904..

DUSSEL, Enrique, "El programa científico de investigación de Carlos Marx (Ciencia social funcional e crítica)", in Herramienta - Revista de debate e crítica marxista, $\mathrm{n}^{\circ} 9$. Buenos Aires, Argentina: Ediciones Herramienta, Outono de 1999, pp. 99-119.

A Produção Teórica de Marx - Um comentário aos Grundrisse.

Tradução de José Paulo Neto, São Paulo: Expressão Popular, 2012. 
FAUSTO, Ruy, "Pós- grande indústria nos Grundrisse (e para além deles)", in Lua Nova, São Paulo, nº 19, pp. 47-67, Nov. 1989.

Marx: Lógica e Política - Investigações para uma reconstrução do sentido da dialética. Tomo I: São Paulo: Brasiliense, 1987.

Marx: Lógica e Política - Investigações para uma reconstrução do sentido da dialética. Tomo III: São Paulo: Editora 34, 2002.

GARIN, Eugênio, Ciência e vida civil no Renascimento italiano. São Paulo: Unesp, 1996.

GIANNOTTI, J. A. Trabalho e reflexão - Ensaios para uma dialética da sociabilidade. São Paulo: Brasiliense, 1983.

GORZ, André. O Imaterial - conhecimento, valor e capital. Tradução de Celso Azzan Júnior. São Paulo: Annablume, 2005.

Metamorfoses do trabalho: crítica da razão econômica. Tradução de Ana Montoia. São Paulo: Annablume, 2003.

GRESPAN, Jorge Luís da Silva, O negativo do capital. São Paulo: Editora Hucitec; FAPESP, 1999.

"As formas da mais-valia: concorrência e distribuição no Livro III de $O$ Capital" in Crítica Marxista n. 33. São Paulo: Fundação Editora da Unesp, 2011, pp. 9-30.

HALE, John R (editor). Dicionário do renascimento italiano. Rio de Janeiro: Zahar, 1988.

HEGEL, Encyclopedia das sciencias philososophicas - Em compêndio. Trad. Lívio Xavier. São Paulo: Impressora Comercial, 1936, in Weffort, Francisco, Os clássicos da Política vol. II. São Paulo: Ática, 1990

HEINRICH, Michael. An Introduction to the three volumes of Karl Marx's Capital. Tradução para o inglês de Alexander Locascio. Nova York: Monthly Review Press, 2004.

, "Capital in general and the structure of Marx's Capital: new insights from Marx's economic manuscript of 1861-1863", in Capital and Class, $\mathrm{n}^{\mathrm{o}} 38$, 1989, pp. 63-79.

HELLER, Agnes. Aristoteles y el mundo antiguo. Barcelona: Península, 1983. O Homem do Renascimento. Lisboa: Presença.

HILFERDING, Rudolf Bohm-Bawerk's Criticism of Marx (published together with Eugen von Bohm-Bawerk, Karl Marx and the Close of his System). Tradução de Eden e 
Cedar Paul. Introdução de Paul Sweezy. New York: Augustus M. Kelley, 1949, pp. 146-147.

HOLLOWAY, John, CECCHETTO, Sergio, "Luchar contra el capital implica siempre luchar contra el trabajo abstracto" (entrevista de Jonh Holloway por Sergio Cecchetto), in Herramienta - Revista de debate e crítica marxista, $\mathrm{n}^{\circ}$ 9, Buenos Aires, Argentina: Ediciones Herramienta. Outubro de 2007, pp. 67-79.

IONNIDES, Alexis, MAVROUDEAS, Stavros, "Work more or work harder? The duration and intensity of work in Marx's Capital", in Sience and Society, vol. 74, $\mathrm{n}^{\circ} 1$, 2010, pp. 85-102.

KATZ, Claudio, "Uma interpretación contemporânea de la ley de la tendência decresciente de la tasa de ganancia" in Herramienta - Revista de debate e crítica marxista, $\mathrm{n}^{\circ}$ 9. Buenos Aires, Argentina: Ediciones Herramienta, Inverno de 2000, pp. 143-166.

KOVALIOV, S. I. “A crise social do século III ao V no Império Romano do Ocidente”, in PINSKY, Jaime (org.). Modo de produção feudal. Col. Textos 1, pp. 25-40, São Paulo: Global, 1982.

LAZZARATO, M., NEGRI, A., COCCO, G., Trabalho imaterial - formas de vida e produção de subjetividade. Tradução de Giuseppe Cocco. Rio de Janeiro: DP\&A editora, 2001.

LUKÁCS, György, Ontologia do ser social - Os princípios ontológicos fundamentais de Marx. Tradução de Carlos Nelson Coutinho. São Paulo: Livraria Editora Ciências Humanas, 1979.

Prolegômenos para uma ontologia do ser social - questões de princípios para uma ontologia hoje tornada possível. Tradução de Lya Luft e Rodnei Nascimento. São Paulo: Boitempo, 2010.

MANDEL, Ernest, "El Capital" - Cien años de controversias em torno a la obra de Karl Marx. México: Siglo veintiuno editores, 1985.

A Formação do Pensamento Econômico de Karl Marx - De 1843 até a redação de O CAPITAL. Col. Biblioteca de Ciências Sociais, Rio de Janeiro: Zahar Editores, 1968. (cap. 7: "Os Grundrisse ou a dialética do tempo de trabalho e do tempo livre")

MANN, Thomas, José e seus irmãos - vol. 1 As histórias de Jacó; O jovem José. Tradução de Agenor Soares de Moura. Rio de Janeiro: Nova Fronteira, 1983.

MORAES NETO, B. R., Marx, Taylor, Ford: as forças produtivas em discussão. São Paulo: Brasiliense, 1991. 
NAPOLEONI, Cláudio, Lições sobre o Capítulo VI (inédito) de Marx. São Paulo: Livraria Editora Ciências Humanas, 1981.

PICO DELlA MIRANDOLA, Giovanni, Discurso sobre a Dignidade do Homem, Lisboa: Edições 70, 1989.

PONCE, Anibal, Educacion e lucha de classes, La Paz: America Editorial, 1999.

PRADO, E. F. S., Desmedida do valor: crítica da pós-grande indústria. São Paulo: Xamã, 2005.

"Pós grande indústria: trabalho imaterial e fetichismo" Disponível em: paje.fe.usp.br/ mbarbosa/dpi/eleuterio2.pdf. Acessado em agosto/2013.

RICARDO, David. Princípios de economia política e tributação. Tradução de Rolf Kuntz. Trechos selecionados. São Paulo: Abril Cultural. Coleção Os pensadores, volume Adam Smith, Ricardo. $2^{\text {a }}$ edição. 1979.

Principles of political economy and taxation, Nova York: Dover

Publications, 2004.

ROMERO, Daniel, Marx e a técnica - Um estudo dos manuscritos de 1861-1863. São Paulo: Expressão Popular, 2005.

ROSDOLSKY, Roman, Gênese e estrutura de O Capital de Karl Marx. Tradução de César Benjamin. Rio de Janeiro: Contraponto, 2001.

ROUSSEAU, J.-J., Discurso sobre a origem e os fundamentos da desigualdade entre os homens. Tradução de Iracema Gomes Soares e Maria Cristina Roveri Nagle. Brasília: ed. UNB; São Paulo: Ática, 1989.

RUBIN, I. I., A Teoria marxista do valor. Tradução de José Bonifácio de S. Amaral Filho. São Paulo: Polis, 1987.

RUSSEL, Kyle, "Apple has 'objectively insane' patent demands for Samsung”, publicado em Business Insider. Disponível em: businessinsider.com. Acesso em: 09/04/2015.

SAYERS, Sean, "The concept of labour: Marx and his critics", in Sience and Society, vol. 71, nº 4, 2007, pp. 431-454.

SMITH, Adam. A riqueza das nações. Tradução de Alexandre Amaral Rodrigues e Eunice Ostrensky. São Paulo: Martins Fontes, 2003.

An inquiry into the nature and causes of the wealth of nations. Chicago: Encyclopedia Britannica, 1952.

SWEEZY, Paul, Teoria do desenvolvimento capitalista. Tradução de Waltensir Dutra. Rio de janeiro: Zahar Editores, 1976. 
TEIXEIRA, Francisco, FREDERICO, Celso, Marx no século XXI. São Paulo: Cortez, 2008.

THUSWOHL, Maurício, 'Legalizados há dez anos, transgênicos vivem 'apoteose' no Brasil", Carta Maior, 11 de novembro de 2013. Disponível em: reporterbrasil.org.br. Acessado em: 09/04/2015.

\section{Websites}

patentlyapple.com

monsanto.com

reporterbrasil.org.br

tecmundo.com

arquivonacionaldepatentes.com.br

dn.pt/inicio/ciência

dabetenet.com.br

brasil.elpais.com 